\title{
The Life and Letters of William Sharp and "Fiona Macleod"
}

\author{
Volume 1: 1855-1894
}


To access digital resources including:

blog posts

videos

online appendices

and to purchase copies of this book in:

hardback

paperback

ebook editions

Go to:

https://www.openbookpublishers.com/product/793

Open Book Publishers is a non-profit independent initiative. We rely on sales and donations to continue publishing high-quality academic works.

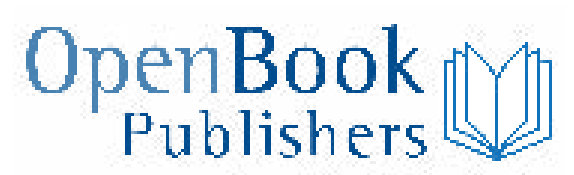

Knowledge is for sharing 


\section{THE LIFE AND LETTERS OF WILLIAM SHARP AND "FIONA MACLEOD" VOL. I}





\title{
The Life and Letters of William Sharp and "Fiona Macleod"
}

\author{
VOLUME I: 1855-1894
}

William F. Halloran 
https://www.openbookpublishers.com

(C)2018 William F. Halloran

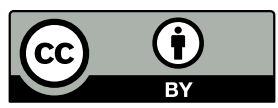

This work is licensed under a Creative Commons Attribution 4.0 International license (CC BY 4.0). This license allows you to share, copy, distribute and transmit the text; to adapt the text and to make commercial use of the text providing attribution is made to the authors (but not in any way that suggests that they endorse you or your use of the work).

Attribution should include the following information: William F. Halloran, The Life and Letters of William Sharp and "Fiona Macleod". Volume 1: 1855-1894. Cambridge, UK: Open Book Publishers, 2018. https://doi.org/10.11647/OBP.0142

In order to access detailed and updated information on the license, please visit https://www. openbookpublishers.com/product/793\#copyright

Further details about CC BY licenses are available at https://creativecommons.org/licenses/ by/4.0/

All external links were active upon publication unless otherwise stated and have been archived via the Internet Archive Wayback Machine at https://archive.org/web

Updated digital material and resources associated with this volume are available at https:// www.openbookpublishers.com/product/793\#resources

Every effort has been made to identify and contact copyright holders and any omission or error will be corrected if notification is made to the publisher.

ISBN Paperback: 978-1-78374-500-5

ISBN Hardback: 978-1-78374-501-2

ISBN Digital (PDF): 978-1-78374-502-9

ISBN Digital ebook (epub): 978-1-78374-503-6

ISBN Digital ebook (mobi): 978-1-78374-504-3

ISBN XML: 978-1-78374-660-6

DOI: $10.11647 / \mathrm{OBP} .0142$

Cover image: "Mr William Sharp: from a photograph by Frederick Hollyer: The Chap-book, September 15, 1894", Wikimedia, https://upload.wikimedia.org/wikipedia/commons/6/6b/ William_Sharp_1894.jpg. Cover design: Anna Gatti.

All paper used by Open Book Publishers is SFI (Sustainable Forestry Initiative), PEFC (Programme for the Endorsement of Forest Certification Schemes) and Forest Stewardship Council ${ }^{\circledR}($ FSC $®$ certified).

Printed in the United Kingdom, United States, and Australia by Lightning Source for Open Book Publishers (Cambridge, UK) 
To the memory of

Noel and Rosemarie Sharp

and

Esther Mona Harvey 



\section{Contents}

Acknowledgements $\quad$ ix

Introduction 1

Chapter One: $1855-1881$

Chapter Two: 1882-1884 65

Chapter Three: 1885-1886 133

Chapter Four: 1887-1888 175

Chapter Five: 1889

Chapter Six: 1890

Chapter Seven: 1891

Chapter Eight: 1892a 359

Chapter Nine: $1892 b \quad 409$

Chapter Ten: 1893

Chapter Eleven: 1894

Notes $\quad 593$

Appendix 683

List of Illustrations $\quad 695$ 



\section{Acknowledgements}

William Sharp's wife and first cousin, Elizabeth Amelia Sharp, became his literary executor when he died in 1905. Upon her death in 1932, the executorship passed to her brother, Noel Farquharson Sharp. When he passed away in 1945, that role fell to his son, Noel Farquharson Sharp, who like his father was a keeper of printed books in the British Museum. When he died in 1978, the executorship fell to his wife, Rosemarie Sharp, who lived until 2011 when it passed to her son, Robin Sharp.

I am heavily indebted to Noel and Rosemarie Sharp for their assistance and friendship. They granted me permission to publish William Sharp's writings and shared their memories of his relatives and friends. I am especially grateful to Noel Sharp for introducing me in 1963 to Edith Wingate Rinder's daughter, Esther Mona Harvey, a remarkably talented woman whose friendship lasted until her death in 1993. Her recollections of her mother, who played a crucial role in the lives of William and Elizabeth Sharp, were invaluable.

Through many years of my involvement with an obscure and complex man named William Sharp, my wife - Mary Helen Griffin Halloran has been endlessly patient, encouraging and supportive. This work has benefited greatly from her editorial skills.

I am also grateful to a succession of English graduate students at the University of Wisconsin-Milwaukee who assisted me in transcribing and annotating William Sharp's letters: Edward Bednar, Ann Anderson Allen, Richard Nanian, and Trevor Russell. Without the support I received from the College of Letters and Science and the Graduate School of the University of Wisconsin-Milwaukee this project would not have seen the light of day. 
The following institutions have made copies of their Sharp/Macleod letters available and granted permission to transcribe, edit, and include them in this volume:

The American Antiquarian Society; Baylor University's Browning Library; The British Library; The Brown University Library; The Library of Colby College; Columbia University's Rare Book and Manuscript Library; The Edinburgh City Libraries; Harvard University's Houghton Library; The Huntington Library of San Marino California; Indiana University's Lilly Library; The Library of Congress; The Manx Museum on The Isle of Mann; The National Library of Scotland; The Newberry Library; The New York Public Library's Berg Collection; New York University's Fales Library; The Northwestern University Library; Oxford University's Bodleian Library; Pennsylvania State University's Pattee Library; The Pierpont Morgan Library in New York City; Princeton University's Firestone Library; The Sheffield City Archives; The Smith College Library; The Stanford University Library; The State University of New York at Buffalo Library; The Library in Trinity College Dublin; The University of British Columbia Library; The University of California Berkeley's University Research Library; The University of California Los Angeles's William Andrews Clark Library; The University of Delaware Library; The University of Illinois Urbana Library; The University of Leeds's Brotherton Library; The University of Texas Austin's Library and its Henry Ransom Humanities Research Center; The University of Toronto's Thomas Fisher Rare Book Library; The University of Wisconsin-Milwaukee's Golda Meir Library; Yale University's Beinecke Library.

The Appendix lists the letters owned by each institution in order to recognize their generosity and ease the way for scholars who may wish to consult the original manuscripts. Without these great libraries, their benefactors, and their competent and caring staffs, a project of this sort - which has stretched over half a century - would have been impossible.

Finally, this project would not have come to fruition had it not been for Warwick Gould, Emeritus Professor and former Director of the Institute for English Studies at the University of London. It was he who supported the first iteration of the Sharp letters as a website supported by the Institute, and it was he who suggested Open Book Publishers as a possible location for an expanded edition of The Life and Letters of William Sharp and Fiona Macleod. His support and friendship have been a beacon of light. 


\section{Introduction}

William Sharp was born in Paisley, near Glasgow, in 1855. His father, a successful merchant, moved his family to Glasgow in 1867; his mother, Katherine Brooks, was the daughter of the Swedish Vice Consul in Glasgow. A talented, adventurous boy who read voraciously, he spent summers with his family in the Inner Hebrides where he developed a strong attachment to the land and the people. In the summer of 1863, his paternal aunt brought her children from London to vacation with their cousins. Months short of his eighth birthday, Sharp formed a bond with one of those cousins, Elizabeth Sharp, a bright girl who shared many of his enthusiasms. Their meeting led eventually to their engagement (in 1875) and their marriage (in 1884).

After finishing school at the Glasgow Academy in 1871, Sharp studied literature for two years at Glasgow University, an experience that fed his desire to become a writer. Following his father's sudden death in August 1876, he fell ill and sailed to Australia to recover his health and look for suitable work. Finding none, he enjoyed a warm and adventurous summer and returned in June 1877 to London where he spent several weeks with Elizabeth and her friends. A year later he settled in London and began to establish himself as a poet, journalist, and editor. Through Elizabeth's contacts and those he made among writers, including Dante Gabriel Rossetti, he became by the end of the 1880s a well-established figure in the literary and intellectual life of the city. During this decade he published biographical studies of Rossetti, Percy Bysshe Shelley, and Robert Browning; three books of poetry; two novels; many articles and reviews; and several editions of other writers. None of those publications brought the recognition he sought. 
By 1890 he had accumulated enough money to reduce his editing and reviewing and devote more time to poetry and prose.

That autumn he and Elizabeth went to Heidelberg for several weeks and then to Italy for the winter. In January, Edith Wingate Rinder, a beautiful young woman and the wife of Frank Rinder, accompanied her aunt, Mona Caird, a close girlhood friend of Elizabeth, on a threeweek visit to Rome. There Edith spent many hours exploring the city and surrounding area with Sharp who fell deeply in love with her. Inspired by the joy he felt in her presence and the warmth and beauty of the country, Sharp wrote and printed privately in Italy a slim book of poems, Sospiri di Roma, that exceeded in quality those he had written previously.

After returning to England in the spring of 1891 and under the influence of his continuing relationship with Edith, Sharp began writing a prose romance set in western Scotland. When he found a publisher (Frank Murray in Derby) for Pharais, A Romance of the Isles, he decided to issue it pseudonymously as the work of Fiona Macleod. In choosing a female pseudonym, Sharp signaled his belief that romance flowed from the repressed feminine side of his nature. The pseudonym also reflected the importance of Edith in the novel's composition and substance. Their relationship is mirrored in the work's depiction of a love affair doomed to failure. Finally, it disguised his authorship from London critics who, he feared, would not treat it seriously if it appeared as the work of the prosaic William Sharp.

Pharais changed the course of Sharp's life. Along with The Mountain Lovers, another west of Scotland romance that followed in 1895, it attracted enthusiastic readers and favorable notices. When it became apparent that his fictional author had struck a sympathetic chord with the reading public and the books were bringing in money, Sharp proceeded to invent a life for Fiona Macleod and project her personality through her publications and letters. In letters signed William Sharp, he began promoting the writings of Fiona and adding touches to her character. He sometimes functioned as her agent. To some, he asserted she was his cousin, and he implied to a few intimate friends they were lovers. In molding the persona of Fiona Macleod and sustaining it for a decade, Sharp drew upon the three women he knew best: Elizabeth, his wife and first cousin; Edith Rinder, with whom he had developed 
a deep bond; and Elizabeth's friend and Edith's aunt, Mona Caird, a powerful and independent woman married to a wealthy Scottish Laird. He enlisted his sister Mary Sharp, who lived with their mother in Edinburgh, to provide the Fiona handwriting. His drafts of Fiona Macleod letters went to her for copying and mailing from Edinburgh.

For a decade before his death in 1905, he conducted through his publications and correspondence a double literary life. As Fiona, he produced poems and stories which, in their romantic content, settings, characters, and mystical aura, reflected the spirit of the time, attracted a wide readership, and became the principal literary achievement of the Scottish Celtic Renaissance. As Sharp, he continued reviewing and editing and tried his hand at several novels. As Fiona's chief advocate and protector, he deflected requests for interviews by insisting on her desire for privacy. If it became known he was Fiona, critics would dismiss the writings as deceptive and inauthentic. Destroying the fiction of her being a real woman, moreover, would block his creativity and deprive him of needed income. So he persisted and maintained the double life until he died. He refused to disclose his authorship even to the Prime Minister of England in order to obtain a muchneeded Civil List pension. The popular writings of Fiona Macleod may have obtained Parliament's approval, but not those of the journeyman William Sharp

His rugged good looks and exuberant manner obscured the fact that Sharp had been ill since childhood. Scarlet fever in his youth and rheumatic fever as a young man damaged his heart. In his forties, diabetes set in, and attacks increased in frequency and seriousness. Given his declining health after the turn of the century, though interrupted by occasional bursts of exuberant creativity, his death in December 1905 was not a surprise to his family and close friends. It occurred while he and Elizabeth were staying with Alexander Nelson Hood, the Duke of Bronte, at his Castello Maniace on the slopes of Mount Etna in Sicily. Sharp is buried there in the estate's Protestant Cemetery where a large Celtic cross marks his grave. 


\section{LIFE}

The introductions to the chapters of letters constitute a chronological biography that focuses on William Sharp as a unique individual who was talented, ambitious, determined to succeed as a writer, and aware of his shortcomings. His writings are discussed when they shed light on his life, his daily comings and goings, his beliefs, his values, and his physical and mental condition. With some exceptions, neither the introductions nor the notes to the letters take account of what others have said or written about William Sharp. The letters reveal more than has previously been known, and Sharp emerges from them as a talented, attractive, sensitive, and conflicted man. Difficult to pin down with precision, he was immersed in the cross-currents of ideas and in the artistic and social movements of the last two decades of the nineteenth century in Great Britain and continental Europe. He participated in spiritualist efforts to affirm the existence of some form of life after death; he embraced new ideas about the place of women in society, the constraints of marriage, the fluidity of gender identity, and the complexity of the human psyche. Those issues and many others are addressed in his letters and, often indirectly, in his writings. They are laid out here in the life sections in such a way that they, along with the letters, may provide the basis for a more comprehensive study of his life and work. This is the first of a projected three-volume work, the second and third to comprise the life and letters from January 1895 until December 12, 1905 when Sharp died at Castello Maniace, the home of Alexander Nelson Hood (the Duke of Bronte) on the slopes of Sicily's Mount Etna. 


\section{LETTERS}

Most of the letters transcribed, dated, and annotated were made available to the editor by libraries and private collectors throughout the world. They are of interest for what they reveal about Sharp, his correspondents, and the topics he addressed. He knew and corresponded with many influential writers, among them Dante Gabriel Rossetti, Walter Pater, George Meredith, Thomas Hardy, and William Butler Yeats. He wrote extensively as William Sharp and as Fiona Macleod to the firms that published his books and to the editors of magazines, journals, and newspapers for which he wrote essays and reviews. Individuals interested in literary and publishing activities in Great Britain and the United States in the 1880s and 1890s may find the letters useful.

The Fiona Macleod letters contributed significantly to Sharp's ability to maintain the fiction of her independent identity. When claims that he was the author emerged in print, he countered by pointing to the different handwriting. He also used the letters to move Fiona from place to place to avoid meetings with avid readers and skeptical journalists. Given her constant travels, it was convenient for her letters to be sent from and received at the address of a good friend she often visited in Edinburgh. It was the address of Sharp's mother and his sister Mary, who supplied the handwriting for Fiona and who was always on guard against visitors seeking her.

Sharp also used the letters to create and mold the person or, perhaps more accurately, the persona of Fiona Macleod. Exercising his imagination and literary skills, he entered the consciousness of an imaginary woman and projected her convincingly to her correspondents. She was well-educated and steeped in Celtic lore. She was well-traveled and well-fixed. She had the good fortune to be sometimes the daughter and other times the wife - there were inconsistencies - of a wealthy Scotsman who owned a yacht that could whisk her away on a moment's notice to the western isles or Scandinavia. She was shy and reclusive, but also firm in her decisions, formal in her manner, and resolved not to let herself be taken advantage of by publishers or diverted from her writing by newspaper reporters or suitors. She also had a sharp tongue which she exercised in correspondence when her privacy or integrity 
was in danger. She was particularly harsh in chastising those brash enough to suggest she was William Sharp.

The poems and stories Sharp published as Fiona Macleod exceeded in quality and popularity those he wrote as William Sharp, but Fiona Macleod herself was his most impressive achievement. Her personality emerges in many stories that describe the people she met and the places she visited, and in dedications and prefatory notes in her books, but it is in the letters that Sharp brought her fully into being. Speaking directly as Fiona, he crafted her distinct personality. Initially a lark, she became a financial necessity. Enjoying the deception, he soon became entranced by the woman he was creating. He continued to embellish his creation to the point he could claim and sometimes believe she was a separate person inhabiting his body. His fictional creation became the perfect means for expressing a strand of his being that had its origin in his childhood summers in Scotland's Inner Hebrides. Cast in this light, the character who emerges in the Fiona letters and other writings is one of the most compelling and provocative literary creations of the 1890s. 


\section{FORMAT}

The letters are divided chronologically into Chapters, and each Chapter begins with a biographical introduction. The letters have a uniform format:

Line one contains the name of the recipient and the date of composition. For undated letters, a date derived from a postmark, internal evidence, or context provided by other letters is placed in brackets. A question mark precedes questionable dates as [January ?12, 1892].

Line two states the place where the letter was written or from which it was mailed. Vertical marks denote line divisions in the original.

Line three contains the salutation if one exists.

Lines four and following contain the body of the letter with Sharp's paragraphing preserved where it can be determined.

Following the body, a single line contains the complimentary close and signature separated by a vertical mark if the close and signature are separate lines in the original.

If the original contains postscripts, they follow the signature.

The form of the original manuscript and its location follow each letter in a separate line at lower left. When a letter has been transcribed from a printed source, that source is indicated. Most letters have been transcribed from the manuscripts or photocopies of the manuscripts provided by institutions and individuals. Their locations are identified, but any previous printings, with a few exceptions, are not identified.

Obvious errors of spelling are silently corrected. Errors of punctuation and grammar are corrected only when necessary to attain clarity of the author's presumed intention. Notes on margins marked as inserts are placed within the body of the text at the point of intended insertion. Postscripts on margins follow the main body and signature. Every effort has been made to attain a balance between authenticity and readability.

The notes explain or clarify references. Given the multitude of people, places, literary and artistic works, and events mentioned in the letters, the process of annotation required editorial judgment about what is too much and what is not enough. 


\section{ABBREVIATIONS}

W.S.

William Sharp

F. M.

Fiona Macleod
E. A. S.
Elizabeth A. Sharp

E. W. R.

Edith Wingate Rinder

William Sharp (Fiona Macleod): A Memoir,

Memoir Compiled by his wife, Elizabeth A. Sharp

(New York: Duffield \& Co. 1910)

These abbreviations describe the form of the original letter:

AD autograph draft

ALS autograph signed letter

ALCS autograph lettercard signed

APS autograph postcard signed

TL typed letter

TLS typed letter signed 


\section{Chapter One}

\section{Life: $1855-1881$}

William Sharp was born on September 12, 1855, at 4 Garthland Place in Paisley, Scotland. ${ }^{1} \mathrm{He}$ was the oldest in a family of five daughters and three sons. His father, David Galbreath Sharp, was a partner in a mercantile house, and his mother, Katherine Brooks, was the daughter of the Swedish Vice Consul at Glasgow. Sharp spent the summers of his childhood in the West country - on the shores of the Clyde, the sea coast, and the Isle of Arran. He swam, rowed, sailed, and cultivated the passionate love of nature he inherited from his father. His Highland nurse, Barbara, told him tales of fairies, Celtic heroes, and Highland chieftains. These stories and the old Gaelic songs seeded his imagination with materials that came to fruition years later when he began writing the tales and poems he published under the pseudonym "Fiona Macleod." Fanciful as a child, Sharp often imagined himself a marauding Viking or a brave warrior. He developed early the sense of an invisible world and communicated freely with "invisible playmates, visible to him." The God he heard about in church was "remote and forbidding," but in the woods of the Inner Hebrides "he felt there was some great power behind the beauty." The "sense of the Infinite touched him there." When he was six, "he built a little altar of stones, $[\ldots]$ and on it he laid white flowers in offering" to a benign and beautiful Presence who ruled the natural world (Memoir 6).

In 1863, when he was seven, his aunt brought her three children from London to spend some time with the Paisley Sharps who had rented a house for the summer at Blairmore on the Gare Loch in western Scotland. One of those children was Elizabeth Amelia Sharp. Years later 
she recalled her cousin William, who would eventually be her husband, as "a merry, mischievous little boy [...] with bright brown curly hair, blue-gray eyes, and a laughing face [...] eager, active in his endless invention of games and occupations" (Memoir 8). Until he was eight, he was educated at home by a governess. In the fall of 1863, he was sent to Blair Lodge, a boarding school in Polmont Woods between Falkirk and Linlithgow. Four years later, the Sharps moved from Paisley to Glasgow and enrolled William as a day student at Glasgow Academy. In the summer of 1871, when he was 15, Sharp developed a severe case of typhoid fever and was sent to the West Highlands to recover. There he formed a friendship with Seumas Macleod, an elderly fisherman whose tales and beliefs found their way into the stories and poems he began publishing in the 1890s as the work of another Macleod whose first name, Fiona, was an abbreviation of Fionnaghal, the Gaelic equivalent of Flora. In the fall of 1871, at age sixteen, he entered Glasgow University. An eager and perceptive student, he excelled in English literature, which he studied under Professor John Nichol who became a close friend.

His most memorable summer was his eighteenth. Wandering near the Gare Loch close to Ardentinny, he encountered and joined a band of gypsies. Without explaining his absence or communicating his whereabouts, he roamed with them for weeks. With his light brown hair, he became their "sun-brother," and he absorbed much of their birdlore and wood-lore and the beliefs they derived from the patterns of the stars and the winds. This magical experience, free and unconventional, informed his later publications, especially Children of Tomorrow, The Gypsy Christ, and Green Fire. Understandably his parents were distressed upon learning their he had "gone with gypsies." When they located him, he relented and returned in the fall of 1872 to his classes at Glasgow University. Worried about his dreaming nature and interest in literature, his father at the close of the 1872-73 academic year placed him in the Glasgow law office of Messrs. Maclure and Hanney with the hope he might take to the legal profession. Though he did not continue towards a degree, he was found "worthy of special commendation" at the end of his second year. He had taken full advantage of the University's library, and at night during his two years as a legal apprentice he continued to "read omnivorously," according to Elizabeth, in "literature, philosophy, poetry, mysticism, occultism, magic, mythology, folklore." He developed "a sense of brotherhood with psychics and seers of 
other lands and days." His reading precipitated a radical shift from the Presbyterian faith in which he was raised toward a belief in the unity of the truths underlying all religions (Memoir 15).

Sharp's second meeting with Elizabeth took place when he spent a week with his cousins at Dunoon on the Clyde in August 1875. Of that occasion, she wrote, "I remember vividly the impression he made on me when I saw the tall, thin figure pass through our garden gateway at sunset - he had come down by the evening steamer from Glasgow and stride swiftly up the path. He was six feet one inch in height, very thin, with slightly sloping shoulders. He was good looking, with a fair complexion and high coloring; gray-blue eyes, brown hair closely cut, a sensitive mouth, and a winning smile. He looked delicate but full of vitality. He spoke very rapidly, and when excited his words seemed to tumble one over the other so that it was not always easy to understand him" (Memoir 17).

After a month in the West, Elizabeth and her sister visited the Glasgow Sharps in September, and before the end of the month, as Elizabeth recalled, she and William, both twenty years old and first cousins, "were secretly plighted to one another." They managed to spend a day together secretly in Edinburgh's Dean Cemetery where William confided "his true ambition lay not in being a scientific man, but a poet, that his desire was to write about Mother Nature and her inner mysteries." As Elizabeth recalled, "We talked and talked - about his ambitions, his beliefs and visions, our hopeless prospects, the coming lonely months, my studies - and parted in deep dejection," as they had no hope of seeing each other again until the next fall. After returning to London, Elizabeth received some of her fiancé's early poems, among them "In Dean Cemetery," a "pantheistic dream in fifty-seven stanzas" commemorating their day together. Elizabeth recalled receiving many more poems as the year proceeded, and commented: "The reason why he chose such serious types of poems to dedicate to the girl to whom he was engaged was that she was the first friend he had found who to some extent understood him, understood the inner hidden side of his nature, sympathized with and believed in his visions, dreams, and aims." That sentence is a revealing description of the foundation of their marriage which occurred several years later and lasted until Sharp died in 1905 at the age of fifty-five. 
In August 1876, a year later, the two Sharp families rented houses next to each other in Dunoon which enabled Elizabeth and William to spend many happy days together "rambling over the hills, boating and sailing on the lochs, in talking over our very vague prospects, in reading and discussing his poems." The families' holiday was brought to an abrupt and unhappy end on August 20 by the untimely death of William's father, an event that was a great shock to William who soon suffered a physical breakdown that raised the danger of consumption. Hoping a complete change of environment might improve his health and spirits, his family arranged passage for him on a ship bound for Australia. He relished the experiences of the voyage and the new country, where he stayed with family friends and spent many days exploring Gippsland and the desert region of New South Wales. He decided to settle in Australia and began looking for suitable work. When that search failed, he changed course and booked passage on the Loch Tay which reached London in June 1877.

Before returning to Scotland, Sharp stayed for a time with Elizabeth and her parents at their house on Inverness Terrace just north of the Bayswater Road in London. This was his first experience of the city that would become his home. Elizabeth introduced him to her friends, among them Adelaide Elder and Mona Alison, who later married the Scottish Laird, Henryson Caird of Casseneary. Elizabeth's mother enlisted the help and influence of her friends to find work for Sharp, but there was no immediate success. At summer's end, he returned to Scotland, joining his mother at Moffat where she had taken a house, and he devoted himself through a lonely fall and winter to writing. Several poems composed during these months appeared in his first volume of poetry, The Human Inheritance, in 1882.

Less than a year after returning from Australia, in the spring of 1878 when he was twenty-two, Sharp returned to London and began work at the London branch of the Melbourne Bank, a position secured for him by Alexander Elder, the father of Adelaide. He rented a room at 19 Albert's Street near Regent's Park and spent weekends with Elizabeth and her family at 72 Inverness Terrace, but their engagement remained secret. Despite an earlier decision to refrain from publishing "until he could do it properly," Sharp became increasingly anxious to appear in print. He submitted a poem, "A Nocturne to Chopin," to Good Words. It was accepted and published in July 1878. Late that summer, Elizabeth 
convinced him to end the secrecy, which he thoroughly enjoyed, and tell her mother they were engaged. When she realized her daughter was determined, she reluctantly approved, but warned others would disapprove because they were first cousins. "From that moment," Elizabeth said, her mother "treated her nephew as her son" (Memoir 28).

On the first of September 1879, William, with an introduction from Sir Noel Paton, the Scottish Pre-Raphaelite painter and a friend of the family, appeared at the door of the famous and aging poet and painter Dante Gabriel Rossetti. Rossetti welcomed the handsome and enthusiastic young writer who became a frequent guest at 16 Cheyne Walk. Sharp soon gained acceptance into the circle of admiring friends who lightened the darkness of Rossetti's final years. He came to know Algernon Swinburne, Theodore Watts (later Watts-Dunton), Hall Caine (another Rossetti acolyte), Robert Francillon, Julian Hawthorne, Rossetti's brother and sister, William Michael and Christina, and Philip Marston, a promising young poet who was blind and became Sharp's closest friend.

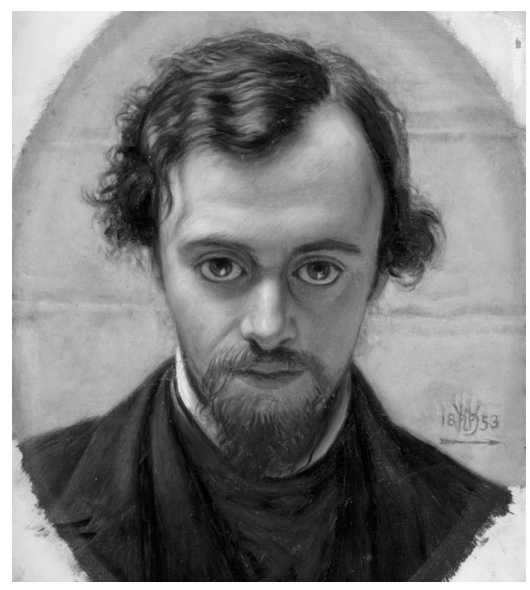

Fig. 1. Dante Gabriel Rossetti in 1850 at age 22. A portrait by William Holman Hunt (c.1883), Wikimedia, https://commons.wikimedia.org/wiki/ File:William_Holman_Hunt_-_Portrait_ of_Dante_Gabriel_Rossetti_at_22_ years_of_Age_-_Google_Art_Project. jpg, Public Domain.

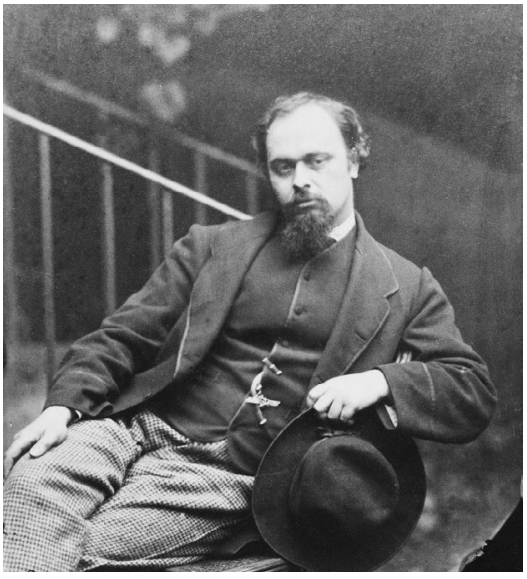

Fig. 2. An albumen print of Dante Gabriel Rossetti. Taken by Charles Lutwidge Dodgson (Lewis Carroll) (1863), Wikimedia, https://commons. wikimedia.org/wiki/File:Dante_ Gabriel_Rossetti_001.jpg, Public Domain. 
In the summer of 1880, Mrs. George Lillie Craik, author of John Halifax, Gentleman and Marston's godmother, entertained Sharp and Marston several times at her home south of London in Kent. During one of those visits Sharp caught a severe cold after being drenched in a thunderstorm. Still ill, he went to Port Maddock in North Wales to visit Elizabeth and her mother who had rented a holiday cottage. There his cold descended into rheumatic fever which forced him to stay an entire month while Elizabeth and her mother nursed him back to health. The illness lasted through the fall and permanently damaged his heart. Despite her worry that Sharp - "weak and delicate" - would not take care of himself, Elizabeth accompanied her mother to Italy for the winter months. By mid-December Sharp was well enough to describe in a letter to Elizabeth a night he spent in a Covent Garden with Francillon, Hawthorne, and thirty or so other artists in the Oasis Club.

In 1881 Sharp published several articles in Modern Thought and increased his contacts with the Rossetti circle. One consequence of his deeper literary involvement was an abrupt end to his banking career. In late August, the Principal of the City of Melbourne Bank offered him the alternative of employment in a remote branch in Australia or resignation. Sharp chose the latter and went to Scotland for two months to visit relatives and friends, among them William Bell Scott and Sir Noel Paton. When he returned to London he spent several weeks looking for another position and finally obtained a post with the Fine Arts Society's Gallery in Bond Street. The Society had decided to establish a section on German and English engravings and hired Sharp, through the good offices of Mrs. Craik, to study the subject for six months and then become the section's director. Shortly after he began work at the Gallery, the society reversed course and withdrew from the project. At year's end, Sharp was again out of work.

His trip to Australia, his persistent ill-health, his relationship with the woman who would become his wife, his determination to become a serious writer, and his lack of interest in banking or any other business or profession defined Sharp's life into his mid-twenties. His prospects were dim at the close of 1881. But another factor turned the tide: the friends he made as a bright and dashing young Scotsman new on the London scene. Some came through Elizabeth, a young girl of means with a fine mind and a sound education. She had a group of similarly 
talented and knowledgeable friends who readily accepted Sharp into their lives, supported his ambitions, and encouraged his development. Others came through Dante Gabriel Rossetti, who in his final years fostered Sharp's development as a poet, confided in him through long opium-fueled nights, and welcomed him into his circle of accomplished and respected painters, poets, and editors. They smoothed Sharp's entry into the literary life of London where he would flourish and attain a position of prominence during the 1880s. 


\section{Letters: 1877-1881}

\section{[1877]}

Braemar | August 21

... I feel another self within me now more than ever; it is as if I were possessed by a spirit who must speak out.... ${ }^{2}$ I am in no hurry to rush into print; I do not wish to write publicly until I can do so properly. It would be a great mistake to embody my message in such a poem as 'Uplands', ${ }^{3}$ although a fifty times better poem than that is. People won't be preached to. Truth can be inculcated far better by inference, by suggestion.... I am glad to see by your note you are in good spirits. I also now look on things in a different light; but, unfortunately, Lill, we poor mortals are more apt to be swayed by mood than by circumstances, and look on things through the mist of these moods.

Memoir 25-26

\section{To Elizabeth A. Sharp, Fall, [1877]}

... I am too worried about various things to settle to any kind of literary work in the meantime. The weather has been wretchedly wet, and the cold is intense. I do trust I shall get away from Scotland before the winter sets in, as I am much less able to stand it than I thought I was. Even with the strong air up here I can't walk any distance without being much the worse for it....

Memoir 26 


\section{To Elizabeth A. Sharp, August 26, 1878}

... Thanks for your welcome note which I received a little ago. I, too, like you, was sitting at my open window last night (or rather this morning) with the stars for my companions: and I, too, took comfort from them and felt the peace hidden in their silent depths. I know of nothing that soothes the spirit more than looking on those awful skies at midnight. Some of our aspirations seem to have burnt into life there, and, tangled in some glory of starlight, to shine down upon us with beckoning hands.... I have told you before how that music, a beautiful line of poetry, and other cherished things of art so often bring you into close communion with myself. But there is one thing that does it infallibly and more than anything else: trees on a horizon, whether plain or upland, standing against a cloudless blue sky - more especially when there is a soft blue haze dimly palpitating between. Strange, is it not? I only half indefinitely myself know the cause of it. One cause certainly is the sense of music there is in that aspect - possibly also the fairness of an association so sympathetic with some gracious memory of the past.

P.S. By-the-bye, have you noticed that my "Nocturne" is in the July number of Good Words?

Memoir 28-29

\section{To John Elder, [August, 1879] ${ }^{4}$}

I am glad you like my short paper in the Sectarian Review ${ }^{5}$ and I think that you understand my motive in writing it. It is no unreasoning reverence that I advocate, no "countenancing beliefs in worn-out superstitions", as you say; no mercy to the erring, but much mercy to and sympathy with the deceived. I do not reverence the Bible or the Christian Theology in themselves, but for the beautiful spirituality which faintly but ever and again breathes through them, like a vague wind blowing through intricate forests; and so far I reverence the recognition of this spiritual 
breath in the worship of those whose views are so very different from my own....

I have been writing a good deal lately - chiefly verse. There is one thing which I am sure will interest you: some time ago I wrote a sonnet called "Religion", the drift of which was to show the futility of any of the great creeds as creeds, and two or three weeks ago showed it to my friend Mr. Belford Bax. ${ }^{6}$ It seems to have made considerable impression upon him, for, after what he calls "having absorbed", he has set it to very beautiful recitative music. There are some fine chords in the composition, preluding the pathetic melody of the finale; and altogether it has given me great pleasure. But what specially interests me is that it is the first time (as far as I am aware) of a sonnet in any language having been set to music. The form of this kind of verse is of course antagonistic to song-music, and could only be rendered by recitative. Do you know of any instance having occurred? The sonnet in question will appear in The Examiner in a week or two, ${ }^{7}$

Lo, in a dream, I saw a vast dim sea

Whose sad waves broke upon a barren shore;

The name of this wan sea was Nevermore,

The land The Past, the shore Futility:

Thereon I spied three mighty Shadows; three

Weary and desolate Shades, of whom each wore

A crown whereon was writ Despair. To me

One spoke, and said, "Lo, I am He

In whom the countless millions of the East

Live, move, and hope. And all is vanity!" -

And I knew Buddha. Then the next: "The least

Am I, but once God's mightiest Prophet-Priest" -

So spoke Mahomet. And then pitifully

The third Shade moaned, "I am of Galilee!"

I also enclose the record of a vision I had lately:

Lo, in that Shadowy place wherein is found

The fruitage of the spirit men call dreams,

I wander'd. Ever underneath pale gleams

Of misty moonlight quivering all around

And ever by the banks of sedgy streams

Swishing thro' fallen rushes with slow sound

A spirit walked beside me. From a mound,

Rustling from poplar-leaves from top to base,

Some bird I knew not shrilled a cry of dole, 
So bitter, I cried out to God for grace.

Whereat he by me slackened from his pace,

Turning upon me in my cold amaze

And saying, "While the long years onward roll

Thou shalt be haunted by this hateful face - "

And looking up, I looked on my own soul!

Memoir 31-32

\section{To John Elder, October, 1879}

19 Albert St., Regent's Park I Oct., 1879

My dear John,

Thanks for your welcome letter of 18th August. My purpose, in my letter of May 7th, if I recollect rightly, was to urge that Reason is sometimes transcended by Emotion - sufficiently often, that is to say, to prevent philosophers from deriding the idea that a truth may be reached emotionally now and again, quicker than by the light of Reason. God may be beyond the veil of mortal life, but I cannot see that he has given us any definite revelation beyond what pure Deism teaches, viz., that there is a Power - certainly beneficent, most probably eternal, possibly (in effect, if not in detail) omnipotent - who, letting the breath of His being blow through all created things, evolves the Ascidian into man, and man into higher manifestations than are possible on earth, and whose message and revelation to man is shown forth in the myriadpaged volume of nature, and the inherent yearning in every human soul for something out of itself and yet of it. Of such belief, I may say that I am.

But my mind is like a troubled sea, whereon the winds of doubt blow continually, with waves of dead hopes and religious beliefs washing far away behind, and nothing before but the weary seeming of phantasmal shores. At times this faith that I cherish comes down upon me like the hushful fall of snow-flakes, calming and soothing all into peace; and again, it may be, it appears as a dark thunder-cloud, full 
of secret lightnings and portentous mutterings. And, too, sometimes I seem to waken into thought with a start, and to behold nothing but the blind tyranny of pure materialism, and the unutterable sorrow and hopelessness of life, and the bitter blackness of the end, which is annihilation. But such phases are generally transient, and, like a drowning man buffeting the overwhelming waves, I can often rise about them and behold the vastness and the Glory of the Light of Other Life.

And this brings me to a question which is at present troubling many others besides myself. I mean the question of the immortality of the individual. I do not know how you regard it yourself, but you must be aware that the drift of modern thought is antagonistic to personal immortality, and that many of our best and most intelligent thinking men and woman abjure it as unworthy of their high conception of Humanity....

But is Humanity all? Has Humanity fashioned itself out of primal elements, arisen and marched down the long, strange ways of time still marching, with eyes fixed on some self-projected Goal - without ever a spiritual breath blowing upon it, without the faintest guidance of any divine hand, without ever a glance of sorrowful and yearning but yet ineffably hopeful love from some Being altogether beyond and transcending it? Is it, can it be so? But in any case, whether with the Nirvana of the follower of Buddha, the absorption of the soul in the soul of God of the Deist and Theist, or with the loss of the individual in the whole of the Race of the Humanitarian, I cannot altogether agree. It may be the "old Adam" of selfishness; it may be poverty of highest feeling and insufficiency of intellectual grasp; but I cannot embrace the belief in the extinction of the individual.

Memoir 29-31 


\section{To Dante Gabriel Rossetti, January 31, 1880}

19 Albert St., Regent's Park N.W. I 31:1:80.

My dear Sir,

I hope you will not consider me ungrateful for the pleasure you gave me last night because I outwardly showed so little appreciation - but I was really so unwell from cold and headache that it was the utmost I could do to listen coherently. But though, otherwise, I look back gratefully to the whole evening I especially recall with pleasure the few minutes in which now and again you read. I have never heard: such a beautiful reader of verse as yourself, and if I had not felt - well, shy - I should have asked you to go on reading. Voice, and tone, and expression, all were in perfect harmony - and although I have much else to thank you for, allow me to thank you for the pleasure you have given me in this also.

I enclose 4 or 5 poems taken at random from my MSS. Two or three were written two or three years ago. That called the "Dancer" is modelled on your beautiful "Card Dealer". ${ }^{9}$

I have also to thank you for your kind criticisms: and hope that you do not consider my aspirations and daring hopes as altogether in vain. Despair comes sometimes upon me very heavily, but I have not yet lost heart.

Yours most faithfully, I William Sharp

Memoir 38

\section{To Mona Caird, ${ }^{10}$ [Early February, 1880]}

Dear Mona,

Was unable after all to resume my letter on Friday night. On Friday morning I had a note from Rossetti wanting me to come again and dine with him - this time alone, I was glad to find. I spent a most memorable 
evening, and enjoyed myself more than I can tell. We dined together in free and easy manner in his studio, surrounded by his beautiful paintings and studies. Then, and immediately after dinner he told me things of himself, personal reminiscences, with other conversation about the leading living painters and poets. Then he talked to me about myself, and my manuscripts - a few of which he had seen. Then personal and other matters again, followed, to my great delight (as Rossetti is a most beautiful reader) by his reading to me a great part of the as yet unpublished sonnets which go to form "The House of Life". ${ }^{11}$ Some of them were splendid, and seemed to me finer than those published more markedly intellectual, I thought. This took up a long time, which passed most luxuriously for me... .

He has been so kind to me every way: and this time he gave me two most valuable and welcome introductions - one to Philip Bourke Marston, ${ }^{12}$ the man whose genius is so wonderful, considering he has been blind from his birth - and the other to his brother Mr. Michael Rossetti, to whom, however, he had already kindly spoken about me. I am to go when I wish to the latter's literary re-unions, where I shall make the acquaintance of some of our leading authors and authoresses. Did I tell you that the last time I dined at Rossetti's house he gave me a copy of his poems, with something from himself written on the flyleaf? On that occasion I also met Theodore Watts, ${ }^{13}$ the well-known critic of The Athenaeum. It is so strange to be on intimate terms with a man whom a short time ago I looked on as so far off. Perhaps, dear friend, when you come to stay with Elizabeth and myself in the happy days which I hope are in store for us all, you will "pop" into quite a literary circle!... I was sure, also, you would enjoy the "Life of Clifford" in "Mod: Thought" ${ }^{14}$ What a splendid man he was: a true genius, yet full of the joy of life, sociable, fun-loving, genial, and in every way a gentleman. I was reading one of his books lately, and was struck with the sympathetic spirit he showed toward what to him meant nothing - Christianity. I wish we had more men like him. There is another man for whom I think I have an equal admiration though of a different order in one sense Dr. Martineau. ${ }^{15}$ Have you read anything of his? 
On Wednesday evening next I am going to a Spiritual Seance, by the best mediums - which I am looking forward to with great curiosity... .

Besides verse, I am writing a Paper just now on "Climate in Relation to the Influences of Art", and going on with one or two other minor things. There now, I have told you all about myself.

Your friend and comrade, I Will

Memoir 38-40

\section{To Dante Gabriel Rossetti, [March 1880] ${ }^{16}$}

19, Albert Street I Regent's Park, N.W. I Sunday

Dear Mr Rossetti

I sent off the sonnets yesterday in such tremendous haste, \& I did not remember till today that the one entitled "The Redeemer's Voice" had two similar terminations $-\&$ found that I had sent you a copy from the unrevised original. I now enclose a corrected one. Also one adapted from an "hexameter" sonnet I once showed you, entitled "The Two Realities" - \& which Philip ${ }^{17}$ admires very much: and lastly two other not over cheerful effusions. As Marston is with me today, I have no time to select or copy others as we have something to do together.

I told him that you had said that you intended asking me to bring him down to see you some evening - \& he was delighted beyond measure. I read him the Sonnet on the Sonnet, which he thought exceedingly fine.

Ever, in great haste, Your most faithfully | William Sharp ALS Lilly Library, Indiana University 


\section{To Dante Gabriel Rossetti, [March, 1880]}

Saturday

Dear Mr. Rossetti,

Thanks for your kind invitation to Philip and myself for Monday night - which we are both glad to accept. I found him in bed this morning on my way to the city - but had no scruple in waking him as I knew what pleasure your message would give. We both thank you also for promising to put us up at night.

I infer from your letter that you do not think "The Two Realities" good enough to send to Caine: ${ }^{18}$ and though of course sorry, I acquiesce in your judgment. I know that none of my best work is in sonnet-form, and that I have less mastery over the latter than any other form of verse. But I will try to improve my deficiencies in this way by acting up to your suggestions. You see, I have never had the advantage of such a severe critic as you before. For instance, I have received praise from many on account of a sonnet you once saw (one of a series on "Womanhood") called "Approaching Womanhood" - which I enclose herewith wishing you to tell me how it is poor and what I might have made of it instead. As I am writing from the city I have no others by me (but indeed you have been bothered sufficiently already) but will try and give one from memory - which I hastily dashed down one day in the office.

Looking forward to Monday night,

Yours ever sincerely, I William Sharp

Memoir 40-41 
To William Michael Rossetti, March 2, $1880^{19}$

$2 \mathrm{March} / 80$

Do not let me disturb you if you are engaged. I am not able to get away in time to call on you at Somerset House, so excuse this liberty.

W.S.

ACS University of British Columbia

\section{To Algernon Charles Swinburne, April 22, $1880^{20}$}

19 Albert St. I Regent's Park. N.W. I 22 April/80

My dear Sir,

It is only because I have the earnest hope of meeting you someday - if only for a few minutes - that I write you this letter and send you the accompanying verses. I would not have cared to send you them at all - they seem very poor indeed in my own eyes - but that my friend Philip Marston ${ }^{21}$ urged me to do so, saying he was sure you would be pleased. I cannot feel sure about this, but if you will not look to the verses as verses but for the meaning that gave them being I shall be content. It was because of the ever growing wonder and admiration which I had for your genius that I wrote them, and I wish that they could convey to you a tenth part of what I feel towards "our greatest lyric poet since Shelley". You are known and unknown to me. I have heard Rossetti speak of you, and Marston frequently, till I felt as if I also knew you personally; but after leaving them I had only the wish, and the knowledge that I did not know you. But then in the "Poems", in the "Songs", in "Atlanta", in "Erechtheus", in "Bothwell" - ah, I found you there. I think the feelings of all young poets towards you must be those of intense gratitude: you have so enriched the glorious garden of English verse, and left such strong and beautiful seeding-fruits. 
It is needless to say that I am looking forward eagerly to your forthcoming volume. Someday it may be my good fortune to meet you; but in any case, I shall never regret having written to you, for I know that you will take it as it is meant. The fledgling cannot be blamed if it yearns to the full-throated lark far above it.

Ever yours sincerely - (have I not a right to conclude thus, though I do not know you personally!)

William Sharp

ALS British Library

To John Elder, November 20, 1880

Nov. 20, 1880

If this note does not reach you by New Year's Day it will soon after - so let me wish you most heartily and sincerely all good wishes for the coming year. May the White Wings of Happiness and Peace and Health brush from your path all evil things. There is something selfish in the latter wish, for I hope so much to see you before long again. Don't despise me when I say that in some things I am more a woman than a man - and when my heart is touched strongly I lavish more love upon the one who does so than I have perhaps any right to expect returned; and then I have so few friends that when I do find one I am ever jealous of his or her absence.

P.S. - I wonder if this Kentish violet will retain its delicious scent till it looks at you in New Zealand. It is probably the last of its race.

Memoir 33 


\section{To Elizabeth A. Sharp, December 13, 1880}

... I spent such a pleasant evening on Saturday. I went round to Francillon' $\mathrm{s}^{22}$ house about $8 \mathrm{o}^{\prime}$ clock, and spent about an hour there with him and Julian Hawthorne. ${ }^{23}$ Then we walked down to Covent Garden, and joined the "Oasis" Club - where we met about 30 or so other literary men and artists, including the D. Christie Murray ${ }^{24}$ I so much wished to meet, and whom I like very much. We spent a very pleasant while a decidedly "Bohemian" night, and after we broke up I walked home with Francillon, Julian Hawthorne, and Murray. Hawthorne and myself are to be admitted members at the next meeting.

Memoir 42

\section{To Dante Gabriel Rossetti, [December, 1880]}

Dear Mr. Rossetti,

... I wished very much to show you two poems I had written in the earlier half of this year, and now send them by the same post. The one entitled "Motherhood" 25 I think the better on the whole. It was written to give expression to the feeling I had so strongly of the beauty and sacredness of Motherhood in itself, and how this is the same, in degree, all through creation: the poem is accordingly in three parts - the first dealing with an example of Motherhood in the brute creation, the second with a savage of the lowest order, and the third with a civilised girl-woman of the highest type.

The other - "The Dead Bridegroom" - is more purely an "art" poem. After reading it, you will doubtless recognise the story, which I believe is true. Swinburne (I understand) told it to one or two, and Meredith embodied it in a short ballad. Philip Marston told me the story one day, and, it having taken a great hold upon me, the accompanying poem was the result. After I had finished and read it to Philip, it took strong hold of his imagination also - and so he also began a poem on the same subject, treating it differently, however, and employing the complete details of the story, instead of, as I have done, stopping short at the lover's death, and is still unfinished. 
It is in great part owing to his generously enthusiastic praise that I now send these for your inspection; but also because much of what may be good in them is owing to your gratefully remembered personal influence and kindness, as well as your own beautiful work. ${ }^{26}$

Memoir 43-44

\section{To Eugene Lee-Hamilton, [late December, 1880] ${ }^{27}$}

19, Albert Street I Regent's Park, N.W. I London I Xmas 1880

Lee Hamilton Esq., Florence.

My dear Sir,

I know you will not consider my writing to you a liberty - there is a freemasonry in art which does away with formalities between brother-artists.

I have of course heard of you from my cousin and fiancée, and she has sent me now and again poems or extracts from poems of yours - which she thought I would like - and some of which have afforded me great pleasure. I have not been able to obtain your book ${ }^{28}$ from Mudie's, so cannot, as I should like, mention by name the poems or individual lines with which I am specially pleased. For one, I liked exceedingly your sonnet having special reference to my friend Philip Bourke Marston and, if you have no objection, I should like to read it to him.

My cousin told me she had read one or two verses from a poem of mine called "Motherhood" with which you were pleased. Thinking that the complete poem might interest you, I now send a copy of it by the same post as this. I took great care in the working out of it, as the subject was extremely difficult to evolve without on the one hand falling into the Scylla of the "Fleshly School" or on the other into the Charybdis of "Mysticism". It was written from a deep sense of the beauty and sacredness of Motherhood in itself, in whatever form and under all circumstances. So I took 3 typical instances: a tigress, as exemplifying the brute creation - an Australian native, as exemplifying the lowest 
human savage - and a high-souled, pure-hearted girl as exemplifying the highest level of cultured civilisation.

As artistic accompaniments to this three-fold idea I gave to the first, rich colouring: to the second, a somberness of hue: and to the third, what amount of solemnity and dignity I could convey.

So much for explanation. Of course, by-the-by, I will not require the MS. returned - as I have 1 or 2 other copies taken by the same "Multifold Writer" process. I may mention that the second part is drawn in great measure from personal reminiscence of the time I spent 2 or 3 years ago in the Australian bush myself.

I think you will understand how deeply and sincerely I feel with you in the difficulties under which you have to pursue your art. But high aims and the precious inward vision of the artist are greater than physical weakness.

This will reach you on Xmas: let me offer you my sincerest wishes that the day may be a happy one, and that the coming year may be still more so.

Believe me, I Yours Most Sincerely, I William Sharp ALS Colby College Library

\section{To Dante Gabriel Rossetti, December 20, 1880}

19, Albert Street, I Regent's Park. N.W. I 20:12:80

Dear Mr. Rossetti

Many thanks for your generous response to my information about the subscription for Marston - the 3 guineas shall be duly put down for the triple period: \& also for the promise of speaking to others likely to join. I hope something practical may be done either with the commencement of the year, or early in January.

Many thanks also for your kind regards as to my recent illness.

In great haste | yours most sincerely | William Sharp 


\section{To Elizabeth A. Sharp, January 24, 1881}

24:1:81.

... Well, last Friday was a 'red-letter' day to me. I went to Rossetti's at six, dined about 7:30, and stayed there all night. We had a jolly talk before dinner, and then Shields ${ }^{29}$ the painter came in and stayed till about 11 o'clock: after that Rossetti read me all his unpublished poems, some of which are magnificent - talked, etc. - and we did not go to bed till about three in the morning. I did not go to the Bank next day, ${ }^{30}$ as I did not feel well: however, I wrote hard at poetry, etc., all day till seven o'clock, managing to keep myself up with tea. I was quite taken aback by the extent of Rossetti's praise. He said he did not say much in his letter because writing so often looks 'gushing' but he considered I was able to take a foremost place among the younger poets of the day and that many signs in my writings pointed to a first-class poet - that the opening of "The Dead Bridegroom" was worthy of Keats - that "Motherhood" was in every sense of the word a memorable poem - that I must have great productive power, and broad and fine imagination and many other things which made me very glad and proud... .

Memoir 44-45

\section{To John Elder, February, 1881}

Feb., 1881.

I may say in reference to the Religion of Humanity that my sympathy with Comtism ${ }^{31}$ is only limited, and that though I think it is and will yet be an instrument of great good, I see nothing in it of essential savingness. It is even in some of its ceremonial and practical details a decided retrogression - at least so it seems to me - and though I do not believe in a revealed God, I think such a belief higher and more precious and morally as salutary as a belief in abstract Humanity. Concrete humanity appeals more to my sympathy when filled with the 
breath of "God" than in its relation to its abstract Self. When I write again I will endeavour to answer your question as to whether I believe in a God or not. My friend, we are all in the hollow of some mighty moulding Hand. Every fiber in my body quivers at times with absolute faith and belief, yet I do not say that I believe in "God" when asked such a question by those whom I am conscious misinterpret me. You have some lines of mine called "The Redeemer"; 32 they will hint something to you of that belief which buoys my soul up in the ocean of love that surrounds it. It were well for the soul, if annihilation rounds off the circle of life, to sink to final forgetfulness in the sea of precious human love; but it is far better if the soul can be borne along that sea of wonder and glory to distant ever-expanding goals, transcending in love, glory, life all that human imagination ever conceived... .

Farewell for the present, dear friend, I W.

Memoir 33-34

\section{To Dante Gabriel Rossetti, [February 3, 1881]}

Thursday Morning

Dear Mr. Rossetti,

Thanks exceedingly: - I shall only be too glad to spend an hour or two with you on Sunday evening, \& shall be with you in time for dinner as you suggest.

I shall bring with me one of my best poems (in its way) - [it is a ballad $]^{33}$ to read to you: it dates since "Motherhood"\& "The Dead Bridegroom".

Marston enjoyed himself immensely the other night - you being what you are to him of course made the event memorable.

Poor O'Shaughnessy ${ }^{34}$ is to buried at 2:15 at Rensal Green.

Ever yrs gratefully \& affectionately | William Sharp ALS University of British Columbia 


\section{To Elizabeth A. Sharp, February 4, 1881}

... I have written one of my best poems (in its own way) since writing you last. It was on Tuesday night: I did not get back till about seven o'clock, and began at once to write. Your letter came an hour or so afterward but it had to lie waiting till after midnight, when I finished, having written and polished a complete poem of thirty verses in that short time..$^{35}$ It is a ballad. The story itself is a very tragic one. Perhaps the kind of verse would be clear to you if I were to quote a verse as a specimen:

And I saw thy face was flush'd, then pale, And thy lips grow blue like black-ice hail, With eyes on fire with the soul's fierce bale, Son of Allan! I may have been pale, and may be red But this night shall one lie white and dead.

(O Mother of God! whose eyes Watch men lie dead 'neath midnight skies).

Both story and verse I invented myself: and I think you will think it equal to anything I have done in power. It was a good lot to do at a sitting, wasn't it? I will read it to you when you come home again... . I enjoyed my stay with Rossetti immensely. We did not breakfast till one o'clock on Tuesday - pretty late, wasn't it? (I told you I had a holiday, didn't I?) He told me again that he considered "Motherhood" fit to take the foremost place in recent poetry. He has such a fine house, though much of it is shut up, and full of fine things: he showed me some of it that hardly anyone ever sees. He has asked me to come to him again next Sunday. Isn't it splendid? - and aren't you glad for my sake? He told Philip $^{36}$ that he thought I "had such a sweet genial happy nature". Isn't it nice to be told of that. My intense delight in little things seems also to be a great charm to him - whether in a stray line of verse, or some new author, or a cloudlet, or patch of blue sky, or chocolate-drops, etc., etc. Have you noticed this in me? I am half gratified and half amused to hear myself so delineated, as I did not know my nature was so palpable to comparative strangers. And now I am going to crown my horrid vanity by telling you that Mrs. Garnet ${ }^{37}$ met Philip a short time ago, and asked 
after the health of his friend, the "handsome young poet"! There now, amn't [sic] I horridly conceited? (N.B. - I'm pleased all the same, you know!)

I wrote a little lyric yesterday which is one of the most musical I have ever done. To-day, I was "took" by a writing mood in the midst of business hours, and despite all the distracting and unpoetical surroundings, managed to hastily jot down the accompanying lyric. It is the general end of young unknowing love... .

I had a splendid evening last night, and Rossetti read a lot more of his latest work. Splendid as his published work is, it is surpassed by what has yet to be published. The more I look into and hear his poems the more I am struck with the incomparable power and depth of his genius - his almost magical perfection and mastery of language - his magnificent spiritual strength and subtlety. He read some things last night, lines which almost took my breath away. No sonnet-writer in the past has equaled him, and it is almost inconceivable to imagine any one doing so in the future. His influence is already deep and strong, but I believe in time to come he will be looked back to as we now look to Shakespeare, to Milton, and in one sense to Keats. I can find no language to express my admiration of his supreme gifts, and it is with an almost painful ecstasy that I receive from time to time fresh revelation of his intellectual, spiritual, and artistic splendour. I fancy one needs to be an actual poet to feel this to the full, but every one, however dim and stagnant or coldly intellectual his or her soul, must feel more or less the marvelous beauty of this wedding of the spirit of emotional thought and the spirit of language, and the child thereof - divine, perfect expression. Our language in Rossetti's hands is more solemn than Spanish, more majestic than Latin, deeper than German, sweeter than Italian, more divine than Greek. I know of nothing comparable to it. He told me to call him Rossetti and not "Mr. Rossetti", as disparity in age disappears in close friendship, wasn't it nice of him? It makes me both very proud and humble to be so liked and praised by the greatest master in England - proud to have so far satisfied his fastidious critical taste and to have excited such strong belief in my powers, and humble in that I fall so far short of him as to make the gulf seem impassable.

Memoir 46-49 


\section{To Elizabeth A. Sharp, [February, 1881] $]^{38}$}

You ask me, if I dislike the Old Masters of Poetry as much as I do those of Painting? and I reply certainly not, but at the same time the comparison is not fair. Most of the old poets are not only poets of their time but have special beauties at the present day, and can be read with as much or almost as much pleasure now as centuries ago. Their imagination, their scope, their detail is endless. On the other hand the Old Masters of Painting are (to me, of course, and speaking generally) utterly uninteresting in their subjects, in the way they treat them, and in the meaning that is conveyed. If it were not for the richness and beauty of their colour I would never go into another gallery from pleasure, but colour alone could not always satisfy me. But take the 'Old Masters' of Poetry! Homer of Greece, Virgil and Dante of Italy, Theocritus of Sicily, and in England Chaucer, Shakespeare, Ben Jonson, Webster, Ford, Massinger, Marlowe, Milton.

The poetry of these men is beautiful in itself apart from the relation they bear to their times. We may not care for Dryden (though I do) or Prior or Cowley, because in the verse of these latter there is nothing to withstand the ages, nothing that rises above their times. In looking at Rubens, or Leonardo da Vinci, or Fra Angelico, we must school ourselves to admiration by saying "How wonderful for their time, what a near attempt at a perspective, what a near success in drawing nature - external and human!" Would you, or any one, care for a painting of Angelico's if executed in exactly the same style and in equally soft and harmonious colours at the present day? Could you enjoy and enter into it apart from its relations to such-and-such a period of early Christian Art? It may be possible, but I doubt it. On the other hand take up the Old Masters of Poetry and judge them by the present high standard. Take up Homer - who has his width and space? Dante - who has his fiery repressed intensity? Theocritus, who has sung sweeter of meadows and summer suns and flowers? Chaucer - who is as delicious now as in the latter part of the fourteenth century. Shakespeare - who was, is, and ever shall be the supreme crowned lord of verse! - Take up one of the comparatively speaking minor lights of the Elizabethan era. Does Jonson with his "Every Man in his Humour", or his "Alchemist", does Webster with his "Duchess of Malfi", does Ford with his "Lover's Melancholy", does Massinger, with his "Virgin Martyr", do Beaumont and Fletcher with their "Maid's Tragedy", does Marlowe with his "Life 
and Death of Dr. Faustus", pall upon us? Have we ever to keep before us the fact that they lived so many generations or centuries ago?

I never tire of that wonderful, tremendous, magnificent epoch in literature - the age of the Elizabethan dramatists.

Despite the frequent beauty of much that followed I think the genius of Poetry was of an altogether inferior power and order (excepting Milton) until once again it flowered forth anew in Byron, in Coleridge, in Keats, and in Shelley! These two last names, what do they not mean! Since then, after a slight lapse, Poetry has soared to serener heights again, and Goethe, Victor Hugo, Tennyson, and Browning have moulded new generations, and men like Rossetti, Swinburne, Morris, Marston, Longfellow, and others have helped to make still more exquisitely fair the Temple of Human Imagination. Men like Joaquin Miller ${ }^{39}$ and Whitman are the south and north winds that soothe or stir the leaves of thought surrounding it.

We are on the verge of another great dramatic epoch - more subtle and spiritual if not grander in dimensions than that of the sixteenth century. I hope to God I live to see the sunrise which must follow the wayward lights of the present troubled dawn....

On Monday evening (from eight till two) I go again as usual to Marston's. I called at his door on my way here this afternoon and left a huge bouquet of wall-flowers, with a large yellow heart of daffodils, to cheer him up. He is passionately fond of flowers....

Memoir 49-51

\section{To Eugene Lee-Hamilton, March 10, 1881}

19, Albert Street, I Regent's Park, N.W. | 10:3:81

Dear Mr. Hamilton,

I trust you have not misconstrued my silence since receipt of your letter on "Motherhood"40 - my only excuse is that I am so hard pressed for time, and what little time is left over from reviewing and [my] own literary work I am generally eager to occupy with reading: and moreover I have of late endeavoured to write as little as possible, owing 
to my not being quite so strong as I ought to be, and the physical act of writing being as a rule far from beneficial.

I honestly thank you for your criticism - what you say in praise is very welcome, and what you have to blame is from your honest conviction. The poet or artist who cannot receive and think over adverse criticism seems to me to lack one of the very qualities most essential to the true artist - humility. Besides, even when adverse criticism appears unfounded it seldom fails of doing at least indirect good - i.e. of course when the criticism is honest and kindly meant.

There was one reason also why I did not answer you again at once - and that was that I saw you completely misunderstood my motive - the raison d'etre of the poem - and not being very well at the time I did not feel up to explanations. You seem to think my object in writing was to describe the actual initial act of motherhood - whereas such acts were only used incidentally to the idea. I entirely agree with you in thinking such a motif unfit for poetic treatment - and more, I think it wd. be in very bad taste and wanting in true delicacy. My aim was something very far from this - and what made me see you had not grasped it were the words "Besides, is not your type of civilised woman degraded by being associated with the savage and the wild beast?" Of course, what I was endeavoring to work out was just the opposite of this. "Motherhood" was written from a deep conviction of the beauty in the state of motherhood itself, of the holy strangely similar bond of union it gave to all created things, and how it as it were forged the link whereby the chain of life reached unbroken from the polyp depths we do see to the God whom we do not see. Looking at it as I did, I saw it transfigured to the Seal of Unity: I saw the bestial life touch the savage, and the latter's low existence edge complete nobility of womanhood, as - in the spirit - I see this last again merge into fuller spiritual periods beyond the present sphere of human life. In embodying this idea I determined to take refuge in no vague transcendentalism, or from any false feeling shirk what I knew to be noble in its mystic wonder and significance: and I came to the conclusion that the philosophic idea could be best embodied and made apparent by moulding it into three typical instances of motherhood, representing the brute, the savage, and the civilised woman. From this point of view, I considered making the choice of the initial act of motherhood (if it can so be called) - of birth - entirely justifiable, and beyond reach of the reproach of impurity, or 
even unfitness. As to the artistic working out of these typical motives, I gave to the first glow and colour, to the second mystery and weirdness, to the third what dignity and solemnity I could.

These were my aims and views, and I have not yet seen anything to make me change them. I told Marston of your objection, and read him the sentence from your letter I have already quoted - and he said he found it difficult to understand your position, but that it was evident you had quite misunderstood my motive. Under the circumstances, you will not think it vain of me when I add that Rossetti - who is now (what I and others have long believed) becoming recognized as not only one of the greatest poets of the XIX century but also one of the greatest since Shakespeare, - considers "Motherhood" in the first order of work, both as regards execution (with one or two exceptions) and idea. He told me that this poem alone should enable me to take a foremost place amongst rising poets: and again that the much-dreaded Theodore Watts, the chief as well as the most influential critic in England (and between whom and myself there is no intimacy, as in the case of Rossetti) spoke of it (so I was told) in altogether exceptional terms, and even got enthusiastic over it. Both these men, whose judgement I must look to as the best, look on the raison d'etre of the poem exactly as I do myself. I know that you will understand I mention these instances not from any false pride, but simply to help to free myself from any implication of self-prejudice.

So much for "Motherhood". As for the "Dead Bridegroom"41 (which I am not sure, by-the-by, whether you have seen or not) I quite admit that the advisability of choosing such subjects is a very debatable one. It is the only one of mine (in my opinion) which could incur the charge of doubtful "fitness". As a poem, moreover, it is inferior in workmanship to "Motherhood".

Well, that's enough about myself I think.

I liked some of the "Poems and Transcripts"42 exceedingly, but I must say even the mastery of it you show cannot reconcile me to the hexameter in its English garb. Here and there our language seems to adjust itself to hexametrical rhythm - but such instances suggest to one the comparison of angel's visits. The pathos of a "Sufferer" and "Elizabeth" struck me most, and there was one beautiful little lyrical piece which gave me great pleasure - the "Ever Young" I think it was called. I think the hexameter-verse almost certain to flag in power and pall the reader after a time. I have never (or at any rate never do now) 
used it - tho' I have written one or two things in what are called "false hexameters", a useful enough irregular measure in certain cases, but which requires to be used very sparingly. "The Redeemer", ${ }^{43}$ which you have seen, is an example of such.

Altho' "Poems and Transcripts" is more interesting in that it is more personal, I on the whole prefer "Gods, Saints, and Men", which I think contains the best things you have done. There are fine things in The Last Love of Venus, both in description and in such fine lyrical verses as these two -

"Say, where is the smoke of her altar,

And where the libations of wine,

And the prayers that the stripling $w d$. falter

And the wreaths that the maidens wd. twine?"

Of the statues once raised in her honour

How many unshatter'd remain?

And the hymns that heaped praises upon her,

Will man ever breath them again?"

The Fiddle and the Slipper I also think particularly good of its kind, and in the Rhyme of the Reeds there is real ballad power. Nor must I forget The Keys of the Convent, despite my having much more sympathy with natural human love than selfish conventual seclusion. In The Bell Founder of Augsburg I notice some particularly fine lines -

"An awful stillness follows sudden crimes.

The furious wave, which has o'erwhelmed and swallowed

Our innocence, by sudden calm is followed,

XXXXX

The wave has passed, and underneath is death".

While the lines in The Witness

"But to be cheated of a single nod,

To be denied the pittance of a smile,

To hear him say, and say again, to God,

That he ne'er saw my face, while all the while

I can read recognition in his eyes".

There is marked fitness of expression - (spoilt slightly by the duplication of the word while).

I was glad to hear The Rival of Fallopius met with the recognition it deserved. 
I often think of you, and it does me good to think of your courage under severe illness: and you will not object I know, to my saying how deeply I sympathize with you. Poetic work must be a great consolation for you, and I hope to hear of your continued success. Are you engaged on anything new just now?

But it is now very late, and I ought to be in bed. Overleaf I send you the last sonnet [I] wrote, and which perhaps you will care for. It is written from the idea that life is sufficient unto itself apart from its destiny, as to which we can only surmise - and that in any case it is not the mere transitory bubble on the face of the stream it is so often compared to, but something infinite and in its essence unchangeable.

With all good wishes, believe me, Dear Mr. Hamilton,

Yours very faithfully, I William Sharp

If at any time you have leisure or desire to write to me I shall be very glad indeed to hear what you are doing in poetry - and also if you still consider "Motherhood" so unworthy. I am looking forward to seeing your sister in the early summer.

\section{Life's Sufficiency}

God rounds our sunlit day with sunless night And incompleted are of life with death: But sunrise every sunset followeth

And darkness travails with new birth of light. Can the soul's fire then be extinguish'd quite, Seeing it is no less than the sun's breath, And more than cluster'd star-spheres borroweth

The central essence of God's infinite might?

Whether, as in the old Lucretian dream,

The corporate being incorporate shall be,

One with the wind, the grass, the hill, the stream -

Or the clear-vision'd soul rejoicing flee

Enfranchis'd - life is more than transient gleam

Of desultory light on death's vast sea.

W.S. 


\section{To Violet Paget ("Vernon Lee") March [17?], 1881, ${ }^{44}$}

19 Albert St: Regent's Park N.W. I March, 1881

\section{Dear Miss Paget}

I have already heard so much of you both from my cousin and Mary Robinson ${ }^{45}$ that I feel I need to make no apology for forestalling our coming acquaintanceship by now writing - especially as I have just received a long letter from you to Elizabeth with reference to some work of mine which you have seen. Before endeavouring to reply to this letter, let me thank you most sincerely for all the trouble you had about the Figura Mystica (decidedly mystica) of "Chiaro dell Erma". Rossetti had taken for granted when he gave me his pamphlet Hand and Soul that I wd. understand the opening was as artistically incorrect as the main portion was allegorically true: but unfortunately I did not find this out until after my cousin had written to you on the matter. ${ }^{46}$ I see your letter to her is dated 14th February - I wish she had forwarded it to me sooner that I might have been able to thank you before this.

And now as to your letter. I wrote a week or so ago to your brother as to his criticism on "Motherhood" ${ }^{47}$ and also with reference to his own poems - and in that letter I broadly stated, if I remember right, my views on the question.

But in case you have not seen it I will go for you over the same ground again, taking your letter in detail. You begin by saying "I have been thinking a good deal of late of the School to which that poem Motherhood belongs, and of the desirability of a young poet like Mr. Sharp joining it".

In the first place, your thoughts have found an anchoring place where neither myself nor my poetical and critical friends have yet done: in other words, "Motherhood" never seemed to me or them to belong to any school at all. It certainly could not be spoken of as belonging to the Fleshly School ${ }^{48}$ nor could it as to the Transcendental, or the Philosophic pure and simple, or the Didactic, or the Narrative, or the Lyric, or the Dramatic, or the Psychologic, or any other "ic" that men may have fashioned unto themselves. It is nearer the Philosophic, or the Natural, than any other - because what really is the poem is the 
beautiful idea: - the poetic garniture shrouding it is only a necessary incidental, worthy or unworthy as the case may be: for of course artistic expression is what constitutes the difference between the man who sees and writes, and the man who only receptively sees, and therefore does not write. I was spending the evening lately with Francillon, the author of "Olympia" 49 and other fine works, and, as a critic, a strong opponent of the Fleshly School of verse - and in talking of some of my writing he said "There is one great charm to me in Motherhood, and that is that it is so strongly original - there is no trace of its belonging to the so-called Fleshly School which is so prevalent now - nor indeed of its belonging to any school, or showing any trace of indebtedness to any particular master".

By the subsequent remarks in your letter, however, and by what I have heard, I infer that by the "School to which Motherhood belongs" you mean the Fleshly School. As you will see by the above, I consider your adjudication mistaken.

As to the latter part of the sentence - "the desirability of Mr. Sharp's joining it" (the Fleshly School) I can honestly assure you that it is the last school of Art to which I shall render my efforts, that I have little sympathy with its present phase, and that I believe both it and mockAestheticism will, sooner or later, die a twin and heaven-to-be praised death. But where we differ, I expect, is in what poets and in which doctrines we consider the Fleshly School to embrace. To me, a fleshly (what a hideous word this is by the by - why not some such word as natural, or physical) poet is by no means necessarily a disciple of the Fleshly School. With all his faults - poetic and artistic - Walt Whitman is a noble and truly great fleshly or natural poet - but I can imagine no great contemporary writer having a greater contempt for what is called the Fleshly School, or more utter repudiation of its habits of expression. Again, Gabriel Rossetti is frequently spoken of as if at the head of this school: no greater mistake could get abroad. He is intensely spiritual and refined, and as far removed both in spirit and work from the crass materialism of such poets as form this School as Milton or Dante. It is materialism that is weighing down an already weary and overburdened nation - materialism everywhere, and most of all alas! in the hearts of the rising generation of young men and woman - not so much materialism that overlooks the soul, as materialism that has practically no soul, that 
scorned appendage nowadays being so carefully hidden away and shrouded up. And this materialism is often thought of and spoken of as intimately associated with advancing intellect and culture! Good God, as if intellect were comparable to character, and as if a thoroughly true and whole character could be evolved without the spiritual element: and is culture to unfold her white wings and unstained hands and walk serenely forward, while the ground underneath is mire and mud and the air overhead is fog and darkening mist? And it is to this materialism - above all this intellectual materialism - that the Fleshly School owes its rise. The tree is known by its fruits.

After this sentence I have quoted from your letter comes a series of remarks following on the statement - "I am persuaded that Mr. Sharp, in choosing the subject he did, was labouring under a confusion of ideas on the subject of what I may call 'The Ethics of Impropriety' which is extremely common" etc.

Permit me in turn to point out what seems to me an equally common confusion of ideas on the subject of how true poets write. A poet who is really a poet does not as a rule choose his subject at all - his subject chooses him. As Buxton Forman says in his critical work on Contemporary English Poetry ${ }^{50}$ - "an artist whose ideas are cut as it were with a red hot blade on his very heart cannot always pick and choose his subject; he must often be chosen by his subject": and again, speaking of a well-known poem, - "it is easy to see that neither the incidents nor the thread were arrived at by painful reasoning, or by any other process than by that real poetic intention concerning the nature of which critics must be content to remain profoundly nescient". I am very glad to see such a well-known critic confessing this inability of non-poets to realise the part-intellectual, part-spiritual, part-emotional quality which is called poetic intuition.

In like manner, Motherhood chose me, not I it as a subject. The idea took hold of me, enthralled me with its beauty and significance, possessed me till I gave it forth again in artistic expression. It was not till after the idea had seized my mind and imagination that I began to think of writing such a poem - and even then the whole details of it came in one intuitive flash, and I saw the poem from first to last as it now stands - I had no careful reasoning to go through, no judging of fittableness; no fears as to propriety or impropriety; - I simply had something in 
me - a pure beautiful idea - and to this I had to give expression. I had nothing to think of afterwards except the mere technical details and artistic presentment - such as glow and colour to the first part, weirdness to the second, dignity and moral beauty to the third.

As to the alleged impropriety of the subject of Motherhood I am at a loss to conceive upon what ground such a statement is put forward. I hope your brother does not still misunderstand me after my recent letter, but previously I know he had completely done so from one short sentence in his letter to me on this subject, where he says - "Besides, is not your type of civilized woman degraded by being associated with the savage and the wild beast?" This showed me that he, as I now see you have done also, looked at the poem and not at what made the poem: he looked at the external description, not at the soul-like animating idea. As Emerson says - it is not metres, but a metre-making argument that makes a poem; - a thought so passionate and alive, that, like the spirit of a plant or an animal, it has an architecture of its own, and adorns nature with a new thing. ${ }^{51}$ Your objection would have been perfectly valid if, say, the 1st part had been put forward by itself as a complete poem - nay more, it wd. be deserving of both artistic and moral censure as a pure Fleshly School production, without any raison d'etre apparently than pride in technical workmanship, and recklessness as to revelling in details of things much better left undescribed. But in Motherhood this first part is only one of the necessary three sides of the triangle of the central idea, and is never meant for a moment to be read by itself. Motherhood is not a theme given in three expository poems: it is one poem.

I see that both you and your brother have fallen into the mistake of thinking that Motherhood was a delineation of Passion, and written to sanctify such. Where the sexual feelings are referred to they are introduced as linked to and giving point to the idea, and never for a moment formed original motifs. Animal desire in the first, savage longing in the second, and reminiscence of pure passion in the third parts are each introduced incidentally to the inner motif. It might just as well be said that the object of the poem was to give a poetical description of travail: and I for one would never so far degrade the art I follow as to write such a poem with such an object. 
I entirely agree with what you say as to the difference between the innocent and the holy and between that which may be done and that which may be described: and also, that merely because such and such a phenomenon exists or has existed it is not therefore desirable or defensible for reproduction in verse. I believe the essence of true poetry to be purity: not the hideous and unnatural malformation, Prudery but Purity. Purity in intellectual, moral, and physical erudition and thought.

For myself, I cannot conceive any man or woman being the worse of reading Motherhood: it seems almost a degradation to myself to stoop to imagine such a thing. If any man could comprehend the spirit, the idea, the teaching of the poem and not be the better of it, he wd. hardly be one we could call high-minded or of refined nature: and if any being (I cannot say man) should find in it nothing but sensual pleasure that gratified and fed his lowest appetites, then I say such a man makes it a mirror wherein his own foulnesses are focussed, and would of necessity be such an one as would sneer at the relationship between Mary Magdalene and Jesus Christ, or such an one as to whom the very name of "woman" carries no faintest breath of purification but only an odour, to a pure man as a death-vapour of unutterable vileness. What Motherhood makes clear is not innocence, but what is altogether holy and sacred. It is above all a poem for men. Pure, intellectual, and refined women like yourself, Miss Paget, do not understand the necessity of theoretical as well as practical purity to men: how men have naturally not only more animalism but also how their outer circumstances tend far more to subdue or destroy their sense of spiritual significance, than in the case of women. I know, as you cannot know, how so many men look on passion, marriage, and motherhood; and not all the poets, critics, and philosophers in Christendom could prevent me thinking that it is a noble aim and worthy of any poet - to help men (blinded by upbringing, or other circumstances) to perceive and realise that passion is not lust, is not alone physical desire, but is a blended yearning of body and spirit: - that marriage is not sexual union for the propagation of the race alone, but a true complementary union between two natures akin to each other for the purposes of growth in spiritual beauty and nobility: - and that motherhood is not an outcome alone of the two foregoing, not a painful and unpleasant natural act, but a fact full of the most spiritual significance - a link of unguessed and immeasurable 
value to the man, a sacrifice of divine import to the woman. This, if I fail not, is and will be one of my main aims in life.

It seems to me that Motherhood is an effort in furtherance of this: and I have not yet seen the shadow of reason that can make me alter my belief in the rectitude and fittingness of what I have done. As far as personal affirmation goes, I emphatically deny that, to use your own words, I have made "a very dreadful prostitution of my powers". Insight is everything; and to those who can honestly see no spiritual affinities in Motherhood, I am afraid it must just forever remain "the hocos-pocus in words" which you describe it. It is thus with half-amusement and half-comprehension of your meaning that I read your statements to my cousin as to "the sophistication of ideas under which I am labouring". There is sophistication and sophistication. It is from no petty pride or self-opinionativeness (for I am ever open to argument and opposite views) that I say we are not likely ever to agree upon this matter, as far as my accepting the view you uphold is concerned: - nor is it likely, I think, that my cousin ever will either. I hope not. And now enough as to Motherhood and its allied questions - and only one word more as to one other of my poems. Mary Robinson tells me you have read "The Satyr":52 - unfortunately you have not done so, but only a copy of the original draft which my cousin had in her little book, and which she had not my authority for showing you. "The Satyr" as Miss Robinson has seen it is a very different poem from the one you have seen - being clarified by a truer classicalism and materially modified as to expression and detail. A clay model often looks suggestive of something less than purity and modesty, while the finished marble statue is white in import as the parian itself.

And now, dear Miss Paget (for I seem to have got to know you better since my letter, and "dear" is the first step from conscious aloofness) believe me when I say I thank you most sincerely for the kind interestedness that prompted your writing the critique you did, and the generous terms in which apart from my subjects, you praise my 'abilities'. It is doubly flattering when from the author of the "Studies". ${ }^{53}$

Pray remember me most cordially to your brother, whose acquaintance I feel it a personal loss I cannot make in the flesh. I earnestly hope he is comparatively well, and that the Poetry which is so much to him is proving an openhanded goodness. 
I am looking forward to seeing you in June, ${ }^{54}$ and tho' I am afraid you will not find a convert, I hope at least you may find a friend in

Yours very sincerely | William Sharp

ALS Colby College Library

\section{To Dante Gabriel Rossetti, April 5, 1881}

5th April/81

Dear Rossetti,

I am very glad to be able to inform you that the assistant at the bookseller's I frequent confused the paper edition of your work ${ }^{55}$ with some other - apparently partially with your sister' $\mathrm{s}^{56}$ and partially with a cheap edition of Lytton's Light of Asia. ${ }^{57}$ The only paper edition he knows of your book is what you spoke of, and the only one that can be procured cheaper - The Tauchnitz. ${ }^{58}$

It's a good thing there turns out to be nothing in it In great haste,

Yrs affectionately | William Sharp

No ill effects of the chill while sonneteering.

\section{TWO SONNETS ${ }^{59}$}

\section{Love's Prayer.}

What gain is it to thee I love thee so,

Through this my love surpasses all loves, sweet?

What profits thee the fervour and the heat

Of my soul's worship - What the gifts I throw 
Of joy, love, hope, tears, and passionate woe

Before thee, to be trampled by thy feet

Or raised to bliss delicious and complete?

What matters it though all of these ye know?

$\mathrm{O}$ thou, that shinest as a moon of love

On wastes of turbulent wild waves that roll

Day and night, night and day, athwart my soul, Look once on me from thy still height above;

Speak one low word that I at least may hear

From thine own lips the doom I know and fear.

\section{Love's Answer.}

Gain beyond measure that thou lovest so,

Gain beyond hope thy love to me is, sweet.

Dear beyond words the fervour and the heat

Of thy soul's worship - and the gifts you throw

Of joy, love, hope, tears, and passionate woe.

I stoop and lift up from before my feet,

And hug them till my bliss is made complete:

The depths of thy delicious love I know.

$\mathrm{O}$ thou who hast made sweet my life with love,

And made its silent placid waters roll

In waves of splendour over my glad soul,

Stoop down and kiss me from thy height above!

Kiss me, and let me cling to thee; I hear

Thy low sweet words, and have no longer fear.

William Sharp

ALS Smith College Library

To Violet Paget, May 16, 1881

19 Albert Street I Regents Park N.W. I 16 May/81

Dear Miss Paget, 
My cousin having kindly made a copy for me of my last long poem ${ }^{60}$ I now send it to you and your brother. It certainly contains some of the best work I have yet attained to. As you will see, it is (as Rossetti calls it) a kind of spiritual Childe Harold, comprising in brief review the rise of Humanity - figured as one man - from a far-off unreachable past thro' successive stages and in various lands down to the present epoch of his history. From the time I first carefully chose the form for its expression (a literary essential not obtaining a quarter of the attention it deserves) to the writing of the last verse I gave it every care, striving to let there be no such thing as an unpoetical verse, and above all seeking to condense judiciously from the mass of material ready to hand.

I have written it from a deep and heartfelt motive, and I hope it will bear to you and others the impress of deep earnestness. Up to a certain point, including the portion dealing with Christ, I know that intellectually you will in the main agree with me - but when in the latter stanzas I unfold my personal belief and aspirations as those that seem to me noblest for Man collectively, I suppose we shall disagree. You told me in your letter that what I believe - what is to me an unspeakable spiritual boon, a hope for the glorious destiny of the individual soul as well as for Mankind collectively - is mere nonsense. Nevertheless, I am weak enough to still determine to cleave to those aspirations and hopes which are to me the highest conceivable, and to try to the utmost of my powers to help others whose spiritual ways are dark, whose souls are oppressed with all the world's woes as well as with personal sorrows.

I am very glad that I did not write this poem two or three years ago, when I shared almost in toto the views you yourself hold. At that time Hegel, and Comte, and Spencer, and Huxley seemed to me the High Priests of Truth, and I had as blind a faith in their Reason as you now have. In time (and thro' not pleasant seasons to look back to) I grew out of this material phase: but so deep was my suffering in it, so little of real hope for Man could it give me, that I am never tempted to speak harshly or scornfully of those who still dwell therein. Charity - the charity that implies the belief others may possibly be right, or at least reaching towards the same ends by diverse ways - is not a common thing, I am afraid. I shall never forget the intellectual debt I owe to those great writers I have mentioned, and especially to Comte, Darwin, and John Stuart Mill, but I now see that each of them were only for me steps leading to the temple. I am not a Christian, in the acceptation of the 
term implying belief in his divinity, but I owe far more to Christ than to any other man. He was philosopher, social reformer, poet, teacher, and prophet in one. Tho' some of my relations in Scotland will have nothing to say to me because of my heterodox and what they call atheistic and blasphemous views, and tho' some even in London consider me as almost hopelessly morally perverted because my creed is simply "I believe in immortality, and in the conscious Will of God" - I think I can still say I love and reverence that noble spirit who suffered for his fellow man 18 centuries ago as deeply perhaps as many Christians. But whether or not the last verse of "The Wandering Jew" conveys to your mind a different impression, whether, instead of my meaning, the "vaster glory" to come is perfected Humanity alone, I yet trust the poem will not seem to you to have been written in vain. It is moreover poetically the best thing I have done yet.

I asked Miss Robinson to tell you how much I liked and admired your paper in the Contemporary ${ }^{61}$ As I told her, I could have written it myself, as far as agreeing with what you say therein is concerned: only, naturally, I could not help feeling annoyed at the (to borrow your own favourite phrase) sophistication of ideas which leads you to judge of me as you do. What Cyril says in the latter half of page 703 corresponds exactly with what I have always believed and urged not only in conversation and correspondence but also in print: - and the succeeding remarks of Baldwin (i.e. you) as applied to myself are utterly unjust. I confess I should side with Cyril in thinking such a young poet (God save the mark!) should be birched. Not only did I agree so thoroughly with your paper, I also extremely admired its literary setting, its clear concise style and artistic finish, and beauty of natural detail. You certainly feel Nature poetically. I confess also that it gave me a higher opinion of your critical and literary powers than your long letter on the same subjects did - the latter giving me the impression of being very young as well as here and there illogical.

You have been very candid with me: shall I be equally candid with you, and tell you that it seems to me you have a very strong tendency to dogmatise upon every subject that turns up, whether you are intimately acquainted with it or only partially so. I know you will not take this unpleasantly, for you are of far too strong mental calibre to be seriously put about by adverse criticism, especially when offered in no unkindly spirit. 
By-the-way, I remember being rather amused (in the letter meant for me addressed to my cousin) at what you said as to my taken-forgranted ignorance of the old dramatists, advising me to read and study them carefully so as to see how pure they were at heart and only unclear in the externals owing to the exigencies of the times they lived in: as for nearly 10 years past they have been my continuous delight. In the first place, I am a little older than yourself instead of younger; in the next, I have had exceptional advantages for wide and varied reading; and in the third, have naturally made myself intimately acquainted with the period which is the most glorious our literature has seen. Apart from this, I have and always have had the most intense love for and ceaseless delight in such men as Marlow, Webster, Massinger, Beaumout, Fletcher, and Shakespeare - so much so that I do not think there are many who know and appreciate these great writers more than myself. You can understand, therefore, how half-provoked half-amused I was at the complacent arrogance of your remarks.

But now I hope we know each other better: I certainly do, and the more I hear, see, and read of you and yours the more I am glad of the possibility of numbering you among my few friends.

Please read the first (explanatory) part of this letter to your brother, to whom I hope the poem will give pleasure. I shall be glad to hear from him when he has read it, if he has time and disposition to write. Give him my most sincere greetings, both as now expressed and in the accompanying sonnet, which I have just written specially for him. I also send you one on that exquisite spirit-like thing, the Wind of Spring - in return for the great pleasure your natural descriptions in the Contemporary gave me.

Looking forward to meeting you before very long, believe me, dear Miss Paget,

Yours very sincerely, I William Sharp

\section{Spring Wind ${ }^{62}$}

\section{O full-voic'd herald of immaculate Spring \\ With clarion gladness striking every tree \\ To answering raptures, as a resonant sea}

Fills rock-bound shores with thunders echoing: 
O thou, each beat of whose tempestuous wing Shakest the winter sleep from hill and lea, And rousest with loud reckless jubilant glee The birds that have not dared as yet to sing:

$\mathrm{O}$ wind that comest with prophetic cries, Hast thou indeed beheld the face that is The joy of poets and the glory of birds Spring's face itself: - hast thou 'neath bluer skies Met the warm lips that are the gales of bliss, And heard June's leaf-like murmur of sweet words?

March/81. I W.S.

N.B. The words "clarion gladness" are taken from the accompanying Wandering Jew, verse 33, but haven't had time to make an alteration in the sonnet yet.

\title{
A Poet's Greeting to a Brother Poet
}

\author{
(W. S. To E.L.H).
}

The month, in whose warm heart is graven deep

The cuckoo's voice, waits smiling behind May, Her frolic sister who upon the way

Strews blossoms laughing: from their long dark sleep

Daily the blessed roses stir and creep

From fold and bud: and thro' the twilight grey

That dreams about the haunts of vanish'd day

The culver calleth from the wooded steep.

I, in the busy haunts of men, but dream

Of these, as thou upon thy weary bed:

Yet every day we know the blue skies gleam,

And every night the star-lamps shine, o'erhead.

Is it not well with us that we can feel

At least such memoried raptures o'er us steal? 


\section{To Dante Gabriel Rossetti, [July 25, 1881]}

19 Albert Street I Regent's Park I Monday

\section{My dear Rossetti}

Sir Noel Paton ${ }^{63}$ is at present in Kent, \& though he is only south for a few days in all he intends if at all possible paying you a brief afternoon visit. He spoke very warmly and enthusiastically of you, and seems really anxious to see you again. It is, however, still uncertain whether he will be able to manage a call or not as he is not only pressed for time but far from well. I told him that to the best of my knowledge you would be at home any afternoon this week, and if he is able to do as he hopes he will look you up on either Tuesday, Wednesday or Thursday. He leaves again on Friday. If he cannot manage it, he told me to give you his kindest remembrances and all good wishes. He has not yet got over the shock of the narrow escape he and Lady Paton \& one of their sons had from drowning, after being upset from a small sailing boat on a lonely Highland loch, all having to swim a long distance in a very exhausted condition.

It is becoming a serious case of hope deferred in regard to your book. ${ }^{64}$ When is it coming out? I do hope soon now.

Ever yours affectionately I William Sharp ALS University of British Columbia

\section{To Dante Gabriel Rossetti, July 28, 1881}

19 Albert St. | Regent's Park N.W. | 28/7/81

My dear Rossetti,

You will be glad to hear that there is no unsatisfactory news of Lady Paton or Sir Noel. I was with the Craiks last night, and Mrs. Craik ${ }^{65}$ was 
telling me of the extreme enthusiasm of Sir Noel after his visit to you. He had not been well or in good spirits for some days previous, but when he returned to Kent that evening he was like another man. He declared the short time he spent at No. 16 was worth coming from Scotland for alone. Deeply and sympathetically as he had always admired your works, the "Beatrice" he seems to have fouéd a crowning work of genius: and he told the Craiks on his return that it was one of the very few pictures he had ever seen that gave him an absolute sense of spiritual restfulness and complete achievement. ${ }^{66}$ The ideal beauty of the colouring \& the whole conception while giving him inexpressible pleasure gave also great pain, for it made him feel, he said, the inferiority of his own work. He would talk of almost nothing else, \& Mrs. Craik says she had never seen him so wrought upon before. He thinks it one of the greatest paintings that have ever been produced.

What I now write to ask you is if some afternoon during August I may bring Mrs. Craik to see the Beatrice. Sir Noel was very anxious she should see it, as she is both one of his chief friends \& he has great faith in her art appreciation. She is a great admirer of your work. I know your objections to seeing strangers, but if you would kindly consent to acceding to Mrs. Craik's request it would not only be gratifying to her and a personal favour to myself but also to Sir Noël.

I am looking forward to seeing the latter when I go to Scotland in September, and also to paying a visit to the scene of the murder of James I, - which I am particularly anxious to see after hearing your splendid ballad. I hear your sister's book is out - I heard the Craiks speaking very enthusiastically about it.

Hoping you are well

Yours affectionately | William Sharp

P.S. I am sorry to say the Civil List application as to Dr. Marston ${ }^{67}$ has not been entertained. It is a great shame. Gladstone declines a thoroughly deserving literary case, yet grants the large sum of $£ 500$ / annum to Lady Redcliffe! ${ }^{68}$ It seems to me very unfair. 


\section{To Dante Gabriel RossetTo Elizabeth A. Sharp, September, 1881}

... Yesterday I spent some hours in a delicious ramble over the moors and across a river toward a distant fir wood, where I lay down for a time, beside the whispering waters, seeing nothing but a semicircle of pines, a wall of purple moorland, the brown water gurgling and splashing and slowly moving over the mossy stones, and above a deep cloudless blue sky - and hearing nothing but the hum of a dragonfly, the summery sound of innumerable heather-bees, and the occasional distant bleat of a sheep or sudden call of a grouse. I lay there in a kind of trance of enjoyment - half painful from intensity. I drank in not only the beauty of what I have just described, but also every little and minute thing that crossed my vision - a cluster of fir-needles hanging steel-blue against the deeper colour of the sky, a wood-dove swaying on a pine-bough like a soft gray and purple blossom, a white butterfly clinging to a yellow blossom heavy with honey, a ray of sunlight upon a bunch of mountainash berries making their scarlet glow with that almost terrible red which is as the blood of God in the sunsets one sometimes sees, a dragonfly poised like a flame arrested in its course, a little beetle stretching its sharded wings on a grey stone, a tiny blue morsel of a floweret between two blades of grass looking up with, I am certain, a sense of ecstatic happiness to the similar skies above - all these and much more I drank in with mingled pain and rejoicing. At such times I seem to become a part of nature - the birds seem when they sing to say things in a no longer unfamiliar speech - nor do they seem too shy to approach quite close to me. Even bees and wasps I do not brush away when they light upon my hands or face, and they never sting me, for I think they know that I would not harm them. I feel at these rare and inexpressibly happy times as a flower must feel after morning dew when the sun comes forth in his power, as a pine tree when a rising wind makes its boughs quiver with melodious pain, as a wild wood-bird before it begins to sing, its heart being too full for music... . O why weren't you there? 


\title{
To Dante Gabriel Rossetti, September 10, $1881^{69}$
}

\author{
Stockbriggs | Lesmahagow | N.B. | Saturday - 10th Sept./81
}

My dear Rossetti,

How I wish you were here, as I am sure you would enjoy it so much... . Stockbriggs is a fine estate of 6 square miles situated amidst the loneliest moors of Lanarkshire, and there is almost everything one needs in order to make the time pass happily: a nice house, and people who are hospitality incarnate - a fruit garden of 2 acres, with strawberries \& gooseberries still in full bloom - the river Nethan, a beautiful trout stream, running close to my bedroom window and for 6 miles thro' the grounds - endless rides in all directions - splendid stretching purple moors within easy distance - around, innumerable places of legendary or historical interest, such as Craignethan Castle (the Tillietudlem of Old Mortality) Douglas Castle, St. Bride's Chapel (where repose the brave hearts of the good Sir James Douglas who brought home with his own dead body the Bruce's heart, now buried in Dunfurnshire, - and that of the fierce Archibald Bell-the-Cat - the ancient priory of Lesmahagow - Broken Cross Muir - etc. etc. Where most I enjoy myself, however, is along the solitary banks of the Nethan; it is a true mountain stream, now rushing along in broken falls, now rippling over shallows of exquisite golden-brown hues - now skipping with slow perfect grace of motion under the overhanging boughs of willow, pine, or mountain-ash - and ever and again resting in deep dark linns and pools in deliciously dreamful fashion, the only signs of life being a silver flash from its depths as some large trout or grilse stirs from the shelter of the mottled boulders banking the sides, or when a dragonfly like a living flame flashes backwards \& forwards after the grey gnats. Indeed, I never saw such a place for dragonflies - I think there must be vast treasures of rubies and emeralds under these lonely moors, and that somehow the precious stones dissolve and become permeated with the spirit of life, and use up living green fires or crimson and purple flames to flash upon the unseen hill-winds instead of upon a woman's bosom or in the Holy of Holies in an Idolater's Temple.

Between the moors themselves and the Nethan my enjoyment is divided. It is delicious to be alone on these lofty plateaux, with nothing 
to meet the eye but an apparently endless stretch of long purple waves of swelling heather, broken perhaps here \& there by the steel-blue of a pine-wood ridging some far off mound, with above and around a semicircle of intense blue sky, thro' which at startled intervals there falls again and again the wail of a curlew or hoarse cry of the moorcock. The wind seems to blow straight from the depths of heaven, so soft is it and yet so invigorating, so fresh and yet so charged with delicious scents from bog-myrtle, heather, and pine. There is a constant underhum of innumerable insects - bees swaying in the bells of mountain flowers, butterflies quivering over orchis and bracken, gnats dancing in ever shifting circles \& seeming to draw a maze of thread against the blue background of the sky, wasps droning out their idle life in the golden sunshine, black, brown, and green beetles rasping away with their sharded wings, voracious dragonflies here there \& everywhere - and many others all in one harmonious concert. Sometimes the more definite sounds are varied by the cry of a wandering hawk or the distant bleat of a sheep - but as a rule the grouse, the curlews, and the plovers have it to themselves.

After the gloaming has dreamt itself into night the banks and woods along the stream seem to become a part of a weird faeryland. The shadows are simply wonderful. White owls come out and flit about on silent ghostly wings with weird uncanny cries, \& bats begin to lead a furiously active existence. The other night I was quite startled by seeing a perfectly white animal slowly approaching me: it looked remarkably like the ghost of a fox or a wild-cat, but I am afraid it was only a white hare.

So much for my surroundings. As for the few people hereabout they are all charmingly of the old time. After dinner, and while the claret, port, \& sherry (the latter, oh so brandied!) are in process of consumption, large toddy goblets with silver spoon ladles and smaller tumblers are handed round to ladies \& gentlemen alike. Then come the large silver flagon with the hot water, the bowl with the strictly symmetrical lumps of sugar, 3 of which go to the large tumbler, and the cut crystal decanter of pure Glenlivet.

The custom has great advantages, but it certainly does not conduce to the safe driving of the dogcart home again. 
Here is a specimen of a purely Scotch Bill of Fare, for some especially noteworthy occasion

\title{
Bill of Fare
}

\author{
A wee drappie Talisher. \\ Callipee Broth. Hotch Potch. \\ Saumon à la Pottit Heed. Pomphlet à la Newhaven. \\ Anither Drappie. \\ Mince Collops. Doo Tairt \\ Haggis. \\ An Eek. \\ Stuffed Bubbly Jocks an Hawm. \\ Gigot of Mutton wi' red curran jellie. \\ Sheep's Head an' Trotters. \\ Tatties Biled \& Champit. Bashed Neeps. \\ Jist a wee Donal! \\ Glesky Magistrates. Sma' peas. \\ Grozet Pies. Aiple Dumplins. \\ Ice Puddin wi' cookies \\ A Guid Dram to keep a' doon.
}

When I have a house of my own I shall give such a dinner some day, and the Sassenach hearts present shall admit there is no dinner like a Scotch one and no whiskey like the heavenly Celtic brew.

At the end of next week (about the 16th) I go to see Sir Noel ${ }^{70}-$ whom I hope to find well.

I hope you are well yourself, though I wish you were in some such place as this instead of rain-haunted London. May I come \& see you again when I come back early in October? I always enjoy so much a visit to 16 Cheyne Walk. Philip ${ }^{71}$ has been rusticating at Deal.

And now, au Revoir,

Ever yours affectionately, I William Sharp I should be much obliged if you wd kindly forward the letter to Hall Caine (by the same post as this) as I do not know his address.

ALS University of British Columbia, excerpt in Memoir (55-57) 


\section{To Dante Gabriel Rossetti, September 17, 1881}

16 Rosslyn Terrace I Glasgow W. | 17th Sept./81

My dear Rossetti,

Just received your letter of the 14th this morning, \& can only reply by a brief note as I am on the point of leaving my mother's house in Glasgow again.

Philip has returned to 191 Euston Road, but unfortunately does not seem to be very well - some kind of suppressed cold, I think.

I am so glad to hear that Dante's Dream ${ }^{72}$ has become the property of the corporation of Liverpool, thus opening to the public such a masterpiece of beauty and conception: and I am also glad to hear that you are going out of town for a little, and I only hope you may have good weather. I shall give your message to Sir $\mathrm{Noel}^{73}$ when I see him on Monday. I had (wonder of wonders for the man of postcards and telegrams) a long letter from him the other day - in which he writes of you as follows: "you will understand how much I am pleased to know that I did not bother Rossetti by breaking in upon his work in June; for I have sometimes feared it must have been otherwise. Certainly I was conscious of being deplorably inarticulate. The fact being that I was so dumbfounded by the beauty of his great picture that I was unable to give any expression to the emotions it excited, - emotions such as I do not think any other picture except the Madonna di San Sisto ${ }^{74}$ at Dresden ever stirred within me. Again and again I have attempted to write to him on the subject - but the memory of such a picture is like the memory of sublime and perfect music: it makes any one who fully feels it - silent.

"I am so glad for the pig-headed public's sake, no less than for Rossetti's own, that it is being exhibited, altho' I could have wished it had been first seen in London, as the centre of a special exhibition of his works. But as it is, it is well. Fifty years hence it will be named among the half dozen supreme paintings of the world".

In much haste

Ever yrs affectionately | William Sharp 
P.S. My old address, 19 Albert St. is now cancelled - and my address in London till I take new rooms (when I will let you know) will be I 72 Inverness Terrace I Kensington Gardens | W. I where I shall be returning before the end of the month.

ALS University of British Columbia

\section{To Dante Gabriel Rossetti, [September 22, 1881]}

Rosslyn Terrace I Kelvinside, Glasgow. I Thursday Evening.

My dear Rossetti,

I promised I would let you know how I found Sir Noël. He is fairly well, but unfortunately both he and Lady Paton have been much pulled down by nursing; their son Victor being just convalescent from typhoid fever. This on the head of the results of their late accident has told against both. It adds also to his insomnia, unfortunately. He is going to give your Camphor remedy a trial, \& thanks you for thinking of it.

He is engaged on a fine painting at present, about which I will tell you when I see you next; \& has also finished a particularly fine relief in bronze, illustrating the by no means new idea of a good \& bad angel striving for the mastery of a man. It is peculiarly his own, however.

You will be glad to hear that when I spoke to him about Shields ${ }^{75}$ not being rewarded for his work according to the measure of its worth, \& being at times in stress of deficient means, he said he thought he would be able to do Shields a service by strongly advising the Duke of Westminster to take the cartoons themselves likewise, and at a good price $-\&$ also letting him know indirectly that in his (N.P'.s) opinion the designs were underpaid. In default of this, Sir Noel knows of another social potentate who may turn out to be of signal service. I do hope his efforts may not be wholly without avail. He sends you his warmest remembrances with many kind auguries - tho' I daresay some of his family wish that Dante's Dream and its author were both permanently 
damned in perdition, hearing the head of the family refer to it so often and so insistently.

His sister (Mrs. D. O. Hill) ${ }^{76}$ has finished the most remarkable and beautiful bust of Shelley I have ever seen. She intends it as a free gift for Shelley's grave, if the Shelleys themselves are agreeable. It closely resembles the fine engraving in Moxon's early edition, ${ }^{77}$ but stronger: and is also founded on Mrs. Leigh Hunt's small (\& to me, repellent) bust of the poet; \& further verified by the small exquisite engraving issued privately for the Shelleys by Colnaghi \& Co., of Percy at the age of 14, from a drawing by the Duc de Montpensier. In this latter, I notice a rather marked resemblance to Keats at a later age.

When is the book ${ }^{78}$ to be out? I, for one, am very impatient.

In haste

Ever yours | William Sharp

ALS University of British Columbia

\section{To Dante Gabriel Rossetti, September 23, 1881}

16 Rosslyn Terrace | Glasgow. W. I Friday. 23 Sept./81

My dear Rossetti,

Your letter from Cumberland dated Tuesday only reached me this morning, hence the delay in reply.

I am glad to be able to comply with your request as to the letter from Sir Noël. My chief reason for not having sent it to you at once was that I might find it useful someday in proving the high opinion an artist like Sir Noël had of yourself - and also as a pleasant record of the two men I most like and admire and who have been so kind and generous to me. However, I am only too glad to render it up if it can be of any service to you - and I quite see how some guarantee of this nature will go a long way with the worthy Liverpool committee, by strengthening their confidence in the good fortune of having purchased your painting. 
As the first page or two related to private matters, I supposed you would not object to its partial dismemberment - however, everything that is necessary for identification is there.

Hoping you will have a pleasant time in Cumberland (thro' which I shall pass on Monday) \& be the better of the change, and have decent weather.

In haste | Your affectionately | William Sharp

ALS University of British Columbia

To Dante Gabriel Rossetti, [early October, 1881]

72 Inverness Terrace | London W. I Thursday.

My dear Rossetti

Just returned from my "villegiatura", \& don't relish London again. Have only time to reply by a hasty line to your note received this morning: I regret what I meant in mere fun was so worded as to make you think it possible Lady Paton \& the others disliked now the mention of your name. Let me assure you, what I wrote was merely from a kind of high spirits \& had no other origin than in my own confounded love of playful badinage. Au contraire, Lady Paton is very glad indeed at her husband having seen you, as it seems to have done him good, \& the only sentiment that exists in the family is that of curiosity to see the man and the work of which the head of the family has such a high and enthusiastic opinion. Lady Paton was just saying she felt quite grateful to you for the good you had done Sir Noël.

As to the letter from the latter, just do as you wish yourself. If you would at all like to keep it, by all means do so.

Glad you are having fine weather, \& hope it will continue, \& that you will be ever so much the better of the change.

In great haste 
P.S. My address in future will be | 13 Thorngate Road I Sutherland Gardens | W. I altho' the address heading this note will always reach me also, being my "young woman's".

ALS University of British Columbia

\section{To Dante Gabriel Rossetti, December, 1881}

The Fine Art Society, I (Limd). I 148, New Bond St. W. I Dec. 1881

My dear Rossetti,

I sincerely hope you are feeling somewhat stronger since I saw you last week - though indeed I was glad to see such a marked change for the better even then. And I trust also that Caine is no longer feeling out of sorts.

I am now writing to you on a matter of business. You have so long refrained from exhibiting that even your best friends are beginning to despair of any such result. But I think you have somewhat changed your mind about this since your Liverpool success. There could not be a better time than next Spring, if an exhibition is ever to come off at all: and I know how much it will weigh with you when I tell you how earnestly (when I was staying with him last September) Sir Noel Paton hoped such an exhibition would now be no longer deferred, and how he urged upon me to use all my persuasive powers to this effect. He meant to have spoken about it when he saw you last July, but forgot in the pleasure his necessarily brief visit afforded him.

An Exhibition early in 1882 could not fail to give very great pleasure to all lovers of art, besides giving a great "fillip" to your reputation, adding in consequence much to the commercial value of your work.

Mr. Huish ${ }^{79}$ has spoken to me with reference hereto, and requests me to write as follows. If you will give your consent to a representative collection of your paintings (say about 15, or from 15 to 20) every assistance will be afforded to you to do so satisfactorily - a well-lit and good-sized gallery would be at your entire disposal, and the hanging 
could be carried on under whatever superintendence you wished, either by those here including myself (and I could always report and describe to you personally, you know, how matters were) or under the superintendence of Shields ${ }^{80}$ or whomever else you would appoint. I should think Mr. Graham, Mr. Leland, Mr. Rae, Mr. Craven, Ionides, and others wd. be only too glad to gratify the many who know your works but slightly, and also add much to your own reputation, by lending two or more each for purposes of Exhibition.

The best time for this would be beginning with March, or no later than April at farthest - so as to give ample time for "the fame thereof to spread abroad" before the artistic and social season is in full swing.

I need hardly say that every care is taken to prevent damage or loss of any description. There could be no better place for exhibition than the Fine Art Society's (and I am not saying this simply because I am in it myself) - for it has got a name for having nothing but highclass exhibitions, often undertaken from the reverse of a commercial standpoint, as witness the exhibition at different times of the works of Hunt and Prout, of the Inmer drawings, of those of Millais, of Beurich, and now of those of Samuel Palmer. ${ }^{81}$

I know you are not using your hand more than necessary at present - so I can look in to talk this matter over (and which I sincerely trust you will acquiesce in) on either Wednesday, Thursday, or Friday nights of this week -

Please send a card to say when you wd. like me to come.

I was in at Ellis \& White's today, and your book ${ }^{82}$ is having a steady sale.

Ever yrs affectionately | William Sharp

P.S. I write now, as this is a matter which requires to be settled months beforehand. The Directors have one or two other important intentions in hand, but would be willing to put everything aside for such an Exhibition as yours would be, only they wd. require to know soon. Monetary, or other matters in connection herewith can be better talked over than written about, as I am in haste.

If you agree, would not it be well to get Watts (the artist) or BurneJones, ${ }^{82}$ or Sir N. Paton to write the notes? 
Pray think favorably of this proposition $-\&$ thus both do good to yourself and give long-anticipated pleasure to others.

W.S.

ALS University of British Columbia 


\section{Chapter Two}

\section{Life: $1882-1884$}

In February 1882 Rossetti became ill and depressed, convinced he was near death. Hall Caine, who was his main caretaker, rented a house on the seacoast near Birchington in Kent in the hope that living near the sea away from the fogs and smoke of London would improve his health and spirits. He invited William Sharp and Theodore Watts for a weekend to help him break through Rossetti's gloom. In a February 13 letter to Elizabeth from Birchington, Sharp described an outing with Rossetti the previous day: "Oh, the larks yesterday! It was as warm as June, and Rossetti and Caine and I went out, and I lay in the grass basking in the sun, looking down on the shining sea, and hearing these heavenly incarnate little joys sending thrills of sweetness, and vague pain through all my being." Years later he expanded on the experience as one of his most cherished memories:

It had been a lovely day. Rossetti asked me to go out with him for a stroll on the cliff; and though he leaned heavily and dragged his limbs wearily as if in pain, he grew more cheerful as the sunlight warmed him. The sky was a cloudless blue and the singing of at least a score of larks was wonderful to listen to. Everywhere Spring odours prevailed.... At first I thought Rossetti was indifferent, but this mood gave way. He let go my arm and stood staring seaward silently, then, still in a low, tired voice, but with a new tone, he murmured, "It is beautiful - the world and life itself. I am glad I have lived". Insensibly thereafter the dejection lifted from off his spirit. And for the rest of that day and that evening he was noticeably less despondent (Memoir 59-60). 
Less than two months later, on April 9, Rossetti died. Sharp described his feelings to Elizabeth on the night before he went to Birchington for the funeral:

He had weaknesses and frailties within the last six or eight months owing to his illness, but to myself he was ever patient and true and affectionate. A grand heart and soul, a true friend, a great artist, a great poet. I shall not meet with such another. He loved me, I know - and believed and hoped great things of me, and within the last few days I have learned how generously and how urgently, he impressed this upon others... . I can hardly imagine London without him.

Rossetti was more than a friend and mentor. Sharp's father rejected his son's artistic bent and died without reconciliation. Rossetti was the first of many who filled that void.

In the years before his death, Rossetti drew first Caine and then Sharp into his circle and depended on them for support and companionship. Soon after he died, both men decided to write a book about the great man. When Caine learned in July that Sharp was preparing a book, he complained bitterly. Since Sharp's book would cut into the sale of his book, he had decided to abandon it. Sharp's letters to Caine were not available to Elizabeth for her Memoir, and Caine is largely absent from that work. Their competing books on Rossetti might well have permanently damaged their relationship. A trove of Sharp letters to Caine preserved in the Manx Museum on the Isle of Man shows, on the contrary, they remained close friends for many years. After a brief period of strain in the summer of 1882, Sharp cleared the air in a letter that assured Caine his book would not be a biography, but "a Study of the Poet - Artist - for in deference to your own work I determined to make the biographical portion consist of only about ten pages or so.... I fail to see where the two will clash." Mollified by this explanation, Caine proceeded with his book - Recollections of Dante Gabriel Rossetti which was published by Elliot Stock in September. Sharp's response to Caine preserved their friendship.

During July, William Michael Rossetti worked with Sharp on the dating and location of his brother's paintings. With that information in hand by early August, Sharp joined his mother and sisters in a rented cottage in western Scotland where he wrote the main body of the book. He finished it after returning to London, and Macmillan published Dante Gabriel Rossetti: A Record and A Study in December. The book's favorable 


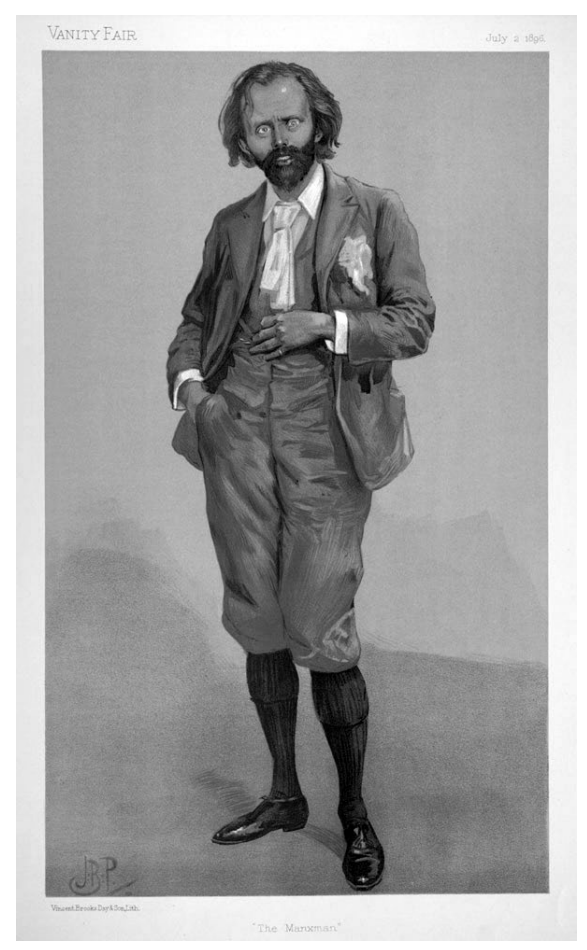

Fig. 3. Hall Caine, The Manxman, as caricatured in Vanity Fair. John Bernard Partridge (1896), Wikimedia, https://en.wikipedia.org/wiki/File:Hall_Caine_Vanity_Fair_2_July_1896. jpg, Public Domain.

reception provided a significant boost to Sharp's literary career. While his descriptions and analyses of Rossetti's paintings, poetry, and prose continue to be of some interest, the book's main lasting value is its Appendix, a detailed listing of the dates, subjects, and then current owners of Rossetti's paintings.

Sharp's first book of poems - The Human Inheritance; The New Hope; Motherhood - was published by Elliot Stock in 1882. He considered this book, according to Elizabeth, the beginning of the "true work of his life." As the title indicates, it consists of three long poems. "The Human Inheritance" contains four sections which depict, in turn, childhood, youth, manhood/womanhood, and old age. "The New Hope" forecasts a spiritual regeneration of the world; and "Motherhood" attempts to demonstrate "by depicting the experience of giving birth" the commonality of experience among all living creatures. Sharp considered 
that poem, which Rossetti had praised, a major accomplishment. When Elizabeth accompanied her mother to Italy in early 1880, she read parts of "Motherhood" to Eugene Lee-Hamilton, an aspiring poet who lived with his mother and sister, Violet Paget (Vernon Lee), near Florence. They thought the poem's depiction of "giving birth" was not a fit subject for poetry. In response Sharp wrote a long letter to Lee-Hamilton and another to Paget in March 1881 (both reproduced in the previous chapter) justifying his effort to demonstrate in the poem that women shared with animals many experiences and feelings. The poem seems not to have produced much consternation when it appeared in the 1882 volume, perhaps because the entire volume evoked minimal notice and sank quietly out of sight. The care with which Sharp wrote and defended "Motherhood," however, is the first sign of his life-long fascination with the inner lives of women. This poem was his first effort to penetrate and portray publically the consciousness of a woman, a manner of thinking and feeling he felt deep within himself that culminated in 1892 in his creation of and identification with Fiona Macleod.

During 1882 Sharp earned small amounts for poems that appeared in The Athenaeum, the Portfolio, The Academy, The Art Journal, and, in America, Harper's Magazine. Toward the end of the year, he had almost reached his last penny. A forty-pound check from Harper's provided some relief, and then out of the blue a two-hundred-pound check arrived from an unknown friend of his grandfather who had heard from Sir Noel Paton that he was "inclined to the study of literature and art." Sharp was to use the money "to pursue his artistic studies" in Italy. The windfall enabled him at the end of February 1883, to leave for Italy where he spent five months in churches and galleries studying paintings by the major figures of the Italian Renaissance. He went first to Florence where he stayed with one of Elizabeth's aunts in her villa on the outskirts of the city, then to Venice where he met Ouida and William Dean Howells and formed a close friendship with John Addington Symonds, then to Sienna, and then to Rome before returning to Florence. He described much of what he saw in a series of lengthy letters to Elizabeth who had seen many of the paintings and frescoes during her trip to Italy with her mother in 1881. He studied the works carefully and developed opinions of their relative merits. He was introduced to paintings by his association with Rossetti and others of the Pre-Raphaelite movement. The Italian experience brought him into direct contact with the work of 
artists who had, in fact, preceded Raphael and provided a solid basis for the art criticism that occupied much of his time and attention in the years that followed.

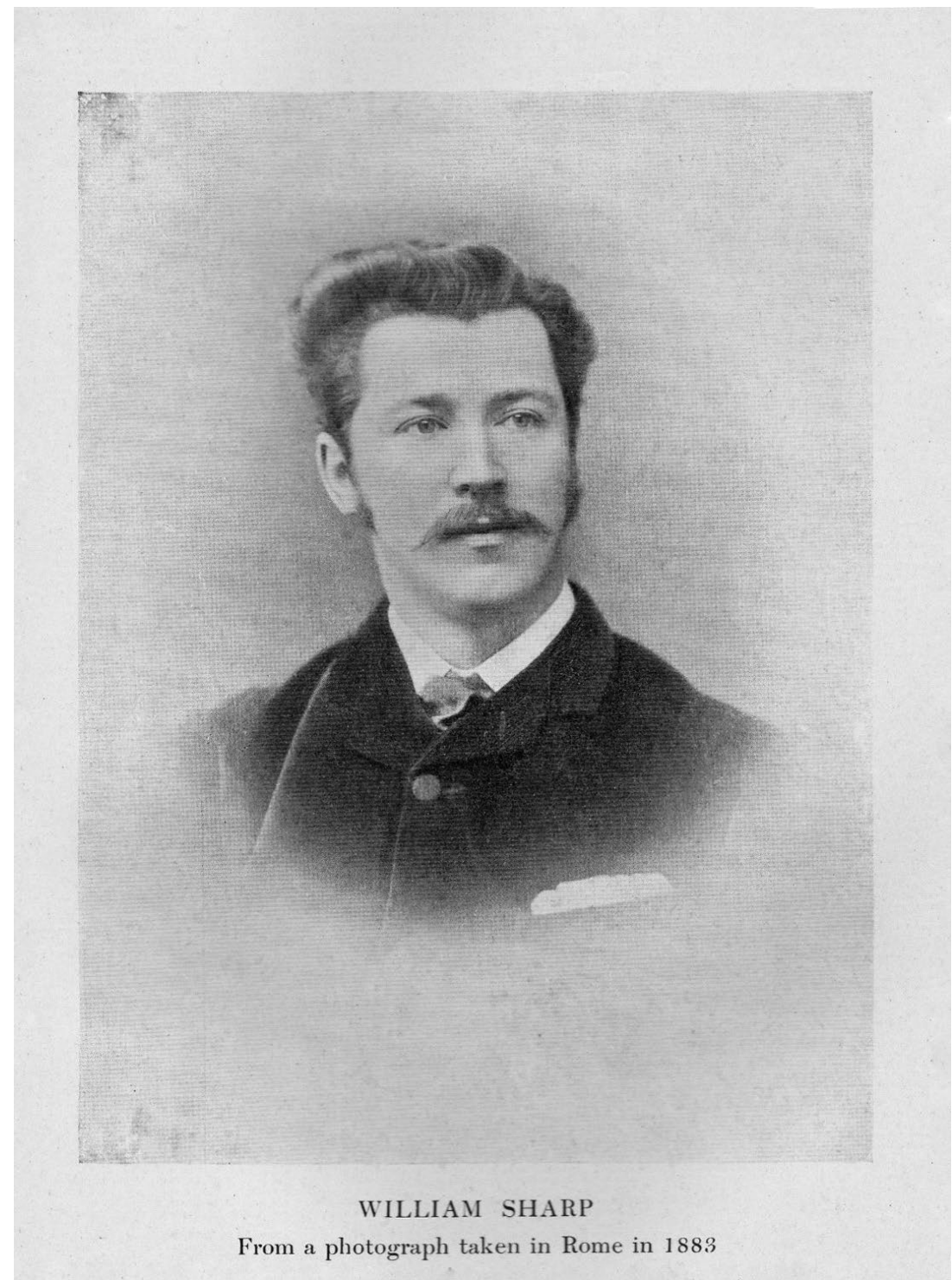

Fig. 4. Photograph of William Sharp taken by an unknown photographer in Rome in 1883. Reproduced from William Sharp: A Memoir, compiled by Elizabeth Sharp (London: William Heinemann, 1910). 
When he returned to London, he wrote a series of articles for the Glasgow Herald on Etrurian cities. In August, he was in Scotland with his mother and sisters in a rented house on the Clyde. While there, he went over to Arran to visit Sir Noel Paton, and from Arran, he went on to Oban, sailed over to Mull, and crossed that large island to the small island of Iona which became a place of pilgrimage for him and would figure prominently in his writings as Fiona Macleod. In September, the Glasgow Herald, probably on the strength of his Italian articles, invited him to become its London-based art critic, a post he held for many years before turning it over to Elizabeth.

On his way to Scotland in early August, he lost a large portmanteau which "in addition to new clothes got in London and valuable souvenirs and presents from Italy, contained all my MSS., both prose \& verse, all my Memoranda (many of them essential to work in hand), all my Notes taken in Italy, my private papers and letters, some proofs, three partly written articles (two of them much overdue), my most valued books - and indeed my whole literary stock-in-trade pro-tem." After retracing his steps in cold, wet weather, trying to locate the missing case, he had no choice but to accept its loss. He wrote to Hall Caine in August 1883: "As a literary worker yourself you will understand what a 'fister' this is to a young writer. I must take this buffet of Fate, however, without undue wincing - and tackle to again all the more earnestly for the severe loss and disappointment experienced. There's no use crying over spilt milk." Elizabeth reported the portmanteau was found about a month after its loss and returned in a wet and damaged condition, but many of the poems and essays were recoverable. Some were published, providing a modest income, in Good Words, The Fortnightly Review, Cassell's Magazine, and the Literary World.

After returning to London from Scotland in September, Sharp had a cold that progressed into a second bout of rheumatic fever, further damaging his heart. His sister Mary came from Edinburgh to join Elizabeth in nursing him back to health. By November he was able to tell Caine: "I am greatly better, so much so that I find it difficult to credit the doctor's doleful prognostications: I feel I must take care, but beyond that I have no immediate cause for alarm. The worst of it is that I am one day in exuberant health and the next very much the reverse. The doctors agree that it is valvular disease of the heart, a treacherous form thereof 
still further complicated by a hereditary bias." He felt well enough to make light of the illness: "a fellow must "kick" someday - and I would as soon do so "per the heart" as, like no small number of my forbears in Scotland, from delirium tremens, sheep-stealing (in hanging days), and general disreputableness." Still, there was a problem: "Even if pecuniarly able, I am forbidden to marry for a year to come - and though waiting is hard now for us both, it is better even for my fiancée that nothing should be done which might result in what would be such a grief to her." Even if he had the requisite money, marriage would put too great a strain on his heart.

During the early part of 1884, Sharp prepared his second book of poems, Earth's Voices, which was published by Elliott Stock in June. Perhaps because he had become friends with more important literary figures, it was more widely noted than the earlier volume. He received a letter of praise from Walter Pater, whose judgment might have been tinged by the volume's dedication to him, and another from Christina Rossetti who liked several poems, especially those praising her brother. In a 1906 Century article on Sharp his friend Ernest Rhys praised some of the poems in Earth's Voices: "His writings betrayed a constant quest after those hardly realizable regions of thought and those keener lyric emotions, which, since Shelley wrote and Rossetti wrote and painted, have so often occupied the interpreters of the vision and spectacle of nature." Rhys found in one of the volume's poems, "A Record," "unmistakable germs" of "some of the supernatural ideas that afterward received a much more vital expression in the works of Fiona Macleod" (Memoir 97-98).

Sharp spent most of March and April in a house in Dover loaned to him by Dinah Maria Craik who understood both his precarious finances and his need to recuperate away from the fogs of London. His friend and fellow poet Philip Marston (1850-1887), who was blinded at the age three, spent a week with him in April. In a Memoir of Marston that Sharp wrote as an introduction to his edition of his poems and to his edition of his stories published in 1888, following Marston's early death in 1887, he described in glowing terms the walks they took together and Marston's excited responses to the warm sea air and sounds he had never heard in London. 
From Dover, Sharp crossed to France in early May for the first of many visits to Paris as an art critic for the Glasgow Herald. He wrote excitedly to Elizabeth about the writers, painters, and other luminaries he was meeting, among them Paul Bourget, Alphonse Daudet, Emile Zola, Frederic Mistral, Adolphe Bouguereau, Fernand Cormon, Puvis de Chavannes, Jules Breton, and, curiously, Madame Blavatsky.

Shortly after he returned from Paris, Sharp suffered another relapse that led him to ask Hall Caine on Sunday, June 15, 1884, if he could stay with him the following night. He was vacating his rented Thorngate Road rooms, which were cold and damp, and had to leave them the next day. He could not stay with Elizabeth's family in Inverness Terrace until Tuesday. The letter indicates how close Sharp and Caine were in this period and provides a revealing insight into the malady Sharp could not escape:

I have had, this afternoon, a narrow escape from rheumatic fever \& must leave here at once. I think I have fought it down, but I must not risk such another chance. I have been crouching over a large fire and with my medicine have got the better of the cursed complaint... . If in any way inconvenient, a postcard will do if you only say all right on it. Wd. come in the evening - but must go west early in the day from here on an urgent matter. Can't say how thankful I am to have escaped this sharp and sudden attack, \& there's no saying what a second bout would do. Excuse a hideous scrawl, but my hands are so chilled and pained I can hardly hold the pen - and have to write at a distance.

Caine replied immediately. Sharp should come the next day to a house Caine rented in Hampstead where he would be well cared for by two ladies and their maid. According to Caine's biographer, Sharp spent that Monday night at Caine's house - Yarra in Worsley Road, Hampstead - where he was looked after by Caine's fifteen-year-old mistress, Mary Chandler, and her maid. [Vivien Allen, Hall Caine: Portrait of a Victorian Romancer (Sheffield: Sheffield Academic Press, 1997), 171.]

Caine had rented the Hampstead house for Mary Chandler because he did not want his family or others to know about his relationship with such a young girl, who was pregnant with his child. Sharp was one of only a few close friends who knew about the arrangement. Long after he recovered, he asked Caine in an August 26th letter from Scotland, 
Is the hour of paternity drawing nigh? I wonder if Maccoll would accept for the Athenaeum a sonnet on "Caine's Firstborn"? I must try. If a boy, please call it "Abel", or in case this would give rise to too many poor jokes, what do you say to "Tubal". Most people would simply think you had called him after "that fellow, you know, in one of George Eliot's poems"!

As it turned out, a baby boy was born on August 15th and named neither Abel nor Tubal, after the Tubal-Cain in Genesis, but Ralph, after Caine's Grandfather, Ralph Hall. The main purpose of Sharp's August 26th letter was to let Caine know about an upcoming change in his own circumstances

Just a line, my dear Caine, in the midst of pressure from urgent work and accumulated correspondence, to let you know (what I am sure you will be glad to hear for my sake) that at last my long engagement is drawing to a close, and that Lillie and I are to be married on All Saints Day - just about two months from date. What we have got to marry on, Heaven knows - for I don't: yet I hope a plunge in the dark will not in this instance prove disastrous. It is not a plunge in the dark as regards love and friendship - and that is the main thing.

The year of waiting prescribed by his doctor was nearly up, and Elizabeth's parents were finally convinced that her marriage to her first cousin was inevitable even though the newly married couple's financial circumstances would remain uncertain. Sharp had proved himself a reliable and constant young man; indeed, his frequent presence at 72 Inverness Terrace, Bayswater, had already made him part of Elizabeth's family.

On October 31st, after a nine-year courtship, Elizabeth and William were married at Christ Church, Lancaster Gate, London. They rented a flat at 46 Talgarth Road in West Kensington which was furnished by their families. They continued to make their way as writers and expanded their circle of literary and artistic friends. In her Memoir, Elizabeth included a list of luminaries whose "literary households" welcomed the newly married couple. Among the many were Walter Pater, Robert Browning, Mr. and Mrs. Ford Madox Ford, Mr. and Mrs. William Morris, Mr. and Mrs. William Rossetti, Mr. and Mrs. Oscar Wilde, and Sir Frederick Leighton, the painter whose beautiful home and studio just off the Kensington High Street is now open to the public. At the 
close of 1884, both Sharps embarked on a six-year period of editing and reviewing that placed them near the center of London's literary elite. Still, William continued to write poetry and harbored a strong desire to gain attention and praise for his imaginative writing in poetry and prose. 


\section{Letters: $1882-1884$}

\section{To Elizabeth A. Sharp, February 13, $1882^{1}$}

Just a line to tell you I am supremely content. Beautiful sea views, steep 'cavey' cliffs, a delicious luxurious house, and nice company. By a curious mistake I got out at the wrong place on Sunday, and had a long walk with my bag along the cliffs till I arrived rather tired and hot at my destination. I was surprised not to find Hall Caine there, but it appeared he clearly understood I was to get out at a different station altogether. I was also delayed in arriving, as I asked a countryman my direction and he told me to the left - but from the shape of the coast I argued that the right must be the proper way - I went to the right in consequence, and nearly succeeded in going over a cliff's edge, while my theory was decidedly vanquished by facts. However the walk repaid it. Oh, the larks yesterday! It was as warm as June, and Rossetti and Caine and myself went out and lay in the grass (at least I did) basking in the sun, looking down on the gleaming sea, and hearing these heavenly incarnate little joys sending thrills of sweetness, and vague pain through all my being. I seemed all aquiver with the delight of it all. And the smell of the wrack! and the cries of the seabirds! and delicious wash of the incoming tide! Oh, dear me, I shall hate to go back tomorrow. Caine is writing a sonnet in your book, Watts is writing a review for the Athenaeum, Rossetti is about to go on with painting his Joan of $\mathrm{Arc}^{2}$ and I am writing the last lines of this note to you.

Memoir 59

To Elizabeth A. Sharp, April 11, 1882

London | 11:4:82

... After spending a very pleasant day at Haileybury with Farquharson ${ }^{3}$ we arrived late in London, and while glancing over an evening paper my eye suddenly caught a paragraph which made my heart almost 
stop. I could not bring myself to read it for a long time, although I knew it simply rechronicled the heading - "Sudden Death of Mr. Dante Gabriel Rossetti". He died on Sunday night at Birchington. I cannot tell you what a grief this is to me. He has ever been to me a true friend, affectionate and generous - and to him I owe more perhaps than to any one after yourself. Apart from my deep regret at the loss of one whom I so loved, I have also the natural regret at what the loss of his friendship means. I feel as if a sudden tower of strength on which I had greatly relied had given way: for not only would Rossetti's house have been my own as long as and whenever I needed, but it was his influence while alive that I so much looked to. Comparatively little known to the public, his name has always been a power and recommendation in itself amongst men of letters and artists and those who have to do with both professions. When I recall all that Rossetti has been to me - the pleasure he has given me - the encouragement, the fellowship - I feel very bitter at heart to think I shall never see again the kindly gray eyes and the massive head of the great poet and artist. He has gone to his rest. It were selfish to wish otherwise considering all things... .

If I take flowers down, part of the wreath shall be from you. He would have liked it himself, for he knew you through me, and he knew I am happier in this than most men perhaps.

Memoir 61

\section{To Elizabeth A. Sharp, April 13, 1882}

April 13, 1882

... I have just returned (between twelve and one at night) tired and worn out with some necessary things in connection with Rossetti, taking me first to Chelsea, then away in the opposite direction to Euston Road. As I go down to Birchington by an early train, besides having much correspondence to get through after breakfast, I can only write a very short letter. I have felt the loss of my dear and great friend more and more. He had weaknesses and frailties within the last six or eight 
months owing to his illness, but to myself he was ever patient and true and affectionate. A grand heart and soul, a true friend, a great artist, a great poet, I shall not meet with such another. He loved me, I know, and believed and hoped great things of me, and within the last few days I have learned how generously and how urgently he impressed this upon others. God knows I do not grudge him his long-lookedforrest, yet I can hardly imagine London without him. I cannot realise it, and yet I know that I shall never again see the face lighten up when I come near, never again hear the voice whose mysterious fascination was like a spell. What fools are those vain men who talk of death: blinded, and full of the dust of corruption. As God lives, the soul dies not. What though the grave be silent, and the darkness of the Shadow become not peopled - to those eyes that can see there is light, light, light - to those ears that can hear the tumult of the disenfranchised, rejoicing. I am borne me down not with the sense of annihilation, but with the vastness of life and the imminence of things spiritual. I know from something beyond and out of myself that we are now but dying to live, and that there is no death, which is but as a child's dream in a weary night.

I am very tired. You will forgive more, my dearest friend.

Memoir 62

\section{To William Michael Rossetti, April 15, 1882}

13 Thorngate Road, I Sutherland Gardens, W., I 15th April, 188[2]. ${ }^{4}$

Dear Mr. Rossetti,

As your wife kindly expressed a wish that I would send you a copy of the sonnet I left in your brother's coffin along with the flowers, I now do so. It must be judged not as a literary production, but as last words straight from the heart of one who loved and revered your brother.

Yours very sincerely, I William Sharp 


\title{
To Dante Gabriel Rossetti ${ }^{5}$
}

\author{
AVE! MORS NON EST! \\ True heart, great spirit, who hast sojourn'd here \\ Till now the darkness rounds thee, and Death's sea \\ Hath surged and ebbed and carried suddenly \\ Thy Soul far hence, as from a stony, drear, \\ And weary coast the tide the wrack doth shear; \\ Thou art gone hence, and though our sight may be \\ Strained with a yearning gaze, the mystery \\ Is mystic still to us: to thee, how clear! \\ O loved great friend, at last the balm of sleep \\ Hath soothed thee into silence: it is well \\ After life's long unrest to draw the breath \\ No more on earth, but in a slumber deep, \\ Or joyous hence afar, the miracle \\ Await when dies at last imperious Death.
}

W.S.

Memoir 63

\section{To William Bell Scott, [April] 22, [1882]}

13 Thorngate Road | Sutherland Gardens | W. | Saturday 22nd

Dear Mr. Scott ${ }^{6}$

Pray accept my best thanks for the very welcome present of your book.

I did not get home till midnight last night, yet it was well on in the morning before I could put the volume down. The peculiar individuality that has always attracted me in your work hitherto is even more observable in some ways here than anything I have yet seen. They are emphatically not verses to read once and lay down for good - for the majority of them are of the kind that delight both the imagination and 
the intellect. I promise myself many a fine thought and pleasurable thrill in the many future perusals I hope to give them. Later on, if you can care to have the opinion of one as young in the art as myself, I should like to let you know what especially touches myself, and wherein in my judgment you have excelled.

I expect my own "first-born" to make its appearance within 10 days at least, if Elliott Stock is true to his word.

Yours very sincerely | William Sharp

ALS University of British Columbia

\section{To Edward Dowden, May 22, 1882}

13 Thorngate Road | Sutherland Gardens | London | W. | 22/5/82

My dear Sir, 7,8

I send you by this post a copy of my first volume, published a week or two ago, - which I trust you will accept as a slight mark of the esteem and regard I hold you in as a poet and critic.

It may interest you to know that much of The Human Inheritance is personal. The descriptions in that poem and elsewhere of Australian \& other scenery are from observation, and not reading - as after leaving college, I knocked about the other side of the world a bit to recover health, which was somewhat shaky.

You may also care to hear that the Sonnet called Spring-Wind (which appeared also, by the bye, in Hall Caine's collection of Eng. Sonnets) was written one windy March Sunday morning of last year in the garden of 16 Cheyne Walk, while staying there with my friend Dante Rossetti.

$\mathrm{He}$, by the bye, I have heard speak most warmly of both your poetical \& critical gifts. His death was indeed a loss, not only to those who knew him well, but to all who loved art and literature. Personally speaking, I know that the encouragement of and belief he had in myself will always be with me an impulse to good work. 
I may mention that I procured your address from a mutual friend.

Very sincerely yours | William Sharp

E. Dowden Esq.

ALS TCD.

To Hall Caine, [June 5, 1882]

Monday Mrg.

My dear Caine

Thanks for the information.

I am afraid my letter must have somewhat misled you, for you seem to be under the impression that I do not sufficiently value the Athenaeum notice. ${ }^{9}$ This is quite a mistake, as it is by far the most important one for me that I have received, and I am exceedingly grateful to Watts for it. What I meant to say was that the Yk. Post's ${ }^{10}$ notice was the best criticism as criticism that I had seen, the Athenaeum's, however important and welcome, being more a valuable notice than really a critique. I should be exceedingly sorry if I thought Watts had any reason to imagine I was not sufficiently grateful for the good service he has done me - and I trust that you have, however inadvertently, not given him this impression.

You will regret to hear that James Thomson (the poet I mean, of course) is dead. ${ }^{11}$ He died at University Hospital on Saty night at 10 o'clock. He came to make a call on Philip on Thursday, \& seemed then all right, tho' very quiet and subdued. Late in the evening we thought it advisable to send for a doctor, \& subsequently I carried him downstairs \& took him to the Hospital in a cab. This was the only step to be taken, as he is absolutely lodgingless as well as homeless. He seemed better on Friday, tho' very weak - and perhaps still better on Saty afternoon - but before midnight the poor fellow had escaped his insomnia and 
other miseries. He's to have another volume coming out in the Autumn I understand.

I let you know this matter as you may wish it for "news"; \& as I don't suppose it's in today's papers.

Hoping erelong that we may see more of each other.

Yours ever sincerely | William Sharp

ALS British Library.

\section{To Hall Caine, [June 15, 1882] $]^{12}$}

My dear Caine

I will obtain 2 more bottles of Hydoleine for you with pleasure - but I have not a disengaged hour this week! you are feeling seedy it wd. perhaps be better for me to come to you than vice versa. So I will endeavor to turn up at No. 16 at the earliest opportunity, sending if practicable a card first.

I will give P.B.M. ${ }^{13}$ your message. He will also be pleased to hear you have quoted his sonnet on Thomson. I don't think I shall ever write anything on Thomson, ${ }^{14}$ as the personal reminiscences are slight, indeed I have only met with about two people who knew him really well. Philip knew him better than I did, personally, tho' I am more acquainted with certain passages in his life. But neither of us are really qualified to write personal reminiscences.

Hoping you will soon be all right again.

In extremity of haste | Yours ever | William Sharp ALS Manx Museum, Isle of Mann. 


\section{To Hall Caine, [July?, 1882]}

Friday Morning

\section{Dear Caine,}

I write this note in case you shd. be out when I call.

If you had made yourself acquainted with the matter as it really stood, you would not have written me the letter I have just received, containing as it does expressions which I cannot but feel insulting.

In the first place, my projected book is not to be a biography at all. ${ }^{15}$ After the Harper's affair fell through I did think of writing a Memoir of Rossetti, but the moment I learned that you intended such a work I threw up my plans, both because I thought you had a prior claim and were in a better position to do it well than myself. ${ }^{16}$ When E. Stock told me of the volume, I knew at once he meant you, and I informed him at once that I wd. be quite willing to miss out the biographical portion altogether. As it is, the book Macmillians are to bring out, is a Study of the Poet-Artist - for in deference to your own work I determined to make the biographical portion consist of only about $10 \mathrm{pp}$ or so. At most, this chapter (the first - "Life") will not be more than a rechauffé of already disseminated information. The main portion of the book will be a critical study of his poetic work. Now, as I understand your book is to be purely a biographical Memoir, with correspondence, \& - I fail to see where the two clash. Stock himself saw this in the same light, \& wd. have been willing to have brought out both books if I had agreed to his terms.

Do you know, I had somewhat hastily \& foolishly concluded I had won your friendship? But I am now disillusioned - otherwise you could not have so insulted me as to infer that I sent the announcement of my book in order to annul the effect of an announcement of your own. And how, moreover, could I know that there was any announcement of yours previously sent at all? I never dreamt you wd. misunderstand the matter. I thought it a fact that your book wd. be out 2 mos. or more before my own, so that, if anything, it wd. be you damaging me instead of the contrary. Whatever I may be in a literary sense, I hope at least I am a gentleman. 
I regret you have withdrawn your announcement. I had been looking forward with the greatest interest to reading your book.

I give you the benefit of the doubt in supposing you did not intentionally insult me by your reason there for. As a known friend of Rossetti's I have no need to "claim intimacy" with him. You will excuse me if I say that your sneer seems to me to cut both ways.

I have much more reason to object to Mr. Tirebuch's $\mathrm{s}^{17}$ writing on the same lines as myself. But I don't, \& will welcome his contribution to our knowledge of R's art and influence. With either Theodore Watts, Wm. R. or yourself, I would not contend - each being far fitter than myself for a biographical Memoir. But I have a right to my own opinions as to his art and poetry, \& if I choose to publish a book engaged by a firm of publishers, embodying those opinions, I do not see that you or anyone else need object. Doubtless your critical faculty is more developed than mine - but despite, in your own words, "your enormous superiority" over myself for the work in question, I may perhaps be vain enough to consider my own judgment not wholly worthless.

Frankly, I must tell you I exceedingly regret this matter having come between us: for I had come to like you, \& to hope that our friendship would grow and fructify. But if you consider my conduct only in the light of what you designate as "journalistic sharp practice", then there must be an end to this friendship.

With every good wish for the success of your book, which I hope you will still proceed with,

I am I Yours very truly | William Sharp ALS Manx Museum, Isle of Man. 


\section{To Edward Dowden, July 16, 1882}

13 Thorngate Road | Sutherland Gardens | London | W.

My dear Sir,

I have heard one or two friends mentioning the probability of your being in London during July, and I now write to say that if this is to be the case I hope I may have the pleasure of seeing you. I have known you a good long time now through both your critical and poetic work, and I have always since wished to meet you in the flesh as well. If you could come and share my quiet dinner with me at my rooms - or, if you are only going to pay a flying visit, if I could come and see you at your hotel or lodging I should be most glad. At the end of this month, or beginning of August, I leave for Scotland for two months - partly for pleasure, partly to finish more rapidly the volume on Pre-Raphaelitism \& on Rossetti and his work in art and literature which Macmillan commissioned me to write. ${ }^{18}$

I have to thank you very sincerely for kind words as to my book in letters to Miss Hickey \& to Mr. Stock. ${ }^{19} \mathrm{I}$ am looking forward to the letter which you mentioned in your note of a month or so ago as intending to write to me thereon. I have been very fortunate in favourable reviews as yet, \& Rossetti's prognostication as to its reception have not been falsified after all.

Hoping the report of your coming over to London for a brief visit is well-founded.

Very sincerely yours | William Sharp

Edward Dowden, Esq.

ALS TCD. 


\section{To William Michael Rossetti, July 21, 1882}

13 Thorngate Road I Sutherland Gardens W. | 21/7/82

Queries in Nos. 8, 9, 10, \& 18

Dear Mr. Rossetti,

I am much indebted to you for your kindness in annotating and correcting my hastily put together trial list. ${ }^{20}$

There is much useful information and corroboration in your notes, though most cases where you have marked 'don't remember this' I have seen the drawings or pictures myself, either in Oxford, Scotland, or in the rooms of owners, besides frequently finding confirmation in the 30 photos or thereabouts Gabriel at different times gave me.

1. As to the Sea-Spell, this I am almost certain is the same as La Ghirlandata, despite the minor difference between the painting having a small harp and the sonnet mentioning a lute. It is a beautiful painting; - I know it well.

2. I did not know about the pencil head of himself belonging to your mother, but I have seen the pen \& ink one I mention.

3. Fra Pace, which I put down at $1850, \&$ which you barely remember but suppose may be later than /50 - this I now think must be one of his earliest. It is exceedingly interesting, and in your brother's early style. I took down a full description of it at the time I saw it. It was, I was told, the first thing of Gabriel's Burne-Jones saw him working at.

4. The 'Annunciation' I know well, \& entered by mistake as a W. Col. ${ }^{21}$

5. 'Morning Music', which you don't know of, I have seen. It is a square water-colour, painted in 1850 - and early found its way to some dealers, $\&$ thence to present owner.

6. 'How They Met Themselves' - The Photo has on it the dates 1851/1860. I take it the design was in 1851, the water-colour in /60, and an improved replica in 1864, now belonging to Mr. Graham. 
7. 'Roman de la Rose', which you don't recollect, is a rather inferior early production. Date 1854 .

8. As to 'Mary Magdalene' was it simply a drawing? It was so mentioned in a contemporary notice, and also in the note to the Sonnet - but Ruskin's remarks I thought applied to a water colour or oil, can you tell me for certain?

9. 'Venus Verticordia' - I have seen the first chalk study, which differs greatly. I am almost certain I am right as to the first oil being 1858 , \& not as you think about 65 or 66 . There was a fine \& slightly altered 'replica' about the latter date, which I think Rae has.

10. 'The Farmer's daughter' - this water colour was either the study for or taken from the idea, of "Found". ${ }^{22}$ The treatment is almost the same as in the oil. It was executed probably in 1861, exhibited in Edinburgh in 1862. Do you think you are right in supposing "Found" to have been begun so long ago as 1853? I remember Gabriel's (I think) telling me that it had been on hand nearly 20 years; this would bring it to about 1861 .

11. In addition to the Hamlet and Ophelia, pen and ink (date unknown to me) - there was a water colour which I have seen. It was finished in April /64. called, as in my list, First Madness of Ophelia, \& quite different from the Pen \& Ink Scene.

12. Il Ramoscello, which you don't remember, is a beautiful little oil, about which I have some interesting particulars. Painted in 1865.

13. The drawing of Christina R. I have put this down at Sept. 1866, which date you doubt, thinking about Dec/60. My only reason for differing is the distinctly stated 'September 1866' in the photo of it Gabriel gave me.

14. Mariana. Surprised you don't remember this as an oil. It is one of the finest of his achievements in depth of colour (blue). Very large picture. Rae's an early water colour. I know of nothing in contemporary art to equal the wonderful management of the hues of deep blue throughout her dress. It has, of course, nothing to do with the Tennyson Illustration. Really a portrait of Mrs. Morris.

15. There are two oils called 'Beata Beatrix', the same as you mean by the Dying Beatrix or B. in trance. 
Much the finer belongs to Lord Mt. Temple, date of beginning the work, as you say, about the latter part of 1862 .

The second belongs to Graham. Not as fine, but has a Predella which the other lacks (not a double Predella, as I mistakenly said). Finished in 1872 - as a favour in return for a kindness of great service. Had been asked before to do it but always refused till 1871 .

16. As to the oil named 'La Fleur du Mari' or 'La Fleur de Marie', I must find out the exact name. I was told at the time it was the former. Save 'Found' it is the only modern work of his I know. Subject contemporary. Lady Standing before an oaken chest. Sage green apron over green-blue dress. Upstretched arms towards a blue vase with yellow kingcups in it. She meant to be another flower herself, Fleur du Mari? Date 1874.

17. Sancta Lilias. My date was 1879, but you think about /73. My authority the date on the drawing in Studio. Also in Photo.

18. I fancy the drawing (W. Colour) (Sprinkling the lintels with blood) I spoke of as in the Taylor Museum at Oxford is really the same as the drawing "The Passover in the Holy Family", described in Sonnet of same name. If so, it must be synonymous with the "Mary gathering the bitter Herbs for the Passover", mentioned by Ruskin in conjunction with Mary Magdalene, as two such noble works.

As you kindly tell me to write on any point of difficulty, I shd be glad (if writing is not hurtful to you at present) to know who owns Helen of Troy, La Donna della Finestra (the painting, not the drawing, which I know) and the Dante \& Giotto. Also Mr. Turner's address, who owns the Frainmetta, which I have not seen. And if you would give me an introduction to Mr. Rae, (his Liverpool address) I should be greatly obliged, as I shall go to Scotland via Liverpool on purpose. Also Leyland's address.

I am causing you I fear a great deal of trouble, but I must again plead that it is not for my sake alone that I wish to be accurate and as complete as practicable. I wish the book to be really an authority, \& to give a full \& true account of Gabriel's life work.

I have read Tirebok's essay - but think very little either of its style or matter. In the first place he is evidently forming an opinion on but little 
basis, \& in the next I doubt much his qualifications for art criticism at all, from what I have heard of him.

There is a very unjust and (apart from my differing from the views taken) very incompetent review of Gabriel's poetry, in the British Quarterly for July. His whole life work is condemned in the most sweeping manner, and with a severity that would be almost out of place in a depreciator of Villon or Baudelaire.

It makes me all the more glad that a friend like myself (who admire, moreover, by no means indiscriminately) should be engaged in what may give a fair and just account of one who beyond all detraction was a great artist and great poet.

Hoping your gout will soon be a thing of the past, and with renewed best thanks for all the trouble you have kindly undertaken on my behalf.

Sincerely Yours, I William Sharp

ALS University of British Columbia

To F. S. Ellis, [July 21, 1882] $]^{23}$

13 Thorngate Road I Sutherland Gardens W.

My dear Sir,

Thanks for your note and permission to see your "Bella Mano" and "Donna della Finestra" (which I am glad to learn you possess as I could not find out who the owner was - tho' I know the chalk study of it belonging to Mr. Graham).

Tuesday forenoon will be much the most convenient time for me, so I will go to Epsom then. I think I know the house, it is not far from my friends the Robinsons' cottage.

With thanks I Yours sincerely | William Sharp

F. S. Ellis Esq. 
P.S. If there are no dates on "La Bella Mano" or "La Donna d. F". I should be much obliged if you would kindly leave a slip of paper with the date of painting of each, or failing this of your purchase. The former if I am not mistaken was either 1874 or 1875.

ALS UCLA.

\section{To F. S. Ellis, [July 25, 1882] $]^{24}$}

13 Thorngate Road I Sutherland Gardens W.

Dear Sir,

I write to say I shd. be greatly obliged if you cd. send me a card with (if you know) the date of the chalk study of "Lilith" I saw next the door in the drawing room. Also the subject of the companion drawing.

I greatly enjoyed the full inspection I had of "La Bella Mano" - it is a most lovely picture. "La D. della F" I was glad to see again also.

With my best thanks for the courtesy I met with at your house,

Yours sincerely | William Sharp.

ACS UCLA

To Theodore Watts [-Dunton], July 27, 1882

Tuesday | 13 Thorngate Rd

I think I must postpone my small dinner party till the autumn, as Philip ${ }^{25}$ leaves London on Wednesday week, \& Miss Blind ${ }^{26}$ not long after.

May the Gods be more favourable next time.

Yours ever sincerely | W. S. 


\section{To Hall Caine, [? September, 1882] [7}

My dear Caine

Tho' overwhelmed with work I must send you a line of congratulatory welcome for your book. It is a most fascinating volume, from its general get-up (which does Stock the highest credit) to the material itself...

... besides staying for a day or two at a time frequently... On the other hand I have to thank you for your very kind reference to myself on p 291 - just saying what is most pleasing to myself: not only that he appreciated my work but also that I cheered him up a bit. He often told me this, but I am glad to have it confirmed...

P.S. I caught it from Mrs. W M R for my "unqualified abuse" of Madox Brown in re his etching.

Manx Museum, Isle of Man

\section{To William Michael Rossetti, October 23, 1882}

13 Thorngate Road I Sutherland Gardens. W.

Dear Mr. Rossetti,

As you said it would do equally for you, and as I now find it would be greatly more convenient for me, I will come unless I hear from you to the contrary on Sunday next about 10 a.m. On Monday I go to Hampshire for a fortnight or more, and it might be too late on my return. I am glad you are agreeable to include the unsold drawings in my Catalogue, ${ }^{28}$ not only because I am anxious to prove by demonstration that Rossetti really did get through a great amount of sterling work - and again because several desirous and likely purchasers both in Scotland and England have asked me to let them know the subjects and sizes etc. of some of those for sale - and I have always replied, that while I should let them hear from me on any one or more drawings which I wd know 
wd be suitable, they would in all probability find all the information in my Supplementary Catalogue, when they could write you direct.

In haste | Yours most sincerely | William Sharp ALS, private

\section{To Richard Garnett, [Early November, 1882]}

Northbrook | Micheldever | Hants. ${ }^{29}$

Dear Mr. Garnett

My best thanks for yr. beautiful little "Shelley" - forwarded to me from London. I have only had time to dip into it yet. The preface I especially liked, \& what you say as to Matthew Arnold is particularly apropos.

I shall value it greatly both for its own sake and for that of the Giver.

When I return to London next week - you must write your name on the first fly-leaf. The vol can hardly fail to become widely popular.

My kindest regards to Mrs. Garnett -

Most sincerely yours I William Sharp

P.S. I expect the Rossetti engraving proofs in a few days. It will be almost perfect as a specimen of wood-engraving, Macmillans considering it about the best thing of its kind they have ever issued.

ALS University of Texas at Austin 


\section{To Eugene Lee-Hamilton, November 18, 1882}

13 Thorngate Road | Sutherland Gardens | London W. | 18/11/82

My dear Hamilton,

I last night finished the perusal of your volume, ${ }^{30}$ most of which was not new to me. I must congratulate you most sincerely and heartily on what seems to me a great advance in poetic power and in technical grasp - not that I mean your previous volumes were not up to the mark on either point, only, from my point of view, this volume contains decidedly the best things you have done. Your dramatic power is very noticeable, so much so that I shd. fancy you could manage very successfully some scenes in dialogue or tragic action, even perhaps a sustained and equable play. The New Medusa and The Mandolin are in this respect specially fine: as to the former, you already know my opinion of it - that it stands at the head of your compositions. It seems to me that there is too great a condensation of narrative preceding the account of the woman on the wreck: of course it is understood that the wreck has been reached, that nothing is found of life or anything else on the dismasted ship save the woman, and that she has been taken off from her support - but the narration of this is so very rapid that the effect is rather an artistic break instead of artistic coherency. The lines beginning "I was awake; there was no sound, no light" down to "And sought the breeze of night etc". are very beautiful and powerful.

I think on such an occasion as that which occurs in the fifth line of page 23 it is better to have an extra syllable than an ugly word. "Contradictory" wouldn't scan but it is preferable to "contradict'ry".

Another very powerful passage is that beginning "I was about to wake her, when the moon" etc. (p. 26). But I must again make the strong objection I made before to your sister, regarding the last line. So greatly does it detract from the fine effect of the poem (I am speaking personally of course) that I have struck a broad line through it so that the poem in my copy finishes with "Moonlit Rocks".

I like the "Sack of Prato" better than the "Ballad of the Plague of Florence", though the latter is fine also: and the "Idyll of the Anchorite" is at once dramatic and a terrible satire. 
I am not certain but I fancy your sister considered The Raft your best poem. I cannot agree with this, though [there] are fine things in it.

"On a Tuscan Road" is indeed beautiful; I think the most musical thing you have written, and in its natural features recalling that vague delicious charm you must have experienced in looking at some of the landscapes of Corot and Millet.

A volume of lyrics with such music as:

Slowly the sunset departs from the shrine

Close to the road, but still touches the fountain;

Fewer are those who pass by with a sign;

Dark grow the maize and the hemp and the vine,

Blue is the Mountain.

would be welcome to all those who know your poems, I am sure.

On the whole, "The Mandolin" is in my opinion the most flawless thing you have done. There are verses in "A Letter" as fine as anything of the kind I remember: but though in the "Elegy" there is one fine passage or rather passages ( $p$ 109) I do not care so much about it from a poetical point of view.

There is not one of the sonnets that is not fine; and "Waifs of Time" I am going to copy into Caine's Treasury of Sonnets, as I see you are not represented there as you ought to have been. If a second edition should be required (as is not improbable) I will see that this Sonnet or some other you might prefer is inserted, as I have some influence with Caine, who is now a friend of mine. ${ }^{31}$

Altogether, I have received a great deal of pleasure from your book, and only regret it is so short.

Remember me most kindly to Miss Paget. I shd. like to have sent you a copy of my Rossetti book ${ }^{32}$ but it is the publisher's matter, and I only get a very few copies which I must give to those who have been of special service to me during its composition, and as I am not exactly reveling in the fleshpots of Egypt I can't purchase copies as I wd. like to do.

My cousin sends you her most kind remembrances. She has had equal pleasure with myself in perusing both the old and new friends in your volume.

If I can come to Florence and Italy - O ye Gods! - but I dare not say anything more. Dreams nearly always evaporate if you concentrate 
your mind upon them: so I hope the dream will enfold me till I waken in the South.

Your sincere friend, I William Sharp

E. A. S. wanted me specially to mention "A Tuscan Road" as specially beautiful, and "The Mandolin" as forcible and dramatic.

ALS Colby College Library

\section{To Frederick Langbridge, ${ }^{33}$ December 2, 1882}

13 Thorngate Road I Sutherland Gardens W, London I 2/12/82

My dear Sir

I have just received your kind letter and thank you for wishing to include something of mine in your forthcoming collection. I don't quite gather if it must be something unpublished: if not, I shall be gratified if you can find something in my volume, ${ }^{34}$ which I send herewith, worthy of insertion, and I have ventured to mark in pencil one or two passages or poems that might suit for the department of your volume you specify. If it is essential that it must be something unpublished kindly send me a card, and I will look amongst my MSS or else write something specially for you - but the truth is that I have just returned to town after an absence of about four months in the country and have all my MSS (except what were composed during that period) locked up and as yet not disinterred or copied out, and moreover I am more than pressed for time with several important articles and also the issue of a large volume on the work in art and poetry of the late Dante Gabriel Rossetti, the proofs of which entail continuous and arduous labour.

You will find the passages I have marked at 78, 106, and 175. Overleaf I enclose a sonnet you may care for. It is by a Mr. Eugene Lee-Hamilton, the author of Gods, Saints, and Men, Poems and Transcripts, and The New Medusa from which last mentioned and just published volume it is taken. It was addressed to me in reply to one of mine affirming 
my intense belief in individual immortality, and though I do not agree with its conclusion I consider it a really remarkable sonnet; in the words of my friend Theodore Watts, "every poet since Landor and Shakespeare has been trying to say something new about the murmurs of a sea-shell and no one has yet notably succeeded, and yet here is an almost unknown and by no means great poet (though true one so far as he goes) who succeeds where so many have failed". The author, poor fellow, exists and has existed for long in a living death (from a terrible spinal affliction) and cannot possibly survive many years. How he can still cling to life (only 2 hours in the day wherein he dare be read to or compose), especially with absolutely no hope or belief for the future as regards to himself, is a mystery to me.

I must thank you doubly for your "Songs in Sunshine": - in the first instance for your courtesy in sending it to me, and in the second for the real and genuine pleasure it has afforded and will continue to afford me. Such a lyric gift as you are the happy possessor of is very unusual, and nowadays is specially welcome when such a tide of Rossettian, Swinburnian, and wearisomely repetitive verses is constantly flowing forth. Many of the poems have the charm that is so characteristic of Herrick at his best, especially such really lovely little lyrics as Norah at the Fair and The Little Roundhead Maid, which I have read several times already. Moonshine and Ripe Cherries have the same delightful charm, and My Own Girl is such a song as must surely reach far and wide. The book has also the great merit of not being too large, and of containing nothing poor; and I only hope I may still get it for review in some magazine or periodical: - if I do; I will write a review of it with a pleasure that is very infrequent in this branch of literature as I have experienced too often. Although in themselves joy in life, gladness in the human delights that make life after all so beautiful, and belief in divine goodness and in immortality do not constitute poetry, they undoubtedly add much to it when spontaneously and convincingly accompanying it, and this is certainly the case in your volume, which I hope again and again to recur to and always with pleasure and refreshment. Indeed, speaking personally, it is refreshment that is its most happy characteristic. My own volume is in a very different style and it is not in the nature of things it can afford you so much enjoyment as yours can myself, unless perhaps you are very susceptible to nature 
which I passionately love and have loved since I can remember and with which my verse is charged throughout. It may interest you to know that the first three parts of The Human Inheritance are personal and practically literally exact, but this information is of course private.

If I do not hear from you to the contrary I shall understand you have found something in my volume that will serve your purpose.

Believe me, I Yours very Sincerely, I William Sharp ALS Pierpont Morgan Library

\section{To Robert Browning, December 10, 1882}

10th Decr. / 82 | 13 Thorngate Road I Sutherland Gardens W.

Dear Mr. Browning

I have been able to procure half a dozen proofs on India paper of poor Rossetti's Sonnet design - the same that forms the frontispiece to my immediately forthcoming volume on his work - artistic and poetic.

The design has a double appeal - both to the poet and artist, \& this combined with your former intimacy with him made me think you would like to possess this his latest original design. The mounters have unfortunately not done their work very neatly, \& have stretched the impression too tightly, but perhaps one ought to be thankful they have not spoilt it altogether.

Sincerely yours I William Sharp

Armstrong Browning Library. Baylor. 


\section{To Edward Dowden, [December 10, 1882]}

13 Thorngate Road I Sutherland Gardens I London I W.

My dear Mr. Dowden,

You may have heard (or I may have told you myself when writing you before) that Macmillans are going to issue a vol. of considerable length (450 pp) on Rossetti's art-work and on his poetry. As a frontispiece Christina R. \& her mother kindly gave me D.G.R'.s beautiful SonnetDesign for engraving purposes, \& it has been finely done on wood. This design has a triple interest - it is the last original design Rossetti made (1880), it has great beauty as a piece of fine draughtsmanship, and it has a special interest to the poet and the lovers of poetry.

I felt certain you would like to have a proof, both for the sake of having something of R's art-work and because of the interest you must necessarily take in such a design as a poet and sonnet-writer yourself and so I send by this post one of the half dozen proofs in India ${ }^{35} \mathrm{I}$ have been able to procure.

I shd. like to have sent you a copy of the book when it comes out (from the 16th to the 20th I understand) but I am obliged to be niggardly in respect of private distribution, as it is a big venture for Macmillans \& I have but few to give away \& can't afford to buy others. Perhaps, however, you may be able to get it for review from the Academy, by application therefor, which I shd. be glad of on two accounts.

Faithfully yours I William Sharp

P.S. If over to see the Rossetti exhibit at Burlington House ${ }^{3637}$ I hope I may have the pleasure of seeing you. 


\section{To Elizabeth A. Sharp, March 14, 1883}

Florence $^{38} \mid$ Wednesday, 14:3:83.

Yesterday morning I went to Sta. Maria Novella, and enjoyed it greatly. It is a splendid place, though on a first visit I was less impressed than by Santa Croce... .

The monumental sculpture is not so fine as in Santa Croce, but on the other hand there are some splendid paintings and frescoes - amongst others Cimabue's famous picture of the Virgin seated on a throne. I admired some frescoes by Filippino Lippi - also those in the Choir by Ghirlandaio: in the Capella dei Strozzi (to the left) I saw the famous frescoes of Orcagna, the Inferno and Paradiso. They greatly resemble the same subjects by the same painter in the Campo Santo at Pisa. What a horrible imagination, poisoned by horrible superstitions, these old fellows had: his Paradise, while in some ways finely imagined, is stiff and unimpressive, and his Inferno simply repellent. It is strange that religious art should have in general been so unimaginative. The landscapes I care most for here are those of the early Giottesque and preRaphaelite painters - they are often very beautiful - for the others, there is more in Turner than in them all put together.

Memoir 79-80

\section{To Elizabeth A. Sharp, March 18, 1883}

Florence, 18:3:83.

Well, yesterday after lunch I went to the Chiesa del Carmine, and was delighted greatly with the famous frescoes of Masaccio, which I studied for an hour or more with great interest. He was a wonderful fellow to have been the first to have painted movement, for his figures have much grace of outline and freedom of pose. Altogether I have been more struck by Masaccio than by any other artist save Michel Angelo and 
Leonardo da Vinci. If he hadn't died so young (twentyseven) I believe he would have been amongst the very first in actual accomplishment. He did something, which is more than can be said for many others more famous than himself, who merely duplicated unimaginative and stereotyped religious ideas. ${ }^{39}$

Yesterday being Holy Thursday we went to several Churches and in the afternoon and evening to see the Flowers for the Sepulchres. Very much impressed and excited by all I saw. I was quite unprepared for the mystery and gloom of the Duomo. There were (comparatively) few people there, as it is not so popular with the Florentines as Sta. Maria Novella - and when we entered, it was like going into a tomb. Absolute darkness away by the western entrances (closed), a dark gloom elsewhere, with gray trails of incense mist still floating about like wan spirits, and all the crosses and monuments draped in black crape, and a great canopy of the same overhead. Two acolytes held burning tapers before only one monument, that of the Pieta under the great crucifix in the centre of the upper aisle - so that the light fell with startling distinctness on the dead and mutilated body of Christ. Not a sound was to be heard but the wild chanting of the priests, and at last a single voice with a strain of agony in every tone. This and the mystery and gloom and pain (for, strange as it may seem to you, I felt the agony of the pierced hands and feet myself) quite overcame me, and I burst into tears. I think I would have fainted with the strain and excitement, if the agony of the Garden had not come to an end, and the startling crash of the scourging commenced, the slashing of canes upon stones and pillars. I was never so impressed before. I left, and wandered away by myself along the deserted LungArno, still shivering with the excitement of almost foretasted death I had experienced, and unable to control the tears that came whenever I thought of Christ's dreadful agony. To-day (Good Friday) the others have gone to church, but I couldn't have gone to listen to platitudes - and don't know if I can bring myself to enter the catholic churches again till the Crucifixion is over, as I dread a repetition of last night's suffering. I shall probably go to hear the Passion Music in the church of the Badia (the finest in Florence for music). How I wish you were with me... .

Memoir 80-81 


\section{To Elizabeth A. Sharp, April 3, 1883}

Florence, 3:4:83.

... The last two days have been days of great enjoyment to me. First and foremost they have been heavenly warm, with cloudless ardent blue skies - and everything is beginning to look fresh and green. Well, on Monday I drove with Mrs. Smillie ${ }^{40}$ away out of the Porta San Frediano till we came in sight of Scanducci Alto, and then of the Villa Farinola. There I left her, and went up through beautiful and Englishlike grounds to the house, and was soon ushered in to Ouida's presence. ${ }^{41}$ I found her alone, with two of her famous and certainly most beautiful dogs beside her. I found her most pleasant and agreeable, though in appearance somewhat eccentric owing to the way in which her hair was done, and also partly to her dress which seemed to consist mainly of lace. A large and beautiful room led into others, all full of bricabrac, and filled with flowers, books, statuettes and pictures (poor), by herself. We had a long talk and she showed me many things of interest. Then other people began to arrive (it was her reception day).

Before I left, Ouida most kindly promised to give me some introductions to use in Rome. Yesterday she drove in and left three introductions for me which may be of good service - one to Lady Paget, wife of the British Ambassador, one to the Storys, and one to Tilton, the sculptor. ${ }^{42}$

Yesterday I perhaps enjoyed more than I have done since I came to Italy. In the morning Arthur Lemon, ${ }^{43}$ the artist, called for me, and being joined by two others (Lomax ${ }^{44}$ an artist, and his brother) we had a boat carried over the weir and we into it at the Cascine and rowed downstream past the junction of the Mugnone and Arno, till Florence and Fiesole were shut from view, and the hills all round took on extra beauty - Monta Beni on the right and Monte Morello on the left glowing with a haze of heat, and beyond all, the steeps of Fallombrosa in white - and Carrara's crags also snowcovered behind us. We passed the quaint old church and village of San Stefano and swung inshore to get some wine... .

We rowed on and in due course came in sight of Signa. We put on a spurt (the four of us were rowing) and as we swept at a swift rate 
below the old bridge it seemed as if half the population came out to see the unusual sight of gentili signorini exerting themselves so madly when they might be doing nothing. We got out and said farewell to the picturesquelooking fellow who had steered us down - had some breakfast at a Trattoria, where we had small fish halfraw and steeped in oil (but not at all bad) - kid's flesh, and delicious sheep'smilk cheese, bread, and light, red, Chianti wine. We then spent two or three hours roaming about Signa, which is a beautifully situated dreamy sleepy old place - with beautiful "bits" for artists every here and there - old wells with lizards basking on them in numbers - and lovely views.

We came back by Lastia, a fine ancient walled town, and arrived in Florence by open tramcar in the evening, finally I had a delicious cold bath. The whole day was heavenly. If the river has not sunk too low when I return from Rome, Arthur Lemon and some other artists and myself are going on a sketching trip down the Arno amongst the old villages - the length of Pisa - taking about two days.

Memoir 81-83

\section{To Elizabeth A. Sharp, [early April, 1883]}

Rome

... It is too soon to give you my impressions of Rome, but I may say that they partly savour of disappointment... . Of one thing however, I have already seen enough to convince me - and that is that Rome is not for a moment to be compared to Florence in beauty - neither in its environs, its situation, its streets, nor its rivers. Its palaces may be grander, the interiors of its churches more magnificent, its treasures of art more wonderful, but in beauty it is as far short as London is of Edinburgh. But it has one great loveliness which can never tire and which charms immeasurably - the fountains which continually and every here and there splash all day and night in the sunlight or in green grottoes in the courts of villas and palaces. I am certain that I should hate to live here - I believe it would kill me - for Rome is too old to be alive - unless 
indeed a new Rome entirely overshadows the past. I don't suppose you will quite understand, and I cannot explain just now - but so I feel. Florence (after the cold has gone) is divine - air, atmosphere, situation, memory of the past, a still virile present - but Rome is an anomaly, for what is predominant here is that evil medieval Rome whose eyes were blind with lust and hate. Ancient Rome is magnificent - but so little remains of it that one can no more live in it than in Karnak or Thebes: as for modern Rome, everything seems out of keeping - so that one has either to weary with the dull Metropolitanism of the capital of Italy or else to enter into the life of the medieval ages... .

I expect and believe that I shall find Rome beautiful in many things, even as she is already majestic and wonderful - and that the more one becomes acquainted with the Eternal City the more one loves or at least reverences and delights in it.

Meanwhile, however, with me, it is more a sense of oppression that I experience - a feeling as if life would become intolerable unless all sense of the past were put away. I hate death, and all that puts one in mind of death - and after all Rome is only a gigantic and richly ornamented tomb... .

How I hate large cities! Even Florence is almost too large, but there at least one can always escape into open space and air and light and freedom at will - and the mountains are close, and the country round on all sides is fair, and the river is beautiful. Do not be provoked with me when I say that Signa, for instance, is more beautiful to me than Rome - and that the flashing of sunlight in the waters of the fountains, the green of Spring in the flowered fields and amongst the trees, and the songs of birds and the little happyeyed children, mean infinitely more to me than the grandest sculptures, the noblest frescoes, the finest paintings. This is my drawback I am afraid, and not my praise - for where such hundreds are intensely interested I am often but slightly so. Again and again when I find myself wearied to death with sightseeing I call to mind some loch with the glory of morning on it, some mountainside flecked with trailing clouds and thrilling me with the bleating of distant sheep, the cries of the cliff hawks, and the wavering echoes of waterfalls: or, if the mood, I recall some happy and indolent forenoon in the Cascine or Monte Oliveto or in the country paths leading from Bellosguardo, where I watched the shadows playing 
amongst the olives and the dear little green and grey lizards running endlessly hither and thither - and thinking of these or such as these I grow comforted. And often when walking in the Cascine by myself at sunset I have heard a thrush or blackbird call to its mate through the gloom of the trees, or when looking toward Morello and the Appenine chain and seeing them aglow with wonderful softness, or on the Arno's banks I have seen the river washing in silver ripples and rosy light to the distant crags of Carrara where the sun sank above the Pisan sea - often at such times my thrill of passionate and sometimes painful delight is followed by the irrepressible conviction that such things are to me more beautiful, more worthy of worship, more full of meaning, more significant of life, more excelling in all manner of loveliness, than all the treasures of the Affix and the Pitti, the Vatican, and the Louvre put together. But whenever I have expressed such a conviction I have been told that the works of man are after all nobler, in the truer sense lovelier, and more spiritually refreshing and helpful - and though I do not find them so, I must believe that to most people such is the case, perhaps to the infinite majority.

And, after all, why am I to be considered inferior to my fellows because I love passionately in her every manifestation the mother who has borne us all, and to whom much that is noblest in art is due?...

Yet I would not be otherwise after all. I know some things which few know, some secrets of beauty in cloud, and sea and earth - have an inner communion with all that meets my eyes in what we call nature, and am rich with a wealth which I would not part with for all the palaces in Rome. Do you understand me, Lill, in this?... Poor dear! I had meant to have told her all about my visit to Orieto (alone worth coming to Italy for - if only to behold the magnificent Cathedral) but instead I have only relieved my mind in a kind of grumbling... .

What fascinates me most in Rome is the sculpture. Well as I knew all the famous statues, from copies and casts, some of them were almost like new revelations - especially the Faun of Praxiteles, of which I had never seen a really good copy. Can't say, however, I felt enthusiastic about the Capitoline Venus.

Memoir 83-86 


\section{To Elizabeth A. Sharp, April 16, 1883}

Rome, I 16th April, 1883

I have just come in from the Campagna where I have spent some of the happiest hours I have yet had in Rome. I went for some three miles across the glorious open reaches of tall grass, literally dense with myriads of flowers - not a vestige of a house to be seen, not a hint of Rome, nothing but miles upon miles of rolling grassy slopes till they broke like a green sea against the bluepurple hills, which were inexpressibly beautiful with their cloudshadows athwart their sides and the lingering snows upon their heights. There was not a sound to be heard save those dear sounds of solitary places, and endless hum of insects, the cries of birds, the songs of many larks, the scream of an occasional hawk, the splash of a stream that will soon be dried up, and the exquisite, delicious, heavenly music of the wind upon the grass and in the infrequent trees... . And a good fairy watched over me today, for I was peculiarly fortunate in seeing one or two picturesque things I might have missed. First, as I was listening to what a dear spark of a lintie was whistling to its mate, I heard a dull heavy trampling sound, and ongoing to a neighbouring rise I saw two wild bulls fighting. I never realised before the immense weight and strength these animals have. Soon after, a herd of them came over the slope, their huge horns tossing in the sunlight and often goring at each other. I was just beginning to fancy that I had seen my last of Rome (for I had been warned against these wild cattle especially at this season) when some picturesquelyattired horsemen on shaggy little steeds came up at full speed, and with dogs and long spears or poles and frantic cries urged the already half furious, half terrified animals forward. It was delightful to witness, and if I were a painter I would be glad to paint such a scene. I then went across a brook and up some slopes (half buried in flowers and grasses) till I came to a few blackthorn trees and an old stonepine, and from there I had a divine view. The heat was very great, but I lay in a pleasant dreamy state with my umbrella stuck tentwise, and I there began the first chapter of the novel I told you before I left that I intended writing. I had been thinking over it often, and so at last began it: and certainly few romances have been begun in lovelier places. Suddenly, through one eye, as it were, I caught sight of 
a broad moving shadow on the slope beyond me, and looking up I was electrified with delight to see a large eagle shining goldbronze in the sun. I had no idea (though I knew they preyed on lambs, etc., further on the Campagna and in the Maremma) that they ever came so near the haunts of men. It gave one loud harsh scream, a swoop of its broad wings, and then sailed away out of sight into the blue haze beyond the farthest reaches I could see.

Away to the right I saw a ruined arch, formerly some triumphal record no doubt, and near it was a shepherd, clad in skins, tending his goats. No other human sign - oh, it was delicious and has made me in love with the very name of Rome. Such swarms of lizards there were, and so tame, especially the green ones, which knew I wouldn't hurt them and so ran on to my hands. The funniest fly too I ever saw buzzed up, and sat on a spray of blackthorn blossom and looked at me: I burst out laughing at it, and it really seemed to look reproachfully at me and for a moment I felt sorry at being so rude. I could have lain there all day, so delicious was the silence save for these natural sounds - and all these dear little birds and insects. What surprised me so about the flowers was not only their immense quantity, but also their astounding variety. At last I had to leave, as it is not safe to lie long on the Campagna if one is tired or hungry. So I strolled along through the deep grasses and over slope after slope till at last I saw the clump of stone pines which were my landmark, and then I soon joined the road... .

Memoir 86-88

\section{To Elizabeth A. Sharp, April 30, 1883}

Sienna | April, 1883

You will see by the above address that I have arrived in this beautiful old city.

I left Rome and arrived in Perugia on Thursday last - spending the rest of the day in wandering about the latter, and watching the sunset over the farstretching Umbrian country. I made the acquaintance of 
some nice people at the Hotel, and we agreed to share a carriage for a day - so early on Friday morning we started in a carriage and pair for Assisi. About 3 miles from Perugia we came to the Etruscan tombs, which we spent a considerable time in exploring: I was much struck with the symbolism and beauty of the ornamental portions, Death evidently to the ancient Etrurians being but a departure elsewhere. The comparative joyousness (exultation, as in the symbol of the rising sun over the chief entrance) of the Etruscans contrasts greatly with the joylessness of the Christians, who have done their best to make death repellant in its features and horrible in its significance, its possibilities.

Only a Renaissance of belief in the Beautiful being the only sure guide can save modern nations from further spiritual degradation and not till the gloomy precepts of Christianity yield to something more akin to the Greek sense of beauty will life appear to the majority lovely and wonderful, alike in the present and in the future.

After leaving the Tombs of the Volumnii we drove along through a most interesting country, beautiful everywhere owing to Spring's feet having passed thereover, till we came to the Church of Sta. Maria degli Angeli - on the plain just below Assisi. We went over this, and then drove up the winding road to the gray old town itself, visiting, before ascending to the ruined citadel at the top of the hill, the Chiesa di Santa Chiara. Lying on the grass on the very summit of the hill, we had lunch, and then lay looking at the scenery all round us, north, south, east, and west. Barren and desolate and colourless, with neither shade of tree nor coolness of water, these dreary Assisi hills have nothing of the grandeur and beauty of the barrenness and desolation of the north - they are simply hideous to the eye, inexpressibly dreary, dead, and accursed. I shall never now hear Assisi mentioned without a shudder, for picturesque as the old town is, beautiful as are the Monastery, the Upper Church, the paintings and the frescoes - they are over weighted in my memory with the hideousness of the immediate hill-surroundings. It made me feel almost sick and ill, looking from the ruined citadel out upon these stony, dreary, lifeless hills - and I had again and again to find relief in the beauty of more immediate surroundings - the long grasses waving in the buttresses of the citadel, the beautiful yellow (absolutely stainless in colour) wallflowers sprouting from every chink and cranny, and the green and gray lizards darting everywhere and shining in the sunlight. Here at least was life, not death: and to me 
human death is less painful than that of nature, for in the former I see but change, but in the latter - annihilation. These poor mountains! once, long ago, bright and joyous with colour and sound and winds and waters and birds - and now without a tree to give shadow where grass will never again grow, save here and there a stunted and withered olive, like some plaguestricken wretch still lingering amongst the decayed desolation of his birthplace - without the music and light of running water, save, perhaps twice amidst their parched and serried flanks a crawling, muddy, hideous liquid; and without sound, save the blast of the winterwind and the rattle of dislodged stones.

Yet the day was perfect - one of those flawless days combining the laughter of spring and the breath of ardent Summer: but perhaps this very perfection accentuates the desert wretchedness behind the old town of St. Francis. Yet the very day before I went I was told that the view from the citadel was lovely (and this not with reference to the Umbrian prospect in front of Assisi, which is fine though to my mind it has been enormously exaggerated) - lovely! As well might a person ask me to look at the divine beauty of the Belvedere Apollo, and then say to me that lovely also was yon maimed and hideous beggar, stricken with the foulness of leprosy.

The hills about Assisi beautiful! Oh Pan, Pan, indeed your music passed long, long ago out of men's hearing... .

Memoir 88-90

To Edward Dowden, April 30, 1883

Casa Tognazzi | 19 Via Sallustio Bandini | Siena | Italy | 30 Apl 83

My dear Mr. Dowden

Your kind note of last Thursday has been forwarded to me from London. I greatly regret the lost opportunity of seeing you, as I have often looked forward to making your personal acquaintance - but I hope Fortune may be more favourable again. I shall not be returning to London till the late autumn, but if you should be crossing the Irish Channel again 
in the winter or following Spring season, I hope you will not forget my desire to meet you.

I am here - in Italy: learning and unlearning. You probably know Siena: - now, with the glory of Spring brightening every hill and valley in this Umbrian country it is at its best - and there is magic in the air. I do not think Italy so winningly beautiful as the north or so glorious as the tropical south, but it has a pathetic loveliness - exquisite and peculiar to itself.

Hoping you are well, and that our meeting is not always to be in futuro.

Sincerely your I William Sharp

ALS TCD

To Elizabeth A. Sharp, May 7, [1883]

Florence I 7th May

On either Wednesday or Thursday last we started early for Monte Oliveto, and after a long and interesting drive we came to a rugged and wild country, and at last, by the side of a deep gorge to the famous Convent itself. The scenery all round made a great impression on me it was as wild, almost as desolate as the hills behind Assisi - but there was nothing repellant, i.e., stagnant, about it. While we were having something to eat outside the convent (a huge building) the Abbé came out and received us most kindly, and brought us further refreshment in the way of hard bread and wine and cheese - their mode of life being too simple to have anything else to offer.

Owing to the great heat and perhaps overexposure while toiling up some of the barren scorched roads, where they became too hilly or rough for the horses - I had succumbed to an agonising nervous headache, and could do nothing for a while but crouch in a corner of the wall in the shade and keep wet handkerchiefs constantly over my forehead and head. In the meantime, the others had gone inside, and 
as Mrs. S. ${ }^{45}$ had told the Abbé I was suffering from a bad headache he came out to see me and at once said I had a slight touch of the sun - a frequent thing in these scorched and barren solitudes. He took me into a private room and made me lie down on a bed - and in a short time brought me two cups of strong black coffee, with probably something in it - for in less than twenty minutes I could bear the light in my eyes and in a few minutes more I had only an ordinary headache. He was exceedingly kind altogether, and I shall never think of Monte Oliveto without calling to remembrance the Abbé Cesareo di Negro. I then spent about three hours over the famous 35 noble frescoes by Sodoma and Signorelli, illustrating the life of Saint Benedict, the founder of the convent. ${ }^{46}$ They are exceedingly beautiful - and one can learn more from this consecutive series than can well be imagined. While taking my notes and wondering how I was to find time (without staying for a couple of days or so) to take down all particulars - I saw the Abbé crossing the cloisters in my direction, and when he joined me he said, "la Signora" had told him I was a poet and writer, and that I thought more of Sodoma than any of his contemporaries, and so he begged me to accept from him a small work in French on the history of the convent including a fairly complete account of each fresco. A glance at this showed that it would be of great service to me, and save much in the way of notetaking - and I was moreover glad of this memento; he inscribed his name in it... .

The more I see of Sodoma's work the more I see what a great artist he was - and how enormously underrated he is in comparison with many others better known or more talked about. After having done as much as I could take in, I went with the Abbé over other interesting parts and saw some paintings of great repute, but to me unutterably wearisome and empty - and then to the library - and finally through the wood to a little chapel with some interesting frescoes. I felt quite sorry to leave the good Abbé. I promised to send him a copy of whatever I wrote about the Sodomas - and he said that whenever I came to Italy again I was to come and stay there for a few days, or longer if I liked - and hoped I would not forget but take him at his word. Thinking of you, I said I supposed ladies could not stay at the Convent - but he said they were not so rigorous now, and he would be glad to see the wife of the young English poet with him, if she could put up with plain fare and simple 
lodging. Altogether, Monte Oliveto made such an impression on me that I won't be content till I take you there for a visit of a few days... .

Memoir 90-92

To Elizabeth A. Sharp, May 10, 1883

Venezia | 10th May

... I came here one day earlier than I anticipated. What can I say? I have no words to express my delight as to Venice and its surroundings - it makes up a hundredfold for my deep disappointment as to Rome. I am in sympathy with everything here - the art, the architecture, the beauty of the city, everything connected with it, the climate, the brightness and joyousness, and most of all perhaps the glorious presence of the sea... . From the first moment, I fell passionately and irretrievably in love with Venice: I should rather be a week here than a month in Rome or even Florence: the noble city is the crown of Italy, and fit to be empress of all cities.

All yesterday afternoon and evening (save an hour on the Piazza and neighbourhood) I spent in a gondola - enjoying it immensely: and after dinner I went out till late at night, listening to the music on the canals. Curiously, after the canals were almost deserted - and I was drifting slowly in a broad stream of moonlight - a casement opened and a woman sang with as divine a voice as in my poem of The Tides of Venice: ${ }^{47}$ she was also such a woman as there imagined - and I felt that the poem was a true forecast. Early this morning I went to the magnificent St. Mark's (not only infinitely nobler than St. Peter's, but to me more impressive than all the Churches in Rome taken together). I then went to the Lido, and had a glorious swim in the heavy sea that was rolling in. On my return I found that Addington Symonds ${ }^{48}$ had called on me - and I am expecting W. D. Howells. ${ }^{49} \mathrm{I}$ had also a kind note from Ouida.

Joyousness, brightness everywhere - oh, I am so happy! I wish I were a bird, so that I could sing out the joy and delight in my heart. 
After the oppression of Rome, the ghastliness of Assisi, the heat and dust of Florence - Venice is like Paradise. Summer is everywhere here - on the Lido there were hundreds of butterflies, lizards, bees, birds, and some heavenly larks - a perfect glow and tumult of life - and I shivered with happiness. The cool fresh joyous wind blew across the waves white with foam and gay with the bronzesailed fisherboats - the long wavy grass was sweet-scented and delicious - the acacias were in blossom of white - life - dear, wonderful, changeful, passionate, joyous life everywhere! I shall never forget this day - never, never. Don't despise me when I tell you that once it overcame me, quite; but the tears were only from excess of happiness, from the passionate delight of getting back again to the Mother whom I love in Nature, with her windcaresses and her magic breath.

Memoir 92-93

\section{To Emma Lucy Rossetti, 50 June 5, 1883}

Hotel des Postes | Dinaut-sur-Meuse | Belgium | June 5/83

Dear Mrs. Rossetti,

After long wanderings a card of date sometime in April last has reached me - asking me to come and see you on a specified date.

In case you did not know (tho' I called twice to tell you and Mr. Rossetti - and told Miss Rossetti) I left England for Italy the end of last February - and have been in that country ever since till two or three days ago when I came to this district of the Ardennes, where (or whereabouts) I shall be with friends till the end of July. ${ }^{51}$

My going to Italy was sudden, but in every way pleasant - having friends in many parts to stay with.

I was glad to hear the "Rossetti Sale" 52 had been a success, and I hope it came up to your anticipations. 
Hoping you have learned long before this that my silence and not calling on you arose out of absence and from not having heard from you -

Believe me | With kind regards to Mr. Rossetti - | Yours very truly | William Sharp

P.S. I hope your father has now quite recovered from his recent serious illness.

ALS John Carter Brown Library, Brown University

To Hall Caine, [early August, 1883]

Primrose Bank | Innellan | by Greenock | N.B.

My dear Caine,

I have not long returned from my long absence on the continent and amongst many things not forwarded to me I found two journals addressed to me in your handwriting, both containing reviews of my "Rossetti".

I think I am right in supposing that you are not the author of either - but for kindly thinking of sending them to me pray accept my sincere though tardy thanks. The notice in the Lity World, consisting of 9 columns, ought to have helped the book - i.e. if the L.W. has an influential circulation.

I was only 3 days in London, when passing thro' - so hadn't time to look you up. I hope you are flourishing professionally, and that your health is better than when I saw you last. I don't expect to be settled in London again till early in October, but look forward to seeing you again then or a little later.

I enjoyed myself greatly in Italy - and was favoured indeed by circumstance: to such an extent indeed that it would be difficult to imagine any subsequent visit transcending in pleasure the one I have just spent. 
But since coming north a great misfortune has happened to me. En route, a large portmanteau was lost or stolen - and this portmanteau, in addition to new clothes got in London and valuable souvenirs and presents from Italy, contained all my MSS., both prose \& verse, all my Memoranda (many of them essential to work in hand), all my Notes taken in Italy, my private papers and letters, some proofs, three partly written articles (two of them much overdue), my most valued books and indeed my whole literary stock-in-trade pro-tem. ${ }^{53}$

Its nonrecovery means at least an immediate loss of about $£ 30$, and prospectively a good deal more. Nine days have passed, \& nothing has been heard of it yet - and I am beginning to lose my last fragments of hope. As a literary worker yourself you will understand what a "fister" this is to a young writer. I must take this buffet of Fate, however, without undue wincing - and tackle to again all the more earnestly for the severe loss and disappointment experienced. There's no use crying over spilt milk.

I suppose you are at work on something of more permanent interest than leaders for the L'pool Mercury?

Will be glad of a line from you if you have time, and believe me

Sincerely yours I William Sharp.

ALS Manx Museum, Isle of Man

\section{To Hall Caine, [November, 1883] $]^{54}$}

13 Thorngate Rd. I Sutherland Gardens | W. I Tuesday Night

My dear Caine

You will have recd. my hurried note from Edinburgh.

On my return to London I at once looked about for the recipe you wanted - but have been unsuccessful in finding it - indeed I am afraid it must be lost, perhaps destroyed amongst other papers when I went to Italy. 
The embrocation was a good for all kinds of rheumatic cold (stiff necks - strained muscles - effects of draughts etc). but I know next to nothing of its composition. The man who ordered it for me for external use in case I shd. require it during the winter following my rheumatic fever in autumn 1880 was Dr. Griffittes, of Portmadoc, North Wales. This, alas, is all the information I can give you about it.

I am greatly better, so much so that I find it difficult to credit the doctor's doleful prognostications: I feel I must take care, but beyond that I have no immediate cause for alarm. The worst of it is that I am one day in exuberant health and the next very much the reverse. The doctors agree that it is valvular disease of the heart, a treacherous form thereof still further complicated by hereditary bias. However, a fellow must "kick" someday - and I would as soon do so "per the heart" as, like no small number of my forbears in Scotland, from delirium tremens, sheep-stealing (in hanging days), and general disreputableness.

I am afraid poor Marston's book has fallen rather flat. ${ }^{55} \mathrm{I}$ have seen only one brief and worthless notice in the Lity. World - tho' I heard from someone today that there was a notice in the Academy of last week, which I have not seen yet.

The truth is, people are tired of the "wail" in poetry, either the individual caterwaul or the general 'howl' - and though P.B.W. is worth a dozen of most of his detractors he is bound to go to the wall unless he will forego what unfortunately he cannot do. Independently of this, he, despite his fine and rare gifts, is too much under the shadow of Rossetti to flourish on his own little open piece of ground.

Thinking people want Hope, Faith, Energy, Joy - more than anything else do they crave that at least someone else should proclaim the last, on which the others are attendant. Joy in life, joy in death, the world will yet come to realize what that means. It is because humanity is sadder at heart than of yore that it must turn from the personality of sorrow to the impersonality of world-joy.

I rejoice to hear that you are fairly well, and that Sandown suits you. But indeed almost any place must be better than the Inferno of London - which I am going to make a strenuous effort in the Spring to leave. Even if pecuniarly able, I am forbidden to marry for a year to come and though waiting is hard now for us both, it is better even for my fiancee that nothing should be done which might result in what would 
be such a grief to her. Moreover, I am medically advised that London is not the place for me at all - so if I can possibly see my way I must try a move in the Spring. Hearing of my illness, Mrs. Craik ${ }^{56}$ offered me her house in Dover for two months in the Spring or early summer, as it wd. then be unoccupied - and there it is possible I may go.

But my art-journalistic work (a very material 'staff' indeed) is the main obstacle. I would need to be in London at least one day every week besides Sunday, and coming up regularly from Saty till Monday would be expensive. How do you manage with the L'pool Mercury at Sandown?

I have just today seen an announcement of your Cobwebs of Criticism - most heartily do I wish it success. I hope I may get it for review somewhere - I remember seeing a small portion of it at Birchington. What memories that name calls up - and what a blank he has left behind him!

When I last saw Watts he was well, and Swinburne kindly condescended to be less deaf than usual. Watt's article on Lewis Morris has been much discussed - bardically approved, publicly but half assented to.

The interest of the hour is fixt on Lord Lytton' $\mathrm{s}^{57}$ autobiography and literary remains. I have the first two vols, and they are certainly most interesting.

You will be sorry to hear that Mary Robinson has had an attack of smallpox - fortunately she has weathered it all right - and when I called yesterday with some flowers to cheer her beautiful eyes the servant told me she was soon to be taken downstairs again. ${ }^{58}$ The Gods preserve her fair young life. Her sister Mabel has also been ill, but I am glad to say is now better.

I am hard at work, in addition to my art-editorial work and commissioned articles for the Art Journal and other magazines, upon two books which may see the light - God knows when. ${ }^{59}$

As in some way relative to my remarks on page 5 of this letter, I enclose some lines written one day last September.

Drop me a line when you have time, and believe me ever yours affectionately 
Don't forget, if you ever want a bed for a night to let me know.

\section{Mater Dolorosa}

She, brooding ever, dwells amidst the hills;

Her Kingdom is call'd Solitude; her name -

More terrible than desolating flame -

Is Silence; and her soul is Pain.

Day after day some weightier sorrow fills

Her heart, and each new hour she knows

The birth of further woes.

And who so, journeying, goes

Unto the land wherein she dwells for aye

Shall not come thence until have pass'd away

For evermore the bright joy of his years.

She giveth rest, but giveth it with tears,

Tears that more bitter be

Than drops of the Dead Sea:

But never gives she peace to any soul,

For how could she that rarest gift bestow

Who well doth know

That though in dreams she can attain the goal,

In dreams alone her steps can thither go:

Solitude, Silence, Pain, for all who live

Within the twilight realms that are her own

And even Rest to those who seek her throne,

But these her gifts alone:

Peace hath she not and therefore cannot give.

W. S. I 18 Sept $/ 83$

ALS Manx Museum, Isle of Man 


\section{To Harry Buxton Forman, [1883]}

13 Thorngate Road | Sutherland Gardens | W.

\section{Dear sir}

Since my volume on Rossetti was published I have come across one or two drawings by D.G.R. which therefore do not appear in my catalogue at the end of the vol. Amongst these is a pen and ink drawing done in the Artist's 19th or 20th year - evidently the study for a later composition - "La Belle Dame Sans Merci". On this study the following verses from Keats' beautiful poem are inscribed, but as they are somewhat differently worded from every edition I have (4) I take the liberty of asking you if you can tell me if they are part of Keats' first draft of the poem - or if they appear in any published copy.

It is a great pleasure to myself as to all lovers of Keats to know that you are engaged upon such an edition ${ }^{60}$ as has been long looked for and I hope its appearance is not to be delayed long.

Believe me | Yours very truly | William Sharp

Inscribed on a sepia drawing (14 7/8 by $67 / 8)$ by D. G. Rossetti in $1848-$

I met a lady in the wood,

Most beautiful, a fairy's child;

Her hair was long, her step was light,

And her eyes were wild.

I walked with her in the green shade,

And nothing else saw all day long,

For sideways would she lean and sing

A fairy's song. 


\section{To Harry Buxton Forman, [1883]}

13 Thorngate Road I Sutherland Gardens I W.

\section{Dear Sir}

Thanks for your reply. I enclose a printed slip from the catalogue of the Burlington Fine Arts Club's Rossetti Exhibition to open on Monday. The drawing in question has not, as you will see, the verses upon it - but the original sepia has. Two figures only in the composition, and no horse as you infer. The original would lend itself for mechanical duplication - but it is at present in the North of Scotland. In the course of six weeks I expect to see it and its owner at Oxford, and if you like would submit your letter to him - unless you would prefer to write direct and at once. I for one would be glad if your idea could be carried out.

The two other drawings I referred to are about the same time (1848 to '51) and are illustrations to poems - one called Genevieve to Coleridge's "Love", and one to Sordello. Another is a design called "Poe's Study".

Very truly yours I in haste I William Sharp H. Buxton Forman Esq 


\section{To Theodore Watts, October 12, 1883}

\section{(A Birthday Sonnet)}

\section{Oct./83.}

Thou hast the crown of laurel, though thy name

Is not yet bruited through the land as one

Whose fire-wing'd words like falling stars have spun

Past many worlds of minds: but yet thy fame

Grows and is sure, as when a for est-flame,

Seen first alone by few, at last doth run

From furthest boundaries where the eastern sun

Uprises, till it rushes the west its aim.

Crowned by the few; is it not better thus

Than with a wider praise to hear the cries

Of those who yell their envy and their spite?

He loved and crowned you who was late with us ${ }^{61}-$

This is thy truest laurel! and the wise

Discern at last the true from tinsel light.

William Sharp

ALS British Library 


\section{To Eugene Lee-Hamilton, [early] 1884}

13 Thorngate Road I Sutherland Gardens I London, W.

\section{My dear Hamilton,}

We are such slaves to petty incidents that the best intentions are constantly being frustrated. I have a frequent wish to write to you - and succeed, well I won't say how seldom: but there are such innumerable little as well as important things always awaiting one's attention that I have let all my correspondence drift hopelessly behind hand. I need hardly say I often think of you, and of our pleasant morning drives. I earnestly hope you are freer from pain than heretofore, and that your Muse is no fickle jade but a constant and cherished friend. Have you been writing much lately - and is there any chance of another volume coming out within mentionable time. It was only the other day that I was reading the "New Medusa" 62 vol over again - and I was even more struck by it on this third complete perusal than on the first occasion. It is remarkably equal, and it has the altogether unusual merit of containing nothing poor - no padding! The sonnets seem to me amongst the strongest of their kind in contemporary literature. I don't know what kind of commercial success it has had, but its readers have neither been very limited nor unappreciative - not only in the literary world but amongst many of the outside public, as I have personally ascertained. I am curious to know what your subsequent work has been - other than the fine MS you lent to me in Florence. It must be a great pleasure to you to know as well as to hope that your poetry has appealed so strongly and (in a literary sense) so widely: and I sincerely hope (and believe) that your next volume will not only sustain but also increase the deserved reputation you have gained. I read a beautiful sonnet of yours in the yearly vol of the Art Journal for 1883 - but of this, by the bye, I think I have already written to you.

I am looking forward to the publication of Mary Robinson's vol., ${ }^{63}$ very little of which I already know. You have seen Marston's WindVoices, ${ }^{64} \mathrm{I}$ know. It contains some very beautiful work, but on the whole it is not as fine as I had hoped. I do not think he has the vivid dramatic emotion, though he has dramatic insight. But his sonnets and lyrics are most 
beautiful - though the unchanging monotony of sentiment palls at last dreadfully upon even the most sympathetic reader. It is doubtless better to play well on one string than to cause frequent discords along the whole diapason of artistic endeavor - but it is a mistake to suppose that the audience of a onestringed player will never weary. And monotony of sentiment (as in Marston's 2nd Vol, "All in All") $)^{65}$ is more fatal than monotony in expression.

Mary Robinson seems well, I am glad to say - and is hard at work as you doubtless know. My cousin ${ }^{66}$ is also working hard, in a different way, at Caldron' $\mathrm{s}^{67}$ studio, and is getting on well. As for myself, I am greatly better, tho' still needing to take care. I hope to bring out my second vol. of poems late in April or early in May. ${ }^{68} \mathrm{I}$ know the contents to be very much in advance of my first book - both in imaginative reach and intellectual grasp as well as descriptive power - this being endorsed by P.B.M. ${ }^{69}$ Watts, and others. Before then my Romance ${ }^{70}$ will be concluded, but not published till the Autumn - and I have also a great amount of artwork in hand and other literary labour.

I can remember no other news at present - save that Swinburne is engaged upon an essay on Wordsworth which will either be extremely (and insincerely) flattering or very condemnatory.

I was visiting Pater ${ }^{71}$ recently, and found him well and hard at work upon his slow but sure 'building'.

Give my kindest remembrances to your sister and mother - and if not too great a trouble drop me a line about yourself and your doing, which will always interest

Your affectionate friend, I William Sharp ALS Colby College Library 
To $M r$. Parsons, $^{72}$ [1884]

13 Thorngate Road I Sutherland Gardens W. I Wendy Night

My dear Mr. Parsons

I have just returned from a brief visit to Oxford - or would have sent you the accompanying ere this. ${ }^{73}$

I hope you may find something in it worthy of your attention - in any case accept it as a token of the regard of

Yours very truly I William Sharp

ALS Princeton

\section{To Hall Caine, [February 11, 1884] $]^{74}$}

Monday night

My dear Caine

Thanks for your note. I am afraid I shall have left London by the time you return, but some Saty. or Sunday morning we must meet somewhere \& renew our conversation in re bardic aims - (for I am coming up from Dover each Saty. till Monday - tho' not to Thorngate Road) -

With reference to our conversation the other night - the drift of it was to effectually put an end to my going on with the poem I was last reading. I am perhaps too indifferent to praise or blame as regards my poetic work - but I have my weak place, and that is, hostile criticism during composition of the poem - while it is yet unfinished.

But if there is anything to regret in it (which I don't know that there is) I have only myself to blame - knowing as I do my inability to take up any subject again after the spell of being possessed by it has been broken. Not even to my cousin can I venture to do this - and though she was eager to hear something of "Sospitra"75 while I was working at 
it I wisely refused to gratify her. In all probability I should never have gone on with it if I had shown it - or the subsequent stanzas would not have been equal.

So I have only myself to blame that my latest bardic effort was, if not exactly nipped in the bud, at any rate prevented from blossoming into full flower.

So it will be published almost as it stood when I read the opening verses of it to you - the addition since being a batch of asterisks and three winding-up stanzas. So I will still call it "A Record" but will add a Fragment. ${ }^{76}$

My view of Poetry entirely coincides with what Watts says and you agree to - but where we perhaps differ is on the scope of Life as the only basis for true work. Two people may look over the same sea and both agree that it is the real ocean that they are looking out upon yet to one the horizon may seem much more remote than to the other. Another instance: I possess great keenness of vision - and some time ago a friend and myself were looking up at the full moon, \& owing to some atmospherical state I distinctly saw three extended rims 'lipping' over each other above the orb - but my friend could only make out one, and that indefinitely. I saw a little further, that is all. In a sense he would have been quite right in previously objecting to a written description wherein this phenomenon was referred to - as quite beyond the pale of experience. But what worth has negative criticism compared with positive assurance?

Perhaps this instance is not a very clear one - but I can't go further into the question just now. The rack many people split upon is Reality. They say so-and-so is merely subjective - or it is not nature - or it is not real. To me everything is real - humanity and its passions most of all. But I do not confuse time with reality: a momentary flash of summer lightning is as real as a prolonged bonfire - a sudden gleam of moonlight on a cloudy night as the star that has been a flaming chaos for aeons past \& which we call the Sun.

Moreover, as Geo. Macdonald"7 (I think) - has said - "To the philosopher a possibility is a fact".

If Shakespeare - greatest because widest and deepest seeing of all men - had drawn only upon life recognizable by all men at once he would not have been the supreme poet he is. He is supreme through 
his magnificent sanity - but it was a sanity that recognized no limits to man's speculative insight. The truest portraitist, he was also the truest Seer. The greatest men have always realized that we are encompassed with mystery. Shakespeare, Goethe, Emerson, - how they would have smiled at the suggestion that the aim of poetry must invariably be human action.

Mostly fervently I agree with you on one point - that we have had more than enough of the personal wail. I am sick of contemporary minor verse, greatly on this score. Who, by all that's pleasant in life, wants to hear the yaup of each damned poetaster over some fancied individual grievance which in reality is common to all men?

My advice to young bards is as follows: -

(1).Don't write at all if you can do without it.

(2).If you do write, see first that you have something in itself worth writing about.

(3).Certain of the worth of your subject (whether a 'daisy' or 'Humanity') do your utmost to render its presentment in verse not only a fitting one but the fitting one.

(4).Having reached this length (knowing your powers and the direction of their development) take no heed of critical opinion save as regards the pointing out of technical flaws.

Each year - perhaps each month - brings more \& more home to me the fact that the creative artist, whether painter, sculptor, poet, or novelist, must attend only to the 'shaping' instinct that is in him and not to what this or that contradictory critic states. We both know the truth of this in literature - and I for one see it daily in art.

Please, in futuro (after the 3rd), remember my only certain address will be

72 Inverness Terrace | Bayswater | W.78

Tho' I may tell you now that my Dover address during March \& April will be 
Please let me have back the Paper on Rossetti by Pater - as I have promised to lend it to someone this week.

Wishing you success in the North I Yours ever I William Sharp ALS Manx Museum, Isle of Man

\section{To Theodore Watts [-Dunton], February 18, 1884}

13 Thorngate Road I Sutherland Gardens W. | 18:2:84

My dear Watts,

I was exceedingly sorry to hear from Caine that you have been unwell - and most sincerely hope you are quite or nearly right again.

I should like if convenient to come out and see you some evening (except Saty. \& Sunday) before the 1st of March. After that date I go to Dover for 2 months.

I am greatly better - and physically as strong as a horse, so long as I don't run or overwalk myself.

In haste I Affectionately yours | William Sharp ALS Brotherton Library, University of Leeds

\section{To Hall Caine, [March, 1884]}

9 Herbert Terrace | Dover | Monday

My dear Caine,

Just a line to ask you to come and pay me a short visit here. I have a pleasant house at my disposal, and the scenery in the neighbourhood is endlessly charming - while I am certain the fresh bracing cliff \& sea-air 
would do you good. Moreover, it would be very pleasant for me to have your company. Could you come down next Friday or Saty (as suits you) for a few days say till Tuesday at any rate. You could bring your work with you, and work as much or as little as you choose.

Please telegraph to me the conclusion you come to - so that I may make consequent arrangements and as time is precious.

If you can come (as I hope) let me know the day and hour and I will meet you.

In haste I Yrs affectly | William Sharp

ALS Manx Museum, Isle of Man.

\section{To Elizabeth A. Sharp, May 10, $1884^{80}$}

Paris | 10th [May] 1884

What remains of me after today's heat now writes to you. This morning I spent half an hour or so in M. Bourget's study ${ }^{81}$ - and was flattered to find a wellread copy of my Rossetti there. He had a delightful library of books, and, for a Frenchman, quite a respectable number by English writers: amongst other things, I was most interested in seeing a shelf of about 30 volumes with letters or inscriptions inside from the corresponding contemporary critics, philosophists, etc. M. Bourget is fortunate in his friends.

I then went to breakfast with him at a famous Café, frequented chiefly by hommes de lettres. At our table we were soon joined by Hennequin ${ }^{82}$ and two others. After breakfast (a most serious matter!) I adjourned with Bourget to his club, La Société Historique, Cercle St. Simon, and while there was introduced to one or two people, and made an honorary member with full privileges. I daresay Bourget's name is better known to you as a poet, but generally his name is more familiar as the author of "Essais de Psychologie" - an admirable series of studies on the works and genius of Baudelaire, Renan, Gustave Flaubert, Taine, and Stendhal. 
He very kindly gave me a copy (which I am glad to have from him, though I knew the book already) and in it he wrote:

À William Sharp

de son confrère

Paul Bourget.

After leaving him I recrossed the Champs Elysées - perspired so freely that the Seine perceptibly rose - sank exhausted on a seat at the Café de la Paix - dwelt in ecstasy while absorbing a glace aux pistaches - then went back to the Grand Hotel - and to my room, where after a bit I set to finish my concluding Grosvenor Gallery Notice.

On Sunday, if I can manage it, I will go to Mdme. Blavatsky. ${ }^{83}$

On Monday Bourget comes here for me at twelve, and we breakfast together (he with me this time) - and I then go to M. Lucien Mariex, who is to take and introduce me to M. Muntz, ${ }^{84}$ the writer of the best of the many books on Raphael and an influential person in the Bibliothèque Nationale. Somebody else is to take me to look at some of the private treasures in the École des Beaux Arts. In the course of the week I am to see Alphonse Daudet, and Bourget is going to introduce me to Emile Zola. ${ }^{85}$ As early as practicable I hope to get to Neuilly to see M. Milsand, ${ }^{86}$ but don't know when. If practicable I am also to meet François Coppée (the chief living French poet after Victor Hugo) - also M. M. Richepin, F. Mistral (author of Miréio), and one or two others. ${ }^{87}$ Amongst artists I am looking forward to meeting Bouguereau, Cormon, Puvis de Chavannes, and Jules Breton. ${ }^{88}$ As much as anyone else, I look forward to making the acquaintance of Guizot ${ }^{89}$ to whose house I am going shortly with M. Bourget. There is really a delightful fraternity here amongst the literary and artistic world. And every one seems to want to do something for me, and I feel as much flattered as I am pleased. Of course my introductions have paved the way, and, besides, Bourget has said a great deal about me as a writer - too much, I know.

Memoir 95-97 


\section{To Edward Dowden, April 26, 1884}

72 Inverness Terrace | Bayswater | London. W. | 26:4:84

Dear Professor Dowden,

Just a line to say that in the course of a few days you will receive through Elliot Stock a copy of my vol. of verse. ${ }^{90} \mathrm{I}$ have not forgotten your kind words about my first vol., and I earnestly hope this one may not disappoint you. Personally, it seems to me an advance in every way.

I did not see my way to putting in this book what you advised - viz some naturally poetic and striking Celtic legend - tho! I yet hope to do so - but you will find instead a rendering of a strange and very beautiful Eastern legend with which I have as yet met no one acquainted. It is called "Sospitra".

The two other long poems are "Gaspara Stampa" (the Venetian Sappho, as some Italian chronicler has described her), and "A Record", the latter embodying my belief in past existences on earth.

Fully half the book is devoted to nature pure and simple - under the headings "Earth's Voices" (26 in all), "Transcripts from Nature" (first and second series), "Australian Sketches", "Graffiti d'Italia", Moonrise-Sketches and Rainbow-Sketches.

Amongst my shorter poems I consider I have reached my highest mark as yet in "The Shadowed Souls" and in the lines printed in italics at the end of the vol. and called "Madonna Natura".

My next object in writing is to say that if you could get the book for review in the Academy I should be very glad indeed. I think Cotton ${ }^{91}$ will give it into friendly hands in any case, but of course a notice by an authoritative critic is worth double that of a comparatively unknown man.

This (with characteristic bardic assurance!) is taking for granted that in the first place you thought the book worth reviewing, \& in the next that you cared to do so.

I think Stock will send the book to the Academy etc. on Friday the 2nd.

If you are to be in town this summer I wd. greatly look forward to the pleasure of seeing you. Up to the 20th of May or so (from the 5th) I shall be in Paris on art-work (the Salon etc). - but during the end of May and 
all June I shall be in London, \& the above address would always find me.

Hoping you are well, and that before very long we shall have another volume of poems from you.

Believe me | Yours sincerely | William Sharp.

ALS TCD.

\section{To Edward Dowden, [May 21, 1884]}

53 Crowndale Road I Oakley Square I N.W.

Dear Mr. Dowden,

On my return from Paris I saw W. B. Scott \& learned that you had been in town. I regret having missed you, but hope for better luck the next time you are in this wearisome metropolis.

I trust the copy of my last book I sent reached you all right - and that you found in it something to please you. You may be interested to hear that it is doing well, and that its critical reception has been gratifying in the extreme.

Hoping you are well, and with much interest in your present Shelley labours -

Believe me | Sincerely yours | William Sharp ALS TCD 


\section{To Hall Caine, [June 16, 1884] ${ }^{92}$}

My dear Caine

If really not inconvenient, could you put me up tomorrow night? I have had, this afternoon, a narrow escape from rheumatic fever \& must leave here at once. I think I have fought it down but I must not risk such another chance. ${ }^{93}$

I have been crouching over a large fire and with my medicine having the better of the cursed complaint.

On Tuesday I go to Inverness Terrace - but as you said Robertson ${ }^{94}$ was not coming back till Tuesday I thought you might be able.

If in any way inconvenient, please send a note or telegram, but not a posteard a postcard will do if you only say all right on it. Wd. come in the evening - but must go west early in day from here on urgent matter.

Can't say how thankful I am to have escaped this sharp and sudden attack, as there's no saying what a second bout would do. Excuse a hideous scrawl, but my hands are so chilled and pained I can hardly hold the pen - and have to write at a distance -

Yrs ever I William Sharp

ALS Manx Museum, Isle of Man

\section{To Hall Caine, August 26, 1884}

Orinbeg | Loch Ranza | Isle of Arran | N.B. | 26:8:84

Just a line, my dear Caine, in the midst of pressure from urgent work and accumulated correspondence, to let you know (what I am sure you will be glad to hear for my sake) that at last my long engagement is drawing to a close, and that Lillie and I are to be married on All Saints Day - just about two months from date. What we have got to marry on, Heaven knows - for I don't: yet I hope a plunge in the dark will not in this instance prove disastrous. It is not a plunge in the dark as regards love and friendship - and that is the main thing. 
I hope you are in good health and that things are going well with you. Are you still at Yarra, \& have you fixed on your next place of residence?

Loch Ranza is a lovely northern sea-loch, surrounded by lofty hills and the serrated ridges of the "Peaks of the Castles" - and for some weeks past I have been enjoying myself here greatly, \& would have done so infinitely more but for the amount of work \& correspondence I have daily to go through.

The other day I had a visit from the Madox Browns and Miss Blind, who drove in a buggy over the mountains from Corrie, where they are staying a few days.

I believe it is terrifically hot in London - so I hope you are going to have a change.

Is the hour of paternity drawing nigh? ${ }^{95}$ I wonder if Maccoll would accept for the Athenaeum a sonnet on "Caine's Firstborn"? I must try. If a boy, please call it "Abel", or in case this would give rise to too many poor jokes, what do you say to "Tubal". Most people would simply think you had called him after "that fellow, you know, in one of George Eliot's poems"!

After Saturday, my letter-address will be 16 Rosslyn Terrace, Kelvinside, Glasgow - and I expect to be in London about the end of September.

In haste | Affectionately yours | William Sharp ALS Manx Museum, Isle of Man 



\section{Chapter Three}

\section{Life: $1885-1886$}

Sharp remained healthy for most of 1885 , and his productivity increased accordingly. He continued as London art critic for the Glasgow Herald, joined the staff of The Academy, and contributed articles to The Art Journal, the Examiner, The Athenaeum, and Good Words. He thought a year or two of reviewing and editing would free him financially to concentrate on poetry and fiction. In early January he wrote to Eugene Lee-Hamilton praising his recently published book of poems (Apollo and Marsyas, and Other Poems). In a letter to Violet Paget, Lee-Hamilton's sister who published pseudonymously as "Vernon Lee," he expressed his disappointment in her recent novel - Miss Brown - in which many of Sharp's friends saw themselves portrayed in a negative light: "You cannot be aware of the deep offense it has given to many good friends.... If I had never read anything else of yours, Miss Brown would effectually have prevented my ever reading or having the faintest curiosity to read anything from your pen." Then he tempered those harsh words: "If it were not for my sincere admiration for you as a writer of much delightful, admirable, and original work - I should not have written to you as I have now done: but it is because of my admiration for the 'Vernon Lee' whom I know that I refuse to recognize as genuine or characteristic a production in every sense inferior to anything she has done." The severe criticism may have derived in part from Paget's negative response to Sharp's "Motherhood" in his first volume of poetry. In any case, the two had little to do with each other following Sharp's letter, though he maintained a cordial friendship with Lee-Hamilton. Paget's relationship 
with her brother also soured following the death of their mother when Lee-Hamilton miraculously arose from the sick bed he had lain in for years, took off for America where he found a wife, and returned with her to a villa near Florence where they frequently entertained the Sharps. Violet Paget moved to Rome.

Sharp wrote both of these letters in bed due to an illness that rendered him liable to his "old trouble" which we now know was rheumatic fever. By February he had recovered enough to write a review of Walter Pater's Marius the Epicurean which appeared as the lead item in the 28 February issue of The Athenaeum (271-73). Athenaeum reviews were unsigned, but Sharp sent a copy to Pater who thanked him on March 1: "You seem to have struck a note of criticism not merely pleasant but judicious; and there are one or two points - literary ones - on which you have said precisely what I should have wished and thought it important for me to have said. Thank you sincerely for your friendly work!" He was pleased that Mrs. Sharp was also interested in the book as it was always a sign to him that he had to some extent succeeded in his literary work when it gained the 'the approval of accomplished women." He hoped Sharp would contact him a week or so ahead of a projected visit to Oxford so they could plan to see as much as possible of each other (Memoir 104-05).

Sharp first met Pater through Dante Gabriel Rossetti in the late 1870s, and their friendship was such by November 1882 that Pater began a letter to Sharp with a parenthetical: "(I think we have known each other long enough to drop the 'Mr')." In 1884, Sharp dedicated his second book of poems, Earth's Voices: Transcripts from Nature: Sospitra and other Poems, as follows: "Dedicated in High Esteem and in Personal Regard to my Friend, Walter Pater, Fellow of Brasenose College, Oxford."

Sometime in the late spring of 1885, the Sharps went "down to Oxford," according to Elizabeth, "so I might meet the Misses Pater at their brother's house" (Memoir 119-20). While there Sharp saw an advertisement for "a desirable cottage to be let furnished, with service, and garden stocked with vegetables" on Loch Tarbert in Scotland which they rented for the month of July.

The cottage was less desirable than advertised, but Sharp described its location glowingly in a July 22 letter to Edward Dowden:

I came here from London some weeks ago, with my wife and a young sister who lives in Glasgow. I forget, by the by, whether I ever told you 
that I was married late last autumn? I am always glad to get north, both loving and knowing the Western Isles and Highlands, and all places wherever broods the Celtic glamour. West Loch Tarbert is one of the loveliest of the Atlantic sea-lochs: severing Knapdale (Northern Argyll) from "wild Cantyre;" its length is about 11 miles, from its commencement east of the islands of Giglia and Islay up to the narrow Isthmus of Tarbert on the western side of Loch Fyne. From our windows we get a lovely view up the loch, looking out on the mountainous district of Knapdale and the small-islanded water towards Tarbert. To the Northeast is Shobli-Ghoil - the Hill of Love - the mountain where that Celtic Achilles, Diarmid, met his death by a wound in the heel through the envy of Fingal. Behind us are endless moorlands, and only one or two cottages at wide distances.

Foreshadowing more overtly his writing as Fiona Macleod, he continued: "I have a stirring and heroic Celtic subject in my mind for poetic treatment, and hope to make a start with it erelong. It will be with regret that we will leave at the end of the month - but we have two or three other places to go to in Scotland before returning to London which we do not intend doing till the end of September." The purpose of the letter was to solicit Dowden's opinions about the placing of several sonnets in an edition of Shakespeare's poems he was working on for inclusion in the Canterbury Poets, a series of inexpensive editions of the works of well-known English poets that was to be issued by the Walter Scott Publishing Company. Having published Shakespeare: A Critical Study of His Mind and Art in 1875, Dowden, a Professor at Trinity College in Dublin, was a leading expert on Shakespeare whose opinions Sharp valued.

The care Sharp exercised in arranging the poems and writing the Introduction for Songs, Poems, and Sonnets of William Shakespeare in the fall of 1885 led the Walter Scott Publishing House to accept his proposal for a book containing a selection of the best sonnets of the century and to appointment him, in 1886, as general editor of the Canterbury Poets. The firm played a crucial role in establishing William Sharp's reputation as a writer and editor. Walter Scott was a prosperous businessman in Newcastle who acquired the bankrupt Tyne Publishing Company in 1882. He named David Gordon, a dynamic Scotsman, as manager of the renamed Walter Scott Publishing House. Gordon convinced Scott he could turn the firm to profitability by speeding up the publication 


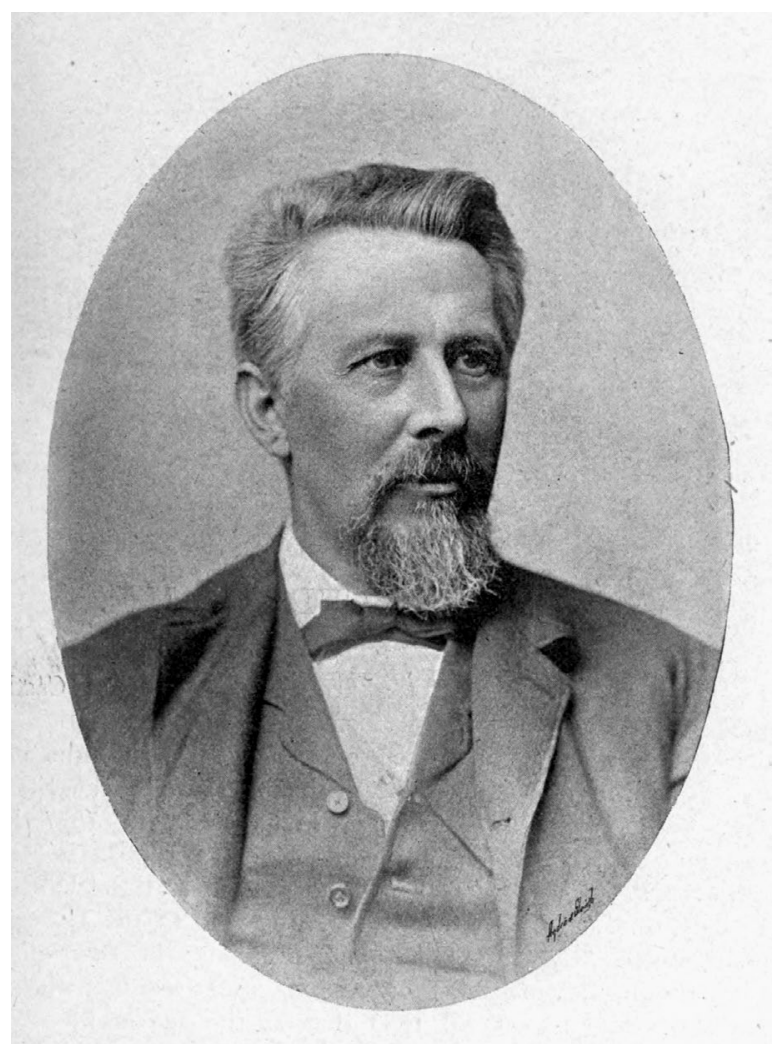

Fig. 5. Photograph of Edward Dowden. Robinson (c.1895), Wikimedia, https://commons. wikimedia.org/wiki/File: Portrait_of_Edward_Dowden.jpg, Public Domain.

of inexpensive editions of major writers, separating them into several series, advertising them aggressively, and selling them at the rate of one per month to an expanding reading public for one shilling. After purchasing and reading one volume, readers would be motivated to acquire another. Gordon proceeded to create in short order not only the Canterbury Poets Series, but also the Camelot Classics Series (for prose works), the Great Writers Series (biographies), and the Contemporary Science Series.

Gordon had turned first to Joseph Skipsey (1832-1903), who was living in Newcastle, to edit the Canterbury Poets. Son of a coal miner, Skipsey taught himself to read and matured into a well-known and highly respected poet. Under his editorship, in 1884 and 1885 the firm 
produced editions of Coleridge, Shelley, Blake, Burns, and Poe (all edited by Skipsey), George Herbert (edited by Ernest Rhys), and Sharp's edition of Shakespeare's poems.

Scott and Gordon knew little about English or any other literature; they were businessmen intent on making money. In his autobiographical Wales England Wed, Ernest Rhys recalled receiving in early 1886 "an unexpected call at his London home from 'two prosperous-looking men in top hats' who turned out to be Walter Scott's representatives." They were there to offer Rhys the editorship of a prose series complementing the Canterbury Poets. Rhys gradually realized the two men thought they were talking to Professor John Rhys, a well-known Celtic scholar. Nevertheless, it was Ernest who got the job, and he described the visit more fully in his earlier Memoir:

One morning two visitors were announced at an awkwardly early hour.... A loud knocking woke me in no state to receive strangers, clad in an old Rob Roy dressing-gown and slippers. It was too late to retreat. One of the callers, a red-haired Scotsman, was already entering.... These morning callers were emissaries of Walter Scott Ltd.... they carted me off to lunch at a City tavern and asked me to edit a prose series for a ridiculously modest stipend. Before we parted, I had sketched a chart of a dozen possible titles. So lightly was I launched on the career of editing (Everyman Remembers, 75-76).

After accepting the offer from the emissaries, one of whom must have been David Gordon, Rhys chose Camelot as the name of the new series, and settled on Sir Thomas Malory, "the father of English prose," for its first volume, which he edited under the title Romance of King Arthur. The Camelot series was a great success, as were the other three series. The volumes disappeared as fast as the Scott firm and its editors could produce them. When the Camelot Series had run its course, Ernest Rhys convinced an unknown publisher, J. M. Dent, to undertake another series of relatively inexpensive editions of higher quality, which became the phenomenally successful Everyman's Library. Dent, its publisher, made vast sums of money, and Rhys, its first and long-time editor, became famous as "Everyman."

Shortly after returning to London in the fall of 1885, Sharp fell ill again. "Disquieting rheumatic symptoms" were noted by Elizabeth, but he was able to work on various writing and editing projects, chief among 
them an anthology of nineteenth-century sonnets for the Canterbury Poets Series. He asked many well-known poets for permission to use one or two of their works and composed the volume's introductory essay - "The Sonnet: Its History and Characteristics" - which George Meredith considered "the best exposition of the sonnet known to him" (Memoir 116). Elizabeth contributed substantially to the selection and arrangement of the poems. By late December, the volume was ready, and it was published on January 26, 1886. It sold well and was reissued several times during the year. Sharp made some revisions during the summer and fall of 1886 for a new edition in December. The anthology went through several more editions and became, after 1899, Sonnets of the Nineteenth Century. Since Sharp was hired by the Scott firm to prepare the book and later to revise it, he did not share in its long-term financial success, but he told Edward Dowden (3 February 1886) the publishers had "behaved very decently" to him. No matter how decent their behavior, it paled in contrast to what Sharp would have earned had he received royalties, and that money would have eased considerably the financial difficulties the Sharps endured for many years. Though Sharp's earnings from the volume were meager, it established his reputation as an editor.

Sharp also managed to write in the fall of 1885 a three-volume sensational novel set in Scotland and Australia called The Sport of Chance which was published serially in The People's Friend in early 1887 and as a book by Hurst and Blackett in 1888. He also began to plan a biography of Shelley for Walter Scott's Great Writers Series, which was edited by his good friend Eric Robertson. For this series, Sharp eventually produced, in addition to the Shelley (1887), biographies of Heine (1888) and Browning (1890). Despite his frequent illnesses in the fall of 1885, he wrote the introduction and edited for the Canterbury Poet's Poetical Works of Sir Walter Scott, a Walter Scott very different from the book's publisher.

When Sharp learned the Scott firm was planning a Camelot prose series with Ernest Rhys as General Editor, he saw an opportunity to make some additional money. He asked a mutual friend for an introduction to Rhys and sought him out with a proposal to edit and introduce Thomas De Quincey's Confessions of an Opium Eater. According to Rhys, Sharp 
"burst in" on him "one summer morning" as he was "having a bath." In his memoir, Everyman described their meeting as follows in Everyman Remembers:

This was William Sharp, the poet, who towered up, a rosy giant, in the low-raftered room. His fine figure and exuberant contours, set forth in unusually resplendent clothes, suggested a stage Norseman. He talked very fast and excitedly, his bright yellow hair brushed up from an open brow, under which blue eyes, rosy cheeks, full red lips, and a pointed yellow beard suggested a picture by some impressionist painter. He had been editing the Canterbury Poets, in which series my George Herbert volume appeared, and had heard from the publishers of my prose argosy. Here was an opening after his own heart. In half an hour he had proposed half a dozen books which he would like to edit for me, and De Quincey's Opium-Eater was there and then allotted to him (Everyman Remembers, 76).

He had described this meeting earlier and at greater length in a 1907 Century Magazine article. Sharp was

joyously and consciously exuberant. He told of adventures in Australian backwoods, and of intrigues in Italy;... and then he turned, with the same rapid flow of brief staccato sentences, to speak of his friend Mr. Swinburne's new volume of poems, or of the last time he walked along Cheyne Walk [where Rhys then lived] to spend an evening with Rossetti. He appeared to know everybody, to have been everywhere.... It is not easy to avoid extravagance in speaking of one who was in all things an illusionist. Sharp's sensations, artistic ideas, and performances were not to be counted by rule or measure. He was capable of predicting a new religion as he paced the Thames Embankment, or of devising an imaginary new theater for romantic drama - whose plays were yet to be written (by himself) - as he rode home from the Haymarket.

And again:

Thanks to his large and imposing presence, his sanguine air, his rosy faith in himself, he had a way of overwhelming editors that was beyond anything, I believe, ever heard of in London, before or since. On one occasion he went into a publisher's office and gave so alluring an account of a long-meditated book that the publisher gave him a check for $100 £$, although he had not written a word. 
Those descriptions capture the appearance and mannerisms that made Sharp appealing to women and men as he was making his way as a writer and editor in the London publishing world.

Elizabeth recalled the start of 1886 as "unpropitious." It was a wet winter, and Sharp was ill and dejected. In mid-February, he sent two sonnets to his friend Eric Robertson for his birthday. The sestet of one reads:

A little thing it is indeed to die:

God's seal to sanctify the soul's advance -

Or silence, and a long enfevered trance.

But no slight thing is it - ere the last sigh

Leaves the tired heart, ere calm and passively

The worn face reverent grows, fades the dim glance -

To pass away and pay no recompense

To Life, who hath given to us so gloriously.

In a letter accompanying the sonnets, Sharp wrote, "There are two 'William Sharps' - one of them unhappy and bitter enough at heart, God knows - though he seldom shows it. This other poor devil also sends you a greeting of his own kind [the sonnet]." From childhood on, Sharp assumed to an unusual extent the guise of different people. Gradually the trait progressed to the point that he began to think of himself as two people inhabiting a single body. This letter is one of the early signs of that consolidation, of his movement, influenced by his reading of psychology, toward duality. In this letter, the duality is defined principally by mood; one W. S. is happy and outgoing, the other unhappy and bitter. He was using the notion of two people in one body as a means of explaining and coping with intense mood swings that plagued him throughout his life. At other times, he defined the duality as the dominance of reason versus dominance of emotion, or as living in both the real world and the spirit world, or of his being both a man and a woman. That trend finally culminated in the creation - perhaps more accurately the emergence - of a fully functional second self in the form of the woman he called Fiona Macleod.

Of the Opium-Eater assignment, Rhys wrote: "But alas! before he [Sharp] had completed the copy or even written his preamble for the book, he caught scarlet fever. Careless of infection, I spent an hour at his bedside when the fever abated, in talking over De Quincey, and then 
wrote the preamble myself over his name." Since the volume appeared on March 26, 1886, Sharp must have been laid low by scarlet fever in February, not long after his first meeting with Rhys. "In the early spring of 1886," Elizabeth wrote, "my husband was laid low with scarlet fever and phlebitis. Recovery was slow, and at the press review of the Royal Academy he caught a severe chill; the next day he was in the grip of a prolonged attack of rheumatic fever" (Memoir 135). The catalogue of Sharp's colds and bouts of rheumatic fever in the nineteen eighties is extensive:

1. In January 1880 a bad cold while visiting Rossetti;

2. In summer and fall 1880, another cold culminating in his initial bout of rheumatic fever;

3. In fall 1883 a second attack of rheumatic fever which seriously damaged a heart valve and drew his sister Mary from Edinburgh to help Elizabeth nurse him back to health;

4. In June 1884 another cold that threatened to produce another episode of rheumatic fever, which Sharp described in a pitiful letter to Hall Caine in a hand so cold and shaky the writing is nearly illegible;

5. In fall 1885, disquieting rheumatic symptoms;

6. In February 1886 scarlet fever and another attack of rheumatic fever.

This record of illnesses contrasts markedly with the robust figure who appeared to Rhys. Sharp had described the dichotomy in a letter to Caine in November 1883: "I am one day in exuberant health and the next very much the reverse."

The rheumatic fever attack in the spring of 1886 was particularly severe. "For many days, Elizabeth wrote, "his life hung in the balance" (Memoir 125-26). Her description of his hallucinations during the illness is especially compelling as it bears upon how his imagination worked and his later creation of the Fiona Macleod persona:

During much of the suffering and tedium of those long weeks the sick man passed in a dream-world of his own; for he had the power at times of getting out of or beyond his normal consciousness at will. At first he imagined himself the owner of a gypsy travelling-van, in which he 
wandered over the to him well-known and much-loved solitudes of Argyll, resting where the whim dictated and visiting his many fisher and shepherd friends. Later, during the long crisis of the illness, though unconscious often of all material surroundings, he passed through other keen inner phases of consciousness, through psychic and dream experiences that afterward to some extent were woven into the Fiona Macleod writings, and, as he believed, were among the original shaping influences that produced them. For a time he felt himself to be practically dead to the material world and acutely alive "on the other side of things" in the greater freer universe. He had no desire to return, and he rejoiced in his freedom and greater powers; but as he described it afterward, a hand suddenly restrained him: "Not yet, you must return."

He believed he had been "freshly sensitized," Elizabeth continued, he "knew he had - as I had always believed - some special work to do before he could again go free." While his illness persisted, Ernest Rhys brought him branches of a tree in early leaf, which Elizabeth placed on the window sill. The effect of their "fluttering leaves," she wrote, helped his imagination. But they had another effect: They "awoke 'that dazzle in the brain, ' as he always described the process which led him over the borderland of the physical into the 'gardens' of psychic consciousness he called 'the Green Life'."

Here Elizabeth broached the psychic experiments - enhanced by drugs - Sharp undertook in the 1890s. She discouraged those experiments because they negatively affected his overall mental state. She worried they might drive him into a state of schizophrenia from which he could not recover. Such experiments led him in the nineties into the orbit of William Butler Yeats, who enlisted both Sharp and Fiona Macleod in his efforts to obtain by psychic experiments the rituals of the Celtic Mystical Order he planned to house in an abandoned castle in the west of Ireland. Many years later Yeats recounted a story Sharp told him and commented "I did not believe him, and not because I thought the story impossible, for I knew he had a susceptibility beyond that of anyone I had ever known to symbolic or telepathic influence, but because he never told anything that was true; the facts of life disturbed him and were forgotten" (Autobiographies, 340).

After pulling through the worst of the 1886 episode, Sharp was unable for many months to engage in sustained writing, and that left him desperately short of money. "At the end of ten weeks," Elizabeth 
wrote, "he left his bed. As soon as possible I took him to Northbrook, Micheldever [in Hampshire], the country house of our kind friends Mr. and Mrs. Henryson Caird, who put it at our disposal for six weeks. Slowly his strength came back in those warm summer days, as he lay contentedly in the sunshine" (Memoir 126).

Writing from Micheldever on August 14, he described his condition to Theodore Watts, who was helping him with the second edition of Sonnets of this Century:

I am gaining strength very satisfactorily. My doctor ran down to see me before going off to Canada on his autumn holiday, and he told me he could now find no trace of heart-disease, though I undoubtedly inherited from the Rheumatic fevers (the recent attack \& that of 5 years ago) a heart-complaint which would require my care for a year or so to come. I am not to work too hard, and never after the afternoon. This is all very well, but whether I can keep to such orders is a different matter.

In a September 7 letter to Frederick Shields, he said he was "progressing slowly but steadily." In a September 13th letter, he told Ford Madox Brown he was "nearly robust again." He had benefited greatly by "his long stay at this pleasant country house." He had begun to do a little work, "chiefly reviewing," but he had been instructed "to wait another month at least before getting in full sail again." He had hoped to be able to go to Manchester to see and review the frescoes Brown was painting for the Great Room of the newly constructed Town Hall, but that would have to wait until spring. His doctor thought he needed "bracing" and advised him to go to his "native air." He and Elizabeth left Micheldever in mid-September and spent two weeks in and around Edinburgh.

In mid-October, Sharp told J. Stanley Little, who would soon become a close and valued friend, that he was incapacitated by a sudden illness. Elizabeth noticed "new disquieting symptoms" as "he began to assert himself. His heart proved to be badly affected, and his recovery was proportionately retarded" (Memoir 126) Nevertheless, he returned to the life of Shelley he had promised for the Great Writers Series. In late November he thanked Edward Dowden for sending as a gift his recently published two-volume Life of Shelley. He needed it for his writing and could not afford at present to buy it. As 1886 came to an end, Sharp had suffered varying degrees of illness for nine months, his health remained precarious, and money was in short supply. 


\section{Letters: 1885-1886}

\section{To Eugene Lee-Hamilton, January 5, 1885}

46 Talgarth Road | West Kensington | W. | 5: 1: 85

My dear friend,

At last I find a moment wherein I am at leisure to send you a brief line concerning your last volume, the present of which has given me such genuine pleasure. ${ }^{1}$

Among the "Poems", I like best 'Apollo and Marsyas', the 'Bride of Porphyrion', 'Abraham Carew', "Pageant of Siena', and 'Ipsissimus'.

Among the Sonnets, 'Idle Charon', 'Lethe', 'Signorelli's Resurrection', 'The Phantom Ship', 'Sunken Gold', 'Torso of Venus', and the last three in the book.

If you will permit me to say so, I think your metrical gift is much more measuredly than lyrical: your sonnets, your blank verse, your heroic couplets, are (to me) invariably immeasurably superior to the majority of your more formally lyrical strains, and I notice this more forcibly in the present volume than in "The New Medusa".

When I contrast "Hunting the King" with such powerful poetic efforts as 'Porphyrion' or the 'Wonder of the World' I cannot but be struck by the essential difference. I am convinced that in either of the two lastnamed it would have been impossible for you to have written such a line as

And more stars overhead came and winked

or

When their horses 'mid clapping of hands tugged away,

And the live limbs of Damius resisted!

The whole of the "Introduction" I liked, and especially noted one line,

The hum of sunripe Nature's million strings. 
There is some exquisite descriptive writing in a "Pageant of Siena", for instance, the vivid and beautiful lines of the second stanza, though it is almost invidious to pick out any single verse when all are good. I don't like the 4th line in 'Ipsissimus', for I don't see how 'vitals' could get 'limp' with anything save some medicinal purge: but the poem as a whole is very powerful.

The sonnets have greatly charmed me: in this measure I think you are strongest. They are full at once of true poetry and vigorous mental insight and grasp, and, as in the case of 'Lethe' and the 'Phantom Ship, ' of something higher still.

There are beautiful lines in 'Acheron' -

And no other light

Evokes the rocks from an eternal night

Than the pale phosphorescence of the wave -

The 'Phantom Ship' seems to me worthy to rank with that splendid sonnet in your last book on the SeaShell. The whole of "Sunken Gold' is very fine, noticeably the last three lines of the sestet.

Altogether I most heartily congratulate you on your new volume - and hope, as I believe, it will bring you more friends and increased reputation.

Excuse a short note, but I am not very well - and am writing in bed. I have been working exceptionally hard lately, and after finishing a "Quarterly" article under great pressure I caught a rheumatic chill, which rather floored me.

Watts is greatly pleased with your work - as I dare say you saw from his review in the Athenaeum. ${ }^{2}$ He has been unwell, but is now up again.

With sincere good wishes for you for 1885 - in which my wife heartily joins, with many kind remembrances -

Ever, my dear Hamilton, I Yours faithfully, I William Sharp ALS Colby College Library 


\section{To Miss Violet Paget, [January 5, 1885] $]^{3}$}

Dear Miss Paget,

Just a line since I am writing to your brother at any rate. As I have told him, I am writing in bed, not being very well - otherwise you wd. have something more from me than a mere note. I am not going to write at length to you about "Miss Brown," for in honesty I am bound to say that I am deeply disappointed with it, not only as a story or as a social sketch but with the manner in which it is written. ${ }^{4}$ You cannot but be aware of the deep offence it has given to many good friends, but of course I believe this was unintentional. I do not wish to enlarge on the subject, but will say simply that if I had never read anything else of yours, "Miss Brown" would effectually have prevented my ever reading or having the faintest curiosity to read anything from your pen.

If it were not for my sincere admiration for you as a writer of much delightful, admirable, and original work - I should not have written to you as I have now done: but it is because of my admiration for the "Vernon Lee" whom I know that I refuse to recognise as genuine or characteristic a production in every sense inferior to anything she has done.

Although this may not be a palatable compliment, it is a true compliment all the same. I think you must know what a great regard I have for your brilliant talent - (I forget if I sent you word as to the extreme pleasure I had derived from "Euphorion" ${ }^{5}-$ a truly remarkable series of essays) - and therefore you will not be offended, I hope, at my being so candid.

I have been working very hard lately - so much so as to render myself liable to a touch of my old trouble: but today, though still in bed, I am practically all right again. Quite a number of people looked in yesterday to see my wife, among whom were Mary Robinson and Walter Pater.

The latter and Theodore Watts are going to spend the evening with us tomorrow. Elizabeth is very busy also just now, and has got sufficient literary work to keep her busy for some time to come.

Both she and I wish health, prosperity, and all good things for you throughout 1885 - and believe me ever, dear Miss Paget, 


\section{To Hall Caine, [mid-February, 1885] ${ }^{6}$}

46, Talgarth Road, I West Kensington. I W.

My dear Caine,

Just a hasty line to congratulate you on the Athenaeum notice which can hardly fail to have a most beneficial effect on the "Shadow of a Crime".

From what Robertson told me I am most anxious to hear what you have done of your new story (in the name of which, by the bye, I don't think you have made a hit) - so hope that sometime soon after next Thursday you will do me the great pleasure of reading your MS to me. R. ${ }^{7}$ is quite enthusiastic about it, - and I rejoice at your success - present \& prospective. I wd. have been at your "reading" the other night - but that I had to write the Pater paper for the Athenaeum. ${ }^{8}$ You have begun well - and that you may prosper continuously is the wish of

Your sincere friend I William Sharp

ALS Manx Museum, Isle of Man.

\section{To Edward Dowden, July 22, 1885}

Kilchamaily Cottage I Whitehouse I West Loch Tarbert I Cantyre I

N.B.

Dear Prof. Dowden 9

I am writing to ask your advice (if you are not too busy with your own lity work to give heed to a casual correspondent).

I am editing a volume containing Songs, Selections from the Poems, and the Sonnets of Shakespeare. ${ }^{10}$

Do you agree or disagree with me in thinking that the sonnet forming the 8th division of the Passionate Pilgrim, "If music and sweet poetry 
agree" is one of the "dark-woman' sequence in the regular series: - and that the sonnet forming the third division of the Passionate Pilgrim "Did not the heavenly rhetoric of thine eye" also belongs to the dark-woman sequence?

In my edition I am placing the sonnets thus

I.

Sonnets I to CXXV.

'Sonnet' CXXVI (Envoy).

II.

Sonnet CXXVII.

"Music and Poetry (but unnumber'd)

Sonnets CXXVIII to CXXXVI.

"“'Did not the heavenly rhetoric etc". (unnumber'd) “CXXXVII to CLIV.

(i.e. Sonnets 127 to 154 in unbroken sequence save for the two unnumbered additions)

I have put the 'Music and Poetry' second in the 2nd section (i.e. between Sonnets CXXVII \& CXXVIII) because, as seems to me, internal evidence points to its connection with this series. By Sonnet CXXVIII we learn that the dark-haired mistress was a musician, hence the greater likelihood of his addressing her in such lover's logic as we find in this 8th division of the Passionate Pilgrim. I at one time fancied it might have been written as a pendant to Sonnet VIII, but here the internal evidence is not nearly so strong, is indeed antagonistic to the conjecture. The octave of No. VIII seems to be a reproach against $S^{\prime}$ s friends' indifference to music, hardly agreeing with the assertion in lines 4-5 and 9-10 of 'Music and Poetry, ' while the statement "You delight specially in sweet music, I in sweet poetry" harmonizes with what we could well imagine S. saying to his dark mistress.

Again, I have placed it before no. CXXVIII, because it seems to be the fitting prelude to that sonnet. 
Did not the heavenly rhetoric etc.

I have inserted this between Sonnets CXXXVI and CXXXVII, because it seems to me to fit in here with peculiar applicability. It is the last time in this series that $\mathrm{S}$. hints there is anything more in his love than thralldom to a strong and subtle passion: while there is also a suggestion of the feebleness of spiritual resolution struggling against the "power of the flesh," of vows being as vapour, with the half-passionate half cynical conclusion

If by me broke, what fool is not so wise

To break an oath, to win a paradise.

To the possible objection that $\mathrm{S}$. would never have addressed the lady of the 130th Sonnet as "Thou fair sun" etc. (10th line) there could be opposed the line in the 147th Sonnet -

For I have sworn thee fair and thought thee bright

(or, again, the 13th line of No. 152).

Of course these additions to the regular sequence being merely conjectural, I would never dream of numbering them, thus throwing out the universally recognized numerical arrangement - and every reader, noting them as conjectural additions, can include them or not as he or she thinks fit. The only book of yours I have beside me here is the delightful Parchment edition of the Sonnets, and from this I have not gathered what conjecture you may entertain on the subject. ${ }^{11}$ Even if you shd. consider it highly probable that the two sonnets in question were originally (or subsequently to the nominal completion) meant for the Dark-Woman series, you may totally disagree with my placement.

Though an ardent student of Shakespeare from the individual standpoint I have but (comparatively speaking) limited acquaintance with the mass of Shakespearian annotation, - moreover, I am here remote from all authorities, save the two books I have with me, viz: the Globe edn. of Shakespeare's works and your Parchment Sonnets: So, for all I know to the contrary, these views of mine may have been already urged.

But I should be very glad to hear what you, one of the foremost authorities, have to say on the subject. I have written to no one else, as at present I wish neither my proposed additions discussed nor my editing 
the volume to be known. The book may be out in the late autumn, but of course an editor has nothing to do with the appearance of commissioned work.

I hope you are getting on with your 'Shelley' - for the publication of which I have been all the more anxious since the issue of Jeaffreson's most unnecessary and (to me) objectionable book, which, however, I only know by many lengthy quotations, as I have no wish to wade through it in detail. ${ }^{12}$ I hope also that your many labours have not prevented your accomplishing some work in verse.

I came here from London some weeks ago, with my wife and a young sister who lives in Glasgow. I forget, by the by, whether I ever told you that I was married late last autumn? I am always glad to get north, both loving and knowing the Western Isles and Highlands, and all places whereover broods the Celtic glamour. West Loch Tarbert is one of the loveliest of the Atlantic sea-lochs: severing Knapdale (Northern Argyll) from "“wild Cantyre," its length is about 11 miles, from its commencement east of the islands of Giglia and Islay up to the narrow Isthmus of Tarbert on the western side of Loch Fyne. From our windows we get a lovely view up the loch, looking out on the mountainous district of Knapdale and the small-islanded water towards Tarbert. To the North-east is Shobli-Ghoil - the Hill of Love - the mountain where that Celtic Achilles, Diarmid, met his death by a wound in the heel through the envy of Fingal. Behind us are endless moorlands, and only one or two cottages at wide distances. I have a stirring and heroic Celtic subject in my mind for poetic treatment, and hope to make a start with it erelong. What with a measure of work, boating, bathing, walking, Royal Fern hunting, and occasional fishing the days fly past rapidly. We live as simply as possible - chiefly on milk and eggs and butter, on trout from a little tarne in the moorland behind, and Loch Fyne herrings (40 for $1 / . ! !)$.

It will be with regret that we will leave at the end of the month - but we have two or three other places to go to in Scotland before returning to London - which we do not intend doing till the end of September. When in London I hope you will come and see us: I think you have my address, but in case you have not, I add it - 46 Talgarth Road I West Kensington I W.

Hoping you are well and having a pleasant summer, I remain 
Very sincerely yours | William Sharp

P.S. I enclose [for] you copies of the last sonnet \& last lyric I have written, thinking you might care to read them.

ALS Trinity College Dublin

[To Theodore Watts[-Dunton], October 12, 1885] $]^{13}$

To A Poet

Out of the heart flew a pray'r

Till far in the blue sky

It met a thought, most fair,

That all alone did fly:

"O whither, golden pray'r?"

"Pray come with me, fair thought-

Thou shalt make the world more fair,

For long it hath thee sought".

This prayer is born of me:

$\mathrm{O}$ may it meet its mate-

For the generations then

Thy name shall consecrate.

W.S

ALS British Library

To William Allingham, ${ }^{14}$ November 11, 1885

46, Talgarth Road, | West Kensington, | W. | 11: 11: '85 


\section{Dear Sir,}

I am about to bring out a selection of the Best Sonnets of this Century, giving to all save the very foremost sonneteers (Wordsworth, Rossetti, Mrs. Browning) an average of two representative sonnets. I have always much admired your work in this direction, and should be glad to see you represented by three.

As beautiful sonnets and coming within my strictly defined plan, I have selected

I. "Autumnal Sonnet"

II. "After Sunset"

("The vast and solemn company of clouds" from a little book edited by Isa Knox Craig, in 1863).

III. “Day Dream's Reflection"

("On the Sunny Shore") "Checkered with woven shadows as I lay"

I should be glad to hear that you are agreeable to my representing you by these three sonnets.

Yours faithfully | William Sharp

William Allingham Esq I etc. etc.

ALS University of Illinois

To Wilfred S. Blunt, November 11, 1885

46, Talgarth Road, I West Kensington. I W. I 11: 11: '85 
Dear Sir,

I am shortly going to bring out a Selection of the Best Sonnets of This Century (i.e. from Wordsworth's down to those of contemporary date), and would certainly not consider it complete if your fine sonnet-work were unrepresented. ${ }^{15}$

I have allowed an average of two to each writer of genuine standing, but in your case I have determined to give five. These I have already selected (subject to your consent), and are as follows - having been chosen not only as specially fine sonnets but as coming within my strictly-defined rules in selection.

From "Proteus" | "An Exhortation"p 33 | "Vanitas Vanitatis" p 53 | "The Pride of Unbelief" p 97 | "On the Shortness of Time" p 103 | "The Sublime" p 113

I should be glad to hear that you are agreeable to being represented by this selection. Allow me to take this opportunity of expressing the very great pleasure I have again and again had in "The Love Sonnets of Proteus" - and the genuine satisfaction I have in being able to draw the attention of some others thereto.

Yours faithfully | William Sharp

Wilfred S. Blunt Esq I etc. etc.

P.S. I would have written to you sooner but that I fancied you were abroad. I hope it is the case, as I understand, that you are now in England - as the Sonnet-matter must be "struck off" at once.

ALS West Sussex Record Office

To James Ashcroft Noble, ${ }^{16}$ November 11, 1885

46, Talgarth Road, I West Kensington.W. 


\section{Dear Sir,}

I am shortly going to bring out a Selection of the Best Sonnets of this Century (with a lengthy introductory dissertation on the Sonnet as a vehicle of poetic thought and on its history and place in English literature) and I should be pleased to see you represented therein.

I have already (subject to your approval) marked down "A Supreme Hour" - but if there is any other you would rather be represented by I would be agreeable. I might be able to print two but cannot fix anything definitely just yet.

I know that the subject is one of interest to you, your essay being one of the best dissertations on the sonnet that I know.

Yours faithfully | William Sharp

\section{J. Ashcroft Noble Esq}

ALS, private

\section{To Edward Dowden, [November 12, 1885] ${ }^{17}$}

46, Talgarth Road, I West Kensington. I W.

Dear Mr. Dowden

I am shortly going to bring out a selection of the Best Sonnets of This Century, and would certainly not consider my selection complete if you were unrepresented.

I have always greatly admired your sonnet-work, and give practical proof thereof in the fact that while I am giving each writer (with the exception of Wordsworth and Rossetti) an average of two. I have selected five of your sonnets: viz: "An Interior" | "Evening near the Sea" | "Awakening" | "Two Infinities" | "Brother Death". These seem to me especially fine and at the same time come within my strictly defined 
plan. ${ }^{18}$ I should be glad to hear that you are agreeable to my using the above.

The principles which have in the main actuated my choice are (1) Structural correctness - (2) Individuality, with distinct poetic value and (3) adequacy of sonnet-motive.

The book will be out towards the end of January, \& will also contain an exhaustive essay on the Sonnet as a poetic vehicle and on its place and history in English literature.

My little book of Shakespeare's Songs, Sonnets, E Selected Poems, should be out on the 1st proximo - and I shall take pleasure in sending you a copy. ${ }^{19}$

Hoping you will come and see me when next you are in London -

Sincerely yours I William Sharp

P.S. I have just had a line from our mutual friend, Wm Bell Scott ${ }^{20}$ : he is stronger, but the doctor won't let him travel - so he will spend the winter at Penkill in Ayrshire. Poor old fellow.

ALS Trinity College Dublin

\section{To John Addington Symonds, November 12, 1885}

12: 11: 85 .

My dear Mr. Symonds,

I am shortly going to bring out a Selection of the Best Sonnets of this Century (including a lengthy Introductory Essay on the Sonnet as vehicle of poetic thought, and on its place and history in English Literature) - and I should certainly regard it as incomplete if your fine sonnetwork were unrepresented. I am giving an average of two to each writer of standing, but in your case I have allowed for five. This is both because I have a genuine admiration for your sonnet-work in the main and because I think that you have never been done full justice to as a 
poet - though of course you have met with loyal recognition in most of those quarters where you would most value it... .

I have taken great pleasure in the preparation of the little book, and I think that both poetically and technically it will be found satisfactory. My main principles in selection have been (1) Structural correctness. (2) Individuality, with distinct poetic value. (3) Adequacy of Sonnet-Motive.

I hope that you are hard at work - not neglecting the shyest and dearest of the muses?

Is there any chance of your being in London in the late Spring? I hope so.

Sincerely yours, I William Sharp

Memoir 113

To Edward Dowden, November 14, 1885²1

Dear Mr. Dowden,

Thanks for your note. You may rest assured as to accuracy in printing - as I shall in each case compare with the original, word with word \& punctuation with punctuation. A sonnet above all things loses thro' some small flaw.

W. Bell Scott's address is Penkill Castle | Girvan | Ayrshire. I know he will be greatly pleased at a friendly line from you.

Yrs. sincerely | William Sharp

ACS Trinity College Dublin. 


\section{To The Reverend R. P. Graves, ${ }^{22}$ November 18, 1885}

46, Talgarth Road, I West Kensington. W. I 18: 11: 85

\section{Dear Sir}

I am very shortly going to bring out a selection of the Best Sonnets of this Century, and would regret not seeing Sir W. R. Hamilton ${ }^{23}$ represented therein. Can you tell me if I am at liberty to excerpt any one, or two Sonnets I may decide upon? I write to you, as I think you are Editor of his "Remains".

Faithfully yours I William Sharp

The Reverend R. P. Graves I Dublin

ALS Private

To Edward Dowden, [December, 1885]

46 Talgarth Road I West Kensington I W.

My dear Mr. Dowden

May your Xmas be pleasant and 1886 a happy and prosperous year. Is there anything of interest to you in your Shelley work in the enclosed note of Leigh Hunt? A great mass of material has lately come into my hands - with much of interest relating to Keats \& others, including Shelley. ${ }^{24} \mathrm{I}$ am engaged, spider-like, in absorbing it before I spin it out again in book-form - a book bound to be widely interesting to all lovers of literature on $\mathrm{a} / \mathrm{c}$ of its bearings on the revered names of two of our great poets of this century, besides "many other attractions" as theatrical slang has it.

I have not had time to examine it except very superficially, yet: but I have made one or two most important "finds". One of the features 
of my book when it does appear (probably not for 18 months yet at any rate $)^{25}$ will be the Adonais with ample notes by Joseph Severn, a commentary of exceeding interest.

But all this is private, of course.

Again with all good wishes -

Sincerely yours I William Sharp

P.S. Please let me have the Leigh Hunt letter back when you have read it.

ALS Trinity College Dublin

\section{To Wilfred Meynell, ${ }^{26}$ [late 1885?]}

46, Talgarth Road, I West Kensington. I W.

My dear Mr. Meynell,

If you could do anything towards "placing" my novel ${ }^{27}$ in another quarter for me I should be much obliged.

It has just been accepted by the "People's Friend," an influential weekly paper published in Dundee and having a large circulation in Scotland and the north of England and Ireland. I retain all rights save that of permitting any other journal to print the story in advance of "The People's Friend". I should be specially glad if it could run (beginning sometime next Spring, the "PF". not intending to issue it till the end of February or perhaps later) in some Australian paper - partly because of my connection with that country and partly because some important chapters have an Australian "background", the scenery and incidents introduced having been written from actual memory and not at secondhand. "False Lights" is a story of exciting incident: it is what is generally called melodramatic, but this in the right sense - and strange and almost incredible as some of the incidents may appear they are all true to fact, though of course, the real incidents did not happen sequent as 
in False Lights, but at different times and in various parts of the civilized and uncivilized world where I have sojourned.

The 2 opening chapters describe a terrible storm that visited the Cornish Coast a long time ago: here a character is introduced that much later is destined to play an active part, and here occurs a shipwreck, with the saving of a single life - a rescue on which the whole plot depends.

After this prelude comes the story itself. The scene is in Perthshire, and deals mainly with a strange mystification anent a forgery on the hero, Hew Armitage, by a person who is really Hew's wife's brother - though of this Mr. Armitage knows nothing, not even the fact of the brother's existence. The mystery deepens, and there is a gradual intensifying of interest on this and other counts. At last comes an accident to Mrs. H. A. - her child is prematurely born - she has brain fever, recovers, but is left in that curious state wherein, while reasonable in most things, she has a sudden insuperable dislike and dread of her husband. He never fully realizes this, \& when at last she secretly leaves the house he is played upon by the villain Leith (the brother) - so that - to be brief - he becomes convinced that his wife and Leith have gone off together. Later chapters describe his despair and further action, his exciting rencontre with Charles Leith, the latter's escape and his plans of mystification to which $\mathrm{H}$. A. succumbs, and at last $\mathrm{H}_{\text {. }} \mathrm{A}^{\prime}$.s pursuit of the couple (as he thinks) to Australia. (Leith has sailed, but of course alone).

Book II. describes Mona Armitage's flight - her shelter with an old Highland nurse - and her tragic death. Also second-sight is introduced. The child Lora is left with the nurse - every precaution being taken.

In Bk III there is described the running down of Leith's vessel by that in which $\mathrm{H}$. A. is a passenger - and their subsequent terrible adventures.

Then comes Australia, and his long chase of Leith there - with various exciting incidents - and at last he tracks him down in Queensland. Ultimate escape of Leith. The unhappy H. A. makes his way home again, but it is on this voyage that the wreck takes place on the Cornish Coast described in the prelude. In the shock, H. A. loses absolutely his memory - and for 20 years remains thus - an actual fact by the way.

Meanwhile the girl Lora grows up - makes good friends - and finds a lover. Suddenly a guardian appointed by her dead father (as it appears) turns up in the shape of a Mr. Farquhar (really Leith). 
The plot becomes intricate \& more exciting than ever, \& chapter by chapter things evolve towards a long-way-off but ultimately satisfactory denouement.

The story was written for serial publication - and it would run to 32 installments of about 3 cols each (average newspaper columns).

Any further information that would be wanted I would willingly afford at once.

Sincerely yours I William Sharp

P.S. In enclosing you some press opinions on my books I send nothing anent any work in fiction, for what I have hitherto done in that way has been under a pseudonym which I particularly wish to stick to without identifying it with my own name. Although I have a story running through a monthly magazine just now no one knows that the author Mr. "Blank" - is me, save a few necessary persons - and even my wife has not read my serial - so you can see my secret has been well kept: nor do I intend to let it eke out if I can help it.

ALS Fales Library, New York University

\section{To Wilfred Meynell, [late 1885?]}

46, Talgarth Road., I West Kensington, I W.

My dear Mr. Meynell,

Just as I was about to send for the enclosed, with a supplementary note, I received a letter from the Proprietors of the People's Friend stating that they would prefer that "False Lights" (a name that is to be changed, by the bye - at any rate in the first instance $)^{28}$ did not appear elsewhere simultaneously.

They add that this will be no real drawback to me, as neither an Australian nor an English journal is likely to object to print a story that has run through a paper whose circulation is in great part confined to Scotland. If it could be managed, I should like to have it run through some 
Australian paper after its appearance in the People's Friend and before its issue in book-form - beginning in Australia say at the commencement of 1887. It would be more satisfactory if some arrangement could be made now - but if this can't be managed, and if the matter were still "open" for consideration later on I should be willing next Spring to submit duplicate proofs as they come out. ${ }^{29}$ Of course if I could arrange satisfactorily otherwise I would do so - as I would rather have the matter settled.

Of course this must be a business arrangement - as indeed it is only right it should be.

If you should be able to "place" my story anywhere, you must of course accept the commission customary in such cases. None the less am I sensible of your friendly interest - and with sincere regards to Mrs. Meynell,

Believe me, cheer confrère, I Yours very truly | William Sharp

P.S. If you could let me have a copy of the Register I shd. be much obliged. ALS Fales Library, New York University

\section{To Frederick Langbridge, [January 5, 1886?]}

This is my "permanent address". I 46 Talgarth Road I West Kensington. W.

My dear Mr. Langbridge

I was glad to hear from you again. Like you, I fancied that your old address no longer held good - for when last year (1884) I sent you a copy of my second vol. of verse - Earth's Voices - I never heard from you in reply. Perhaps, on the other hand, you never received it: if so, you must permit me to remedy the mischance at this late date.

I forget whether I was in Italy or Belgium or France when I last heard from you - or where: anyway, I think it is since then that I 'married my 
old love' and have since been correspondingly happy - neither of us regretting that as yet no children have made their appearance. My wife's first book is to be out this Spring, ${ }^{30}$ but she has had literary experience before this, though she is more the artist and musician than the writer.

I am glad that you have collected your charming ballads into a volume $^{31}$ (one or two of which, dipping into the uncut volume, I find to be old acquaintances) and as soon as I have the leisure I will read the book through and write to you my opinion thereon.

I am frantically busy at present with an appalling amount of literary work of different kinds to attend to: and I only returned yesterday from the Lake Country where I have had the honor and pleasure of being Ruskin's guest for a most delightful visit - so you will understand my present inability to read the volume you have so kindly sent to me.

My sonnet-book is to be published tomorrow. ${ }^{32}$ It consists of 265 select sonnets, with a prefatory essay on the sonnet of about 70 pages, and about 60 pages of notes in nonpareil type on the authors represented. If I can get Scott's people to allow me another copy - which is uncertain - I shall send you one. They look upon it more as a splendid advt. than as a paying thing, as you may imagine when I tell you it consists of 400 pages. I think he has made all arrangements for a long time to come, and not accessible to any new offers.

Meanwhile I must say au revoir.

Sincerely Yours | William Sharp

ALS Princeton

\section{To Edward Dowden, February 3, 1886}

46, Talgarth Road, I West Kensington. I W. I 3: 2: '86

My dear Dowden,

Many thanks for your most kindly worded notice of my "Shakespeare's Songs and Sonnets" in the "Academy" of last week which I have just seen 
- a pressure of correspondence, proof-correcting, and other literary work having prevented my glancing through that paper heretofore.

Ten days ago I sent to you a copy of my just published "Sonnets of This Century," which duly reached you, I hope. I trust you like the appearance of your five beautiful sonnets therein. I believe there is a great run upon the book - of which I am glad for the publisher's sake, as they behaved very decently to me.

There are several provoking misprints - but these I hope to rectify before long. I trust yours are free from flaws of this kind? I hope you will be in London this Spring that we may meet at last.

In haste | Sincerely yours | William Sharp ALS Trinity College Dublin

To Eric S. Robertson, [mid-February, 1886]

46 Talgarth Road, W.

My dear Friend,

I join with Lillie in love and earnest good wishes for you as man and writer. Accept the accompanying two sonnets as a birthday welcome. ${ }^{33}$

There are two "William Sharps" - one of them unhappy and bitter enough at heart, God knows - though he seldom shows it. The other poor devil also sends you a greeting of his own kind. Tear it up and forget it, if you will.

But sometimes I am very tired - very tired.

Yours ever, my dear Eric, I WAS. 


\section{TO ERIC SUTHERLAND ROBERTSON}

\section{(On his birthday, 18: 2: 86)}

Already in the purple-tinted woods

The loudvoiced throttle calls - sweet echoing

Down leafless aisles that dream of bygone springs:

Already towards their northern solitudes

The fieldfares turn, and soaring high, wheel broods

Of wild swans with a clamor of swift wings;

A tremor of new life moves through all things

And earth regenerate thrills with joyous moods.

Let not spring's breath blow vainly past thine heart,

Dear friend: for Time grows ruinously apace:

Yon tall white lily in its holy grace

The winds will draggle soon: for an unseen dart

Moves ever hither and thither through each place,

Nor know we when or how our life 'twill part.

II

A little thing it is indeed to die:

God's seal to sanctify the soul's advance -

Or silence, and a long enfevered trance.

But no slight thing is it - ere the last sigh

Leaves the tired heart, ere calm and passively

The worn face reverent grows, fades the dim glance -

To pass away and pay no recompense

To life, who hath given to us so gloriously.

Not so for thee - within whose heart lie deep

As ingots 'Neath the waves, thoughts true and fair.

Nor ever let thy soul the burden bear,

Of having life to live yet choosing sleep:

Yea even if thine the dark and slippery stair,

Better to toil and climb than wormlike creep. 


\section{To Hall Caine, [? February, 1886]}

46, Talgarth Road I West Kensington. I W.

My dear Caine,

I have sent the undernoted para: to the Athenaeum, among one or two other bits of gossip. It has just occurred to me that you [may] not be agreeable to its appearance $-\&$ if this be the case, drop me a line and I will countermand it. (I suppose you got the "Sonnet-Book" all right?) ${ }^{34}$

Yours in haste I William Sharp

"We understand that Mr. Hall Caine, in collaboration with Mr. Robert Buchanan, is engaged on the dramatization of his highly successful novel of last season, The Shadow of a Crime" ${ }^{35}$

ALS Manx Museum, Isle of Man

\section{To Theodore Watts [-Dunton], February 15, [1886] ${ }^{36}$}

My dear Watts,

I have not a copy of the reissue of the Sonnets of this Century, or I would send it to you. Browning's sonnet is all right (as are Symonds's) and the old boy wrote me such a nice letter there anent this morning.

I have had a preposterous letter from that ass Pfeiffer $^{37}$ this morning about Symonds' reference to Mrs. Pfeiffer in his article. He thinks it an insult to class her with such names - \& says she is acknowledged by all the best judges as the first living sonneteer: that she and Rossetti are the acknowledged masters of the craft, \& so forth: and that Symonds is one of the ring of London authors banded together to depreciate his wife.

What a fool the man is.

Ever yours affectly I William Sharp ALS Brotherton Library, University of Leeds 


\title{
To Theodore Watts[-Dunton], August 14, $1886^{38}$
}

\author{
Northbrook | Micheldever | Hants
}

\section{My Dear Watts,}

I sent you a line by this morning's post, acknowledging receipt of your letter and sonnet-matter. ${ }^{39}$

Best thanks again for all the trouble you have taken with the latter. Your suggestions are always valuable, and in the majority of instances I have acted upon them. I think I shall adopt, pretty well in your own words, those on pp. $313 \& 320$ - and undoubtedly they do, as you say, enrich the notes. I quite agree with the Swinburne additions. What a charming subject you have in the Rosy Seas, and the sonnet is worthy of it - though I must say my ear revolts at leaned (1st line) and wind as rhymes.

I won't forget to let you see the proofs of all the prose matter (Introdn. \& notes) - also your own sonnets - if you will give me your address, for there is no time to lose. The book is to appear in October (but don't announce it yet, please) - and I send the Introdn. to the printer on Monday (16th). ${ }^{40}$

Thanks for lending me your interesting sonnet article - which I won't forget to return to you early next week. I have been reading with interest your review of Stevenson's book: ${ }^{41}$ I like the article much, \& think R. L. S. will be greatly pleased. By the by, I think I recognised your hand in a notice of a new novel by Robinson ${ }^{42}$ some two or three weeks ago. When is Aylwin ${ }^{43}$ to be out: I wish you would send me the proofs of the 3rd vol; do, like a good fellow.

I am gaining strength very satisfactorily. ${ }^{44} \mathrm{My}$ doctor ran down to see me before going off to Canada on his autumn holiday, and he told me he could now find no trace of heart-disease, though I undoubtedly inherited from the Rheumatic fevers (the recent attack \& that of 5 years ago) a heart-complaint which would require my care for a year or so to come. I am not to work too hard, and never after the afternoon. This is all very well, but whether I can keep to such orders is a different matter.

I heard today from the Newspaper Press Fund. My application was considered a thoroughly just one - but alas! the amount of the grant 
they have made to me is only $£ 25$ - which won't go far to meet medical and other bills. However, I daresay I'll pull through all right somehow.

I shall be here till about the 25th at any rate - after that date my movements are as yet somewhat uncertain, so, unless you hear from me to the contrary, my best address will be 46 Talgarth Road.

What have you arranged to do for Eric Robertson's series? ${ }^{45} \mathrm{G}$. Borrow, I suppose, if any. And have you heard if Meredith is going to do Rossetti? I have promised to undertake Shelley, though not among the first 6 or 8 volumes. ${ }^{46}$

Yours ever affectly I William Sharp

P.S. Don't forget to let me know your address when you leave town and please don't forget to send me proofs of the 3rd vol of Aylwin.

ALS Edinburgh University Library

\section{To Frederick Shields, September 7, 1886}

Northbrook House | Micheldever | Hants | 7: 9: '86

My dear Shields,

It was a true pleasure to me to see your handwriting again. I am sorry to see that you are in London during this fine weather - but perhaps you have already had a change somewhere.

Since Dr. Moir left for his holiday I have progressed slowly but steadily. I am not of course robust yet, but I can now walk a fair distance (half a mile or so) without fatigue. The quiet and fresh air here have done us both good - but the place is a little relaxing.

I am not sure yet when we shall be settled in town again - probably about the middle or latter part of October. After leaving here we go for "bracing up" to Edinburgh for a fortnight or so - and then I hope I shall see Sir Noel Paton. I had a long letter from him about a fortnight ago. In it he wrote "Shields' drawing "for Lady Dundas is very fine. He sent it here some time ago, where it awaits her coming north - and as yet I am ashamed to say I have only acknowledged it by a brief telegram. But 
heaven help me! What can I do? correspondence becomes more \& more impracticable".

I am afraid he is far from being up to the mark. We are going to stay for a week with Mrs. D. O. Hill (his sister, and a wellknown sculptor) ${ }^{47}$ - \& I am much looking forward to seeing her again. No noblernatured woman was ever born.

I still write very little - so excuse more at present. My wife sends her kindest remembrances to you both - and I am ever, my dear Shields

\section{Affectionately Yours I William Sharp}

P.S. I look forward to seeing you again soon after we settle down once more.

ALS Spencer Library, University of Kansas

\section{To Ford Madox Brown, September 13, 1886}

Northbrook House I Micheldever I Hants. I 13th Sep/86

Dear Mr. Brown,

Thanks for your note and kind invitation. Since I wrote to you our plans have changed, and we do not now expect to be in the Manchester neighborhood until next Spring. My doctor thinks I want bracing \& that [I] should go to my native air - so my wife and I go shortly to Edinburgh.

Otherwise I - or rather my wife and I would have had genuine pleasure in accepting your kind invitation. ${ }^{48}$

I am pretty sure to take a run down to Manchester either in the winter or in the spring, and in that case would be very glad indeed to stay at any rate a night with you.

We are going to stay with Mrs. D. O. Hill in Edinburgh, the sister of Sir Noel Paton and, in Scotland, a well-known sculptor. She is a most delightful woman - but perhaps you know her?

I am now nearly robust again - \& have greatly benefited by my long stay at this pleasant country house. I have begun to do a little work 
again - chiefly reviewing: tho' I must wait another month at least before getting in full sail again.

Looking forward to seeing you and your fine work when I am next in Manchester, and again with thanks for your kind invitation.

Yours most sincerely | William Sharp ALS private (Transcript of letter sold by Sotheby's on December 18, 1995)

\section{To J. Stanley Little, ${ }^{49}$ [mid-October, 1886]}

46, Talgarth Road, I West Kensington. I W. I Saturday Afternoon

Dear Sir,

I have been incapacitated, through sudden illness, from applying ere this for tickets for "Hellas". ${ }^{50}$

Will you kindly give bearer (or send me, when I will remit whatever may be due) the following: - The 2 Balcony Tickets which are due to me as a member - also 4 others (2/6 Balcony Tickets) which I will take and give to friends so as in a small way to help the performancefunds.

Yours faithfully, I William Sharp

Jas. Stanley Little Esq I Hon: Sec: "Shelley Socy"51

My servant will pay what is due, if you will ask her for it.

ALS Princeton 
To , November 8, 1886

46, Talgarth Road, I West Kensington. I W. I London I 8th November/86

\section{Dear Sir}

Would it be agreeable to you if I were to submit for your consideration an article entitled Boy-Poets? It wd. be partly biographical and anecdotal, and partly wd. consist of critical and comparative exposition of the highly interesting work in verse of certain English poets, known and unknown, - from Cowley and Chatterton down to Rossetti and Oliver Madox Brown. ${ }^{52}$ In addition to known poets who wrote striking verse at a very youthful age, I know others (three or four living) whose precocity is really remarkable.

The paper wd. deal with poems written between the ages of nine and seventeen: and accompanying the description of several written there cd. be engraved portraits.

Yours very truly I William Sharp

Author of "Dante Gabriel Rossetti: "Record \& Study"

"The Human Inheritance: And Other Poems"

"Earth's Voices: Sospitrá, and Other Poems"

"Transcripts from Nature" etc. etc.

Editor of "Shakespeare's Sonnets"

"Sonnets of this Century: An Anthology". etc. etc. etc.

I enclose also for your consideration two sonnets and two short lyrical pieces. If you should care to accept one of them - please do so knowing that I reserve the copyright, and that I intend to print all four in a forthcoming volume of poems which will probably be published next May. ${ }^{53}$

W.S. 


\section{To Edward Dowden, [November 26, 1886] ${ }^{54}$}

46, Talgarth Road, I West Kensington. I W. I Friday Evening

Dear Mr. Dowden,

On reaching my house this evening I found your note awaiting me. I am glad you like the Sonnet book: it has been a great success; I am glad to say.

It is exceedingly kind of you to send me your "Life of Shelley"55 - a book I shall always value for its own sake and for that of the donor. Your gift of it is especially welcome - as I was just persuading myself that I ought to buy it - a proceeding which I am hardly able to afford at present. In the new series of "Great Writers" that is shortly to come out, I am to do Shelley - and of course could do nothing worth[while] unless I had your new work to go upon for definite facts etc. So the book you so kindly send me will be of great service to me as well as affording me much \& frequent pleasure.

I see long \& important notices of it in the "Daily News" and "Standard" of today. I think, however, it is hardly fair in the Standard or any paper to quote the hitherto unpublished poems you give in your book: a journal ought simply to direct readers, not to pick out "tit-bits" from important books.

I'm afraid our mutual friend, poor old Bell Scott, won't be south again: not, however, that he is especially unwell at present.

Sidney Colvin's "Keats" will be out in Jany, I believe; \& tho' on a much smaller scale than your "Shelley," will hold something like the same authoritative place. Wm. Rossetti is going to do "Keats" in the "Great Writers" series: Garnett is to do Carlyle: Joseph Knight, Rossetti: Hall Caine, Coleridge: Darcy Thompson, Darwin. My Shelley, I fancy, is to be out either in May or June. ${ }^{56}$

The "Life of Shelley" has not yet come from K. Paul \& co. - but doubtless will do so shortly.

Again, with sincere thanks,

Cordially yours I William Sharp. 


\section{To Edward Dowden, November 27, 1886}

46, Talgarth Road, I West Kensington. I W.

My dear Mr. Dowden,

Your "Shelley" has come since I posted my letter to you. The volumes are beautiful, and the matter tempting on every page glanced at. I am indeed glad to possess it.

Alfred Austin has just looked in to see me. I have shown him the book, and (being one of the fortunates with abundance of cash) he is going to purchase a copy at once, rightly judging it to be a necessity for any lover of Shelley's poetry to possess this work.

In haste, \& with renewed thanks, | Sincerely yours | William Sharp ALS Trinity College Dublin

\section{To Robert Lewis Stevenson, December 14, 1886}

46, Talgarth Road | West Kensington | W. | 14: 12: ‘86

Dear Mr. Stevenson,

Over a month ago I sent you one of the few copies which the publisher placed at my disposal of the large quarto edition deluxe of my Sonnets of this Century. I hope it duly reached you. If so, you will have noticed that it contained the two sonnets you were so good as to send to me.

I now write to ask if there is any misprint in - or if you wish to make any alteration in the [se]lection of, these Sonnets - or if you would like them reversed? The publisher is shortly going to reprint the book in the small form (similar to that which I sent to you before) at 1/-. This reissue is to follow the text (which was much revised \& improved in the Introd ${ }^{\mathrm{n}}$ \& notes, and contains several new sonnets, with others improved) of the large quarto. 
The book has had a very great success. Within about 10 months 15 , 000 copies have been sold - (i.e. seven 1/- editions of 2, 000 each, and the quarto edition at $12 / 6 \& 20 /-)$ and the reissue is to consist of 10,000 copies, most of which the publisher expects to clear speedily. Who can say after this that sonnets are unpopular, or that poetry is a mere drug in the market?

Hoping you are in fair health and rejoicing in the knowledge that you are engaged in a sequel to Kidnapped.

Believe me I Yours very truly | William Sharp Robert Lewis Stevenson, Esq

P.S. I forgot to state the publisher wants my finally Revised "copy" this week if possible.

ALS Yale Beinecke

\section{To Mrs. Bland, December 26, 1886}

46, Talgarth Road, I West Kensington. W

I have just received your volume of "Lays and Legends" - which I am very glad to possess. I hope to be able to notice it in an influential quarter in due time.

I am so very busy at present \& have had so many Xmas packages that I have been unable to do anything more than glance through some uncut pages. That glance, however, afforded tempting perspectives. With best wishes.

Yrs very truly | William Sharp

Private 



\section{Chapter Four}

\section{Life: $1887-1888$}

In the spring of 1887, Sharp succeeded his friend Eric Robertson as editor of the "Literary Chair' in The Young Folk's Paper, a widelycirculated weekly paper for boys. This appointment brought "steady work" and "a reliable income, a condition of security hitherto unknown to us, which proved an excellent tonic to the delicate editor" (Memoir 127-28). Assisted by Elizabeth, Sharp was responsible for reading, evaluating, and responding to "efforts in prose and verse of the "young folk' who wished to exercise their budding literary talents." The best pieces appeared in the paper "prefaced by an article of criticism and instruction written by their editor and critic."

Though he remained weak, Sharp continued to work and travel. After resting for a time at the Caird's country house in Hampshire, he and Elizabeth went to Paris in early May to review the Salon for the Glasgow Herald. On April 28, before leaving for Paris, he asked Ford Madox Brown, who was in Manchester painting frescoes in the new Town Hall, if it would be convenient for him to stay with him on May 16 or 17. He hoped to go to Manchester for the Royal Jubilee Exhibition celebrating the fiftieth year of Queen Victoria's reign. All manner of merchandise and crafts were displayed in a huge hall, including paintings Sharp wanted to review for the Glasgow Herald. He must have gone to Manchester, since in a letter to Brown in January 1890, he recalled and praised a framed etching of Brown's "Entombment" he had seen in the Exhibition. In his May 1887 letter to Brown, he said he had finished a long and laudatory introduction to a volume of Phillip Marston's poetry called For a Song's Sake, which was 
published by the Scott firm later in the year. Brown had known Phillip and was close to the Marston family. Sharp hoped he would be pleased with the volume, especially its introduction. Of the volume's reception, Sharp wrote in July to Louise Chandler Moulton, another friend of the Marstons, that it was selling well almost solely because of the Memoir Sharp wrote as its introduction; one reviewer said Philip "was at least fortunate in death to have such a biographer."

Along with his articles and editorial work on The Young Folk's Paper and for the Walter Scott firm, Sharp's main endeavor in 1887 was his monograph on Shelley for Scott's Great Writers Series. He continued to correspond with Shelley experts, chief among them Edward Dowden, and devoted considerable effort to the book, which was published on the first of October. It contained instead of a dedication a "special acknowledgment of indebtedness" to Dowden "whose two comprehensive volumes on Shelley form the completest and most reliable record extant, and at the same time constitute the worthiest monument wherewith the poet's memory has yet been honored." Elizabeth's description of his choice of Shelley for his first Great Writers book is telling. Shelley was the inspiring genius of his youth, she wrote, and "He was in sympathy with much of Shelley's thought: with his hatred of rigid conventionality, of the tyranny of social laws, with his antagonism to existing marriage and divorce laws, with his belief in the sanctity of passion when called forth by high and true emotion" (Memoir 131). A letter Sharp wrote to a Mr. Clarke in December 1887 demonstrates the strength of his convictions regarding women's rights. He called the views of women in a poem Clarke sent him for comment "absolute lies and absurdities." In a second letter to Clarke, he affirmed the influence of Shelley: "instead of my reverence for true womanhood falling off, it is yearly growing more strengthened, till now with Shelley it is one of my cardinal faiths - the equality of the sexes." Those were the sentiments of Mona Caird and, indeed, Elizabeth herself. By mentioning them in the context of the Shelley biography, Elizabeth was setting the stage for the events that would change of the course of their lives in the following decade.

In August 1887 Sharp received a letter of concern from Hall Caine who knew more about Sharp's health than anyone apart from his immediate family. His response, from North Queensferry in Fife on September first, is a frank and detailed account of the heart problem that plagued him: 
I think you are the only one of my friends who has recognised what a secret enemy my ill-health is. I look so robust, and (often at a great effort) try to be cheerful and sanguine that many think I have little to complain of. You, however, realise something of what I have really to endure. There are perhaps few people who know what "angina pectoris" really is, though "snake in the breast" gives them some idea it is not pleasant. If from hereditary taint it sometimes attacks the most robust natures, \& is then deadliest. The agony of it is sometimes too great for conscious endurance, and over one's head always hangs the shadow of sudden death. The doctor has warned me it may come at any moment; I may stoop too suddenly, may fall, may receive startling news - anything of the kind may bring about instant death. This, added to the precariousness of the literary life and its incessant hard work, gives me many a dark hour. Sometimes I awake at night with the dull gripping pain which is ominous of attack, and as I lie by my sleeping wife I do not know if I shall ever see the morning's light. Then I think of the hard struggle of life, and what my death would mean to my wife, and - well, I needn't dilate on the subject.

He continued, revealing more about his approach to life and death:

But partly because it is my natural bias and in great part because I have trained myself to this kind of self-control, I betray nothing of all this to any one. The other day a friend remarked to my wife that I was looking so well and was so cheerful \& confident that I must surely be exceptionally well - and yet this was shortly after an attack so violent and dreadful that it was some time before I came round. If, however, I did not keep this 'brave front' before the world, I would give way to the shadow that dogs me always. I never allow it to overcome me: if it be too appellant I face it and as it were frown it down. I have no fear of death, which the soul in me knows to be but the gate of life. The world is so very beautiful, and full of such transcendent hints of the divine, that death should be as welcome to all as the first breath of summer to the hillslopes and meadows. Yet oh I do cling to life too! There is so much I want to do, so many dreams which I would fain should not all pass oblivion-ward unaccomplished.

Finally, he confirmed the singularity of his relationship with Caine: "You are the only one of my friends to whom I have written this - but you drew it from me by your brotherly sympathy. And now having read my words destroy and forget them." Fortunately, Caine ignored that direction for in this letter we have Sharp's deepest thoughts and feelings about life and death. We feel the pain that often gripped him and the burden of recognizing each day might be his last. 
Improved finances enabled the Sharps to move, at the close of 1887, from a flat on Talgarth Road in West Kensington to a larger house in South Hampstead where "the air was purer and access to green fields easier." In early November, in good health and spirits, Sharp told Caine he had taken "a most delightful house" in Goldhurst Terrace, South Hampstead, and planned to move in at the end of December. He suggested Caine do the same as the neighborhood is "well sheltered from fog \& east wind - is otherwise healthy $-\&$ is not inconvenient." It would be grand to have Caine as a near neighbor. Later in the month ill-health struck again. Elizabeth took her husband to the Isle of Wight to recover from "inflammation of the lungs." They returned in early January and settled into the South Hampstead house they leased for three years and called Wescam. It had a sunny study on the ground floor so the "invalid" would not have to deal with stairs. It needed a name because its address $-17 \mathrm{a}$ Goldhurst Terrace - was frequently confused with 17 Goldhurst Terrace, the house in front facing the street. They began holding Sunday evening "at homes" which were attended by "all those with whom we were in sympathy," and the list of guests Elizabeth provided in the Memoir includes many well-known writers and editors. As winter turned to spring Sharp's health held in the new location. His editorial work and Elizabeth's well-placed friends and charm as a hostess solidified their position near the center of London's literary life.

Elizabeth's good friend Mona Allison Caird and her husband James Alexander Henryson Caird, a wealthy Scottish landowner, had a much larger house a few blocks north on Arkwrite Road where the Sharps were frequently entertained and met many of Mona's well-placed friends, including Thomas Hardy. She was a formidable figure who was gaining a reputation, praised by many and denigrated by more, as an advocate for women's rights, especially greater equality in marriage. The American women's rights activist Elizabeth Cady Stanton visited Mona Caird in February 1888 and later recalled: "Mrs. Caird was a very graceful, pleasing woman, and so gentle in manner and appearance that no one would deem her capable of hurling such thunderbolts at the long-suffering Saxon people." [Eighty Years and More: Reminiscences 1815-1897 (1898)]. The Sharps shared Mona's views on marriage and women's rights, and when they needed help, she invariably came to their rescue.

Elizabeth was pleased by her husband's improved health, and better health enabled greater productivity. Sharp selected poems and wrote 
prefaces for an anthology of odes and a book of American sonnets, both published in Scott's Canterbury Series, of which he was General Editor. He contributed reviews and critical articles to The Academy, The Athenaeum, and the Literary World. In April, he reviewed the French Salon for the Glasgow Herald and described it to Frederick Shields as "the resort of the evil rather than of the good spirits of art." The Sharps spent Whitsuntide with George Meredith at his home near Box Hill in Surrey. Sharp described the visit in a May 22 letter to Richard Le Gallienne: "I have just returned from my delightful visit to the loveliest part of the loveliest county in Southern England - and with glorious weather \& such a host as George Meredith I need not say that I have enjoyed the last few days immensely." From Box Hill, they walked over to Dorking to see their friend Grant Allen who was entertaining Joseph Cotton, editor of The Academy. Sharp told Cotton he was pleased by Le Gallienne's Academy review of his edition of Philip Marston's poetry. Meredith and Sharp had long conversations during the day and, Elizabeth recalled, Meredith read from his novels at night: "The reader's enjoyment seemed as great as that of his audience, and it interested me to hear how closely his methods of conversation resembled, in wittiness and brilliance, those of the characters in his novels" (Memoir 145). On May 23, Sharp wrote to Theodore Watts: "What a charming fellow G. M. is - is he not? The more I see of him, the more I admire and like him."

Sharp also told Watts on the 23rd that he would send him a copy of his third book of poetry - Romantic Ballads and Poems of Phantasy which had just been published by Walter Scott. It was "maturer work," and he hoped Watts would find it an improvement over his first two volumes of poetry.

In substance, it is imaginative in the truest sense - as I do not hesitate to say. It honestly seems to me that with all its demerits there is stuff in it of the purely imaginative kind such as you will not easily find in the work of other contemporary minor poets. Of course I shall be disappointed if no one likes it, or thinks highly of it - but for the first time in my life I am indifferent to adverse criticism: for I feel well assured that the little booklet is sterling - and with this assured confidence a bad reception can at the worst be but unfortunate and disagreeable.

Having described the main qualities of the book, Sharp said he was not urging Watts to review it (in The Athenaeum where he was a poetry 


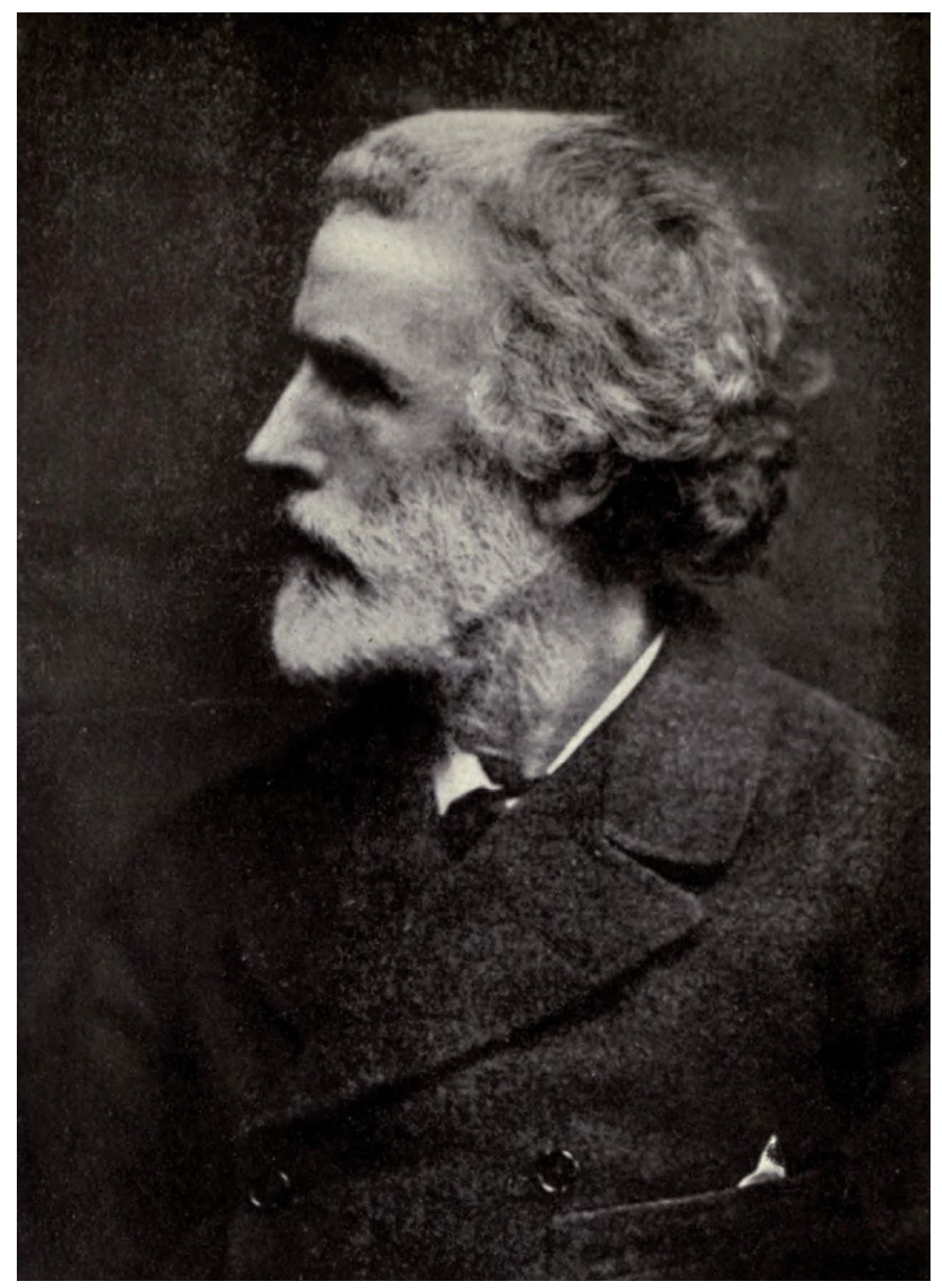

Fig. 6. George Meredith, no later than 1913, in Robert Louis Stevenson: A Bookman Extra Number 1913 (London: Hodder \& Stoughton), p. 138, Wikimedia, https://commons. wikimedia.org/wiki/File:George_Meredith\%27s_Portrait.jpg

critic), but the letter spells out what he hoped Watts would say should he decide to do so.

Sharp intended to print only a hundred copies, but given the "unexpected and gratifying anticipatory demand" he agreed to a "larger 
edition - most of which is already engaged." Perhaps the high demand would encourage Watts to write or solicit a review. In the "Dedicatory Introduction" to the volume Sharp expressed his "earnest conviction" that "a Romantic revival [is] imminent in our poetic literature, a true awakening of genuine romantic sentiment." He dedicated the volume to his wife who has had "a sterling appreciation of imaginative literature." She shared with him "the true Celtic passion for the weird and supernatural, and for vividly romantic sentiment and action." In predicting a turn away from realism and formalism, Sharp hoped the volume would inspire a third romantic movement in the century's poetry, the first begun by Wordsworth and Keats and the second by Rossetti and William Morris. A few poems in the volume are a marked improvement over those published earlier, but its main interest is the "Dedicatory Introduction" which forecasts the poetry Sharp would write as Fiona Macleod. The volume did not have the broad impact Sharp anticipated or bring him the recognition he sought.

As 1888 proceeded, Sharp developed a close friendship with Richard Le Gallienne, an aspiring poet who lived in Liverpool and would move to London in 1891 to write for The Star. On May 19, he thanked Le Gallienne for his friendly and sympathetic Academy review of his Marston book. Three days later he asked Le Gallienne to let him know when he would be in London as he looked forward to the pleasure of meeting him. In early June, Le Gallienne did come to London, and Sharp sent him a special invitation: "If you have not made any other arrangement could you come here on Sunday evening next? We don't "dress" on Sunday evenings, as friends sometimes drop in then promiscuously: and indeed on Sunday next we are, I believe, to have 'high tea' in place of dinner, for the sake of domestic convenience of some kind." He asked Le Gallienne to come at six so they could have a private "hour's chat" before the other guests arrived. He had sent Le Gallienne a copy of Romantic Ballads and wanted to talk with him about the new Romantic movement its preface forecast. He sensed from reading Le Gallienne's poems that he might be a willing recruit for the new Romanticism and recognized his potential as a major actor in London's literary life in the 1890s. Sharp's interest in Le Gallienne and the attention he received when he moved to London were due in no small measure to the young man's carriage and physiognomy - indeed, his physical beauty. 


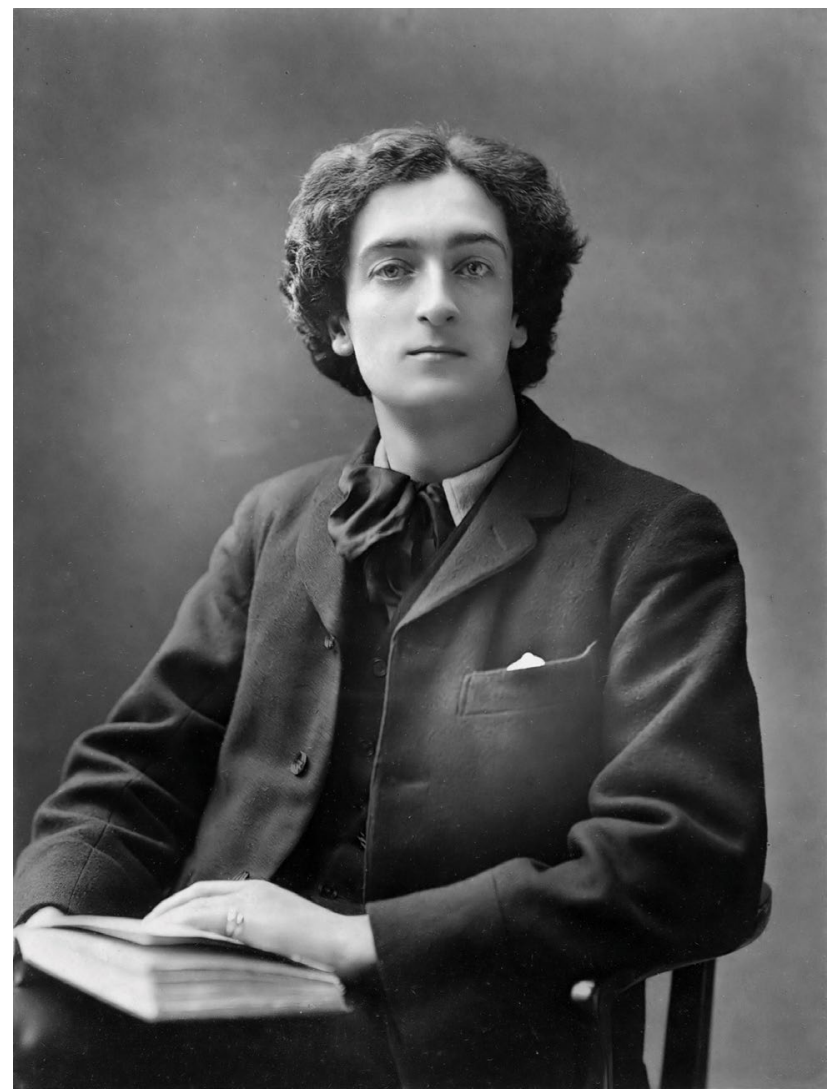

Fig. 7. Arthur Ellis (c.1894). Photograph of Richard Le Gallienne. Wikimedia, https:// commons.wikimedia.org/wiki/File:Richard_Le_Gallienne,_by_Alfred_Ellis.jpg, Public Domain.

Le Gallienne also valued their relationship as he affirmed strikingly in his The Romantic Nineties (Putman and Sons, London and New York, 1926):

When I reached London [from his native Liverpool], Sharp was already known as the biographer of Rossetti, the editor of an excellent anthology of sonnets, a popularizer of poetry. As editor of the famous "Canterbury" series, model of many such to follow, [and] something of a poet himself.... It was his personality that mattered most. He was probably the handsomest man in London, a large flamboyant "sun-god" sort of creature, with splendid, vital, curling gold hair and a pointed golden beard, the bluest of Northern eyes, and the complexion of a girl. Laughing energy radiated from his robust frame, and he was all 
exuberance, enthusiasm, and infectious happiness, a veritable young Dionysus.... No one could know him without falling under the spell of his generous magnetic nature, and I was proud to count him among my dearest friends.

Le Gallienne's description of Sharp rivals and confirms that of Ernest Rhys in Everyman Remembers, and they differ substantially from the William Sharp portrayed in his September 1887 letter to Hall Caine. In 1900 Le Gallienne dedicated his Travels in England to Sharp with affection and a brief but compelling piece of doggerel:

\section{Will, you have travelled far and wide \\ On many a foreign country-side, \\ Tell me if you have fairer found \\ Than honeysuckled English ground; \\ Or did you, all the journey through, \\ Find such a friend, dear Will - as you?}

In August 1888, the Sharps went to Scotland where they stayed two and a half months visiting family and friends. In a mid-October birthday letter to Theodore Watts, Sharp said there had been only four "wholly wet days" during their visit. They had spent most of their time near the sea in the west Highlands or on the east coast, "but we were also for some weeks at a glorious spot in Strathspey, a lovely moorland farm a thousand feet above the sea, among the Grampians, in Morayshire" just northwest of Aberdeen. While in Scotland he finished his second book for Walter Scott's Great Writers Series, a study of the German poet Heinrich Heine (1897-1865). He was seldom ill during his annual visits to Scotland, and his letters were invariably cheerful. Even the letter he sent Caine from Fife in September 1887 describing his bouts of illness concluded, "I have been in a strong mental and spiritual ferment lately, and I think I shall speedily write something I have long had in my mind." Perhaps it was the fresh air and familiar surroundings augmented by relief from the pressures and tensions of London.

When he returned to London in the fall, Sharp asked Andrew Chatto if his firm, Chatto \& Windus, would like to publish a romance he was writing called Sampriel. The novel was "a romance of the adventurous mind, an attempt toward further stimulating the advent of the true romantic sentiment." Chatto accepted the offer and published it in 1889 under the title Children of Tomorrow. The love affair at the center of the 
romance embodied many of the Shelleyan ideas Sharp found appealing. As enumerated by Elizabeth in the Memoir 146, those ideas reflected the influence of Mona Caird who had written a book Sharp asked Chatto to consider publishing. Children of Tomorrow, like Romantic Ballads and Poems of Phantasy, exemplified what he called in the letter to Chatto the "new romantic movement." Just as the poems represented a flowering of Romanticism, the novel was "destined to revolutionize contemporary fiction."

The renewed good health Sharp enjoyed during the summer in Scotland lasted through the fall, enabling him to continue the writing and editing that produced a reasonable income. Although these two years - 1887 and 1888 - had been marked by bouts of ill health, they also included periods of hard work that brought improved financial circumstances and acceptance and respect within the London literary establishment. In the end, however, neither Romantic Ballads and Poems of Fantasy nor Children of Tomorrow brought Sharp the accolades and acolytes he sought. The new Romanticism proclaimed in the books was undercut by the quality of the product. Oscar Wilde made that point bitingly in reviewing Romantic Ballads: the introduction announcing the new Romanticism was the "most interesting part of the volume," but it heralded "a dawn that rose long ago," and the poems were "quite inadequate." The critical response to the two volumes - and the lack of it - caused Sharp to believe his reputation as an editor and critic hampered his effort to gain acceptance and approval for his poetry and fiction. That belief influenced his decision to break from editing in 1890 and launch a new life, which culminated four years later in his creation of a new personality - Fiona Macleod - through whom he relaunched his "new Romanticism" pseudonymously under the umbrella of the Celtic revival. 


\section{Letters: 1887-1889}

\section{To J. Stanley Little, January 3, 1887}

46, Talgarth Road I, West Kensington I, W I. 3: 1: 87

My dear Sir,

Herewith I enclose my cheque for one guinea - being my subscription to the "Shelley Socy" for 1887.

I am engaged on a volume on "Shelley"1 for the new series "Great Writers" $^{\prime}$ - so wd. be obliged if I could have the Socy publications now due as soon as practicable.

Yours faithfullyl, William Sharp

Jas. Stanley Little Esq I. Hon Secy

ALS Princeton

To Edward Dowden, [early January, 1887]

46 Talgarth Road I West Kensington I W

Dear Dowden

Your card just to hand. Don't forget that if you can arrange to spend a few days in London on your return to Ireland my wife and I wd. have sincere pleasure in putting you up. A spare bedroom always is ready for friendly occupation, - and you wd. at least have a warm welcome here. Do you know Mrs. D. O. Hill in Edinburgh - the sister of Sir Noel Paton and the most eminent woman-sculptor our country has produced? She is an ardent Shelleyan - and has, moreover, produced a fine bust of Shelley. 
Hoping your lectures will be highly successful, \& cautioning you to be more careful against cold etc. than poor Sydney Dobell was when he lectured for the first \& last time at the Philosophical - also trusting that you may return via London -

Sincerely yours | William Sharp

ALS TCD

\section{To J. Stanley Little [January?, 1887]}

46, Talgarth Road I, West Kensington I. W.

Dear Mr. Little,

I am much indebted to you for sending me your treatise on aspects of art. $^{3}$ I already knew it, and admire and agree with it heartily. You take the manly and honest, and as it seems to me, the only true view of art in its widest sense. Some of the chapters are particularly noteworthy. I trust the book has had a wide sale: the more widespread the influence of such teachings the better for all workers in Art, Poetry, and Fiction - in all the Arts: and for those to whom these workers appeal.

With thanks, and kind regards,

Yours very truly I, William Sharp ALS Princeton 


\section{To Richard Le Gallienne, ${ }^{4}$ [late February, 1887]}

46, Talgarth Road I. West Kensington I, W.

... My other vols (original I mean) are not easily procurable now, but if you have not seen my last vol. of poems (1884) - "Earth's Voices - Sospitra - etc". I should be glad to send a copy to so kindly and sympathetic a reader.

Believe mel, Yours very truly I, William Sharp

P.S. I have just finished an article upon Rossetti for the March number of The National Review, in a footnote to which I have referred to poor Philip Marston's death, and quoted Rossetti's sonnet to him - which I see you know. ${ }^{5}$ I have forgotten to say that I am interested about your own poems. Are you going to publish in London? If so, you may have to come to town - pray come and see me, if you do.

ALS (fragment) University of Texas at Austin

\section{To James Cotton, ${ }^{6}$ [Spring, 1887?]}

Thursday

My dear Cotton,

My memory is so infernally bad just now - \& I find I forgot two things when I saw you today. One was to give you a copy of the reissue of "Sonnets of This Century" in its cheap form. It is now thoroughly revised - \& contains 12 sonnets not in other editions. In this - practically the ninth - I have put two of my own: I always refused to do so hitherto. And for half a dozen special friends I have had inserted as frontispiece a silhouette of myself done by my wife.

The other was to ask you if you would care to edit a vol. sometime in the Canterbury Poets? It does not pay when there is much trouble, 
but when it simply means a little arrangement (perhaps not even that) and a short introduction, it is sometimes worthwhile. As your tastes are scholarly it struck me that you might care to do a nominally classic vol. I think a reprint of Chapman's Homer would be interesting. What think you?

Before I saw you today I called on Marzials, ${ }^{7}$ prepared to throw up my book on Shelley: but he very kindly shifted it on till August.

Robertson saw my cousin ${ }^{8}$ in Bombay: he does not seem to have improved in health.

Yours ever| W.S.

ALS Huntington

\section{To May Clarissa Gillington, [Spring, 1887]}

46, Talgarth Road I, West Kensington. W.

Dear Miss Gillington ${ }^{9}$

I am glad that I have been able to be of any encouragement and help to you.

Under the circumstances I think I may venture upon a certain explanation. Some months ago Mr. Eric S. Robertson - who was one of my chief friends - gave up the Literary Editorship of Young Folks Paper on his appointment as Professor of Literature at the University of the Punjab in northern India. At the time you receive this he will be lecturing to his students at Lahore!

On his resignation, the Editorship was offered to me by the Proprietor of the paper, and I accepted it. While Mr. Robertson was getting ready to start, your MS. vol came to him, and was by him passed on to me. At the time I did not know your work, and took the vol. indifferently - for I am afraid that having reviewed in our chief literary journals many scores of books has made me somewhat more callous than I used to be. The night before Mr. Robertson sailed I dined with him, and then 
told him that I had looked into your vol., \& your poems in back nos. of the Y.F.P. and was really impressed by the genuine poetic impulse they betrayed - in fact, that I had a distinctly higher opinion than he himself had formulated.

Since then I have thought often of your work. Editorially I always strive to be absolutely just - as perhaps you have inferred! Although, comparatively speaking, a young man myself, it is now many years ago since I fairly made my debut in literature - and it is the memory of my own experiences which makes me glad to be of any assistance to those whom I consider to be genuine poets at the outset of their literary life.

I was in So. Hampstead the other day and thought of calling upon you to talk over your poems but found time pressed me too greatly to enable me to do so.

When you and your sister are next in town perhaps you will let me know (writing to me under my own name, \& to my private address).

Since you are so pleased at my having inserted a sonnet of yours in the latest edition of my "Sonnets of this Century," ${ }^{10}$ I think you will be gratified also at a letter you will likely receive erelong from my wife, who also is somewhat of a victim to cacoethes scribendi.

The more I think of it the more I am convinced of the advisability of your and your sister's bringing out a vol. of poems conjointly. I should like to talk the matter over with you before you "proceed to extremities". I am glad to hear that your sister is also a sea-painter. As an art critic this interests me, and I hope that some day I may encounter her work professionally.

There are good reasons why an Editor as far as possible preserves his "incognito," therefore kindly consider my confidence as strictly private, i.e. to go no further. Except when addressing me privately and to this address, I must remain the Editor of Young Folks Paper.

With sincere good wishes I, Yours most truly I, William Sharp ALS Princeton 


\title{
To Richard Garnett, [Spring, 1887]
}

\author{
Northbrook House I Micheldever I Hants
}

Dear Dr. Garnett

I was in town a day or two ago for a few hours, and among various letters \& packets found your "Carlyle"11 which you so kindly sent. I am looking forward to reading it tomorrow. As I had already ordered a copy, I gave the one you sent into the hands of my wife - as from you

- knowing how much she would value it. From a hasty dipping into the book it looks most entertaining, and satisfactory to the Carlylean. But I shall let you know again what my impressions are. I suppose you received the copy of Sea Music ${ }^{12}$ which Mrs. Sharp sent to you? I liked all of yours therein, but especially the very beautiful "When shall we cross the sandy bar?" - which, if I am not mistaken, was published in your poems. ${ }^{13}$

Hoping you and yours are well

Sincerely yours | William Sharp

Shelley ${ }^{14}$ is almost out of my hands.

ALS University of Texas at Austin

To Ford Madox Brown, [April 28, 1887]

46, Talgarth Road I West Kensington I W.

Dear Mr. Madox Brown

You were so good last year as to ask me to stop a night with you if I were in your neighbourhood. I intend to be in Manchester for a day or a night about the 16th or 17th of May - for the Exhibition - and it wd be so very pleasant [for] me to pay you a visit if it were convenient for you. ${ }^{15}$ 
My wife and I go over to Paris (for the Salon) on Saturday morning, and we shall not return till about the 14th.

Hoping you are well and that your work at the Manchester Town Hall Frescoes is progressing satisfactorily.

Sincerely yours | William Sharp

P.S. I have just finished the Memoir of poor Philip Marston to precede his forthcoming volume of stories. ${ }^{16}$

Transcript of ALS sold by Sotheby's on December 18, 1995

\section{To Edward Dowden, [June 7, 1887] $]^{17}$}

46 Talgarth Road I West Kensington I London I. W. ${ }^{18}$

\section{My dear Dowden}

Just a line to let you know how greatly one of your readers has enjoyed your most able and brilliant article in the current "Fortnightly" - the best article of the kind which I ever remember to have read. ${ }^{19}$ It has been much admired by others also, I can assure you from my own knowledge. What pleases me most is its broad outlook - its wide survey - no mere platitudes of generalization, but the genuine all-embracingness of fine vision. But I am also delighted with its moderation, tolerance, wide sympathy, and high tone. Even an editor can wax enthusiastic over it (or one practically an editor) for Verschoyle ${ }^{20}$ was speaking to me about it the other day in no measured terms.

I hope you are to be in London this summer. Did you ever meet a Mr. Silsbee? ${ }^{21}$ I had a long talk with him at his rooms the other day. He has resided for some years with Claire Clairemont $-\&$ has several Shelley MSS. He told me several unpublished stories about Shelley. I wonder if Claire Clairemont's statements are quite reliable. ${ }^{22}$

Hoping you are well, and writing some poetry (which, though I admire all you have written, is the foremost thing). 
P.S. I sent you a copy - a fortnight ago - of poor Philip Marston's posthumous vol, with my Memoir of him: which I hope duly reached you. ${ }^{23}$ They say that only ladies go in for PSS, but I find I must add another: - I had a letter some time ago from an unknown correspondent about my "Sonnets of This Century" wherein she mentioned that she had been so much struck by your sonnets, theretofore unknown to her, that she had purchased your "Poems". W. S.

ALS TCD

\section{To Louise Chandler Moulton, ${ }^{24}[\text { ? July 3, 1887 }]^{25}$}

Sorry to have had to leave your charming "afternoon" so abruptly today. I will explain to you how imperative the reason was, another day. If I had stayed, I wd. have had to have been rude (unavoidably) \& this I wished to avert.

You were looking "blooming". I am glad to see you so well. The "Song's Sake"26 is going well (Roberts Bros. have sent a preliminary order for 250) but, the publisher tells me, almost solely on a/c of the Memoir. The stories have not taken very well, as yet. Reviews all very flattering: one just to hand says $\mathrm{P}^{27}$ was at least fortunate in death in having such a biographer. I'm so glad.

W.S. 


\title{
To Edward Dowden, [? August, 1887]
}

\author{
16 Rosslyn Terracel Kelvinside। Glasgow ${ }^{28}$
}

Dear Mr. Dowden

Thanks for your note, forwarded to me from London to above address (good, for letters, throughout Augt. \& Sept?).

I should be very glad to have the loan of Tyler's unpublished Essay as you kindly offer - if you care to entrust it to me and to risk postal mischances.

No, thank the Gods, whatever my demerits I have not yet died only succumbed to a different kind of 'fatal dart': but I shd. much rather have died than have written the volume to which you refer, by someone of the same name whom oblivion hath mightily overtaken.

If you can spare time I shd. be most glad to hear from you again, but don't want to be a nuisance.

In extreme haste | Sincerely yours | William Sharp

ALS TCD.

\section{To Hall Caine, September 1, 1887}

St. Margaret's| North Queensferry| Fife| N.B।. 1: 9: 87

My dear Caine

I was very pleased to receive your sympathetic letter. I think you are the only one of my friends who has recognised what a secret enemy my illhealth is. I look so robust, and (often at a great effort) try to be cheerful and sanguine that many think I have little to complain of. You, however, realise something of what I have really to endure. There are perhaps few people who know what "angina pectoris" really is, though "snake in the breast" gives them some idea it is not pleasant. If from hereditary taint 
it sometimes attacks the most robust natures, \& is then deadliest. The agony of it is sometimes too great for conscious endurance, and over one's head always hangs the shadow of sudden death. The doctor has warned me it may come at any moment; I may stoop too suddenly, may fall, may receive startling news - anything of the kind may bring about instant death. This, added to the precariousness of the literary life and its incessant hard work, gives me many a dark hour. Sometimes I awake at night with the dull gripping pain which is ominous of attack, and as I lie by my sleeping wife I do not know if I shall ever see the morning's light. Then I think of the hard struggle of life, and what my death would mean to my wife, and - well, I needn't dilate on the subject.

But partly because it is my natural bias and in great part because I have trained myself to this kind of self-control, I betray nothing of all this to any one. The other day a friend remarked to my wife that I was looking so well and was so cheerful \& confident that I must surely be exceptionally well - and yet this was shortly after an attack so violent and dreadful that it was sometime before I came round. If, however, I did not keep this 'brave front' before the world, I would give way to the shadow that dogs me always. I never allow it to overcome me: if it be too appellant I face it and as it were frown it down. I have no fear of death, which the soul in me knows to be but the gate of life. The world is so very beautiful, and full of such transcendent hints of the divine, that death should be as welcome to all as the first breath of summer to the hillslopes and meadows. Yet oh I do cling to life too! There is so much I want to do, so many dreams which I would fain should not all pass oblivion ward unaccomplished.

And after all, my complaint may be kept in check: five, ten, even twenty years may yet be mine. The doctors are very hopeful that my almost phenomenal vitality and recuperative power may enable [me] to triumph over my insidious enemy.

You are the only one of my friends to whom I have written this - but you drew it from me by your brotherly sympathy. And now having read my words destroy and forget them. I do not complain, and would fain not be thought one of those who wail against inevitable laws. The gods have given me so much in my life, that if I were not brave \& hopeful under my petty troubles I would be very poor stuff indeed. 
After two or three happy days in the Border country (close to Abbotsford) I am now at one of the loveliest estates in eastern Scotland. The grounds are wild \& beautiful, and the views oversea and land are divine. I have been in a strong mental and spiritual ferment lately, and I think I shall speedily write something I have long had in my mind.

Please do as you suggest about Appleton's. Their reprints are to be better than ever, and, as you know, they were at all times better than Harpers'. I can pretty safely give you the assurance up to at least, 15. (Harper's only give from, 8 - to, 10). Please tell Lang[?] \& co. you are dealing direct, and kindly send me the "copy" at your early convenience (no pressing hurry) of course. The interest grows keener \& keener. It is a great romance, I believe - a book it will be impossible to overlook. ${ }^{29}$ Every word seems to have come through the crucible of pure emotion: higher praise I could not give.

Ever I dear friend I Sincerely yours I William Sharp

PS I shall be here till Wedny or Thursday next - thereafter for two or three weeks, at least, my letter address will be Glen Cottage I Murrayfield I Edinburgh.

ALS Manx Museum, Isle of Man

\section{To Edmund Stedman, [early October, 1887] $]^{30}$}

...Since you are so kindly going to do me the honour of mention in your forthcoming supplementary work, I should not like to be misrepresented.... I am a student of much else besides literature. Life in all its manifestations is of passionate interest for me, and I cannot rest from incessant study and writing. Yet I feel that I am but on the threshold of my literary life. I have a life-time of ambitious schemes before me; I may perhaps live to fulfill a tenth part of them....

Memoir 129 and 150 


\section{To J. Stanley Little, [mid-October?, 1887]}

Monday Afternoon

Dear Mr. Little

Thanks for yr card. I sent you a line yesterday to yr Forest Hill address.

By the by, is the Epipsychidion reprint out? ${ }^{31}$ In sending back the proofs of the Shelley bibliography to the compiler, I told him not to include the 'Epipsychidion' unless he knew it to be out. Yet here it is, and in 1886 ! As I have never recd any copy, there must be a misunderstanding somewhere.

I regret that my incessant and overwhelming work forces me to decline any promise as to a Shelley paper for 1887-1888. If you are a busier man than I am - well, I pity you! I seldom work for less than 10 hours a day, sometimes for 12 and even 14 - i.e. at fiction, criticism literary and artistic, general literary work, and editorial.

In great haste and with best regards,

William Sharp

ALS Princeton

To J. Stanley Little, October 27, 1887

46 Talgarth Road I West Kensington | WI. 27: 10: 87

My dear Mr. Little,

It is very kind of you to suggest that I should use your Hogarth ticket, but I can only consent to do so on the distinct understanding that you really do not wish to utilise it yourself. 
I know your brother's work very slightly, and do not think that I have ever noticed it journalistically - and I should certainly much like to see his portrait of Haggard. ${ }^{32}$ But just do as you feel inclined; for I could doubtless obtain a ticket otherwise

Hoping your indisposition is of a slight and transitory nature, I am,

Yours Sincerelyl, William Sharp

P.S. I wanted to send a copy of my just-issued Shelley to the Secy of the Socy, but as I had mislaid the new address and as G. White ${ }^{33}$ could give me no other than your present one, I took the liberty of directing the publisher to send a copy there.

ALS Princeton

To J. Stanley Little, [October 31, 1887]

New Athenaeum Club I, 26, Suffolk Street I, Pall Mall.

My dear Mr. Little

I was not fortunate enough to encounter your brother last night at the Hogarth, but enjoyed seeing his portrait-picture, which seemed to me very good indeed,

Some day, when in the neighbourhood of Portugal St., I hope to look you up.

Hoping you are having a pleasant stay in Surrey,

In haste, Sincerely Yours I, William Sharp

ALS Princeton 


\section{To Hall Caine, [early November, 1887]}

46, Talgarth Road I, West Kensington I. W.

\section{My dear Caine}

I was unable to go to the theatre last night, but my wife went for me. She is a good substitute, as she is well qualified for that kind of work.

Herewith I enclose her brief report.

I have taken a most delightful house in Goldhurst Terrace, at South Hampstead (Finchley Rd. Station), \& we move in at Xmas-tide. If you are coming to this part of the world do come to So. Hampstead. You can get really delightful houses, on short leases too, from, $50 .{ }^{34}$ It would be delightful to be near neighbors. It is well sheltered from fog \& east wind - is otherwise healthy $-\&$ is not inconvenient. Try \& come.

I have rapidly run thro' the Athenaeum review of Austin. It seems to me very acute, and, I must say, just. But I'm going to read it properly tomorrow.

I am very curious to know what you will think of the notice of the Deemster ${ }^{35}$ in same issue. Meanwhile "I reserve my own opinion".

Thanks for all your kind expressions, my dear fellow, \& believe me ever,

Affectly yours I William Sharp

I am going to speak as much as possible to the numerous people I meet, abt. the "Deemster" so as to make them ask at Mudies".

ALS Manx Museum, Isle of Man.

To Edward Dowden, November 14, 1887

46, Talgarth Road I, West Kensington I. W I. 14: 11: 87

My dear Dowden 
Have you made any arrangements for the American public'n of your "Victorian Literature: and Other Essays". And are you free to do so?

If so, if you could let me have advance sheets, possibly Appleton \& Company - for whom I have agreed to act (when it suits me!) as literary agent in this country - [will] reprint the book - thus saving it from the pirates and putting a small sum in your pockets.

I hope you duly received the copy of my "Shelley" which I sent to you over three weeks ago: also that the "note" (the nearest to a dedication I was allowed) pleased you.

Sincerely yours | William Sharp

Have just issued a 3 vol novel The Sport of Chance ${ }^{36}$ written 3 or 4 years ago, \& been running serially.

ALS TCD.

To Clarke, ${ }^{37}$ [December 19, 1887]

Monday

My dear Clarke,

I have read your poem. It is damned rubbish.

Yrs faithfully | William Sharp

P.S. Of course you will understand by "damned rubbish" I mean the statements you put forward. After making all due allowance for cant that is often talked about women, purity, \& so on - the statements you make are absolute lies and absurdities.

Of course it wd. not be yours if it were not well put together, but this makes it all the worse. I trust you're not going to insert it in yr. book. It is a clever firework, mon cher ami, - nothing else - save that it might fall on some fool's head and make him sillier than before. 
N.B. This is not a poem you can disavow by saying it is from another point of view, not necessarily yr. own opinion, etc. - hence the foregoing. ALS American Antiquarian Society

\section{To} Clarke, December 20, 1887

The Fine Art Society | (Limd).। 20: 12: 87

My dear Clarke,

Glad to find you were not offended by the somewhat blunt expression of my sentiments.

Of course, I know well (indeed, one unfortunately can't go through the world without knowing) that your strictures are often deserved - but when I said your statements were absolute lies and absurdities I meant only as applicable to womankind in general. In one sense, therefore, I withdraw the term absolute. Only when I speak or think of womankind I do not think of prostitutes or fools, any more than when speaking of our noble English Literature I think of Ernest Wildings or the "authors" who hatch their filth in Holywell St. It is for this reason I don't think your verses justifiable - they apply only to a very small and worthless portion of womankind and not to womankind in general. It would not be a bit more absurd to say that all men are without reasoning powers, because in your or my or anyone's experience all the men who had come into contact with us seemed devoid of mind.

If I had seen the poem at yr. diggings, I should simply have dissented from it, at the same time being amused \& taken with its point of forcibleness - for then I should simply have looked at it as written from momentary spleen, or as a clever jeu d'esprit. But printed and circulated lines are a different thing altogether.

If they really represent your opinions I am honestly sorry - for I like you personally and think highly of your powers - but I could not disguise from myself the impossibility of any man rising to lasting worthy reputation who kept insistently to such necessarily degrading and "un-manning" a belief. 
If in the meantime you really hold to them I believe \& hope you will in time come to a somewhat truer and higher belief in your fellow creatures. You must have had an exceptionally unfortunate experience: possibly, I have had the reverse: but from experience alone I can flatly deny yr. statements as general statements.

I am no longer at the age, you know, where every young woman seems an angel of innocence and ignorance, nor when love or passion blinds the eyes to visible defects, yet instead of my reverence for true womanhood falling off it is yearly growing more strengthened, till now with Shelley it is one of my cardinal faiths - the equality of the sexes. In the past I prefer to be, however humbly, in the company of Shakespeare, Milton, Blake, Wordsworth, Shelley, and Keats, - and in the present with Tennyson, Browning, and Rossetti - than with the Wycherleys and Congreves, the Rochesters and Sedleys, or the luscious-and-lust poeticules and the Swinburnes.

If Browning and Rossetti \& Victor Hugo had had the same views on women as Swinburne, they might still have been greater - but not so immeasurably so as they are.

If I did not think well of you \& your powers I should not give the matter a second thought - leaving both author and verses to well merited damnation: - as it is I do hope you won't be so rash as to publish them in yr. book.

In haste | Yrs ever sincerely | William Sharp ALS American Antiquarian Society

\section{To Alfred H. Miles, ${ }^{38}$ December 31, 1887}

Wescam | 17a Goldhurst Terrace I South Hampstead I N.W I. 31/12/87

\section{My dear Sir}

On my return from the Isle of Wight I find your letter awaiting me. I have known for some time about your forthcoming book - in fact, I have on one or two occasions acted as literary judge as to the selections. 
I am of course complimented that you should wish to include anything of my verse: and since you do me the courtesy of permitting me to indicate my own preferences I shall be pleased to name a few poems for you to select from.

I think the best (all round) selection that has been made from my writings is in the latest volume of Mr. D. H. Edwards" "Modern Scottish Poets" - I forget whether the 9th or 10th, but the same vol as that in which Robt. Louis Stevenson, Wm. Black, \& others appear.

I am at present staying with friends while "house-moving" (the address I have given is that of my new residence) and have none of my books within reach. Tomorrow I go to Essex (The Mill House, Felstead, Essex) for a week or ten days, and on my return to my new house would be pleased to see you there at any time. In any case I shall ask your acceptance of my second book of verse (the first, The Human Inheritance, was sold out some four years ago) - but if you wish to select at once I will direct a copy to be sent to you. Otherwise I shall wait till you find it convenient to call - best by appointment.

Yours very truly | William Sharp

Alfred H. Miles Esq

ALS University of British Columbia

\section{To [Richard Garnett], [Early 1888]}

Wescam I Goldhurst Terrace I S.H. N.W.

Cher Ami

I have finished your Emerson. ${ }^{39}$ I think it is a most able piece of work quite the best study extant of the man and his work. Greatly as I like the Carlyle I think that on the whole I consider the Emerson finer. I agree almost in toto with what you say about his philosophy - altho' on some minor points I differ from your estimate of some of the poems. I think 
your remarks on the Essays on History and Art are particularly to the point.

As for the charming close, I can call to mind nothing more delightful. How I envy you those last two sentences. Happy man, that your "Exhibit" be of such haunting, unforgettable kind.

Ever cordially yours | William Sharp

ALS University of Texas at Austin

To [ [? early 1888]

Wescam I 17a Goldhurst Terrace I So. Hampstead I NWI Sunday

My dear Sir,

I shall be glad to make your personal acquaintance. But I never am at 'Warwick Lane' which is only an agency and not an editorial or managerial office save when Mr. Scott's manager chances to be in town.

I am dining out tomorrow (Monday) evening - but would be pleased to see you in the afternoon, anytime between $3 \mathrm{o}^{\prime}$ clock and 5: 30, or up to 6 . This is the only opportunity, I fear. I am always at work in my study in the mornings. If, however, you are to be in town on Tuesday, I could arrange to meet you at my club, as above, around 4: 30. At least, I think I could, tho' I cannot say yet, definitely.

But it wd. be more convenient if you could come out to So. Hampstead tomorrow: that is, if it be not too far for you to come.

If you come from London itself come by Metropolitan Ry (via Baker St) to "Finchley Rd., So. Hampstead". Goldhurst Terrace is 3 minutes walk from the station. If you come from Holloway your quickest way, I fancy, would be by North Western Ry to Loudoun Rd., which is about 5 minutes from us in another direction - or if the L.\&N.W. Ry is not available, then by the North London Ry via Kentish Town etc. to Finchley Road. This is the first station beyond "Hampstead", on the North London or 
Midland, and is about 4 minutes further west than the Metropolitan Finchley Rd.

\author{
Yours faithfully| William Sharp
}

ALS Fales Library, New York University

\title{
To Richard Le Gallienne, [late January?, 1888]
}

Wescam I. 17A Goldhurst Terrace I South Hampstead I N.W.

Dear Mr. Le Gallienne

I am ashamed to have so long kept you waiting for an answer - but the truth is that all of my correspondence is so hopelessly in arrears that I expect weeks must elapse ere in my brief leisure moments I shall be able to materially reduce its appalling bulk.

I have long - how long I dread to think - owed you a letter about your charming volume of poems, ${ }^{40}$ but alas, have never yet done what should have been a pleasant duty. As regards the Canterbury application, my excuses are illness, absence from town, and house moving. In the early winter I got inflammation of the lungs \& had to knock off work \& go to the Isle of Wight: since Xmas we have been house-moving ${ }^{41}-$ an experience more dire than ever befell Ulysses in all his wanderings.

I regret that I find myself unable to entertain your friend's proposal: pray assure him of my regret when giving my thanks for the offer.

As for your own proposal I have to say what amounts to the same thing - tho' with the addition that ultimately it is possible I might be able to commission the volume. Meanwhile the publisher wishes me to make no more arrangements, as we have already enough on hand to keep the series going for two years. ${ }^{42}$

Is there any chance of your being in London this half-year? If so, I trust to have the pleasure of making your acquaintance in person. The above is my new address - and here you are likely to find me anytime 
till the end of July - save the first fortnight of May, when my artwork calls me to Paris.

With best wishes | Sincerely Yours | William Sharp ALS University of Texas at Austin

\section{To the Editor of the New York Independent, [January or February, 1888]}

Wescam | Goldhurst Terrace | South Hampstead | London | N.W.

\section{Dear Sir}

Could you undertake a serial that has already begun to appear in an English periodical? My Romance of Adventure, entitled "The Secret of the Seven Fountains" commenced in the Xmas number of Young Folks Paper, ${ }^{43}$ and will conclude about the end or middle of April. (34 chapters)

It has, so far, I am told, proved a great success. It is a story of exciting adventure, for the first half laid in the little known Fen Lands of East Anglia, and thereafter in Turkey and the Danubian principalities. The central motive is a clue to immense treasure - the clue being the Secret of the Seven Fountains. The interest is continuous and cumulative, and the mystery is preserved to the concluding chapter.

Again, do you ever reprint stories that are unknown in America? Last year I wrote serially an historical romance dealing with the discovery of the Pacific: ${ }^{44}$ and the previous year a boy's romance entitled "The Great Pearl" (Jack Noel's Legacy) ${ }^{45}$ which took so well that the publisher paid me a considerable amount over the very fair sum originally arranged. Would it be any use sending either of these to you for publication?

Again, would you care for any regular literary letter (or London correspondences) from me, if your present arrangements do not preclude any such agreement? I am the London correspondent of one of the chief Scottish papers - on the staff of The Academy, Athenaeum, Scot's Observer, etc. etc. and have, I may add, quite exceptional facilities. 
Believe me | Yours faithfully | William Sharp

Author of "The Sport of chance" (3 vols) "A Venetian Idyll" etc. etc. "Life of Heine", "Biography of Shelley" (Great Writers) "Rossetti: A Record and a Study", "The Human Inheritance: and Other Poems", "Earth's Voices: Sospitra: Transcripts from Nature": "Romantic Ballads and Poems of Phantasy": "A Memoir of Philip Bourke Marston": etc. etc. and Editor of "Sonnets of this Century" etc - General Editor "The Canterbury Poets" - etc.

The Editor $\mid$ The New York Independent

ALS Pierpont Morgan

\section{To Alexander Anderson, ${ }^{46}$ February 10, 1888}

Wescam I. 17A. Goldhurst Terrace I South Hampstead I. N.W.

Dear Mr. Anderson,

If there are any vacancies on next winter's lectures-list, do you fancy the committee would care to have a lecture by me? ${ }^{47}$ If so, I may add that it would have to be before or about Xmas - as I intend to accept the invitation to lecture in New York, Boston, etc. early in 1889. The lectures I would prefer to deliver in Edinburgh (unread elsewhere) would be: -

(1) Dante Gabriel Rossetti as Painter and Poet (or, more explicitly, "Rossetti's personality as displayed in his Poems and Pictures")

(2) The Great Russian Novelists Nikolai Gogol - Count Tolstoi - Ivan Turgéniev - and F. Dostoëvsky.

With best wishes for your health and welfare throughout the year that is still "new" -

Yours sincerely| William Sharp 


\section{To Richard Le Gallienne, [early May, 1888] ${ }^{48}$}

Wescam I. 17A Goldhurst Terrace I, South Hampstead I. N.W.

Dear Mr. Le Gallienne

After over 48 sleepless hours of work, travel, and work again (for I have only this morning returned from Paris) I find your letter among a host of others awaiting attention.

Herewith I send "Wind-Voices" ${ }^{49}$ which please return when done with, as it was given me by P. B. M. himself and I do not wish to lose it. I am glad you are to notice the Poems in the Academy, for I know you appreciate P. B. M'.s poetry. ${ }^{50}$

My forthcoming booklet ${ }^{51}$ is but a tiny affair - though of condensed romanticism, I hope and venture to believe. You shall have a copy when it does appear. Probably 10 days, or perhaps less, hence.

I am very pleased to hear that you are to be in town in June. Let me know a week or more beforehand if possible, as my time is always difficult to arrange. As a rule I am always engaged Wedys and Sunday evenings. We must have a dinner \& chat, if you are to be in town for any length of time.

Sincerely Yours | William Sharp

ALS University of Texas at Austin

To Frederick Shields, [early May, 1888] ${ }^{52}$

Wescam I. 17A. Goldhurst Terrace I. South Hampstead I. N.W.

My dear Shields

I have just returned from Paris where I have been "doing" the Salon. It is, I fear, the resort of the evil rather than of the good spirits of art. 
Sir Noel's ${ }^{53}$ son never answered a letter of mine of a fortnight or so ago - so I presume is away somewhere.

I am very sorry indeed to hear that the Manchester journey was so unproductive. I have spoken to various friends about your "Death and Love", but as yet apparently without success. However, I still venture to hope that fortune lurks in Scotland.

I shall be very pleased to receive the little volume to which you allude.

I am very very busy just now - and much worried by some troublesome matters of a private sort: but otherwise, I am thankful to say, things are well with me.

My wife joins me in ever kind remembrances -

In great haste I I am ever, dear Shields

Affectionately Yours I William Sharp

ALS Spencer Library, University of Kansas

\section{To Richard Le Gallienne, [May 19, 1888]}

Wescam I 17A, Goldhurst Terrace I. South Hampstead I. N.W.

My dear Mr. Le Gallienne

It is midnight, and I have just returned from dining out and found my Academy here with your most sympathetic and friendly article. ${ }^{54} \mathrm{I}^{\prime} 1 \mathrm{l}$ write to you in more detail in a day or two - tho' if you do not hear from me till Tuesday do not think it negligence. I'm going to spend my Whitsuntide ${ }^{55}$ at Burford Bridge with George Meredith, but will be back by Monday evening most likely: but I may be able to write before then.

Meanwhile, with thanks for your friendly allusions to myself in your excellent and critical article on P. B. M. ${ }^{56}$

Believe mel, Most cordially yours I, William Sharp 


\section{To Richard Le Gallienne, [May 22, 1888]}

Tuesday Night

Dear Mr. Le Gallienne

I have just returned from my delightful visit to the loveliest part of the loveliest county in Southern England - and with glorious weather \& such a host as George Meredith I need not say that I have enjoyed the last few days immensely. ${ }^{57}$

When are you coming to town: I remember you said you wd. be here ere very long? Please give me as much warning of your visit to London as practicable: for while I much look forward to the pleasure of seeing you I am so much engaged in every way just now that I have generally to arrange my plans well beforehand.

Your Marston-review in the Academy ${ }^{58}$ afforded me - as I have already told you - much pleasure. I am glad you agree with me in thinking that his lyrics have the true Elizabethan note and, broadly speaking, perhaps his sonnets: and of course it is doubly pleasant to have a review from the pen of one who is not only an admirer of Philip Marston but who is himself a true poet.

Yesterday I walked over from Burford Bridge to look-up Grant Allen, ${ }^{59}$ \& there I found Cotton of the Academy. ${ }^{60} \mathrm{I}$ told him how pleased I was with your article - the first, I fancy, you have done for the Academy.

In a few days I shall be able to send you a booklet of my own "Romantic Ballads: \& Poems of Phantasy", in which I hope you may find something to care for.

In great haste | Sincerely Yours | William Sharp ALS University of Texas at Austin 


\title{
To Theodore Watts, [May 23, 1888] $]^{61}$
}

\author{
Wescam I. 17A. Goldhurst Terrace I South Hampstead I N.W I. \\ Wedny Night
}

\section{My Dear Watts}

You did not dream, but understood in all verity that I am Messrs. Appletons' literary deputy, or rather agent, in this country. I have all along been hoping that you may come to some arrangement with Appletons. Did you ever see their reprint of "The Dreamster" - a much better get up than any of the other houses who reprint English books. Is there any chance of your being Chancery-Lanewards tomorrow (Thursday)? I intend to be at Cotton's at or shortly before 3: and could meet you anywhere in that neighborhood if you wired to me early in the forenoon (Wescam, Goldhurst Terrace, Hampstead is sufficient for telegrams)..

The weather was so glorious that we were persuaded by George Meredith to remain yet another day - and I enjoyed it immensely. He read me some exceedingly fine poems, far surpassing anything he has yet done in verse - and also a considerable portion of a new novel. ${ }^{62}$

On Monday by the by I walked over to Dorking \& called on Grant Allen. He was very sorry that you had not called on him when in the neighborhood, but I explained that, in the circumstances, it was impossible - \& that you were as sorry as he could be. I found Cotton there, and he and I walked back in company and he made Meredith's acquaintance.

What a charming fellow G.M. is - is he not? The more I see of him the more I admire and like him.

The enclosed brief beginning of a short note I had yesterday from Caine is all the direct news I have had - tho' I hear that the play is a great success. ${ }^{63}$

Tomorrow - or next day - I shall send you a copy of my little book of "Romantic Ballads". I hope - as it is maturer work - it may satisfy you more so far as execution is concerned. In substance it is imaginative in the truest sense - as I do not hesitate to say. It honestly seems to me that with all its demerits there is stuff in it of the purely imaginative 
kind such as you will not easily find in the work of other contemporary minor poets. Of course I shall be disappointed if no one likes it, or thinks highly of it - but for the first time in my life I am indifferent to adverse criticism: for I feel well assured that the little booklet is sterling - and with this assured confidence a bad reception can at the worst be but unfortunate and disagreeable.

However, you will soon be able to see and judge for yourself. A few of the poems have already been seen by friends. Of a short one entitled "The Deathchild," Stedman - for instance - writes that he knows nothing more weird and original \& imaginative in recent modern poetry. It is certainly original - whatever else it may be. But the strangest work is in "The Weird of Michael Scott" - particularly in Part III.

Even if you care for the book very much I do not urge you to review it - as I know your kind friendship will prompt you to do - for I know how busy you are: but do you think you could persuade Maccoll ${ }^{64}$ to let someone give it a separate notice? I shall not send a review copy to the Athenaeum till I hear from you.

I had originally intended to issue only 100 copies, as I thought there would be no demand for such a little book (only some $80 \mathrm{pp}$ including Preface, Title-Pages, etc). - but there has been such an unexpected and gratifying anticipatory demand [all the more so as - being privately printed - the price is unknown. Of course I've made it small $-2 / 6$ or 3/-] that I have agreed to a larger edition - most of which is already engaged.

If you are not to be in town tomorrow you might drop me a line or, perhaps, after receipt of my booklet, which, however, may not arrive till Friday or Saturday, tho' I expect one or two early copies tomorrow.

Ever yours affectionately | William Sharp

I am so glad to hear that you are going to publish the poem you recited part of to me the other day. It was exceedingly fine. 


\section{To Mr. Osborne, ${ }^{65}$ June 4, 1888}

Wescam, ${ }^{66}$ | 17a Goldhurst Terrace I, South Hampstead I. London, N.W.

\section{Dear Mr. Osborne}

The only influential member of the Reform club whom I can call to mind just now as an acquaintance is Sir James Caird, the well-known Agriculturist and Land commissioner. I will see what can be done with him.

Best wishes for your success. If fortune favour you let me know, so that I may be among the first to congratulate you.

In great haste | Sincerely Yours | William Sharp

ALS, UWM Library.

\section{To Richard Le Gallienne, [early June, 1888]}

Wescam, ${ }^{67} \mid$ Goldhurst Terrace | So: Hampstead I N.W.

Dear Mr. Le Gallienne

If you have not made any other arrangement could you come here on Sunday evening next?

We don't "dress" on Sunday evenings, as friends sometimes drop in then promiscuously: and indeed on Sunday next we are, I believe, to have 'high tea" in place of dinner, for the sake of domestic convenience of some kind.

If you could be with me by 6 o'clock we could have an hour's chat ere "appeasing the demon" as the Japanese say. At 7 o'clock Mr. \& Mrs. Tomson will look in. "Graham R. Tomson's" name you doubtless already know as that of one of the most accomplished of the ballade and rondeau singers (though she has done other \& far stronger [unpublished] 
work). ${ }^{68}$ She is a lovely creature and a genuine poet. Her husband, Arthur Tomson, is one of the coming men among our younger artists. They "move" to our neighborhood this week, to our great pleasure.

Thereafter we may or may not be alone: Walter Pater or some other literary or artistic friend may drop $\mathrm{in}^{69}-$ but if you are not pressed for time you can stay after any casual visitors have gone. But to make sure, try and come about 6 , when I shall be alone and disengaged.

I don't know from what part of the town you will be coming - but it may be as well to tell you that our station is Finchley Road (Metropolitan) (South Hampstead), and that you will have to change at Baker Street.

When you leave Finchley Rd. Station turn down to the right into Broadhurst Gardens, \& below its left (east) end you will see two terraces meeting at an angle - that to the left is Goldhurst T.

Let me know if you can come on Sunday. By the by a copy of my book ${ }^{70}$ was sent to you today.

Yours sincerely | William Sharp

ALS University of Texas at Austin

\section{To Richard Le Gallienne, July 7, 1888}

Dear Mr. Le Gallienne

I meant to write to you yesterday but mislaid the card with your address - which I have only now found.

Owing to the sudden "flopping" upon us of a friend from Germany - \& other reasons as well - I much regret the unlikelihood of our meeting again during this visit. I may add, however, that we are always "home" to any visitors on Sunday evenings (about 8), and also on Monday afternoons (4 to 6). Just do as you feel inclined. In great haste, \& with best wishes,

Sincerely Yours I William Sharp 


\title{
To Theodore Watts, [mid-October, 1888]
}

\author{
Wescam | Goldhurst Terrace | So. Hampstead I N.W.
}

\section{My dear Watts}

I have just returned from Scotland after my two and a half months absence from London: and I hurriedly send this line to wish you every good wish for your birthday. May your New Year be prosperous in every respect - and health abide with you.

I have had good fortune with weather - only four wholly wet days all the time I've been in the north. Most of the time we were by the sea - either in the west Highlands or on the east coast, but we were also for some weeks at a glorious spot in Strathspey, a lovely moorland farm a thousand feet above the sea, among the Grampians, in Morayshire. ${ }^{72} \mathrm{I}$ also stayed a bit in Roxburghshire and the south Border.

I have been very busy. I am now very much occupied. My monograph on Heine is off my hands, I am glad to say, and will be out in a fortnight.

I heard from Caine this morning. He is staying near Keswick, but has been seedy "dyspeptically," as he says. He is up to the ears in authorship - has done splendidly with his play - engaged on another - and so forth.

Perhaps you will be able to find time to review Lee Hamilton's new book - Imaginary Sonnets - just out. Probably a copy has been sent to you at his request. Poor fellow - it is wonderful that such good work can be produced in such circumstances. In his letter to me he says it is an attempt to introduce into the sonnet a dramatic element which it has not hitherto had, and to make it express in the first person emotions \& passions more vehement and tragic than heretofore. He adds "I have spent the most terrible Spring and Summer - unable to endure the slightest conversation and in absolute immobility of body and even hand. I suffer too greatly still even to sign this letter with my own hand".

I spent some pleasant hours with Nichol while we were both staying at Crieff - also with Minto at Aberdeen - and other friends elsewhere. ${ }^{73}$

Again with affecte good wishes I, Yours ever, William Sharp 


\section{To Richard Garnett, [Fall, 1888]}

Wescam | Goldhurst Terrace I So. Hampstead I N.W.

\section{My dear Garnett}

In the case of exceptionally noteworthy books it is in my power to dilate upon them in the "London Letter" of the Glasgow Herald - which, as I daresay you know, is the most influential paper in the North. While a "London Letter" notice does not preclude another review in ordinary course, it is very much more serviceable owing to the prominence it gives, and the greater number who see it - and also from the fact that the literary items of the G. H'.s London Letter are copied by other papers throughout the north.

I therefore read thro" the "Twilight of the Gods"74 on the evening I received it - and as soon as possible sent off the enclosed to the G. H. office here. I hope it may prove serviceable to the book.

I am just bolting off to the Press View at the Grosvenor - so must postpone further remarks about your new book for a little. But I cannot close without telling you again that it is very long indeed since I have had such a literary festa. The book is a delight to me from the first page to the last - and both in matter and style it seems to me a volume that will take very high rank indeed. It is literature. I did not know that you had the rare and delightful Heinesque genius in prose composition - greatly as I knew you to be in sympathy with Heine. Any book so original as well as so charming must be sure of its place - and I congratulate you most heartily.

Again thanking you for so kindly giving me a copy (I shall ask you to "inscribe" in it someday).

In hastel Most sincerely yours I William Sharp

I had sent Unwin a P/card, telling him of the notice - in case he shd. be in need of something to start with as a quotation from the Press. 
To: 1888

Wescam I Goldhurst Terrace I So. Hampstead I NW

\section{Dear Sir}

There is a good photograph of Philip Marston taken by Van der Weyde, 182 Regent $\mathrm{St}^{75}$

Whether Mr. Van der Weyde has any copies - or the negative - or the right to sell, I cannot say. There is a still better up-looking one - but I forget who did it. Here is an engraved likeness of P.B.M. (after Van de W's portrait) which serves as Frontispiece to the vol. of Marston's tales published a year or so ago (with an earlier version of my Memoir) by Mr. Walter Scott at a small sum, 3/6 I think, or perhaps 4/6. The book is called "For a Song's Sake: and other Stories".

Friends of "Y.F.P". are always cropping up unexpectedly. I am glad you are one of them. It is a good paper, and Olympic is doing really good work. I certainly don't regret the time I have given and give to it - tho' after all it occupies but a small portion of my busy life.

Your very truly | William Sharp P.S. Yes the romance entitled "Alwyn" is by Theodore Watts. Though well-known to many literary friends, and in type, it has not yet been published. I understand that it will be issued early in 1889. W. S.

ALS. Princeton

\section{To Andrew Chatto, [Fall 1888] ${ }^{76}$}

Wescam I Goldhurst Terrace I So. Hampstead

Dear Mr. Chatto

As I am writing at any rate about Mrs. Caird I take the opportunity to broach another matter. 
I am engaged upon a romance (for one volume issue) which I believe to be a book which could not be overlooked. ${ }^{77}$ (You will excuse the inevitable seeming arrogance - but this is a matter of assured conviction with me). It is the outcome of much into which I need not enter, except to say that it is an attempt toward further stimulating the advent of the true romantic sentiment. It is not, I should explain, a romance of the adventurous mind: it is, in spirit, a romance, say for illustration's sake, of the "Scarlet Letter" or Oliver Madox Brown's "Black Swan" type. I have critically and otherwise identified myself very closely of late with the new romantic movement which is in the air, and, I believe, is destined to revolutionise average contemporary fiction. To enable you to more clearly comprehend what I mean I send you a copy of my last vol. of verse ${ }^{78}$ in the preface of which you will find my "pronounciamento".

The edition was sold out within a few days of publication, and I have only one or two reserve copies left - but it would afford me pleasure if you would accept the one I send.

As for the romance, it is called "Sanpriel" (from the heroine's name). The idea of heredity is at the base of it, though more as an occult than a specified or obviously-worked out motive. It is but fair to explain that it would have one very strong situation near the close - an episode that would invite, no doubt, as much antagonism as appreciation. I know that I can rely upon your keeping strictly to yourself the basis of the episode in question. To a certain extent you will be able to infer it from the incident related by Pope to Lady Mary Wortley Montague, and upon which Sir Stephen de Vere wrote a little lyric entitled "On Two Lovers Killed by Lightning".

The summer sun is passed and gone

Again shines out the summer sun

On lips that are, tho' pale and dead,

With living smile still garlanded.

They lived, they loved, and loving died,

By God's own lightning purified.

He saw their truth, and, pitying, gave

At once a bridal and a grave.

I have, I should explain, a standing offer from a publisher for this romance, whenever I finish it, at a very fair royalty. 
Now of course I cannot expect you "to jump at" a book of which your reader has seen nothing - but what I wish to ask you is if you care to consider the following suggestions: -

That you should nominally commission this romance of "Sanpriel", to be placed in your hands by the end of February. That in consideration of my finishing it by that date (earlier than I should otherwise do) and giving you the right of publication, you guarantee me, 50 on receipt of completed MS. If you decide to take it, after inspection, we can then come to terms as to the sum you feel inclined to offer: in which case the, 50 to be reckoned as on account.

If, after consideration, you decide against publication, then I to return you half of the guarantee-amount, viz, 25.

I should like very much to publish with you - and to convince you that my proposals are not unreasonable I may add that in addition to the Royalty-Promise alluded to I have a private assurance from another house of inclusion of the book (about which nothing is known, however; save that I have put my heart into it, as the saying is) in a series of onevolume novels, at a sum-down of, 30 .

Please consider all I have written as strictly private.

The reason why the earliest date for delivery of MS. would be Feby 28th is that I have not yet finished a serial romance (of an entirely different kind) which is to commence at Xmas: and I have in the meantime to cease working at "Sanpriel".

If you would like to see me further on the matter, perhaps you could call on me at my club (the Grosvenor club, $135 \mathrm{New}$ Bond St). on some specified day, at any hour convenient to you after 2 o'clock, except Mondays.

In any case, I dare say you will be able to say yea or nay very shortly.

Believe me | Yours very truly | William Sharp 


\section{To Richard Garnett, [Fall, 1888]}

Wescam | Goldhurst Terrace | So. Hampstead I NW

My dear Garnett

My friend Mrs. Graham Tomson, to whom you wrote consenting to the inclusion of some of your epigrams in the Canterbury vol. of the Greek Anthology selections,$^{79}$ is anxious for a reader's ticket at the Museum. She is not up to the mark at present, and so cannot apply personally. I forget what is the present procedure in the matter, but it would much oblige me if you would send me the necessary paper to sign, which I should take to Mrs. Tomson.

She also wants to meet you - and I told her that some day erelong I would go with her to the B.M. and introduce her to you.

By the way - I am to review the "Twilight" elsewhere, but not for a fortnight or three weeks yet.

In haste I Sincerely yours | William Sharp

ALS University of Texas at Austin

\section{To Richard Garnett, [Fall, 1888]}

Wescam | Goldhurst Terracel So: Hampstead

My dear Garnett

I was in St. Edmund's Terrace to say au revoir to Miss Blind, ${ }^{80}$ and simply called at your house on the off chance of seeing you. I thought the opportunity also would be a good one to tell you how I like your new book ${ }^{81}$ more and more. I have recommended it to several people, though I refuse to lend it, partly because I don't like lending author's copies, and partly because those who wish to read it should buy it or get it from the library. I also wanted to ask you if you could tell me anything 
about Azrael, the Talmudic angel of death. I want to find something that would justify the relevancy of "The Wing of Azrael" as title of a novel - something in the sense of "The Shadow of Death", "The Shadow of Fate", "The Sword of Damocles", or the like.

Perchance you know or can put me on some clue. There is, however, no urgency. Anytime within a week or so would do, if you should happen to light upon anything accidentally.

Yours most sincerely | William Sharp

I hope the "Twilight" is going on propitiously. I do not think Unwin advertises enough: but I am only judging from what I happen to seel. Tomorrow or next day I hope to send you a copy of my Heine. ${ }^{82}$

By the way, I had a note on Saturday from Olive Schreiner. ${ }^{83}$ Her address is Hotel Mediterranie, Alassio, Italy. She intends to be in London for a few weeks next May, and will, I hope, stay with us for a day or two. ALS University of Texas at Austin

\section{To A. Williams, ${ }^{84}$ [? November, 1888]}

Wescam I Goldhurst Terrace I So. Hampstead I London N.W.

My Dear Sir,

I thank you very much for sending to me the very kind and appreciative criticism from the $N$. Wales Express on my "Heine" - and my indebtedness is the more emphatic if you are the writer as well as the transmitter of it.

Heine is so seldom understood in this country that I am most pleased with the tone as well as the criticism of the article.

Believe mel, very truly yours I, William Sharp

It may interest you to hear that the book is selling rapidly, and that it is shortly to be translated into German, and perhaps into French.

A. Williams Esq

ACS Pennsylvania State University 


\section{Chapter Five}

\section{Life: 1889}

The high point of 1889 for Sharp was his first visit, in late summer, to Canada and the United States. His interest in North America increased as he edited in early 1889 a collection of American sonnets for Scott's Canterbury Poets, and he came to view the States as a market for his work. In January, he offered the Century Publishing Company in New York the American rights to Children of Tomorrow, which was scheduled for British publication by Chatto \& Windus in April. Also in January, he proposed two articles for publication in Lippincott's Magazine in Philadelphia. In the spring, he thanked Thomas Wentworth Higginson, the American man of letters and friend of Emily Dickinson, for a book of poetry and said he would try to mention it favorably in print. He told Higginson, who planned to be in London shortly, that he would hold a copy of American Sonnets to present in person. In July, he sent copies to Frank Dempster Sherman and Clinton Scollard, both represented in the anthology. The accompanying letters praised their poems and expressed his hope to meet them in the fall when he planned "to pay a short visit to E. C. Stedman and one or two other friends in New York."

A New York banker and a poet, anthologist, and critic, Stedman was the most powerful literary figure in the United States. He exerted substantial influence over publishers and editors in New York, which had supplanted Boston as the literary center of the country. Sharp could not have chosen a better advocate in the American publishing world. His contacts with Stedman began in the fall of 1887 when he wrote to say he was a Scotsman, not a "Colonial." Relying on the Australian poems 
in Sharp's The Human Inheritance, Stedman had placed him among the colonial writers in an article on the younger British poets in the October issue of the Century Magazine. "Since you are so kindly going to do me the honour of mention in your forthcoming supplementary work," Sharp wrote, "I should not like to be misrepresented" (Sharp letter to Stedman, 7/22/82). Sharp knew the Century article was to become a supplementary chapter on younger British poets in the thirteenth (Jubilee) edition of Stedman's groundbreaking study of Victorian Poets first published in 1875. Stedman replied warmly: "Something in your work made me suspect that, despite your Australian tone, etc., you did not hail (as we Yankees say) from the Colonies. So you will find in my new vol. of Victorian Poets that I do not place you with the Colonial poets, but just preceding them, and I have a reference to your Rossetti volume" (Memoir 129).

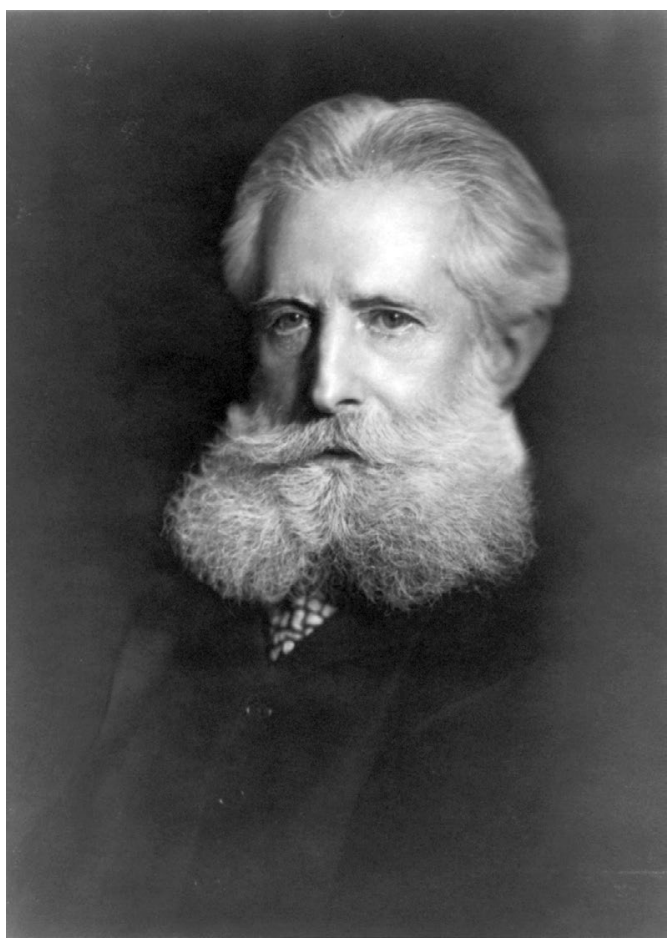

Fig. 8. An 1897 photograph of Edmund Clarence Stedman (1833-1908), an American poet, critic, essayist, banker, and scientist.

Wikimedia, https://commons.wikimedia.org/wiki/File:Edmund_Clarence_Stedman_ cph.3a44372.jpg 
This exchange, Elizabeth Sharp noted, "led to a life-long friendship" with Stedman who had "so genial a nature that, on becoming personally acquainted in New York two years later, the older poet declared he had adopted the younger man from across the seas as his 'English son"' (Memoir 129). That offhand comment contains an important insight. Sharp's father, who disapproved of his son's interest in literature and his desire to become a writer, died when Sharp was twenty-one. From that point forward, he sought out older literary men, worked to gain their friendship and approval, and depended on them for advancement, not an unusual pattern for young people making their way in the world. The list of such men in Sharp's life - Dante Gabriel Rossetti, John Addington Symonds, Walter Pater, George Meredith, to name only a few of the most prominent - is unusually long, and the son/ father trope pervades his correspondence with them. Of all these, his relationship with Stedman, conducted mainly through trans-Atlantic correspondence, was the most intense and long-lasting. After their initial meeting in 1889, when Sharp stayed with Stedman and his wife Laura in New York, Sharp's letters became increasingly familiar until Stedman began to function as both a father confessor and a trusted comrade. The first of the surviving letters among the Stedman papers at Columbia University dates from the summer of 1889 , shortly before Sharp left for North America. Excepting the short quotation from an 1887 letter that Elizabeth Sharp included in her Memoir, earlier correspondence between the two men has not surfaced. Sharp surely corresponded with Stedman in 1888 as he prepared his anthology of American Sonnets. His dedication of that volume to Stedman - "the Foremost American Critic" - was an expression of gratitude for Stedman's help in choosing the poets and poems for the volume.

In a February 16 letter, Sharp told Theodore Watts [later WattsDunton] he was staying for a fortnight or more with his friend Sir George Douglas at his estate near Kelso. He was working hard and enjoying the "beautiful old place - near the junction of the Teviot and the Tweed, both of which flow through D.'s property. The Teviot is but 200 yards from my window, and some 300 yards away is the picturesque mound-set ruin of the ancient Roxburghe Castle. Last night I fell asleep to the hooting of the owls blended with the brawling undertone of the Teviot." The main purpose of the letter was to inform Watts, poetry 
editor of The Athenaeum, that the second edition of his Romantic Ballads and Poems of Phantasy containing "many important alterations" and a new poem would be published the following week. When the first edition appeared the previous May, he sent Watts a copy and spelled out what he would like to see in a review of the book while telling Watts he did not expect him - given their friendship - to write the review. Now he told Watts he was "a little hurt" that MacColl had not printed a review. He had also been disturbed by some negative remarks Watts reportedly made, but he had chalked that up to "misapprehension" and refused to let it interfere with their friendship. Now he asked Watts, if not inconvenient or disagreeable, to send Norman MacColl, editor of The Athenaeum, a paragraph simply announcing the second edition with alterations and additions. The appearance of such a paragraph in the prestigious Athenaeum would help the book's sales.

Sharp began his February 16 letter to Watts by asking what he thought of Hall Caine's new play. "From what I hear privately (from my wife, Cotton, and others) I gather that it is a very third-rate affair though with some strong melodramatic situations." Caine's "Good Old Times" which had recently opened in London's Princess Theatre was drawing enthusiastic crowds and generating a good deal of money. Sharp and his host George Douglas had little regard for William Barrett, who produced the play and acted in it. They thought Caine should be turning his attention to more serious and consequential fiction and drama. On March 4, back in London, Sharp expressed their concern in a letter to Caine. He was delighted to hear of the play's financial success,

...though I honestly admit that you, with your high abilities, should be working at more enduring stuff than ordinary melodrama. We need a true dramatic writer, and you have it in you to be the man - but! I have your reputation so truly to heart that what you yourself say is good news to me. Still, it is always something to have achieved so great a financial success in these difficult days - though the financial aspect, with a man like you, ought to be - and in your case is - of secondary import... Douglas [Sir George] believes in you - but dislikes what he calls Wilson Barrettish melodrama: and he expressed an earnest hope the other day that your next play would be, in truth, a big thing. I'm delighted to hear what you say about your prospective novel and play.

In mid-month, he would try to get down to Bexley, then a village where Caine was living and now a Borough of Greater London, to talk 
about that and other matters. He hoped Caine, should he be in town the following Saturday, would find his way out to Wescam, the Sharp's home in South Hampstead, for a party: "Some seventy to eighty literary and artistic friends have been asked - and probably somewhere about 40 or 50 will come." Those numbers demonstrate the extent to which he and Elizabeth had immersed themselves in London's literary society.

Concern about Caine's work took a back seat in mid-month when Sharp decided to stand for election to the Chair of Literature at University College, London. The Chair was vacant following the retirement of Henry Morley (1822-1894), one of the first Professors of English Literature and a dynamic lecturer who had occupied the chair since 1865. Sharp requested and received supporting letters from Caine, Edward Dowden, and Richard Garnett, and, according to Elizabeth, his candidacy was also supported by Robert Browning, George Meredith, Walter Pater, Theodore Watts, Alfred Austen, Professor Minto, Sir George Douglas, Aubrey De Vere, and Mrs. Augusta Webster. That he sought this post despite having spent only two years studying literature at Glasgow University reflects the self-confidence he gained through his reading, editing, and reviewing. The list of his supporters reflects the extent to which his work and his forceful personality had penetrated and gained the respect of fellow authors. Despite the support of these literary luminaries and the prestige and security the post would bring, Sharp withdrew from consideration when, again according to Elizabeth, his doctor advised his heart might not withstand the strain. Whatever the reason, he was greatly relieved when he was left "in possession of his freedom." For all his gregariousness, Sharp became agitated whenever he was asked to give a formal lecture or even speak informally before an audience. Realizing this deficiency and concerned about the condition of his heart, his doctors continued to advise against lecturing. As Professor of English at University College, he would not have been able to replicate Morley's dynamic lecturing and vast knowledge.

On May 5, the Sharps left London to review the Salon in Paris. On the 9th, Sharp wrote to thank Richard Le Gallienne for his second book of poetry, Volumes in Folio, which he declared he would read with interest when he returned to London in a week or so. In the letter accompanying the volume, which was forwarded to Paris, Le Gallienne said he was planning to accompany the actor Wilson Barret, for whom he served as 
secretary, on his tour of America in October. Setting aside his opinion of Barret, Sharp told Le Gallienne he would also be there in October and suggested they meet. As it turned out, an attack of asthma prevented Le Gallienne from traveling. On the 10th, Elizabeth sent a short review of the sculpture exhibited in the Salon to James Mavor who printed it without attribution following her husband's unsigned review of the Salon's paintings in the June number of The Scottish Art Review. The Sharps left Paris on May 11 to spend a week or so in the countryside. When they returned to London, Sharp asked James Mavor when he needed the manuscript for Pt. I of H. P. Siwäarmill's "Emilia Viviana" which Mavor had agreed to publish in the July number of the review. In a postscript, he asked Mavor to be sure and preserve the secret of his identity with Siwaarmill. He had used H. P. Siwaarmill, an anagram of William Sharp, for epigraphs in his Romantic Ballads and Poems of Fantasy in 1888 and again for bits of supposed wisdom in Children of Tomorrow which was published on May 10 while the Sharps were in Paris. The pseudonym demonstrates his predilection - well before he created Fiona Macleod - for disguising his true identity. There is no sign of "Emilia Viviana" in the Review which means Sharp failed to produce it - most likely - or Mavor decided not to print it.

In a mid-July letter to Louise Chandler Moulton, Sharp said he was pleased she had found something attractive in Children of Tomorrow, which had been "badly received by the press." He was

vain enough to believe that with all its faults \& demerits it is not altogether a book of "today". I have written it as an artist - and someday, if not now, it will gain its measure of recognition. At the same time, it is only a tentative effort, or a herald rather, of a new movement. I see the Athenaeum of today passes it by with "damning indifference" - and, on the other hand, Public Opinion has a long \& sympathetic (tho' faultfinding) review beginning "a remarkable book by a remarkable man".

His friend James Mavor printed a carefully worded notice in the June issue of The Scottish Art Review. He recognized the novel's effort to portray in prose fiction the manifesto of the new Romantic School, whose advent Sharp had forecast in his introduction to Romantic Ballads. For that reason, the novel was interesting in itself and, in an ambiguous phrase, "of no ordinary interest in the history of current literature." In portraying the complications of two married couples falling in love 
with each other's spouses, Sharp had constructed a "powerful drama of passion and destiny." For the details and "for information regarding the sect called Children of Tomorrow," Mavor referred "readers to the book itself." Despite his reservations, Mavor found a way to accommodate Sharp's request for a notice while preserving their friendship.

The "book itself" was quite remarkable for its time. It went even further than Sharp's friend Mona Caird in critiquing the restraints of marriage. The "Children of Tomorrow" would be free to realize their potential and preserve their sanity by developing "romantic" relationships outside the bonds of marriage. Sharp would soon find cause to join those children, but the novel predicted a future of free love that neither reviewers nor readers could sanction. Despite their response, Sharp believed the novel would be recognized in time as a herald of things to come. The strict bonds of marriage surely relaxed as the twentieth century unfolded, but the density and excesses of Children of Tomorrow and the dark improbabilities of its action render it even less readable today than when it appeared.

Sharp's plans for North America crystallized during the summer. Mona Caird asked Elizabeth to accompany her to Austria for "the Suncure at Valdes in the Carpathian mountains," and they left in mid-July (Memoir 149-50). William went down to Box Hill to spend a few days with George Meredith. His health had not been good, and his doctor had prohibited him from lecturing during his trip to America. On July 27, he told Stedman he had been staying with Meredith in Surrey and was now feeling much better; he had "regained [his] power to sleep," and it would be good "to get away, and to see no proofs, letters, or MSS for ten days at least." Of the American trip, Elizabeth wrote, "going by himself seemed to promise chances of complete recovery of health; the unexplored and the unknown beckoned to him with promise of excitement and adventure" (Memoir 150). There is no mention of illhealth during his tour of Northeastern Canada where he stopped on his way to Boston and New York, despite the rough conditions he encountered while exploring wilderness areas. Elizabeth's comments are the first indication the Sharps' marriage had begun to inflict strains that intensified and prolonged their frequent bouts of ill-health.

Word of Sharp's reputation had made its way across the Atlantic where, in August and September, he was warmly welcomed, first in 
Canada and then in the United States. Stedman's sponsorship paved the way, but Canadian and American editors and writers were familiar with Sharp's Rossetti book, his two books of poetry, his editing and writing for the Walter Scott firm, and his articles in British journals. Their desire to strengthen contacts with London's literary establishment - augmented by Sharp's handsome appearance and Scottish charm resulted in his treatment as a celebrity by prominent literary figures in Canada, Boston, and New York.

Sharp chronicled his North American trip, as he had his 1884 Italian trip, in a series of letters to Elizabeth. The portions she printed in the Memoir enable us to follow the course of his visit. Charles G. D. Roberts - a well-known poet and a Professor of English Literature at King's College in Windsor, Nova Scotia - met him when he arrived in Halifax. In a letter to Stedman on August 17, he said he was leaving at once on a trip to Prince Edward Island and elsewhere with Roberts, Bliss Carman - Roberts' brother-in-law and an aspiring poet and editor - and James Longley, the Attorney General of Canada. He expected to be back in Windsor on August 25 or 26, and he planned to reach New York in early October where he would stay with the Stedmans. After returning from what turned out to be an extensive excursion with Roberts, he described it enthusiastically for Elizabeth:

Prof. Roberts and I, accompanied for the first 100 miles by Mr. Longley, started for Pictou, which we reached after 5 hours most interesting journey. The Attorney General has kindly asked me to go on a three days' trip with him (some 10 days hence) through the famous Cape Breton district, with the lovely Bras D'Or lakes: and later on he has arranged for a three days' moose-hunt among the forests of Southern Acadia, where we shall camp out in tents, and be rowed by Indian guides... I went with Charles Roberts and Bliss Carman through Evangeline's country. En route I traveled on the engine of the train and enjoyed the experience. Grand Pré delighted me immensely - vast meadows, with lumbering wains and the simple old Acadian life. The orchards were in their glory - and the apples delicious! At one farmhouse we put up, how you would have enjoyed our lunch of sweet milk, hot cakes, great bowls of huckleberries and cream, tea, apples, etc.! We then went through the forest belt and came upon the great ocean inlet known as the 'Basin of Minas', and, leagues away the vast bulk of Blomidon shelving boughlike into the Sea.... 
The trip with Roberts was only the first of many auspicious occasions during his remaining four weeks in Canada. In Halifax, he stayed with the family of Attorney General Longley who took him on the two excursions and introduced him to many of the "leading people."

On September 12, his birthday, he told Elizabeth he was now alone for the first time. There was nothing definite about him in the newspapers "save that I 'abruptly left St. John' (the capital of New Brunswick) and that I am to arrive in Quebec tomorrow." He was glad to leave New Brunswick with its "oven-like heat," endless forests of living and dead trees, and forest fires that nearly scorched him. After reaching the St. Lawrence River he "made a side excursion up the Saguenay River for 100 miles to Ha! Ha! Bay before proceeding up the St. Lawrence" to Quebec where he was the guest of George Stewart, editor of the Daily Chronicle. On September 16 he traveled further up the St. Lawrence to Montreal. From there he wrote to ask Joel Asaph Allen, the father of his London friend Grant Allen, if he could visit him on September 21 at Alwington, an area of Kingston, Ontario and the name of the house where Allen lived. He may not have made it to Alwington as he wrote again to Stedman on the 17th to say he was leaving Montreal for Boston on the 22nd and hoped to reach New York on the 24th where he would spend 12 or 14 days before sailing home on October 6 or 8 . Stedman expressed some annoyance at Sharp's "bewildering changes of plans" as he wanted to settle his plans for the fall. Sharp apologized in a letter of September 22 and asked Stedman to say when he wanted Sharp to stay with him and for how long. He had other friends in New York and would probably have to advance his date for sailing home.

On Friday, September 22 Sharp went "through the States of Vermont, Connecticut, and Massachusetts" to Boston where he spent the weekend with Arthur Sherburne Hardy (1847-1930), a well-known engineer, novelist, poet, and Professor of Mathematics at Dartmouth College. Boston was "a beautiful place - an exceedingly fine city with lovely environs" (Memoir 153). Hardy introduced Sharp to members of the Harvard faculty and took him to Belmont to visit the novelist W. D. Howells whom he had met in Italy in 1883. Sharp finally arrived in New York on September 25 where the Stedmans' house became his base for ten days. He spent the weekend of September 28 with Henry Mills Alden (editor of Harper's Magazine) and his family in Metuchen, 
New Jersey. In the city, he met Richard Watson Gilder, editor of the Century Magazine; Henry Chandler Bowen, editor of The Independent; and - among others - Richard Henry Stoddart, whom he christened the "father" of recent American letters. He was elected an honorary member of the "two most exclusive clubs" in N. Y. - the Century and the Players - and he attended a special meeting at the Author's Club where he was "guest of the evening." Before sailing from New York on October 4, he left instructions with a florist to deliver on Stedman's birthday (October 6) both a bouquet and a letter, which was the first of many annual birthday letters to Stedman. During the seven weeks of his Canadian and American visit Sharp was entertained, feted, and through the good offices of Stedman introduced to editors of the prominent literary journals.

In a letter on October 1 from New York, Sharp told Elizabeth about a couple he met in New York: Thomas Allibone Janvier - a journalist and native of New Orleans - and his wife Catherine Ann Janvier, a member of the prominent Drinker family of Philadelphia and an aunt of the twentieth-century novelist Catherine Drinker Bowen. "They are true Bohemians and most delightful," Sharp wrote, "He is a writer and she an artist... . We dined together at a Cuban Cafe last night. He gave me his vol. of stories called "Colour Studies" and she a little sketch of a Mexican haunted house - both addressed to "William Sharp. Recuerdo di Amistad y carimo." Soon the Janviers began stopping in London on their way to and from southern France where they spent winters. They became fast friends of the Sharps who, in turn, visited them often in Southern France. Catherine and William developed a special bond. She would be the first non-family member to recognize the writings of Fiona Macleod as the work of William Sharp.

Sharp landed in Liverpool in mid-October and went on to Germany at the end of the month to meet Elizabeth and accompany her home. Buoyed by his reception in Canada and the United States, he set to work with renewed vigor. Following Robert Browning's death in Venice on December 12, Sharp wrote a long elegiac poem that appeared in the February 1890 number of The Art Review, and he began a biographical/ critical study for the Great Writers Series. He also began a series of prose "Imaginary Journals" modeled after Browning's dramatic monologues in poetry. One of the projected stories was to be called "The Crime of 
Andrea dal Castagno" which Sharp described as "A fragment from the Journal of this murderer painter and successful hypocrite, written not long before his death." He described his plans for the "Imaginary Journals" in a December 18 letter to Richard Watson Gilder, who decided against publishing them. One - "Fragments from the Lost Journal of Piero di Cosimo" - saw the light of day in the January and April 1890 numbers of The Art Review, a short-lived successor to The Scottish Art Review. When he heard Sharp had begun a book on Browning, Oscar Wilde reportedly remarked, recalling the Rossetti books, "When a great man dies, Sharp and Caine go in with the undertaker." 


\title{
Letters: 1889
}

\section{To the Century Publishing Company, ${ }^{1}$ January 11, 1889}

\author{
Wescam | Goldhurst Terrace | So. Hampstead | London, N.W. |
}

11:1:89

\section{Dear Sirs}

I write to ask if you would care to purchase the American rights of a one-volume novel by me. ${ }^{2}$ It is to be published by Messrs. Chatto \& Windus in the late Spring (probably about the end of April). That firm commissioned the book, on what I consider very good terms, without having seen a page of it or even knowing its plot, or what it is about. They only know that it is a romance upon which I have expended great care, and for which I hope much.

Its present name, and the name I prefer, is Sanpriel (from the name of the heroine), but as Messrs. Chatto \& Windus seem to think that a more attractive title to the general reader would be better. I think of calling it The Labyrinth of Love.

To a certain extent it is a romance of artistic life, but its main motive is the inexorableness, what Guy de Maupassant calls the brutality and indifference, of Fate; and, over and above this, the tragic play of the passions in two fine natures. Sanpriel herself is racially of the Jewish people (not religiously), and the central idea is the struggle on her part between the Judaic passion and an overpowering love, a love that involves sacrifice of everything save love's own reward. The close of the book is, so far as I am aware, unlike anything narrated in English fiction.

I have to deliver the completed MS by the middle of March at latest. I am not willing to arrange about stereos, for reasons into which I need not enter, but if you entertain my proposal and your terms seem to me reasonable I shall send a type-written copy of my MS to you for publication very nearly contemporaneously with the English edition, though of course the latter, for copyright purposes, must have nominal precedence. 
It is only fair to add that I have written by this mail to two other American houses with a similar proposal. ${ }^{3}$ Requesting the favour of a reply at your early convenience, by return if practical.

I am, Gentlemen, I Yours faithfully, I William Sharp Author of "Life of Heine": "Monograph on Shelley": "Rossetti: A Record and a Study": "Earth's Voices: Sospitra etc.": "Romantic Ballads": “The Sport of Chance": and three serial romances. Editor of "Sonnets of This Century", etc. etc.

P.S. I forgot to say that the book will not be a long one - about $250 \mathrm{pp}$, widely leaded.

ALS New York Public Library, Berg Collection

\section{To the Editor of Lippincott's ${ }^{4}$ Magazine, January 26, 1889}

Wescam | Goldhurst Terrace | So. Hampstead | London N.W. | 1/26/89

Dear Sir

Would you care to have an article from my pen upon

(1) Two New English Poets (W. E. Henley and Mathilde Blind)

(2) The Prose Writing of William Morris.

I daresay my name as poet and critic is known to you, and will be sufficient guarantee.

Lippincott's is the only American magazine I take in regularly: as apart from the [function?] of illustration, I find it the most generally interesting, hence my wish to be one of your contributors.

Yours faithfully | William Sharp 
Author of "Life of Heine", “Romantic Ballads", etc. etc. etc.

Editor of "Sonnets of This Century"

If your reply be in the affirmative, please state when the MS would be wanted, and maximum length.

ALS State University of New York at Buffalo

\section{To Mrs. David Octavius Hill, [late January, 1889]}

Wescam I Goldhurst Terrace I South Hampstead I N.W.

My dear Mrs. Hill

This is a line to introduce to you my friend Sir George Douglas, ${ }^{5}$ who is anxious to make your acquaintance. He is not only a lover of art and literature, but himself a poet and author, and I know that you will find much in common.

I am going to stay with him (near Kelso) in the latter part of February, and hope, when passing through Edinburgh from St. Andrews (whither I am going on Monday or Tuesday next) to look in upon you. I was very sorry to hear about the Patons ${ }^{\prime 6}$ fresh troubles - how unfortunate they are.

Lillie joins with me in love.

Ever your affectionate friend I William Sharp ALS New York Public Library, Berg Collection 


\section{To James Mavor, ${ }^{7}$ [February 8, 1889]}

Friday

My dear Mavor,

Are you to be in Edinburgh next week?

I expect to be there all the week, (\& to arrive on Monday evening next). If so, perhaps we could arrange to meet.

My address will be | 2 Coltbridge Terrace | Murrayfield I Edinburgh

Yours in haste I William Sharp

ALS University of Toronto

\section{To James Mavor, [February 10, 1889]}

The Marine Hill | St. Andrews I Sunday

Dear Mr. Mavor

I gather from your kind note that you took the trouble to call at the Central to enquire for my lost "Lareg". Many thanks for your courtesy. I wrote to the Manager, and he forwarded it on to me. (Better luck than I deserved, you will doubtless think). I return to Edinburgh on Tuesday night. On Wednesday afternoon, unfortunately, I am engaged to "sit" to Mrs. D. O. Hill from 3 till 4:30 - and at 4:30 some friends are to drop in to meet me. ${ }^{8}$ So, I am sorry to say, I shall be unable to look up $\mathrm{Mr}$. Geddes ${ }^{9}$ when you are with him. (Before 3, I am engaged).

How long are you to be in Edinburgh? I wish you could give me the pleasure of dining with me. Could you and your friend Mr. T. C. Martin dine with me at $7 ?^{10}$ (I understand that the Waterloo Hotel is one of the best places to dine with me at, but as I know nothing of it, it would be best to arrange to meet at the portico of the General Post Office a couple of minutes or so before 7). Failing your being able to do this could you look in at Mrs. D. O. Hill's about 5 o'clock. You would probably meet Sir 
Noel Paton, Mrs. Traquair, Joseph Thomson (the explorer), J. M. Gray, \& one or two others there - and Mrs. Hill would give you a hearty welcome. ${ }^{11}$ Her address is Newington Lodge, Mayfield Terrace. Take the Powburn car from The Post-Office, and ask to be put down at the opening for Mayfield Terrace. Mrs. Hill's house is the last on the right, at the gates opening upon Dalkeith Road.

Does Mr. Martin reside in Glasgow or Edinburgh, \& what is the Leader address? If in Edinburgh, I might call on him. I am indebted to you for your suggestion and friendly offices, and like the idea.

Please drop me a line by return to 2 Coltbridge Terrace I Murrayfield I Edinburgh

\section{Yours sincerely | William Sharp}

I cannot attempt anything of the kind for several weeks at earliest but how would Théophile Gautier do to start the "Villon series"? His personality and such books as his "Mlle de Maupin" and "Emaux at Canées" would give satisfactory scope.

ALS University of Toronto Library

\section{To Theodore Watts, February 16, 1889}

Sir George Douglas, Bart | Springwood Park | Kelso, N.B | 16/2/89

My dear Watts

What do you think of Caine's new play? From what I hear privately (from my wife, Cotton, and others) I gather that it is a very third-rate affair though with some strong melodramatic situations. I am sorry he should have Barrett ${ }^{12}$ for a collaborateur as I am convinced the man has little in him.

I have left the coast and am now staying with my friend Douglas for a fortnight or more, where I am working hard. This is a beautiful old place - near the junction of the Teviot and the Tweed, both of which flow through $\mathrm{D}^{\prime}$.s property. The Teviot is but 200 yards from my 
window, and some 300 yards away is the picturesque mound-set ruin of the ancient Roxburghe Castle. Last night I fell asleep to the hooting of the owls blended with the brawling undertone of the Teviot.I hope you are well and hard at work. The second edition of my "Romantic Ballads" will be out next week. ${ }^{13}$

The prefatory remarks have been considerably added to: and there are many important alterations in the rest of the poems, besides the inclusion of a new poem, a short one-page lyrical piece called "The Isle of Lost Dreams". "The Death-Child" and the last verse of "Michael Scott" (Part I) have, in particular, been improved. I do not know how the book has been got up, as it is the publisher's affair and not mine.

I am a little hurt (after what he wrote to me) that $\mathrm{MacColl}^{14}$ has not printed a review of it. It was published ten months ago, and other vols. of verse, Mary Robinson's, Henley's etc., which had subsequently appeared, were all reviewed ere the summer was over. However, it does not much matter.

Let me take this opportunity of saying that I do not expect you now or at any time to exert yourself about anything of mine. Your remarks about me and your reviewing of me duly came round to me - and I should be distressed if you should feel our friendship to involve any bond, however informulate. I think you were unjust in your remarks about me, but through misapprehension, I feel well assured, and from no other cause - and so I dismissed the matter from my mind, after the first surprise and chagrin. Friendship would be worthless indeed if it could not stand save on a "reviewing" basis.

But as a paragraph is sometimes helpful and does not involve any expression of opinion, perhaps you could kindly send a para to MacColl saying that the second edition of my Romantic Ballads E Poems of Phantasy, with some alterations and additions will be issued shortly (week after next at latest) by Walter Scott. But just if not either in the least inconvenient or disagreeable to you.

I hope to see you again when I return in March. I have felt for some time as if something were coming between us, and for this I should be very sorry.

Yours affectionately | William Sharp 


\section{To Hall Caine, [March 4, 1889] ${ }^{15}$}

... I am delighted to hear $\mathrm{it}^{16}$ is such a financial success though I honestly admit that you, with your high abilities, should be working at more enduring stuff than ordinary melodrama. We need a true dramatic writer, and you have it in you to be the man - but! I have your reputation so truly to heart that what you yourself say is good news to me. Still, it is always something to have achieved so great a financial success in these difficult days - though the financial aspect, with a man like you, ought to be - and in your case is - of secondary import... Douglas ${ }^{17}$ believes in you - but dislikes what he calls Wilson Barrettish ${ }^{18}$ melodrama: and he expressed an earnest hope the other day that your next play would be, in truth, a big thing. I'm delighted to hear what you say about your prospective novel and play. Some day after the middle of March I'll run down to Bexley, and have a chat over these and other matters. If you are to be in town next Saturday afternoon you might be able to find your way out here. Some seventy to eighty literary and artistic friends have been asked - and probably somewhere about 40 or 50 will come. If you can come you will be welcome...

ALS Manx Museum, Isle of Man

\section{To [James Mavor ${ }^{19}$ ], [mid-March, 1889]}

... the Muhrmann ${ }^{20}$ article \& what length \& what illustrations are to be in it.

She had so set her heart upon getting regular art-criticism (of contemporary art) to do, that she has let her feelings carry her away.

Overlook it, like a good fellow.

Have you made up your April poetry-sheet yet? If not, would you care for the enclosed song? If you don't care about it, let me know. If, however, you like it, it would be of no use to you, I fear, unless pubd. in April number, for it appears in my romance "Children of Tomorrow" (Sanpriel) which Chatto \& Windus will publish somewhere about April 20th. ${ }^{21}$ 
Don't forget you are pledged to stay with us when you run up to town $-\&$ come soon.

Your friend I William Sharp

ALS (Fragment) University of Toronto

\section{To Edward Dowden, [March 18, 1889] $]^{22}$}

Wescam, I 17A, Goldhurst Terrace, I South Hampstead. I N.W.

My dear Dowden,

I am writing to ask you if you will do me the great favour, if you conscientiously can, of a testimonial as to my fitness in your opinion for the post of Professor of English Literature. I am a Candidate for the Chair at London University which Prof. Henry Morley has just resigned.

Excuse such a succinct note, but there is very little time for the obtaining and remission of Testimonials. It is as a literary man, and as one who has also been much engaged in what may fairly be called educational literature (General Editor "The Canterbury Poets", Editor of the "Literary Olympic" in Young Folks Paper - a periodical which circulates over quarter of a million weekly - Editor of "Sonnets of This Century", now in its 30th thousand, etc. etc). that I mainly base my claim, though my philological studies will no doubt stand me in good stead.

It will materially add to my indebtedness if you will let me hear from you at your earliest convenience.

Sincerely yours I William Sharp ALS Trinity College Dublin 


\section{To Hall Caine, March 19, 1889}

Wescam | 17a Goldhurst Terrace I South Hampstead I N.W.

My dear Caine

I am writing to ask you to do me the great favour, if you conscientiously can, of a Testimonial as to my fitness in your opinion for the post of Professor of English Literature. I am a candidate for the Chair at London University which Prof Henry Morley has just resigned.

Excuse much a succinct note, but there is very little time for the obtaining and remission of Testimonials. It is as a literary man, and as one who has also been much engaged in what may fairly be termed educational literature (General Editor "The Canterbury Poets" - Editor of the "Literary Olympic" in the Young Folk's Paper - a periodical which circulates over quarter of a million weekly - Editor of "Sonnets of This Century", now in its 30th thousand, etc., etc). that I mainly base my claim, though my philological studies will no doubt stand me in good stead.

You will naturally add to my indebtedness if you will let me hear from you at your earliest convenience.

Sincerely yours | William Sharp

ALS Manx Museum, Isle of Man

\section{To Richard Garnett, [mid-March, 1889]}

Wescam. I 17A. Goldhurst Terrace. | South Hampstead. I N.W.

Dear Garnett

I am writing to ask you if you will do me the great favour, if you conscientiously can, of a testimonial as to my fitness in your opinion 
for the post of Professor of English Literature. I am a candidate for the Chair at London University which Mr. Henry Morley had just resigned.

Excuse such a succinct note, but there is very little time for the obtaining and remission of Testimonials. It is as a literary man, and as one who has also been much engaged on what may fairly be called Educational Literature (General Editor "The Canterbury Poets" Editor of the "Literary Olympic" in Young Folk's Paper - a periodical which circulates over a quarter of a million weekly - Editor of "Sonnets of this Century", now in its 30th thousand, etc. etc). that I mainly base my claim, though my philosophical studies will no doubt stand me in good stead.

It will materially add to my indebtedness if you will let me hear from you at your earliest convenience.

Sincerely yours I William Sharp

ALS University of Texas at Austin

To Thomas Wentworth Higginson, ${ }^{23}$ [April, 1889]

Wescam | 17A Goldhurst Terrace | South Hampstead

My dear Sir

I am much obliged to you for kindly sending me your charming "Afternoon Landscape". ${ }^{24} \mathrm{I}$ have read the volume with much interest and sincere pleasure, and find that it is one I shall go back to again - a rare thing with a hardened critic like myself. I hope I may be able to say a few words about it in print. It is not only musical and poetic in a high degree, but it has the note of distinction. I wish it all success both here and oversea.

My anthology of the best American Sonnets ${ }^{25}$ is almost ready - but as I notice in an American paper that you are coming to London erelong I shall retain the copy I intend for your acceptance till you arrive. If you will call on me when you do come it will give my wife and myself much 
pleasure (Monday afternoons and Sunday evenings are best for us), and also, please, bring your collaborators in A.L. ${ }^{26}$

Where will your address be in London?

My wife and I will be in Paris from the 1st till about the middle of May - but thereafter at home.

With kind regards, I Sincerely yours, I William Sharp T. Wentworth Higginson Esq.

ALS Pierpont Morgan

\section{To John Stuart Verschoyle, [May 1 or 2, 1889] ${ }^{27}$}

Wescam | 17a Goldhurst Terrace | So: Hampstead | N.W.

My dear Verschoyle

In case you write making any appointment with Moore, as you suggested, I send this to say that on Friday or Saty I am going to Paris for about three weeks, so must postpone seeing you till the end of May. ${ }^{28}$

By the way, what about Mrs. Macdonald's proposal as to Rousseau?

You once told me that you might be able to review any novel of mine. Are you still in a position to do so? If so, I should like if you could say something about my forthcoming "Children of Tomorrow", which Chatto \& Windus will issue about the middle of next week. A great deal depends on the reception of this book - against which there will be a dead set in certain quarters. The American publishers have withdrawn from their agreement on the score of the "objectionable tone and morals" of the story - but it is a perfectly frank and honorable and honest exposition of a romantic theme - and nothing more: and is, from the true point of view, a moral - in the sense that it is ethical, fundamentally - book.

Can you conveniently say a word for it anywhere? If so, I should tell C. \& W. to send you a copy. 
In haste | Sincerely yours | William Sharp I post you a copy of my "Testimonials", including your own: as you may care to see other.

ALS UCLA

\section{To J. Stanley Little, May 4, $1889^{29}$}

Letter to hand just as I am starting for Paris (for 2 or 3 weeks): \& only time for a hurried $\mathrm{P} / \mathrm{C}$.

It is a shame about "The Breaking Morn". ${ }^{30}$ Taking everything into consideration I should advise trying Olympian. It may attract all the more notice as a refusé. But first could yr. brother not see if either Gonfils or the Fine Art Socy (Bond St). would take it, either outright - or on view \& sale.

Thanks for Pioneer. I hope to read in transit.

W.S.

ACS Princeton

To Richard Le Gallienne, May 9, 1889

Paris | $9 / 5 / 89$

Dear Mr. Le Gallienne

Your note has just reached me (I have a packet of letters sent over only once weekly).

I shall not be at home again for a week or so: but when I do return I shall read your book with interest. 
I did hear, at the time, of your arrival in Hampstead, \& once or twice (when Mr. Cotton ${ }^{31}$ or someone has mentioned you) have wondered why you did not call at Wescam.

I hope you will benefit (you know the sense I mean) by your new life. In the autumn, by the way, we may meet in America, as I am going there for October and November.

In great haste, | Yours Sincerely, | William Sharp ACS University of Texas at Austin

\section{To James Mavor, May 10, $1889^{32}$}

Paris I May 10th

Dear Mr. Mavor

I herewith send the very short - according to your instructions notice of the Sculpture at the Salon.

Mr. Sharp will be writing in a day or two and will then give our next address - we leave Paris tomorrow.

Yours sincerely | Elizabeth Sharp

Mrs. Elia A. Sharp | May 10th, 1889

ALS University of Toronto 


\section{To James Mavor, [late May, 1889] $]^{33}$}

London

My Dear Mavor

I have returned to town - but have mislaid your letter: will you kindly send me a line mentioning again the latest date on which you wish to receive Pt. I of Siwäarmill's "Emilia Viviana" for the July No.

I don't wish to worry you about what may be only in nebulous but is there any better basis than before ${ }^{34}$ to The Scottish Art Review's passing into the hands, editorially, of Henley? ${ }^{35}$ The Tomsons ${ }^{36}$ were at our house last night, and informed us that they had been authoritatively told by R. A. W. Stevenson ${ }^{37}$ that Henley is to take over the editorship of the S.A.R. two months hence?

Half an hour ago I saw Gleeson White, and he also told me that "Henley has arranged to edit the S.A.R. two months from now".

In both instances I conditionally contradicted the statement: but I should like to hear definitely from you, whichever way the matter lies. If there is no truth in it, I think you should take some steps to put an end to a chronic rumour which has undoubtedly something malicious in it.

Please let me have a line from you.

Sincerely Yours, I William Sharp

I am getting on with "Emilia Viviani" and think you will like it. Be sure and preserve the secret of my identity with H. P. Siwäarmill. I hope you will like my "Children of Tomorrow". 
To early June, 1889

Murrayfield I Edinburgh

My dear Sir

I am very sorry I have not the book with me of which I wrote to you. It is to be published a week or so hence, I understand. I shall be back in London by the 25th at latest \& could send you the matter then, if that will suit you. ${ }^{38}$

No, please, do not include Mr. Meredith's printed letter about myself re: my candidature for the Literature Chair at London University. In no sense is it published-and its mention would be disagreeable both to G. M. \& myself.

In haste | Yours sincerely | William Sharp P.S. I may, in all probability shall, be home by Sunday the $23^{\text {rd }}$. If you care to look in upon me that evening I could show you the book in question. ${ }^{39}$

ALS Princeton

\section{To Frank Dempster Sherman, July 9, 188940}

Wescam | Goldhurst Terrace | So. Hampstead I N.W.

Dear Mr. Sherman

I have much pleasure in sending you a copy of my American Sonnets and Quatrains, wherein you figure to such advantage. The book is going well, and you have been quoted several times, particularly the Quatrain on the Quatrain.

Perhaps we may meet in the Autumn? I am going to pay a short visit to E. C. Stedman \& one or two other friends in New York in October, and I should be sorry to miss you. 
A friend lent me your "Madrigals and Catches" - a delightful volume.

Best regards, I Yours sincerely | William Sharp ACS University of Texas at Austin

\section{To Louise Chandler Moulton, July 13, 188941}

My dear Louise

Thanks for your kind note. I am glad you find something in my book ${ }^{42}$ to attract you. It has been, on the whole, badly received by the press as I, of course, fully anticipated: but I have been gratified beyond words by the letters I have had from authors whom I look to as masters, from many friends \& acquaintances, and even from strangers. Nothing I have ever done seems to have aroused so much enthusiasm. But quite apart from praise and blame, I am vain enough to believe that with all its faults \& demerits it is not altogether a book of "today". I have written it as an artist - and someday, if not now, it will gain its measure of recognition. At the same time, it is only a tentative effort, or a herald rather, of a new movement. I see the Athenaeum of today passes it by with "damning indifference" - and, on the other hand, Public Opinion has a long \& sympathetic (tho' fault-finding) review beginning "a remarkable book by a remarkable man". ${ }^{43}$

Well - time will solve this and all other small matters as efficiently as the great events of this "forlorn little star of earth".

I hope particularly to come to see you soon - if possible early on Tuesday - but I am frantically engaged at present, every afternoon \& evening, besides much work. At the end of the week we are to stay with George Meredith for a little, \& then make a flying visit to Grant Allen. About the beginning of August we both go away, Lillie to the Tyrol, I to Canada and afterward to the States.

Did I ever tell you by the by that my "Romantic Ballads" was exhausted almost immediately upon issue - and that the second edition (much improved) is going well. ${ }^{44}$ 
So far as I have read, I like your new book ${ }^{45}$ extremely: but I shall write when I have read it. As yet I have enjoyed the two first stories only.

Ever yours affectionately I Will: Sharp P.S. Your Sonnets in my "American Sonnets" have been much admired, and have several times been selected for quotation.

ALS Library of Congress, Louise Chandler Moulton Collection

\section{To Clinton Scollard, ${ }^{46}$ July 19, 1889}

Wescam | Goldhurst Terrace | So. Hampstead. N.W.

\section{Cher Confrìre}

I have had pleasure in sending you a copy of my "American Sonnets", containing your own beautiful examples. The book is going very well here, and in the Colonies, \& one or two of your sonnets have been noted several times.

Perhaps we may meet in the Autumn. I am going to pay a short visit to Mr. Stedman \& one or two other friends in New York in October. It should add much pleasure to the prospect if I thought I should meet you.

Yours sincerely | William Sharp

A friend lent me your "Old \& New World Lyrics", with which I was greatly charmed.

APCS University of Wisconsin-Milwaukee Library 


\title{
To Edmund Clarence Stedman, ${ }^{47}$ July 27, 1889
}

\author{
C/o Prof. Chas. G. D. Roberts ${ }^{48}$ | Kingscroft | Windsor | Nova Scotia |
}

$27 / 7 / 89$

\section{My Dear Stedman}

Although I put the above address to this note I do not arrive there till somewhere about the 15th of August. I am still in London, though I leave in a few days now. Since my wife's departure for Austria, I have been staying with George Meredith in Surrey, and am now feeling much better, having again regained my power of sleep: yet I shall be thankful to get away, and to see no proofs, letters, or MSS, for ten days at least.

You will ere this have received my reply to your last letter, saying how much I appreciated your kind invitation, and how eagerly I look forward to my New York visit, and to meet Mrs. Stedman and yourself in person.

I shall stay with Roberts for some time, and then go elsewhere in Nova Scotia, New Brunswick, and Upper Canada, throughout August and September. Early in October I hope to be in New York. But I do not wish to be in any way a drag upon any plans you may have entertained. I shall trust to your letting me know if my visit might prove inconvenient.

Meanwhile I am going to ask you to oblige me in a small matter. Will you kindly direct your bookseller to send me, at above address, to await my arrival, the two following books (the first of which will save me carriage of books - for I am engaged to write something on Swinburne soon: and the second of which will be helpful for excerpts, for another matter): and I can either remit amount to him or to you as may be most convenient.

It seems like going to see an old friend - to see you: and I am already impatient to be at 44 East 26th St.!

\section{Cordially Yours I William Sharp}

Roberts' will be my letter-address for most of the time - at any rate until I write to you with another. 


\section{To Edmund Clarence Stedman, August 17, [1889]}

August 17th

My dear Stedman,

I have just arrived in Halifax, and have been met by Roberts, who wants me to go off with him at once for a short trip to Prince Edward Island and elsewhere, so I have only time for this hurried $\mathrm{P} / \mathrm{C}$ in answer to your kind note. We return to Windsor about Friday or Saturday next.

Yes, I shall be in N.Y. early in October. Sorry as I am not to see N.Y. in the season, I have perforce to depart so as to get home by the end of October at the latest - so I find meanwhile at any rate. But your friendly hospitality and courtesy already make me look to N.Y. as "home" over here - and to see you will be to meet the American author I most wish to meet. I shall write you again from Windsor, when my movements are arranged, and also (when I return) about the books etc.

Ever yours, I William Sharp

ACS Columbia

\section{To Elizabeth A. Sharp, [late August, 1889]}

[At Halifax, which he considered] worth a dozen of the Newfoundland capital, [he was met by Professor Charles Roberts who had come] ${ }^{49}$ to intercept me so as to go off with him for a few days in Northern Scotia and across the Straits to Prince Edward Island. So, a few days later Prof. Roberts and I, accompanied for the first 100 miles by Mr. Longley, ${ }^{50}$ started for Pictou, which we reached after 5 hours most interesting journey. The Attorney General has kindly asked me to go a three days' trip with him (some 10 days hence) through the famous Cape Breton district, with the lovely Bras D'Or lakes: and later on he has arranged for a three days' moose-hunt among the forests of Southern Acadia, where we shall camp out in tents, and be rowed by Indian guides... . I went 
with Charles Roberts and Bliss Carman ${ }^{51}$ through Evangeline's country. En route I traveled on the engine of the train and enjoyed the experience. Grand Pré delighted me immensely - vast meadows, with lumbering wains and the simple old Acadian life. The orchards were in their glory - and the apples delicious! At one farm house we put up, how you would have enjoyed our lunch of sweet milk, hot cakes, great bowls of huckleberries and cream, tea, apples, etc.! We then went through the forest belt and came upon the great ocean inlet known as the Abasin of Minas', and, leagues away the vast bulk of Blomidon shelving boughlike into the Sea....

Memoir 151

\section{To Elizabeth A. Sharp, [late August, 1889]}

... Mr. and Mrs. Longley were most kind, and so were all the many leading people to whom I was introduced. I was taken to the annual match of the Quoit Club, and was asked to present the Cup to the winner at the close, with a few words if I felt disposed. Partly from being so taken aback, partly from pleased excitement, and partly from despair, I lost all nervousness and made a short and (what I find was considered) humorous speech, so slowly and coolly spoken that I greatly admired it myself!

Memoir 150-51

To Elizabeth A. Sharp, September 12, [1889]

(On the St. Lawrence), I 12th Sept.

To-day has been a momentous birthday on the whole - and none the less so because I have been alone, and, what is to me an infinite relief, quite unknown. I told no one about my Saguenay ${ }^{52}$ expedition till the 
last moment - and so there is nothing definite about me in the papers save that I "abruptly left St. John" (the capital of New Brunswick) and that I am to arrive in Quebec tomorrow. I sent you a card from Rivière du Loup, the northernmost township of the old Acadians, and a delightful place. I reached it from Temiscouata (the Lake of Winding Water) - a journey of extreme interest and beauty, through a wild and as yet unsettled country. The track has only been open this summer. Before I reached its other end (the junction of the St. John river with the Madawaska) I was heartily sick of New Brunswick, with its oven-like heat, its vast monotonous forests with leagues upon leagues of dead and dying trees, and its all present forest-fires. The latter have cause widespread disaster... Several time we were scorched by the flames, but a few yards away - and had "to rush" several places. But once in the province of Quebec, everything changed. The fires (save small desultory ones) disappeared: the pall of smoke lightened and vanished: and the glorious September foliage made a happy contrast to the wearisome hundreds of miles of decayed and decaying firs. It was a most glorious sunset - one of the grandest I have ever seen - and the colour of the vast Laurentian Mountain range, on the north side of the St. Lawrence, superb. It was dark when we reached the mouth of the Saguenay River - said to be the gloomiest and most awe-inspiring river in the world - and began our sail of close upon a hundred miles (it can be followed by canoes for a greater length than Great Britain). The full moon came up, and the scene was grand and solemn beyond words. Fancy fifty miles of sheer mountains, one after another without a valley-break, but simply cleft ravines. The deep gloom as we slowly sailed through the noiseless shadow brooding between Cape Eternity and Cape Trinity was indescribable. We anchored for some hours in "Ha! Ha! Bay", the famous landing place of the old discoverers. In the early morning we sailed out from Ha! Ha! Bay, and then for hours sailed down such scenery as I have never seen before and never expect to see again.... At Quebec I am first to be the guest of the well-known Dr. Stewart, ${ }^{53}$ and then of Mons. Le Moine ${ }^{54}$ at his beautiful place out near the Indian Village of Lorette and the Falls of Montmorenci - not far from the famous Plain of Abraham, where Wolfe and Montcalm fought, and an Empire lay in balance.

Memoir 152-53 


\title{
To Rev. Joseph Antisell Allen, ${ }^{55}$ [September 16, 1889]
}

C/o W. D. Lighthall Esq | 913 Dorchester St. | Montreal | Quebec | Monday Mg

My dear Sir

Your son and my valued friend, Grant Allen, has kindly given me the accompanying note of Introduction to you..$^{56} \mathrm{I}$ expect to spend a night this week in Kingston (probably Thursday, but I cannot say definitely yet, till I reach Montreal, whither I go from Quebec today) and if it would not be an intrusion upon your valuable time, or in any way inconvenient for you, I should much like to look in at "Alwington" for an hour or so.

Believe me | Yours very truly | William Sharp

\author{
J. A. Allen Esq
}

ALS University of Toronto

\section{To Edmund Clarence Stedman, September 17, [1889]}

C/o W. D. Lighthall Esq. | 913 Dorchester St. | Montreal | Tuesday, 17th Sept.

\section{My Dear Stedman}

I have had to forego many of my projected visits, for I find that I must return to London earlier than I had anticipated. This involves my going to New York even sooner than the date I mentioned to you in my last.

I now expect to arrive in New York (from Boston) about this day week - that is, about Monday evening or Tuesday of next week. I hope to be in New York for either 12 or 14 days - but I shall not inflict myself upon you all that time, as I am going to spend a night or so with Mr. Alden and probably elsewhere. 
However, I won't be a great drag upon Mrs. Stedman and yourself - for the mornings I must spend in correspondence and writing, and in the afternoons I shall have much to see and many friends in New York to "look up", not to speak of promised evenings.

May I go to you directly on arrival from Boston (either next Monday or Tuesday, probably the latter)? If in any way inconvenient for Mrs. Stedman or yourself, just let me know, of course.

I an impatient to be in New York, which I have so long wished to visit - one of the Trinity of Greatest Cities.

I leave here about Friday of this week for Boston, where (or in Hanover) I hope to see Arthur Sherburne Hardy ${ }^{57}$ and one or two others.

With kind regards to Mrs. Stedman. I Cordially Yours, I William Sharp ALS Huntington

\title{
To Edmund Clarence Stedman, [September 22, 1889]
}

\author{
Montreal | Friday
}

Cher Ami,

Be merciful and forgive! I see now how inconsiderate I have been - but I had somehow got the impression that you were a "fixture" in town during September and October. I am very remorseful for having been so irritatingly uncertain a factor in your plans. The best way to show that you forgive, will be to tell me frankly just when you had arranged, or when you want, to go into the country: I would not for a good deal deprive so hard a worker of long-looked-forward-to days of rest. I have other friends I could go to, you know: and, moreover, I expect my stay will have perforce to shrink even a little more yet.

In some justification of what you only too truly call my bewildering changes of plans, I have to plead my anxiety about my wife. She has been at the Sun-Cure in Southern Austria (Illyria), and tho' now in Dresden and somewhat better, seems to have been anything but "cured". In fact, 
she has been, and is, suffering from intermittent fever. I have, therefore, been doing all I can to cut off unessential portions of my programme, so that I may get home earlier than arranged, and, if advisable, go out to Germany to meet her. Fortunately, her note represents her health as much better. All the same, I must now leave New York as soon as practicable. So to this extent, overlook my inconsiderate changes of plan. A man in love (which I still am, though married nearly 4 years) is not a reasoning animal - not a reasonable one at any rate!!

Cordially yours, I William Sharp

I shall wire from Boston on Monday morning as to my arrival etc. and as to whether on Monday or Tuesday evening (probably Tuesday).

ALS Columbia

\section{To Elizabeth A. Sharp, [late September, 1889]}

New York, New York

... So much has happened since I wrote to you from Montreal that I don't see how I'm to tell you more than a fraction of it - particularly as I am seldom alone even for five minutes. Last week I left Montreal (after having shot the rapids, etc). and traveled to Boston via the White Mountains, through the States of Vermont, Connecticut and Massachusetts. Boston is a beautiful place - an exceedingly fine city with lovely environs. Prof. A. S. Hardy ('Passe Rose', etc). was most kind.... Cambridge and Harvard University are also very fine. I enjoyed seeing Longfellow's house (Miss L. still occupies it) and those of Emerson, Lowell, etc. I spent brief visits to Prof. Wright of Harvard, to Winsor the historian, etc. ${ }^{58}$ On Sunday afternoon I drove with A.S.H. ${ }^{59}$ to Belmont in Massachusetts, and spent [the] afternoon with Howells, the novelist. ${ }^{60}$ He was most interesting and genial - I had the best of welcomes from the Stedmans. ${ }^{61}$ They are kindness personified. The house is lovely, and full of beautiful things and multitudes of books. I have already more 
invitations than I can accept: everyone is most hospitable. I have already met Mr. Gilder, the poet, and editor of the "Century"; Mr. Alden, of "Harper's",62 Mr. Bowen, of the "Independent",;6 R. H. Stoddart, the "father" of recent American letters; ${ }^{64}$ and heaven knows how many others. I have been elected honorary member of the two most exclusive clubs in N.Y., the "Century" and "The Players". Next week there is to be a special meeting at the Author's Club, and I am to be the guest of the evening....

Memoir 153-54

\section{To Richard Watson Gilder, September 30, 1889}

44 East 26th Street | N.Y. | Monday Morning | 30 Sept. '89

Dear Mr. Gilder

Have just returned from Metuchen, where I have been spending Saty \& Sunday with Mr. Alden, of Harper's Mag. Before I left, I gave instructions about the transmission to you of a copy of my "American Sonnets" but I forgot that it would have to go without inscription. I shall try and look in some day, partly to rectify that omission, and also for the pleasure of seeing you again. If the fates be adverse to this modest plan, then you must accept the will for the deed - or let this hurried note serve the end.

I understand now the meaning of a para I read somewhere - that Jersey mosquitoes are big enough to spank! That war with America would be justifiable, if she sent us a healthy young married mosquitocouple, is the opinion of the suffering Briton who signs himself,

Sincerely Yours, I William Sharp

ALS Stanford 


\section{To Elizabeth A. Sharp, October 1, 1889}

New York | 1:10:89.

Can only send you a brief line by this mail. I enjoyed my visit to Mr. Alden at Metuchen in New Jersey very much. Among the new friends I care for most are a married couple called Janvier. ${ }^{65}$ They are true Bohemians and most delightful. He is a writer and she an artist... and both have traveled much in Mexico. We dined together at a Cuban Cafe last night. He gave me his vol. of stories called "Colour Studies" and she a little sketch of a Mexican haunted house - both addressed to "William Sharp. Recuerdo di Amistad y carimo".

Memoir 154

\section{To Richard Watson Gilder, [early October, 1889]}

Dear Mr. Gilder

If you have not already posted Mr. DeKay's ${ }^{66}$ books to me will you kindly do so to me at my London address.

In haste, I Sincerely yours, I William Sharp

Address: Wescam, Goldhurst Terrace, So. Hampstead, London, NW

ACS Huntington

\section{To E. C. Stedman, October 6, $1889^{67}$}

My dear Stedman

This, along with some flowers, will reach you on the morning of your birthday, while I am far out on the Atlantic. May the flowers carry to 
your poet-soul a breath of that happy life which seems to inspire them - and may your coming years be full of the beauty and fragrance of which they are the familiar and exquisite symbols. You have won my love as well as my deep regard and admiration - and so I leave you to understand how earnestly and truly I wish you all good.

Once more let me tell you how deeply grateful I am to you and Mrs. Stedman for all your generous kindness to me. We have all, somewhere, sometime, our gardens, where - as Hafiz says - the roses have a subtler fragrance, and the nightingales also a rarer melody; and my memory of my last "fortunate Eden" will remain with me always.

But I shall not be content till I hear (not by letter but by Postcard) that you have had your long delayed holiday, and have gained new vigour. Do be careful of yourself: You, who have done so much, have yet so much to say and to do - so, at least listen to that plea.

I shall always think of you, and Mrs. Stedman, and Arthur, ${ }^{68}$ as of near and dear relatives. Yes, we are of one family.

Farewell, meanwhile, I Ever your affectionate I William Sharp ALS University of Wisconsin-Milwaukee and Memoir, 154-55

\section{To Laura Hyde Stedman, October 12, [1889]}

\section{S.S. "Sierria" I Saturday 12th Octr}

My dear Mrs. Stedman

It is too rough for me to attempt to write with pen and ink - so I am sending you a brief pencilled note. Sometime in the middle of the night, or early in the morning, we expect to reach Queenstown to disembark a few passengers and land the mails. On the whole, we have had a pleasant passage, though with some heavy rolling and a good share of rain and fog. Now that we are nearing the British coast we are coming into true October weather, - blue skies, with fresh keen air. I have made some pleasant acquaintanceships on board - and, curiously enough, with an 
artist and his mother and sister who live quite close to me in London. There is no one of artistic or literary note on board, except Alfred East, ${ }^{69}$ the well-known landscape-painter, who is returning from a paintingexpedition to Japan.

I need hardly to say that often and often I think of you and yours, and remember with ever fresh pleasure the visit which your kindness did so much to make delightful. Believe me, I shall never forget, nor cease to have a "warm corner in my heart" for you, and your husband, and son. I do trust that Mr. Stedman is feeling better, and that by the time this reaches you, you will both be in the country, and enjoying a thorough rest. I am sure you both need it. Arthur, I know, was only going away for a few days, but into these I hope he has crammed a month of health.

I'm afraid I must come to an abrupt conclusion - but the rolling of the vessel is so great that I can hardly keep my seat. I shall be thankful to see Queenstown, and still more to reach Liverpool, some fifteen or eighteen hours later. I expect that two or three letters will arrive for me in New York from my wife - but Arthur kindly promised to send any letters on at once, though I wanted to relieve him of that trouble by instructions to the General or District Post Office.

I must stop, or I'll be rolled overboard - and then there will be an end of me as well as of my letter. With affectionate regards to you and yours,

Believe me, dear Mrs. Stedman, I Ever sincerely yours, I William Sharp

P.S. I hope the florist (at the corner of Broadway and Madison Sq). did not forget to deliver my letter to E.C.S. and the flowers so as to arrive as a birthday greeting on the morning of the 8th. I made him promise to send them round before 10 o'clock. May he and you live to see many happy, ever happier, returns of the 8th!

\section{ALS Columbia}




\title{
To Thomas Robert Macquoid, [mid-October, 1889] ${ }^{70}$
}

\author{
17a Goldhurst Terrace I So. Hampstead. N.W.
}

Cher Confrére,

Herewith I send you, for consideration for E. \& W., a very fine sonnet by Prof. Chas. Roberts, the foremost of the younger poets in Canada. He is well-known here, as well as in Canada and the States. His third vol, which will be out in 1890 (autumn), is full of remarkable studies in poetic realism.

Have you had time to consider the suggestion or two I made to you?

In haste \& with best wishes for the success of your Xmas No.

Yours sincerely | William Sharp

I sincerely trust Mrs. Macquoid is feeling better.

ALS Private

To Richard Watson Gilder, [late October, 1889]

17a Goldhurst Terrace I So. Hampstead I London N.W.

Dear Mr. Gilder

The books by your brother-in-law, and the present writer, arrived almost simultaneously this evening in London. I had a pleasant passage. Already my most delightful visit to New York seems dreamlike.

Kindest regards to you and other friends with you and to Mrs. Gilder,

Faithfully Yours, I William Sharp

ACS Huntington 


\section{To Robert Underwood Johnson, ${ }^{71}$ November 6,1889}

6th Nov./89

My dear Mr. Johnson

Just returned from Germany, so excuse this hurried P/C as I have a great pile of correspondence awaiting me.

Many thanks for Mrs. Dodge's fine sonnets. ${ }^{72}$ Please do not forget your other promise.

Kindest remembrances to yourself and confréres -

Sincerely yours, | William Sharp

ACS Huntington

\section{To Kineton Parkes, [November 6, 1889] ${ }^{73}$}

Wescam | Goldhurst Terrace | So. Hampstead. N.W.

I sent you a line from Germany a few days ago which I fear cannot have reached you. I forgot your address, \& simply put after your name. Editor of Comus, Birmingham. Perhaps you wd recover the $\mathrm{P} / \mathrm{C}$ by enquiring at the G.P.O.

In haste I William Sharp

ACS Private 


\section{To James Mavor, December 14, 1889}

Handed in at the Swiss Cottage To Mavor I 93 Hope St. I Glasgow

Can you reserve me two to three pages February number for Elegiac poem in memoriam Browning ${ }^{74}$

William Sharp

Telegraph, University of Toronto

To Edmund Clarence Stedman, [December 15?,1889]

London

My dear Friend

I was so sorry - so grieved for you - to hear of the death of your mother. You who have had so much trouble, and borne it all with such heroic heart and brave demeanour, have again been saddened by disaster. I wish I could say or do something to lighten your pain: you know at any rate that you have my loving sympathy. I gave myself the satisfaction of writing a short account of your mother in a paper here, based on that in a paper you sent me.

And so Browning ${ }^{75}$ - beloved and revered friend and great poet has gone!

But a Xmas-note must not be all sad. We will think of you and yours, and drink your healths in loving remembrance. May the gods give you in 1890 the leisure you require, and may your strenuous high song make itself heard in renewed strength and heart.

Always affectionately yours, I William Sharp 


\section{To Henry Chandler Bowen, December, 1889}

17a Goldhurst Terrace I South Hampstead I London I NW

Dear Mr. Bowen, ${ }^{76}$

Just as I was about to begin one of my promised articles for you, I have been asked to write the monograph on Robert Browning for the Great Writers Series. As it is wanted speedily, and as this is a very heavy addition to my already numerous outstanding commissions, I shall, I am genuinely sorry to say, be unable to send you anything till Spring at best.

But it occurred to me that you might care to have the Sonnet I wrote three nights ago, on hearing the sad tidings from Venice of Browning's death. I loved the man as a friend as well as revered him as a great poet. I had meant to print it in the Academy, or elsewhere here - but send it to you instead.

And as I am writing at any rate, I send two other short poems for your consideration.

How often I think of my delightful visit to New York! I wish you would come over next, as a reversal. Both Edgar Fawcett and Edgar Saltus have been paying us short visits. Of the Harlands (Sidney Luska) we see much.

Allow me to wish you a pleasant Noeltide and a fortunate and happy 1890.

With friendly remembrances | Yours sincerely | William Sharp ALS Princeton 


\section{To Richard Watson Gilder, December 18, 188977}

17a Goldhurst Terrace | So. Hampstead I London. | N.W. | 18:12:89 |

Dictated

\section{Dear Mr. Gilder}

I am engaged upon a series of "Imaginary Journals", and wonder if you would care to have one for The Century.

As the style and scope of the series will of course be various, no one example will quite show you a precedent: still, as an essai pour servir, perhaps you may care to glance at the enclosed.

The proofs are duplicated of an "Imaginary Journal" by me which is to appear in the January issue of The Art Review. In each of the series, my effort is to reach the real self of the person represented: to show them in quintessential moods. Collectively, they will (in some measure) demonstrate the strange mental and spiritual complexities of the Modern Renaissance, a period which I hold to have begun its efflorescence earlier than is commonly granted, and hold, also, to have undergone suspension, or perhaps a Protean interfusion, till the beginning of this century, when it has been, and still is, culminating.

Two others of the series will in due course appear in The Art Review: one in Blackwoods: and one in Macmillan's.

I am slowly (work of this kind is necessarily very gradual and careful) writing the others which will complete my work. Perhaps you would care to have one of these.

(Fragments from)

\section{The Lost Journal of Gaspara Stampa}

"il Saffo de Nostri Tempi", as she was called. The beautiful Venetian poetess, whoselover, Collalto, was seduced by Diane de Poitiers when he went to the French Court as an ambassador.

\section{2. $\underline{\mathrm{D}}^{\circ}$ [ditto] of Giorgione}

Dealing with his love of colour and music; etc.

\section{3. $\underline{D}^{\circ}$ [ditto] of Gerard de Nerval}


The French Romanticist poet, whose strange manner of death has never been satisfactorily explained.

\section{4. $\underline{D}^{\circ}$ [ditto] of Baudelaire}

a purely psychological revelation.

\section{The Reverie of Bazzi.}

Fragments from The Journal of Bazzi (Sodoma) while painting the St. Benedict Frescoes at the Convent of Monte Oliveto in the wilds of Umbria.

\section{The Passion of Parmigiano}

His "passion", as it literally was, at the end of his life, was Alchemy. It ruined him, but not until it had first ruined his art.

\section{The Crime of Andrea dal Costagno}

A fragment from the Journal of this murderer painter and successful hypocrite, written not long before his death. (Vide Vasari)

\section{A Dark Day of St. Francis}

If you would care to have any of these you might specify the two you fancy most, and I should send you one of them. But could you print for certain in $1890 ?^{78}$

Best wishes for Xmas and the New Year!

Yours sincerely | William Sharp

P.S. I enclose two short poems for yr. consideration. ${ }^{79}$

ALS New York University Fales Library 



\section{Chapter Six}

\section{Life: 1890}

After spending a pleasant Christmas with friends - the painter Keeley Halswelle and his wife Helena - near Petersfield in Hampshire, the Sharps entertained friends for dinner at their South Hampstead home on New Year's Day. A good deal of alcohol was consumed, or so he told Ford Madox Brown in a letter thanking him for his New Year's card, a proof of his Samson and Delilah etching. In the first two months of 1890, Sharp recorded his activities in a diary, parts of which his wife preserved in the Memoir. In early January, he was working on the Browning monograph and beginning a novel, "The Ordeal of Basil Hope," which never saw the light of day. He was also writing articles for the Scottish Leader and "London Letters" for the Glasgow Herald. In mid-January, to escape the distractions of London, he went to Hastings where he worked steadily on the Browning biography and enjoyed long walks with the poet Coventry Patmore who was living there. After his return to London in February, he continued to work on the Browning manuscript and "Basil Hope." In mid-March, he wrote to congratulate Bliss Carman, the poet he had met the previous summer in Canada, on his appointment as an editorial writer for the New York Independent. The letter was written in Edinburgh where he had gone for a few days to visit his mother and rest his eyes and head after intense work on the Browning book. In an April 7 letter to Frank Marzials, general editor of Walter Scott's Great Writers Series, he said he had nearly finished reviewing and revising proofs of the Browning book and would return 
them in the morning. The half-dozen advanced copies which were printed several days later must not have contained Sharp's corrections as he felt obliged to send an "Errata and Addenda" slip to at least two potential reviewers. On April 16, he told J. Stanley Little that his Life of Browning was "going splendidly - already about 10,000 copies disposed of."

While working on the Browning biography and "Basil Hope," Sharp also wrote the Browningesque prose piece "Fragments from the Lost Journal of Piero di Cosimo" which appeared in two parts in the January and April issues of The Art Review, the short-lived successor to The Scottish Art Review that James Mavor edited and Walter Scott published from January to June 1890 . He also selected the poems and wrote the introduction for Great Odes: English and American, a Canterbury volume that appeared in April. He wrote a play, "The Northern Night," that see the light of day in 1894 in a collection of short dramas called Vistas. He wrote an article on D'Annunzio for The Fortnightly Review and an article on American literature for The National Review. In early May, he went to Paris to review the Salons and returned to London nine or ten days later to write the review for the Glasgow Herald. He was reading extensively in contemporary French, Belgian, and Italian literature, and he wrote a "Critical Memoir" for an English translation of SainteBeuve's Essays on Men and Women which appeared in September in David Stott's Masterpieces of Foreign Authors series. Sharp's interests ranged widely, and he worked especially hard in 1889 and the first half of 1890 on projects that produced income and are only of passing interest.

There are exceptions, and one is a poem that stands out for its stark imagery and what it portends. In mid-May, he sent an essay and a poem to Bliss Carman for possible publication in the New York Independent. The essay was not accepted, but the poem, "The Coves of Crail," appeared in the July 3 issue. Sharp had included the poem in the second (1889) edition of his third book of poems, Romantic Ballads and Poems of Phantasy. Since that volume was not published in the United States, the poem had not appeared there. 


\section{"The Coves of Crail"}

The moon-white waters wash and leap, The dark tide floods the Coves of Crail; Sound, sound he lies in dreamless sleep Nor hears the sea-wind wail.

The pale gold of his ozzy locks, Doth hither drift and wave; His thin hands plash against the rocks, His white lips nothing crave.

Afar away she laughs and sings A song he loved, a wild sea-strain Of how the mermen weave their rings Upon the reef-set main.

Sound, sound he lies in dreamless sleep, Nor hears the sea-wind wail, Tho' with the tide his white hands creep Amid the Coves of Crail.

Crail is both a small village on the rocky east coast of Scotland and the name of the harbor the village overlooks. The handsome man in the poem who now moves only with the waves was lured to the sea by the song of a mermaid and drowned in his attempt to reach her in a realm inhabited only by mermaids and mermen. The poem's subject, tone, and form anticipate the poetry Sharp would write later and attribute to Fiona Macleod. He had heard its story many times from the men and women of the Inner Hebrides. It reflects the dangers of life on the sea for fishermen and all sailors as well as the danger of efforts to cross the boundary between the world we know and the spirit world we would like to know. A common theme in fairy tales of all languages, it became a frequent motif in the writings Sharp published as Fiona Macleod.

Sharp's burst of writing and editing in the winter and spring of 1890, enabled by a period of good health, finally produced enough money for a break from editing, reviewing, and the fast pace of life in London. As early as January 23, 1889 he told Hall Caine he hoped to be settled in Rome the next winter: "I am tired of living in this abominable climate, and of so much pot-boiling. I want to retire for a year and devote myself to original work." On February 22 he wrote to Richard Watson Gilder: 
"Next October I am going to leave England for six months at any rate, and perhaps for 18, and return to my well-loved Italy. I am sick of potboiling and wish to get on with purely original work. The Drawback is - heavy pecuniary loss. However, I feel I must do it, now or never." Finally, in a long letter to Stedman on June 17, he announced his decision to "begin literary life anew:"

As for us, we are both at heart Bohemians - and are well-content if we can have good shelter, enough to eat, books, music, friends, sunshine, and free nature - all of which we can have with the scantiest of purses. Perhaps I shd be less light-hearted in the matter if I thought that our coming Bohemian life might involve my wife in hard poverty when my hour comes - but fortunately her 'future' is well assured.

The Sharps divested themselves of some writing and editing obligations, stored their furniture, and on June 24 left the South Hampstead house they called Wescam. They would travel while Sharp devoted himself to serious literary work, but their financial circumstances precluded a complete break. Sharp transferred to Elizabeth the post of London art critic for the Glasgow Herald and resigned his lucrative though timeconsuming position with The Young Folks' Paper, but he retained his Canterbury Poets editorship. After leaving Wescam, the Sharps spent a week in the Caird's Northbrook House in Micheldever, which he described in a June 17 letter to Stedman as "a friend's place 7 miles across the downs north of Winchester." When they returned to London, they stayed awhile with the Cairds in their large South Hampstead house and decamped to Scotland at the end of the month.

Before leaving London, Sharp wrote a letter to William Wetmore Story that requires some explanation. During a weekend in Surrey in the summer of 1887 or 1888 with Sir Walter and Lady Hughes, friends of Elizabeth's mother, Sharp met Walter Severn, a well-known painter who was familiar with Sharp's book on Rossetti. He asked Sharp if he would like to undertake a biography of his father, Joseph Severn, also a painter, who had accompanied the poet John Keats to Rome and cared for him there as tuberculosis took his life. When Sharp agreed to undertake the project, Severn gave him a large quantity of unpublished manuscripts written by and related to his father. He began working intermittently on this project in the Spring of 1890, and on July 15, he wrote to ask Story, whom he had met in Rome in 1883, if he had known Severn, who 
spent many winter months in Rome and eventually served as British Ambassador to Italy. Elizabeth reproduced a portion of Story's reply:

I knew Mr. Severn in Rome and frequently met and saw him but I can recall nothing which would be of value to you. He was, as you may know, a most pleasant man - and in the minds of all is associated with the memory of Keats by whose side he lies in the Protestant Cemetery in Rome. When the bodies were removed, as they were several years ago, and laid side by side, there was a little funeral ceremony, and I made an address on the occasion in honor and commemoration of the two friends (Memoir 169).

An American lawyer, sculptor, poet, and novelist, Story (1819-1895) moved permanently to Rome in 1850 . His apartment became a gathering place for British and American artists and writers, among them Elizabeth and Robert Browning, Nathaniel Hawthorne, and Henry James (who wrote his biography). His monumental sculptures, mostly of Biblical and Classical figures, are displayed in museums in the United States and Britain, as are some of the paintings of both Joseph Severn and his son Walter. Sharp's letter to Story probably had the secondary purpose of reestablishing contact so that he might be welcomed into Story's social network when he reached Rome in December.

When Eric Sutherland Robertson left London in 1887 to fill a chair in literature and logic at the University of Lahore, Sharp succeeded him as editor of the "Literary Chair" in The Young Folk's Paper. That position provided a regular income for the next three years and increased Sharp's visibility and influence in the London literary scene. When they were in Scotland in early August of 1890, the Sharps learned Robertson had returned briefly to London. On August 15, Sharp told Robertson he was anxious to see him: "I have often missed you for, as you know, I was strongly drawn to you from the first, and look upon you as one of my very few "deep" friends. My most intimate friend since you left is Theodore Roussel, the French painter, who now lives in London." He gave Robertson their Scotland itinerary in case he could meet them there. On the next day, August 16, they were going to the West Highlands - Tarbert on Loch Fyne in Argyll - for three weeks. Sharp believed it would be best if Robertson could join them there, but if not perhaps elsewhere in Scotland. From September 8 to 12, he was in Glasgow, and Elizabeth was visiting a friend in South Bantaskine. From 
the 12th to the 17th both Sharps were in North Queensferry, a village across the Firth from Queensferry just northwest of Edinburgh. On the 17th they went north to Aberdeen, and on the 22nd they were back in Edinburgh staying with Sharp's mother. At the end of September or the beginning of October, they returned to London to Elizabeth's mother's home, 72 Inverness Terrace in Bayswater. Robertson did not meet them in Scotland, but he did see them after they returned to London. In a letter of October first or second, having just returned from Scotland, Sharp told Theodore Watts he thought Elizabeth intended to invite him for afternoon tea on Saturday, October 4 with Eric Robertson and George Meredith.

The main purpose of the letter to Watts was to convey Dr. Donald Macleod's willingness to speak with him about the possible serial publication of Watts' novel - Alwyn -in Good Words. While Sharp was in Tarbert in late August and early September, he spent a good deal of time with Macleod, an eminent Presbyterian clergyman, a respected theologian, and a talented and prominent minister who served in Park Church, Glasgow from 1869 until 1901. He also edited from 1872 until 1907 the evangelical journal Good Words. Under his editorship, the journal had begun to branch out from it purely religious base to include non-religious essays and works of fiction. Thus his interest in Watts' Alwyn. Macleod was also a repository of Celtic myth and the source of many of the tales Sharp would write as Fiona Macleod. Sharp indirectly acknowledged his debt by adopting Macleod's surname to provide a measure of authenticity and prestige for Fiona. During this visit, Elizabeth recalled, Macleod sang to Sharp "with joyous abandonment a Neapolitan song" and asked him to send him from Italy an article for Good Words. Sharp's "Reminiscences of the Marble Quarries of Carrara," which appeared in Good Words late in 1890, must have derived from a visit to the quarries during Sharp's first trip to Italy in 1883 since the Sharps did not reach Tuscany on their way to Rome until December 1890, too late for that month's Good Words.

On Saturday, October 11, Sharp told Stedman he and Elizabeth were leaving the next day for Germany where they planned to stay until the end of November. In the letter he asked Stedman for a "line of introduction" to Blanche Willis Howard, an American novelist who had recently married Dr. Julius von Teuffel, the court physician of 
Württemberg. The Sharps went first to Antwerp, stopped in Bonn, and went on to Heidelberg where, he told his friend James Mavor, they were "very comfortably settled in a romantic old house adjoining the Castle grounds - and with interesting literary associations. Goethe himself wrote one of his poems in the balcony of the quaint, picturesque room I occupy." According to Elizabeth, her husband was disappointed with the Rhine, and he expressed some surprising anti-German, pro-French sentiments to an unknown friend: "The real charm of the Rhine, beyond the fascination that all rivers and riverine scenery have for most people, is that of literary and historical romance. The Rhine is in this respect the Nile of Europe." He thought it should be the boundary between Germany and France.

Germany has much to gain from a true communion with its more charming neighbor. The world would jog on just the same if Germany were annihilated by France, Russia and Italy: but the disappearance of brilliant, vivacious, intellectual France would be almost as serious a loss to intellectual Europe, as would be to the people at large the disappearance of the Moon.

Sharp wrote again to Stedman on November 4 to thank him for the introduction to Blanch Willis Howard. He had forwarded it and asked to see her late in the following week. In sending the introduction, Stedman asked Sharp if he had a hidden motive in wishing to meet her, and thus began the repartee between Sharp and Stedman regarding possible extramarital affairs that continued for many years. Sharp replied that indeed he was going to Stuttgart alone, but only because Elizabeth was otherwise occupied in Heidelberg. He did plan "to cut about a bit" on his own, visiting "Karlsruhe, Mannheim, the Neckar, and so forth" and he was going alone to Frankfurt at the end of the week to hear Wagner's 'Rienzi'." Then another complaint about Germany: "Mon Ami, it is only too easy to be virtuous here. The women - ah, "let us proceed!" He and Elizabeth planned to leave Heidelberg on November 25 and stay for a time with her aunt in her villa near Florence before going on to Rome.

When they reached Rome in December, Sharp conveyed a somewhat more balanced opinion of Germany in a letter to Catherine Janvier in New York: 
Well, we were glad to leave Germany. Broadly, it is a joyless place for Bohemians. It is all beer, coarse jokes, coarse living, and domestic tyranny on the man's part, subjection on the woman's - on the one side: pedantic learning, scientific pedagogism, and mental ennui; on the other: with, of course, a fine leavening somewhere of the salt of life.

He went on to describe their six weeks in Heidelberg as "wet," but to admit it was "only fair to say we were not there at the best season." Stuttgart was his favorite German city. "Wonderfully animated and pleasing for a German town," it had a charming double attraction both as a medieval city and as a modern capital." He now had a friend there in Blanche Willis Howard, who was rejoicing in the title "Frau Hof-Arzt von Teuffel." Her husband, Doctor von Teuffel, was "one of the few Germans who seems to regard women as equals." Sharp's visit to the von Teuffels had a curious result: an epistolary novel called A Fellow and his Wife in which Howard wrote the letters of a male aristocrat who stayed home in Germany while Sharp, while in Italy, wrote the letters of his wife who had taken off for an extended stay in Rome. This tour de force became the first instance of Sharp adopting and sustaining with remarkable consistency the persona of a woman.

The Sharps left Heidelberg on November 23 and reached Tuscany, "flooded in sunshine and glowing colour," in the second week of December. After a few days with Elizabeth's aunt in Florence, they went on to Rome and settled in rooms on Via delle Quattro Fontane, near the summit of the Quirinal Hill. He described for Catherine Janvier the literary works he planned to write, but Rome soon eclipsed them. The many "schemes he planned mentally," Elizabeth wrote, "were never realized.... A new impulse came, new work grew out of the impressions of that Roman winter which swept out of his mind all other cartooned work." Under the spell of the warmth and beauty of Rome and its surroundings, Sharp in his mid-thirties fell in love with a beautiful woman ten years his junior, a woman he knew in London who took on a compelling new radiance in Rome where she changed the course of Sharp's life and the trajectory of his work. 


\section{Letters: 1890}

\section{To Ford Madox Brown, January 1, 1890}

17a Goldhurst Terrace | So Hampstead I NW I New Year's Night

My dear Mr. Brown,

I cannot tell you how touched and gratified I was, as well as pleased, by your most kind present. It is very beautiful, and, I need hardly say, will now and always be among the most treasured possessions of my wife and myself. How earnestly we both wish you and yours all prosperity and happiness in 1890. I have written so often about, and felt such an artistic delight in, your work that I am pleased beyond measure to have something from you - although I already have one or two things by you; among others, one of our most valued ornaments in our drawing room (and always admired by visitors) being the framed etching of your "Entombment" - the same that, despite its shamefully stupid hanging, impressed me so much as anything in all the Exhibition at Manchester. We had a pleasant Xmas down in South Hampshire with the Keeley Halswelles.

This evening several friends looked in upon us, with the result that not only my two remaining bottles of champagne but (several of them being Scotch) our store of whisky have gone the way of all flesh. One French gentleman, whose English was very shaky, departed with extreme difficulty, and not till he had said impressively to my wife, "Godam, my dear madame, your visk is superbe, magnifique". In fact, his "Godams" became rather excited. But we had a jolly evening, and the only little cloud since was my dear wife's catching me kissing our handsome housemaid Kate under the mistletoe. I explained that I felt full of fatherly love, but somehow Mrs. S. did not see it. As somebody says in Dickens, "women is rum's devils". Mrs. Caird also looked in earlier, and the Americans, the Harlands. By Jove, how Mrs. Caird did, so to say, jump upon Harland, who tried to "do" her with witticisms. And now I must be off to bed. I'm in a repentant mood, for last night, I much regret to say I threw back my arm in my sleep and not only gave my sposa an unpleasantly impressive salute on the nose, but woke her 
from her dreams of meeting me as an angel in heaven by calling out (as she declares) "Ireland forever! Hell and Blazes!".

Our love to Mathilde - and best greetings to Mrs. Brown and yourself. And again accept my warmest thanks. Hoping to see you soon, $\&$ to find you in your old visions.

Ever sincerely yours, I William Sharp

You are not meant to trouble about readjusting the stretching of the etching. I'll see to that.

ALS Private

\section{To Thomas A. Janvier, January 4, 1890}

London. I January 4, 1890

Many thanks for the Aztec Treasure House, which opens delightfully and should prove a thrilling tale. I don't know how you feel, but for myself I shall never again publish serially till I have completed the story aforehand. You will have seen that I have been asked and have agreed to write the critical monograph on Browning for the Great Writer's Series. This involves a harassing postponement of other work, and considerable financial loss, but still I am glad to do it.

The Harlands spent New Year's Day with us, and the Champagne was not finished without some of it being quaffed in memory of the dear and valued friends oversea. You, both of you, must come over this spring.

Ever yours, I William Sharp

Memoir 159-60 


\section{To Arthur Stedman, January 4, 1890}

4th January 1890

My dear Stedman

I hope the New Year has opened well for you and yours. May it bring prosperity and happiness to each of you.

I am immersed in work, and would that the days were thrice as long and that eyes and brain could stand the strain. The Harlands have got quit of their colds, and are becoming acclimatized. They spent New Year's Day with us.

I am uncertain whether anything of my small fund remains, or even if I am not in your debt: but in any case, please let me know, after you have added to your many kindnesses by sending me a book recently published at a dollar by Harper's, "The Odd Number'," by Guy de Maupassant, with an Introduction by Henry James.

You will have seen that I have undertaken to write the critical monograph on Browning, for the Great Writers series.

Ever yours, I William Sharp

ACS Yale University

\section{To Hall Caine, January 6, 1890}

Monday

My dear Caine

I was delighted to hear from you and most heartily reciprocate all your good wishes for 1890. I envy you at Keswick. Very glad to hear about your book, and about your play. What a far-reaching audience you now have! Well, I am sure no man deserves success better.

I can send you only a brief line today as I am not only very busy, but have neuralgia in my eyes. 
I was with George Meredith at Browning's funeral, and there I met and shook hands cordially with Watts.

Still - what a poseur he is! His article (interview) in the Globe, à propos of Browning, has several misleading assertions and even inveracities. However, it doesn't matter. He is a good fellow below it all - and we have, each of us, our own weaknesses and shortcomings.

I am deep, deep, deep in a multiplicity of things - magazine-articles etc., etc., etc. The two or three big undertakings I have on hand have to stand over meanwhile, as I have been asked and have agreed to write the critical monograph on Browning for the Great Writers series. I have a curious kind of article (one of several appearing in various quarters) on the Lost Mural of Piero di Cosimo in "The Art Review" for Jany. By the way, I should particularly like you to read the long stanzaic elegiac poem on Browning which I have written for the February issue of "The Art Review". Poor old Dr. Westland Marston died last night; of Bright's disease.

Again with all good wishes for you and yours

Ever yrs affectly I William Sharp

P.S. I was out of town, staying with Keeley Halswelle, or should have looked you up before you left Victoria St.

P.S. 2. [On back of envelope] I suppose you know that Buchanan has been \& still is very seedy, and has been ordered away for some time to a milder climate.

ALS Manx Museum, Isle of Man

\section{To Louise Chandler Moulton [mid-January, 1890]}

My dear Louise,

I have been from home - hence my delay in acknowledging your most kind and welcome present of "In a Garden of Dreams": and now I find myself enforced to a brief note, having (in addition to great pressure 
of work) an oncoming cold which I fear is at least a first cousin to the Influenza from which Lillie and my sister-secretary are already prostrated.

But all the more reason for acknowledging at once and however briefly your kind present. The book is beautiful indeed, externally. But what is of more importance is that its contents are more beautiful still. The beauty and poetic power of these lovely poems must win you a host of new friends and admirers, here as well as in America. Some of the lyrics are simply exquisite, particularly those with something of the vague Elizabethan charm in them. I think that "Eros" and "If There Were Dreams to Sell" are my favourites - but then, I immediately remember others of like haunting grace and beauty.

The Sonnets make a very remarkable sequence. Every one without exception is good, and some have a weightiness of poetic message and poignancy of poetic emotion combined with exquisite art that place them in the front rank of recent Sonnet-literature. I envy your having written many of these lovely and noble poems.

For the last section of the book I care less: partly, I may add, because of the outworn media themselves. All the same you have written the only triolet which I think worth remembrance among the myriads of these objectionable trifles which have been perpetrated - the altogether delightful little "Thistle Down".

I have written a review of the book for "The Scottish Leader" - the most literary of the big dailies - and when it appears, which may not be till next week (Thursday is Review Day) or possibly even the week after, I shall send you a copy.

So the poor old Doctor is gone. I did not see him, at the last, or at all for nearly a $1 / 2$ year past. I got no word from anyone of his funeral - but in any case, my cold would have prevented my going. None can lament his death - which must have been a release.

I hope we may calculate on seeing you here with May or June. It is wretched weather just now: you are well out of London. Next winter we hope to be settled in Rome. I am tired of living in this abominable climate, and of so much pot-boiling. I want to retire for a year and devote myself to original work. 
You will have seen in the Papers that I have been asked and have agreed to write the "Life of Browning" for the Great Writers series. The book should be out either in April or at latest in May.

Again, heartily thanking you \& Sincerely Congratulating You I am,

Always Admiringly and Affectionately Yours

William Sharp

ALS Louise Chandler Moulton Collection, Library of Congress

\section{To Hall Caine, January 23, 1890}

10 Caroline Place I Hastings

My dear Caine

Will you oblige [me] and my friend Mr. J. Dykes Campbell by some information respecting Coleridge. In the letter you printed in the Athenaeum you alluded to some interesting marginalia in the copy of the Biographia Literaria in your possession: but did not give it, then or later?

Didyou incorporateitinyourColeridgebookintheGreatWritersseries? Or has it been printed elsewhere? If not, have you the book in your possession? If so, would you care to part with it, and what wd. you expect for it?

Please let me have a line by return - as my stay here is uncertain.

I came here a short time ago, and am getting on well with my "Life of Browning". It will have more novel biographical detail than I anticipated. It will be published in the late Spring. My "Life of Heine" is having a big sale in America and abroad, by the way.

Hope you like your new quarters.

Best remembrances to you \& yours Affectly I William Sharp 
P.S. Just going off to dine with Coventry Patmore.

ALS Manx Museum, Isle of Man.

\section{To John Lane, [February 14, 1890]}

My dear Sir

I have just come back, and am under extreme pressure finishing my "Life of Robert Browning" for the Great Writers Series. In a couple of days - perhaps ten - I shall send you the information you want.

In haste, I Very truly yours, I William Sharp

ACS Princeton

\section{To Richard Watson Gilder, February 22, 1890}

17a Goldhurst Terrace | So. Hampstead | London N.W. | 22:2:90

Dear Mr. Gilder,

Herewith Receipt, with thanks. I am pleased you care for "Remembrance"

Next October I am going to leave England for six months at any rate, and perhaps for 18, and return to my well-loved Italy. I am sick of potboiling, and wish to get on with purely original work. The Drawback is - heavy pecuniary loss. However, I feel I must do it, now or never.

Is there anything you would care to commission me to do for the Century in Italy: article say on Contemporary Italian Literature (Salvatore Farina, etc) or Art, or National Ideals \& the present outcome, or descriptive of any kind? It would be of material service to me, if practicable for you to do so. 


\section{To [John Lane], February 22, 1890}

17a Goldhurst Terrace ISouth Hampstead I N.W. I 22:2:90

My dear Sir

I can now snatch a spare moment to reply to your note of the 13th last.

Yes - you are right in believing me to be a (profound) admirer of George Meredith - whom I also know well personally. I have written about him two or three times, but with one important exception I cannot remember when or where. But last year I wrote an article on him as a poet, which was a good deal commented on. It appeared in "The Art Review" (then called "The Scottish Art Review") just a year ago, that is, in Feby 1889.

I remember that I was asked by the Editor of the Athenaeum - no, the Academy, to review his "Poems and Ballads of Tragic Life". For some reason, it was impracticable, and it was done by a friend of mine, $\mathrm{Mr}$. John M. Gray, Edinburgh. This would be in "The Academy" for the autumn of 1888, I suppose, or perhaps in May or June. It was not very appreciative, if I remember rightly.

I do not know if your bibliography is to be so complete in method as, say, the Browning Socy's. If so, you will insert particular allusions as well as articles, I presume. In my shortly forthcoming "Life of Browning" (Great Writers Series) - the following occurs in Chapter VI.

"Only two writers of our age have depicted women with that imaginative insight which is at once more comprehensive and more illuminative than women's own invision of themselves - Robert Browning and George Meredith. But not even the latter, most subtle and delicate of all analysts of the tragi-comedy of human life, has surpassed "Pompilia". The meeting and the swift uprising of love between Lucy and Richard, in the "Ordeal of Richard Feverel", is, it is true, on the topmost peak of the highest altitude of prose romance", but (then about the distinction between the prose method and the poetic).

Again, in the 9th Chapter, in alluding to Browning's funeral in Westminster Abbey, I say: "All of his peers, all who would be of his Brotherhood, who could be present, were there, somewhere in the ancient abbey. One of them, one of the greatest, loved and admired by 
the dead poet, had already put the mourning of many into the lofty dignity of his verse": (and then I quote G.M'.s sonnet, which appeared in The Pall Mall Gazette).

If I remember rightly, R. L. Stevenson has one or more allusions to G.M. in his article on "Romance", in the first number of Longman's Magazine.

No doubt you know the now rare stories entitled "A Tale of Chloe" and "The House on the Beach"? And of course you know the American Memoir and the vol. of Selections from his prose and verse? The latter I brought over with me from New York recently.

By the way, if you do not know of it, I could transcribe for you a very interesting "essayette", or "opinion" upon the essentials for authorship, which G.M. has contributed to a forthcoming book by (I forget whom at the moment - but I have had advance sheets sent me to look at).

I also forgot to say that I included his fine sonnet on "Lucifer in Starlight" in my "Sonnets of This Century" (with a note upon G.M. as poet and novelist, in the Appendix, where I also include five of his "Modern Love" 'undated sonnets', Nos. 16, 29, 43, 49, 50). I think this was in the 1 st Edn, certainly in all which have followed, 10 or 11. In a forthcoming edition (May) of Great English Odes I shall include his "France".

I don't suppose any other subject than G.M. would have drawn so long a note from me - which must also be my excuse to you.

Wishing all success to what should be a most interesting book, I am, dear Sir,

\section{Yours faithfully | William Sharp}

P.S. I quite forgot to add that I have dedicated my forthcoming volume of Essays from the French of Sainte-Beuve with a study of S.B. - to G.M. in the following terms: "These Few Essays I By The I Most Brilliant and Profound Critic of France I Are Inscribed To I George Meredith | The Most Profound and Brilliant of I The Novelists of England" 


\section{To James Mavor, March 18, 1890}

My dear Mavor

Very sorry that the extreme pressure I am under (with, too, Scott's printers waiting for me, \& cursing deeply) that I cannot manage the Glasgow trip. It is very doubtful if I can run thro' for an hour or so even: if I can it will be tomorrow afternoon - but it is very doubtful. You might leave word at yr. office as to yr. movements, if you have to be out: in case I can manage. Wedmore, I understand from him, is anxious, as a Browning specialist, to review my R.B. somewhere. Wd. you have any objections to letting him do it for the A.R. An unsigned notice wd. hardly do there, on account of the connection. What say you?

I'll try tomorrow.

W.S.

P. S. No, I find I shall not get into Glasgow at all. I shall be here till Monday.

ACS University of Toronto Library

\section{To [Bliss Carman?], [March 21, 1890]}

Friday

My dear old fellow

I am in Edinburgh for a few days - having somewhat hurt eyes \& head with extreme literary work over Browning etc.

I shall write you shortly - but cannot delay to send on my heartfelt congratulations on your appointment. I am as glad as if some good fortune had befallen myself. Don't overwork yourself $-\&$ take in all the fresh air and exercise you can - live out of New York if possible - and above all don't let the poet disappear in the 
editor, \& remember too that another overwrought poet and editor has always a loving remembrance of you.

$$
\text { In great haste, | Always yours, | William Sharp }
$$

You shall have one of the earliest copies of my "Browning".

ALS Pattee Library, Pennsylvania State University

\section{To John Lane, [March 21, 1890]}

Edinburgh | Friday, 20th

Dear Mr. Lane,

Please come on Sunday after next, that is, on Sunday evening the 30th, as I cannot be South this week after all.

In haste, Yours sincerely, I William Sharp

ACS Princeton

To Frank Marzials, April 7, 1890

The Canterbury Poets | 24 Warwick Lane | London

I can, at the moment, do no more than put Anderson on a possible due[?]....I'1l try and let you have not only the early parts but the whole of Browning by the morning.... cannot send any in advance of that - for some recasting will be necessary. 


\section{To Frederick Wedmore, [mid-April, 1890]}

Hope this will catch you. I find that some of my corrections were not given effect to, owing to the "rush" with the proofs at the last.

I enclose the "Errata and Addenda" Slip which is to be sent out with each copy issued.

Glad to find that the Browning 'circle' themselves are so pleased with the book - indeed, I am more than gratified by the letters I have received already.

Hope you will have a pleasant time in Paris.

Sincerely Yours | William Sharp

ALS University of British Columbia

\section{To John M. Gray [mid-April, 1890]}

My dear Gray,

Yours being one of the first half dozen copies printed off, for 'advance copies", it had not the "Errata and Addenda" slip which accompanies each copy sent out. I enclose it herewith.

I am delighted to find that the Browning 'circle' is so pleased with the book - indeed, I am more than gratified by the letters I have already received.

In haste, | Sincerely yours, | William Sharp

The book is too near me yet for me to feel if I have impressed the man and the poet upon the reader's mind - but to judge from letters I am hoping I have succeeded. 


\section{To J. Stanley Little, April 16, 1890}

Wednesday | 16 April 1890

My dear Little

Many thanks for your kind invitation. Later on (after my return from Paris, abt 12th or 15th, whither I go about the 3rd or 4th) it will give us both much pleasure to pay you and your brother a brief visit.

Please remember that we are always (which means 'always' except, as it happens, either May 4th or 11th) at home on Sunday evenings, and delighted to see any friends who will look in informally.

You know - or I fancy you do - what a sincere admirer I am of your brother's work. It is hard that good work should find so many things in its way. You may be sure that whenever it is practicable for me to put in a spoke anywhere "will" shall not lag behind "can".

What you tell me about his "Lap of Winter" interests me much. I shd. be much obliged if you wd. send me a PIC saying when the 19th Century Art Socy has its Press View. Why does not your brother try Glasgow - now the most 'selling places' \& rapidly becoming an artcentre. I'll do what I can for him in the Glasgow Herald, the chief paper there \& in Scotland - of which I am art-critic and correspondent.

I have been frantically busy - as usual: but am now slacking off a bit. My "Life of Browning" for the Great Writers series was a stiff pull. It is going splendidly - already abt 10,000 copies disposed of.

Hoping to see you soon (send me the PIC!) \& with best regards, congratulations, and, if he will allow me to say so, encouragement to your brother,

Always Sincerely Yrs, I William Sharp

ALS Princeton 


\title{
To The Reverend John Stuart Verschoyle, [mid-May, 1890]
}

\author{
17a Goldhurst Terrace I So: Hampstead I NW
}

My dear Verschoyle,

Do, like a good fellow, give me an answer (I hope a favorable one!) about "The Future of Canada" article by the Hon. W. Longley, Attorney General of Nova Scotia, which I sent you some time ago.

We are soon going to give up our house, \& go and live in Italy. I wish you could look in tomorrow (Wedny) afternoon. Watts \& a good many others will be here. I promised my wife that I wd give you your invitation orally. Heaven knows how long ago, but I had to go to Paris, $\&$ since then I have been in a maelstrom of work. (By the way I wrote to you from Paris). And now if I tell her that I have put off asking you till the last moment almost, she'll pitch into me!

Come if you possibly can.

Sincerely yours I William Sharp

ALS UCLA, Clark Library

\section{To Bliss Carman, [mid-May, 1890]}

17a Goldhurst Terrace I So. Hampstead I London N.W.

My dear Carman

I have just returned from Paris. I send you (in my amanuensis' very legible handwriting) a brief article which I think your readers will find entertaining - that is if you care for it and are able to find room for it.

I should have posted it to you a day or two ago but I delayed till I could get a copy of a poem which I thought you would care for: and this, "The Coves of Crail", I enclose also. 
I hope you are flourishing, in health and otherwise. We give up our London house a few weeks hence - and I shall be very far from sorry to leave London. It is far too big a town, and life in it is a weariness to the spirit and an unhealthy toil for the body. We will go to Scotland for the early autumn - then to the Rhineland (headquarters, Wiesbaden) for two months - and then south to Rome, where we are going to settle for a time.

The above, however, will remain as my address till the end of July. After that my letter-address will be 2 Coltbridge Terrace I Murrayfield I Edinburgh.

By following mail I shall send you a copy of some "Odes: English and American" I have edited. In the preface I allude to your fine Matthew Arnold Threnody.

Always, my dear fellow, cordially yours, I William Sharp ALS Fales Collection New York University

\section{To [Bliss Carman], [mid-May, 1890]}

Cher Ami,

I forgot to enclose for you, if you care for it, one of a series of unrhymed lyrics I am writing. I think you at any rate will like this 'Paris Nocturne'. Of course I shd. expect more for it than the nominal $£ 1$ or 30 s - which seems to be the Independent's payment for short poems. My terms to any magazine here for anything save a very short poem are $5 €$. However, I am content to take what you can fairly allow.

Yrs in haste I William Sharp

P.S. I had to send off my letter and article without enclosing this. Perhaps, indeed, this may miss the mail. 


\section{To W. Kineton Parkes, [May 29, 1890]}

Grosvenor Club | Bond Street W.

Dear Mr. Parkes

I am sorry to have missed you. I am afraid I am not 'findable' again till Monday afternoon next, probably: except Saturday (see overleaf).

Tomorrow afternoon I have to go to a Matinee (Mrs. Augusta Webster's play), and have promised to look in at an 'afternoon' elsewhere - so I can't well be at the Brit. Museum. It was today I half expected to be there - but I could not manage it.

I have only rapidly glanced thro' your MSS (for the very neat and workmanlike condition of which allow a worried editor to thank you) but am well satisfied so far. I hope, and think, it will be a taking book.

As I think you know, the series is now issued every alternate month. The next vol is just finishing at the printers and binders: i.e. the July volume "Owen Meredith". Yours I have arranged to come next, to be published on August 25th as the September vol (one of the best months to issue in - for our purposes the best).

Personally, I am quite in favour of the large paper edn. It has been done only twice before: once the experiment was a disastrous failure, once a reasonable success. I'll see what the publisher has to say to it.

Yours very truly | William Sharp

The publisher will want to see the Rossetti and other copyright letters of publishers. So far as I can tell, I shall be at home on Saturday, between two and three o'clock, if you particularly wish to see me:

W.S. 


\section{To James Mavor, June 12, 1890}

Wescam | Goldhurst Terrace | So. Hampstead | Thursday, 12 June, 1890, A.D.

My dear Mavor,

Firstly, let me draw your attention to the fact that this note is fully dated: Secondly, I send herewith a letter from Mrs. Emily Hockey, the poet etc. Kindly answer it direct.

Thirdly, please note that we leave our house "for good and all" on Monday the 23rd of this month. Thereafter, till 15th July (when we go to Scotland, then or thereabouts) we shall be staying with Mrs. Mona Caird. My address will therefore be I C lo J. A. Caird Esq I 3 Lyndhurst Gardens I Hampstead | London N.W.

Fourthly, are we to have the pleasure of seeing your Phiz. in London this summer? If not we must meet in Glasgow or Edinburgh. We shall certainly be in Glasgow for a visit at some point (probably in September). I fancy that when we go north it will be, first, for two or three weeks somewhere on the East Coast.

Fifthly, I wish you could be with us this coming Sunday. Stepinak, F. Bate, and others are coming to tea, and a good many later on. 'T will be the last of our 'Sunday evenings' here.

We both hope you are flourishing and send you our affectionate regard,

À vous, cordialement I William Sharp 


\section{To Edmund C. Stedman, June 14, 1890}

14 June $\mid 90$

My dear Stedman

Your long letter most welcome. I hope to write to you next mail. We are breaking up our home in London, and are at present in great confusion. Meanwhile I send you a copy of a little book I edited: a vol. of great odes. As you will see, I have included your "Pastoral Romance". It has been widely noticed \& praised (I mean your ode). I hope it is all right in text: it had to be "read" in proof by someone during my absence in Paris. If not, let me know, as next edition will be out in Autumn. Love to you all.

Affectly yours, I William Sharp

ACS Columbia

\section{To Edmund Clarence Stedman, June 17, 1890}

London: 17th June':90

My dear Stedman

You will ere this have received the copy of the little book of "Great Odes: English and American" which I sent to you. It was really a "loop" volume, having to be done swiftly in default of something that fell through on the part of an editor: yet it has been unexpectedly well received. I think I told you that your own beautiful "Ode to Pastoral Romance" has appealed to many people, and will, I hope and believe, send new readers to you, among the new generation, as a poet. Please do not lend it to any one for reviewing, as the latter half is copyright in the States. 
I have time for only the briefest letter - as we are in all the discomfort of leaving our house, and I have enough to do and look after within the next few days to drive one half frantic.

Well, we are breaking up our home, and are going to leave London for a long time - probably forever as a fixt "residentz platz". Most of my acquaintances think I am very foolish thus to withdraw from the 'thick of the fight' just when things are going so well with me, and when I am making a good and rapidly increasing income - for I am giving up nearly every appointment I hold, and am going abroad having burned my ships behind me, and determined to begin literary life afresh. But truly enough wisdom does not lie in money-making - not for the artist who cares for his work at any rate. I am tired of so much pot-boiling, such unceasing bartering of literary merchandise: and wish to devote myself entirely - or as closely as the fates will permit - to work in which my heart is. I am buoyant with the belief that it is in me to do something both in prose and verse far beyond any hitherto accomplishment of mine: but to stay here longer, and let the net close more and more round me, would be fatal. Of course I go away at a heavy loss. My income will at once drop to zero, and even after six months or so will scarce have risen a few degrees above that awkward limit - though ultimately things may readjust themselves. Yet I would rather - I am ready - I should say we are ready, to live in the utmost economy if need be. We shall be none the less happy: for my wife, with her usual loving unselfishness and belief in me, is as eager as I am for the change, despite all the risks.

There are too many examples of the ruin that comes from yielding to a cheap vogue: Andrew Lang, for instance, brilliant and able fellow though he is, has quite run to seed, and will never do anything now. Among the younger writers few have the surely not very high courage necessary to give up something of material welfare for the sake of art. As for us, we are both at heart Bohemians - and are well-content if we can have good shelter, enough to eat, books, music, friends, sunshine, and free nature - all of which we can have with the scantiest of purses. Perhaps I shd. be less light-hearted in the matter if I thought that our coming Bohemian life might involve my wife in hard poverty when my hour comes - but fortunately her 'future' is well assured. So henceforth, in a word, I am going to take down the board: 


\begin{tabular}{c} 
WILLIAM SHARP \\
LITERARY MANUFACTURER \\
(all kinds of jobs undertaken) \\
\hline
\end{tabular}

and substitute:

\section{WILLIAM SHARP}

GIVEN UP BUSINESS. MOVED TO BOHEMIA.

PUBLISHERS AND EDITORS NEED I NOT APPLY. FRIENDS CAN WRITE TO

W. S. clo "DRAMA" "FICTION", OR "POETRY".

LIVE-AS-YOU-WILL QUARTER, BOHEMIA

This day week we leave our house for good. My wife and I then go into Hampshire to breathe the hay and the roses for a week at a friend's place 7 miles across the downs north of Winchester: then back to London to stay with our friend Mrs. Mona Caird I 3 Lyndhurst Gardens I Hampstead I N.W. I till about the 20th of July. About that date we go to Scotland, to my joy: and will be by the sea or among the hills, and in Edinburgh, till close on the end of September. Thereafter we return to London for a week or so, and then go abroad. We are bound first for the lower Rhineland, and intend to stay at Carlsrühe (being cheap, pretty, thoroughly German, with good music and a good theatre) for about two months. Then, about the beginning of December, we go to Rome, where we intend to settle: climatic, financial, and other considerations will decide whether we remain there longer than six months, but six ideal months at least we hope for - 
"Mihi sex menses satis sunt vitae: Septimum Orco spondeo". ${ }^{1}$

Neither the sex nor the septimum to be taken too literally, you know.

It was such a pleasure to hear from you again. Often I think of you and yours: my wife, indeed, declares she knows you all intimately. The Harlands are flourishing: the Janviers are having a good time of it down by Aries and Nimes and old Roman France. We are hoping that they will join us in Rome for the winter. I am so glad that the "Dictionary" is at last off your hands. ${ }^{2}$ If a copy can be conveniently sent, it wd. need to reach London before the 25th of September at latest. Address: Clo J. A. Caird Esq, 3 Lyndhurst Gardens, Hampstead, N.W. You are to give us more of yourself yet - though your gift is already so extensive and so treasurable. My love to Arthur, ${ }^{3}$ and I am sure Mrs. Stedman will let me send my love to her also, since my wife joins in it, and as it includes you. The memory of you all is as fragrant as hawthorn-blooms.

Always gratefully and affectionately yours, I William Sharp ALS Huntington

\section{To [John Lane], [June 20,?1890] ${ }^{4}$}

17a Goldhurst Tce I S.H.

I forget if I told you that I had decided to dedicate another \& $\underline{\text { later }}$ (original) book to G.M. ${ }^{5}$ instead of the St. Beuve, ${ }^{6}$ which is to be dedicated to Paul Bourget.

We leave this house "for good \& all" next Tuesday. My letter-address thereafter

The Grosvenor Club I New Bond St.

Best regards I William Sharp ACS New York Public Library, Berg Collection 


\section{To James Mavor, July 7, 1890}

3 Lyndhurst Gardens | Hampstead I N.W.

My dear Mavor

I shd. be much obliged if you wd. direct Constables ("or others") to send me the two numbers of the Art Review containing my "Piero di Cosimo".. ${ }^{8}$ All my books etc. are stored - and I particularly want these. I suppose the A.R. doors are now closed.

We shall be here till the 29 th $-\&$ then off to north Berwick or elsewhere.

À vous toujours, | Wiliam Sharp

You sent Mr. Stevenson ${ }^{9}$ to 17 a Goldhurst Terrace \& we missed. However, I hope to see him on his way back from France.

ACS University of Toronto Library

\section{To J. Stanley Little, July 10, 1890}

3 Lyndhurst Gardens | Hampstead N. W. | 10:July:90

My dear Little,

The stars in their courses fight against us in regard to our lookedforward-to visit. The moving from our late residence, and the infernal weather we have [been] enduring, have played the mischief with my wife. If practicable we should leave London at once for a quiet haven in Scotland (whither we go about the 25th or shortly after) but this I cannot do. So my wife is going to friends in Hampshire, to rest and recruit: though I am so busy that I cannot even run down to join her for a day or two. I am afraid, therefore, that I must postpone our visit, even my single visit, to a more favourable opportunity (not, I trust, Ad Er. Kal)..

On the other hand, I may have to go on business of a literary kind in connection with my "Severn Memoirs"10 to Surrey, for a day, somewhere 
between the 17th and 24th. If so, I shall try to spend the evening with you: but I cannot promise. I have a great deal to do within the next week or two: far more than I at present see my way to accomplishing. Yet I am anxious to see you and your brother. If I can see my way I shall write or telegraph.

Meanwhile all good wishes for you both.

Cordially yours, I William Sharp

ALS Princeton

\section{To Kineton Parkes, July 13, 1890}

3 Lyndhurst Gardens I Hampstead N.W.

Dear Mr. Parkes,

Herewith I send you editorial revise of your Introduction. ${ }^{12}$ I regret to have to trouble you, but it will require great recasting - perhaps, indeed, it would be easier to rewrite it and reduce it considerably. To be candid, it might be better to omit the Introduction altogether: particularly if the notes are voluminous.

You no doubt wrote it under pressure and so allowed many things to pass which your better judgment would rectify.

Please return the proofs of the Text direct to the printers - Mr. Walter Scott, \{Publisher, Felling (R.S.O). Co Durham: but the Proofs of Preface \& Introduction to me, at above address.

Please revise the Proofs of Text with all due care. In glancing hurriedly here and there, out of curiosity, I noticed e.g. "Lake Berva" for Lake Bewa" on p. 68 \& 'melts' for 'melt' on p. 69; 'Song' for 'Songs' on p. 91; lack of a comma in last line of first stanza on p. 93; 'Compo' for 'Campo' on p. 96; semicolon after second word in Louise Jopling's very poor stuff on p. 112, \& 'yearnings' for 'yearning' on same; 'slip' for 'step' at p. 114; defective last line p. 117; 'thought' for 'though' at p. 132; check 2nd line of 3rd tercet on p. 134; "South land" instead of "southland" p. 142; 'as' for 'are' in sestet of Rossetti's sonnet p. 156; \& 'waves' for 'wave' 
in R's [? ] on p. 157. In Index. A. Easts's poem shd be Bewa (not Berva), \& "Selwin Image" shd be "Selwyn".

I shall be at above address for the next fortnight (my old address is cancelled) - thereafter my letter address for a long time will be clo Miss M. B. Sharp ${ }^{13}$ | 2 Coltbridge Terrace | Murrayfield I Edinburgh.

Yours very truly I William Sharp

P.S. The long \& short of your essay shd be that a painter shd be a painter and a poet shd be a poet - and that the only interconnection is the fundamental one of authentic (rhythmic) emotion. Rossetti himself would have laughed at the idea of a poetic 'motif' saving an inferiorly painted picture.

ALS, UWM Library

\section{To William Wetmore Story, July 15, $1890^{14}$}

2 Coltbridge Terrace I Murrayfield I Edinburgh

Dear Mr. Story ${ }^{15}$

Did you know Joseph Severn in Rome: and if so have you ever written about him anywhere? I am anxious to get all information I can, as I wish to finish the "Severn Memoirs"16 before we go abroad for the Autumn and Winter (the late winter we shall spend in Rome).

The family put the papers in my hands 2 or 3 years ago, but various things have hitherto delayed me. If you can give me any hints or reminiscences or direct me in any way I shall be indebted.

Excuse a $\mathrm{p} / \mathrm{c}$ in haste. The above is my letter-address, as I have given up my house in London.

Sincerely Yours, I William Sharp

ACS Harvard Houghton 


\section{To E. C. Stedman, July 21, 1890}

c/o Miss M. B. Sharp I 2 Coltbridge Terrace | Murrayfield | Edinburgh

My dear Stedman

The enclosed letter has evidently been sent to me by mistake: and perhaps the "Notes" on Great Odes also. I read the latter with much interest, thinking they were meant for me: but it struck me that perhaps they were not.

I am too unwell with lumbago to do more than say how very sorry I am that you are so seriously indisposed. My consolation is that you are at Kelp Rock and in good hands.

Don't dream of writing to me about Great Odes or anything else for months to come, as you love me. Perhaps Arthur will kindly send me a $\mathrm{P} / \mathrm{C}$ about you.

Affectionately yours I William Sharp I leave town in a week for Scotland, I am unutterably thankful to say. The above will be my letter address for a year.

ALS UC-Berkeley

\section{To Bliss Carman, July 25, 1890}

$25|7| 90$

Dear old Boy

Herewith my latest — which I hope you will like.

I hope you are going to have a good holiday.

I say - I think you shd. now bring out a vol. of poetry. Publish simultaneously if possible here and States. A small edn. here, say even only $150, w d$. serve your purposes that is, if no one wd. take it up - a rare thing even with well-known writers. I could arrange, I think, for it to cost you a small sum - say $£ 10$ or $£ 12$.

Love to you - and may the muse be with you. 
In two or three days now I'm off to the Scottish Coast - after a bit to the neighborhood of the Coves of Crail! Thanks for the slips. Will you kindly send me a few of the same when my Paris Nocturne ${ }^{17}$ comes out?

Yours ever | W.S.

ALS Smith College Library

\section{To James Mavor, [mid-July, 1890]}

My dear Mavor,

Good-bye - take care of yourself $-\&$ come back soon: \& if you come to Broadhurst Gdns ${ }^{18}$ again so much the more pleased we shall be.

Wedmore's notice is very kind. ${ }^{19}$

Yours ever, I William Sharp

P.S. When you are writing next on A.R. matters, you might remind them that I have not yet recd. cheque for Piero di Cosimo. ${ }^{20}$

ALS University of Toronto Library

\section{To James Mavor, [early August, 1890]}

1 Lorne Square I North Berwick

Glad you had such a good time of it in Ireland, \& hope you are much the better for it. I think my wife has already written to your mother telling her of our plans \& thanking her for her very kind invitation. We shall be here till the 14th \& somewhere else on the East Coast till Sept. 6th or 7th - then I, at any rate, shall be west for a day or two. By the way I never recd. the two nos. of the A.R. (containing "Piero di Cosimo") which you kindly said you wd. direct to be sent. Could I have them here? 
Yrs ever | W.S.

ACS University of Toronto Library

\section{To [Eric Sutherland Robertson], ${ }^{21}$ August 15, [1890]}

2 Coltbridge Terrace | Murrayfield | Edinburgh | Friday 15th Augt.

\section{Dear Old Fellow,}

Most heartily do I welcome you back again, and hope that you will have a delightful visit. I should say "we" but I understand that Elizabeth is writing you on her own account. We are both looking forward to seeing as much of you as practicable, which I trust will be a good deal. What a lot we have to talk about! I have often missed you, for, as you know, I was strongly drawn to you from the first, and look upon you as one of my very few "deep" friends. My most intimate friend since you left is Theodore Roussel, the French painter, who now lives in London.

We go off today to the West Highlands, (Mrs. Wm. Murray's | Otterburn I, Tarbert-on-Lochfyne, I Argyll) and if we find the accommodation etc. to our liking we shall remain there till the 6th or 8th of September. How delightful it would be if you could look us up there: it could be done easily per the "Iona" or "Columba", either from Oban or from Glasgow or Edinburgh.

On the 8th till the morning of the 12th we go to some friends Mrs. Wilson | South Bantaskine | nr. Falkirk (or rather Lillie will be there that time, as I shall be in Glasgow from the 8th till the afternoon of the 10 th \& then together - staying probably at 4 Elmbank Crescent). From the 12th till the 16th we shall be at Mrs. Elder's I St. Margaret's I North Queensferry I [Fife] about half an hour's journey from Edinbro' via Forth Bridge (with lots of trains) \& so within easy reach if you are in Edinburgh on the 13th or 14th.

On the 17th we go to Aberdeen or Banchory for a few days - and then again at my mother's here in Murrayfield on or about the $22^{\text {nd }}$ for a few days. 
We shall be about a week in London at the end of Sept or beginning of October, probably, before going to Heidelberg: at I 72 Inverness Terrace I Bayswater I W.

There, now, I have given you all my movements. It would, of course, be most delightful if you could join us while we are at the West Coast, as we should see more of you: but, at any rate, let us see as much of you as possible. I enclose a few verses of mine which appeared in an American weekly:22 also, a line from a Young Folk's Paper correspondent, with something pleasant about yourself - which please destroy afterwards (at least so says Panting!)

With love from us both I Affectionately Yours I William Sharp ALS, private

\section{To John Stuart Verschoyle, August 20, 1890}

Letter - address in Scotland

2 Coltbridge Terrace I Murrayfield I Edinburgh

My dear Verschoyle,

I am sending this from a remote place in the Highlands, but put my definite letter-address during my stay in Scotland at the head.

I have asked you so often for a definite reply about the Hon. W. Longley's (Attorney Gen. of Nova Scotia) on "The Future of Canada" that I am beginning to resent what seems an altogether inexplicable silence. It is months ago now since the matter was first broached.

I wish, also, you would kindly drop me a line or a $\mathrm{P} / \mathrm{C}$ about another, and personal matter.

I hear from Mr. E. C. Stedman that Messrs. Webster \& Co. are, at his request, sending me a set of the now complete (just completed this month) set of the "Library of American Literature" in 11 vols: an invaluable and most suggestive work. 
Will you allow me to write just a short article apropos? It would deal with the drift of Amer. Literature up to the present, and the outlook. As perhaps you know, I am, at any rate, a Specialist in American literature. The article could be sent in early October, for use when wished.

I should much like to do this, and would write an interesting, suggestive, and discussable article, though brief.

Please let me hear from you at your very earliest convenience.

Sincerely yours I William Sharp

I shall be at the address noted on margin till the end of August: - [in margin] c/o Mrs. William Murray, Otterburn I Tarbert on Loch Fynne I Argyllshire.

ALS UCLA, Clark Library

\section{To Louise Chandler Moulton, August 23, 1890 $0^{23}$}

Mrs. Wm. Murray | Otterburn | Tarbert | Loch Fyne | Argyll | Saty

My dear Louise,

Just time for a hurried line, though even this may be too late for the post, and there is none now for a day or two. No, I know nothing of Philip's ${ }^{24}$ Swinburne letters, or of any others. There was nothing in the Secrétaire: Dr. Marston went through it with me before it was dispatched, secretdrawers and all: and I had occasion afterwards to have it thoroughly cleaned and done up, and all the drawers were taken out in my study.

Surely such valuable letters cannot have gone astray? I have a vague idea that they and o[the]rs from Rossetti etc. etc. were in a scrap book. Was this so? Were there not several things missed during the last year of Philip's life? I fancy Dr. M. told me so. Perhaps the same individual has taken the Swinburne letters who walked off with the copy of "Villon" which Philip destined for me but which I have never seen to this day!

A loss of this kind is most annoying: though I still hope you may find them. I suppose all Dr. M'.s receptacles have been carefully overlooked? 
We shall be here and elsewhere in Scotland for some time yet: but though we go abroad at the beginning of October (first to Heidelberg) there is, I am sorry to say, no chance of our being in Paris.

Love from us both (we are going off in a fishing smack across Loch Fyne in half an hour, when the tide-rush permits)

Yours affectly ever I William Sharp ALS Louise Chandler Moulton Collection, Library of Congress

\section{To Edmund Clarence Stedman, September 22, 1890}

2 Coltbridge Terrace I Murrayfield Edinburgh | 22nd Sept. 90

My dear Stedman,

The above address is only my letter address, for I am writing this at a lovely place above the Firth of Forth. I hope that it will reach you on the morning of your birthday, ${ }^{25}$ but of course it may arrive a little earlier or later: but in any case, you must know that you have my most affectionate good wishes for your coming year - which I hope will be a golden time of rest, intellectual enjoyment, and poetic vigor. How I wish I could look in upon you to give you my good wishes in person - though selfishly I don't like to think of you in a house I do not know! You are one of the few men who need not deeply regret the advent of birthdays: for though we all deplore the ominous milestones on the highway of life, you are of the happy company who are essentially young and will be young even into old age. It was my own birthday a few days ago (Sept. 12th) and I can sympathise with you in the feeling of lost opportunities and shortening time which a birthday inevitably brings with it: but otherwise it is so well to be alive, and to have a life so full of interests as is the good fortune of each of us - that these annual visitants should really be high festivals.

I shall not be in a position to judge aright of the immensity and value of your undertaking in the "Lib: Amer: Lit" 26 till I return to London a fortnight or less hence. Meanwhile I have gone through the last volume with extreme interest and pleasure: and find in it much of 
great significance and importance. The keen critical taste, and exquisite literary flair, displayed by you and your collaborator, have triumphed over difficulties that hitherto proved insurmountable. More about this - in MS and print - later on.

I want you to give my love to Mrs. Stedman, whom I often think of with affectionate remembrance. I kiss her hand from afar - tho' I would rather kiss her lips - in the words of the old Scots song, "her bonnie lips, her bonnie eyes, her bonnie face and a'!" And to Arthur, ${ }^{27}$ too, remember me fraternally. I hope he'll come over some summer soon and enjoy London even half as much as I enjoyed my stay in New York.

I append a little birthday-lyric for you - and remain now as ever, my dear Stedman,

Affectionately and Cordially, I Your friend, I William Sharp.

Erelong you will have the Janviers in New York again. They sail from Naples shortly, and will probably be in N.Y. about the beginning of November.

P.S. In three weeks now we leave for the continent. From Oct. 13th till end of November, our address will be c/o Frau Rath Nebel, Karl Strasse 16, Heidelberg, Germany. Thereafter, via Florence and Siena, we go to Rome. But my Edinburgh address is always sure to reach me: or that of my wife's mother, 72 Inverness Terrace, Bayswater, London W.

ALS Columbia

\section{To Theodore Watts, [October 1 or 2, 1890] $]^{28}$}

72 Inverness Terrace | Bayswater | London | W. | Monday Evening

My dear Watts

Have just arrived in London. Among my letters one of Friday last (in answer to my latest, with your message) from Dr. Macleod. ${ }^{29}$ As the quickest way to explain I enclose a note. Will you kindly answer him direct at Messrs. Isbister, 15 Tavistock St., W.C. - or call, as may be most 
convenient. I hope to see him tomorrow, but cannot dine with him as he proposes.

I have no time now to thank you for your most friendly and encouraging letter: but believe me I value it. I think it is my wife's intention to ask you and Eric Robertson \& Mr. Meredith and one or two others, to afternoon tea on Saty: if so, she will write tomorrow as it is too late, \& she is tired tonight. And I hope you will come.

Meanwhile, in great haste I Ever Sincerely yours I William Sharp P.S. You will see that Macleod wd. not want the story till winter of next year.

ALS Brotherton Library, University of Leeds

To: [Percy] Macquoid, [October 10, 1890] $]^{30}$

72 Inverness Terrace | Kensington Gardens W. | Friday Evening

Dear Macquoid

My aunt - Mrs. Sharp - with whom my wife and I are at present staying, is having some friends in to dinner tomorrow (Saturday) evening at $7 \mathrm{o}^{\prime}$ clock.

If you care to come over ( $\&$ you can get a train almost to the door, by coming to Queen's Road, Bayswater) she as well as my wife and I would be glad to see you - and I shd be able to talk over a Canterbury volume with you. I don't know if you are acquainted with Miss Mathilde Blind: she, I fancy, will be the only one of the four or five guests whom you are likely to know.

With kind regards to your father \& mother

Yours very truly I William Sharp

ALS private 


\section{To Edmund Clarence Stedman, October 11, 1890}

bei Frau Rath Nebel | Karl Strasse, 16 | Heidelberg | 11|10|90

My dear Stedman,

We go to Germany (till the end of November) tomorrow, and I send you this $\mathrm{P} / \mathrm{C}$ to say that besides one or two primalistic 'expatiations' on it I have written an article on the L.A.L. for the National Review. ${ }^{31}$ I arranged at first with the Fortnightly, but several months wd. have to elapse ere appearance of the article, so it is to appear in the National Review, probably in the December number, though possibly the Editor may not be able to squeeze it in till a little later. I think it will please, and interest, American readers.

By the way, can you send me a line of introduction to Blanche Willis Howard, ${ }^{32}$ saying something as to my being a fellow-scribbler. She lives in Stuttgart, I understand, and I have to be there at any rate and would like to meet her. I shall write a little later, from Germany.

Love to all, I W. S.

P.S. I wrote you for your birthday, \& hope you got my letter. It requires no answer, however.

ACS Columbia

\section{To Theodore Watts [-Dunton], [October 11, 1890]}

bei Frau Rath Nebel | Karl Strasse, 16, | Heidelberg | Germany

My dear Watts

By the time you receive this we shall be en route for Heidelberg, where we shall remain till the end of November at any rate: going to Rome, via Florence and Orvieto, sometime in December. I send this brief note 
partly to say how sorry I am not to have seen you before our departure, as I had hoped and so far arranged: and partly to give you a word of friendliest greeting from us on your birthday, which, if I remember aright, is on Sunday. We shall drink your health in Rhine-wine at Bonn, if there in time: and we shall wish all good things for you - health, and weal, and new friends and admirers.

I am wondering if anything came of the interview with Dr. Macleod. In any case I hope Aylwin won't now be long delayed.

Again thanking you for the welcome and friendly letter which you sent me some time ago.

In haste | with love in which my wife joins | Affectionately yours | William Sharp

ALS Brotherton Library, University of Leeds

\section{To James Mavor, October 18, 1890}

Frau Rath Nebel | Karl Strasse, 16, | Heidelberg | 18|10|90

My dear Mavor,

We are very comfortably settled here in a romantic old house adjoining the Castle grounds - and with interesting literary associations. Goethe himself wrote one of his poems in the balcony of the quaint picturesque room I occupy.

The Vintage is not yet over, and all is movement \& excitement among the vineclad hills above the Neckar. The Student life is this week in full swing for the winter: and Heidelberg is almost without English or other foreigners, the season being over, \& the early So. German winter at hand.

Hope you are flourishing. Remember me kindly to your mother \& sisters when you see them next.

Yours ever, I W. S. 
To [October 1890]

... The real charm of the Rhine, beyond the fascination that all rivers and riverine scenery have for most people, is that of literary and historical romance. The Rhine is in this respect the Nile of Europe: though probably none but Germans feel thus strongly. For myself I cannot but think it ought not to be a wholly German river, but from every point of view be the Franco-German boundary.... Germany has much to gain from a true communion with its more charming neighbor. The world would jog on just the same if Germany were annihilated by France, Russia and Italy: but the disappearance of brilliant, vivacious, intellectual France would be almost as serious a loss to intellectual Europe, as would be to the people at large the disappearance of the Moon....

Memoir $169-70$

To Edmund Clarence Stedman, October 22, 1890

Karl Strasse 16 | Heidelberg | 22 October 1890

Just a hurried plc to acknowledge safe receipt of your welcome letter. Shall write in a day or two. The above is our best address till the end of November.

W.S.

ACS Columbia 


\section{To Mrs. Oliphant, ${ }^{34}$ October 30, 1890}

Heidelberg | bei Frau-Rath Nebel | Karl Strasse, 16

Dear Madam

(Or I may be mistaken in thinking that Mrs. Oliphant is still Editor of the "Foreign Classics") would you care to have, from my pen, in your series a volume upon Sainte-Beuve, the most influential and the ablest of critics of literature. I have for years made a special study of SainteBeuve, as critic, novelist, poet, \& historian; of his predecessors and his circle; and of his direct and indirect influences. More and more attention has been paid to him in Great Britain of late years, particularly since the emphatic eulogies of Matthew Arnold and John Morley.

When Mr. D. Stott recently prepared to undertake a volume of selected essays from Sainte Beuve, he commissioned me to write a short critical study of the man and his work - but of course I could but skim the subject in the space at my command, and had to leave much unsaid. The book ("Essays upon Men \& Women, by Sainte-Beuve") was published a few weeks ago by Mr. Stott, in his Masterpieces of Foreign Literature Series - and, if you would like to see it, I could direct him to send a copy to you. Unfortunately, I have no copy here, save an early mutilated one. ${ }^{35}$

I could not set about the book at once, as I have important literary work on hand, but I could begin it shortly, and would probably finish it in Rome (where I spend the winter and spring). In Rome, I should have everything to hand, though, as a matter of fact, my voluminous notes already cover the whole of Sainte-Beuve's career. If you should be inclined to entertain the idea kindly let me know from you as to terms and as to the approximate date when you would wish to receive completed 'copy'.

Believe me, I Yours very truly | William Sharp ALS National Library of Scotland 


\section{To Edmund Clarence Stedman, November 4, 1890}

Heidelberg | 4th November 190

My dear Stedman,

I send this $\mathrm{PIC}$ at once to acknowledge with thanks the receipt of your introductory letter to the "Frau Hof-Arzt von Teuffel" ${ }^{36}$ I have sent it on to her, and asked if I might have the pleasure of seeing her someday in the latter part of next week. But, you wicked sinner, I go alone. My wife is too much occupied here to care to leave Heidelberg meanwhile, though I am cutting about a bit, to Carlsruhe, Mannheim, up the Neckar, and so forth: and am going to Frankfurt at the end of the week to hear Wagner's "Rienzi". Mon ami, it is only too easy to be virtuous here. The women - ah, "let us proceed!"

Please note that we have decided to leave here on the 25th inst. Our Italian address till I send you a definite Roman one will be I i.c. Mrs. Smillie, ${ }^{37}$ Villino Ellera, I 5, Via Michele di Lando, I Florence.

Hug the Janviers for me. Love to you all; and, by the way, I am of course most pleased about the poem in the Independent..$^{38}$

Yours ever, I W.S.

ACS Columbia

\section{To Frederick Langbridge, November 13, [1890 $]^{39}$}

Heidelberg (Germany) | Karls Strasse, 16, I 6 Frau-Rath Nebel | 13th

November

My Dear Langbridge,

Your letter of the 27th Oct must have wandered about after me, as I received it only today.

I write at once to tell you with what extreme regret I hear of your heavy pecuniary loss. So true a poet and charming a writer deserves better 
hazard from circumstances - but I do trust things will be so wrought for you that the disaster will not be so overwhelming as it must now seem.

I do not learn from your note or the prospectus where your book is to appear: and anything I might be able to say about it may now be too late. Yet I'll think it over, and try one good quarter at any rate. And when it appears - though I shall be abroad - in Rome - I will do what I can in reviewing. Meanwhile I can give a small lift (alas, that I can do no more, now especially that I and my wife are wandering Bohemians again for I have left London to gain greater freedom for literary work of a congenial kind, with naturally unsatisfactory pecuniary, if otherwise pleasant, results) by begging you to reserve for me five copies at the subscription price. One of these please send to me c/o Messrs. Maguay Hooker \& Co., 20 Piazza di Spagna, Rome. If, however, published before the end of the first week of December, then to me c/o Mrs. Smillie, Villino Ellera I 5, Via Michele Di Lando, I Florence I (in this case do not post till the 1st. Dec). As for the other four, they must be sent to quarters where special attention will be paid to them. In each you might insert a slip, with written thereon "Sent for favour of a review, at special suggestion of Mr. William Sharp").

(1) Bliss Carman Esq | "The New York Independent" | 251 Broadway I New York

(2) John Reade Esq I "The Dommian Illustrated" | St. James St. I Montreal I Canada

(3) A. B. Symington, Esq I Editor "the Sun" | c/o Mr. A. Gardner: Publisher | Paisley | N. B.

(4) Rev. W. W. Tulloch I c/o Editor "The Weekly Citizen" | St. Enoch Square I Glasgow

I shall be here for about a week yet: then to Munich for a few days, \& then southward by Verona to Florence. We have been staying in Heidelberg for some time past, but it is now becoming too cold and damp.

Again with sincerest sympathy and all good wishes 


\section{To Horace Scudder, November 15, $1890^{40}$}

Heidelberg | Germany | 15 Nov:90

Dear Mr. Scudder,

Thanks for your letter. I have to leave an unfinished reply till the next mail, or at any rate till this evening - as I have an important engagement today. Briefly, however, I may say at the moment that I shall send you some valuable new material of some kind.

In case of any miscarriage of my evening letter (and I am under great annoyance at present from loss of a dozen or more valuable letters, through Post Office Stupidity and Red Tapism here, for tho' the authorities know of me well by this time a whole week of last month's \& some of this week's correspondence has gone to Berlin, and thence been returned to " $a$ ' the airts"). I send you a definite address for the winter and Spring, from 1st Decr.: - c/o Messrs. Maquay Hooker \& Col. 20, Piazza di Spagna, I Rome I Italy.

With kind regards I Yours faithfully, I William Sharp

Permanent London Letter-address I c/o Mrs. Sharp | 72 Inverness Terrace I Kensington Gardens I London W.

ALS Harvard Houghton

To Catharine Janvier, [late] December, 1890

Dec. 1890

... Well, we were glad to leave Germany. Broadly, it is a joyless place for Bohemians. It is all beer, coarse jokes, coarse living, and domestic tyranny on the man's part, subjection on the woman's - on the one side: pedantic learning, scientific pedagogism, and mental ennui; on the other: with, of course, a fine leavening somewhere of the salt of life. However, it is only fair to say that we were not there at the best season in which to 
see the blither side of Germans and German life. I saw a good deal of the southern principalities and kingdoms - the Rhine provinces, Baden, Würtemberg, and Bavaria. Of course Heidelberg, where we stayed six wet weeks, is the most picturesque of the residential places (towns like Frankfort-am-Main and Mannheim are only for merchants and traders, though they have music "galore"), but I would rather stay at Stuttgart than any I saw. It is wonderfully animated and pleasing for a German town, and has a charming double attraction both as a mediaeval city and as a modern capital. There, too, I have a friend: the American novelist, Blanche Willis Howard (author of Guenn, The Open Door, etc)., who is now the wife of the Court-Physician to the King of Würtemberg and rejoices in the title "Frau Hof-Arzt von Teuffel". Dr. von Teuffel himself is one of the few Germans who seem to regard women as equals.

But what a relief it was to be in Italy again, though not just at first, for the weather at Verona was atrocious, and snow lay thick past Mantua to Bologna. But once the summit of the Apennines was reached, and the magnificent and unique prospect of Florentine Tuscany lay below, flooded in sunshine and glowing colour (though it was in the second week of December) we realised that at last we were in Italy... . When we came to Rome we had at first some difficulty in getting rooms which at once suited our tastes and our pockets. But now we are settled in an "apartment" of $3 \frac{1}{2}$ rooms, within a yard or so of the summit of the Quirinal Hill. The $1 / 2$ is a small furnished corridor or ante-room: the comfortable salotto, is at once our study, drawing-room, and parlour.

We have our coffee and our fruit in the morning: and when we are in for lunch our old landlady gives us delightful colazioni of maccaroni and tomatoes, or spinach and lentils, or eggs and something else, with roasted chestnuts and light wine and bread. We have our dinner sent in from a trattoria.

In a sense, I have been indolent of late: but I have been thinking much, and am now, directly or indirectly, occupied with several ambitious undertakings. Fiction, other imaginative prose, and the drama (poetic and prose), besides a lyrical drama, and poetry generally, would fain claim my pen all day long. As for my lyrical drama - which is the only poetic work not immediately modern in theme - which is called 'Bacchus in India', ${ }^{41}$ my idea is to deal in a new and I hope poetic way with Dionysos as the Joy-Bringer, the God of Joyousness. In the first part there is the union of all the links between Man and the World he 
inhabits: Bacchus goes forth in joy, to give his serene message to all the world. The second part, 'The Return', is wild disaster, and the bitterness of shame: though even there, and in the Epilogue, will sound the clarion of a fresh Return to Joy. I transcribe and enclose the opening scene for you - as it at present stands, unrevised. The 'lost God' referred to in the latter part is really that deep corrosive Melancholy whom so many poets and artists - from Dante and Durer to our own time - have dimly descried as a terrible Power.

At the moment, I am most of all interested in my blank verse tragedy. It deals with a most terrible modern instance of the scriptural warning as to the sins of the father being visited upon his children: an instance where the father himself shares the doom and the agony. Then I have also schemed out, and hope soon to get on with, a prose play, dealing with the deep wrong done to women by certain existing laws. Among other prose books (fiction) which I have "on the stocks" nothing possesses me more than a philosophical work which I shall probably publish either anonymously or under a pseudonym, and, I hope, before next winter. How splendid it is to be alive! $O$ if one could only crush into a few vivid years the scattered fruit of wasted seasons. There is such a host of things to do: such a bitter sparsity of time, after bread-and-butter making, to do them in - even to dream of them!

Memoir $170-72$

\section{To [Bliss Carman [late] December, 1890]}

19 Via delle Quattro Fontane I (piano, 2) I Rome, Italy

My Dear Old Man, ${ }^{42}$

This is but a brief word to send you from Italy - but more is impossible for me at the moment.

But this carries with it my love and heartiest greetings, and friendliest belief in and earnest wishes for your success as a poet. May the high Gods have you in charge, Dear Son of Apollo!

Here we are anchored for a time, perhaps for some months. 
Your affectionate, I William Sharp.

Letter-address had best remain cl o Messrs. Maquay Hooker and Co., 20 Piazza di Spagna, Rome.

ACS Nicholas Salerno 


\section{Chapter Seven}

\section{Life: 1891}

The Sharps arrived in Rome in early December of 1890 and stayed until March. Elizabeth recalled those months as "one long delight" for her husband, which "amply fulfilled even his optimistic anticipation. He reveled in the sunshine and the beauty; he was in perfect health; his imagination was quickened and worked with great activity" (Memoir 173). In mid-December, Edith Wingate Rinder came from London to spend three weeks with Mona Caird, a close friend of the Sharps who was wintering in Rome "for her health." A beautiful and intelligent young woman of twenty-six, Edith had married Mona's cousin, Frank Rinder, less than a year earlier, on February 17, 1890. Edith and Frank were childhood sweethearts who had grown up as landed gentry on neighboring farms in the north of England. Educated at home and locally, Edith spent a year studying in Germany and worked for a time as a governess in Lincolnshire upon returning home. Frank was also educated in Lincolnshire and sent to Fettes College, a well-established boarding school in Edinburgh. During his first year - 1883-84 he became ill with cerebral meningitis which left him somewhat crippled and in ill-health for the rest of his life. Back in Lincolnshire, feeling isolated, deprived of culture, without prospects, and unable to overcome their parents' opposition to their marrying, the young couple set their sights on London. Mona Caird, Frank Rinder's first cousin, had married in 1887 a wealthy Scottish Laird - James Alexander Henryson Caird of Cassenary, Creeton, Kirkendbrighten - and settled into a substantial house in South Hampstead. An early advocate of freedom 
from the stultifying restraints of high Victorianism, Mona invited Edith Wingate and Frank Rinder to London, adopted them for a time into her household, and facilitated their marriage, which took place not at a church, as was customary, but at a London Registry Office on February 27, 1890.

The Sharps knew Edith and Frank Rinder in London before and after their marriage. Their South Hampton house was only a few blocks from Mona Caird's, and there was frequent entertaining back and forth. By December 1890, the glow had worn off Edith's marriage, and Sharp's relationship with Elizabeth had devolved into that of a mother overseeing her frequently-ill child whom she called "my poet." In any case, the friendship between the handsome William Sharp, free of pressing obligations and revitalized at the age of thirty-five, and the strikingly beautiful Edith Rinder, who was twenty-six, blossomed under the warm Italian sun into a close and lasting relationship. Edith would become the mysterious unnamed friend Sharp frequently alluded to in letters and conversations and the principal catalyst for the Fiona Macleod phase of his literary career. In an 1896 letter to his wife, Sharp said he owed Edith his "development as 'Fiona Macleod' though, in a sense of course, that began long before I knew her, and indeed while I was still a child." "Without her," Sharp continued, "there would have been no 'Fiona Macleod'." After quoting from this letter in the Memoir 222, Elizabeth continued, with remarkable generosity, "Because of her beauty, her strong sense of life and the joy of life; because of her keen intuitions and mental alertness, her personality stood for him as a symbol of the heroic women of Greek and Celtic days, a symbol that, as he expressed it, unlocked new doors in his mind and put him 'in touch with ancestral memories' of his race." When Pharais: A Romance of the Isles, the first Fiona Macleod book, was published in 1894, it was dedicated to "E. W. R." - Edith Wingate Rinder.

Sharp and Edith took long walks together in the Roman Campagna in late December and early January. The beauty of the countryside and the joy of his new found love moved Sharp to compose in February a sequence of exuberant poems that were privately printed in March as Sospiri di Roma, sighs of Rome. Of that volume and Edith Rinder's role in its genesis, Elizabeth wrote 
The "Sospiri di Roma" was the turning point. Those unrhymed poems of irregular meter are filled not only with the passionate delight in life, with the sheer joy of existence, but also with the ecstatic worship of beauty that possessed him during those spring months we spent in Rome when he had cut himself adrift for the time from the usual routine of our life, and touched a high point of health and exuberant spirits. There, at last, he found the desired incentive towards a true expression of himself, in the stimulus and sympathetic understanding of the friend to whom he dedicated the first of the books published under his pseudonym. This friendship began in Rome and lasted throughout the remainder of his life (Memoir 222).

Elizabeth included in the Memoir excerpts from Sharp's diary that detail his activities and his writing during January and February. On January 3, he and Edith traveled by train to the village of Albano south of Rome and walked from there to Genzano where they looked down into Lake Nemi, which "looked lovely in its grey-blue stillness, with all the sunlit but yet somber winterliness around. Nemi, itself, lay apparently silent and lifeless, 'a city of dream,' on a height across the lake." He continued, "One could imagine that Nemi and Genzano had once been the same town, and had been riven asunder by a volcano. The lake-filled crater now divides these two little hill-set towns."

This excursion stands out among others Sharp described because of what it came to mean to him in the context of his relationship with Edith Rinder and his creation of Fiona Macleod. On February 8, after Edith had returned to London, he wrote a poem called "The Swimmer of Nemi (The Lake of Nemi: September):"

White through the azure,

The purple blueness,

Of Nemi's waters

The swimmer goeth.

Ivory-white, or wan white as roses

Yellowed and tanned by the suns of the Orient,

His strong limbs sever the violet hollows;

A shimmer of white fantastic motions

Wavering deep through the lake as he swimmeth.

Like gorse in the sunlight the gold of his yellow hair,

Yellow with sunshine and bright as with dew-drops,

Spray of the waters flung back as he tosseth

His head $i^{\prime}$ the sunlight in the midst of his laughter; 
Red o'er his body, blossom-white 'mid the blueness,

And trailing behind him in glory of scarlet,

A branch of red-berried ash of the mountains.

White as a moonbeam

Drifting athwart

The purple twilight,

The swimmer goeth-

Joyously laughing,

With o'er his shoulders,

Agleam in the sunshine

The trailing branch

With the scarlet berries.

Green are the leaves, and scarlet the berries,

White are the limbs of the swimmer beyond them

Blue the deep heart in the haze of September,

The high Alban hills in their silence and beauty,

Purple the depths of the windless heaven

Curv'd like a flower o'er the waters of Nemi.

In his diary, Sharp followed the poem's title with "(Red and White) 42 lines" though it was shortened to thirty-one lines when it appeared in Sospiri di Roma. This poem and others in the volume represent a departure into the realms of free verse and impressionism in an effort, following Walt Whitman and others, to break the rigidity and formalism of poetry, as J. W. Turner had done and Whistler and the French impressionists were doing in painting.

There is more to be said about the Nemi poem. Sharp must have known the paintings of the lake by John Robert Cozens (1777) and George Inness (1857) and of Turner's many depictions of the lake and its surroundings. He must also have known the lake was the most famous place of worship of the Roman Goddess Diana Nemorensis ("Diana of the Wood") who was the goddess of wild animals and the hunt and identified with the Greek goddess Artemis, a goddess of the moon and fertility. He must also have been aware of the myth central to James Fraser's ground-breaking Golden Bough, which appeared in 1890. The King of the Woods - Rex Nemorensis - guards the temple of Diana Nemorensis, Diana of the Wood, with a golden bough that symbolizes his power. Annually, reflecting the progress of the seasons and the harvest, another man plucks a bough from the golden tree, swims Lake Nemi, kills the King, assumes his powers, and guards Diana's temple. 
In his poem, Sharp idealizes himself in the handsome and powerful swimmer who carries the red-berried ash bough, a symbol of dynamic life, to lay at the feet of Diana's reincarnation as the beautiful Edith Rinder.

Sharp's fascination with Lake Nemi, its renewal myth, and the day - January 3, 1891 - he visited Nemi with Edith Rinder did not end with the poem. Years later he cast the day in a different guise, but with the same significance. He transformed the poem's handsome male swimmer into a beautiful woman. Ernest Rhys, in his Everyman Remembers, recalled Sharp telling him that

His first meeting with Fiona was on the banks of Lake Nemi when she was enjoying a sun-bath in what she deemed was virgin solitude, after swimming the lake. "That moment began", he declared, "my spiritual regeneration. I was a New Man, a mystic, where before I had been only a mechanic-in-art. Carried away by my passion, my pen wrote as if dipped in fire, and when I sat down to write prose, a spirit-hand would seize the pen and guide it into inspired verse. We found we had many common friends: we traveled on thro' Italy and went to Rome, and there I wrote my haunting Sospiri di Roma".

Rhys took Sharp's words to mean there was "an objective Fiona Macleod," and "the passion she inspired gave Sharp a new deliverance, a new impetus." Though Rhys did not know who she was, he was correct. A real woman figured crucially in Sharp's creation of Fiona Macleod. The male swimmer in Sharp's Nemi poem, "'Ivory-white, or wan white as roses I Yellowed and tanned by the suns of the Orient," was initially an idealized self-portrait. Years later, he had become Fiona "enjoying a sun-bath in what she deemed was virgin solitude, after swimming the lake." The lengthy diary account of his first day-long walk with Edith Rinder and the importance he placed on their visit to Nemi suggest that may have been the day their relationship deepened. It was she, not the imaginary Fiona, who was responsible for his "spiritual regeneration," for his becoming a "New Man, a mystic," where before he "had been only a mechanic-in-art." She was responsible for the burst of creativity that produced the poems of Sospiri di Roma and eventually for the emergence of Fiona Macleod.

On February 8, he wrote "A Winter Evening" I (An hour after Nightfall, on Saturday, January 17, 1891) । [To E. W. R.], which 
describes his walk through a heavy snowstorm on January 17. His diary entry for the 17th begins "Winter with a vengeance. Rome might be St. Petersburg." In the late afternoon, he had gone alone for a walk on the Pincio Terrace in the whirling snow.

Returning by the Pincian Gate, about 5:45 there was a strange sight. Perfectly still in the sombre Via di Mura, with high walls to the right, but the upper opines and cypresses swaying in a sudden rush of wind: to the left a drifting snow-storm: to the right wintry moonshine: vivid sweeping pulsations of lightening from the Compagna, and long low muttering growls of thunder. (The red light from a window in the wall). (Memoir 176-77).

When he turned this experience into a poem on February 8, the same day he wrote "The Swimmer of Nemi," he focused on that red light:

Here all the snow-drift lies thick and untrodden, Cold, white, and desolate save where the red light

Gleams from a window in yonder high turret

And the poem ends:

Here in the dim, gloomy Via dell'Mura,

Nought but the peace of the snow-drift unruffled,

Whitely obscure, save where from the window

High in the walls of the Medici Gardens

Glows a red shining, fierily bloodred.

What lies in the heart of thee, Night, thus so ominous?

What is they secret, strange joy or strange sorrow?

Why he chose this poem to dedicate to Edith we cannot know, but it is tempting to speculate. Walking home, he observed the contrast between the sweeping winds above and the relative peace below as the lightning and thunder approached the city, the rush of wind and snow on one side and wintry moonshine of the other. He was walking alone, and the dedication to Edith suggests the poem was meant to describe the experience for her. If so, the red light high in the dark wall may represent Edith as a steady, though now remote, beacon of warmth and contentment for the poet, alone and buffeted between periods of moonlit joy and stormy depression.

After Edith returned to London in mid-January, the Sharps became more active in the literary and artistic life of Rome, attending lectures 
and visiting art studios. Sharp's diary shows he sampled a remarkable array of writers: Elie Reclus, Pierre Loti, George Meredith, Robert Browning, Charles Swinburne, Coventry Patmore, Antonio Fogazzaro, Gabriel D'Annunzio, Henrik Ibsen, Edgar Allen Poe, Henri de Balzac, and Sainte-Beuve. He wrote articles for the New York Independent and the British National Review and a poem for Belford's Magazine. He met Elihu Vedder who wanted to know what the British press had written about his illustrations for Omar Khayam. On January 10, Sharp thanked Bliss Carman, literary editor of the New York Independent, for sending the issue of December 25 that printed his a poem, "Paris Nocturne," an unrhymed impressionistic poem that anticipated those he was writing in Italy.

On January 30, Sharp turned in earnest to the poems that would become Sospiri di Roma. By February 2, he had written fourteen and remarked in his diary, "Such bursts of uncontrollable poetic impulse as came to me today, and the last three days, only come rarely in each year." The next day, February 3, he sent several poems to Carmen and asked him to consider publishing them or send them to other American editors for possible publication. If accepted he asked that they should appear before they were included in the volume of poems he planned to publish in March. On February 10 and 11, Sharp sat for a drawing by Charles Holroyd that became the etched portrait Sharp used to face the title page of Sospiri di Roma:

In late February, Charles Ross, a Norwegian painter, asked Sharp to sit for him and produced a pastel portrait that Elizabeth reproduced in the Memoir. The many surviving portraits of Sharp suggest that painters and photographers considered him a handsome and imposing figure.

Sharp arranged to have the poems he was writing printed by the Societa Laziale's press in Tivoli at his expense, and he continued writing and revising until mid-March when Elizabeth left for Florence to spend more time with her aunt. Sharp stayed on in Rome and went to Tivoli for a few days to put his poems in their final shape and oversee their type setting. Julian Corbett, a friend and a prominent British naval historian who had just published a biography of Sir Francis Drake, accompanied him, and the two men spent mornings working and afternoons exploring Tivoli and the surrounding hills. During a visit to the castle of San Poli dei Cavalieri, they met a "comely woman" who gave them some wine. She also told a tale that found its way, along 
with the town and surrounding scenery, into Sharp's "The Rape of the Sabines," a convoluted story that appeared the following year in the first and only issue of Sharp's Pagan Review.

Towards the end of the month Sharp joined Elizabeth in Pisa, and from there they went to Arles in the south of France where they stayed until the end of March. On March 30, Sharp sent Catherine Janvier a letter from Provence in which he told her his Sospiri di Roma was being printed that very day

to the sound of the Cascades of the Anio at Tivoli, in the Sabines - one of which turns the machinery of the Socièta Laziale's printing-works. I do hope the book will appeal to you, as there is so much of myself in it. No doubt it will be too frankly impressionistic to suit some people, and its unconventionality in form as well as in matter will be a cause of offense here and there. You shall have one of the earliest copies.

About seventy-five copies were printed and sent to Sharp who sent them selectively to his friends and to newspapers and periodicals where they were most likely to be well received. He told Mrs. Janvier that Marseilles was unattractive compared to Rome. He and Elizabeth preferred Arles, but it paled in comparison to the hill towns of the Apennine and the Sabines:

When I think of happy days at the Lake of Nemi, high up in the Albans, of Albano, and L'Ariccia, and Castel Gandolfo - of Tivoli, and the lonely Montecelli, and S. Polo dei Cavalieri, and Castel Madamo and Anticoli Corrado, etc., among the Sabines - of the ever new, mysterious, fascinating Campagna, from the Maremma on the North to the Pontine Marches, my heart is full of longing.... You will find something of my passion for it, and of that still deeper longing and passion for the Beautiful, in my "Sospiri di Roma", which ought to reach you before the end of April, or at any rate early in May.

On May 1, Sharp wrote again to Catherine Janvier, this time about the critical response to Sospiri di Roma:

It is no good to any one or to me to say that I am a Pagan - that I am "an artist beyond doubt, but one without heed to the cravings of the human heart: a worshipper of the Beautiful, but, without religion, without an ethical message, with nothing but a vain cry for the return, or it may be the advent, of an impossible ideal". Equally absurd to complain that in these "impressions" I give no direct "blood and bones" for the mind to gnaw 
at and worry over. Cannot they see that all I attempt to do is to fashion anew something of the lovely vision I have seen, and that I would as soon commit forgery (as I told someone recently) as add an unnecessary line, or "play" to this or that taste, this or that critical opinion. The chief paper here in Scotland shakes its head over "the nude sensuousness of "The Swimmer of Nemi', 'The Naked Rider', 'The Bather', 'Foir di Memoria', 'The Wild Mare' (whose 'fiery and almost savage realism!' it depreciates - tho' this is the poem which [George] Meredith says is 'bound to live') and evidently thinks artists and poets who see beautiful things and try to fashion them anew beautifully, should be stamped out, or at any rate left severely alone.

Here Sharp seemed to reject the idea of being called a "Pagan," which connoted an unrestrained sensuality and the absence of Christian beliefs. The more he thought about it, however, the more he warmed to the term. The statues he saw in and about Rome and described in the Sospiri poems were certainly pre-Christian and therefore Pagan. The poems reflect the renewed energy - sexual as well as artistic - that Sharp experienced in Italy, and soon he would write under various pseudonyms the stories and poems in the first and only issue of his Pagan Review.

It is no wonder the papers and journals that received copies of the book were put off by the form of the poems and their "nude sensuous." The male nude swimmer in the Nemi poem is one of several white nudes - men and women and even a white mare pursued and mounted by a dark stallion - that populate the volume. Shortly after his previous volume of poems - Romantic Ballads and Poems of Phantasy - appeared in 1888, Sharp wrote to a "friend:" "I am tortured by the passionate desire to create beauty, to sing something of the 'impossible songs' I have heard, to utter something of the rhythm of life that has touched me. The next volume of romantic poems will be daringly of the moment, vital with the life and passion of today." Three years passed before he fulfilled that promise in a month-long burst of creativity in Rome. Sharp saw himself as part of a wider effort to break through the constraints of late Victorianism, but the assault on poetic forms and sexual norms that resulted from his "passionate desire to create beauty" in Sospiri di Roma met resistance or avoidance among all but a few close friends who shared his goals. George Meredith was one of those friends. In a letter to Sharp, he praised the volume with some reservations: "Impressionistic work where the heart is hot surpasses all but highest verse.... It can be 
of that heat only at intervals. In 'The Wild Mare' you have hit the mark." That is the poem the Scottish paper criticized for its "fiery and almost savage realism."

From May until mid-August, Sharp spent most of his working hours on the biography of Joseph Severn that Severn's son had asked him to write. The Sharps stayed in Provence until the end of April. Sharp went to London in early May and intended to go back to France where they would spend the summer in the Forest of Fontainebleau. While he was away, Elizabeth became ill with an "insidious form of low fever" and returned to England for treatment. Along with medication, she needed rest so they went to Eastbourne on the Sussex coast for two weeks where she could have the fresh sea air, and he could work undisturbed on the Severn book. After several weeks Sharp went to see his mother in Edinburgh while Elizabeth, restored to health, stayed with her mother in London. In mid-July they met in York and went to Whitby on the Yorkshire Coast for six weeks. On August 21, back in London, Sharp asked the Editor of Blackwood's Magazine if he might be interested in publishing a story curiously entitled "The Second Shadow: Being the Narrative of Jose Maria Santos y Bazan, Spanish Physician in Rome." Blackwood's declined, but Bliss Carman published it in the New York Independent on August 25, 1892. Sharp finished the last revisions of his Severn book on August 28, and he and Elizabeth left for Stuttgart where Sharp and Blanch Willis Howard would plan their collaboration.

The two writers settled on a title and a plot. A line from Shakespeare's Othello - "A fellowe almost damned in a faire wife" gave them a title. Their novel would be called A Fellowe and his Wife, and the main characters would be a German Count and his beautiful young Countess who decides to live in Rome and become a sculptor. Sharp would draw upon his experience in Rome to write the letters of the "faire wife" while Howard would draw upon hers in the German court to write the Count's replies. In Rome, the wife falls under the spell of a famous sculptor who seduces and then betrays her. Though it takes a great deal of heightened prose, especially on the wife's part, the husband finally goes to Rome, confronts the sculptor, forgives his wife, and takes her back to Germany. Sharp's decision to play the part of the Countess was logical enough given his immersion in Rome. His easy adoption of the role and his obvious pleasure in molding the female character through 
her writing foreshadowed his decision to adopt a female authorial voice and pseudonym for his first Fiona Macleod romance in 1894. A Fellowe and his Wife, published in both America and Britain in 1892, contains a good deal of Sharp's enchantment with the beauty and culture of Rome and Howard's with the German aristocracy she had recently joined by marriage.

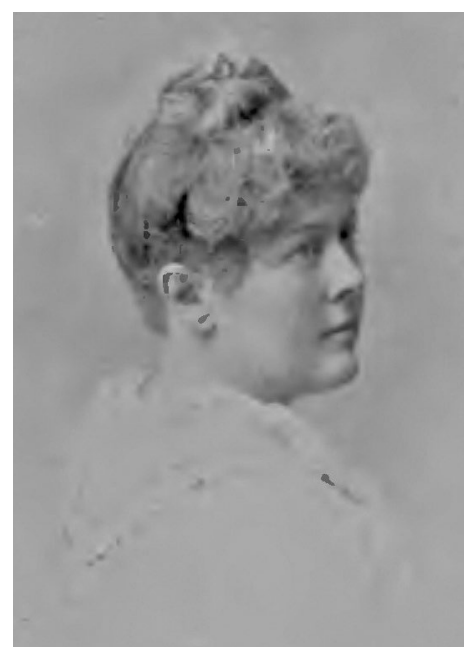

Fig. 9. Blanche Willis Howard, in F. E. Willard, A Woman of the Century: Fourteen Hundredseventy Biographical Sketches Accompanied by Portraits of Leading American Women in all Walks of Life (Buffalo, N. Y.: Moulton, 1893), p. 735, Wikipedia, https://commons.wikimedia.org/ wiki/File:BLANCHE_WILLIS_HOWARD_VON_TEUFFEL._A_woman_of_the_century_ (page_745_crop).jpg

Sharp was energized by the warm fall weather in southern Germany and by his relationship with Howard, who enjoyed being called the Frau Hof-Arzt von Teuffel. In a letter to Catherine Janvier on September 3, he said he was "electrified in mind and body:"

The sun flood intoxicated me. But the beauty of the world is always bracing - all beauty is. I seemed to inhale it - to drink it in - to absorb it at every pore - to become it - to become the heart and soul within it. And then in the midst of it all came my old savage longing for a vagrant life: for freedom from the bondage we have involved ourselves in. I suppose I was a gypsy once - and before that 'a wild man o' the woods'. 
Also on September 3, he wrote excitedly to Bliss Carman:

How strangely one drifts about in this world. Not many days ago I was on the Yorkshire moors or along the sea-coast by Whitby: a few days ago I was in Holland, and rejoicing in the animated life of that pleasant 'water-land': last Sunday I was strolling by the Rhine or listening to the music in Cologne Cathedral. And now we are temporarily settled down in this beautiful Vine-land - in Stuttgart, the loveliest of all German capitals. It is glorious here just now. The heat is very great, but I delight in it. These deep blue skies, these vine clad hills all aglimmer with greengold, this hot joyous life of the South enthralls me - while this glorious flooding sunshine seems to get into the heart and the brain.

He concluded the letter to Catherine Janvier on that high note:

I have had a very varied, and, to use a much-abused word, a very romantic life in its external as well as in its internal aspects. Life is so unutterably precious that I cannot but rejoice daily that I am alive: and yet I have no fear of, or even regret at the thought of death. There are many things far worse than death. When it comes, it comes. But meanwhile we are alive. The Death of the power to live is the only death to be dreaded.

Having finished the Severn biography, Sharp had returned to a warm and beautiful place and remained in good health. He had developed a close friendship with a newly noble woman who was also an established novelist. He experienced in Germany in September and October 1891 a joy that came seldom, but powerfully. Soon after arriving in Stuttgart, he confided in his diary, "What a year this has been for me: the richest and most wonderful I have known. Were I as superstitious as Polycrates I should surely sacrifice some precious thing lest the vengeful gods should say, 'Thou hast lived too fully: Come!'”

In his diary on September 6, Sharp called Howard a "charming woman." He "liked her better than ever" and had to remind himself he was there to collaborate with her on a novel. Conscious of his propensity to fall in love with attractive women, he wrote, "I must be on guard against my too susceptible self." In his late September annual birthday letter to E. C. Stedman, he wrote more expansively:

I am here for a literary purpose - though please keep this news to yourself meanwhile - i.e. collaborating with our charming friend Blanche Willis Howard (von Teuffel) in a novel. It is on perfectly fresh and striking lines, and will I think attract attention. We are more than 
half through with it already. She is a most interesting woman, and is of that vigorous blond race of women whom Titian and the Palmas loved to paint, and whom we can see now in perfection not in Venico but at Chioggia, further down the Adriatic. But if I fall too deeply in love, it will be your fault - for it was you who introduced me to her! I told her about your birthday, and I think she is going to send you a line of greeting. We see each other for several hours daily, or nightly, and well, literary life has its compensations! But our affectionate camaraderie is as Platonic as - say, as yours would be in a like instance: so don't drag from its mouldy tomb that cynic smile which lies awaiting the possible resurrection of the Old Adam! Your ears must sometimes tingle as your inner sense overhears our praises of you as man and writer.

He went on to tell Stedman he planned to visit America in early 1892 and give a series of public lectures in Boston, Philadelphia, Baltimore, Cincinnati, Chicago, Buffalo, Albany, \& perhaps elsewhere. He listed fourteen possible topics ranging from the Pre-Raphaelites to "Poets and Poetry Today" and asked Stedman for advice and assistance in making the arrangements. More immediately, he and Elizabeth left Germany in mid-October and returned to England via Amsterdam on October 20.

The extreme high Sharp experienced in Germany collapsed into physical illness and a deep depression in London. Elizabeth wrote, "The brilliant summer was followed by a damp and foggy autumn. My husband's depression increased with the varying of the year." On November 9 he spent all day at his London club - the Grosvenor and wrote as follows in a note to Elizabeth who was spending the day with her mother.

I have been here all day and have enjoyed the bodily rest, the inner quietude, and, latterly, a certain mental uplifting. But at first I was deep down in the blues. Anything like the appalling gloom between two and three-thirty! I could scarcely read, or do anything but watch it with a kind of fascinated horror. It is going down to the grave indeed to be submerged in that hideous pall. As soon as I can make enough by fiction or the drama to depend thereon, we'll leave this atmosphere of fog and this environment of deadening, crushing, paralysing death-in-life respectability. Circumstances make London thus for us: for me at least - for of course we carry our true atmosphere in ourselves - and places and towns are, in a general sense, mere accidents (Memoir 192).

In December he wrote to Catherine Janvier in New York, "Do you not long for the warm days - for the beautiful living pulsing South? This 
fierce cold and gloom is mentally benumbing." He looked forward to reading for her in three weeks one of the pieces of "intense dramatic prose" he had written in Germany.

While dealing with his depression and proceeding with his "Dramatic Interludes," Sharp had to return to his Severn biography. The publisher - Sampson Lowe, Marston \& Company - decided to issue the work as one volume rather than two. Sharp thought he had finished the biography, but he was forced to condense the first volume and eliminate most of the second which chronicled Severn's life after Keats died, including the twenty years he spent as British Counsel in Rome. Shortly after returning to London, Sharp wrote an article called "Joseph Severn and His Correspondents" that Horace Scudder published in the December 1891 issue of the Atlantic Monthly. In early December he wrote to Scudder:

If practicable, within the next fortnight or 3 weeks I shall send you the promised "Unpublished Incidents in the Life of Joseph Severn" (or such title as you prefer). I am glad there is a chance of these reminiscences appearing in a conspicuous place - for it appears that many people both in America and here are mainly anticipating the record of Severn's consular life (partly, no doubt, after Ruskin's splendid eulogium of him in Praeterita) - which is, so far as the book is concerned, regrettable.

Scudder published that article as "Severn's Roman Journals" in the May 1892 issue of the Atlantic.

On December 8 Sharp informed Bliss Carman he had booked passage on the Teutonic which would sail from Liverpool on January 6 and arrive in New York on January 12 or 13 . He had been forced to postpone all lecturing.

I am going out partly to attend to some private literary business, best seen to on the spot; partly to arrange for the bringing out in America of a play of mine which is to be produced here; and partly to get a glimpse of the many valued friends and acquaintances I have in N.Y. and Boston. I shall be in N.Y. for three weeks at any rate. Perhaps later on, say in your issue for the first week in January, you will be able to oblige me by inserting in the Independent a para to the above effect: as this would save me letting a lot of people know, and enable me to economize my limited time. 
According to Elizabeth, Sharp's doctor had "strictly prohibited" him from giving lectures in the United States. Once in New York, he used that excuse to decline a request from a Harvard faculty member to lecture there "upon a subject of contemporary literature." His doctor probably warned Sharp to avoid stress, but the fact that no lectures were prepared and none given followed a pattern of planning and then canceling. That pattern, I believe, was rooted in a deep insecurity about the depth of his knowledge - something akin to stage fright - which caused his weak heart to race uncontrollably before and during any presentation to a potentially critical audience. 


\section{Letters: 1891}

\section{To Richard Garnett, [early January, 1891] ${ }^{1}$}

19, Via delle Quattro Fontane (p.z). I Rome

Amico Mio,

After a glorious walk of over 15 miles across the loveliest part of the Campagna, in a perfect flood of hot sunshine (which, with a bumble-bee, a lizard, some daisies, and campagna-violets, made Spring seem already come) I have been spending a pleasant afternoon at Elihu Vedder's. ${ }^{2} \mathrm{He}$ is eager to see all that has been written in England about his "Omar Khayam" and I told him I thought you had written something. Is that so? If so, I wish you could send it to me if practicable: and I would take it to him. He is delighted at the idea that you have written about it all, but I warned him that I might be mistaken, though I fancy I am not. He has strongly imaginative things in his studio just now.

I am writing a lyrical drama, ${ }^{3}$ and other imaginative work: though hitherto circumstances have been somewhat against that leisure \& repose to which I had so looked forward. However, after this week things will be better for me in this respect.

Cordially Yours, | William Sharp P.S. I shall write again, about Pope Alexander's tomb, \& about Keats' \& Shelley's graves.

ACS University of Texas at Austin 


\section{To Bliss Carman, January 10, 1891}

Clo Messrs. Maquay Hooker and Co., I 20, Piazza di Spagna, Rome 19, Via delle Quattro | Fontane I(p.z). I Roma | 10 Jan 91

Dear old Chap,

A hurried line to thank you for your welcome Christmas-Greeting welcome as from the Sender, welcome for its own beauty. You will doubtless also have received the brief Greeting I sent.

Thanks, too, for the N. Y. Independent, with my poem, just to hand. ${ }^{4}$

I send you one of my African poems - the 'colour' of which will perhaps please you. I hope it may suit you for the Independent. ${ }^{5}$

Would you care for two or three papers on Contemporary Italian Literature - not so much critical, as to give an idea of what intellectual life and stir there is in Italy of today. Do you know any Magazine or Paper which would care for them? Don't bother about the matter, however. I am rather full of it at present.

With love; dear Carman, I Yours ever I William Sharp

P.S. Don't forget to go and see my dear friends the Janviers, at 20, Seventh Avenue, if you have not yet done so.

P.S. I think we shall remove ourselves to Venice about the beginning of March.

ALS Smith College Library 


\section{To Bliss Carman, February 3, 1891}

19, via delle Quattro Fontane | (p.z). | Rome | 3:2:91

My dear old Boy

I have got so utterly out of the way of all unnecessary letter writing that I often fear my distant friends will all agree to "curse me and forget". You, however, understand, I know.

I am writing much in verse just now, to the serious detriment of my finances! Late in the spring I am going to bring out a little volume possibly I shall have it printed here, and perhaps for private circulation only - of poems dealing entirely with certain impressions of Rome, the Sabine and Alban hill-country, and the Campagna: a few at most, and all in irregular and unrhymed measures - a poetic 'species' in which I take great delight. The volume will be called "Sospiri di Roma". (Keep all this to yourself, meanwhile). The more important happen also to be the longer, but I send some herewith of the shorter.

I should be particularly pleased if you could use what you like best, and soon, so as not to cause a delay with the issue of my booklet. Can you manage this, amico mio.

As I managed the "Universal Review" affair for you, I am also going to ask you to think over if you can 'plant' any of the other MSS herewith which you can't use - if you can plant them somewhere, I don't care where so long as they appear without much delay, and bring me some of the needful.

I am doing this, however, in full trust that if the matter should be a burdensome or in any way disagreeable business for you, that you will proceed no further in it.

It is glorious weather now, and full Carnival. We leave here about the 25th of February - go to Spezia (probably) for a week - then elsewhere along the coast, St. Raphael or Antibes, and then into Provence for a month or so. ${ }^{6}$ Would you like some Provence sketches - in prose, I mean? 
I was delighted to get your charming and characteristic Christmas remembrance.

Letter-Address henceforth | 72 Inverness Terrace | Bayswater | London. $\mathrm{W}$

ALS Smith College Library

\section{To Catherine Janvier, March 30, 1891}

30:3:91.

\section{Gento Catarine,}

You see I address you à la Provençale already! We left Italy last week, and came to Provence. Marseilles, I admit, seemed to me an unattractive place after Rome - and indeed all of Provence we have seen as yet is somewhat chill and barren after Italy. No doubt the charm will grow. For one thing, Spring is very late here this year... .

Arles we like much. It is a quaint and pleasant little town: and once I can get my mind free of those haunting hill-towns of the Sabines and Albans I love so much - (is there any hill range in the world to equal that swing of the Apennines stretching beyond Rome eastward, southward, and southwestward?) - I shall get to love it too, no doubt. But oh, Italy, Italy! Not Rome: though Rome has an infinite charm, even now when the jerry-builder is fast ruining it: but "greater Rome", the Agro Romano! When I think of happy days at the Lake of Nemi, high up in the Albans, of Albano, and L'Ariccia, and Castel Gandolfo - of Tivoli, and the lonely Montecelli, and S. Polo dei Cavalieri, and Castel Madamo and Anticoli Corrado, etc., among the Sabines - of the ever new, mysterious, fascinating Campagna, from the Maremma on the North to the Pontine Marches, my heart is full of longing. I love North Italy too, all Umbria and Tuscany: and to know Venice well is to have a secret of perpetual joy: and yet, the Agro Romano! How I wish you could have been there this winter and spring! You will find something 
of my passion for it, and of that still deeper longing and passion for the Beautiful, in my "Sospiri di Roma", which ought to reach you before the end of April, or at any rate early in May. This very day it is being finally printed off to the sound of the Cascades of the Anio at Tivoli, in the Sabines - one of which turns the machinery of the Socièta Laziale's printing-works. I do hope the book will appeal to you, as there is so much of myself in it. No doubt it will be too frankly impressionistic to suit some people, and its unconventionality in form as well as in matter will be a cause of offence here and there. You shall have one of the earliest copies.

Yesterday was a fortunate day for arrival. It was a great festa, and all the women were out in their refined and picturesque costumes. The Amphitheatre was filled, tier upon tier, and full of colour (particularly owing to some three or four hundred Zouaves, grouped in threes or fours every here and there) for the occasion of "a grand Bull-Fight". It was a brilliant and amusing scene, though (fortunately) the "fight" was of the most tame and harmless kind: much less dangerous even for the most unwary of the not very daring Arlesians than a walk across the remoter parts of the Campagna.... .

Memoir 182-83

To Catherine Janvier, May 1, 1891

1st May, 1891.

... Whether coming with praise or with blame and cast me to the perdition of the unrighteous, the critics all seem unable to take the true standpoint - namely, that of the poet. ${ }^{7}$ What has he attempted, and how far has he succeeded or failed? That is what should concern them. It is no good to any one or to me to say that I am a Pagan — that I am "an artist beyond doubt, but one without heed to the cravings of the human heart: a worshipper of the Beautiful, but, without religion, without an ethical message, with nothing but a vain cry for the return, or it may be the advent, of an impossible ideal". Equally absurd to complain that in 
these "impressions" I give no direct "blood and bones" for the mind to gnaw at and worry over. Cannot they see that all I attempt to do is to fashion anew something of the lovely vision I have seen, and that I would as soon commit forgery (as I told someone recently) as add an unnecessary line, or "play" to this or that taste, this or that critical opinion. The chief paper here in Scotland shakes its head over "the nude sensuousness of 'The Swimmer of Nemi', 'The Naked Rider', 'The Bather', 'Foir di Memoria', 'The Wild Mare' (whose "fiery and almost savage realism!' it depreciates - tho' this is the poem which Meredith says is 'bound to live') and evidently thinks artists and poets who see beautiful things and try to fashion them anew beautifully, should be stamped out, or at any rate left severely alone... .

In work, creative work above all, is the sovereign remedy for all that ill which no physician can cure: and there is a joy in it which is unique and invaluable... .

Memoir 185-86

To Theodore Watts-Dunton, May 7, [1891]

72 Inverness Terrace | Bayswater | W. | Friday, May 7th

My dear Watts

Many thanks for your kind and friendly letter. I have time only for the most hurried reply. I had to come over to London on private matters, and was about to return to France, when my wife unexpectedly came over, having been medically ordered to do so. She has been unwell for some time, and lately seriously. She is now gaining ground, but it will be a few weeks before she is herself again. An insidious form of 
low fever is the nominal cause. I am inclined to think she has never quite recovered from an attack of influenza last year: but besides this the arteries got harm from the bad drainage \& bad water in Provence.

We are going to Eastbourne at the beginning of the week for a fortnight $-\&$ that will do her much good, I expect.

Of course all our plans have been upset: and I do not know what we are going to do between the end of May and September, when we intend to go to Southern Germany [for] two months. As soon as we return from Eastbourne we are going to pay a short visit to George Meredith. It will be a pleasure to me to tell him how highly you appreciate his new book. Nothing has gratified me so much as the letter he wrote to me about "Sospiri di Roma". Curiously enough (considering author's vanity) I can't quite see why the short poem "The Wild Mare" is so fine as he would have it. He says it is "unrivalled in its kind, a superb bit of living verse", and that "it lives in him". I am delighted - but, as the Yankees say, I don't quite 'catch on'. By the way, I had such a friendly \& kind (though by no means 'palavery') note from Gosse. The book, of course, will bring me nothing in cash - tho' it has paid its expenses: but it seems to have struck many and divers kinds of people.

I know little of the Coulson Kernahan ${ }^{8}$ to whom you allude. He made a hit a year or so ago by a book (which first appeared serially in Lippincott's) called "A Dead Man's Diary". He is now settled in London, and doing good journalistic work. He is writing occasional papers on literary men of the day for The Echo and The British Weekly.

I have not yet overcome my Rome-sickness - and long to be back again. I loved Rome many years ago, and despite all the spoiling of it that goes steadily on I loved it this last winter \& spring more than ever.

I hope to see you when we are in town again. If, perchance, you shd. be in Eastbourne, you would find us at 6 Moslyn Terrace.

Ever yours sincerely | William Sharp

If my wife were 'up', or knew that I was writing, she would send cordial greetings.

ALS British Museum, typescript at Brotherton Library, University of Leeds 


\section{To Bliss Carman, [mid-July, 1891]}

Letter Address | 2 Coltbridge Terrace | Murrayfield | Edinburgh

\section{My Dear Old Man}

I wonder if this will reach you in New York, or if you are away somewhere on what must be a much needed holiday. If you are in or should be going to Nova Scotia give my love to dear old Roberts, ${ }^{9}$ who seems by the way to have quite forgotten me, as he has taken no notice of two letters I wrote to him from Italy, and has never acknowledged "Sospira di Roma".

I am writing this at Whitby, on the Yorkshire Coast, where I shall remain for the next six weeks, and hope to finish my long-delayed "Severn Memoirs". ${ }^{10}$ Then we go to Germany (Stuttgart). From there I hope to send you one or two interesting \& novel travel papers, in lieu of those I was supposed to have sent from Italy and Provence.

I hope the enclosed may suit you. It would no doubt interest a great many even among those who have never visited the Italian islands.

Best Greetings, old fellow, I from Yours Affectionately Ever I William Sharp

When are you going to publish your poems in Book Form?

ALS University of Iowa

\section{To The Editor, Blackwood's Magazine, August 21, 1891}

72 Inverness Terrace | Bayswater | London W. 21 Aug:91

Dear Sir:

On my return to England for a short time I find the enclosed among some MSS. which had accidentally been sent home, in the Spring from Rome, in a box. 
I shall be very pleased if it suit you; and I must ask your indulgence for its being sent in 'Pencil'. I am just finishing my long delayed Severn Memoir, and, moreover, go abroad again next week (Friday: from this address): and I have, consequently, too much to do to attempt copying: "The Second Shadow" ${ }^{11}$ However. My MS. is clear \&legible.

Yours very brief I William Sharp

If unsuitable, please return MS. (my only copy) to Miss Mary Sharp, 2 Coltbridge Terrace, Murrayfield, Edinburgh.

If accepted: And if proofs are sent anytime from the 1st till the end of September: my address will be bei Frau Leisewitz, Johannes Strasse 33, Wurttemberg, Germany.

ALS National Library of Scotland

\section{To Catherine Janvier, September 3, 1891}

Johannes Strasse 33, ${ }^{12}$ | 3:9:91.

... I know that you would revel in this glowing golden heat, and in the beautiful vinelands of the South. Southern Germany in the vintage season is something to remember with joy all one's life. Yesterday it seemed as if the world were one vast sea of deep blue wherever a great glowing wave of light straight from the heart of the sun was flowing joyously. I revel in this summer gorgeousness, and drink in the hot breath of the earth as though it were the breath of life. Words are useless to depict the splendour of colour everywhere - the glimmer of the golden-green of the vines, the immeasurable sunfilled flowers, the masses of ripening fruit of all kinds, the hues on the hill-slopes and in the valleys, on the houses and the quaint little vineyard-cots with their slanting red roofs. In the early afternoon I went up through the orchards and vineyards on the shoulder of the Hasenberg. It was a glory of colour. Nor have I ever seen such a lovely purple bloom among the green branches like the sky of faerieland - as in the dark-plum orchards. There was 
one heavily laden tree which was superb in its massy richness of fruit: it was like a lovely vision of those thunderclouds which come and go in July dawns. The bloom on the fruit was as though the west wind had been unable to go further and had let its velvety breath and wings fade away in a soft visible death or sleep. The only sounds were from the myriad bees and wasps and butterflies: some peasants singing in the valley as they trimmed the vines: and the just audible susurrus of the wind among the highest pines on the Hasenberg. There was the fragrance of a myriad odours from fruit and flower and blossom and plant and tree and fructifying soil - with below all that strange smell as of the very body of the living breathing world. The festival of colour was everywhere. As I passed a cottar's sloping bit of ground within his vineyards, I saw some cabbages high up among some trailing beans, which were of the purest and most delicate blue, lying there like azure wafts from the morning sky. Altogether I felt electrified in mind and body. The sunflood intoxicated me. But the beauty of the world is always bracing - all beauty is. I seemed to inhale it - to drink it in - to absorb it at every pore - to become it - to become the heart and soul within it. And then in the midst of it all came my old savage longing for a vagrant life: for freedom from the bondage we have involved ourselves in. I suppose I was a gipsy once - and before that "a wild man o' the woods".

A terrific thunderstorm has broken since I wrote the above. I have rarely if ever seen such continuous lightening. As it cleared, I saw a remarkably beautiful sight. In front of my window rose a low rainbow, and suddenly from right there was a bright steel-blue bolt, seemingly hurled with intent right through the arch. The next moment the rainbow collapsed in a ruin of fading splendours... .

I have had a very varied, and, to use a much abused word, a very romantic life in its external as well as in its internal aspects. Life is so unutterably precious that I cannot but rejoice daily that I am alive: and yet I have no fear of, or even regret at the thought of death. There are many things far worse than death. When it comes, it comes. But meanwhile we are alive. The Death of the power to live is the only death to be dreaded... .

Memoir 186-88 


\title{
To [Bliss Carman], ${ }^{13}$ September 3, 1891
}

\author{
Johannes Strasse 33 III | Stuttgart | Wurtemberg | 3:Sept:91
}

\section{My dear old man}

Thanks for your letter and enclosure, which reached me just before I left London for Holland. I am hoping that you are away in Villegiatura this divine month of September. If anywhere near dear old Roberts, ${ }^{14}$ give him my love: and say that I hope he duly received "Sospiri di Roma" with my letter. And by the way, if you come across C. F. Hall, ${ }^{15}$ tell him that I sent him a copy also. He wrote to me some time ago to say that he was sending or was going to send a copy of some magazine containing something about myself by him - but either it was not sent or it missed me. By the way, in your last note you said something about never having recd. back the photo of myself from the "Magazine of Poetry". My memory is confused about this: but you shall have another some day. Has any article about me ever appeared in the Mag. of Poetry? If so, I have not seen it.

How strangely one drifts about in this world. Not many days ago I was on the Yorkshire moors or along the sea-coast by Whitby: a few days ago I was in Holland, and rejoicing in the animated life of that pleasant 'water-land': last Sunday I was strolling by the Rhine or listening to the music in Cologne Cathedral. And now we are temporarily settled down in this beautiful Vine-land - in Stuttgart, the loveliest of all German capitals. It is glorious here just now. The heat is very great, but I delight in it. These deep blue skies, these vine clad hills all aglimmer with green-gold, this hot joyous life of the South enthralls me - while this glorious flooding sunshine seems to get into the heart and the brain. Even as a town Stuttgart is charming, with its old and new parts, and its magnificent Anlagen leading to Cannstadt. There is ample entertainment of all kinds-open-air concerts, the opera, \& so forth. But if you were here, we would leave the town, charming as it is, and go away on the tramp through the golden vinelands and up through the blue Alps of Suabia and Franconia. South Germany in the blithe season of the Vintage is one of the loveliest places in this beautiful world.

But no more South for us this year, once this golden month of September is over. Early in October we shall be in Nuremberg and 
thence rapidly north not only to Holland but to the far north of Holland - Helder and Hoorn on the Zuyder Zee. About the 20th of October we shall be in England again, as I have art-work that must be attended to. I shall then go off by myself for one of my vagrant gipsy-tramps - either in the west of Scotland (probably round the Island of Arran) or else through the Fen-lands, or perhaps loaf on the upper Thames Reaches. Thereafter I shall be in or close to London, and working very hard.

And now for some good news: in all probability I shall see you and other friends in New York at the end of January or beginning of February. But please meanwhile keep this to yourself: for, until my plans are more decided I do not wish my intended visit known even to friends. I intend to go a-lecturing for about two months in the States. It will be a great happiness to see you again, old fellow, and I look forward to seeing you among the first friends - you, and the Stedmans, and the Janviers, and H. W. Alden. ${ }^{16}$

Thank heaven, I have at last finished my long-delayed Severn Memoir. ${ }^{17}$ The book will be out in November probably.

I don't know if you ever print humourous verse. If so you may care to print the following parody of Hamlet's famous speech, by "Joseph Severn the friend of Keats" àpropos of Etching, at the time when that art first began to be practiced in England by the modern school. I asked my copyist to make a double version of it: so I can send you one herewith. If printed, it would of course, have to appear before the issue of the book - which, however, cannot be till the beginning of November at the earliest.

You say you send me your latest experiment - "an overgrown lyric": but unfortunately you only say so, for there was no enclosure save the cheque. I look forward to your poem on Shelley. ${ }^{18}$

I doubt if New York or neighbourhood will be particularly pleasant at the beginning of February - but still we must manage a day out of the city somewhere. For myself I love, too, the solitude of nature in the days of deepest winter.

But whether in the north or south I often bear you in loving remembrance: as I hope that you too do,

Your affectionate friend, I William Sharp 


\section{To Horace Scudder, September 18, 1891}

Letter address: 72 Inverness Terrace, Bayswater, London, W.

Johannes Strasse 33 III | Stuttgart | Würtemberg | 18th Septr |91

Dear Mr. Scudder,

As you will have surmised - imperative reasons have interfered with the appearance of the Severn Memoirs: but at last the book is in the printer's hands. My wife's serious illness, and our frequent journeyings this year, together combined against my getting on with "Severn" or sending you one of the promised articles.

But today I have sent you one that I think you will be pleased to have. You can call it what you like: I name it simply "A Batch of Letters".$^{20} \mathrm{I}$ have, you will see, adopted your suggestion, and kept the explanatory text succinct as practicable. The mere fact that it contains the first letters written in Venice by the sculptor Westmacott ${ }^{21}$ the painter Geo. Richmond R. A. ${ }^{22}$ and by Mr. Ruskin ${ }^{23}$ - a long and important epistle - would make it interesting: but there is other readable matter. The letters of that remarkable man Seymour Kirkup ${ }^{24}$ will be read eagerly by many Americans as well as English - for he knew literally hundreds of your countrymen in the course of his long life in Italy.

I think the article is not beyond the limits you gave me. If too long, you can strike out Severn's letter etc. to Unwin's ${ }^{25}$ at pp 17 to $17^{\mathrm{c}}$.

Messrs. Sampson Low Marston \& Co. are to publish the book, and they have suddenly put a swift step forward and wish to get the book out in November if practicable, probably about the middle of that month or about the 25th. Hence my telegram to you today, which I would have made more explicit, but for the heavy charge: however, I daresay it will be plain to you, giving you notice, as it occurred to me that the MS. might arrive so late as to cause you inconvenience.

I thought the book would be out early in 1892. Owing to this sudden change, and pressure, I can send off only one Severn article - so the two other magazines which wanted a "Correspondence" article must perforce go without. 
I am writing this from Germany, but I hope this letter and the MSS. will reach you with not more than a day or so's delay than if sent from England.

You shall hear from me further either by the same or the next post: but meanwhile I hurriedly close, so as to be sure of this one.

Faithfully Yours, I William Sharp

ALS Harvard Houghton

\section{To Horace Scudder, September 19, 1891}

Letter address: 72 Inverness Terrace, Bayswater, London, W.

Johannes Strasse 33 III | Stuttgart | Wurtemberg | 19th September |91

Dear Mr. Scudder,

Yesterday I wrote to you, and sent my MS. Batch of Letters, ${ }^{27}$ to be used, if practicable, in your November issue.

I had not time to add that (chiefly owing to technical matters connected with illustrations, and questions of outlay etc). it was decided that the Severn Memoirs would be issued in one instead of its two bulky volumes. This involved a complete reconstruction of the book, and, as I have found to my cost, a complete reconstruction of that reconstruction. In accomplishing this I not only removed over 500 MS. pages of unnecessary though often most entertaining matter, but have practically done away with the record of Severn's life during close on 20 years, the period which he himself thought, and in his experience undoubtedly was, the most interesting of all. This is his Consular period. It was impracticable to steer a middle course with so eventful a period and with so much interesting material to draw upon: and as it was impossible to give the record adequately I have preferred to reduce it to a few sentences, leaving it to be understood that I shall 
make up for this omission elsewhere. When Severn went to Rome in 1861 as Consul (for the "King of Sardinia" as well as for Great Britain), the Temporal Power was daily falling away: there was constant friction between the French and the Roman troops and citizens; in the North there were the advancing shadows of Victor Emmanuel and Cavour and "United Italy", in the South the more ominous shadows, Garibaldi and Republicanism. In Rome itself the Pope was plotting against Italy, the Catholic Ambassadors against the Pope, Cardinal Antonelli against everybody: and in the city were daily broils, murders, and violent perturbation. Severn was an indefatigable diarist, and his daily record is unbroken all through the eventful years (a social and artistic and general as well as a political record) till that eventful year when Italy became one the Great Powers, and the Sovereign of "The United Kingdom", though excommunicated, walked safely to and fro through the streets of Rome: when France declared war against Prussia, and the Pope decreed his own infallibility; and when, as Severn relates with half unconscious anticlimax, a lady was elected to the chair of Literature at Bologna! Nor was he a whit less scrupulous as a diarist from 1870 onward till a few weeks before his death in 1879 .

It is my intention now, therefore, to take the honey out of these diaries, and publish the matter irrespectively of my Severn Memoirs. But as I think of, in the first instance, going further back so as to include some of the striking episodes which I have been unable to interpolate in the Memoirs, it may be necessary for me to throw these "Incidents in the Life of Joseph Severn" into two sequent articles. ${ }^{28}$ However, I shall be better able to judge a week hence. You certainly shall have it or them, if you wish - though I would need to know before very long, as it would be as well to print them on the wave of new interest about Severn which will be excited by the Memoirs. I should add that the Diaries contain many gossipy amusing anecdotes.

I have also kept out the great bulk of Chas. Armitage Brown's letters, for separate use: and other correspondence. These I shall probably print elsewhere, unless you have any special reason for wishing to see them.

I have not forgotten my promise to send you a copy of Severn's portrait of Keats, and you shall have it yet.

I am at present in Stuttgart collaborating with Blanche Willis Howard in a novel of a new and peculiar kind - but please keep this piece of 
personal news strictly to yourself. ${ }^{29}$ We hope to score both a literary and a monetary success with our venture, which is nearly un fait accompli.

It is possible (and here again I have to obtrude my claim for privacy) that I may be in Boston early in 1892, and I look forward with great pleasure to the prospect of making your acquaintanceship in person.

With kind regards, I Yours faithfully, I William Sharp P.S. I enclose a poem which I wrote a short time ago. Perhaps you may give it a haven in the Atlantic M..$^{30}$ If you do not care for it may I ask you to return it to me at your earliest convenience.

ALS Harvard Houghton

To Edmund Clarence Stedman, [late September, 1891 ${ }^{31}$ ]

72 Inverness Terrace | Bayswater | London $\mathrm{W}^{32}$

Johannes Strasse 33 III I Stuttgart I Wurtemberg

My dear Stedman,

When I wrote to you for your birthday last year I was in Scotland somewhere - at a place called St. Margaret's, if I remember rightly and this time it is from South Germany, from pleasant Stuttgart. But not less cordially and affectionately than then do I send you, my dear fellow, my heartiest greetings and good wishes. If loving remembrance could keep you and your dear wife and Arthur from any avoidable ills of life you would be safe from harm. It would be unflattering as well as commonplace to say that I often think of you - for of course I do: but I would have you understand that I would at times snatch an hour for the purpose of writing to you were it not that I know your time to be so terribly exploited by correspondence - so that even letters not requiring an answer are extra burdens, however pleasant. Some time ago I nearly launched upon you a long letter, with pages of a new dramatic poem, 
but remembering how it would help to tire your eyes and perhaps reach you when you were busy with original work, I tore it up, or so much of it as was done.

But I cannot let your birthday go past without a brief word. You and yours occupy a suite of rooms in the mansion of my heart - and strangers have at any time only to mention the word 'Stedman' and they are open to them too.

Someday my wife and I hope to have you and your wife as welcome guests - though we are still vagrants on the face of the earth. I think I told you that after Italy we went to Provence, and thence meant to go to the Forest of Fontainebleau for the summer - but my wife became unwell, from a kind of low fever as we thought, but possibly an unpleasant kind of influenza - and so we crossed to England. A few weeks at Eastbourne set her up again. Then I went to Scotland, and we met later at York. Then we went for nearly two months to Whitby on the Yorkshire Coast: and thence at the end of August to Holland. We came to Stuttgart about three weeks ago: and shall be here till mid-October, when we go to Amsterdam for a few days and then back to England.

I am here for a literary purpose - though please keep this news to yourself meanwhile - i.e. collaborating with our charming friend Blanch Willis Howard (von Teuffel) in a novel. It is on perfectly fresh and striking lines, and will I think attract attention. We are more than half through with it already. She is a most interesting woman, and is of that vigorous blond race of women whom Titian and the Palmas loved to paint, and whom we can see now in perfection not in Venico but at Chioggia, further down the Adriatic. But if I fall too deeply in love, it will be your fault - for it was you who introduced me to her! I told her about your birthday, and I think she is going to send you a line of greeting. We see each other for several hours daily, or nightly, and well, literary life has its compensations! But our affectionate camaraderie is as Platonic as - say, as yours would be in a like instance: so don't drag from its mouldy tomb that cynic smile which lies awaiting the possible resurrection of the Old Adam! Your ears must sometimes tingle as your inner sense overhears our praises of you as man and writer.

You know of course your cognate Old-English surnames, 'Stedman' 'Steadfast' and 'Standfast'. I have made an "epigramicle" thereon as a birthday-greeting for you. Have you ever heard the phrase "he's stead" or "he's a stead-man"? I fancy it lingers only in Yorkshire and perhaps 
the northern counties. A 'stead-man' is a man not to be daunted - and is distinct from 'steady', which in the north means rather 'prosperous' or 'financially sound', 'sure'.

And now for my other piece of news - which also, by the way, I presume had better not get about for the present.

You may see me in the latter half of January! In other words, I think of giving some lectures (so as 'to raise the wind' - a process urgently needful!) in America during February \& perhaps the first half of March. I have heard that New York is not so "lectory" a place as other cities, so I had best leave it out of my calculations, I suppose. But I think of throwing this unparalleled and magnificent chance of intellectual development to the citizens of Boston, Philadelphia, Baltimore, Cincinnati, Chicago, Buffalo, Albany, \& perhaps elsewhere.

It is my present intention to leave England somewhere about the 10th of January; and it depends on lecturing-circumstances whether I go first to Boston - or, as my heart prompts, to New York. If I go first to New York, may I find shelter with you for the night of my arrival \& perhaps the following day?

And now, amico mio, will you help me in this scheme if you can? A good deal depends upon my being able to carry it out - but this you will understand, as otherwise I would not go in for it.

If you can possibly spare me time to answer the following - or if your eyes are troubling you, perhaps Arthur in the goodness of his heart may do so for you.

1) Do you know any good lecturing-agents in whose hands I could put myself?

2) How should I apply?

3) I think of lecturing thrice a week, evenings. I might also lecture occasionally at some Ladies College or Institute in afternoons.

4) Approximately, what terms should I expect?

5) I suppose Lectures in America, as here, extend to about an hour?

If in any way you can further my aims in this respect you will do me a material service. Could you, for instance, put me "on the lines" at Baltimore? 
Perhaps you will be able to send me a line soon - as I have many necessary arrangements to make. Here is my tentative List of Subjects:

I. The Preraphaelite Movement in English Arts and Literature: What it was, and its influence.

II. Dante Gabriel Rossetti: The Man and the Artist,

III. Dante Gabriel Rossetti: The Poet, and His Circle: Theodore Watts: Wm. Bell Scott: Philip Marston: O'Shaughnessy: Oliver Madox Browne: John Payne: etc.

IV. Swinburne

V. George Meredith.

VI. The Aesthetic School: What it really means and is.

VII. Critics and Criticism.

VIII. Poets and Poetry of Today

IX. On Catholicity of Taste in Literature

X. Literary Education: What it means.

XI. Current Tendencies in Art and Literature

XII. Our Women Poets

XIII. Women as Novelists

XIV. Episodes of the Literary Life (Possibly)

Which of these do you think likeliest to "take' in America? In a word, suggest to me what you can.

What a shame to land all this upon you. But your big heart will forgive \& understand.

Love to you all. I Your affectionate friend I William Sharp ALS Private 


\section{To Bliss Carman, October 15, 1891}

Oct. 15,1891

\section{Amico Mio,}

This is only a flying p $\mid \mathrm{c}$ as I am leaving Germany to return to England.

Do you remember that story "The Second Shadow"? $?^{33}$ If it has not perchance found a haven, please oblige me by sending it for me to Maclure ("Syndicate Maclure" - N. Y. Tribune Offices) and ask if he will buy it for his syndicate. He knows me. I think $£ 5 \mathrm{wd}$. be a fair price - tho' he may give more. It would come in well at the Xmas or New Year 'bogey-story' season.

In great haste | Yours ever | William Sharp

ACS Smith College Library

\section{To Richard Le Gallienne, [late October, 1891]}

72 Inverness Terrace | Bayswater | London I W

My dear Mr. Le Gallienne

I have returned, for a time, from abroad ${ }^{34}$ - to find that many interesting things have happened during my absence other than those I chance to have heard of: and among them the publication of your "Bookbills of Narcissus". ${ }^{35}$ And I might not have seen it at all, but that I have been staying with George Meredith. This morning I found your book on Miss Meredith's table, and dipped into it with great interest. Since I came to town today I have tried to obtain a copy but in vain. If the book is not sold out, will you be so good as to send me a copy, and at the same time let me know the amount of my indebtedness. Miss Meredith also informed me that you were about to be married: perhaps 
by this time you already are. ${ }^{36}$ If so pray accept my cordial good wishes for you both, and for that other welfare which I know is so dear to you.

Sincerely Yours | William Sharp

ALS University of Texas at Austin

\section{To H. Buxton Forman, November 6, [1891]}

16 Winchester Road I Swiss Cottage N. W. | Friday Evening | Nov. 6

\section{My dear Sir}

I find on looking at my notes that there are no Trelawny letters belonging to or in the care of Mr. Rayner Storr. I may be wrong in thinking that you said his names were rightly Edward John and that the letters you have are signed E.J. I have letters signed both E.J. and J.E. and "Edward Trelawny" - and one simply "Trelawny" ${ }^{37}$ I enclose one signed J.E. for your inspection. Pray let me have it again at your early convenience. ${ }^{38}$

If you have any notes concerning persons directly "inspired" by Keats's writings, possibly you may be able to tell me something of the author of a romance called "Titian"; written circa 1840 (presumably). It is an interesting "Keatsian" letter - but only the first four pages have been preserved. It is dated Oxford 1844 and bears an extraordinary resemblance to Mr. Gladstone's ${ }^{39}$ handwriting of that period: but though W. E. Gladstone did become intimate with Severn in the early 'forties there is no record of his having published any work of this kind. The Severns cannot tell me anything of the writer: the letter I found among a batch of some 20 to 30 notes by Mr. Gladstone - presumably placed there by Walter ${ }^{40}$ or someone on account of the already alluded to resemblance in handwriting. I have vainly sought for the author's name or the book at the Brit. Museum, and with the friendly help of R. Garnett and W. A. Fortiscue. ${ }^{41}$ 


\section{To Elizabeth A. Sharp, November 9, 1891}

Grosvenor Club, I Nov. 9th, 1891.

... I have been here all day and have enjoyed the bodily rest, the inner quietude, and, latterly, a certain mental uplifting. But at first I was deep down in the blues. ${ }^{42}$ Anything like the appalling gloom between two and three-thirty! I could scarcely read, or do anything but watch it with a kind of fascinated horror. It is going down to the grave indeed to be submerged in that hideous pall... . As soon as I can make enough by fiction or the drama to depend thereon we'll leave this atmosphere of fog and this environment of deadening, crushing, paralysing death-inlife respectability. Circumstances make London thus for us: for me at least - for of course we carry our true atmosphere in ourselves - and places and towns are, in a general sense, mere accidents... .

I have read to-day Edmond Schérer's Essais on Eng. Literature: ${ }^{43}$ very able though not brilliant - reread the best portions of Jules Breton's delightful autobiography, ${ }^{44}$ which I liked so much last year... all George Moore's New Novel, Vain Fortune.

I had also a pleasant hour or so dipping into Ben Jonson, Beaumont and Fletcher, and other old dramatists: refreshed my forgotten acquaintanceship with that silly drama "Firmilian": 45 and, generally, enjoyed an irresponsible ramble thro' whatever came to hand. I am now all right again and send you this little breath, this little 'Sospiro di Guglielmo' to give you, if perchance you need it, a tonic stimulus. No, you don't need it!

Memoir 192-93

To Bliss Carman, December 8, 1891

16 Winchester Road | Swiss Cottage | London N.W. | 8| December | 91

My Dear Old Man 
It is with a thrill of keen pleasurable anticipation that I let you know of my speedy visit to New York: for I have taken my passage by the "Teutonic", due to sail from Liverpool on Wedny, Jany 6th - and so may expect to be in New York City somewhere about the 12th or 13th, for I suppose the midwinter passages are about a day longer than those of the summer season.

It will be a delight to see you again. What a lot we shall have to talk about.

I have postponed all lecturing for this year. I am going out partly to attend to some private literary business, best seen to on the spot; partly to arrange for the bringing out in America of a play of mine which is to be produced here; and partly to get a glimpse of the many valued friends and acquaintances I have in N.Y. and Boston. I shall be in N.Y. for three weeks at any rate. Perhaps later on, say in your issue for the first week in January, you will be able to oblige me by inserting in the Independent a para to the above effect: as this would save me letting a lot of people know, and enable me to economise my limited time. My first movements when I do get to N.Y.C. are as yet uncertain: perhaps the safest address wd. be c/o Thos. A. Janvier, 20, Seventh Avenue, (although I may go direct to the Stedman's at first).

Is there any chance of old Roberts ${ }^{46}$ being in N.Y. in the middle of Jany? If you see Mr. Clarence Bowen, ${ }^{47}$ pray tell him that I look forward to seeing him again. You might add that Mrs. Coleridge was with us yesterday, and was asking after him.

George Cotterell was much gratified by your friendly and appreciative letter, and I too thank you for it.

Herewith I enclose two short poems which I hope you may be able to use.

$\mathrm{Au}$ revoir, dear Carman,

Yours Ever | William Sharp

P.S. My long delayed "Severn" is at last practically off my hands, and will be pubd. in the latter part of Jany. 


\section{To Catherine Janvier, [December ?, 1891]}

... You will be the first to hear my new imaginative work. Although in a new method, it is inherently more akin to "Romantic Ballads" than to "Sospiri", but it is intense dramatic prose. ${ }^{48}$ There is one in particular I wish to read you - three weeks from now... . Do you not long for the warm days - for the beautiful living pulsing South? This fierce cold and gloom is mentally benumbing... . Yes you are right: there are few women and perhaps fewer men who have the passion of Beauty - of the thrilling ecstasy of life.

Memoir 193

\section{To Horace Scudder, [? early December, 1891]}

72 Inverness Terrace I London W.

I enclose as a "Xmas Card" the long promised photo of Keats, after the drawing by Severn which he regarded as the truest likeness of the poet.

Dear Mr. Scudder,

Your foresight proved correct - for the December number of the Atlantic Monthly has been out some time, and the Severn Memoirs are as yet unborn. ${ }^{49}$ The trouble over the illustrations, and the need to include some important early-period matter, necessitated unexpected delay: and a week or so ago it was decided that the book should be held over till sometime in January. I hope the article has interested your American public: that in this country seems very appreciative. Let me acknowledge again with many thanks the cheque duly remitted to me a short time ago.

The publishers seem to expect a large demand for the book - and in America two leading firms have, I understand, applied for 'an edition'. I am as sorry as the Severns, and other friends and interested persons, at the necessity I have been under of giving the purest bird's-eye-view of Severn's consular years in Rome - but it was imperative that I should 
avoid entering upon so large and complex a part of his life. There was no course between extreme constriction and adequate detail - and the latter was impossible owing to the scheme of the Memoir as finally arranged. However, I may write a supplementary volume.

If practicable, within the next fortnight or 3 weeks I shall send you the promised "Unpublished Incidents in the Life of Joseph Severn" (or such title as you prefer $){ }^{50} \mathrm{I}$ am glad there is a chance of these reminiscences appearing in a conspicuous place - for it appears that many people both in America and here are mainly anticipating the record of Severn's consular life (partly, no doubt, after Ruskin's splendid eulogium of him in Praeterit $^{51}$ ) - which is, so far as the book is concerned, regrettable.

I hope to leave for America (this time without my wife, I regret to say) on the 6th of January, by the Teutonic; due at New York somewhere about the 13th. I have postponed lecturing till another year: and am coming out only to visit some friends, and to attend to some private matters of my own. I expect to be about three weeks in New York in all, and, if practicable, a week in Boston. Indeed, I should go there if only to have the pleasure of making your acquaintanceship in person, if you are certain to be there. If business or pleasure should take you to New York in January (after 14th), and you could afford me the pleasure of an interview, I could always be heard of (if not found at!) E. C. Stedman's or at Thos. Janvier's, 20, Seventh Avenue.

With cordial Greetings for Xmas and the Coming Year -

Sincerely Yours, I William Sharp

ALS Harvard Houghton

To Horace Scudder, December 29, 1891

72 Inverness Terrace | Bayswater | 29th Dec|91

Dear Mr. Scudder,

Fortunately I have been able before my departure for America to complete the double-article comprising excerpts from the Roman diaries of Joseph Severn. ${ }^{52}$ 
I found it wd. be impracticable to cover the whole period (1861-1879), so chose the most eventful, that of the decade (1860-1870) wherein the Papal Temporal Dominion collapsed. All the matter I send you is untouched in my book (for which already, I am glad to say, there is a great demand in advance) and otherwise unpublished - with the exception of Baron Bunsen's letter given at page 1a. This, it seems to me, shd. be retained: but as you will.

I have done my utmost to restrict the length to your article-limit. The complete MS. represents, so far as I can calculate, from 15,000 to 16,000 words. Probably one article of 7,500 words and one of $8,000 \mathrm{wd}$. represent it. (I think the inset marginalia shd. be retained?)

But I leave you a free hand to curtail when you think advisable. I have endeavoured to compile a generally interesting Olla Podrida $a^{53}-$ as a purely political-excerpt article $\mathrm{wd}$. be heavy perhaps. The personalia about Cardinal Antonelli, ${ }^{54}$ John Gibson, ${ }^{55}$ Oberbeck, ${ }^{56}$ the Americans Miss Cushman ${ }^{57}$ and Miss Hosmer ${ }^{58}$ etc. etc. come in well, I daresay you will agree with me.

I leave here next Wednesday (6th) per "Teutonic" and expect to be in New York by the 12th or 13th at latest. My letter-address there is c/o Mr. Tho. A. Janvier, 20, Seventh Avenue, N. Y. City.

In haste, and with all good wishes for 1892,

Cordially Yours, I William Sharp

P.S. I have not divided the article, leaving this to you to decide. The title, by the way, can be whatever you like.

The Severn book is ready - and will probably be issued circa Jany 20th.

M.S. by Registered Book-Post Herewith.

William Sharp 



\section{Chapter Eight}

\section{Life: January-June, 1892}

Sharp left for America on January 6 aboard the Teutonic and arrived in New York a week later where he stayed initially with the Stedmans at 173 West 78th Street. Through his friendship with the Stedmans and others who he met during his first visit to New York in 1889, he had immediate access to the literary and publishing elite of the city. Chief among them was Richard Henry Stoddard, a poet and man of letters who with Stedman presided over the literary life of the city. Stedman also arranged for Sharp to meet J. M. Stoddart who edited the prestigious Lippincott's Monthly Magazine in Philadelphia. When Sharp wondered if it might be possible to meet Walt Whitman, who lived in Camden, New Jersey across the Delaware River from Philadelphia, Stedman's son Arthur, who knew Whitman, offered to write a letter of introduction. Whitman was a revered figure in the literary circles Sharp frequented in London, and the possibility of actually meeting him was enormously attractive. After arriving on Wednesday, January thirteenth Sharp went by train to Philadelphia on the fifteenth and the next morning he called on Stoddart to discuss possible articles for publication in Lippincott's. When Sharp said he hoped to meet Whitman, Stoddart immediately contacted Horace Traubel who clerked in a nearby bank.

A handsome man of thirty-four who was himself a poet, Traubel was Whitman's principal caretaker and would become his literary executor and biographer. He is best known for transcribing and compiling nine volumes of daily conversations entitled With Walt Whitman in Camden. 
His main concern in 1892 was keeping Whitman in good health and good spirits. Unable to get his letter of introduction to Sharp before he left New York, Stedman sent it to a Philadelphia bookseller for Sharp to retrieve. Traubel said a letter of introduction was unnecessary and offered to take Sharp to Camden that afternoon to meet Whitman who was bedridden, but able to receive guests. Sharp described the visit in a letter to his wife. Whitman was lying in "his narrow bed, with his white beard, white locks, and ashy-gray face in vague relief, in the afternoon light, against the white pillows and coverlet." They discussed the London literary scene, and Sharp assured the ailing poet he was revered by many British writers. In his parting words, Whitman gave Sharp a mission::

William Sharp when you go back to England, tell those friends of whom you have been speaking, and all others whom you may know and I do not, that words fail me to express my deep gratitude to them for sympathy and aid truly enough beyond acknowledgment. Good-bye to you and to them - the last greetings of a tired old poet.

Two months after Sharp's visit, Whitman died.

After returning to New York, Sharp continued meeting with publishers and friends. On Friday, he crossed the Hudson River with Henry Mills Alden, editor of Harper's Magazine, and spent the weekend with his family in Metuchen, New Jersey. On Monday, he returned to the city with Alden and boarded a train to Boston to meet with Horace Scudder, editor of the Atlantic Monthly. On Tuesday or Wednesday in Cambridge, he visited Louise Chandler Moulton who was frequently in London and shared Sharp's affection for the Marston family, especially Sharp's friend Philip Marston who died prematurely in 1887. He had considered extending his stay in America to talk with more editors and publishers, but shortly after arriving in Boston he received word of his younger brother Edward's unexpected death and decided to sail for home as planned the following Wednesday, February 3. He returned to New York on Thursday and spent the night with Arthur Stedman. On Friday he moved to E. C. Stedman's house, and on Saturday evening had dinner with Mrs. Thomas Harland, the mother of Henry Harland, an American writer and a good friend who was living in London. During the weekend he met again with Henry Alden and, in a letter thanking Scudder for his hospitality, reported Mrs. Alden's health was 


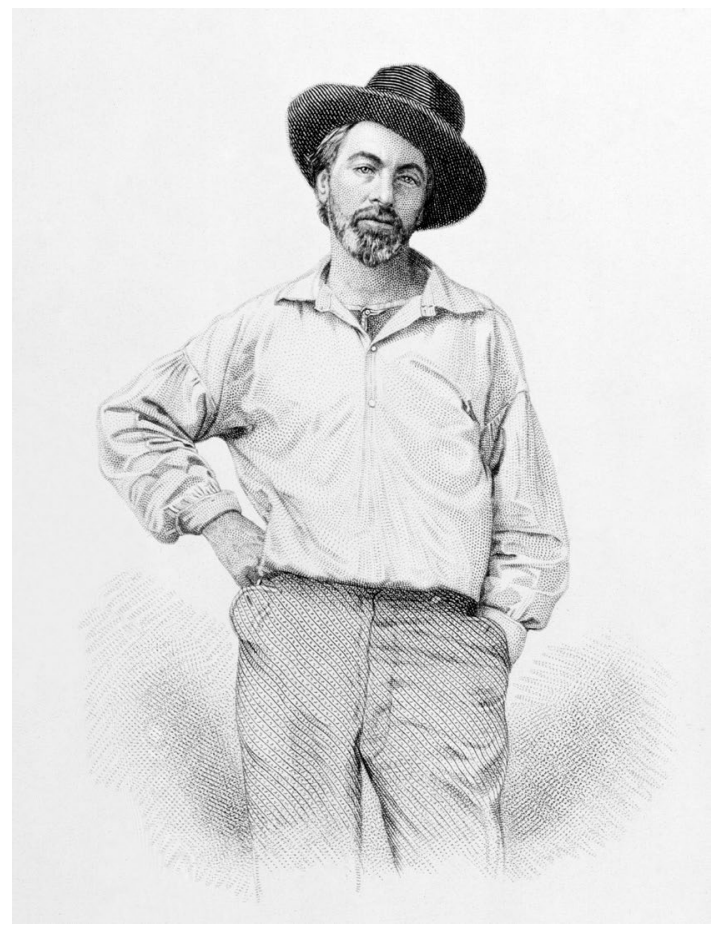

Fig. 10. Walt Whitman, aged 37, from the frontispiece to Leaves of Grass (Fulton St., Brooklyn, N.Y, 1855). Steel engraving by Samuel Hollyer from a lost daguerreotype by Gabriel Harrison (1854), Wikimedia, https://commons.wikimedia.org/wiki/File:Walt_Whitman,_ steel_engraving,_July_1854.jpg, Public Domain.

deteriorating. Scudder and Alden met as undergraduates at Williams College and remained life-long friends. On Tuesday he moved to a midtown hotel and boarded the Majestic early the next morning.

Despite its sad ending, Sharp's eighteen-day visit in the United States was both pleasant and productive. He solidified his friendships with the editors of Harper's Magazine, The Atlantic Monthly, and The New York Independent and met the editor of Lippincott's Monthly Magazine. He gained a better idea of the kind of articles and poems they would publish and discussed various writing projects. Like so many British writers Sharp wanted to take advantage of the growing American market, to increase his income. He received an offer from a leading American theatrical manager to buy the rights to the play he was writing based on A Fellowe and His Wife. Through Arthur Stedman, he negotiated successfully with Charles Webster and Company for the 
American publication of Romantic Ballads and Sospiri di Roma in a single volume that appeared in the latter part of 1892 as Flower o' the Vine. Sharp wanted his friend Bliss Carman, a fellow poet, to write the introduction to the volume, but Stedman preferred another friend of Sharp's, Thomas Janvier, a short story writer, not a poet, but better known than Carman. Sharp relented and informed Stedman that Janvier would write the introduction if properly compensated. A deal was struck, and Janvier produced a glowing introduction for which Sharp was grateful.

After a rough mid-winter crossing, Sharp arrived in Liverpool on February 10 and spent a few days recuperating in London before going north on February 14 to comfort his mother. In Edinburgh, he explained in a letter to Arthur Stedman why he was not enthusiastic about giving his next book, which he now called "Dramatic Vistas," to Charles Webster as a follow-up publication to Flower o' the Vine. Acting as an agent for Webster and Company, Arthur had written to say Sharp's reluctance in this regard was "shabby." Sharp said he did not wish to issue these "new things in a new dramatic form" in an ordinary way, but in a small privately printed edition and under a pseudonym. He was convinced the lukewarm reception of his Romantic Ballads and Sospiri di Roma was due, at least in part, to his reputation as an editor and to enemies he made as a reviewer.

I have my own reasons for wishing to issue them in this way in the first instance. They are new in method and manner, and are, I believe, the best work of the kind I can do. Work of this kind is so dear to me that I am relatively indifferent to its financial success: and, in addition, I am particularly curious to see how these "Dramatic Vistas" will be received, without any of the bias for or against involved in the attachment of my name to them.

He said C. L. Webster could publish a trade edition of the book as by William Sharp, but only after he issued a small private edition for friends and reviewers under the pseudonym H. P. Siwaarmill, an anagram for William Sharp. When he was in Germany working with Blanch Willis Howard on A Fellowe and His Wife in October 1891, he purchased Maurice Maeterlinck's La Princess Maleine and Les Aveugles, read straight through them, and, in his diary, called their author a "writer of singular genius." Over the next two days, he produced under the influence of Maeterlinck five "Dramatic Interludes" and 
decided to publish them under the pseudonym. In February 1892 the five short dramas had grown to eight entitled Dramatic Vistas, and when the book finally appeared in 1894 it became simply Vistas with William Sharp as author.

Back in London by February 19, Sharp thanked Thomas Janvier for a copy of his recently published The Uncle of an Angel, and Other Stories and said he was planning to settle down in London for a period of intense writing. He had finished his "Dramatic Vistas," some of which he read to Catherine Janvier in New York. In a letter of February 23, he told Laura Stedman he had rented rooms at 11 Bedford Gardens, near Campden Hill in Kensington which had a studio where Elizabeth, who had many friends in the area, was doing some painting. They took the rooms for only a brief period because they planned to rent "a cottage or small house somewhere in the country - probably at a place a few miles north of Cookham Dene and the Woods of Waldegrave." They would remove all their books and furniture from storage, and "either live in it for weeks at a time, or for a day or two as the humour takes us, or either of us." The house would provide a retreat where Sharp could focus on "more serious and lasting work," but it would have to be near London so both Sharps could continue writing and reviewing for the periodicals and papers.

In late February or early March Sharp's Life and Letters of Joseph Severn finally appeared, and in March, A Fellowe and His Wife was published by Osgood, McIlvaine \& Company in London and Houghton and Mifflin \& Company in Boston. It was issued simultaneously in Germany in the Tauchnitz Collection of British Authors. In March Sharp visited Thomas Hardy in Dorset, a visit that resulted in an article on Hardy in the July Forum. Sharp had also made a new friend, J. Stanley Little, an art critic who lived with his brother George Leon Little, a painter, in Bucks Green, a small village in Sussex. In a letter of March 9, Sharp asked Little if he knew of any cottages or small houses (two sitting rooms, four bedrooms, and near a station) available for a modest rental. He would come down and see anything that might be available.

By mid-April, the Sharps had given up their rented rooms in Kensington. The return address on his April 13 letter to E. C. 
Stedman - 16 Winchester Road I Swiss Cottage - was the home of Edith and Frank Rinder. He told Stedman he was about to go to France for some weeks and continued: “The 'Old Adam' calls me, and alas I am weak." Elizabeth, he said, had gone with friends to the Isle of Wight for a week or so and would join him in Paris "three weeks hence." He added this passage: "My love to Mrs. Stedman - but do not let her know that I am a backslider, as she already has but an indifferent opinion of my much tried virtue. I really am going to reform - but 'owing to unavoidable circumstances' must not begin all at once or too hurriedly!" It is hard to read such a passage without speculating that Elizabeth and William, in all their moving about and absences from each other, were attempting to adjust to the presence of Edith Rinder in their lives, trying to make room and find spaces for Edith and William to be together. Some of his letters from France imply Edith was with him for at least part of his first two weeks in France. Sharp's desire to be alone for periods of time with Edith, which Elizabeth seems to have accepted, must have been a factor in the plans for a house in Sussex.

Before he left for Paris Sharp returned the proofs of the "Sospiri di Roma" section of Flower o' the Vine to Charles Webster along with the manuscript of a new poem entitled "Epilogue I Il Bosco Sacro I To ." In the letter accompanying the proofs, he said he would not "let Sospiri appear again without the 'Epilogue' - which, to my mind, is one of the most essential things in the book." It is a love poem in which Sharp adopted the voice of the feminine Dusk "on the dim Campagna" who is "hushfully seeking I the Night, her lover." Silence reigns until
Suddenly...... thrilling
Long-drawn vibrations!
Passionate preludes
Of passionate song!
$\mathrm{O}$ the wild music
Tost through the silence.

But the music recedes, and the stillness returns. It was too "wild" and "sweet" to last. Dusk recalls the day when "Together we gather'd I The perfect blooms," but "Here is one only I Longing forever, I Longing, 
longing I With passion and pain." The voice of the Night remains silent until finally it returns in rapture:

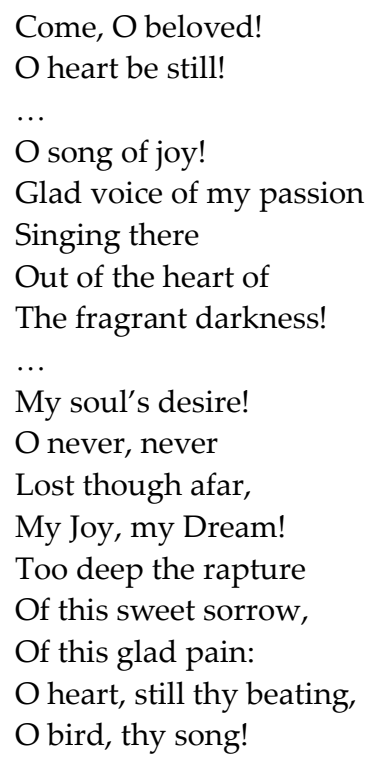

Her soul's desire is "afar," but she hears, or recalls, his "song of joy" emerge from the darkness. The "Joy" and "rapture" was too sweet to disappear despite the distance. The dedicatee following the title was left blank, but surely the poem was intended for Edith Wingate Rinder who, after she returned from Italy to London, was "afar," but "never lost."

Sharp's insistence on adding the "Epilogue" while omitting the "Preface" to the 1888 Romantic Ballads and Poems of Phantasy is significant. The "Preface" announced the dawn of a new Romanticism in which imagination would take precedence over formal perfection in poetry. The poems in that volume initiated the dawning age, but his next volume would reflect its full glory. "I am tortured by the passionate desire to create beauty, to sing something of the 'impossible songs' I have heard, to utter something of the rhythm of life that has most touched me." The next poems "will be daringly of the moment, vital with the life and passion of today, yet not a whit less romantic." Three years passed before he was able to realize that objective in a burst of creativity in Rome. The "Epilogue" added to the sospiri section of Flower o' the Vine typifies the sensuousness that 
infused those poems but was absent in the volume's first section, the romantic ballads of the 1888 volume. Influenced by the nude statuary in and around Rome and by the frank sexuality he experienced or, more likely, imagined during his walks on the Roman Campagna, the "beauty' he sought in the sospiri poems included that of the human body framed by the beauty of the natural world. The two sections of Flower o' the Vine reflect what Sharp viewed as a progression from the elusive romanticism announced as a "new movement" in the 1888 "Preface" to the sensuality of the "Epilogue," "daringly of the moment and vital with life and passion." The very title of the volume, Flower o' the Vine, evokes Bacchus, who frequents the sospiri poems in various guises, among them the masculine but elusive Night beloved by the feminine Dusk in "Epilogue." By mid-1892, Sharp had found a name for the transformation he experienced in Rome in 1891. The sospiri poems were an initial expression of the Paganism he would soon proclaim more directly in his Pagan Review.

On April 23, Sharp thanked Thomas Janvier for his over-generous introduction to Flower o' the Vine, which he read in the proofs from the Webster firm:

I thank you most heartily for what you say there, which seems to me, moreover, if I may say so, at once generous, fittingly reserved, and likely to win attention. You yourself occupy such a high place in Letters oversea that such a recommendation of my verse cannot but result to my weal.

He told Janvier he was trying to keep down his "too cosmopolitan acquaintanceship" in Paris and assured him that "after the second of May" he was "going to reform and remain reformed." In the meantime, "after a week or so of the somewhat feverish Bohemianism of literary and artistic Paris, we shall be happy at our 'gypsy' encampment in the Forest of Fontainebleau." The "we" implies Edith Rinder was with him both in Paris and at the "encampment." If so, she must have returned home by May 2 when Elizabeth, having succeeded her husband as the paper's London art critic, arrived to review the Salons for the Glasgow Herald. Sharp described for Janvier the beauty of Paris in the spring, mentioned a chance meeting with Paul Verlaine, and listed some of the writers and artists he was meeting: 
I went round to Leon Vanier's, where there were many of les Jeunes Jean Moréas, Maurice Barrés, Cazalis, Renard, Eugène Holland, and others (including your namesake, Janvier). To-night I ought to go to the weekly gathering of a large number of les Jeunes at the Café du Soleil d'Or, that favourite meeting place now of les decadents, les symbolistes, and les everything else.

He concluded by listing his plans for the rest of the year:

(1) Lill joins me in Paris about 10 days hence and remains to see the two Salons, etc.

(2) From the middle of May till the middle (14th) of July we shall be in London.

(3) Then Lill goes with friends to Germany, to Bayreuth (for Wagnerian joys) and I go afoot and aboat among the lochs and isles and hills of the western Scottish Highlands.

(4) We meet again in Stirling or Edinburgh, early in August - and then, having purchased or hired a serviceable if not a prancing steed, we go off for three weeks vagabondage. The steed is for Lill and our small baggage and a little tent. We'll sometimes sleep out: sometimes at inns, or in the fern in Highlander's cottages. Thereafter I shall again go off by myself to the extreme west "where joy and melancholy are one, and where youth and age are twins" as the Gaelic poet says.

(5) The rest of September visiting in Scotland.

(6) Part of October in London then (O Glad Tidings).

(7) Off for 6 months to the South: first to the Greek side of Sicily: then to Rome (about Xmas) for the Spring. Finally: a Poor-House in London.

Few of those plans materialized. In early June, J. Stanley Little came upon a neighboring house available for leasing and thought the Sharps might find it suitable. They were staying with Mona Caird in Hampshire and planned to visit Bucks Green over the first weekend of June, but Elizabeth, on June 3, developed an extremely high fever, a relapse of the malaria she contracted in France in the spring. Sharp went alone to Bucks Green on Tuesday June 7, found the house desirable, and signed a three-year lease. When she was able to travel, Elizabeth visited the house which she described in the Memoir as 
a little eight-roomed cottage, near Rudgwick, with a little porch, an orchard and garden, and small lawn with a chestnut tree in its midst... . [It] stood at the edge of a little hamlet called Bucks Green, and across the road from our garden gate stood the one shop flanked by a magnificent poplar tree, that made a landmark however far we might wander. It was a perpetual delight to us.

In a history of Bucks Green, Roger Nash of the Rudgwick Preservation Society identified the house across from the shop on Guildford Road as the Toll House, a misleading name because it is not on the site of the house that collected tolls for using the road.

It was built in the curtilage of the smithy, first called Arun Villas, then The Laurels, then Phenice Croft, before its present post-war name [Toll House]. The name Phenice Croft (a place in Crete, referred to in the Bible) was given by William Sharp about 1892, who lived there somewhat secretly, for 2 years. He was a much travelled Scottish writer of a troubled disposition who invented his pseudonym 'Fiona McCloud' whilst in Bucks Green, writing a book titled Pharais. He was a friend of another literati, Stanley Little, who lived in Rudgwick rather longer, and at the time was lodging at Bucks Green Place. Both, I think, were drawn to the area by its Shelley connections.

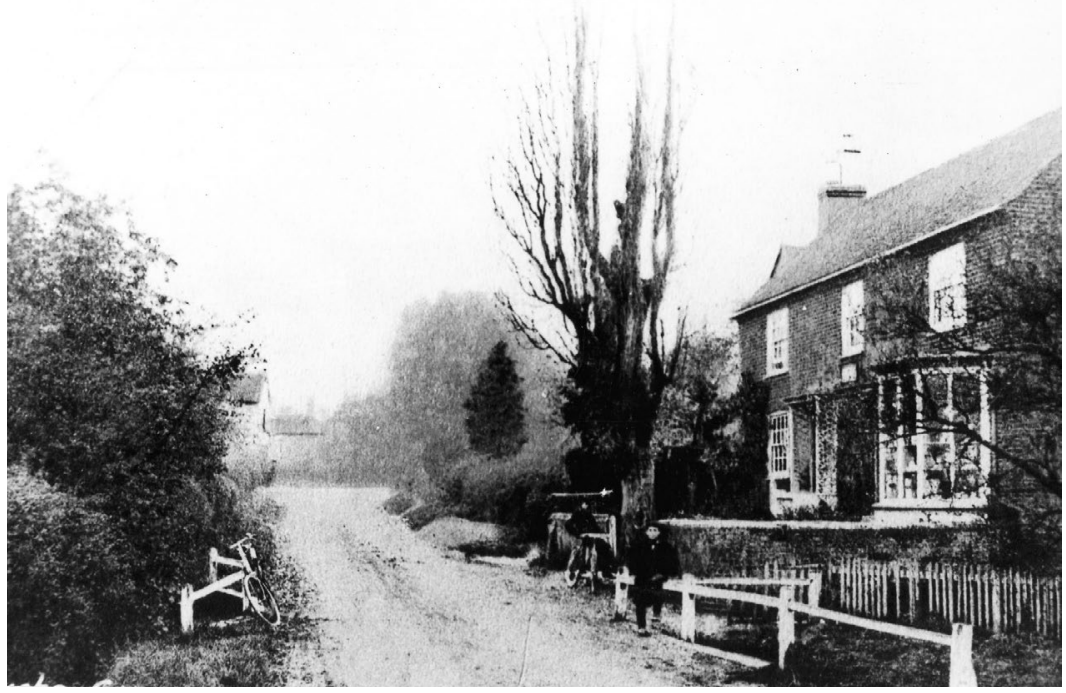

Fig. 11a. Early 20th century photograph of Bucks Green, Rudgwick, Sussex. @Rudgwick Preservation Society. Courtesy of Roger Nash, Chair, Rudgwick Preservation Society, https://www.rudgwick-rps.org.uk 


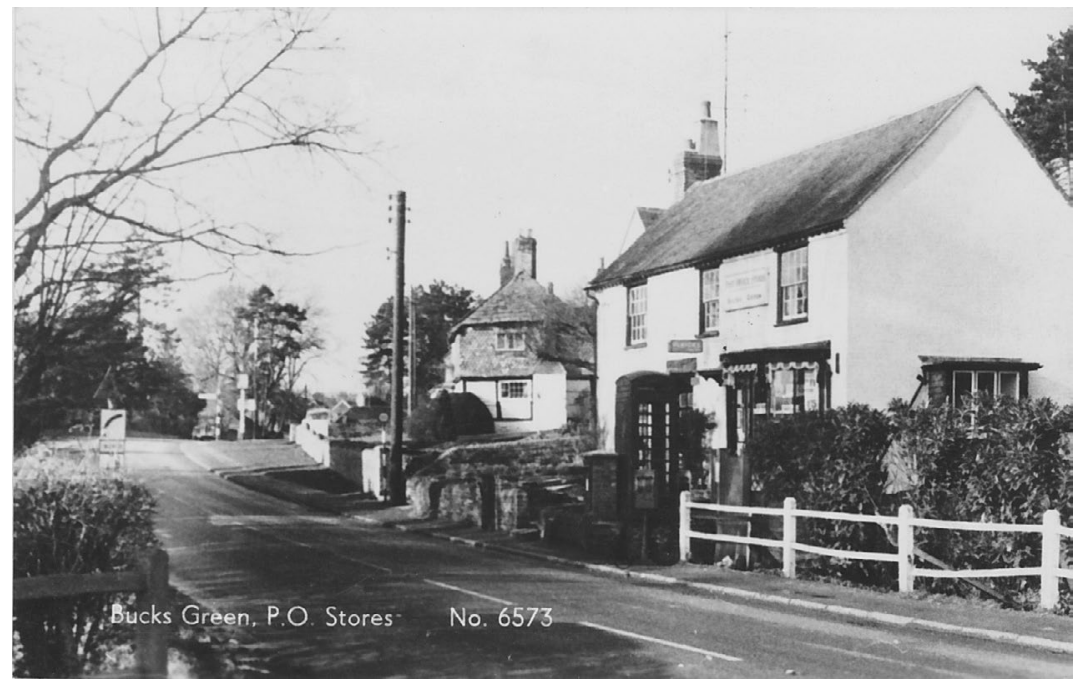

Fig. 11b. Mid-20th Century photograoph of Bucks Green, Rudgwick, Sussex. Phenice Croft, now the Toll House, is across the road from the building, now white, which housed the shop. (The Francis Frith Collection, https://www.francisfrith.com/bucks-green/ bucks-green-the-village-c1965_b587001

Nash's history includes this photograph of the "one shop" across the road from Phenice Croft, which dates from the early twentieth century, before the highway was paved and with the "magnificent poplar tree" described by Elizabeth Sharp, here denuded of its leaves. Below is a later photograph of the "one shop," now painted white, with the poplar tree gone but the bare branches of the chestnut tree visible in the front lawn of Phenice Croft.

According to Nash, "In 1890 James Stanley Little and his brother George Leon Little were borders in Bucks Green at The Kraal, a house in Lynwick St, now called The Old School House. In 1891, J Stanley Little lodged with William Kensett, a dairy farmer at Bucks Green Place, who was a near neighbor of the Sharps." Nash speculated correctly that the Little brothers were in Rudgwick before Sharp, and may have influenced his arrival. It was only because Stanley Little found an available house the Sharps found suitable that they became residents of Bucks Green.

For the remainder of June both Sharps corresponded regularly with Little about the house. On the twenty-second, he asked Little to please tell a man named Napper that "Mr. Sharp says he has nothing to do with any extra labour unauthorised by him, and that this engaging extra 
assistance without consulting him first, is a thing he will not tolerate again." He also passed on rather specific instructions from Elizabeth:

She would like (if nothing has yet been done) if the paint of the stairway, landing, and doors belonging thereto be done in a dark red (Pompeian red) - of one colour only, instead of the two shades already approved to match the paper. The doors in the Hotel at Littlehampton are responsible for this change of view. Again, if the drawing room has not been gone on with, we would now like if the painting of the skirting, doors, and mantel piece be uniformly of the pale tint of yellow, instead of the pale and yellow, as first arranged - but the inside of the doorless cupboard to be entirely of the deeper shade of yellow.

He told Little he expected "enter the house with the furniture about the 13th or 14th of July - just when E. goes away for a fortnight to Germany." At the close of June 1892, the Sharps were set for a new phase of their lives in a house in rural Sussex. It was called "The Laurels," but they rechristened it first "Kingscroft" in recognition of a former resident named King. Then they settled on "Phenice Croft" which combined the Greek name for the Phoenix, a unique bird that burned itself on a funeral pyre and rose from the ashes with renewed youth to live through another cycle, and the Scottish name for a rural cottage. The stage was set for "renewal" and the period of concentrated writing in which Sharp produced first The Pagan Review and then the early writings of Fiona Macleod. 


\title{
Letters: January-June, 1892
}

\section{To Richard Le Gallienne, January 6, 1892}

\author{
R.M.S. “Teutonic” | At Sea | 6th January/92
}

\section{Dear Mr. Le Gallienne ${ }^{1}$}

Many thanks for your cordial greetings and friendly remembrance. I value both. (By the way, if you know - and should shortly see Mr. Caine ${ }^{2}$ of the Mercury, please thank him for the kindly farewelltelegram I have just received.). I am delighted to have "Narcissus" ${ }^{\prime 3}$ with me, and value it none the less for your sister's generous sacrifice: and I am also much pleased to learn that you are to bring out a new volume next $\mathrm{March}^{4}$ - for which I not only wish all success but hope to be able to give a further welcome to in the Academy or elsewhere (I shall be back before its appearance I hope: my present plan is to return before the end of February). In this connection I shd. add that my London letteraddress is | 72 Inverness Terrace | Bayswater | W. It will give me sincere pleasure to receive your "Poems' - but certainly not as a 'makeweight'. I'll be able to offer you a counter-courtesy by that time perhaps.

As for Severn ${ }^{5}$ - which cannot but interest you, from the nature of its contents - I believe it is to [be] published somewhere about the 20th next. It is an expensive book, and I am not sure whether S. Low and Co. will be liberal with review copies: but of course if you see your way to a special review, they would doubtless pay immediate attention to the accompanying request.

With my cordial regards to you both - and all good wishes for $1892-$

Sincerely yours, I William Sharp 


\title{
To Louise Chandler Moulton, January 12, 1892
}

\author{
R.M.S. Teutonic | C/o Thos. A. Janvier \\ 20 Seventh Avenue | New York City | Tuesday 12th
}

Chère Amie,

I daresay you have heard that I am to be out here for a few weeks (probably 3 weeks in and around New York and a few days at least in Boston). ${ }^{6}$ I am looking forward very much to seeing you, and hope you are to be in Boston during the coming weeks.

I am glad to get away oversea for a bit, as I have been working pretty close recently. My long delayed Severn Memoirs are at last off my hands, and are to be issued in Gt. Britain and America somewhere about the end of this month I understand. The book contains a great deal of matter of interest to all students of literature, \& will I think (and the publishers believe) go well all round. It is a very handsome book though I speak without certain knowledge of its exterior - with several highly interesting illustrations and facsimiles etc.

Another book that will be published simultaneously in U.S.A. and England in the Spring is the novel in which Blanche Willis Howard and I have collaborated.7 (I spent last Autumn in Stuttgart, to this end).

Of course I have other things on hand: including a play which I hope will be out erelong.

I reviewed Philip's posthumous volume in the Academy a week or so ago. ${ }^{8}$ I hope it is at once honest and generous: I meant it to be both. It has given pleasure, I hear, to some of Philip's truest admirers - and almost the last thing I heard before leaving London was the particular approbation of two such very different judges as Roden Noel and Robert Buchanan. The book touched me deeply in many ways: and I liked your graceful and tender preface.

I think I shall go straight to the Stedmans on my arrival in New York tomorrow - but it is possible I may have to alter the dates of my promised visits. But in any case I am having all my correspondence (as I fancy I told you in my Xmas card) addressed to me I C/o Thos. A Janvier Esq I 20, Seventh Avenue I New York City 
Always affectionately yours I William Sharp.

P.S. I forgot to say that Lillie is not with me. She has left Germany \& is now in London, where I hope to join her sometime in latter half of Feby. ALS Library of Congress, Louise Chandler Moulton Collection

\section{To Elizabeth A. Sharp, [January 18 or 19, 1892]}

... During a memorable talk on literature of the two countries past and to come, the conversation turned upon a vivid episode." "That was when you were young?" I asked. The patriarchal old poet - who lay in his narrow bed, with his white beard, white locks, and ashy-grey face in vague relief, in the afternoon light, against the white pillows and coverlet - looked at me before he answered, with that half audacious, wholly winsome glance so characteristic of him, "Now, just you tell me when you think that was!"

Then, with sudden energy, and without waiting for a reply, he added, "Young? I'm as young now as I was then! What's this grey tangle" (and as he spoke he gave his straggling beard an impatient toss), "and this decrepit old body got to do with that, eh? I never felt younger, and I'm glad of it - against what's coming along. That's the best way to shift camp, eh? That's what I call Youth!"... He said to me with halting breath: "William Sharp when you go back to England, tell those friends of whom you have been speaking, and all others whom you may know and I do not that words fail me to express my deep gratitude to them for sympathy and aid truly enough beyond acknowledgment. Good-bye to you and to them - the last greetings of a tired old poet".

Memoir 193-94 


\section{To Horace Scudder, [January 21, 1892] ${ }^{10}$}

137 West 78th Street I Thursday

Dear Mr. Scudder,

I am gratified by your friendly and courteous attention - and accept your invitation with sincere pleasure. As I have no wish to "gallivant" in Boston, but simply to attend to some business, and to call on one or two friends, nothing could suit me better. I was just writing to a correspondent to say that I wd. probably put up at the Parker House Hotel, when your letter came. The baggage I shall take with me will be of a portable kind - so I shall have no bother.

I will endeavour to leave New York by the 10 A.M. train - so as not to cause Mrs. Scudder any inconvenience: failing this being practicable (as I have to come from Metuchen N.J). I'll come on by the 11 train. However, as I know that Mr. Alden ${ }^{11}$ goes early into town I am almost certain I can catch the former. If I miss it, I shall telegraph to Mrs. Scudder.

I have to return to New York on Friday morning from Boston possibly on Thursday morning.

In haste, Sincerely Yours, I William Sharp

P.S. Glad you are to use "Severn". I think the matter will interest a wide circle. Mrs. Stedman reciprocates your kind greetings. E.C.S. has gone to Philadelphia.

ALS Harvard Houghton

\section{To Louise Chandler Moulton, January 21, [1892] ${ }^{12}$}

Just time for a hurried $\mathrm{P} / \mathrm{C}$. No, of course, chère amie, there is no misunderstanding. I shall be frantically hurried in Boston, but I'll make a point of seeing you - Probably on Wednesday forenoon or possibly Tuesday afternoon. 
W.S.

Max O'Reilly's daughter still an invalid, but better, and able to sit up. Mrs. S. sends her love. E.C.S. has gone to Philadelphia.

ACS Louise Chandler Moulton Collection, Library of Congress

\section{To Arthur Stedman, [January 22?, 1892] $]^{13}$}

137 West 78th Street.

My dear Arthur,

I am much indebted to you, not only for your trouble as to the prompt delivery of the letter, but for your potent friendly services in the negotiation with Messrs. Webster \& Co. The terms seem to me to be very good, and fair to all concerned: and I gladly accept. I'll arrange later with you about title, for neither "Romantic Ballads" nor "Sospiri di Roma" will now serve. I think I shd. like some such title as "Flower $\mathrm{o}^{\prime}$ The Vine" with the under-motto "Earth is my Vineyard: these grew there". Browning.

I think also that the Preface to "Romantic Ballads" shd. be omitted. The reprint should be from the 2nd edition: a copy of which it so happens I brought out for you - as I do not think you have it. The improvements upon the first are very marked, and there is another poem ("The Isle of Lost Dreams"). It, too, is now rare.

On reconsideration - if you are agreeable (and I told Mr. Hall ${ }^{14}$ that either Mr. Janvier ${ }^{15}$ or Mr. Bliss Carman would act as my "best man") I think that I wd. much rather it were done by Carman. Janvier knows nothing of poetry, and cares less, though he is good enough to express himself warmly about my verse. Carman is a poet, keenly sympathetic, critical, and judicious - and his name, moreover, is much better known than perhaps he himself is aware.

Moreover, he has agreed to revise any proofs for me: and this arduous task I am going to entrust to his friendly care. 
Please let me know if you and Mr. Hall agree to the title of "Flowers o' The Vine", and to Bliss Carman as 'introducer'.

I am afraid, cher ami, that I cannot possibly get back in time for the Author's Club. I have so much to do with Houghton \& Co. etc. ${ }^{16}$

I leave Alden's early on Monday morning, so as to get to Boston by the early evening. There my address will be c/o Horace E. Scudder I 17 Buckingham St. I Cambridge I (Mass). I think it is very likely I shall go to a hotel for the evening of Tuesday the 2nd - so as to run less risk of missing my steamer on Wednesday morning. In this case, I shd. like to spend the evening with you better than with anyone else. I could say good-bye to Mrs. Stedman earlier in the day, and perhaps you would dine with me as my guest, at the Century?

Ever, my dear fellow, I Cordially yours, I William Sharp ALS Columbia

\section{To Arthur Stedman, [January 26, 1892]}

C/o Horace E. Scudder, I 17 Buckingham St I Cambridge I Tuesday

My dear Arthur,

All right - I'll write to Janvier and see if I can persuade him.

The "Green" edition of Whitman was to be published yesterday (Monday). ${ }^{17}$ Mr. McKay ${ }^{18}$ got me the first bound copy as a favour - as I wanted to get it for you. I could not get one for myself, though the other edn. served my purpose just as well. I understood from Mr. McKay that this is only a new edition to please a fancy of W.W'.s - and that as it does not contain any new matter it would not be sent out to the press. I also understood - though perhaps mistakenly - that this "Green" edition is a limited one.

I am going to leave here on Thursday morning; but have probably to break somewhere enroute. If I should be able to go to New York same 
evening I shall telegraph to you - as in that case I should like to avail myself of your kind suggestion, and put up for the night at your house, if such an arrangement can be made without inconveniencing you (and of course, cher ami, I go there on my own account).

In haste, I Sincerely yours, I William Sharp

P.S. On reconsideration of my plans it is highly likely that I shall get to New York on Thursday evening - but not till late, and certainly not in time for the Author's Club. I find that all idea of postponing my departure must be given up - in fact, if I could manage it I should go home on Saty - for I have just heard of the sudden and tragic death of my brother Edward. My mother is profoundly affected: and I want to see her as soon as I can.

W.S.

ALS Pierpont Morgan

\section{To Laura Hyde Stedman, [January 27, 1892]}

17 Buckingham St. I Cambridge | Mass. | Wednesday Night

Dear Mrs. Stedman

Just a hurried line to tell you that I leave here tomorrow instead of Friday - though I shall not inconvenience you by turning up before Friday night. I want to be in New York to conclude all my arrangements, as there is now no chance of my prolonging my stay, as I had nominally arranged with the shipping Co. to do if I found it advisable: indeed, were it practicable - which it is not - I should sail earlier. For I have just received news of the sudden and tragic death of my brother Edward: and I wish to get home as soon as possible.

I had a delightful time in Philadelphia, and have also enjoyed my stay here: but I am looking forward to returning to your hospitable care, where I feel so much at home, and where my affections are so strongly 
placed. Sunday I have of course kept free so that I should at least get some glimpses of Mr. Stedman. On Saturday night I have promised to dine with Mrs. Harland. ${ }^{19}$ I shall have to say good-bye sometime on Tuesday.

I shall probably be at Arthur's tomorrow (Thursday) night.

Ever affectionately yours, I William Sharp ALS Columbia

\section{To Horace Scudder, [January 29, 1892] $]^{20}$}

... prolonged strain of this twelfth one is alarming her as well as trying her physically. She keeps repeating over and over her wish to be at home once more. I gave them all manner of kind messages from you - tho' I doubt if Mrs. Alden quite understood. I'll try and call again before I go, and shall let you hear how she is. I expect to see Mr. Alden in any case. I fear that you, too, have suffered some loss - for I saw in the Boston Herald today that a Judge Scudder, "cousin of the novelist Horace E. Scudder" died yesterday.

I am so sorry to have had to cut short my stay at Cambridge ${ }^{21}$ - but I carry away with me the pleasantest recollections, and shall always think of you and yours with sincere regard and that happy sense of intimacy which is the fragrance of friendship.

Again thanking you for all your considerate hospitality, \& best remembrances to you all,

In haste, I William Sharp 


\section{To Horace Scudder, January 29, 189222}

C/o Edmund Clarence Stedman | 137 West 78th Street | New York City

Dear Mr. Scudder,

Do you think that, later on, you would care for two articles - one on the new literary movement in Belgium and one on the most recent French achievement in belles-lettres? I can fairly claim to be a specialist here, and to be in a position to know what has been done both by La Jeune Belgique and La Jeune France - what is being done - and what tendencies are obvious or predictable. ${ }^{23}$

It has occurred to me that a work of this kind wd. be artful and suggestive as well as welcome to many - and I am writing also to Messrs. Houghton Mifflin \& Co. to see if they care to entertain the idea for ultimate book-publication.

Of course, writing away from my notes and material, I can give you only a tentative list of the more or less notable authors, who, in some degrees manifest the "new modernity" of which so much is heard. But here is a tentative list, which for convenience I shall give alphabetically. The names with an asterisk are members of La Jeune Belgique: and those with an $X$ are of men recently dead. ${ }^{24}$

No doubt I have omitted one or two names - but I don't think my memory has played me a trick in any important instance. (Of course the late Theodore di Banville is scarcely within the group).

I have taken my passage by the Majestic, and sail on the morning of Wednesday (or late evening of Tuesday).

Sincerely Yours | William Sharp

P.S. On reconsideration I shall wait till I hear from you, before I lay the book-idea before Messrs. Houghton Mifflin \& Co. The book would consist of the articles much amplified and rearranged - with 
translations in rhythmic prose of representative poems by each author (sometimes several): with biographical and critical pastels etc.

Perhaps, indeed, you could broach the matter from this letter.

W.S.

ALS Harvard Houghton

\section{To Arthur Stedman, [February 2?, 1892] $]^{25}$}

Charles L. Webster \& Co., Publishers | 67 Fifth Avenue, New York

My dear Arthur

Just been at your rooms, and missed you by a brief time. (I left an invitation-note for you from somebody, which your mother asked me to give you).

The most friendly \& generously worded letter which you addressed to Walt Whitman on my account is safely in my hands. By the way, it seems that its non-receipt by me is, so far as your father is concerned, entirely my own fault. He says he explicitly told me that it was waiting me at Mr. Henderson's. ${ }^{26}$ Unfortunately, I had to go to Mr. Traubel's ${ }^{27}$ first, so as to catch him ere his bank closed: then I was detained sometime by Mr. Stoddart ${ }^{28}$ at Mr. Child's: ${ }^{29}$ and by that time Mr. Henderson's office was closed. Saturday morning I was engaged with Mr. Stoddart, $\&$ while on my way to Mr. Henderson's learned from Mr. Traubel that if I were to see Walt Whitman at all I must go down before the afternoon. By the time that, accompanied by my fair companion (tautological, but never mind) I had returned to Philadelphia, I found that as it was Saturday, business places had all closed early. Hence my not seeing Mr. Henderson at all.

Your father seems to me sadly nervous and overwrought. I fear the strain of lecturing \& going about so much is telling upon him. He ought to have a complete rest. 
I want to talk to you about the Brown-Paper copy of Whitman. This morning your father told me he particularly wished me to have this duplicate copy, as a present from him and as a remembrance of W.W. Now it occurred to me that in the first place this copy, or the other, may possibly have been meant by W.W. for you - and, in the next, that in any case you will wish to retain it, as it is a privately bound one. If so, I shd. most certainly wish you to remain its possessor. But you know your father, \& you see my difficulty. I want your frank advice on the matter, by which I will abide.

Will you kindly tell Mr. Hall ${ }^{30}$ (who is out) that Janvier will write a brief Introduction to my Poems, but that of course he will expect some honorarium as he has so many important commissions on hand, and cannot afford his valuable time for nothing. I also wanted to ask Mr. Hall

(1) When he will print and issue the book

(2) When he will want Janvier's Introduction

(3) What about the title

By the way I want North and South to appear somewhere: say "Of The North", "Of The South": I don't mean in the title - but on title-page or on second leaf or Contents.

(4) What about the Romantic Ballads "Preface" (the vol. must be printed from the $\underline{2}^{\text {nd }} \underline{\text { Edition)}}$.

(5) What about a brief Preface to "Sospiri"

(6) Shall fully set-up Proofs be sent to me - or do you not wish to send proofs oversea.

(7) Can I have some author's copies sent to me in England? Also on what terms I can buy copies if I want more, for English friends, at any time.

If you can come in tomorrow evening perhaps you may be in a position to inform me concerning these points. 
P.S. In thanking you again for your Whitman letter I may assure you that no hint escaped me concerning the private projects confided to me. ALS Columbia

\section{To Laura Hyde Stedman, February 3, 1892}

R.M.S "MAJESTIC" | Wednesday, February 3, 1892

Dear Mrs. Stedman,

A hurried last word, per the pilot, to thank you again for all your many kindnesses - one of the pleasantest of the many pleasant remembrances I carry away. Your house has indeed been my home in the happiest sense of the word.

Adieu, I W. S.

If I have left Mr. J. W. Young' $\mathrm{s}^{31}$ letter (to E.C.S. about my lecturing) will you kindly send it to me. 72 Inverness Terrace I Bayswater I London W. ALS Columbia

\section{To Laura Hyde Stedman, [February 13, 1892]}

72 Inverness Terrace I Bayswater, London W.

Dear Mrs. Stedman,

I was unable to write to you on the voyage, as it was a frightful passage, and as, moreover, I was very unwell the whole time I was on board. But I am safe at home again, and find my wife well, I am thankful to say. Tomorrow morning I go off to Edinburgh to see my mother, but shall be 
north only a few days. As soon as I am back, if not before, I shall write you a letter with all news. Meanwhile my love to you and Mr. Stedman and to Arthur, and kind remembrances to Miss Coleman.

Ever sincerely yours, I William Sharp

I may add that the latest news of Harry Harland is distinctly more favourable.

ACS Columbia

\section{To Arthur Stedman, [February 16?, 1892]}

2 Coltbridge Terrace | Murrayfield I Edinburgh

My dear Arthur,

Many thanks for your letter just received, and for all your trouble in the matter of the poems. ${ }^{32}$

But let me explain at once, my dear fellow, that you are under some misapprehension when you say that my reticence about my dramatic volume was "shabby". You did not clearly gather what I said, or all I said. If you had, you would have understood that there is no question of conflicting interests. What I told you was that I had written some new things in a new dramatic form ${ }^{33}-$ but that I was not to publish them in the ordinary way: but simply going to have a certain number of copies printed for distribution - and, moreover, under a pseudonym. Had I intended to publish a new book, either of verse or of any imaginative work, I should certainly have told you about it at once.

I have my own reasons for wishing to issue them in this way in the first instance. They are new in method and manner, and are, I believe, the best work of the kind I can do. Work of this kind is so dear to me that I am relatively indifferent to its financial success: and, in addition, I am particularly curious to see how these "Dramatic Vistas" will be received, 
without any of the bias for or against involved in the attachment of my name to them.

So now you understand, no doubt. I may add that when I was in Boston I dropped some hint about this matter, though not nearly as explicitly as I have done to you - but sufficiently to make Houghton Mifflin wishful to take up the little book either at once or later: but here I at once "drew off", for by that time you had come forward about "Sospiri" etc., and I felt that I could conclude or suggest no agreement without giving C. Webster \& Co. first option. I could not explain all this before Janvier etc. the last night at your rooms: and then, too, I thought you understood the semi-private nature of my projected venture.

To convince you that I am not playing with words, I may add that I, for my part, am quite willing that Messrs. Webster \& Co. take up this little book if they wish to do so, and be its publishers both in America and Great Britain. If so I should print privately only 100 copies, for private distribution to individuals and to "critical organs", and set forth as by "H. P. Siwäarmill" (my anagram - which I tell you in strict confidence). When issued from a publishing house either in the late Spring or in the Autumn it can go forth as by "William Sharp" and probably with a suggestive 'forward' from myself.

The little book will occupy about 100 pages. It will be called "Dramatic Vistas": and, on Front-Page, Dramatic Vistas, with "The Passing of Lilith". The Contents comprise the following pieces, all, with the exception of the imaginative visionary "Lilith", studies in various phrases of what I may call spiritual terror.

1. The Passion of Père Hilarion

2. The Birth of A Soul

3. A Northern Night

4. Finis

5. The Hazard of Melchior Van Holk

6. The Black Madonna

7. The Lute Player

8. The Passing of Lilith 
I had time to read a portion of above to only two friends in America. Had you been alone the last night, I was going to have shown you a couple of pieces, and spoken to you about them. If you wish to know anything about them you can refer to Mrs. Janvier or to Bliss Carman. The pieces they heard are I The Birth of A Soul I Finis I The Passing of Lilith I (and Mrs Janvier also "A Northern Night").

Bliss Carman seemed profoundly impressed by what he heard. If you do speak to either you can adduce my authority.

Once more, if you do take it up you could, if you prefer, postpone "Flower o" The Vine" till the Autumn.

So now, my dear boy, you see I am both willing and ready to meet you half way: and after this explanation trust you will remove the charge of shabbiness - which has hurt me somewhat, and would have hurt me a good deal more if I did not understand how the misapprehension arose.

I return to London the day after tomorrow, and very shortly thereafter shall call on Austin Dobson ${ }^{34}$ and give him your book. We have taken pleasant rooms in Kensington, at Bedford Gdns, in Campden Hill - but you had best not be confused with any other address then the permanent letter-address I gave you,

We had a horrible passage - and I was ill a good part of the way. Even now, nearly a week after arrival in England, I am not quite myself again.

By the way, I forget if I told you that I want to dedicate "Flowers $\mathrm{o}^{\prime}$ The Vine" to... ${ }^{35}$ or do you think something a little more elaborate would be better?

Just going off to hunt in some of the old Edinburgh bookshops for errant "Whitmans". I don't expect success right off - but, patience!

Please give my love to your father and mother. Tell the latter that I gave her kind message of sympathy to my mother. ${ }^{36}$ Also her messages to my wife about my being just a model husband, and having been a very 'good boy'.

Yours Ever, my dear fellow, I William Sharp 


\section{To J. D. Marshall, February 19, 1892}

72 Inverness Terrace | Bayswater, London W. | 19:Feby:92

\section{Dear Sir,}

I meant to write to you recently while I was the guest of Mr. Edmund Clarence Stedman in New York, but my stay in America was abruptly cut short owing to private bereavement at home.

I was given your name and address by several friends, as that of a firm likely to want such literary work as I have to dispose of. I do not know if my name and repute as novelist and general writer be known to you - if not I could refer you to Mr. Stedman, or to Mr. Edgar Fawcett, ${ }^{37}$ or many others - and I may add Mr. J. Clarence Harvey, ${ }^{38}$ Editor of Lovells' series, who reissued my romance Children of Tomorrow. I may further add that Messrs. Houghton, Mifflin and Co. in Boston, and Messrs. Osgood McIlvaine and Co. in Gt. Britain, will early in March publish a novel which I have written in collaboration with Blanche Willis Howard ${ }^{39}$ - and that another leading American house has commissioned another novel. ${ }^{40}$

May I ask if you have room for short stories of say 5 to 6,000 words: and what rates of payment you can offer.

Just before leaving New York I had an offer from a New York syndicate - but the terms were not such as made me particularly anxious to agree. I have nothing quite new at the moment ready to send to you - and in any case prefer to wait till I hear from you: but by this post I forward to you, a duplicate set of proofs of an Italian story of some length which is to come out in an early number (probably April) of Good Words. ${ }^{41}$ Possibly you may be able to do something with it in the meantime.

Yours faithfully, I William Sharp

J. D. Marshall, The American Press Association 


\section{To Thomas Janvier, [February 20?, 1892]}

Dear Old Man,

I have read your stories (as I wrote the other day) with particular pleasure, apart from personal associations. ${ }^{42}$ You have a delicate and delightful touch that is quite your own, and all in all I for my part fully endorse what Mr. Howells ${ }^{43}$ wrote about you recently in Harpers' and said as emphatically in private. So - amico caro - "go in and win!"

I am settling down in London for a time, and am more content to abide awhile now that the writing mood is at last upon me again - and strong at that!

I have not yet put my hand to any of the commissioned stories I must soon turn to - but tell la sposa that I have finished my "Dramatic Vistas" (two or three of which I read to her), and even venture to look with a certain half-content upon the last of the series - "The LutePlayer" - which has been haunting me steadily since last October, but which I could not express aright till the other day... .

Memoir 195

\section{To Laura Hyde Stedman, February 23, 1892}

11 Bedford Garden | Campden Hill, London W |. 23:Feby:92

My dear Mrs. Stedman

Now that I am settled down again to my London life, my American visit seems to me almost like a dream - though much more vivid than any dream is my remembrance of all the kindness and thoughtfulness of you and yours. My wife is almost as grateful as I am, for I have told her so much about you all. She is delighted, too, to have so good a report of my doings, and to know on your authority that I was "so good a boy" during my stay in America.

By this time you will have Mr. Stedman at home again - which will be pleasant for both. It grieved me to see him so sorely overwrought: 
but I suppose it is part of the penalty he has to pay for his personal and public popularity. I trust he attended to his business in Philadelphia, and did not "go gallivantin" with fascinating young authoresses! I could tell you sad tales about his misdoings - but I spare his feelings, and yours!

We have taken rooms in Kensington, in a part known distinctively as the artists' quarter: and as my wife has many friends close by, and is herself painting in a friend's studio, I think she likes it better than Hampstead - at any rate until the Spring [it] is really un fait accompli.

We are also going to rent a cottage or small house somewhere in the country - probably at a place a few miles north of Cookham Dene and the Woods of Waldegrave. Here we shall put all our stored furniture, and either live in it for weeks at a time, or for a day or two as the humour takes us, or either of us. If you and Mr. Stedman come we'll have a picnic there in a neighbourhood hallowed to poets by memories of Shelley and others on to Matthew Arnold.

Alas for the vanities of Christian Science! Tell Miss Coleman that if she is going to cross the Atlantic I would recommend her to supply herself with some material remedy against seasickness as well.

We dined last Sunday with the Harlands and his mother, ${ }^{44}$ who arrived a few days after I did. Harry strikes me as worse. He is very weak, and most despondent: and I fear his term of life cannot be a long one. And yet a good deal of his trouble is due to a form of nervous hysteria: and it is just possible that a change of climate and cessation from excitement of any kind may benefit him. He and Aline and his mother leave London in a week for the South of France or the Riviera. I have seen almost no one since my return, having been busy: but either today or tomorrow I hope to call on Austin Dobson and give all your remembrances and Arthur's copy of his "Biographies". ${ }^{4}$

My wife sends you both her warmest regards (and special thanks to Mr. Stedman for his portrait, which now ornaments our drawing room mantelpiece, in company with George Meredith). And you know that I am always affectionately yours,

William Sharp 


\section{To Arthur Stedman, [March 7, 1892]}

11 Bedford Gardens, Campden Hill I Kensington, W.

\section{Cher Ami}

Will you kindly obtain for me, and send, a little book called "How To Judge of a Picture" by John Van Dyke ${ }^{46}$ pubd. by The Chautauqua Press (New York: Phillips \& Hunt). I forget if you have any small fund of mine in hand: if not let me know amount to remit. If the same author's "Principles of Art" ${ }^{\prime \prime 7}$ is not more than a $\$ 1$ or $\$ 1.50$ please send it also. They are for my wife, and she will be greatly obliged to you.

In haste, Yours ever, [W. S.]

ACS Columbia

\section{To J. Stanley Little, [March 9, 1892]}

11 Bedford Gardens I Campden Hill | Kensington W.

My dear Little, ${ }^{48}$

On my return from America I find among my letters and magazines etc. a copy of the first number of "The Library". ${ }^{49} \mathrm{I}$ have read your sensible and right article with much appreciation: and I hope many readers will take it to heart.

Are you ever in town on Friday or Saturday afternoons? One of these days is likeliest for the finding me at my club (the Grosvenor, New Bond St).: or if ever this way you might chance finding us at home, though but a bare chance. We'll be in these rooms till the end of April.

Do you know of any cottages or small houses to be let unfurnished at your place or in your neighbourhood? We are looking out for something, say with 2 sitting rooms, 4 bedrooms etc.: at a moderate rental, and not too far from a station. We would put our stored furniture in: and we 
could go to it for a few weeks at a time, or two or three months, or a Friday till Monday, as the spirit moved us.

I might run down some afternoon to see anything, and to have a long chat with you and your brother Léon ${ }^{50}$ if this would not inconvenience you? What is he doing just now? I admire his work greatly, and hope much from him. And yourself? Busy no doubt. Pour moi, I am as hard at work as usual.

From what my wife tells me, I fancy that either a letter from you concerning, or a book by Miss Vartz Smith, ${ }^{51}$ came for me \& was sent to New York. I returned sooner than I intended, and my 'postages' are slowly finding me by different routes and directions and after long delays. By the way, I suppose your brother \& you are still together at Bucks Green?

Cordially yours I William Sharp

ALS Princeton

\section{To Edmund Clarence Stedman, April 13, 1892}

16 Winchester Road I Swiss Cottage, London N.W. I 13th April 92

Master and Friend, All hail!

Just a hurried line ere my departure for some weeks to France. The "old Adam" calls me, and alas I am weak!

A thousand thanks for your welcome letter, I am glad you like "A Fellowe and His Wife". Here it is going famously. In tonight's paper I have been reading your beautiful memorial lines on Whitman which accompanied the wreath you sent. ${ }^{52}$ Every one here is heartily disgusted at the ungracious and ungentlemanly signed article in The Athenaeum a week or so ago, by Theodore Watts. ${ }^{53}$ How he could so far forget himself I don't understand. Certainly the article will do him a lot of harm, and even those who broadly agree with his estimate of Whitman resent his 
arrogant and ill-bred tirade. It is a great pity everyway, and as one of T. $W^{\prime}$.s friends I am doubly sorry.

The last news of Harland ${ }^{54}$ are [sic] perhaps somewhat better. But I won't see him just now, as he is at Biarritz, and I am not going beyond Fontainebleau. My wife has gone with friends to the Isle of Wight for a week or so, but will join me in Paris some three weeks hence.

I hope to read the two Poetry papers before long, and am looking forward to them greatly.

My love to Mrs Stedman - but do not let her know that I am a backslider, as she already has but an indifferent opinion of my much tried virtue. I really am going to reform - but "owing to unavoidable circumstances" must not begin all at once or too hurriedly!

We'll be here in the summer. In the early autumn Lill and I are going through the West Highlands on horseback and on foot - a gipsy life for a few weeks, full of charm. Then, in October, we hope to sail to Sicily (the Greek side) and stay there till about Xmas - and then to Rome again.

Love to you dear friend - to you and yours -

Ever gratefully and affectionately, I William Sharp

ALS Columbia

\section{To Charles Webster E Co., [mid April, 1892]}

Address till middle of July | 16 Winchester Road I Swiss Cottage |

London N.W. 2

\section{Dear Sirs}

Herewith the proofs of second part of Flower o' the Vine. Also, the MS. of the Epilogue to Sospiri di Roma. I do not, of course, expect to see Proofs of this Epilogue, and Mr. Arthur Stedman (to whom I am also writing) will no doubt read them carefully with the original for me. Only, I may add, that I must request (to which I am sure you will agree, even if on 
no other ground than as a favour) that this Epilogue on no account be omitted.

I hope to write to you early next week about sale of copies here. Meanwhile I may say that there are difficulties of all kinds in the way if Flower o' the Vine consist merely of reprints. But with the textual revisions, the inclusion of "The Last Voyage of Keir" in the first Section, and of the Epilogue to Sospiri in the second, these difficulties will be greatly overcome. In any case, of course, I did not mean to let Sospiri appear again without the Epilogue - which, to my mind, is one of the most essential things in the book.

I think it would be as well, from every point of view, (as, certainly, to my personal advantage) to indicate somewhere that this Reprint of Romantic Ballads = the Third Edition, and of Sospiri di Roma $=$ the Second.

By the way, if you have not already done so, it does not matter about the inclusion in Part I of the small pieces "The Coves of Crail" and "Valleys of Dream": in any case, they are essential, as is the "Epilogue to Sospiri".

Contents-Page will have now to be rectified of course.

I think I have already noted that I want the original Alfred Austin ${ }^{55}$ dedication to Sospiri omitted - and simply a blank page with "N'être que toi, mon Rêve"

I sent you some useful "Press Opinions" the other day - both British \& American, \& relating to both Romantic Ballads and Sospiri. The best about the former you will find at end of the Edition you have printed from. I have just found another American one (there were only 2 or 3 altogether) - viz: from the Boston Literary World (concerning Romantic Ballads). ${ }^{56}$ 


\section{To J. Stanley Little, [mid-April, 1892]}

Grand Hotel | Paris

My dear Little,

Thanks for your letter. There is no man to whom I would more freely depute any work of mine than to yourself - but at present my wife is doing my art-work for me, and for the brief time when she will be with me in Paris, a definite arrangement which cannot now be broken has already been made. It is very likely, however, that I may have important art-work to depute for a long period, beginning next autumn. More of this again.

No, I have not yet seen the L.W. ${ }^{57}$ notice. No doubt it will come to me - and I thank you cordially in advance. A charming review has reached me from an important daily $-\&$ several flatteringly good ones from America and the Continent.

I doubt if any of the Reviews wd. take a Summer Shows article ${ }^{58}-$ but it is always worthwhile trying. I have been so busy since I came here that I have seen or read nothing.

Ever yours, I (in haste) | W. S.

ALS Princeton

To Thomas Janvier, April 23, 1892

Paris, 23rd April, 1892.

... Many thanks for your letter, my dear fellow, and for the "Introduction", which I have just read. ${ }^{59}$ I thank you most heartily for what you say there, which seems to me, moreover, if I may say so, at once generous, fittingly reserved, and likely to win attention. You yourself occupy such a high place in Letters oversea that such a recommendation of my verse cannot 
but result to my weal. I have been so deep in work and engagements, that I have been unable to attend to any correspondence of late - and have, I fear, behaved somewhat churlishly to friends across the water, and particularly to my dear friends in 7th Avenue. But now the pressure of work is over for the moment: my London engagements or their ghosts are vainly calling to me d'Outre-Manche: I am keeping down my too cosmopolitan acquaintanceship in Paris to the narrowest limit: and on and after the second of May am going to reform and remain reformed. If you don't object to a little "roughing", you would enjoy being with me and mes camarades this coming week. We like extremes, so after a week or so of the somewhat feverish Bohemianism of literary and artistic Paris, we shall be happy at our "gipsy" encampment in the Forest of Fontainebleau (at a remote and rarely visited but lovely and romantic spot between the Gorge de Frenchard and the Gorge d'Apremont). Spring is now here in her beauty: and there is a divine shimmer of green everywhere. Paris itself is en fete with her vividly emerald limes and sycamores, and the white and red spires of the chestnuts must make the soul of the west wind that is now blowing rejoice with gladness. The Seine itself is of a paler green than usual and is suggestive of those apple-hued canals and conduits of Flanders and by the "dead cities" of north-east Holland. I forget if you know Paris - but there is one of its many fountains that has an endless charm for me: that across the Seine, between the Quai des Grands Augustins and the Bld. St. Germain - the Fontaine St. Michel - I stood watching the foaming surge and splash of it for some time yesterday, and the pearl-grey and purplebased doves that flew this way and that through the sunlit spray. It brought, as it always does, many memories of beloved Rome and Italy back to me. I turned - and saw Paul Verlaine beside me: and I was in Paris again, the Paris of Paris, the Aspasia of the cities of the World, the only city whom one loves and worships (and is betrayed by) as a woman. Then I went round to Leon Vanier's, where there were many of les Jeunes - Jean Moréas, Maurice Barrés, Cazalis, Renard, Eugène Holland, and others (including your namesake, Janvier). ${ }^{60}$ To-night I ought to go to the weekly gathering of a large number of les Jeunes at the Café du Soleil d'Or, that favourite meeting place now of les decadents, les symbolistes, and les everything else. But I can't withstand this flooding sunshine, and sweet wind, and spraying of waters, and toss-toss and 
shimmer-shimmer of blossoms and leaves; so I'll probably be off. This won't be off if I don't shut up in a double sense.

My love to "Kathia"61 and to you, dear fellow Pagans.

Ever yours rejoicingly, I William Sharp

P.S. - Tell K. that when I have "reformed" I'll write to her. Don't let her be impertinent, and say that this promise will be fulfilled ad Graecas Kalendas!

Here are my proposed "coming-movements":

(1) Lill joins me in Paris about 10 days hence, and remains to see the two Salons, etc.

(2) From the middle of May till the middle (14th) of July we shall be in London.

(3) Then Lill goes with friends to Germany, to Bayreuth (for Wagnerian joys) and I go afoot and aboat among the lochs and isles and hills of the western Scottish Highlands.

(4) We meet again in Stirling or Edinburgh, early in August - and then, having purchased or hired a serviceable if not a prancing steed, we go off for three weeks vagabondage. The steed is for Lill and our small baggage and a little tent. We'll sometimes sleep out: sometimes at inns, or in the fern in Highlander's cottages. Thereafter I shall again go off by myself to the extreme west "where joy and melancholy are one, and where youth and age are twins" as the Gaelic poet says.

(5) The rest of September visiting in Scotland.

(6) Part of October in London then (O Glad Tidings)

(7) Off for 6 months to the South: first to the Greek side of Sicily: then to Rome (about Xmas) for the Spring. Finally: a Poor-House in London. Memoir 195-98 


\section{To Edmund Clarence Stedman, April 23 [1892]}

Paris 23rd April

Letters from England have reached me just in time for a hurried acknowledgment by $\mathrm{P} / \mathrm{C}$ - if I am to catch the outgoing mail of this week-end. Many thanks for your note and enclosure (Your kind letter I have already acknowledged) The W.W. ${ }^{62}$ farewell lines are just what the old poet would have wished: \& that is the best praise. I am so glad to have them, \& insert in my copy of W. from you. Anytime Arthur is writing - or if you could simply put another slip in an envelope - my wife wd. be proud to have one also. A thousand loving greetings to you and yours.

W.S.

ACS Columbia

\section{To J. Stanley Little, [April 23?, 1892?]}

Paris: Tuesday

My dear Stanley, I did not call for the letters that have come for me, until today: hence my delay in writing to thank you for the $L / W, \&$ for the Personal Note in it. With remerciements! I am enjoying burning the candle at both ends, extremely! Reformation definitely begins in May; a lasting one. Ergo: there is still a lot of hay to be made, \& only a week's sunshine! Well, 't is a good world in the main. Today I go to the 'Vermissage' at the New Salon - a swell affair, but enjoyable from the number of French and other friends sure to be met there. After this I am going to spend every morning from 9 till 12:30 at the Hotel. St. Romain in the room I took there d'avance, in writing.

Hoping you are well, 


\section{To J. Stanley Little, May 19, 1892}

16 Winchester Rd | Swiss Cottage | W. | Thursday Night | 19 May 1892

My dear Little,

Thanks for your letter. We both look forward to visiting you on Saturday of next week.

I have read your Hardy Counterblast ${ }^{63}$ with extreme interest. There is one passage in it in particular which says ably and succinctly what many men and women are thinking - I mean the close of the penultimate paragraph on Slip 2: the passage beginning "Broadly considered, physical beauty denotes etc".

I have copied this for future use. It is admirably put.

Ihave sent the slips on to a man to whom I have already spoken warmly of you and your work. I think some work, of an ordinarily remunerative kind will come to you through him. He or I will communicate with you probably next week. It is not much - but "many littles make a muckle".

Ever yours, I In haste, | William Sharp

ALS Princeton

To Henry Hyde Champion, ${ }^{64}$ May 19, 1892

May 19, 1892 | Monday Evening

My dear Champion

I send you Proof-Slips of a reply-article by my friend Stanley Little, the critic etc, of whom I spoke to you in connection with the Novel Review. They will give you a good idea of his style - and as he is a fearless and able writer \& excellent critic I think he is just the man to prove a serviceable ally. 
À vous toujours | William Sharp

ALS Private

To Arthur Stedman, May 21, $1892^{65}$

Just time (for today's mail) to send a hurried P/C of acknowledgment of your long \& friendly letter, of the unbound copy of my poems \& of receipt of the copies of "Flower o' The Vine" - got today at 72 Inverness Terrace. They are charmingly got-up, and in every way I am pleased.

Hope to write by next mail: must post this at once, or I'll miss the mail.

W.S.

ACS Columbia

\section{To J. Stanley Little, May 25, $1892^{66}$}

My dear Little

Just time for a hurried line - Yes - the palates of both of us cry "All Hail" - at the idea of Guinea Fowl. Be assured we will be well content with everything.

It will be impracticable for us to get away on Saty before the 3:55 train from Victoria - arriving at Rudgwick at 5:30.

I had a pleasant glimpse of your brother ${ }^{67}$ and his wife last Saty.

À vous toujours | W. S. 


\section{To J. M. Stoddart, ${ }^{68}$ May 25, 1892}

25/May/92 | London

Dear Mr. Stoddart

On returning from Paris I find your letter among others awaiting me. Sorry "The Second Shadow" did not suit you.

I thought I had already written to you about Mrs. Blanche W. Howard. I gave her your message. At the moment, we are not in a position to collaborate, but it is quite possible she may have something of her own ready for you. If so, no doubt she has by this time communicated with you.

Do you think you would care for a romance by myself for the magazine? It would be called "Monsieur Yank", and is a story of love and exciting episodes in and around Paris during the Franco-German war and the Commune. The hero is a young American, who becomes known as Monsieur Yank. I am working occasionally at it - but will now wait till I hear from you.

Please tell Miss Lillian North my long silence about the MS with which she entrusted me does not imply forgetfulness on my part. I shall write to her erelong.

Best regards to you and yours

Yours cordially | William Sharp 


\section{To J. Stanley Little, June 4, 1892}

Saty. June 4.92

My dear Little,

You will have received the telegram I so regretfully dispatched this morning. It is a great disappointment to us both.

But last night Elizabeth had a relapse, and I had to go out at an early hour to fetch the doctor. He found her rallying again (it seems to be a kind of malarial fever - a recrudescence of what she had abroad once) - but now absolutely forbids her moving: as the risk would be too great. Besides, she is too weak.

He hopes she may be able to get away by Wednesday: possibly by Tuesday. I want her to go to the sea: but she clings to the idea of Rudgwick. Then she "doesn't want to be bothered with strangers", and looks upon you as a friend: indeed, I can assure you, she has conceived a very warm feeling for you in every way, as friend and comrade and writer - a feeling, my dear fellow, you will allow me to say, I share to the full. Will you be at home during the coming week? (By the way, I must put off Champion, ${ }^{69}$ having written to him to propose next Thursday). If not: are the rooms comfortable at the Martlett (?): and, in particular, is there any garden where E. could sit in the sun?

If she can't get away till Wedny, it is possible I may run down on Monday to see [?] about the wall-papers: but I cannot be sure till I see how E. gets on. ${ }^{70}$

We are treating you at your word, you see: but I won't apologise, for I know how wholehearted your kindness is.

In gt. Haste | Affectionately Yours | William Sharp

Thanks for the "Wealden School" paper. I'll do what I can. ALS University of British Columbia 


\section{To Laura Hyde Stedman, [June 7?, 1892]}

Bucks Green I Rudgwick I Sussex

Dear Mrs. Stedman,

I shd. have written before this to ask about Mr. Stedman since his Jamaica trip (tell him his Poetry Articles ${ }^{71}$ are being much appreciated here) but all correspondence has been impossible lately, owing to my wife's sudden and severe illness - a recrudescence, in part, of malarial fever caught at Genoa. She is now, I am glad to say, out of danger.

At the end of June we "settle" at the above place - lovely country and healthy if somewhat remote. It will be our pied-à-terre at any rate.

Ever yours, | William Sharp

ACS Columbia

\section{To Bliss Carman, June 11, 1892}

Letter-address after this | The Laurels ${ }^{72}$ | Bucks Green | Rudgwick | Sussex

My dear old Man,

I hope the change from the Independent is in every way to your advantage.

I wish you could get some good post over here!

And now do publish a selection of your best work in verse: it is a mistake to postpone too long.

I wish very much you would do me a favour and send me by return a copy of the new magazine "The Knight Errant".

Entre nous: It is possible I may shortly myself bring out a magazine of a strikingly "modern" kind - one such as we do not have in England in any form. ${ }^{73}$ If so, no contributor's name will be more welcome than that of my dear friend and true poet, Bliss Carman.

Ever yours | William Sharp 


\section{To Arthur Stedman, [?June 11], 1892}

New address | The Laurels | Bucks Green | Rudgwick - Sussex

All correspondence has been impossible lately owing to my wife's sudden and severe illness - a kind of recrudescence of a malarial fever. She is now out of danger I hope. We hope to "move into" the above address at the end of June - a pleasant and healthy if somewhat remote country.

Hope you and yours are well

W.S.

ACS Columbia

\section{To J. Stanley Little, June 20, 1892}

16 Winchester Road | Swiss Cottage | N.W. | 20 June 1892

My dear Little

On arrival here we found 2 copies of "Heine", which seems to have been pubd. on Saty. ${ }^{74}$

E. sends on one at once to you. She will write her name etc. in it the first time she is at Rudgwick.

By the way, I find that F. J. Palgrave' $\mathrm{s}^{75}$ address is 15 Chester Terrace, Regents' Park, N.W. An early caller is at the door - I must be off -

Yours ever, I W.S. 


\section{To. J. Stanley Little, June 21, 1892}

21 June 1892

My dear Little

I did not see Champion ${ }^{76}$ after all. He seems to have left town - but where or for how long I do not know.

So I think it will be better to postpone your visit to us on Friday night, till the following week (or whenever a meeting can be arranged) - all the more for the reason that I must set-to on Friday and write perhaps all day and night and the greater part of Saturday at an important article which must be finished by the week-end. I apologise for thus putting you off, so far as my share in the act is concerned, for I know you will make all allowances.

When are you to be in town in any case, on Friday or Saty?

Affectionately Yours, camerado mio, | W. S.

ALS Princeton

To J. Stanley Little, June 21, 1892

Tuesday Night | 21/VI.92

My dear Fellow,

I snatch a moment before the midnight post to answer yours to hand a little ago.

Yes: Mary $^{77}$ has, I think, charged too little for the copying. It is my fault mainly. I told her in this instance to charge at the same rate as she does for me or any particular friend - forgetting that the last thing she did for me was a long affair, done at leisurely intervals and at a nominal rate. So she conscientiously abided by "the letter of the law". I think if 
you send her $7 / 6$ - or even in this instance the 10/ - you suggest, as she had to get a new type-ribbon on purpose - she will be well satisfied. You might say you had consulted me, and that in future (i.e. if you are willing to send more copying to her to do) you wish to pay for it at the same rate: i.e. about half the price charged by professional typists. She will be very glad to copy for you at that rate (as this is the only way she can get any irresponsible pocket-money, owing to my mother's limited means now) - and she is generally both expeditious and expert. But of course, don't in any way feel bound to send to her unless entirely convenient in every way. If you do feel so inclined, you can always send without enquiring as to whether she can do it or not: unless you want it in a great hurry, in which case it might be advisable to ask if she is free. (Any time except from July 25th to August 20th -3 weeks in which she will be at the West Coast.)

Thanks, old chap, for "The Wealden Painters". ${ }^{78}$ I'll try a para. about it in one or two quarters.

Do take care of yourself - and not overwork. (By the way, have you the 'rights' of "Barracks and Bohemia": ${ }^{79}$ if so, why not try a shilling paper-copy edn. of it - say with Scott or some other firm, at a royalty?)

Elizabeth has gone to bed, very tired, but not unwell, though she wishes she was back at Littlehampton or under your hospitable and friendly care - both, alas, out of the question meanwhile: or else she would join in love to you.

Hurriedly Yours, I W. S.

ALS Princeton 


\section{To J. Stanley Little, June 22, 1892}

Wednesday, 22 June 92

\section{My dear Little}

Many thanks for your long letter about the house - which we now think of calling "Kingscroft", as that name has a raison d'être from what you say about old Farmer King.

I have written to my sister Mary, about the other matter, and told her that you wd. not agree to such a nominal honorarium.

I enclose Postal Notes for 18s/-, which please hand over to Napper (being the stipulated amount, 2/6 per day with $6 \mathrm{~d}$ for beer, for five days): and it wd. much oblige me if at the same time you would inform him that we want nothing more done to the garden at present. I shall see to the further doing-up of it when I come to Rudgwick. When handing him the money, please say that Mr. Sharp says he has nothing to do with any extra labour unauthorised by him, and that this engaging extra assistance without consulting him first, is a thing he will not tolerate again. But if the scything has really been done, and Napper [has] done his work well, I am willing to let the 3s/ - I already advanced on a/c go as drink-money for his assistants.

This is perhaps a worry for you, old chap? If so, don't do it, and I'll write direct: I am sure you have enough on your hands as it is. Your P.S. about the letters and book-packets you did up makes me shudder. Honestly, my dear fellow, you must 'draw in', or you will waste all your energies. At least, wait till you have a sposa amorosa to help you!

Elizabeth says she would like (if nothing has yet been done) if the paint of the stairway, landing, and doors belonging thereto be done in a dark red (Pompeian red) - of one colour only, instead of the two shades already approved to match the paper. The doors in the Hotel at Littlehampton are responsible for this change of view.

Again, if the drawing room has not been gone on with, we would now like if the painting of the skirting, doors, and mantel piece be uniformly of the pale tint of yellow, instead of the pale and yellow, as first arranged - but the inside of the doorless cupboard to be entirely of the deeper shade of yellow. 
The sanitary surveyor is to be at the house on Thursday afternoon I understand.

We don't want earth-closets, owing to the worry and expense of the frequent cleaning. We'll use only one water-closet: but I'll wait till I hear from Mr. Brooks and Mr. Jay before deciding further.

I think now I'll enter with furniture about the 13th or 14th of July just when E. goes away for a fortnight to Germany.

I have read your "Wealden Painters" 80 again with great interest. It seems to me a pamphlet like that ought to bring you work, if some copies were properly placed. I'll give you some special introductions for America, to try and get an "art-letter" to do.

In gt. haste - | Affectly Yours | William Sharp

ALS Princeton

To J. Stanley Little, June 24, 1892

24 IJune 92

My Dear Little

A thousand thanks for all your trouble.

We have now fixed upon a charming name for the house - if Jay be agreeable - namely "Phenice Croft": which adjusts itself, too, to his own place at Great Bookham - Phenice Farm. ${ }^{81}$

I return the Shelly Signature-List, with minimal suggestions as to the order in which I, if I were in your place, would line them. Also, Draft of the Prospectus, with one or two minor suggestions - scarcely, perhaps, worth suggesting. Both there \& in the list - as invariably, either in print or MS. - I wish my name given in full, \& not as "W. Sharp" or "Mr. Sharp": as "William" is so recognizably part of my literary name that mention of it is much the same as to write to or of Theodore Watts as "T. Watts", or Walter Crane as "W. Crane", ${ }^{82}$ or Stanley Little as "S. Little". 
You understand of course, old Chap, that my slight emendations are mere suggestions: and that I am in no way interfering with you or Mr. Robinson, The prospectus is excellent - \& my hurried \& minor suggestions, hurriedly noted down, are merely to the end to give no handle to the ever ready 'corking reviewer'. Very likely, I am hypercritical.

My dear boy, we are both very sorry about the play, and the matter of the return: and fully sympathetic with you in the chagrin caused you. You have made so long and brave a fight, that the only thing to offer is Rossetti's favorite and family mote "Frangas non Flectas" 84 - for you, we are sure, are one who may be broken but will never be bent. The tide must turn: so say and believe Your affectionate friends

William Sharp and Elizabeth A. Sharp

\section{ALS Princeton}

\section{To J. Stanley Little, June 30, $1892^{85}$}

Thursday

\section{My dear Stanley Little}

I really do not know how to thank you for the splendid review you have written of my Heine. ${ }^{86}$ It will be of the greatest service to me, for you have said the best thing possible for me where you say "we are deluded with the belief that we have the work of a perfect master of the English language expressing himself quite naturally in his native tongue" - Also the sentence "She has absorbed Heine \& given him back etc".

It is [a] generous appreciation indeed! And gives me confidence to go on with this sort of work, wherein the essential necessity is to reproduce the essential qualities of the writer under translation in a foreign tongue. To be literal in the sense rather than merely in the words, for often the nominal equivalent in English of a word in another language is not the real equivalent. 
I have no additions to suggest - your review is so good, far better than I expected to receive. Thank you so much; for I know you would not say what you do not think, and therefore your praise is precious.

I did not answer sooner about other translations because I have been trying to find out particulars. Leland is revising his whole translation of prose and poetry and is bringing it out volume by volume in England now! I have so far forestalled him with the Letters on the French Stage. There is one vol: of miscellaneous prose in the Canterbury Series; and there are one or two odd volumes of prose - one by Snodgrass called, I think, "The Humour \& Pathos". But, excepting Leland's American edition I believe that the present contents of my book have no... ${ }^{87}$

It vexes me to think you have had so much work on my account but I appreciate it hugely.

Certainly I will go and see your brother's picture. I am always glad of the opportunity of seeing his work, which I thoroughly admire.

[Elizabeth A. Sharp] 


\section{Chapter Nine}

\section{Life: July-December, 1892}

On July 8, Sharp apologized to Julia Ward Howe's daughter, Maud Howe Elliott, for being unable to entertain her since he had no residence in London. His wife, moreover, was leaving in a few days for the Wagner festival in Bayreuth, and he was "going into Sussex to superintend the arrival of our furniture at a country place I have taken there." Elizabeth left for Germany on July 11, and Sharp went down to Buck's Green on the fourteenth where he stayed with Stanley Little pending the furniture's arrival. It arrived while Elizabeth was abroad, and when she returned in the third week of July, the Sharps settled into the old stone house that would be their home for two years.

On July 10 Sharp wrote a letter that includes his response to Little's request that he give the main address at an early August celebration of the centennial of Percy Bysshe Shelley's birth. The letter contains details about the state of his health and his opinions about several contemporary writers.

And now about the Shelley address. For several reasons it would be a pleasure as well as an honour - but the truth is that I dare not venture just now on anything of the kind, for physiological reasons. My doctor has just warned me of this vein-trouble that I have not yet satisfactorily got under. The least thing may bring it back - and this must not be, as it might easily become dangerous ('clotting'). One requisite is - not to stand. Walking does not now hurt me if in moderation: but even a short stand involves pain and discomfiture. And though I may be all right again by the end of the month I really must not risk the danger involved in the fatigue of standing to address. 
This passage demonstrates that as early as 1892, when he was only thirtyseven, Sharp had developed symptoms of diabetes. He went on to say he could write an address for Little or someone else to read, but it would be far better to have a more prominent Shelleyan give the address. He thought the best choice would be Stopford Brooke, next Edward Dowden (two Irishmen), next Roden Noel, next John Nichol (two Scotsmen), next Sir George Douglas, or why not Little himself who was organizing the event. Richard Garnett, Sharp warned, was "not a good speaker and has not the right manner," and surely not H. Buxton Forman who was "a jellyfish" and "a Philistine of the Philistines in manner and address."

Shelley was born in Horsham, Sussex on August 4, 1792, and the commemoratory event took place there on August 4, 1892 at the stately home of Mr. Hurst of Horsham Park "with its beautiful gardens laughing in the sunlight of a lovely summer day" and affording "to visitors no untrue glimpse of the surroundings amid which Shelley as the son of an English squire was brought up." Many literary luminaries attended; and according to the August 11 issue of the West Sussex Gazette "The hall was crowded; all classes were represented, and Horsham, the county, and London, divided the audience fairly amongst them." As it happened, Little followed Sharp's advice in engaging as the principal speaker Professor John Nichol with whom Sharp studied at Glasgow University. The September issue of The Artist reported "What Nichol said about Shelley, at Horsham, was the very thing that needs to be said." He "completely carried his audience." The organizers, principally Stanley Little, were "brilliantly successful in their arrangements" With Sharp as his adviser, Little gathered together a committee and many illustrious sponsors to raise money for a Shelley Museum in Horsham, and their efforts survive today as substantial collection of books, manuscripts, portraits and sculptures in the Shelley Gallery of the Horsham Museum.

The main purpose of Sharp's July 7 letter was to ask Little, who was in Buck's Green, to tell the local postman the house formerly called the Laurels is now Phenice Croft. All mail addressed to the Sharps and all mail addressed to Mr. W. H. Brooks at Bucks Green, Rudgwick was to be placed in a post bag to be picked up by a boy in the forenoons. Sharp had settled on a name for the quarterly he would produce at Phenice Croft - The Pagan Review - and the pseudonym he would use for its editor - W. H. Brooks. The pseudonym would disguise the review's 
editorship, and the real editor - Sharp - would produce the entire content of the first issue under various pseudonyms. Sharp began working on the content of the review when he and Elizabeth were staying with the Cairds at Northbrook, Micheldever in early June. His diary entry for June 2 begins: "In the early forenoon, after some pleasant dawdling, began to write the Italian story, "The Rape of the Sabines," which I shall print in the first instance in my projected White Review as by James Marazion." The color white also figured prominently in the poems of Sospiri di Roma, white marble statues, white flowers, white statues, and white human bodies, but as the content of the review evolved "pagan" supplemented "white" in the magazine's title. In a letter from Paris dated April 23, Sharp had addressed Thomas Janvier and his wife as "fellow Pagans." He told Janvier he was deeply involved in the "feverish Bohemianism of literary and artistic Paris" and described one of those involvements:

I went round to Leon Vanier's, where there were many of les Jeunes Jean Moréas, Maurice Barrés, Cazalis, Renard, Eugène Holland, and others (including your namesake, Janvier). To-night I ought to go to the weekly gathering of a large number of les Jeunes at the Café du Soleil d'Or, that favourite meeting place now of les decadents, les symbolistes, and les everything else.

It may have been in Paris that Sharp settled on the term Paganism to define his loss of Christian faith, his encounter with the remnants of the Roman past in Italy, and his desire to join the decadents in breaching the restraints of high Victorianism.

Dennis Denisoff and Loraine Kooistra in "The Yellow Nineties Online," describe the "Foreward" to The Pagan Review as having "the urgency of a manifesto ... declaring on behalf of the 'younger generation' that the magazine's contributors challenged both the religion and the ideals of their forefathers."

The editor's apparent preference for authors with French names, the foreward's discussion of art for art's sake, and the publication's references to Charles Baudelaire, Theophile Gautier, Oscar Wilde ... signal Sharp's wish to have his readers associate the magazine with aestheticism. By 1892, the Aesthetic Movement had already had a lengthy run of popularity and was shifting into its final, decadent phase... . To this phase of the Aesthetic Movement, The Pagan Review offers a notable contribution. 
"Its emphasis," they continue, is "on the dissident, mythic, and obscure. Its tendency toward overwrought descriptions and archaic dialogue are reminiscent of decadent authors and artists, ... and its mystical depictions of alternative gods and spiritualities aligns it with paganism in a more earnest and disconcerting way than many other British contributions to the decadent movement." (https://www.ryerson.ca/ $\mathrm{cdh} /$ projects/yellow-nineties-online)

Having announced in the preface to Romantic Ballads in 1888 the advent of a new Romanticism, Sharp added to that initiative in 1891 the sensuality and escape from rhyme in Sospiri di Roma. By the summer of 1892, he had settled on New Paganism as the name of the movement he was trying to launch and for which The Pagan Review served as a manifesto. Its "first number," dated August 15, 1892, contained:

A lengthy unsigned "Foreward."

Two poems ("The Coming of Love" by W. S. Fanshaw and "An Untold Story" by Lionel Wingrave).

Three stories ("The Pagans: A Memory" by Willand Dreeme, "The Rape of the Sabines" by James Marazion, and "The Oread: A Fragment," by Charles Verlaine).

The "Opening Fragment of a Lyrical Drama" called "Dionysos in India" by Wm. Windover and a "dramatic interlude" called "The Black Madonna" by W. S. Fanshaw. The latter reappeared in Vistas by William Sharp in 1894.

A review by "S" of Stuart Merrill's Pastels in Prose (Harper \& Brothers, New York, 1890).

A "Contemporary Record, Me Judice" a series of comments signed W. H. B., the supposed editor, on recently published works of literature by well-known writers, many Sharp's friends, including Swinburn, Hardy, Meredith, and Hall Caine.

A final section announced the next issue of the Review, to include an article titled "The New Paganism" by H. P. Siwaarmill, the anagram of William Sharp he had invented the previous fall in Germany for the author of the "Dramatic Interludes." These "Interludes" eventually became Vistas by William Sharp.

On the back cover, an advertisement for a book soon to be printed privately as Vistas: Dramatic Interludes by W. S. Fanshawe (no longer H. P. Siwaarmill), the supposed author of one of those interludes included in the first and only number of The Pagan Review. 
Each of these items merits discussion for what they reveal about Sharp's state of mind, what he hoped to accomplish as a writer, and his method of composition. Two stand out because they are directly traceable to his recent experience in Paris.

First, the review of Stuart Merrill's Pastels in Prose which contains Merrill's translations of "prose poems" by contemporary French writers. Sharp's decision to attribute the review to " $\mathrm{S}$ " is as close as he came to acknowledging his responsibility for the new periodical. The review associates The Pagan Review with the symbolist poets and the decadence infusing literature in Paris and London. It also reflects Sharp's genuine interest in alternatives to rhymed and cadenced poetry. The prose poem differs, he wrote in the review, from a "quoted specimen of poetic prose." It must be brief and complete in itself, the equivalent of a pastel in the art of painting. The pastel artist must be "what is somewhat too vaguely called an impressionist" whose aim is "suggestion, not imitation." The prose poem is "a consciouslyconceived and definitely-executed poetic form." Sharp concluded the review by quoting from William Dean Howell's description of the form in his introduction to Merrill's book: "The very life of the form is its aerial delicacy: its soul is that perfume of thought, of emotion, which these masters here have never suffered to become an argument. They must be appreciated with sympathy by whoever would get all their lovely grace, their charm that comes and goes like the light in beautiful eyes." Sharp experimented with this form in the writings of Fiona Macleod.

Second, "The Pagans: A Memory" by Willand Dreeme. Which is identified as "Book One" at the start and "To be Continued" at the end. As with the poems of Sospiri di Roma, the story recounts his personal experience overlaid by dreams and imaginings. Unlike the sospiri, a pseudonym removes the possibility of identifying the true source of the experiences. The appendage to the title ("A Memory") and the name of the author ("Willand Dreeme") invite the reader to wonder if the content is Willand's memory or his dream. The narrator of the story and its main character is Wilfred Traquair, who is called Will. Sharp was known to his relatives and close friends as Will. The title signals the story as the most pagan of the contributions to The Pagan Review, and the three quotations that preface it - from George Eeckhoud's Kermesses, 
from "The Song of Solomon," and from Oscar Wilde - associate it with the French and English decadence.

Sharp wrote the story on June 3 and 4, less than a month after returning from France. The story's narrator recalls walking with his beloved in an unidentified warm landscape among the trees 'under the deep blue wind-swept sky" where they "first realized each had won from the other a lifetime of joy." His recollection is Sharp's romanticized recollection of his walks with Edith Rinder on the Roman Campagna fifteen months earlier.

The snow lay deep by the hedges, and we had to slip through many a drift before we reached the lonely woodland height whither we were bound. But was there ever snow so livingly white, so lit with golden glow? Was ever summer sky more gloriously blue? Was ever spring music sweeter than that exquisite midwinter hush, than that deep suspension of breath before the flood of our joy?

Soon Clair had to return to Paris, and the narrator returned to the London he "hated so much, there to write concerning things about which I cared not a straw, while my heart was full of you, and my eyes saw you everywhere, and my ears were haunted day and night by echoes of your voice." When he accumulated enough money to be independent of London, he went to Paris, and he recalls his joy in meeting Clair again and finding "that we loved each other more than ever." Shifting effortlessly between third-person narration and directly addressing his beloved, he recalls "that bygone Spring,"

Those hours at twilight, in the Luxembourg Gardens, when the thrush would sing as, we were sure, never nightingale sang in forest-glade, or Wood of Broceliande: those hours in the galleries, above all before our beloved Venus in the Louvre; ah, beautiful hours, gone forever, and yet immortal, because of the joy that they knew and whereby they live and are even now fresh and young and sweet with their exquisite romance.

He wonders "if ever two people were happier?" Yes, they were happier when they left Paris behind and went away together, "as light-hearted as the April birds, as free as the wind itself."

Letters Sharp wrote from Paris in April to E. C. Stedman, Thomas Janvier, and J. Stanley Little, implied the woman he loved was with him in Paris for the last two weeks of April after which he intended to "reform." Though details differ, this story about the two Pagans parallels 
the experiences of Sharp and Edith: their meeting in Rome in January 1891, their parting when she returned to London, and Sharp's recent escape from London to Paris where the April birds were singing. It is, of course, possible that Sharp was recounting only what he imagined it would have been like to have Edith with him in Paris, but the innuendos are so telling, the parallels so obvious, and the writing so impassioned it is hard to avoid concluding she was there. As in the Sospiri poems after Edith left Rome in January 1891, so in this story, Sharp's intense feelings begged for release. If there is an adolescent tinge to the writing and the insinuations, it may be explained, if not excused, by the likelihood that this was Sharp's first experience of falling in love. William and Elizabeth were first cousins who became engaged as teenagers. Their relationship, while very close, was from the start intellectual, a meeting of minds, and a matter of convenience. It developed over time into a deep friendship in which Elizabeth functioned as a protector, nurse, and enabler overseeing the well-being of her "poet." Throughout the 1890s the wealthy Mona Caird, imposing and forceful, figured prominently in the lives of the Sharps and the Rinders. Their ideas and actions were inevitably influenced by her campaign to loosen the restraints imposed by marriage.

The body of "The Pagans" contains a long and detailed description of the beautiful Clair. She is a painter living with her brother, also a painter, who is hyper-concerned about his reputation and status. Clair's skin was "pale as ivory, but "touched with a delicious brown, the kiss of sunshine and fresh air." It was "in keeping with the rich dark of her hair and sweeping eyebrows and long lashes." As it continues, the elaborate description mirrors a surviving portrait of Edith Rinder, which was known to her family as "the Lady Green Sleeves." The picture is not colored, but her velvet dress was green. Clair's brother disapproves of her relationship with Wilfred and threatens to take away her inheritance, as is his right, if she persists, but persist she does. She leaves her brother and goes off with Will, unmarried, flouting her brother's standards of acceptable behavior and his beliefs about the subservience of women to men. As they leave, the brother gives Wilfred a letter addressed to a "Vagrant, of God-knows where" which reads: 
That my sister has chosen to unite herself with a beggarly Scot is her pitiable misfortune: that she has done so without the decent veil of marriage is her enormity and my disgrace.... neither you nor the young woman need ever expect the slightest tolerance, much less practical countenance from me. You are both at liberty to hold, and carry out, the atrocious opinions (for I will not flatter you by calling them convictions) upon marriage which you entertain or profess to entertain. I, equally, am at liberty to abstain from contagion of such unpleasant company, and to insist henceforth upon an unsurmountable barrier between it and myself.

Here the brother espouses the traditional views of marriage opposed by Mona Caird and her friends. The story ends: "Outcasts we were, but two more joyous pagans never laughed in the sunlight, two happier waifs never more fearlessly and blithely went forth into the green world." Though the story was "To be continued" it was not, but it would be told over and over again with different characters - mostly "beggarly Scots" - in the stories Sharp would tell as Fiona Macleod. The beginning sentences of "The Pagans" speaks of Clair Auriol in the past tense. The relationship that was so wonderful has ended for some unexplained reason. Sharp focused on the beginning of passionate relationships while recognizing the likelihood of their sad endings. This story is the first of many renditions of the impossibility of permanence in his relationship with Edith since neither could or would sever their marital ties, she to Frank Rinder and he to Elizabeth Sharp.

Sharp sent copies of his Pagan Review to friends and editors of periodicals where it might warrant notice. He sought subscribers at twelve shillings a year, and he welcomed contributions of short stories and poems that conformed to the purposes described in the first number's Foreword. On August 13 Sharp wrote to E. C. Stedman from Selsey Bill on the Sussex Coast, where he and Elizabeth had gone to escape the extreme heat of Buck's Green. He was sending a copy of The Pagan Review, and he confessed he was responsible for all of its contents. It was to be the voice of "Neo-Paganism," a "new movement in letters ... unlike any that has taken place in England before, in the Victorian Age at any rate: though indeed it is a movement that is at hand rather than really forward." Sharp was initiating yet another "movement."

E. C. Stedman subscribed, but must have expressed reservations since Sharp's letter to him on September 28 contained the following passage: 
I thank you for your lovely \& friendly letter. I feel there is a good leaven of truth, to say the least, in what you say about the "Pagan Review." But set your mind at rest: the poor thing is dead. There is a possible resurrection for it next year as a quarterly, but this is still in nubibus. It has, however, so far accomplished its aim of stimulus among the younger people, and that is good. I return herewith your subscription, with sincerest thanks. Have mislaid it. No time to hunt for it now. Hope to send it by next post. By the way, keep your $\mathrm{P} / \mathrm{R}$. It is already being sought by collectors. I can send you another if you wish.

Elizabeth said the review was born of Sharp's "mental attitude at that moment, ... a sheer reveling in the beauty of objective life and nature, while he rode the crest of the wave of health and exuberant spirits that had come to him in Italy after his long illness and convalescence" (Memoir 204-07). He soon realized he could not continue the Review as it would be hard to repeat the tour de force, and he would have to write most of the material under various pseudonyms. The one number had served its purpose "for by means of it he had exhausted a transition phase that had passed to give way to the expression of his more permanent self." For Elizabeth, the Review was a step toward the writings of Fiona Macleod. Sharp returned all the subscriptions and submissions with the following memorial card:

On the 15th of September, still-born The Pagan Review.

Regretted by none, save the affectionate parents and a few forlorn friends, The Pagan Review has returned to the void whence it came. The progenitors, more hopeful than reasonable, look for an unglorious but robust resurrection at some more fortunate date. "For of such is the Kingdom of Paganism."

In a "solemn ceremony," with Sharp's sister Mary and Stanley Little as "mourners," they buried the Review in the corner of the garden at Phenice Croft and marked the spot with a framed inscription.

R[obert] Murray Gilchrist, a writer Sharp corresponded with when he edited the "Literary Chair" of Young Folk's Papers, submitted a story for The Pagan Review called "The Noble Courtesan," which Sharp read with interest. Writing first as W. H. Brooks, Sharp said he thought it would be much improved "by less - or more hidden - emphasis on the mysterious aspect of the woman's nature. She is too much the 'principle of Evil,' the 'modern Lilith.'" Then on October 22, he wrote 
again, this time as William Sharp, to thank Gilchrist for his "friendly and cordial article" about The Pagan Review in The Library. When the Review is revived next year as a quarterly, Sharp wrote, he would look to Gilchrist "as one of the younger men of notable talent to give a helping hand." Born in Sheffield in 1867, Gilchrist was apprenticed to a manufacturer of cutlery after attending grammar school. In 1888 he decided to become a writer, left the apprenticeship, and moved to Highcliffe Farm, near the village of Eyam several miles southwest of Sheffield in Derbyshire. He was soon joined there by George Alfred Garfitt, who was also born and educated in Sheffield. Five years older than Gilchrist, Garfitt may have been a fellow apprentice. In any case, he became a manufacturer of cutlery, an amateur historian, and Gilchrist's life-long partner. Sharp concluded his letter to Gilchrist by asking him to visit Phenice Croft when he next came south. "I can offer you a lovely country fare, a bed, and a cordial welcome." As it happened, Gilchrist and Garfitt did not visit Phenice Croft until 1894, but Sharp visited them in Eyam in September 1893. At this first meeting, the three men formed a close friendship that lasted many years and impacted the course of Sharp's publications.

It is a matter of some interest that when John Lauritsen established his Pagan Press in 1982 to publish "books of interest to the intelligent gay man" the first book he published was Edward Carpenter's Ioläus, An Anthology of Friendship which had been out of print for many years. In 1891, when Carpenter was teaching in Sheffield, he met and formed a relationship with George Merrill, a working-class man 22 years his junior. In 1898 they began living together in rural Millthrope, Derbyshire only a few miles from Holmesfield, Derbyshire where Gilchrist and Garfitt had moved into a large manor house they shared with Gilchrist's mother and sisters. The two couples became close friends. Both chose, quite sensibly, to live quiet lives miles away from the uproar caused by the Oscar Wilde trial in London. Paganism, a fascination with preChristian Roman and Greek civilizations, has a long history preceding and following Sharp's "New Paganism." By necessity if not by choice, Sharp's paganism was heterosexual, but he had many homosexual friends during his life, and he was perfectly comfortable with love and desire no matter its form. He would be amused by the coincidental linkage a century later of his "New Paganism" with the first product of 
Lauritsen's Pagan Press by two couples living quietly as near neighbors in remote Derbyshire.

In Sharp's August letter to Stedman, he objected to Stedman classifying him as "an Australian poet" in the latest edition of his study of Victorian poets and asked him to remedy that error in the volume's next edition. After describing The Pagan Review and asking Stedman what he thought of it, Sharp continued:

By the time you get this - no, a week later - I shall be in Scotland, I hope. My wife cannot go north this year. If all goes well - this ought to be one of the happiest experiences of a happy life. I cannot be more explicit: but perhaps you will understand. But even to be in the Western Highlands alone is a joy. Then I am going to reform and work hard all winter. I rather doubt if we'll get away to Greece after all: funds are villainously low for such exploits.

Again he implies that he and Edith Rinder would be together in the Western Highlands where the Rinders rented a house every September. The implication is strengthened by a passage in a letter to Bliss Carman, also in August: "Think of me early in September (from August 30th) in the loveliest of the West Highlands - \& in one of the happiest experiences of my life. I can't be more explicit - but you will understand! Thereafter I am going to reform - definitely."

When Alfred, Lord Tennyson died in early October, some began to question the need to appoint a successor Poet Laureate. Sharp considered joining those who opposed another appointment, but on October 9 he told Stanley Little he had decided not to take any initiative in the "abolishment scheme." After attending Tennyson's funeral in Westminster Abbey on the twelfth, Sharp sent a letter to the poet Alfred Austin saying he was pleased to have seen him at the funeral. After describing his removal to "a small house in a remote part of Sussex" where the rent was cheaper than in London, he turned to the Laureateship. "If you, as many think, are to be the heritor, the laurel will go to one who will sustain the high honor with dignity and beauty." Austin did inherit the title, and he may have recalled this letter in 1902 when Sharp was desperately in need of money. A Civil List Pension was out of the question because Sharp refused to reveal to members of Parliament his authorship of Fiona Macleod's popular writings. His friend Alexander Nelson Hood, who was the Duke of Bronte, and Alfred 
Austin, the Poet Laureate, were the principals in the effort to obtain the pension, and they were supported by George Meredith, Thomas Hardy, and Theodore Watts-Dunton. Finally, Sharp agreed to allow Austin and Hood to tell the recently-elected Prime Minister, Arthur Balfour, in strict confidence that Sharp was the author of the writings of Fiona Macleod, whereupon Balfour found the money for a grant that provided needed relief.

Sharp concluded his August 13 letter to Stedman by saying he doubted he and Elizabeth would be able to carry through on plans to go to Greece during the winter as funds were "villainously low for such exploits." He hoped to continue with his creative work in the fall, but Elizabeth's health intervened. She had not fully recovered from the malaria she contacted in Italy in the spring of 1891. In her words (Memoir 208), "The prolonged rains in the hot autumn, the dampness of the clay soil on which lay the hamlet of Buck's Green, made me very ill again with intermittent low fever." It was imperative, her doctor said, that she spend at least part of the winter in a dry climate. Since they lacked the funds for traveling south, Sharp put aside his "dream work" and wrote between October and December two boys' adventure stories. "The Red Rider: A Romance of the Garibaldean Campaign in the Two Sicilies," appeared serially in the Weekly Budget in late 1892, and "The Last of the Vikings: Being the Adventures in the East and West of Sigurd, the Boy King of Norway" was accepted by Old and Young and published in 1893. Both appeared subsequently in book form from James Henderson and Sons, Ltd. These efforts and other writings by both Sharps provided money for them to go south for the first two months of 1893. By midNovember, they had given up Greece and planned to go to Italy. In early December Sharp told Stanley Little they were planning to go to Florence via Switzerland and the Gothard Pass and then on to Sicily and North Africa. He urged Little to accompany them as far as Florence or Rome as he needed a break from work and would find wonderful paintings to view and assess. By mid-December, they had decided to go to the Mediterranean by ship "as it is at once considerably less expensive, \& more restorative for E."

In mid-November, Sharp became involved in a controversy following the publication of the reminiscences of the Pre-Raphaelite poet and painter William Bell Scott, who had died in 1890. Autobiographical 
Notes of the Life of William Bell Scott appeared in two volumes edited by William Minto, a Scottish critic and novelist. In a letter to Arthur Stedman at the end of November, Sharp said he had just "finished reviewing for the Academy the book of the season in literary circles here - the late Wm. Bell Scott's Autobiography." Though "full of misstatements and illintentioned half-statements," it was a fascinating book because of its letters and anecdotes. Swinburne was going "to slate it unmercifully (and very foolishly) in the December Fortnightly." He had been dining at Swinburne's house in Putney a few days previously and found him "very excited over 'The Monster' [Scott] to whom he has paid so many affectionate tributes in verse!" Swinburne's review entitled "The New Terror" appeared in the December issue of The Fortnightly Review, and Sharp's in the December issue of The Academy.

Scott had emphasized his close friendship with Rossetti while diminishing the roles of Swinburne, Theodore Watts [Dunton], Sharp, and others in Rossetti's life. Sharp's opinion of the book had evolved as he read more of it. Initially, he told Watts that Scott had "persistently pooh-poohed your good \& gracious service to him" and portrayed himself as Rossetti's only true "nurse \& friend." He claimed D. G. R. had made use of Watts. Sharp continued,

As to the lies current that you, and others including myself, assisted rather than deplored D. G. R.'s chloral habit, \& made out that he was much worse than he was, will gain some colour by the implication in the second allusion to yourself. I think you know how I love and reverence Gabriel Rossetti's memory. I am not blind, of course, \& I know his faults \& weaknesses - but he was a great genius, \& as man he won my love, \& shall have it till I die. I have glanced thro' the D. G. R. passages since I wrote to you last, \& with deepest pain.

Sharp then complained about Scott's "insultingly cruel epithet to Ruskin" and expressed his amazement that Minto, the editor, had "let pass uncorrected (if he could not suppress, as he ought to have done) so much that ought not to have seen the light." He was outraged by

the remarks about Swinburne - one of the greatest poets of our century. The more one knows \& rereads his work, \& critically \& comparatively, the more one admires it \& his high attitude throughout. He was my idol in old days, \& now again I realise how great a poet he is. And just as the public mind is slowly veering towards that high acceptation of him 
which is his due - out comes this foolish \& spiteful nonsense, which will spread abroad to his detriment! Well, W. B. S. can't hurt A. C. Swinburne, nor a thousand W. B. S.'s.

Sharp said he would send his review for Watts and Swinburne to read and suggest revisions.

Several days later, he told Watts he was having trouble writing the review and had decided to start over from scratch.

Now that I have finished the book \& gone carefully into it, I not only more than ever regret Swinburne's article but think we have all underestimated the good in the book. There is a great deal of interesting matter, particularly in the letters introduced: and I do not see how the book is to be killed, or that it should be killed. Frankly, the book has far more chance of life than Hake's far more genial \& generous as the latter is. Once pruned of its misstatements and otherwise carefully revised, it would be extremely entertaining and to future students of the period profoundly interesting \& even valuable. One must be fair all round. It is a damnably difficult thing to do in this instance: but I'll have one more shot anyway!

Sharp decided that Swinburne's attack, which he read or heard about at dinner, was regrettable since, apart from the passages diminishing the role of others, the work contained much of interest and value. After starting work on the review during the night, he sent Watts the next morning "the Article, as written up to the point where I turn to indicate what is "worthy and of good report" in Scott's Memoirs. Again he remarked in a postscript: "It has been an infernally difficult review to write. I began, after a third trial, in this more moderate \& advisable fashion. I found I could not omit mention of Minto, but have done so pleasantly. Please do not cut out or alter in any way my MS. but jot any suggestions in pencil on a separate slip."

After the review appeared Sharp thanked Watts for his

generous appreciation, though I'm bound to say I don't see anything particular in the review, except tact - for it was infernally difficult to be just to what is good in the book and yet to blow the counterblast. From what I hear, it has been a good deal noted in the very quarters I wanted it to be - namely among those who bear neither you nor me any good will: and it is admitted that my frank outspokenness knocks the ground from under "Scotts's" feet as regards D. G. R., your relations to him and so forth. 
He knows there will be one or two American critics "who will hold up W. B. S. as a trustworthy authority to show how poor a fellow D. G. R. was, how deserted by his worthiest friends, and how you were only "a minor newcomer," \& so forth." He planned to go out of his way to have his review reproduced in one or two influential American journals to set the record straight. Despite the difficulty of writing the review during the last two weeks of November, he thought he had reached the right balance, and the review appears to have been well-received.

On November 18 Sharp wrote to Kineton Parkes to propose a review of a" remarkable book" by E. C. Stedman - The Nature and Elements of Poetry - which was a revised reprint of his "much-noted essays on Imagination, Truth, Beauty, Melancholia, etc. which have been appearing in The Century." He would try to write it for the December issue of the Library Review, but the very next day he wrote again to Parkes to say he was too busy to write an adequate review as he wanted to do more than a mere notice. He could, though, send Parkes an article on Scott's "'Reminiscences' with its wealth of addenda concerning the poet-painters and painter-poets of the Pre-Raphaelites. On November 28 he wrote to the editor of Blackwood's Magazine in Edinburgh to say he would be able to submit an article about William Bell Scott's relations with other painters and poets in the Rossetti circle by the end of the week. Writing again on December 5, he said he was too busy with commissioned articles and other literary work to finish the Scott article for the January number. The promises and retractions indicate the extent to which he was overextending himself trying to acquire funds for the impending trip.

He did, however, accomplish a good deal of writing in 1892, and there were a sizeable number of publications. His Life and Letters of Joseph Severn appeared in February, and A Fellowe and His Wife appeared in the spring in England, America, and Germany. He published articles on Philip Marston and Maeterlinck in The Academy and on Thomas Hardy in The Forum. Flower o' the Vine, poems from Romantic Ballads and Sospiri di Roma, was published in the United States. The excessively-titled "Second Shadow: Being the narrative of Jose Maria Santos y Bazan, Spanish Physician in Rome" was published in the Independent in New York, and an article titled, "Severn's Roman Journals" appeared in Boston's Atlantic Monthly. He completed and submitted Vistas, the Maeterlinckean short 
dramas or interludes he started writing in Germany in the fall of 1891, to Elkin Mathews in England and Charles Webster in America. They decided not to publish it, but the volume would see the light of day in 1894. In mid-1892 the Sharps had settled into Phenice Croft where they hoped to experience a Phoenix-like rebirth, but the need to generate money forced a delay in their plans for creative work. 


\title{
Letters: July-December, 1892
}

\section{To Maud Howe Elliott, 1 [July 8 or 9? 1892]}

\author{
16 Winchester Road I Swiss Cottage I N.W.
}

Address after July 15th I Phenice Croft I Rudgwick I Sussex

Dear Mrs. Elliott

I received so much courtesy and friendliness when I was in New York and Boston (Cambridge) last winter, that - even apart from the exceptional pleasure of seeing you again - it would have given my wife and myself much pleasure if we could have seen you and your husband here. But at present we are only in apartments, having given up our house in town as we have been so much abroad during the last two years: and there, moreover we leave in a few days - my wife going over to Germany to see "Parsifal" etc. at Bayreuth, and I going into Sussex to superintend the arrival of our furniture, etc. at a country place I have taken there.

I had just ventured to express to Mrs. Moulton ${ }^{3}$ how much pleasure it had given me to meet you, when my friend Charles Graham ${ }^{4}$ told me that he was to call on you some evening soon, and that you had kindly invited him to let me be his companion on the occasion.

I told him that next Wednesday was my first free night, and we agreed to go then, and to take our chance of finding you at home.

But I have just recollected hearing you say something to Mrs. Moulton about your going out of town next week: and though I think you specified Thursday, you may be going earlier, or you might not want to be interrupted on Wedny evening.

Otherwise, pray do not trouble to reply to this note, as I am sure you must be glad to lay aside the pen altogether for a while - a luxury which we writing people are seldom allowed to enjoy. I shall regard silence as equivalent to approval of Mr. Graham's and my joint proposal.

I did not realize till after we parted that you were Maud Howe, the author of the "San Rosario Ranch"' and "Atlanta in the South." ${ }^{5}$ Forgive me if I have not remembered the names exactly, but it must be two years 
or more since I had the pleasure of reading them, during my first visit to America.

Believe me | Yours very truly | William Sharp ALS Brown University Library

\section{To J. Stanley Little, July 10, 1892}

Sunday 10 July 92

My dear Little,

Thanks for your letters. I do not expect to get to Rudgwick till early on Friday morning, but if I can manage it will be down by the evening of Thursday. I'll take advantage of your hospitable kindness at the set-off: but I want to come to some arrangement with you.

Meantime will you please oblige me (1) by keeping in your charge any letters or books etc. that come for either of us.

(2) by going at your convenience to the Post-office and telling the Post-official that the quondam "Laurels" is now Phenice Croft. Further, you might inform the Station Master of the same, in the case of parcels or enquiries. We are giving as address simply 'Phenice Croft, Rudgwick,' and omitting Bucks Green.

(3) Will you at the same time draw particular attention to the fact that all letters, packets, etc., addressed to Mr. W. H. Brooks, ${ }^{6}$ Bucks Green, Rudgwick are to be delivered at Phenice Croft (or kept till called for by me). I enclose a note of authorisation if necessary. Entre nous, "W. H. Brooks" is an editorial pseudonym. For obvious reasons, I do not wish to give 'Phenice Croft' as Mr. Brooks' address, but simply "Bucks Green, Rudgwick" or "Rudgwick."

The best plan would be for me to have a post-bag: in which all letters for Mr. and Mrs. W. S. and Mr. W.H.B. could be put. I think I'd send a boy up in the forenoons.

More about this when we meet. 
Elizabeth leaves here tomorrow: I on Wednesday: (for 72 Inverness Terrace W). I'll write or wire as soon as I know my definite movements.

And now about the Shelley address. For several reasons it would be a pleasure as well as an honour - but the truth is that I dare not venture just now on anything of the kind, for physiological reasons. My doctor has just warned me of this vein-trouble that I have not yet satisfactorily got under. The least thing may bring it back - and this must not be, as it might easily become dangerous ('clotting'). One requisite is - not to stand. Walking does not now hurt me if in moderation: but even a short stand involves pain and discomfiture. And though I may be all right again by the end of the month I really must not risk the danger involved in the fatigue of standing to address.

What I can do, if no suitable person can be had, and if otherwise advisable, would be to write an address, for you or someone to read.

But I do think that special effort should be made to get some prominent Shelleyan. Of the names you suggest, I think much the best to be Stopford Brook. ${ }^{7}$

Thereafter, Dowden: ${ }^{8}$

Thereafter, I should say the Hon. Roden Noel ${ }^{9}$ rather than Garnett ${ }^{10}$ or B. Forman. ${ }^{11}$ Garnett is the better man for the purpose of course, but he is not a good speaker and has not the right manner: and B.F. is a Philistine of the Philistines in manner and address.

Thereafter I can think only of Prof. Nichol ${ }^{12}$ as a possibility: or, among young men, of Sir George Douglas.

Why not yourself?

Still, Garnett might do. He is sympathetic in his bad manner, and that is much. B. Forman is a jelly-fish.

The date is an unfortunate one for getting hold of people.

In great haste, I Ever affectly Yours, I William Sharp ALS Princeton 


\title{
To Edmund Clarence Stedman, August 13th, [1892]
}

\author{
Somewhere on Selsea Bill ${ }^{13}$ | Sussex Coast | 13th August \\ Continuation of letter of $10 \mathrm{th}^{14}$
}

Amico Mio,

I had to send off my letter so hurriedly by the last mail that I did not write so fully as I intended. As the August heat became trying we left our Phenice Croft and came off to the remotest part of the sea-coast in this region. I am rather apprehensive lest a remark near the end of my letter wd. be misread by you: for, of course, far from being resentful of your kind mention of me in Victorian Poets, ${ }^{15}$ I was and am grateful. Only, as I said, that unfortunate classification of me among the Australian poets has been taken ample advantage of by those who honour me by their enmity: to the end that I should always be ranked as a colorist, with all that pertains to such classification. Of course I am now so much better known that in a sense I need mind it no more - yet the very small worry dies hard. Only last week Gosse ${ }^{16}$ (who has known of me as a writer, for at least 10 years, and has written me voluntarily more than one flattering letter) protested to a friend that he knew next to nothing of me, and assured him (vide V.P.) that I was only one of many an insignificant band of Australian colonists.

All this is such a small matter that I am half ashamed to trouble you with it. Petty literary malice and jealousy are known to all lands - and I daresay you know Gosse's and others' reputation. Certainly now that the tide has turned I need not bother: and yet dear E.C.S., if in your power in any "definite edition" later on, please either transfer your kind mention of me to another part, or simply strike the passage out.

You will, I am confident, not misunderstand me? I put the small matter before you as a younger man before an elder, for his friendly consideration.

But pray do not dream of writing to me, directly or indirectly, on this point. As I say, I merely draw your attention to a small rectification.

I sincerely hope that the fierce heats you have been experiencing in America have not too severely tried Mrs. Stedman or yourself. 
Needless to say, I often think of you both, and often wish to see you again.

I have sent to you by this post the first number of a new magazine of a new kind in this country - for which I am responsible: though this is sub rosa. ${ }^{17}$ The new movement in letters here is unlike any that has taken place in England before, in the Victorian Age at any rate: though indeed it is a movement that is at hand rather than really forward. "The Pagan Review" is to be the voice of this Neo-Paganism. A hint of our drift is given in my "Foreword," and it will be more fully expressed in a paper on "The New Paganism" in the October number. I hope your volume on Poetics ${ }^{18}$ will have a special article there: for you, certainly, are of those who do not need to count years, but are young always. It would greatly interest me if you would tell me sometime - by a message thro' Arthur, or your secretary, for I do not expect you to write - what you think of the "Pagan Review" and its contents and aims. I may add, again sub rosa, that I am responsible for a good deal more than the "Foreword"! It is entirely my venture, and though I naturally do not expect to make it pay (and it was not undertaken to this end) I hope its subscription-sale may pay actual expenses. A minimum of 500 copies monthly must be sold: otherwise the "Pagan Review" must join the congested Limbo of premature births. So if you know any one athirst for "Paganism" tell him, her, or them to subscribe (to "W. H. Brooks," as per editorial note).

By the time you get this - no, a week later - I shall be in Scotland, I hope. My wife cannot go north this year. If all goes well - this ought to be one of the happiest experiences of a happy life. ${ }^{19}$ I cannot be more explicit: but perhaps you will understand. But even to be in the Western Highlands alone is a joy.

Then I am going to reform, and work hard all winter. I rather doubt if we'll get away to Greece after all: funds are villainously low for such exploits.

Don't forget what I said in my last note about your autograph "Ariel" for the Shelley Library. ${ }^{20}$

Ever, dear friend,

Admiringly and Affectionately Yours, I William Sharp 


\title{
To Bliss Carman, [August 13?, 1892]
}

\author{
Phenice Croft | Rudgwick | Sussex
}

My dear old fellow

I wonder where you are just now: anyway, not in New York I hope, where the heat must be intolerable. I am writing this on Selsea Bill, a lonely promontory on the southwest Sussex coast, where we have come for a few days from the above address, to escape the August heats. I hope you like your new post, though I was sorry to hear of your having left the Independent.

I sent to you by this post the first number of a new magazine ${ }^{21}$ for which I am directly responsible - though this at present is sub rosa. It appeals to a new sentiment that is arising. I shall be curious to know what you think of "The Pagan Review," its contents and aims. Please write to me as fully as you can spare time: with any suggestions. And will you contribute later on, when the exchequer provides payment (if it ever does!) It is a pure labour of enthusiasm at present - and though I do not expect to make the venture pay ( \& it was never undertaken to this end) I hope it may repay its expenses - though to this result there must be a minimum subscription list of 500 copies. If you can help in any way, officially or privately, I frankly ask you to do what you can.

This and the next number will create a good deal of interest I expect. I may confide to you, again sub rosa, that I am responsible for a good deal more than the "Foreword" and editorial notes \& Record! Indeed, you would probably recognise one piece at any rate, "The Black Madonna," though I forget if this is one of the "Vistas" I read to you in New York. But remember that at present I do not wish "William Sharp" to be read into "W. S. Fanshawe".

I shall be very curious to hear from you. By the way, I have posted two copies: one to you privately, and one for "Current Literature," where I hope you may be able to do something to draw attention to it. And as I do not know the addresses, will you further oblige me by sending on the copies I send to your care to Edmund Collins ${ }^{22}$ and $\mathrm{Mr}$. Bower $^{23}$ respectively - with a request to do what they can. 
What about your Poems? When is that longed for volume to come out? I have been reading a lot of your privately printed verse lately with renewed and even greater pleasure. I wonder how dear old Roberts ${ }^{24}$ is. Think of me early in September (from August 30th) in the loveliest of the West Highlands $-\&$ in one of the happiest experiences of my life. I can't be more explicit - but you will understand! Thereafter I am going to reform - definitely. ${ }^{25}$

Ever, dear Carman,

Affectionately Your Friend \& Comrade (\& Fellow Pagan)

William Sharp

ALS Fales Library, New York University

\section{To Edward Dowden, September ?, $1892^{26}$}

Phenice Croft I Rudgwick I Sussex

My dear Dowden

Just a line of most cordial congratulation on your appointment as Clark Lecturer at Cambridge - a deserved honour for you and a reputable honour for the University.

Selfishly, too, I am glad: for the chances of meeting you in person are now enhanced.

Cordially Yours I William Sharp

ALS Trinity College Dublin 


\section{To Subscribers of The Pagan Review, [September 15, 1892]}

On the 15th September, still-born The Pagan Review. Regretted by none, save the affectionate parents and a few forlorn friends, The Pagan Review has returned to the void whence it came. The progenitors, more hopeful than reasonable, look for an unglorious but robust resurrection at some more fortunate date. "For of such is the Kingdom of Paganism." ${ }^{27}$

W. H. Brooks.

Memoir 207

\section{To Edmund Clarence Stedman, September 28, 1892}

Phenice Croft | Rudgwick, | Sussex | 28th September 1892

My dear Poet,

I have just remembered that if I do not send you a birthday greeting today, there will be no chance of its reaching you by the 8th. It must, perforce, be a brief one - for not only am I overwhelmed in work just now (though the extreme and too severe pressure will be over in a day or two), but our sole day-post goes out immediately.

But it does not require many words to send you my love and homage, and to wish for you prosperity and happiness in the coming year. If affectionate goodwill and loyal friendship could secure for you all that makes life best worth living, you would be well "set up." And I am so glad that towards the end of the year that has gone you have broken into such sweet and high song. It is a good augury. I am hopeful that we shall have much of "Stedman the poet" in your new year. You have had a brilliant and worthy career, and won a high name and place: but there are many who, as myself, believe that you have some "high utterance" to give us yet.

You have had a fortunate life, amico mio: and that is much: to me, I admit, the supreme thing. I would rather have lived, as I have done, 
intensely, and as you have done, than win any mere repute at the expense of the bitter-sweet of varied \& keen life.

Well - all happiness and good be yours.

I thank you for your lovely \& friendly letter. I feel there is a good leaven of truth, to say the least, in what you say about the "Pagan Review." But set your mind at rest: the poor thing is dead. There is a possible resurrection for it next year as a quarterly, but this is still in nubibus. It has, however, so far accomplished its aim of stimulus among the younger people, and that is good. I return herewith your subscription, with sincerest thanks. Have mislaid it. No time to hunt for it now. Hope to send it by next post.

By the way, keep your P/R. It is already being sought by collectors. I can send you another if you wish.

I am looking forward greatly to your book of Poetics: ${ }^{28}$ the essays ought to have a wide and deep effect.

My love to you and yours - with cordialest greetings from my wife. I hope to write erelong and more fully (but with nothing calling for any reply - for you must conserve your energies) -

Now and always affectionately,

Your friend, I William Sharp

P.S. In the "Shelley Centenary" record - for "popular" distribution throughout the country - published today, with brief biographical notes on the leading signatories - you are entered thus: - "Ed - C - S - : An American biographer, essayist, \& poet of the highest distinction. Mr. Stedman's poem 'Ariel' was conspicuously successful among the centenary odes in honour of Shelley."

ALS Columbia 


\section{To Elbert F. Baldwin, September 28, 1892}

Phenice Croft | Rudgwick | Sussex | 28th Sept/92

Dear Mr. Baldwin ${ }^{29}$

In response to your last kind letter I send you a story of a 'bogie' kind, "Dr. Aylmer's Ordeal," which may suit you. It is perhaps a little longer than you want - but is, if I am not mistaken, a good deal shorter than "The Second Shadow."

I hope it will please you.

Cordially yours I William Sharp

Elbert F. Baldwin Esq., Editor, "The N.Y. Independent”

ALS Private

To Thomas A. Janvier, [October, 1892]

Rudgwick, Sussex.

Dear Mr. Janvier,

For though we are strangers in a sense I seem to know you well through our friend in common, Mr. William Sharp!

I write to let you know that The Pagan Review breathed its last a short time ago. Its end was singularly tranquil, but was not unexpected. Your friend Mr. Sharp consoles me by talking of a certain resurrection for what he rudely calls "this corruptible": if so the P/R will speak a new and wiser tongue, appear in a worthier guise, and put on immortality as a Quarterly.

In the circumstances, I return, with sincerest thanks, the subscription you are so good as to send. Also the memorial card of our late lamented friend - I mean the P/R, not W. S. Talking of W. S., what an admirable 
fellow he is! I take the greatest possible interest in his career. I read your kind and generous estimate of him in Flower o' the Vine with much pleasure - and though I cannot say that I hold quite so high a view of his poetic powers as you do, I may say that perusal of your remarks gave me as much pleasure as, I have good reason for knowing, they gave to him. He and I have been "delighting" over your admirable artistic and charming stories in Harper's. ${ }^{30}$ By the way, he's settling down to a serious "tussle." He has been "a bad boy" of late: but about a week previous to the death of The Pagan Review he definitively reformed - on Sept. 11th in the early forenoon, I believe. I hope earnestly he may be able to live on the straight henceforth: but I regret to say that I see signs of backsliding. Still, he may triumph; the spirit is (occasionally) willing. But, apart from this, he is now becoming jealous of such repute as he has won, and is going to deserve it, and the hopes of friends like yourself. Mrs. Brooks' love to Catherine ${ }^{31}$ and yourself: Mine, Tommaso Mio, You know you have...

W. H. Brooks.

P.S. Elizabeth A. Brooks was so pleased to receive your letter.

Memoir 204-05

\section{To Robert Murray Gilchrist, ${ }^{32}$ October, 1892}

Rudgwick, Sussex, 10:92

My dear Sir,

As it is almost certain that for unforseen private reasons serial publication of The Pagan Review will be held over till sometime in $1893,{ }^{33}$ I regret to have to return your MS. to you. I have read "The Noble Courtesan" with much interest. It has a quality of suggestiveness that is rare, and I hope that it will be included in the forthcoming volume to which you 
allude... . It seems to me that the story would be improved by less or more hidden - emphasis on the mysterious aspect of the woman's nature. She is too much the "principle of Evil", the "modern Lilith." If you do not use it, I might be able - with some alterations of a minor kind - to use it in the $P / R$ when next Spring it reappears - if such is its dubious fate.

Yours very truly, I W. H. Brooks

P.S. It is possible that you may surmise - or that a common friend may tell you - who the editor of the $\mathrm{P} / \mathrm{R}$ is: if so, may I ask you to be reticent on the matter.

Memoir 206

To Richard Le Gallienne, October 7, 1892

Phenice Croft | Rudgwick | Sussex | 7th Oct:'92

Dear Mr. Le Gallienne,

I am at present from home - but expect to return tomorrow. As soon thereafter as practicable, I mean to write to you about your "English Poems, ${ }^{\prime 34}$ which I received today.

Meanwhile I send this brief word of acknowledgment - and to thank you heartily for the gift of your book: a large-paper copy, to boot!

You may be sure that it is welcome, and will be valued aright "For the sake of the song that is sung and the singer that sings the song." ${ }^{\prime 35}$

Tonight, I am too busy to write more.

By a coincidence, I was on the point of writing to you today about your promised visit: but I found that both next week-end and that succeeding are impracticable.

But soon thereafter my wife and I hope that Mrs. Le Gallienne and yourself will come to us from a Friday till Monday. I'll let you know possible dates a little later. We can promise you a pleasant country with 
innumerable walks - honey and cream and other country fare - books galore, and a writing-room if you wish it, and a hearty welcome.

Our cordial remembrances to you both,

Sincerely Yours, | William Sharp

ALS University of Texas at Austin

To J. Stanley Little, October 8, 1892

Phenice Croft, | Rudgwick, | Sussex | Saty Night, Oct.8.92

My dear Stanley

We have just returned here.

On reconsideration I have decided not to take any initiative in the Poet Laureate abolishment scheme. In any case, the idea is so much in nubíbus at present that I wouldn't refer to it as a movement already actually started but simply vaguely entertained. So go in for it yourself by all means if you wish - I thank you all the same for considering my possible wishes and determination in the matter. I am actually quite willing that you, instead of W. S., should take up the matter.

If there is any chance of your being here on Sunday, we shall no doubt see you: but I shall send this on in case you do not come.

In haste,

Ever Affectly Yours, I William Sharp 


\section{To J. Stanley Little, October 9, 1892}

Sunday Morning | Oct-9-92

\section{Dear Stanley}

You will, I know, be very sorry to hear of Woolner's sudden death on Friday night. ${ }^{36}$ It is strange, coming so abruptly on Tennyson's.

I add this to say - let the Biography affair stand over till you return.

My pen is driven too hard at the moment for aught that can be avoided.

Ever yrs. I W.S.

ALS University of British Columbia

To Alfred Austin, [October 14?, 1892]

Phenice Croft, | Rudgwick, | Sussex.

My dear Austin

It was with quick pleasure that I saw you at Westminster Abbey on Wednesday, and noticed, too, how well you were looking. ${ }^{37}$

It seems a very long time since we met; but what with my absences abroad and in America, and my ever busy life here my opportunities have after all been very few. Still, I should have made a more direct effort to see you.

We have taken a small house in a remote part of Sussex - at first as much with the idea of its being a good pied-à-terre as of its becoming a permanent residence - the rent does not come to much more than what we had to pay for storage etc.: and we thought, too, it would be easier for us financially than to be in London - which I find to be a delusion. 
Still, it is quieter: and for some things we deem it more fortunate - though it remains to be seen how the climate will suit my wife - at present, I fear, it does not.

You will, I know, be glad to hear of the success of my novel, à deux, "A Fellowe and His Wife", and of the literary success of my long delayed "Severn Memoirs."

As for yourself, you are I hope not only well but doing that which is so dear to you, "making a sweet song out of the things that be."

I, in common with everyone, wonder how the Laureateship is to be settled. ${ }^{39}$ If you, as many think, are to be the heritor, the laurel will go to one who will sustain the high honour with dignity and beauty.

If Mrs. Austin remembers me, pray give her my best regards.

My wife is from home today, or would join with me in remembrances to you both.

Always Cordially Yours I William Sharp

P.S. Is there any chance of your being in London between the 22nd and 28th?

ALS Yale

\section{To R. Murray Gilchrist, October 22, 1892}

Phenice Croft, Rudgwick, | 22:10:92

Dear Mr. Gilchrist,

Although I do not wish the matter to go further, I do not mind so sympathetic and kindly a critic knowing that "W. S." and "W. H. Brooks" are synonymous.

I read with pleasure your very friendly and cordial article in The Library. By the way, it may interest you to know that the "Rape of the Sabines" and - well, I'll not say what else! - is also by W. H. Brooks. But this, no outsider knows... . The Pagan Review will be revived next 
year, but probably as a Quarterly: and I look to you as one of the younger men of notable talent to give a helping hand with your pen.

I suppose you come to London occasionally. I hope when you are next south, you will come and give me the pleasure of your personal acquaintance. I can offer you a lovely country, country fare, a bed, and a cordial welcome.

Yours sincerely, I William Sharp.

Memoir 206-07

To Edmund Clarence Stedman, October 28, 1892

Phenice Croft I Rudgwick I Sussex

Just a hurried line, amico mio, to say that all other addresses may be canceled for the above, which is my "permanent" one. Either that or 72 Inverness Terrace, Bayswater, London. (if you don't remember the first) will always find me.

William Sharp

ACS Columbia University Library

To Alfred H. Miles, October 31, 1892

Phenice Croft, | Rudgwick, | Sussex.| 31:Oct:92

My dear Sir, ${ }^{40}$

I have just received and glanced through with great interest the latest two additions to your admirable series. 
It has occurred to me that you might care to have the notice of Philip Marston from myself - partly for the obvious reason of our intimacy, partly because I could give some interesting particulars (unknown to anyone else) concerning the posthumous fame he has further achieved. I am glad to know that I have been instrumental in doing such service to that well-loved friend by my critical selection of his best poems in my Canterbury volume.

I have written to Messrs. Hutchinson \& Co. with a proposal - but on second thoughts do not send it till I have first communicated with you, lest I should be encroaching on what you may regard as your own province. I enclose the letter for you to see: if you consider it beyond your scope, and a matter only for Messrs. Hutchinson's decision, will you kindly forward it to them - or to me, as may be most convenient.

Yours very truly I William Sharp

Alfred H. Miles Esq

ALS University of British Columbia

\section{To Alfred H. Miles, November 4, 1892}

Phenice Croft | Rudgwick | Sussex | 4th Nov. '92

My dear Sir,

I am obliged to you for your frankly explicit letter.

It seems to me that the most courteous thing for me to do is to refrain from sending the letter to Messrs. Hutchinson \& Co. ${ }^{41}$ and this I shall do whether I come to a definite arrangement with Mr. Walter Scott or do not. $^{42}$

You have frankly let me infer your plans with regard to the extension of your series: let me be equally frank (and speak equally sub rosa) and tell you that I have for years been engaged on a volume of the 'Romantic' 
and contemporary French poets, and that I hope to issue this early in 1893.

I have arranged to write a long and important article in one of the leading monthlies - you will excuse me, I know, from saying which at present - on "The Poets and the Poetry of the century," apropos of your admirable series, as soon as it is complete. I shall then bear in mind what you say about the whole publication being of your own planning and arrangement.

Yours very truly I William Sharp

ALS Princeton

To J. Stanley Little, [November, 1892]

Phenice Croft, I Rudgwick, I Sussex. I Monday

My dear Stanley,

I have no time to answer your letter in detail. It must suffice at present to say that the idea you have a black mark against you at the Athenaeum office is, to put it plainly, sheer nonsense. As for Watts ${ }^{43}$ himself, he quite understands $-\&$ you need not have a moments thought further on that score.

I do not see that there is the slightest call for you to alter towards your friend. He is no doubt an excellent fellow - though personally I am prejudiced enough not to wish a further acquaintanceship.

I shall leave here tomorrow afternoon and be back by Thursday evening. At the end of the week I suppose you will be back: there are one or two things then I want to talk over with you.

I trust you will find Bosham ${ }^{44}$ as entertaining as other parts of the Selsea Peninsula.

We are both enjoying the rheumatic damp of happy Budgwick [sic].

A rividerla, Camerado egregio, I W. S. 


\section{To Theodore Watts [-Dunton], [November ?14, 1892]}

Phenice Croft, I Rudgwick, I Sussex.

... of you: ${ }^{45} \&$ who have persistently pooh-poohed your good \& gracious service to him. For then, naturally, there is 'proof' here that $S \operatorname{cott}^{46}$ was almost the only true 'nurse' \& friend, - \& that D.G.R. simply made use of you. As to the lies current that you, and others including myself, assisted rather than deplored D.G.R.'s chloral habit, \& made out that he was much worse than he was, will gain some colour by the implication in the second allusion to yourself.

I think you know how I love and reverence Gabriel Rossetti's memory. I am not blind, of course, \& I know his faults \& weaknesses - but he was a great genius, \& as a man he won my love, \& shall have it till I die. I have glanced thro' the D.G.R. passages since I wrote to you last, \& with deepest pain.

That insultingly cruel epithet to Ruskin suits much of the book only too well. I am amazed Minto ${ }^{47}$ should let pass uncorrected (if he could not suppress, as he ought to have done) so much that ought not to have seen the light.

I feel the outrage of the remarks about Swinburne - one of the greatest poets of our century. The more one knows \& rereads his work, \& critically \& comparatively, the more one admires it \& his high attitude throughout. He was my idol in old days, \& now again I realise how great a poet he is. And just as the public mind is slowly veering towards that high acceptation of him which is his due - out comes this foolish \& spiteful nonsense, which will spread abroad to his detriment! Well, W. B. S. can't hurt A. C. Swinburne, nor a thousand W. B. S.'s.

My article ${ }^{48}$ - which I must make a long one - will be out on Friday week: that is the Friday after next.

I will send it to you on Thursday night, if, as I hope I may, I cannot call that ... 


\section{To J. Stanley Little, [November ?15, 1892]}

Phenice Croft, I Rudgwick, I Sussex. I Tuesday Night

\section{My dear Stanley}

I left via Guildford but not feeling up to the mark, \& thinking that E. was feeling very dull owing to the infernal weather, I came back. I'll leave tomorrow at 8:14 \& be back probably on Thursday. I shall probably be here on Saty night and Sunday - but it is possible I may be at George Meredith's. If you are here on Friday please look in. Almost certain to be here from Friday onwards - I want to tell you about our "final revised plans" for Jany-Feby: and to see how far you can adapt your plans to suit. [We shall leave London on the 2nd Jany. The more I think of it, the more I am sure you shd. have a change too - even if only for a few weeks. You ought to do it every way. Let us talk it over on Friday]. I find they [plans] must be on a more moderate financial scale, and not so far afield - so Italy now takes the place of Greece, etc.

Take care of yourself, my dear fellow, in this cursed damp. Put me in mind, and I'll give you some Rossetti memoranda for the Selsea paper $^{49}$ - i.e., if, as I suppose you will, you intend to include Bognor. ${ }^{50}$ Do not eat too many Selsea lobsters - stand neither yourself nor others too many gins and bitters - smoke not at all - avoid the siren that bewitcheth - and come back whole and flourishing to Kensettian and Phenice-Croftian Budgwick.

Ever yours, I Will S.

Your letter came just as I'm leaving. There's nothing come between us, you silly but dear old chap. As for K. G. M's sin it's not heinous! It is only that it discredits, for me, his testimony in other matters. It wd be absurd to make too much of a little 'gas' otherwise. Be assured I think no more of the matter.

\section{ALS Princeton}




\section{To Theodore Watts-Dunton, [November 18, 1892]}

Phenice Croft, I Rudgwick, I Sussex. I Friday

My dear Watts

I find that the lab[?] bràve I had calculated on is off for the winter season - so you cannot receive MS. ${ }^{51}$ till sometime tomorrow forenoon.

It is just possible I may bring it in person.

I simply cannot do this review. I must start afresh. About 9 o' clock I'll sit down to it \& write all night if necessary. If at all possible, let me have it again as arranged. If not, I daresay Cotton ${ }^{52}$ will manage if he receives it from me first thing on Tuesday morning: for if you don't post before 5, I can't receive on Sunday. Now that I have finished the book \& gone carefully into it, I not only more than ever regret Swinburne's article, but think we have all underestimated the good in the book. There is a great deal of interesting matter, particularly in the letters introduced: and I do not see how the book is to be killed, or that it should be killed. Frankly, the book has far more chance of life than Hake's $s^{53}$ far more genial \& generous as the latter is. Once pruned of its misstatements and otherwise carefully revised, it would be extremely entertaining and to future students of the period profoundly interesting \& even valuable.

One must be fair all round. It is a damnably difficult thing to do in this instance: but I'll have one more shot anyway!

In haste | Sincerely Yours | William Sharp ALS British Library 


\title{
To Kineton Parkes, November 18, 1892, ${ }^{54}$
}

\author{
Phenice Croft, Rudgwick, Sussex
}

Dear Mr. Kineton Parkes,

I am constrained to break my rule of never writing except on payment, and payment at my own terms, in order to review a remarkable book which I understand will not be sent out to the press in this country, or, at most, not to more than three leading weeklies: although, I expect, it will have a large sale.

I allude to E. C. Stedman's "The Nature and Elements of Poetry." It is a revised reprint of the much-noted essays on Imagination, Truth, Beauty, Melancholia, etc. which have been appearing in The Century.

I fear that I am too busy to promise the article in time for your December issue - particularly as it may be a somewhat long one.

But, if you would care for it, let me know what is your last sending-in day.

I hope the Library Review is going well. It deserves to succeed.

With kind regards I Yours very truly I William Sharp ALS Private

\section{To Kineton Parkes, November 19, 1892}

\author{
Phenice Croft, I Rudgwick, | Sussex
}

Dear Mr. Kineton Parkes,

Since I wrote to you I find that it will be impossible for me to write a really adequate review of Stedman's "Nature \& Elements of Poetry" at present - as I do not care to "notice" the book merely, and to do anything more involves closer thought and work than I can afford to add to my other engagements. 
But, instead, if you like, I will send you an article on W. Bell Scott's fascinating "Reminiscences" (2 vols. Osgood \& co., 36f) - with its wealth of addenda concerning the poet-painters and painter-poets of that group.

In haste | With best wishes | Sincerely yours | William Sharp ALS UWM Library

\section{To Theodore Watts [-Dunton], [November 19, 1892]}

Phenice Croft, I Rudgwick, I Sussex. I Saturday.

My dear Watts,

I send the Article, as written up to the point where I turn to indicate what is "worthy and of good report" in Scott's Memoirs. Rectify me if necessary anywhere.

What a much more charming book, in spirit, Hake's is: but it has not the same inherent interest. W. B. S. certainly gives some memorable pictures, and not a few noteworthy data.

If you can manage to post it tonight - before 12 - I will receive MS. again first thing on Monday morning. Sunday, I fear, would run me too close - as the second post does not come till too late for me, as I am going to G.M. ${ }^{55}$ then, as I could not manage it last Thursday.

In haste I (Hoping your cold is better) | Yours ever, I William Sharp. P.S. It has been an infernally difficult review to write. I began, after a third trial, in this more moderate \& advisable fashion. I found I could not omit mention of Minto, but have done so pleasantly. Please do not cut out or alter in any way my MS. but jot any suggestions in pencil on a separate slip. 
P.S. I enclose a notice on Maeterlinck ${ }^{56}$ which I think one of my best critical articles. It was widely noted in Belgium, France, \& America - \& indeed here. Please let me have it again.

W.S.

ALS Brotherton Library, University of Leeds

To Edmund Clarence Stedman, November 19, $1892^{57}$

Phenice Croft I Rudgwick I Sussex

Just a line of acknowledgment (with sincerest thanks) of books.

I will read the book ${ }^{58}$ carefully before I write, which will be in about a week I expect.

William Sharp

ACS Columbia University Library

To Editor of Blackwood's Magazine, November 28, 1892

Phenice Croft, | Rudgwick, | Sussex. | 28 Nov:92

\section{Dear Sir}

In reply to your note, I hope to be able to submit the Scott etc. Reminiscences article to you by the end of the week at latest: possibly by Wedny or Thursday.

Yours faithfully | William Sharp

The Editor of "Blackwood's Magazine"

ALS National Library of Scotland 


\section{To Arthur Stedman, November 29, 1892}

Phenice Croft | Rudgwick | Sussex | 29th Nov:92

My dear Arthur,

Thanks for your note. My wife has already obtained "How to Judge a Picture etc."' otherwise: but she would like to have the "Principles." 59 In the unlikely event of there being any cash to the good, will you kindly send her a box of Stubb's long-pointed medium J pens. She cannot get them here, and likes them better than any other. Failing these, there is a maker Esterbrook or some such name, of whose somewhat similar pens I got some in New York.

Please note that until next March our best letter address will be 72 Inverness Terrace, Bayswater, London. On 1st January we leave for two months in Capri and Sicily. Work and financial reasons make it advisable that we do not go abroad this year, but on the other hand we both long terribly for the south, and my wife's health makes it almost imperative that we go.

Is there any good in my looking forward to anything in the way of cash from Flower $o^{\prime}$ the Vine: and if so is there any chance of its being remitted soon? If so, please let the draft be crossed "Union Bank of London, Regent St. Branch, a/c William Sharp." I have had painful experiences in losing cheques.

I must postpone a proper letter for a little while yet. I am in the midst of a great mass of work - and for a fortnight or more will have little "breathing-space." Please tell E. C. S. ${ }^{60}$ that I am daily reading a little of his winsome and altogether delightful book on Poetry, and, hope to write to him erelong.

Just finished reviewing for The Academy the book of the season in literary circles here - the late Wm. Bell Scott's Autobiography. It is full of misstatements and ill-intentioned half-statements but yet by virtue of its letters etc. is a fascinating book. Swinburne is going to slate it unmercifully (and very foolishly) in the December Fortnightly. ${ }^{61} \mathrm{I}$ was dining at his house in Putney the other day: he was very excited over "The Monster"62 to whom he has paid so many affectionate tributes in verse! 
Most cordial regards, Arturo Mio, I Yours ever, I W. S.

ALS Columbia

\section{To Editor of Blackwood's Magazine, December 5, 1892}

Phenice Croft I Rudgwick I Sussex | 5/12/92

\section{Dear Sir,}

I find, after all, that it is impracticable for me to send the Scott, etc. Reminiscences paper to you in time for your January number. My wife's health involves my going abroad with her soon after Christmas, and the pressure of commissioned articles and other literary work is too great to enable me to undertake an article on chance of acceptance, even for a later number than your next.

If you should wish the article, I think I could do it soon after the 20th inst - from that to the 26th. It would be on different lines (anecdotal, and illustrative of the "P. R. B." ${ }^{13}$ period) than that taken up in my long review of W. B. Scott's Memoirs in the current number of The Academy.

In any case I can do no more than promise to write it if I possibly can - but possibly you may now prefer that the matter be dropped.

In haste | Yours very brief | William Sharp

The Editor, "Blackwood's Magazine" 


\section{To Theodore Watts [-Dunton], [December 7, 1892]}

Phenice Croft, I Rudgwick I Sussex.

\section{My dear Watts}

Thanks for your generous appreciation, though I'm bound to say I don't see anything particular in the review, except tact - for it was infernally difficult to be just to what is good in the book and yet to blow the counterblast. From what I hear, it has been a good deal noted in the very quarters I wanted it to be - namely among those who bear neither you nor me any good will: and it is admitted that my frank outspokenness knocks the ground from under "Scotts's" feet as regards D.G.R., ${ }^{64}$ your relations to him and so forth. Old W.B.S.' $\mathrm{s}^{65}$ book proved quite a windfall to some small fry who, from combined envy and malice, delight in detraction. As I know that there are one or two among them who "do the literary stuff" for certain American papers, and who will hold up W.B.S. as a trustworthy authority to show how poor a fellow D.G.R. was, how deserted by his worthiest friends, and how you were only "a minor newcomer," \& so forth, I'll go out of my way - for I am not given to 'nobbling' in any form - to have my article reproduced in America in one or two influential places. As you probably know, there have been some most ungenerous things written about you in America, but in one or two cases I know them to have gone thence from London. Some individual has gone out of his way to send me the "Republican" with some silly nonsense about you and your Athenaeum work. But I allude to this - not in the spirit of the too kind friend who "thinks you would like to know, you know" - only to show that I do not speak at random.

I was to have written a more detailed article on "Recent Reminiscences" for Blackwood's - but two days ago I sent word to "beg off." I am so busy, and have so much more urgent \& remunerative work to do before we go abroad. Still, if I can manage it, I may even yet do it for B's or elsewhere. The only chance with a book like this as to deal with it promptly: otherwise the harm is done, and it takes years for the much-adulterated decoction to clarify. 
Herewith I return the A. C. S. paper, and, as you wish it, your own letter. I was, however, going to destroy the letter, for obvious reasons. ${ }^{66}$ ALS University of Leeds, Brotherton Library

\section{To W. Kineton Parkes, December 7, $1892^{67}$}

\section{Phenice Croft I Rudgwick I Sussex}

Dear Mr. Kineton Parkes

Thro' not having heard from you I concluded that either you did not care abt the Scott article or were in no hurry for it. It is now too late for me to undertake it, as I am overwhelmed with commissioned work that must be done before I go abroad abt Xmastide. Blackwood's suggested my sending an article on the subject, but I have had to write \& "beg off," as it is impossible to do it for a Jany number. I'll send you a line later on, à propos.

In haste, | Sincerely yours I William Sharp ALS, UWM Library

\section{To J. Stanley Little, [December 8, 1892]}

\section{Thursday Night}

My dear Stanley

We leave on the 2nd, for Sicily and North Africa. This, from what you tell me, will be beyond your means I know, but why not come with us as far as Florence? We go straight there via Switzerland and the St. Gotthard Pass, stopping one night on the way (Milan): and shall be there a few 
days. We could give you introductions to friends in Florence, \& also in Rome, if you went on there. I think you cd. manage this trip, with say 3 weeks stay abroad, for an inclusive sum of $£ 30$. I think you ought to try it - for your art-work's sake as well as for health, \& the impulse it wd. probably give you everywhere.

Our trip, alas, requires $£ 50$ planted down before we leave London!

Please let me know if you think you will come.

I suppose you are having a pleasant time at Bosham?

My Scott article ${ }^{68}$ seems to have attracted a great deal of attention. On the other hand, I hear that Minto is going to take up the cudgels.

I had a very pleasant visit to G.M. ${ }^{69}$ the other day.

Elizabeth is a good deal better, partly from slacking off a bit in work, I think.

When are we going to see you again? Can you dine with us on Saturday? Next week I shall be away Tuesday, Wedny, \& Thursday.

Love from us both

Yours ever I William Sharp

ALS Princeton

To Messrs. Williams \& Norgate, December 10, $1892^{70}$

Phenice Croft, I Rudgwick, I Sussex

Dear Sirs

Baron Tauchnitz writes to me that he will forward me 4 copies of my joint-novel "A Fellowe \& His Wife" on my authorization to the Customs. ${ }^{71}$ Will this note suffice?

Yours very truly I William Sharp

Messrs. Williams \& Norgate 
To Elkin Mathews, 72 December 11, 1892

Phenice Croft I Rudgwick

Dear Sir,

Thanks - "Vistas" is safely to hand. I am sorry you did not find it in your particular way. With kind regards, Yours very truly,

William Sharp

Elkin Mathews Esq.

ACS Princeton

To J. Stanley Little, December 11, 1892

December

My dear Boy

If you should be coming back by tomorrow at any rate look in and see Elizabeth, as she will be alone and rather dull I fear. We are both missing you very much.

In haste, I Affectly Yours I Will

ACS Princeton 


\section{To J. Stanley Little, [December 13, 1892]}

Grosvenor Club

Dear S.

I got your letter this morning just as I left. Do you mean that Robinson ${ }^{75}$ is to be with you Saty-Sunday at Rudgwick? If so I hope to see him.

My dear fellow, I look upon a radical change as imperative for you. Art-work alone would repay you. Do all you can to come to Florence. The keen sweet air there, the lovely place, the congenial surroundings, etc. will work like a charm. You can easily do it for £30, going and coming and stay there for say 3 weeks. Beg, borrow, or steal the money!

No time to write abt the excellent W. S. G. ${ }^{76}$ notice.

Yours ever | W. S.

E. is in town, and I understand is going to write you also.

ALS Princeton

\section{To Edmund Clarence Stedman, December 14, 1892}

So overwhelmed with work and things to see to that I must write to you from Sicily, a fortnight or so hence (i.e., after your receipt of this). We go there to lie in the sunshine and dream dreams, for Jany \& Feby.

I take your book with me: and when at Taormina or Syracuse shall write the article upon it for the Academy, ${ }^{78}$ as by arrangement just made with the editor. Even if I wrote it sooner he could not use it for several weeks, owing to press of matter.

Letter-address till middle of March | C/o Frank Rinder Esq | 32 Goldhurst Terrace | So. Hampstead | London | N. W.

Ever Yours, with best Xmas greetings \& affectionate remembrances to you \& yours,

William Sharp 


\section{To J. Stanley Little, [December 17, 1892]}

Phenice Croft, | Rudgwick, | Sussex. | Saty.

My dear Stanley

Are you trying for the post of 'oldest inhabitant' of Bosham? When are we to see you again? In your last note you said to me you would be home early in the week. I came down from town yesterday, as much to see you as for any other reason, for E. had work in London, \& I have to go up for today.

Will you be here during the coming week? E. will be here till Wednesday inclusive, and I till Friday night or possibly Saty morning.

If we don't meet this week I'm afraid we can't see you till the Spring. Every afternoon \& evening during our short stay in London I, at any rate, am pre-engaged.

As it is at once considerably less expensive, \& more restorative for E., we are now going to the Mediterranean by sea. Is your coming also really out of the question? You ought to make every effort.

In haste | Ever yrs. Affectionately | William Sharp

ALS Princeton

To Edward Dowden, [December 20?, 1892]

72 Inverness Terrace | Bayswater | London | W. ${ }^{79}$

My dear Dowden

Except on the printed page I don't often hear of or from you now - but now as ever I look for all manner of 'high things' from you.

Is there any chance of your being in London between the 28th inst and Jany 6th? I wish there were. On the 7th my wife and I go away again for a time. ${ }^{80}$ We are born wanderers, and I in particular have fared far 
and wide within the last 12 years. We work like slaves for a time, \& then go off rejoicingly. This time we are set upon seeing what is left of ancient Carthage and of sojourning at Tunis and Tripoli and elsewhere along Moorish Africa - \& then to Sicily (the Greek past).

Will you accept from me with my most cordial good wishes for Xmas and 1893 the accompanying vol. An American firm recently volunteered to bring out an Amer. Edn. of my two last vols of verse in one vol. So I revised \& added to them naturally, gave the double vol a new name, Flower o' the Vine: and they added a photograph, which I don't think much of (must have been borrowed, for they never got it from me) \& a Memoir-introduction by Thos. Janvier - the ablest of the new men oversea. The book I am glad to hear has gone (to me) surprisingly well.

You like ourselves are always busy - so I need not say anything about work.

Cordially yours I William Sharp

ALS Trinity College Dublin

\section{To Arthur Stedman, [December 23, 1892]}

Many thanks for letter. By the time this reaches you I shall be at the village of Sidi-Boda-Said (ancient Carthage) or at any rate in the Tunis part of North Africa.

The only book I take with me is "Nature and Elements of Poetry" which please tell E.C.S. I shall review there for "The Academy."

Please note that my letter address till after mid-March is | C/o Frank Rinder Esq | 32 Goldhurst Terrace | So. Hampstead I N.W. I which I dare say I have already told you. Shall write to you from Africa or Sicily.

All happiness be yours in 1893.

W.S.

I have cause for nothing but gratitude for everything to do with "Flower o' The Vine." 



\section{Chapter Ten}

\section{Life: 1893}

The Sharps boarded a ship bound for North Africa on January 7, 1893 and arrived a week later in Algiers. "Everything is charming to the eyes after London fogs," he wrote to Arthur Stedman on January 16, "the greenness, the palms, the orange and lemon trees, the roses and brilliant creepers, the blue of the sea and the deeper blue of the sky." After spending some time in Algiers, they traveled west, mostly by train, and on January 22 they were in Blidah at the base of the Atlas Mountains. They told Stanley Little in a letter of that date they were headed to Tlemcen and planned to push on "across the frontier of Morocco to the city of Oudjda... if the tribes are not up." The landscape was "strange \& beautiful: miles of orange and tangerine trees in full fruit à terre, and on high the grand heights and fantastic peaks of the Atlas range." After crossing into Morocco for a few days, they returned to Algiers and then went south across the mountains and out into the desert. On February 2, they were in a Moorish Hotel in Biskra, "El Biskra-ed-Nokkel, to give it its full name (the City of Palms)." From there he wrote to "a friend," probably Edith Rinder who made some of the letters she received from Sharp available to Elizabeth for the Memoir: "Here we are in the Sahara at last! I find it quite hopeless to attempt to give you any adequate idea of the beauty and strangeness and the extraordinary fascination of it all." He proceeded, nonetheless, to describe vividly their arrival the previous night. The sun was setting, and the hills became a deep purple: 
For the rest, all was orange-gold, yellow-gold, green-gold, with high over the desert a vast effulgence of a marvelous roseate flush, Then came the moment of scarlet and rose, saffron, and deepening gold, and purple. In the distance, underneath the dropping sparkle of the Evening Star, we could discern the first palms of the oasis of Biskra. There was nothing more to experience till arrival, we thought: but just then we saw the full moon rise out of the eastern gloom. And what a moon it was! Never did I see such a splendor of living gold. It seemed incredibly large, and whatever it illumined became strange and beautiful beyond words (Memoir 211).

From Biskra they pressed further into the desert to the oasis of SidiOkba "with its 5,000 swarming Arab population" before heading back north to Constantine.

On February 12, he wrote again to "a friend" to say he had plunged into the "Barbaric East." Like so many nineteenth-century travelers from northern Europe, Sharp was captivated and liberated by the availability of drugs and sex on the streets of North African cities. On the night of February 11, he wandered through the narrow, crowded streets of Constantine observing

the strange haunts of the dancing girls: the terrible street of the caged women - like wild beasts exposed for sale: and the crowded dens of the hashish-eaters, with the smoke and din of barbaric lutes, tam-tams, and nameless instruments, and the strange wild haunting chanting of the ecstatics and fanatics.

I went at last where I saw not a single European: and though at some risk, I met with no active unpleasantness, save in one Haschisch place where, by a sudden impulse, some forty or fifty Moors suddenly swung round, as the shriek of an Arab fanatic, and with outstretched hands and arms cursed the Gaiour-kelb (dog of an infidel!): and here I had to act quickly and resolutely.

Thereafter one of my reckless fits came on, and I plunged right into the midst of the whole extraordinary vision - for a kind of visionary Inferno it seemed. From Haschisch-den to Haschisch-den I wandered, from strange vaulted rooms of the gorgeously jewelled and splendidly dressed prostitutes to the alcoves where lay or sat or moved to and fro, behind iron bars, the caged beauties whom none could reach save by gold, and even then at risk; from there to the dark low rooms or open pillared places where semi-nude dancing girls moved to and fro to a wild barbaric music... . 
I wandered to and fro in that bewildering Moorish maze, till at last, I could stand no more impressions. So I found my way to the western ramparts, and looked out upon the marvelous nocturnal landscape of mountain and valley - and thought of all that Constantine had been (Memoir 213).

So a late-nineteenth-century Scot experienced and described the exotic world of Arabia. The passage implies Sharp sampled the hashish. It may have been his first use of the drug, which, despite his wife's disapproval, he used later to invoke visions at Phenice Croft and later when he joined Yeats in the effort to obtain through visions the rituals for a Celtic Mystical Order.

From Constantine, the Sharps went north and east to Tunis where William visited the ruins of ancient Carthage, the "London of 2000 years ago:"

The sea breaks at my feet, blue as a turquoise here, but, beyond, a sheet of marvelous pale green, exquisite beyond words. To the right are the inland waters where the Carthaginian galleys found haven: above, to the right, was the temple of Baal: right above, the temple of Tanit, the famous Astarte, otherwise "The Abomination of the Sidonians". Where the Carthaginians lived in magnificent luxury, a little out the city itself, is now the Arab town of Sidi-ban-Said - like a huge magnolia-bloom on the sun swept hill-side. There is nothing of the life of to-day visible, save a white-robed Bedouin herding goats and camels, and, on the sea, a few felucca-rigged fisher boats making for distant Tunis by the Strait of Goleta. But there is life and movement in the play of the wind among the grasses and lentisks, in the hum of insects, in the whisper of the warm earth, in the glow of the burning sunshine that floods downward from a sky of glorious blue. Carthage - I can hardly believe it (Memoir 214).

After a few days in and around Tunis, the Sharps crossed to Sicily where they stayed in Taormina, the beautiful old town set high above the Bay of Naxos with grand views of Mt Etna. This visit was the first of many to Taormina.

There exists an unpublished manuscript poem in Sharp's handwriting (blue ink on a folded piece of onion skin paper) that he must have written during or just after his North African trip. It is quite a good poem and another reflection of his "plunge into the Barbaric East." 


\section{The Sheik}

\section{(A Portrait from Life)}

With heavy Turban o'er his brows And white robe folded close to him, Ismail, the Sheik, with aspect grim Looks towards the desert's burning rim.

Before his tent the camels drowse In the fierce heat: within, a shade Is cast by curtains, rich with braid Of gold, with jewels inlaid.

All round the sloping canvas walls Bright cloths are placed; gay Syrian hues Of crimson, green, and purple-blues With which stray sunbeams interfuse.

Adown their midst a striped skin falls, Against whose fur sharp weapons lean Ablaze with steely light, and keen As any deadly Damascene.

Beside the Sheik a table stands With fragrant coffee, spices rare, Dates that have known the desert-air The wild fig and the prickly pear.

Beyond him stretch the burning sands:

Behind him pale Iskandra lies, Nude, and with drowsy half-closed eyes Still dreaming of Circassian skies.

A lithe brown boy close to his feet Upon a reed a soft low tune Doth make, and sings an Arab rune Of love beneath the Desert-moon.

Still grows the blazing, burning heat: Yet ever toward the sand-wastes rim Looks forth, with gaze no glare makes dim, Ismail, the Sheik, with aspect grim. 
If this poem was, in fact, written "from life," the Sharps must have succeeded in entering Morocco. There is no record of Sharp in North Africa apart from this trip, and he told Richard Watson Gilder in a letter dated June 3 he had traveled "from the frontiers of Morocco across the Sahara and the African Highlands to Carthage and the Tunisian littoral and desert."

The poem is highly suggestive. The Sheik's name is a variant of Ishmael, Abraham's and Hagar's son in the Book of Genesis. Shah Ismail I (1487-1524) ruled a vast Persian Empire from 1501 until his death. Iskandra, the nude boy in the background dreaming of his Circassian home, is a variant of Alexander and invokes Alexander the Great (356$323 \mathrm{BC}$ ), the Macedonian who conquered and ruled another vast empire. The allusion invokes the commonly-supposed homosexual relationship of Alexander the Great and his life-long friend Hephaestion. Sheik Ismail is pleased to have the "lithe brown boy close to his feet" singing "an Arab rune of love beneath the Desert-moon." The poem asks if the Sheik captured or lured for his pleasure the drowsy nude Iskandra lying half asleep behind him dreaming of his homeland on the eastern bank of the Black Sea, another allusion to Alexander. The poem's sensual and suggestive overtones probably account for it not being published. That Sharp wrote and carefully copied it, perhaps for one of his many gay friends, reveals again the association of the Arab world with what he might have called pagan sexual practices. It also signals his sexual fluidity, his growing sense of being both a man and a woman.

At the end of February, the Sharps returned to England. When he wrote to Charles Webster, the American publisher, on March 23 proposing that he publish Vistas, he was just back from North Africa and had not yet returned to his house in the country. By the twentyninth both Sharps were in Phenice Croft wondering why Stanley Little was staying in Kensington. "It is glorious weather, \& the Rudgwickian country, Buck's Green, and Phenice Croft are all looking their best." According to Elizabeth, it was "the finest English Spring in a quarter century." She listed some of the guests who visited them: Richard Whiteing, Mona Caird, Alice Corkran, George Cotterell, Richard and Edith Le Gallienne, Roden Noel, Percy White, Dr. Byres Moir, the Frank and Edith Rinder, R. A. Streatfield, Laurence Binyon, Agnes Farquharson Sharp (Elizabeth's mother), Robert Farquharson Sharp 
(Elizabeth's brother), and Mary Sharp (William's sister), who would soon begin to serve the essential function of copying Fiona Macleod's letters so that her handwriting became that of Fiona Macleod.

Sharp began working on a series of articles about his experience in North Africa: "French African Health Resorts" appeared in the December 1893 Nineteenth Century; "The New Winterland of French Africa" in the January 1894 Nineteenth Century; "Tclemcen and Its Vicinage" in the February 1894 Art Journal"; "Cardinal Lavigerie's Work in North Africa" in the August 1894 Atlantic Monthly; and "Rome in Africa" in the June 1895 Harper's Monthly. He also began a new life of Rossetti, which was commissioned by Swan Sonnenschein and Company. According to Elizabeth, Sharp became "very dissatisfied" with his 1882 Rossetti book; he "considered his judgment to have been immature." He wrote only a few sentences of the new biography and a "Dedicatory Chapter" to Walter Pater. The paragraphs Elizabeth reproduced in the Memoir 69-72 are all the dedication that survives. They praise Rossetti and Pater and Pater's essay on Rossetti. "Of all that has been written of Rossetti's genius and achievement in poetry nothing shows more essential insight, is of more striking and enduring worth, than the essay by yourself included in your stimulating and always delightful Appreciations."

In an April 19 letter to Henry Mills Alden, editor of Harper's Magazine, Sharp said he was busy "more maturely, more serenely, more hopefully, if with more mental \& spiritual stress than heretofore. I shall write sometime \& tell you more." What, we may wonder, caused his mental and spiritual stress? Elizabeth said her husband "was happy once more to be resident in the country, although the surroundings were not a type of scenery that appealed to him." She then touched on the stress:

At Phenice Croft his imagination was in a perpetual ferment.... Once again he saw visions and dreamed dreams; the psychic subjective side of his dual nature predominated. He was in an acutely creative condition; and, moreover, he was passing from one phase of literary work to another, deeper, more intimate, more permanent. So far, he had found no adequate method for the expression of his 'second self' though the way was led thereto by Sospiri di Roma, The Pagan Review, and Vistas (Memoir 221-22). 
His stress was due in part to what Elizabeth called his "psychic experiments," his efforts, some no doubt aided by drugs, to contact spirits and invoke visions.

In early May Elizabeth went to Paris to review the salons for the Glasgow Herald. On May 7 Sharp wrote a card to Stanley Little while waiting in Horsham station for the train that would take him to the coast for a ferry to the Isle of Wight. He had expected Little to drop in the previous night. He had stayed up waiting until two in the morning and finally went to the house where Little was staying, found it dark, and returned to Phenice Croft. He could forgive Little only because he was leaving to spend a week leading a "virtuous life" on the Isle of Wight. On the tenth, he responded from "somewhere or other near Freshwater" to Little's letter of apology. He understood, of course, that Little was preoccupied with his guests, one of whom must have been a young woman. Sharp would not have gone looking for Little at two in the morning if a "young charmer" had been sitting up with him discussing "debatable subjects." He expanded, "It is glorious here. By Jove, Life is well worth living!" He and Little will "have a chat over sins and sinners" when he returns to Rudgwick. It sounds as though Sharp, with Elizabeth in France, arranged the week on the Isle of Wight so he and Edith Rinder could be alone together.

In late June Sharp told Louise Chandler Moulton, who had come to London from the United States, that he was working very hard, "making the wherewithal for 'daily bread' but not omitting dreaming and the weaving of dreams." He was also enjoying life in rural Sussex during an "unparalleled Spring \& Summer! Here, in Sussex, we have had no rain (save 3 brief showers, 2 nocturnal) for $31 / 2$ months, \& an almost unbroken succession of blue skies." He wrote again to Moulton in mid-July to apologize for not arranging to see her before she returned to America.

Alas, I have been so overwhelmed with work requiring the closest continuous attention that I have postponed and postponed and postponed. Besides this, I have purposely withdrawn from everything this year - having realized that my paramount need at present is isolation - or as much as can be had even at this distance from town. Each finds at last what he needs in order to do his best work. I do not know if I have found it yet: I doubt if I shall ever find it in England: but I am nearer to what I want than I have yet been. 
He hoped to be able to call on her before the end of the month, when he and Elizabeth were going to Scotland for two months.

In a letter written the previous October, Sharp asked Robert Murray Gilchrist to visit him in Buck's Green when he next came to London from his home in Derbyshire. Gilchrist did not accept Sharp's invitation until the Spring of 1894, but he invited Sharp to visit him in Derbyshire when he was traveling back or forth to Scotland. He also mentioned Frank Murray, a bookseller in Derby, who had agreed to publish his novel, Frangipani, as the first in a projected Regent's Library series. Perhaps Murray would consider a book by Sharp for the series. So, in early summer Sharp asked Murray if he would like to publish a romance he had in mind. Murray responded favorably but said he could offer Sharp only ten pounds. In a July letter to Murray, Sharp said the terms for the projected romance were insufficient, but he would accept ten pounds for another book he had on hand. It was his "most individual imaginative work - a series of psychological problems or reveries wrought in a new form, nominally dramatic,... a series of seven studies collectively entitled 'Vistas'." Having offered that volume unsuccessfully to Elkin Mathews in London and Charles Webster in America, he was anxious for someone to issue it.

At the end of July, the Sharps went to Scotland where they spent three weeks in St. Andrews, stayed for a time with Marian Glassford Bell at Tirinie, near Aberfeldy in Perthshire, and then went to Corrie on the Island of Arran for a fortnight. In mid-September, Elizabeth left to visit friends, and William went to Arrochar and other places in the West. An early-August letter to Little from St. Andrews described his writing: "my 'Rossetti', my new one-vol. novel, my vol. of short stories, \& my French studies, fully occupy my mind here - when I am not swimming or walking, eating or sleeping or 'dreaming'." The new "onevol. Novel" that became Pharais was the most "consequential" work he had in progress. He planned to call the "vol. of short stories" Comedy of Woman. It became the volume of short stories published in 1895 by Stone and Kimball in Chicago as The Gipsy Christ and Other Tales and in 1896 by Archibald Constable in London as Madge o' the Pool: The Gipsy Christ and Other Tales.

On August 18 he asked Murray Gilchrist if it would be convenient to spend a night with him in Derbyshire on his way back to London, 
probably on September 24. He wanted to meet Gilchrist, but he also wanted to visit Frank Murray, the Derby bookseller, to discuss arrangements for the publication of Vistas. On September 30, after two months in Scotland, the Sharps left Edinburgh; Elizabeth went straight to London, and Sharp - by a complicated series of branch trains - to Eyam, the village in Derbyshire, where Gilchrist lived. After spending two nights with Gilchrist, he stopped in Derby on his way to London. On October 7 he was back in Phenice Croft where he thanked Gilchrist for the "lovely day we had last Sunday," walking on the moors. He was sending Gilchrist a copy of the etched portrait Charles Holroyd made of him in Rome and, for George Garfitt, Gilchrist's partner, a copy of The Pagan Review. The first meeting between Sharp and Gilchrist and Garfitt went very well, and Sharp told Gilchrist he found Frank Murray "a decent sort of chap." He added, betraying his class consciousness: "He dropped his " $h$ 's" occasionally, and in certain small matters was oblivious of what some of us consider to be good breeding." Nonetheless, he thought Murray had "a genuine love of literature."

After mentioning his "one-vol. Novel" to Little in early August, he wrote on the twelfth to Catherine Janvier describing "a scene in a strange Celtic tale I am writing called Pharais, wherein the weird charm and terror of a night of tragic significance is brought home to the reader... by a stretch of dew-wet moonflowers glimmering through the murk of a dusk laden with sea mists" (Memoir 225). He went on to say "I was writing in pencil in Pharais of death by the sea - and almost at my feet a drowned corpse was washed in by the tide and the slackening urgency of the previous night's gale." This is the first recorded use of "Pharais," or Paradise, as the title of the novel that became the first publication by Fiona Macleod. It was the "romance" he had in mind when he told Frank Murray in mid-July that the terms he offered for it were unacceptable. Elizabeth said he wrote sometime in November to Richard Stoddart proposing for serial publication in Lippincott's Magazine a romance he called Nostalgia, which never materialized, and "another story, Pharais," which he described as "written deeply in the Celtic spirit and from the Celtic standpoint" (Memoir 225). That letter has not surfaced, and neither proposal was accepted. In December he stated in his diary that he had done "the first part of a Celtic romance called Pharais;" it was one of the things he needed to finish (Memoir 
216). In his December 20 Christmas greetings to Murray Gilchrist, he wrote: “Today I write 'finis' to my Celtic Romance - long dreamed of - I wish I could read some of it to you. It is out of my inmost heart and brain." The Celtic Romance was Pharais.

Sharp had described Pharais by name to at least three correspondents - Catherine Janvier in August, Richard Stoddart in November, and Murray Gilchrist in December - without saying he planned to publish it pseudonymously. The first recorded indication of his intention to publish it not only pseudonymously but as written by a woman occurs in a late December letter to Frank Murray. When he visited Murray in his Derby bookshop in September and saw the high quality of the paper, boards, and designs he was using for his Regent's Library series, Sharp decided Murray should publish Pharais as well as Vistas despite the fact that he could pay very little. He may have discussed pseudonymity in that meeting or raised the matter in subsequent correspondence, as his December letter implies the issue was not new to Murray:

You will be interested to hear that last week I wrote "finis" to Pharais: and have not only finished it but think it the strongest \& most individual thing I have done. For several reasons, however, I wish to adhere rigidly to the 'Fiona Macleod' authorship. I think the book will attract a good deal of notice, on account of the remarkable Celtic renaissance which has set in \& will inevitably gather weight: it touches, too, new ground and, I think, in a new way. What is perhaps best of all is that it is written literally out of my heart - and indeed, though the central incident has nothing to do with me, most else is reminiscent.

It is, in fact, your agreement to accept my two most paramount conditions - pseudonymity and publication by the end of March - that weighed with me against a letter from the Editor of one of the leading magazines in America, offering me high terms for a romance written not 'to order' but really con amore. However, for reasons into which I need not enter at present, I prefer to lose at the moment so as to gain in every way later.

Sharp enclosed with this letter the "opening section" of Pharais; his copyist, presumably his sister Mary in Edinburgh, had the rest and was more than halfway through the book. There is no evidence of an offer from an American publisher. 
Sharp had sent as a possible frontispiece for Vistas a rare etching by William Bell Scott of a William Blake design for Milton's Paradise Lost that portrays Adam and Eve in an embrace and Satan, entwined as a serpent, hovering above them. If Murray objected (presumably to the nudity) perhaps he would ask the artist who produced the design for Gilchrist's Frangipani, another Murray book, to "do something satisfactory." If neither alternative met with Murray's approval and he would pay, Sharp could ask his "friend Theôdore Roussel to do something." Murray used the Bell Scott etching, which is quite beautiful. Presumably Sharp thought the depiction of Adam and Eve in each other's arms with the snake about to strike would foreshadow the joy undercut by sorrow depicted in the book's "vistas." As for Pharais, Sharp could ask his friend William Strang to do an etching for the frontispiece. As always, Sharp was interested in the book as an artistic object. Murray produced for Pharais an edition of only seventy-five numbered copies on beautiful paper with handsome type, each numbered and signed, though not by Sharp or his sister Mary. Its frontispiece is not an etching but a photograph of a cold and vacant northern sea with its waves breaching the shore, a scene that reflected the book's atmosphere and content.

Sharp's decision to publish Pharais pseudonymously is not surprising. He had experimented with pseudonyms during the past two years. He liked the mystery of disguise, and he believed creative work published under his name would generate skepticism or disdain due to the reputation he had developed and the enemies he had made as an editor and reviewer. His decision to publish under a woman's name was new and unusual. In 1881 he wrote a poem called "Motherhood" that described a tigress, a primitive woman, and a contemporary woman giving birth. Though an unusual subject for poetry, it demonstrated his empathy with women. In 1891, he enthusiastically wrote the letters of the wife in the epistolary novel, A Fellowe and His Wife. These are only a few of many instances of Sharp's demonstration of his dual nature. "During the writing of Pharais," Elizabeth wrote in the Memoir 227, "the author began to realize how much the feminine element dominated in the book, that it grew out of the subjective, or feminine side of his nature. He, therefore, decided to issue the book under the name Fiona Macleod." She went on to say the name "flashed ready-made" into his mind, but the suddenness of the flash is questionable. The name "was 
born naturally", Sharp wrote, "(of course I had associations with the name Macleod). It, Fiona, is very rare now. Most Highlanders would tell you it was extinct - even as a diminutive of Fionaghal (Flora). But it is not. It is an old Celtic name (meaning 'a fair maid') still occasionally to be found" (Memoir 226-27). Now, because of Sharp, though few know it, many women in Scotland and beyond are Fiona. As for the family name, it was Seumas Macleod from whom Sharp learned Celtic lore when he was a young boy during summer holidays in the Hebrides.

More than a recognition of his feminine qualities descended on Sharp at Phenice Croft in the summer of 1893. Elizabeth wrote:

The quiet and leisure at Phenice Croft, the peace, the "green life" round were unspeakably welcome.... Once again, he saw visions and dreamed dreams; the psychic subjective side of his dual nature predominated. He was in an acutely creative condition; and, moreover, he was passing from one phase of literary work to another, deeper, more intimate, more permanent. So far he had found no adequate method for the expression of his "second self" though the way was led thereto by Sospiri di Roma and Vistas (Memoir 221-22).

In 1877, when he was only twenty-one, Sharp confided in a letter to Elizabeth: "I feel another self within me now more than ever; it is as if I were possessed by a spirit who must speak out" (Memoir 25). At Phenice Croft, he began to entertain seriously the possibility not only that he had both masculine and feminine qualities, but that he was two people in one, both a man and a woman.

The emergence of her husband's "second self" began, Elizabeth said, in Rome in the winter/spring of 1890-91. "There, at last, he had found the desired incentive towards a true expression of himself, in the stimulus and sympathetic understanding of the friend to whom he dedicated the first of the books published under his pseudonym. This friendship began in Rome and lasted for the remainder of his life." This friend was "E. W. R." to whom he dedicated Pharais, and the initials are those of Edith Wingate Rinder. To be clear, in that dedication he was writing as a woman to another woman, and the disguise released him to speak with sincerity about their relationship, which was one of deep affection and commonality. Although Edith Rinder grew up in the north of England, her family had deep roots in Scotland and usually spent the month of September in the Inner Hebrides. 
In the first sentences of the dedication, we hear the voice that Sharp adopted for Fiona Macleod: "In the Domham-Toir there are resting places where all barriers of race, training, and circumstance fall away in the dust. At one of those places of peace we met, a long while ago, and found that we loved the same things, and in the same way." Most love the West of Scotland only "in the magic of sunshine and cloud," but Edith loves the land "when the rain and the black wind make a gloom upon every loch and fill with the dusk of storm every strath, and glen, and corrie. Not otherwise can one love it aright." Edith and Fiona worship at the fane of Keithoir, the Celtic god of the earth: "It is because you and I are of the children of Keithoir that I wished to grace my book with your name." We believe "the Celtic Dream" is not doomed to become "a memory merely." A few writers, Fiona among them, will revive Anima Celtica and lead readers to "that Land of Promise whose borders shine with the loveliness of all forfeited, or lost, or banished dreams and realities of Beauty," lead readers to "Pharais." In concluding, Sharp has Fiona associate her objectives with those of William Butler Yeats and the Irish Renaissance: “The sweetest-voiced of the younger Irish singers of to-day has spoken of the Celtic Twilight. A twilight it is; but, if night follow gloaming, so also does dawn succeed night. Meanwhile, twilight voices are sweet, if faint and far, and linger lovingly in the ear." The final paragraph returns to Edith by asserting a Paradise of Friendship wherein "we both have seen beautiful visions and dreamed dreams. Take, then, out of my heart, this book of vision and dream." By identifying with the beautiful Edith Wingate Rinder, Sharp had found a model for the feminine side of his nature and a voice for his "second self."

In a letter of instructions to Elizabeth in the event of his death, written before a trip to the United States in 1896, Sharp said "to her [Edith Rinder] I owe my development as 'Fiona Macleod"' and "without her there would have been no 'Fiona Macleod."' After reproducing this statement in the Memoir 222 and without identifying Edith, Elizabeth commented with remarkable candor and generosity:

Because of her beauty, her strong sense of life and the joy of life; because of her keen intuitions and mental alertness, her personality stood for him as a symbol of the heroic women of Greek and Celtic days, a symbol that, as he expressed it, unlocked new doors in his mind and put him 'in touch 
with ancestral memories' of his race. So, for a time, he stilled the critical, intellectual mood of William Sharp to give play to the development of this new found expression of subtler emotions, towards which he had been moving with all the ardor of his nature.

Her husband's two natures were frequently at odds. They required different conditions, different environments, and different stimuli. As this internal conflict developed, it "produced a tremendous strain on his physical and mental resources; and at one time between 1897-98 threatened him with a complete nervous collapse." As time passed the two sides of his nature developed into two distinct personalities "which were equally imperative in their demands on him." He preferred the dreaming creative feminine existence, facilitated by the presence of Edith, in which he could produce the writings of Fiona Macleod. "The exigencies of life, his dependence on his pen for his livelihood... required of him a great amount of applied study and work." He came to associate Elizabeth - his first cousin, ever-supportive wife, and breadwinning critic and editor - with the mundane, practical side of his nature.

So Phenice Croft was linked by both Sharp and his wife with his dreaming, creative side, with the birth of Fiona Macleod, and with Edith Rinder. Sharp "always looked back with deep thankfulness" to the two years at Phenice Croft. Initially, Elizabeth shared her husband's enthusiasm. "The summer of 1893," she wrote, "was hot and sunny; and we delighted in our little garden with its miniature lawns, its espalier fruit trees framing the vegetable garden, and its juvenile but to me fascinating flowers beds." Things began to change in the fall. She became ill again with the lingering effects of malaria. She attributed her continuing health problems to the moist air and clay soil of Rudgwick. She began to spend more time with her mother in London. During those periods of absence, Edith Rinder was often a guest at Phenice Croft, and her presence may have been a factor in Elizabeth's change of heart. Her comments about Phenice Croft and Rudgwick in the Memoir were as close as she came to suggesting her relationship with her husband was strained.

There was another reason for her feelings about Phenice Croft. There, she said, Sharp was "testing his new powers, living his new life, and delighting in the opportunity for psychic experimentation." The last seemingly innocuous "psychic experimentation" reveals 
Sharp was attempting to communicate with the spirit world. For such experimentation, Elizabeth wrote, "the place seemed to him to be peculiarly suited." To her, it seemed "uncanny" and "to have a haunted atmosphere - created unquestionably by my husband that I found difficult to live in unless the sun was shining" (Memoir 223). Edith may have been cooperating in the experiments, which were widespread at the time. Indeed, Elizabeth went to mediums after her husband died in 1905 and left a record of her communications with his spirit. In 1893, however, she recognized the disturbing impact of the psychic experiments on her husband's mental balance. As we shall see, a crisis befell Sharp in the summer of 1894 which, coupled with Elizabeth's ill health and growing distaste for the place, caused them to leave Phenice Croft and return to London. 


\section{Letters: 1893}

To Dr. Ward, early 1893

Phenice Croft I Rudgwick I Sussex

Dear Dr. Ward

This time I am writing to you about someone other than myself: \&to ask you if you can use any of the accompanying publ, or commission any other of the kind. They are by a well-known physician and scientific man, a friend of my own who I esteem \& admire - Prof. E. Savare d'Odiardi (the Duc de Rovigo, though he prefers to be known by his family name, $\&$ that by which he has made his repute. ${ }^{1}$ If wished, however, he is quite willing that his contributions shld. be set forth as by the Duke of Rivigo. He was an intimate friend of Napoleon III: knew the late Czar: Heine: \& all sorts of conditions of man. His Memoirs would, I should say, be very interesting.

He is now living in London, where for some years he has devoted himself to his hospital \& other work, including the medical chemistry for which he has been gold-medaled by the French Government.

For some time past he has been in poor health, \& is anxious to put his once busy pen into frequent use again: either as contributor of papers such as the enclosed, or as a regular Scientific Correspondent. I send the 3 papers under separate cover.

With cordial regards | Yours sincerely | William Sharp ALS, Princeton 


\section{To Alfred Austin, January 1, 1893}

Phenice Croft | Rudgwick | Sussex | January 1, 1893

\section{My dear Austin}

One thing after another has prevented my writing to you as I had often intended and wished to do, to thank you again most heartily for your new book, ${ }^{2}$ and to say how heartily I have enjoyed it. It gave me keen pleasure to see, the other day, the announcement of its having gone into a second edition.

"Fortunatus" is full of charm and beauty with all your wonted lyric grace. To me it appeals more, on the whole, than "Prince Lucifer", ${ }^{3}$ though that dramatic poem has always been a great favorite with me. I wonder how often I have repeated those splendid lines, in the speech of Franklin

There was a time I had a feud with Death",

- - the superb passage beginning

"For us the spacious bounty of the air,

The impregnable pavilion of heaven,

And silent muster of the disciplined stars".

down to the end.

It is a magnificent passage throughout, with many haunting lines - e.g.

Freshness of dawn and frankincense of eve,

And vestal hush of meditative night.

and the Homeric

Helm-plumes unhorsed, and women wailing round

The wind-blown smoke of crackling funeral pyres.

Naturally, there is much else I delighted in and would like to indicate: but my old enemy is upon me, neuralgia in the eyes, from the cold (and late writing) and I must perforce stop. My wife and I leave here tomorrow to go to Tunis. When we return some weeks hence (end of February or early in March) I will give myself the pleasure of calling on 
you, \& telling you more of what I think about your most able \& poetic work.

Best wishes for 1893 to Mrs. Austin \& yourself, \& kindest remembrances from us both -

Cordially yours I William Sharp

ALS Yale

\section{To J. Stanley Little, January 7, 1893}

7 Jany 1893

My dear Stanley

I return the Leon MS meanwhile, as D.C.T. ${ }^{4}$ does not want the article for some months. Please hold it over for me.

I have written to Scott \& sent him the "Current Fiction" paper etc. He will communicate with you at Woodville F. H. I have been writing \& working till 2, 3, \& 4 a.m. for the last 10 days: \& am about tired of it. Just off to N. Africa. In about a week hence we hope to reach the oasis of El Biskra, some 200 miles inland, \& on the verge of the Northern Sahara.

Take care of yourself. I am going to write no letters when I am away, but I'll send a postcard now \& again when in civilised parts.

Addio, old chap

Yours ever I William Sharp

My letter-address will be I chez MM. Thos Cook \& Son | 6, Rue de la République, I Algiers I Algerie. They will take care of \& forward everything to me.

ALS University of British Columbia 


\title{
To Arthur Stedman, January 16, $1893^{5}$
}

\author{
Mustapha Sn. - Algiers.
}

We have enjoyed our first week in North Africa immensely. Even apart from the Moorish and oriental life, everything is charming to the eyes after London fogs - the greenness, the palms, the orange and lemon trees, the roses and brilliant creepers, the blue of the sea and the deeper blue of the sky.

We leave tomorrow for the inland and little visited city of Tlemcen in the S.W. of the Province of Oran, near the frontiers of Morocco. Thereafter we shall return to Algiers for some days of rest and idleness ere we start on our many wayfarings thro' Kabylia (the African Highlands), the Province of Constantine, El Biskra and the Oases of the Sahara, the Holy City of Sidi-Okbar (in the desert), Tbessa, Lambessa, etc., and thence if practicable to Kairouan (the Mecca of N. Africa) and thence thro' the kingdom of Tunisia to Tunis \& Carthage.

Kindly hand on this P/C to E.C.S., to whom I shall write later. I have sent one by same post to the Janviers. ${ }^{6}$

Hope you are flourishing, cher ami,

W.S.

ACS Columbia

To J. Stanley Little, January 22, 18937

Blidah. I At the base of the Atlas Mtns, I North Africa

I forgot to say in my last that I sent back the L. L. MS. ${ }^{8}$ to you before I left (or rather left it with R. F. S. ${ }^{9}$ to post) \& also wrote to Scott. ${ }^{10}$

I have had no home letters since we left, except one with enclosures from America: so I am behindhand with all news.

We are here en route for Tlemcen. It is very strange \& beautiful: miles of orange and tangerine trees in full fruit à terre, and on high the grand 
heights and fantastic peeks of the Atlas range. As I write, I hear the Imam in the Mosque close by chanting the evening prayer of the Muslim: \& below me a constant coming and going of stately shrouded Moors and Arabs.

After Tlemcen, if the tribes are not 'up', or are not unduly fanatical, we may push on across the frontier of Morocco to the city of Oudjda.

W.S.

ACS Princeton

To February 2, $1893^{11}$

Biskra, 2nd Feb., 1893.

... Here we are in the Sahara at last! I find it quite hopeless to attempt to give you any adequate idea of the beauty and strangeness and the extraordinary fascination of it all. The two days' journey here was alone worth coming to Africa for! We left Mustapha shortly before dawn on Tuesday, and witnessed a lovely day-break as we descended the slopes to Agdz: and there we saw a superb sunrise streaming across the peaks and ranges of the Djurdjura of Kabylia (the African Highlands) and athwart the magnificent bay. The sea was dead calm, and in parts still mirrored the moon and a few stars: then suddenly one part of it became molten gold, and that nearest to us was muffled into purpleblue wavelets by the down-wind. The sound of it washing in, almost at the feet of the palms and aloes and Barbary-figtrees was delicious. We had a long and delightful day's journey till sunset. Our route was through Grande Kabylie, and the mountain scenery in particular was very impressive. At many places we had a long stop: but everywhere here railway-traveling is more like journeying in a carriage, the rate of speed not being much more, with ample facilities for seeing everything en route. The Kabyles are the original inhabitants of Mauritanian Africa - and both in language and appearance these Berbers differ markedly from the Moors and the nomadic Arabs. They are the hardiest and most 
industrious though also the most untamable, of the native races. They live in innumerable little villages scattered among the mountains and valleys and plains of the Djurdjura country.

The sun sank over the uplands of Kabylia as we mounted towards the ancient Roman outpost city, Setif. Setif stands about 3,500 ft. high: and crossing the plateaux beyond it was like making an excursion through Scotland in midwinter. Still, despite the snow on the hills, and even along the roads of Setif itself, the cold was not so severe as we expected.

At four next morning we steamed slowly out of Setif in full moonlight. An hour or so later dawn broke as we passed a series of Arab encampments, and then came another sunrise over a wild and desolate country. We were now entirely in Mahommedan lands, for there are comparatively few Europeans south of the city of Constantine.

At a place called Guerrara we stopped for half an hour for déjeuner. Soon thereafter we passed the Salt Lakes, covered with wild-fowl, flamingoes, and other birds. It was hereabouts that we first saw some camels. Once more we mounted, and soon were high among the Aurès mountains, perhaps the most delightful hill-region of North Africa, with certainly the finest population, Berbers like the Kabyles, but Berber "aristocrats" - Berbers refined by potent inherited strains from the Romans of old. From Batna onwards the journey was an endless delight. We came more and more into the East, and soon grew wholly accustomed to Arab encampments, herds of camels, Moors and Negroes coming in with herds of bouricoes (little donkeys) wild black goats and gaunt sheep, Nomads travelling southward or eastward, picturesque Saharians or Spahis dashing past on grey Arab horses, and semi-nude agriculturous Berbers. At last the desert (the hill-desert) was entered. Here one can realise the full significance of the French epithet tourmenté: and, as one fares further, of the Biblical phrase, the abomination of desolation. The whole country seemed under the curse of barrenness: nothing but gaunt ribbed mountains, gaunt ribbed hills, gaunt ribbed sand-plains - this, or stony wastes of an arid desolation beyond words. But though the country did not become less awful in this respect, it grew wilder and stranger as we neared El Kantara. I never saw scenery so terrific. The entrance to the last Gorge was very exciting, for beyond the narrow outlet lay the 
Sahara and all torrid Africa! North of this last outpost of the colder zone the date-palm refuses to flourish: and here, too, the Saharan Arab will not linger: but in a quarter of a mile one passes from this arid waste into African heat and a superb oasis of date-palms. It is an indescribable sensation - that of suddenly swinging through a narrow and fantastic mountain-gorge, where all is gloom and terror, and coming abruptly upon the full splendour of the sun-swept Sahara, with, in the immediate foreground, an immense oasis of date-palms, all green and gold! The vistas - the vast perspectives - the glory of the sunflood! From that moment, one can hardly restrain one's excitement. Very soon, however, we had fresh and unexpected cause for excitement. The train slowly came to a stop, and crowds of Arabs came up. The line had been destroyed for more than half a mile - and we were told we must walk across the intervening bit of desert, and ford the Oued-Merjarla, till we reached the train sent to meet us. We could see it in the distance - a black blotch in the golden sunlight. One account was that some revolted Arabs (and some of the outlying tribes are said to be in a chronic state of sullen ill will) had done the mischief: another, and more probable, that the hill-courses had swollen the torrent of the Oued-Biskra, which had rent asunder the desert and displaced the lines. The Arabs carried our baggage, and we set forth across our first Sahara-stretch. Despite the heat, the air was so light and delicious that we enjoyed the experience immensely. The river (or rather barren river-bed with a pale-green torrent rushing through a deep cleft in the sandy grit) was crossed on a kind of pontoon-bridge. Soon after this the sun sank. We were in the middle of a vast plain, almost surrounded by a series of low, pointed hills, which became a deep purple. Far to the right was a chott (or salt lake) of lucent silver. For the rest, all was orange-gold, yellow-gold, green-gold, with, high over the desert, a vast effulgence of a marvellous roseate flush. Then came the moment of scarlet and rose, saffron, and deepening gold, and purple. In the distance, underneath the drooping sparkle of the Evening Star, we could discern the first palms of the oasis of Biskra. There was nothing more to experience till arrival, we thought: but just then we saw the full moon rise out of the Eastern gloom. And what a moon it was! Never did I see such a splendour of living gold. It 
seemed incredibly large, and whatever it illumed became strange and beautiful beyond words.

Then a swift run past some ruined outlying mud-walls and Arab tents, some groups of date-palms, a flashing of many lights and clamour of Eastern tongues - and we were in Biskra: El Biskra-edNokkel, to give it its full name (the City of the Palms)! We found pleasant quarters in the semi-Moorish Hotel on Sahara. It has cool corridors, with arched alcoves, on both sides, so that at any time of day one may have coolness somewhere. In the courtyard are seats where we can have coffee and cigarettes under the palms, beside two dear little tame gazelles... .

This morning we had many novel and delightful glimpses of oriental life. In one narrow street the way was blocked by camels lying or squatting right across the road. As they are laden, they open their mouths, snarlingly, and give vent to an extraordinary sound - part roar, part grunt of expostulation... .

We came across a group of newly arrived camels from the distant Oasis of Touggourt, laden with enormous melons and pumpkins: and, hopping and running about, two baby camels! They were extraordinary creatures, and justified the Arab saying that the first camel was the offspring of an ostrich and some now extinct kind of monster... . Oh, this splendid flood of the sun!

Memoir 208-12

\section{To J. Stanley Little, [early February, 1893]}

El Oasis Sidi Okba I (The Sahara)

Your postcard reached me just as I left Biskra. Sorry abt. Scott. ${ }^{12}$ I did my utmost.

I write this from under the palms belonging to the Sheikh of Sidi Okba, right in the Sahara. The heat outside is very great, but there is shade under the date-palms here, and the cool sound of water - always a delight in the Desert. 
Yesterday I was at the Oasis of Chetma, guest of the old Sheikh Lagdan. The journey thither was a marvelous ride across the desert, with a fine Mirage thrown in. But at Chetma the Arabs were pleasanter. Here (perhaps because it is a 'Holy City') they are fanatical, and one has constantly to be on one's guard, even when going about with an escort. Today I heard Kelb (dog) and Djifa (Infidel dirt) again and again.

But a wise insouciance carries one through all right. It is all very barbaric, very fantastic, in many ways very savage and even repellent: but then, the desert - the daily sunflood - the vast perspectives - the brilliant and picturesque, or alternately austere but not less fascinating Sahara-life!!

À vous, I W. S.

ACS Princeton

To February 12, 1893

Constantine, 12th Feb., 1893.

It would be useless to attempt to give you any idea of all we have seen since I last wrote. The impressions are so numerous and so vivid until one attempts to seize them: and then they merge in a labyrinth of memories. I sent you a $\mathrm{P} / \mathrm{C}$ from Sidi Okba - the memory of which with its 5,000 swarming Arab population has been something of a nightmarerecollection ever since. I can well believe how the City of Constantine was considered one of the seven wonders of the world. It is impossible to conceive anything grander. Imagine a city hanging down the side of gorges nearly 1,000 feet in depth - and of the most fantastic and imposing aspect. In these terrible gorges, which have been fed with blood often, the storks and ravens seem like tiny sparrows as they fly to and fro, and the blue rock-doves are simply wisps of azure... .

Last night I had such a plunge into the Barbaric East as I have never had, and may never have again. I cannot describe, but will erelong tell you of those narrow thronged streets, inexplicably intricate, fantastic, 
barbaric: the Moorish cafés filled with motley Orientals - the turban'd Turk, the fez'd Jew, the wizard-like Moor, to the Kabyl, the Soudanese, the desert Arab: the strange haunts of the dancing girls: the terrible street of the caged women - like wild beasts exposed for sale: and the crowded dens of the Haschisch-eaters with the smoke and din of barbaric lutes, tam-tams, and nameless instruments, and the strange wild haunting chanting of the ecstatics and fanatics. I went at last where I saw not a single European: and though at some risk, I met with no active unpleasantness, save in one Haschisch place, where by a sudden impulse some forty or fifty Moors suddenly swung round, as the shriek of an Arab fanatic, and with outstretched hands and arms cursed the Gaiour-kelb (dog of an infidel!): and here I had to act quickly and resolutely. Thereafter one of my reckless fits came on, and I plunged right into the midst of the whole extraordinary vision - for a kind of visionary Inferno it seemed. From Haschisch-den to Haschisch-den I wandered, from strange vaulted rooms of the gorgeously jewelled and splendidly dressed prostitutes to the alcoves where lay or sat or moved to and fro, behind iron bars, the caged beauties whom none could reach save by gold, and even then at risk; from there to the dark low rooms or open pillared places where semi-nude dancing girls moved to and fro to a wild barbaric music... . I wandered to and fro in that bewildering Moorish maze, till at last I could stand no more impressions. So I found my way to the western ramparts, and looked out upon the marvellous nocturnal landscape of mountain arid valley - and thought of all that Constantine had been -

$212-13$

To February 19, [1893]

Carthage, I Sunday, 19th Feb.

How strange it seems to write a line to London from this London of 2,000 years ago! The sea breaks at my feet, blue as a turquoise here, but, beyond, a sheet of marvellous pale green, exquisite beyond words. To 
the right are the inland waters where the Carthaginian galleys found haven: above, to the right, was the temple of Baal: right above, the temple of Tanit, the famous Astarte, otherwise "The Abomination of the Sidonians". Where the Carthaginians lived in magnificent luxury, a little out the city itself, is now the Arab town of Sidi-ban-Said - like a huge magnolia-bloom on the sunswept hill-side. There is nothing of the life of to-day visible, save a white-robed Bedouin herding goats and camels, and, on the sea, a few felucca-rigged fisherboats making for distant Tunis by the Strait of Goletta. But there is life and movement in the play of the wind among the grasses and lentisks, in the hum of insects, in the whisper of the warm earth, in the glow of the burning sunshine that floods downward from a sky of glorious blue. Carthage - I can hardly believe it. What largesse of the mind the word creates!...

Memoir 214

\section{To Charles Webster, March 23, 1893}

Phenice Croft | Rudgwick | Sussex | 23/March/93

Dear Sirs,

Herewith I submit for your consideration an unpublished book by myself, entitled "Vistas", about which I think Mr. Arthur Stedman once spoke to you, and at whose standing suggestion I now send the MSS.

You will see that it is at least out of the ordinary groove in so far as subject-matter and method are concerned. It has been written for more than two years, but I have purposely held it over. It has occurred to me that, following upon Flower $o^{\prime}$ the Vine you might be able to do better with it than I could do myself - for at one time I thought of issuing a limited edition privately somewhat in the same way as I did my Sospiri di Roma. 
If you take it up (needless to say, in that case I must myself see the proof revision) I would like, if you could, to arrange with someone here to sell copies in England - possibly you have regular agents - or else for myself to take a certain number of copies for a numbered limited sale here, through myself.

Mr. H. M. Alden, Mr. Bliss Carman, and other friends in New York have seen one or more of the pieces in Vistas - and spoke and wrote to me in exceptional terms of praise concerning them - and on their "novel and striking originality".

I have just returned from North Africa and have not yet gone to my house in Sussex: and I fancy that I have a more thoroughly revised MS of Vistas there. This, however, is a minor detail. What I now send is practically the book as it wd. appear, save for a few textual alterations.

Will you please let me hear from you at your early convenience: and if you are willing to undertake the book, with the terms you feel able to propose.

With kind regards

Yours very truly I William Sharp

P.S. Vistas is the name I arrived at after long deliberation. It not only goes for the contents collectively, but is meant to indicate the new method in imaginative composition to which I have endeavored to give expression. All the pieces are unpublished save that which is entitled "The Black Madonna".

ALS Wake Forest University

\section{To J. Stanley Little, March 29, $1893^{13}$}

Phenice Croft I Wedny.

My dear Stanley,

Yours just recd. What an erratic fellow you have become! 
When are you to be here again? Both Elizabeth and I shall be very glad to see you once more, and have the pleasant sense of your neighbourhood and neighbourlyness.

In your last note or P/C you said "certainly you thought" you wd. be here during Easter-tide. Farquharson ${ }^{14}$ and my sister Madge come tomorrow. Are we to see you?

It is glorious weather, \& the Rudgwickian country, Buck's Green, and Phenice Croft are all looking their best.

Yours Ever, I W. S.

What is Dalmon's ${ }^{15}$ present address?

ACS Princeton

To J. Stanley Little, April 3, $1893^{16}$

Monday

My dear Boy

"Keep your mind easy and etc. etc".

No: the individual to whom you allude is not my friend - indeed, I have never even heard of Mrs. Louis Diehl. ${ }^{17}$

There's one of your recent review books I shd. like to see when you return to your forsaken Kensettian nest - F. Moore's "I Forbid the Banns". ${ }^{18}$

$\mathrm{I}$ 'm doing what I can at the $\mathrm{B} / \mathrm{M}$ for Dalmon.

In haste, I Yours Ever, I W. S.

ACS Princeton 


\section{To [Henry Mills Alden], April 19, 1893}

Phenice Croft, I Rudgwick, | Sussex. I 19:April:93

\section{My Dear Friend,}

I was glad indeed to receive your welcome private letter - as well as so much indebted for your kind \& considerate editorial one, which I have already affirmatively acknowledged..$^{19}$

I should be sorry not to hear from you occasionally. There are few men for whom I have so affectionate a regard, \& this though we have met a few times only. But I feel as if I know you well, and had known you for long. Some of this, of course, is due to your beautiful book, ${ }^{20}$ which I have been reading to my wife lately - finding in it fresh and lovely things, with a rare \& beautiful breath of spiritual life. More \& more I find it something deep, germinal, quintessential: and to be quintessential voilá le motif de tout artist sérieux.

For this, or with this \& other complex reasons, I am grieved more than I can say about what you write me concerning Mrs. Alden. She has suffered so much - is of so brave a temperament, so sunshine-like in her naivité, it seems too hard that she should suffer as she does. I am haunted by that lovely verse of Malherbe ${ }^{21}$ when I think of her, and the Rose on Perrin

Mais elle était du monde vis les plus belles choses ont le pire destin; It rose, elle a vécu ce que vivent les roses L'espace d'un matin

More than once - strange as it may seem - I have almost felt the pain she endures, as it were vicariously. And yet - it may yet be well.

I hope the letter I send herewith to her (for her and you) may come with something of that freshening air which alien sight \& sound sometimes have. And you, amico mio - I am glad you are writing again. I too am busy: more maturely, more serenely, more hopefully, if with more mental \& spiritual stress, than heretofore. I shall write sometime $\&$ tell you more.

Ever affectionately your friend, I William Sharp ALS University of Delaware Library 


\section{To Nina F. Layard, May 1, 1893}

Phenice Croft I Rudgwick I Sussex

I have read your MS. with interest. I find it difficult to know what to say, for I do not know what kind of opinion you want - I mean, if as a critic, as a publisher's reader, or merely a lover of poetry.

I have certainly no hesitation in thinking your book distinctly above the average. Technically, it is unequal: but there are a few poems which are of exceptional merit in all respects - notably the unambitious "A Penalty" and "Sweet Peas". In the first named it seems to me that you touch your high water mark - for it has the great quality of being artistically complete while reserved in expression.

Your longest poem has many poetic passages in it: but I admit that it seems to me overlong, and to be occasionally crude in conception as well as in execution. This, however, is an opinion rather than a criticism. I may be quite wrong: and the fault lie with me.

Well, to come to the point: I do not think any publisher will undertake the book on his own risk, not because the collection is not good enough to sell, but because there is so much that is good daily going a begging for the buyer that cometh not: because there are very few purchasers for verse by writers who have not won a wide repute: and because the possibilities of return of outlay are so limited. These are hard facts, but, alas, facts they are. ${ }^{22}$

If you publish in your own account you must be prepared to find little return financially for your outlay. My advice would be: if you can afford it, print at your own expense, through some local printer (not a publisher), say 300 copies, bound simply, in thick paper or cloth. This should not cost beyond 25 shillings at the outside. You could then send say 50 copies to the leading papers \& periodicals, and either place the remainder with some publisher or bookseller to dispose of for you at a commission of $10 \%$, or such portion of the remainder as you cannot dispose of privately.

I would gladly send you a more encouraging letter - but I cannot honestly do so. With equal candour I may add that I shall be genuinely pleased if on all points I am disproved, and you are enabled to throw out more stone at the Great Cairn of the Folly of Critics! 
I send back your MS. by registered post: kindly send a line or $\mathrm{P} / \mathrm{C}$ acknowledging its receipt.

If you will forgive the commonplace phrase for the sake of the essential truth that underlies it, let me say that, in any hazard, poetry is its own exceeding great reward. And I often think that the more we love it, the more intimate with it we become, the less exigent are we as to such matters as vogue, popularity, uncritical acclaim.

With good wishes I Sincerely yours | William Sharp ALS private

\section{To [Swan Sonnenschein and Company], May 4, 1893 ${ }^{23}$}

Phenice Croft, | Rudgwick I Sussex

Dear Sirs

My attention has been drawn to the fact that your agreement and mine, re "Rossetti", are both unstamped, and therefore both invalid in point of law.

How can this now be rectified? Would not the simplest way be a fresh Agreement Form similar to that existent between us, stamped in duplicate? The date can be altered to the present time.

Yours faithfully, I William Sharp 


\section{To Kineton Parkes, [May 6, 1893] ${ }^{24}$}

Phenice Croft, Rudgwick, Sussex

Dear Mr. Parkes

If you can send me John Davidson's "Fleet St Eclogues" (just pubd by E Mathews \& Lane) I will do you an article on Recent Poetry apropos of Davidson's "Eclogues", Mathilde Blind's "Songs \& Sonnets", and W. Renton's "Poems". (I have the two last named).

Yours in haste I William Sharp

Let me know the latest convenient date for the June number. Address to me at Alum Bay Hotel, Isle of Wight.

ALS private

To J. Stanley Little, May 7, $1893^{25}$

Sunday Morning | Horsham Station | 7. May 93

Well, you are a fraud, J.S.L! I suppose you got screwed and forgot all about your promise to come in? I worked till about 1 a.m., \& then fiddled about and waited doing odds and ends till 2:15. I then went out, but the ancestral mansion of the Kensetts was buried in a gloom as profound as its greatest ornament's pessimism. I particularly wanted to see you abt. one or two points in my Art-article, abt a letter from Sonnenscheins, ${ }^{26} \&$ about a small matter I wanted you to do for me. (By the way, did you pay Horsham Bookstall a/c \& tell them to discontinue D/Chronicles?)

It is only the prospect of the virtuous life I am going to live during the coming week that makes me forgive you. The sense of well spent time makes one kindly to sinners like you.

W.S. 
I'll send you a line in a day or so.

ACS Princeton

\section{To Kineton Parkes, May 10, 1893}

Freshwater Bay Hotel I Isle of Wight

Dear Mr. Parkes

All right - only give me your latest convenient date. I could not send any MS before the 19 th or 20th. Would it do if you received it on the 22nd?

Send me a $\mathrm{P} / \mathrm{C}$ here.

Sorry you are in financial troubles with the L. R. ${ }^{27}$ It is too good a periodical to come to grief.

In greatest haste | Yrs sincerely | William Sharp I shall leave here in a few days - \& be back in Rudgwick by the 17 th but send me the $\mathrm{P} / \mathrm{C}$ here.

PS Of course if there is real urgency, I might be able to send it by this week-end. But I would rather not. If so, you had better wire to me (Lambert's, Freshwater).

ALCS UWM Library 


\section{To J. Stanley Little, May 10, 1893 ${ }^{28}$}

Somewhere or other near Freshwater

My dear Boy

Of course I understand. I am quite certain I should omit an aftermidnight call on you, if a "young charmer" would sit up with me till 2 a.m. and discuss debatable subjects!

I hope you had a really pleasant time of it with your guests altogether. It is glorious here. By Jove, Life is well worth living!

Well, if you are in Rudgwick on Monday next we'll have a chat over sins and sinners - always a fascinating subject. But perhaps you'll go to Paris: perhaps I'll be dead, or won't get away from here so easily.

Ever, old man, Affectionately Yours,

Will

K. P. seems in a bad way with the Library Review.

ACS Princeton

\section{To Richard Garnett, [June?, 1893] ${ }^{29}$}

Rudgwick

Have been away from home: hence delay in receipt of book, for which I am most grateful. Shall write in a day or two: meanwhile, cordial thanks.

W.S. 


\section{To Richard Watson Gilder, June 3, 1893}

Phenice Croft | Rudgwick | Sussex | iii:vi:xciii

Dear Mr. Gilder

I have recently returned from a long journey across French Africa, from the frontiers of Morocco across the Sahara and the African Highlands to Carthage and the Tunisian littoral and desert.

Naturally I want to turn my experiences to literary account, with further intent to issue ultimately in book-form.

I obtained, often with difficulty, a great number of interesting photographs: and from these I think good illustrations could be made.

Here is a list of suggested papers, for which I took material, memoranda, etc. on the spot.

**1) Tlemcen the Magnificent: A Note on Moorish Civilisation.

*2) A Winter in the Sahel: Algeria.

**3) The Algerian Sahara (with description of the oases of El Kantara, Biskra, Chetma, the Holy city of Sidi Okba etc. etc).

*4) The City in the Air Descrip: \& Historic Romance of Constantine

5) The Country of St. Augustine E Apuleius (from Bonâ on the Coast to M'daourouch near the Tunisian frontier — the latter almost unvisited)

*6) Fleurs D'Orient (Tunis) with special note of the changed condition \& probable future now that the Sea Canal has been cut from Goletta through the lake El Bahira.

*7) The Country of Salammbô.

8) Carthage Today and Tomorrow (Descriptive, briefly retrospective, and with a forecast of what it may become)

9) The French in North Africa

10) Winter HealthResorts in French Africa. 
I hope you may see your way to commission one of these. I have put an asterisk against those with which I could send photos for illustrative purposes.

With kind remembrances, I Yours very sincerely, I William Sharp Richard Watson Gilder Esq. ${ }^{30}$

ALS Huntington

\section{To Louise Chandler Moulton, June 20, 1893}

Phenice Croft | Rudgewick | Sussex | 20:vi:xciii

My dear Louise

I am glad to learn that you are again in England. Naturally, it would have given me great pleasure to be with you today, but, apart from the fact that I never go to town in the middle of the week (\& rarely even on Fridays in this glorious summer when I grudge every hour from work and the country) - apart from this, we have a guest with us whom I cannot leave. I will try to see you some day soon, of course: \&, failing success, will be with you on next or the following Tuesday.

What an unparalleled Spring \& Summer! Here, in Sussex, we have had no rain (save 3 brief showers, 2 nocturnal) for $3 \frac{1}{2}$ months, \& an almost unbroken succession of blue skies. As we spent the winter in the Sahara \& elsewhere in North Africa, we have had one continuous flow of sunshine since Xmas.

I wish we could have a long talk "by ourselves". But this literary life of ours is so exigent. The pressure becomes greater: and, I find, more \& more imperative: the need to isolate oneself from many distractions, and to concentrate one's energies if a definite good is to be reached even approximately near.

I am working very hard: making the wherewithal for 'daily bread' but not omitting dreaming and the weaving of dreams. You, I hope, 
are well: the poet I know so well and admire so much, is she also doing well? Let her give us some more beautiful breaths from her charmed Garden of Dreams.

Ever, dear Louise

Affectionately your friend I William Sharp ALS Library of Congress, Louise Chandler Moulton Collection

\section{To Will Foster, June 21, 1893}

Phenice Croft | Rudgwick | Sussex | xxi:vi:xciii

My dear Sir,

I have been from home, or would have answered your letter and kind present of your book sooner. ${ }^{31} \mathrm{I}$ found it among several others awaiting me, and took it up, I admit, with indifference. But I soon recognized with genuine pleasure that the author of The Fallen City etc. is a poet. Your book seems to me very good indeed in parts: and by this I mean not the conventional significance but what the words actually convey. You are, I take it, a young man: so I infer from the markedly derivative notes in certain poem - e.g. the Wordsworthian in the Ode on Spring, the Rossettian in the Ode on Remorse, the Shelleyan in "Sleep". Here, and particularly in "Sleep", the atmosphere of other poetic minds than your own is too obtrusive. But, after all, this mainly proves that you have a natively keen \& true love for the best, and that you have a sensitive ear. Elsewhere I find a fine and alert poetic sense, a worthy investiture of the thought or idea, and the welcome note of native music. Your sonnets are now and again excellent: excellent, too, from a general as well as from the particular present standpoint. Of the several fine lyrical pieces I think I like best the fine Ode on the Mystery of Life: as, of the shorter pieces, I note particularly the highly poetic Songeuse.

With such a real talent as yours, you should do well. Nothing is beautiful but Beauty. So, at least, all poets should hold. This belief will 
make a true poet more and more exigent, more and more austerely illcontent of anything mediocre in thought, emotion, or expression, more $\&$ more relentless in wise renunciations.

With cordial good wishes | Yours very truly | William Sharp ALS University of Leeds, Brotherton Library

To June 22, 1893

Phenice Croft I Rudgwick I Sussex I xxii: vi: xciii

My Dear Sir

I thank you for your note \& suggestion. The latter has been made to me scores of times - but copyright and other reasons have said 'nay' where 'yea' would gladly be said by

Yours very truly I William Sharp P.S. If you have reason to believe that you could get (or if you already have) Dr. Holmes and/or his publisher's consent to a vol. of selected poems, I should be glad to hear from you again. But I fancy the sole British rights are in the firm which has issued Holmes' poems in this Country. ${ }^{32}$

ALS Private

To Alfred H. Miles, June 30, 1893

Phenice Croft | Rudgwick | Sussex | 30:vi:xciii

Dear Mr. Miles, 
Thanks for sending me your duplicate-set. ${ }^{33}$ There are several misreadings, but I suppose these will appear correctly in the book.

I shall write to you shortly for some information for my article on Victorian Poetry. At the moment, I am finishing a long commissioned article which must go off this week-end.

In great haste

Yrs. very truly, I William Sharp

ALS University of British Columbia

To Robert Underwood Johnson, July 15, $1893^{34}$

Phenice Croft | Rudgwick, Sussex I xv:vii:xciii

Dear Mr. Johnson,

On my return from abroad, I find your letter awaiting me - for which, thanks.

I do not wish to bother you or Mr. Gilder ${ }^{35}$ with unsought suggestions - but as you say you do not at present wish descriptive articles (such as the North African paper I proposed) it has occurred to me that you might care to have one of the over noted articles upon which I am now intermittently engaged or for which I have accumulated material. No. I would deal with Meredith's keenest delineations from life: and with his extraordinary insight, understanding of, and power of depicting woman's nature. No. II with the personality \& varied literary achievement of Lang. ${ }^{36}$ No. III with R. Buchanan, Lang, R. L. Stevenson, Barrie, Traill, Sir. Geo. Douglas, Walter C. Smith, John Davidson, ${ }^{37}$ etc. etc. among the writers - Richardson, ${ }^{38}$ the younger men of the Nature School, the new Glasgow School, etc. among the artists. If you care for No. IV, I would need to stipulate for its appearance by February next at latest - as it will probably serve as Introduction to a book next Spring or early Summer. No. V will deal with the questions at issue in 
contemporary fiction - in particular with the ideals and methods of the English \& American, where they meet, where they differ, \& the outlook.

I append the list overleaf.

With kind regards to you and to Mr Gilder.

Sincerely Yours I William Sharp

Suggested Articles

I. George Meredith as Student of Life

II. Andrew Lang

III. The Scottish Contingent to Contemporary Art \& Literature

IV. Contemporary Celtic Poetry

V. Contemporary Fiction: a Dialogue between Mr. Smith of London and Mr. Browne of New York.

VI. A. C. Swinburne as Dramatist.

ALS Huntington

\section{To Louise Chandler Moulton, July 15, 1893}

Rudgwick I xv:vii:xciii

My dear Louise,

Your kind card has added to my self-reproach. Had the ability concurred with the will, I would long ere this have called: but, alas, I have been so overwhelmed with work requiring the closest continuous attention that I have postponed and postponed and postponed. Besides this, I have purposely withdrawn from everything this year - having realized that my paramount need at present is isolation - or as much as can be had even at this distance from town. Each finds at last what he needs in order to do his 
best work. I do not know if I have found it yet: I doubt if I shall ever find it in England: but I am nearer to what I want than I have yet been.

Indeed, my going-out this season has literally been confined to three occasions: a lunch at Henry Arthur Jones ${ }^{39}$ in May, a lunch at Mrs. Knowles' $\mathrm{s}^{40}$ in June, and an afternoon-tea at Mrs. Pennell' $\mathrm{s}^{41}$ (when I chanced to be in town at any rate on literary business). Still, I should be regretful indeed if I did not see you. I shall try to call on Tuesday: failing this on the ensuing Tuesday. About the end of that week (28th or 29th) we go to Scotland for two months.

I know there is no chance of my wife being able to call on Tuesday next (she returns today with a guest) but I hope she may be able to do so on the 25 th.

I, too, much regret that we see so little of each other now. But now \& always I am proud \& glad to sign myself

Affectionately Your Friend I William Sharp

I wonder if Dalmon ${ }^{42}$ has called yet, or forwarded my letter to you.

ALS Library of Congress, Louise Chandler Moulton Collection

\section{To Frank Murray, July 19, 1993}

Phenice Croft | Rudgwick | Sussex | 19:July:93

My dear Sir,

While it is not feasible for me to publish a romance on the terms indicated by you in your reply to my first suggestion, on account of the conditions specified by yourself, I have decided, if you are willing, to entrust to you the MS. of my most individual imaginative work - a series of seven studies collectively entitled "Vistas". ${ }^{43}$ I thought of publishing them myself, privately, - as I did (from Rome) in the instance of my Sospiri di Roma - but do not now feel free to undertake the trouble etc. necessarily involved during and after publication. 
"Vistas" is a series of psychological problems or reveries wrought in a new form, nominally dramatic. I had them with me - or some of them - when I was in New York a year ago: and Mr. W. D. Howells, Mr. Stedman, Mr. W. H. Alden, \& Mr. Bliss Carman were among the friends whose names will be known to you, who spoke with emphatic praise of their originality \& appeal.

Here I have shown them to very few - but in each case I have found the same thing: that their novelty of form \& substance has an exceptional appeal. One of them only has been printed: "The Black Madonna" which attracted a great deal of attention, favorable and adverse, a year ago.

I should be quite willing to accept your aforementioned terms for "Vistas" - as my chief object is to have the book issued by a publisher more or less identified with work of a new \& noteworthy kind.

Please let me hear from you at early convenience - as I leave here for Scotland by the middle of next week.

Yours faithfully | William Sharp

ALS National Library of Scotland

\section{To J. Stanley Little, [July 27, 1893]}

Thursday Morning

My dear Stanley

Herewith I send you, with many thanks old chap for your considerate \& timely aid, a cheque for $£ 5$, in repayment of your loan to me.

I have asked that all letters for us be sent to you till Sunday inclusive. If anything come[s] for us, will you kindly redirect to us at 72 Inverness Terrace Bayswater: Sunday only if you catch the 10 post.

Thereafter I have directed the post people to send everything to Scotland. 
Take care of yourself old fellow. You have my deepest sympathy \& esteem in your struggle with adverse circumstances.

Nevertheless I believe the turning of the tide is nearer than you think.

If you do not come north, do not mind if I am a bad correspondent as is my wont: I feel the need of as much cessation from writing (for eyes as well as for head) as is practicable.

Adieu. Begin the new romance soon: there is your line of least resistance: go along that, alertly, determinedly, expeditiously. You will be at the goal while you think it is still below the horizon.

Yours affectionately, I Will

ALS Princeton

To J. Stanley Little, [early August, 1893]

6 Albany Place I St. Andrews

My dear Stanley

I have asked Annie, our servant, to take you the key of our house (or to let you in) - \& I wd. be much obliged if you wd. go to my study and obtain \& send to me what I want.

(1) In the lower shelves at the desk near the door is a bundle of The Pagan Review. I want 3 copies.

(2) On the brown wickerstand near the lounge is a little red-clothbound book: "Flashes of French Wit and Wisdom". If not there (where I left it), it will be in the swing-case or on the table behind the lounge. It belongs to a friend who wants it back.

(3) In my dressing-room book-case - in (I think) a lower shelf of the section next the window - among translations - is a book by Pierre Loti, called either Pecheur d'Islande, or "An Iceland Fisherman". ${ }^{44}$ This I want also.

Will you take this trouble for me? 
My Belgian article will be out in the September Nineteenth Century, I understand it comes to 20 full pages in print.

My 'Rossetti', my new one-vol. novel, my vol. of short stories, \& my French studies, ${ }^{45}$ fully occupy my mind here - when I am not swimming or walking, eating or sleeping or 'dreaming'.

Thanks for your letter, old man. I knew you wd. understand. All the same, both E. \& I hold to our opinion.

[Unsigned]

ALS Princeton

\section{To Catherine Janvier, August 12, 1893}

St. Andrews | 12th August 1893

Your letter from Narragansett has just reached me... . The white flowers you speak of are the moon-daisies, are they not? - what we call moon-flowers in the west of Scotland and ox-eye daisies in England, and marguerites in France?... Your description of them as seen in that nocturnal glamour is worthy of any Celtic poet from Muireadach Albannach down to Duncanban MacIntyre - a seven centuries compliment!

It is very strange that you should write about them to me just as I was working out a scene in a strange Celtic tale I am writing (called "Pharais") wherein the weird charm and terror of a night of tragic significance is brought home to the reader (or I hope so) by a stretch of dew-wet moon-flowers glimmering white through the mirk of a dusk laden with sea mist. Though this actual scene was written a year or two ago - and one or two others of the first part of "Pharais" - I am going to re-write it, your letter having brought some subtle inspiration with it. $^{46}$

"Pharais" is a foil to the other long story I am working at. ${ }^{47}$ While it is full of Celtic romance and dream and the glamour of the mysterious, the other is a comedy of errors - somewhat in the nature, so far, of "A 
Fellowe and His Wife" (I mean as to style). In both, at least the plot, the central action, the germinal motif, is original: though I for one lay little stress on extraneous originality in comparison with that inner originality of individual life... . I have other work on the many occupied easels in the studio of my mind: but of nothing of this need I speak at present. Of minor things, the only one of any importance is a long article on a subject wherein I am (I suppose) the only specialist among English men of letters - the Belgian literary Renaissance since 1880. It is entitled "La Jeune Belgique" and will appear in (I understand) the September number of the Nineteenth Century.

We must each 'gang our ain gait'. I'm singularly indifferent to what other people think in any matter where I feel strongly myself. Perhaps it is for this reason that I am rarely 'put out' by adverse criticism or opinion - except on technical shortcomings. I do a lot of my own work here lying out on the sand-dunes by the sea. Yesterday I had a strange experience. I was writing in pencil in "Pharais" of death by the sea - and almost at my feet a drowned corpse was washed in by the tide and the slackening urgency of the previous night's gale. The body proves to be that of a man from the opposite Forfar coast. It had been five days in the water, and death had played havoc with his dignity of lifeless manhood. I learned later that his companion had been found three days ago, tide-drifted in the estuary of the Tay. It was only a bit of flotsam, in a sense, but that poor derelict so sullenly surrendered of the sea changed for me, for a time, the aspect of those blithe waters I love so well. In the evening I walked along the same sands. The sea purred like a gigantic tigress, with a whisper of peace and rest and an infinite sweet melancholy. What a sepulchral fraud... .

Life seems to move, now high and serene and incredibly swift as an albatross cleaving the upper air, now as a flood hurled across rocks and chasms and quicksands. But it is all life - even the strangely still and quiet back-waters, even, indeed, the same healthful commonplace lagoons where one havens so gladly often... .

Memoir 224-25 


\section{To Robert Murray Gilchrist, August 18, 1893 ${ }^{48}$}

c/o Mrs. Glasford Bell | Tirinie | Aberfeldy | (Perthshire) | 18:Aug:93

Dear Mr. Gilchrist,

Have you forgotten your kind invitation to me to stay a night with you at Eyam?

If not, and if you are to be at home, and if the visit would be in no way inconvenient for you, it would give me much pleasure to join you on or about the 24th of September.

It is difficult for me to fix an exact date at this time - but I think the 23rd or 24th or 25th the likeliest - \& particularly so the 24th.

I leave here on Aug. 28th, \& go to my mother's in Edinburgh (Murrayfield) for 3 or 4 days, \& on the 1st to the Isle of Arran for a fortnight. After that my movements are somewhat uncertain: but Murrayfield, Edinburgh, will always find me.

If by good hap I am to have the pleasure of seeing you I hope that pleasure may be enhanced by meeting your mother also, of whom I have heard - both privily \& of course in a literary sense.

With kind regards I Cordially yours I William Sharp It may interest you to know that I am bringing out something through Mr. Frank Murray of Derby. ${ }^{49}$

ALS Sheffield City Archives

\section{To Robert Murray Gilchrist, August 18, 1893}

Just a supplementary card to say that - granting the proposed visit be convenient at all - it will probably have to be a day or two later than the date suggested by me.

W.S. 


\title{
To Robert Murray Gilchrist, September [10?], 1893
}

\author{
Corrie Hotel | Isle of Arran | Scotland
}

Dear Mr. Gilchrist

At last I am able to fix my travel-dates. I leave here on Friday the 15th, \& shall be moving about for a little \& then be in Edinburgh till the 29th inclusive.

On Saty the 30th my wife \& I leave Edinburgh by the King's Cross morning express. Mrs. Sharp will go straight on to London - and I (if still quite convenient for you) will branch off, so as to spend Saty evening \& Sunday with you. I must leave again early on Monday.

As there is no Bradshaw here - \& I cannot find Eyam in my other timetables - will you kindly let me know where I shd. diverge from the L. \& N.W. Ry main line (by which we have return tourist tickets) presumably, I take it, at either Preston or Crewe? - and how thence I am to reach Eyam.

My letter address is 9 Up. Coltbridge Terrace, Murrayfield, Edinbro' - But I shall be here, at Corrie, in Arran till Friday of this week.

I hope you are enjoying as glorious weather in Derbyshire as we are in Arran.

Cordially yours I William Sharp

ALS Sheffield City Archives

To Robert Murray Gilchrist, September 23, 1893

9 Up. Coltbridge Terrace | Murrayfield | Edinbro'; | 23:9:93

Dear Mr. Gilchrist,

Thanks for your kind note. With your suggestions and a Bradshaw which I have at last been able to obtain, I can now write definitely. 
I find that I can leave Manchester (i.e. on Saty 30th) by the Victoria Station after all. I'll reach Manchester, from Preston, at 3:10: I leave Manchester for Derbyshire at 3:28, by the train due at Hassop at 5.0 o'clock - where you kindly say you will meet me.

Of course this arrangement is dependent on the punctuality of the Edinburgh-London express. It is due at Preston at 2.5: and the Manchester train goes at 2:15 - \&, if the trains are not in connection, there is the obvious hazard of catching the 2:15. (If I miss this train I find that I can reach Hassop at 6:38).

However, I fancy there will be a connection with Manchester. I regret that I cannot avail myself of your cordial invitation to prolong my visit, but I must be in London on Monday night \& wish to talk [sic] Derby en route: ${ }^{51}$ so that I must leave Miller's Dale at 10:34 (or at latest Hassop at 11 ) on the 2 nd.

It will be a pleasure to me to meet you.

Till then I à rivederta | William Sharp ALS Sheffield City Archives

\section{To J. Stanley Little, [September 23, 1893] $]^{52}$}

Murrayfield: Edinburgh

\section{My Dear Stanley}

I have dropped here unexpectedly from the West Highlands. Elizabeth is in Dumbartonshire - no, today by the by she'll be in Fifeshire: and comes here on Monday. We leave for London on the 30th. (I breaking the journey till the 3rd) and go back to Phenice Croft on the 6th.

I am sorry I overlooked replying to your questions about apples. Let old Ticknor (or any one else you wish) have all the fallen apples. 
Those on the trees to remain. Thanks for what you have ordered or recommended Ticknor to do. Whatever is seasonable shd. be done.

I am selfishly sorry you are to be away when we arrive: but hope you will have a good time in Ireland - tho' not in point of weather, I fear, for a cold autumn has set in apparently. Very glad to hear about the Wealden Tragedy, ${ }^{53}$ though sorry at the financial deadlock.

Impecuniously and Affectionately Yours, old Chap, I Will ALS Princeton

\section{To Robert Murray Gilchrist, October 7, 1893}

Phenice Croft | Rudgwick | Sussex | Saturday 7th Oct/93

\section{My Dear Murray Gilchrist}

I have been so busy since I left Eyam that I find it difficult to realize I was with you so recently as this day last week. Tomorrow I will think of you on the moors. What a lovely day we had last Sunday. I envy you your isolation in so beautiful and inspiring a locality. You should do good work there. I hope you will make immediate and steady progress with your romantic novel. There's a clear perspective for you there: other paths may, meanwhile at any rate, prove each a cul-de-sac or at least a bewildering byway. Possibly you may be able later to vary with advantage your line of advance,

I send you the Etching of myself I promised: ${ }^{54}$ also to Mr. Garfitt,, ${ }^{55}$ a copy of The Pagan Review. Let me know if it reaches you without soilure.

I much enjoyed my brief visit to Eyam. Here, in the passive South, I would give much for such moorland \& upland as we walked over last Sunday.

Greetings to you both I Cordially yours I William Sharp We came here last night - I am thankful to get out of London. 
P.S. I found Murray a decent sort of chap. He dropped his " $h$ 's" occasionally, and in certain small matters was oblivious of what some of us consider to be good breeding. I did not know he was a cousin of Austin Dobson ${ }^{56}$ - did you? I think he has a genuine love of literature.

He showed me a charming (though, in drawing, not immaculate) design for the frontispiece of Frangipanni, which he hopes to publish before the end of October. ${ }^{57}$

ALS Sheffield City Archives

\section{To Louise Chandler Moulton, [October 9, 1893] $]^{58}$}

Phenice Croft | Rudgwick I Sussex I Monday

My dear Louise

Thanks for your card. We have just returned to Sussex, \& there is far too much to attend to after our long absence to permit of either of us getting to London tomorrow, or indeed any day this week. But both of us and I, so far as I can see, for certain - will be with you the following Tuesday afternoon (17th). I hope Coulson Kernahan may come that day also - so that we may meet.

Hoping you are flourishing $-\&$ begging you to excuse a short \& hurried note

Affectionately yours I Will

ALS Princeton 


\section{To: Horace Scudder, [October 10, 1893]}

Phenice Croft | Rudgwick | Sussex | 10:10:93

Dear Mr. Scudder,

It is a long time since we have had communication: but I for my part have often thought of you and yours in your Cambridge home, and of my pleasant visit there. I have not been much in England since I last wrote to you - that is, dissociating Scotland and England, for I have been for some time past in the West Highlands.

As you may have heard from the Stedmans or the Aldens, my wife and I went across French Africa and the Northern Sahara last winter \& spring. We had a delightful time of it, \& passed from the frontiers of Morocco right to the Tunisian eastern littoral, by the way of the Sahara, the African Highland of the Province of Constantine, and Northern Tunisia to Carthage.

And now as to business. I send herewith by Book Post for your consideration a typed copy of a story by myself, mostly written during an autumn I spent at Heidelberg in the very house etc. described in the tale - a house once occupied by Goethe, and where he wrote part of his Ohinbalische Divan. I hope it may suit you.

In connection with my North African experiences, is there anything you would care to have from me? I am specially interested in historical subjects, particularly when they illustrate the great law of flow and ebb, and among those for which I accumulated special material are the following:

(1)The Vandal March (dealing with the extraordinary \& eventful descent of the Vandals upon North Africa: the extent of their March: the duration of their power: and the Outcome).

(2) In the Steps of Jugurtha 'The Country of Cista \& its neighbourhood: now the Province of Constantine)

(3) Tlemcen: A Note on the Moorish Civilisation: (Tlemcen is to Mauritania what Florence was to Medieval Italy - \& more: the head and fount of all its learning and art, African \& MauroHispanish).

I would prefer No. 3 \& No. 1. 
Of descriptive travelarticles, I would suggest

4. "Through the Liban" (Northern Sahara)

5. "The African Highland" (Prov. of Constantine)

6. “Through Tunisia" 59

Are there any of these that you would care to commission?

I shall be at home all winter. Family matters have involved me in considerable financial strain, and any going away is, alas, impossible at present. However, I can't complain - having had more than my share of gadding about.

Kind remembrances to you and yours, I William Sharp I hope to be with our common friend Shields $s^{60}$ tomorrow, at the funeral of poor old Ford Madox Brown. ${ }^{61}$

Horce Scudder, Esq

ALS Harvard Houghton

To J. Stanley Little, November $28,1893^{62}$

Rudgwick

My dear Stanley,

Thanks for your letter. I hope you are enjoying yourself in London and not knocking yourself up with doing too many things.

Will you, if you are coming back tomorrow, dine with us? We'll expect you if we do not hear to the contrary. (We'll be away on Thursday and Friday).

In haste, | Affectly Yours, | Will 


\section{To Nina F. Layard, ${ }^{63}$ November 29, 1893}

Phenice Croft | Rudgwick | Sussex | 29:11:93

Dear Miss Layard,

I thank you for the volume you have so kindly sent to me - and for which I wish good fortune in all respects, as it certainly deserves:

I have read the poems with much interest and appreciation. Some of them seem to me very good indeed - by which I mean something more than so hackneyed a commendation may seem to convey. But my own taste inclines me to the shorter lyrics - there it seems to me you are at your best: Let me tell you what I like best in your book - though the telling may disappoint you - first (and by a long way) "The Scot of Hollnodine" - then "Sweet Peas" and "Virgin Lily". But these are preferences, not criticisms -

With cordial good wishes | Yours sincerely | William Sharp ALS University of Kentucky, W. Hugh Peal Collection

To Ingram ${ }^{64}$ December 14, 1893

Phenice Croft | Rudgwick | Sussex | 14:12:93

Dear Mr. Ingram,

Excuse my delay in replying to your letter. I have been (and still am) from home and my correspondence is in arrears accordingly.

Naturally, I sympathise with your wish. This, however, is one of the instances (having reference, as it does, to a living writer) where I cannot act without the full consent of the publisher.

I will write to him tomorrow as an advocate, I need hardly say and let you hear from me at an early date.

Yours faithfully, I William Sharp 


\section{To [Laura Hyde Stedman], [mid-December, 1893] $]^{65}$}

Phenice Croft: Rudgwick

With affectionate greetings (in which my wife says she must be allowed to take part) to you and yours, for Christmastide and the Coming Year I William Sharp

Thank E.C.S. for his welcome letter which I hope to answer early in January.

ACS Pennsylvania State University

\section{To Robert Murray Gilchrist, December 20?, 1893}

Amico Mio,

May Christmas give you happiness, and the New Year add weal to it and health and good work. Skoal to "The Labyrinth".

Today I write finis to my Celtic Romance - long dreamed of - I wish I could read some of it to you. It is out of my inmost heart and brain.

Vistas, I hope, will be out by the end of Jany. The final revises went back a few days ago.

Greetings \& good wishes to Garfitt. If you are with your mother, or she with you, my homage to her.

Cordially your friend I William Sharp

P.S. You are to come here in the early Spring, remember! Come as soon as The Labyrinth is finished. I am glad we have become friends. Something drew me to you from the first. 


\section{To Frank Murray, December 27, 1893}

72 Inverness Terrace | Bayswater | W. | 27:12:93

Dear Mr. Murray

I have sent to you yesterday my (unframed) etching of the late W. Bell Scott after Blake's design. ${ }^{66}$ It was given to me by himself many years ago - \& I do not know who published it, or in what form it was published - though I think it was in book form (privately published probably).

If you like the design for [the] frontispiece to Vistas, I do not know to whom application for consent (if it be necessary at all) should be made: but presumably to Mrs. Scott who, I believe, is still living, and could be addressed I c/o Miss Boyd I Penkill Castle I [Girvan?] I Ayrshire I or, if you think it better, $\underline{I}$ could write to her.

If you do not care for the Blake design - perhaps the artist who worked for you for Frangipanni could do something satisfactory - or, if you will let me know what you can pay for a drawing, I could ask my friend Theôdore Roussel to do something. I think it is likely I shall be able to get an etched frontispiece for "Pharais" from Mr. Strang.

Please take all care of this Blake Etching: as it is rare, \& I have never seen any other copy.

You will be interested to hear that last week I wrote "finis" to Pharais: and have not only finished it but think it the strongest \& most individual thing I have done. For several reasons, however, I wish to adhere rigidly to the 'Fiona Macleod' authorship. I think the book will attract a good deal of notice, on account of the remarkable Celtic renaissance which has set in \& will inevitably gather weight: it touches, too, new ground and, I think, in a new way. What is perhaps best of all is that it is written literally out of my heart - and indeed, though the central incident has nothing to do with me, most else is reminiscent.

It is, in fact, your agreement to accept my two most paramount conditions - pseudonymity and publication by the end of March - that weighed with me against a letter from the Editor of one of the leading magazines in America, offering me high terms for a romance written not 'to order' but really con amore. However, for reasons into which I need not enter at present, I prefer to lose at the moment so as to gain in every way later. Herewith I send you the opening section. My copyist is now 
busy with the remainder, \& I daresay is more than halfway through with the book. I would be glad if you would direct the printer not to place blank pages between the several chapters. The book is in sections, rather than in 'Chapters': \& it will look much better to have each begin halfway down a page \& simply with "V" or "VI".

As to length: I suggest that a slightly smaller type than that of "Frangipanni" be used. Pharais is somewhat longer. Taking the average full Frangipanni page, I estimate it to contain, say, 200 words. At this estimate, "Frangipanni" is about 32,600 words in length.

I have estimated Pharais twice, \& in two ways. Estimating at full pages, it is as follows: Minimum: 35,000 | Max: 39,000. Estimated Length after both tests: From 37,500 to 38,500 . You can judge from this as to the type to be used. I will send you the following sections (VII in all) as I receive \& revise them: You will probably have all by the 11th or 12th of January.

I presume that, as you have undertaken to have the book out by the end of March, you will put it in hand immediately. Personally, I may add, this will be very much more convenient for me - as I shall be in town throughout January, now, I expect: and in March may possibly have to go abroad for a few weeks.

That is why I send the first installment to you without delay - now that the book is finished, revised, \& sent to be copied.

I don't know if you are yourself interested in Celtic matters. If so, you will find a good deal in Pharais that will interest you - particularly the strange chants \& weird superstitious women in the romance.

Of course the proofs should come to me under my own name. I shall be at above address until I communicate with you again.

When is Vistas likely to be published? I am asked often about it, \& can say nothing definite.

With all greetings of the Season I Yours sincerely | William Sharp 


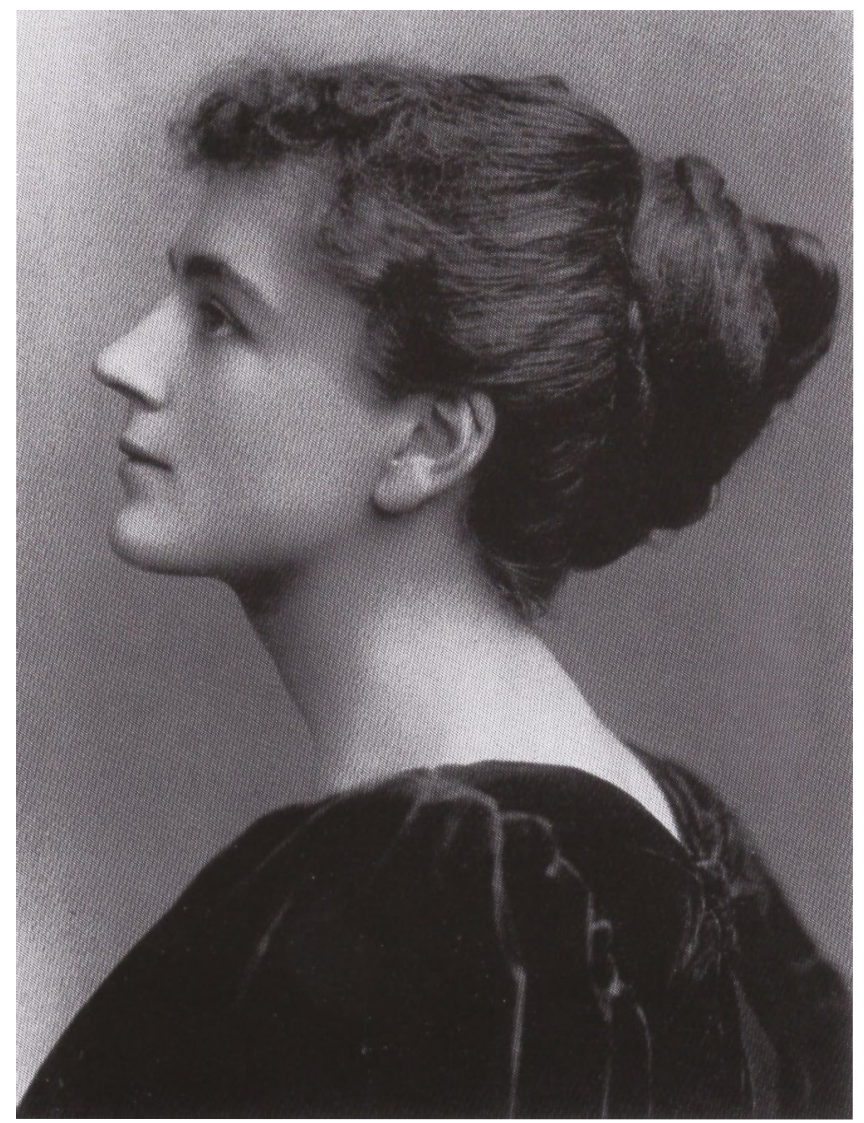

Fig. 12. Portrait of Edith Wingate Rinder (c.1894). Photographer unknown. Courtesy of the family of Edith Rinder. 


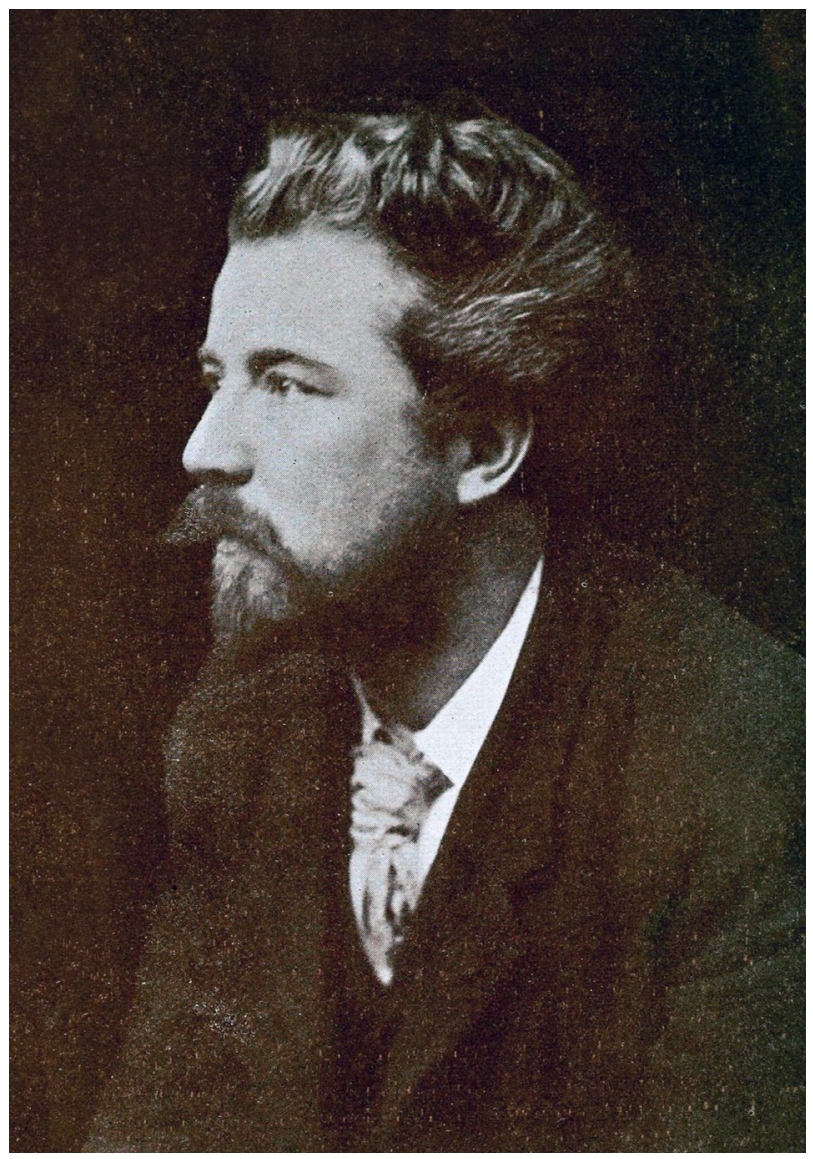

Fig. 13. Photograph of William Sharp in 1894 by Frederick Hollyer. Reproduced from Poems by William Sharp. Selected and arranged by Mrs. William Sharp (London: William Heinemann, 1912). 


\section{Chapter Eleven}

\section{Life: 1894}

In the fall of 1893 Elizabeth Sharp became increasingly uncomfortable at Phenice Croft: "The damp, autumnal days in the little cottage on its clay soil, and the fatigue of constantly going up and down to town in order to do the work of the Art Critic for the Glasgow Herald - which I for some time had undertaken - proved too severe a strain on me. And I found that in the winter months I could not remain at Phenice Croft without being seriously ill (Memoir 233)." The Sharps rented a flat in January 1894 - number seven in Kensington Court Gardens, a new mansion block south of the Kensington High Street - where Elizabeth would live throughout the winter while her husband traveled back and forth from Phenice Croft. At the end of the month, the Sharps tried to revive the "Sunday evening informal gatherings" they held in the late eighties in South Hampstead. Sharp invited Grant Richards for dinner on Sunday, February 4. Edith and Frank Rinder would be there, and others - including the publisher John Lane - would drop by later for a cup of coffee and to smoke a cigarette. Back in Phenice Croft on the ninth and hoping for a positive review, he sent Richard Le Gallienne an advance copy of Vistas, which would be published by Frank Murray on the fifteenth. On Saturday the tenth he was back in London writing to Stanley Little. Elizabeth was "better on the whole." He would be back in Phenice Croft the next day and in London again at the Grosvenor Club the following Saturday. He hoped Little would drop by to see him. Before the month was out, traveling back and forth in the mid-winter gloom affected his health. 
In early December Sharp told Murray Gilchrist he could not visit him in Derbyshire in January, but hoped Gilchrist would visit him in Buck's Green. In his Christmas greeting to Gilchrist, he wrote, "You are to come here in the early Spring, remember!" Though it was not early Spring, correspondence and the pattern of events indicate Gilchrist accepted Sharp's invitation in mid-February. In a letter dated only "Wendy" which was probably February 14 or 21, he told Gilchrist he would be happy to welcome him and Garfitt at Phenice Croft the following Friday. This visit was important for what it reveals about the atmosphere Sharp had created in Buck's Green and the state of his mental and physical health.

In a letter to Murray Gilchrist more than a year later, on September 26, 1895, Sharp drew his attention to a section of Fiona Macleod's The Sin Eater called "Tragic Landscapes." By that time Sharp had told Gilchrist, exacting a pledge of secrecy, that he was Fiona Macleod. In The Pagan Review, Sharp reviewed favorably a volume of prose poems and asserted they are not simply "quoted specimens of poetic prose." They must be brief and complete in themselves, the equivalent of pastels in painting. The pastel artist, he wrote, must be "what is somewhat too vaguely called an impressionist" whose aim is "suggestion, not imitation." The prose poem is "a consciously-conceived and definitelyexecuted poetic form." The three "Tragic Landscapes" in The Sin Eater are "prose poems."

The first, called "The Tempest," is a detailed word painting of a natural setting in which a storm is approaching. "The human element is wholly insignificant and accidental," he told Gilchrist, but humans appear near the close to emphasize the magnitude of the storm. It threatens to sweep away the natural world and all living inhabitants. The second "Tragic Landscape," called simply "Mist," portrays the post-apocalyptic natural world: "A dense white mist lay upon the hills, clothing them from summit to base in a dripping shroud. The damp, spongy peat everywhere sweated forth its over-welling ooze.... There was neither day nor night, but only the lifeless gloom of the endless weary rain: thin soaking, full of the chill and silence of the grave." Eventually, a shadow appears in the gloom, and a slow-moving man "stood beside a tarn. And was looking into it, as the damned in hell look into their souls." A stag appears on an overhanging rock and vanquishes 
his rival whereupon: "Night crept up from the glen and strath - the veil of mist grew more and more obscure, more dark.... there was a uniform pall of blackness. In the chill, soaking silence not a thing stirred, not a sound was audible."

The third "Tragic Landscape," called "Summer-sleep" portrays a hot, dry vista that is peaceful and drowsy with some signs of life:

The high-road sinuated like a snake along the steeper slope of the valley.... The gloom of July was on the trees. The oaks dreamed of green water. The limes were already displaying fugitive yellow banners. A red flush dusked the green-gloom of the sycamores.... The sky was of a vivid blue, up whose invisible azure ledges a few rounded clouds, dazzling white or grey as swans-down, climbed imperceptibly.... In the air was a pleasant murmur of the green world. The wild-bee and the wasp, the dragon-fly and the gnat, wrought everywhere a humming undertone.

The landscape is descending into a dreamy sleep with but a murmur of the "green life:" "Peace was upon the land and beauty. The languor of dream gave the late summer a loveliness that was all its own, as of a fair woman asleep, dreaming of the lover who has not long left her, and the touch of whose lips is still upon her mouth and hair." Through this personified natural world, which differs markedly from that of "The Tempest" and "Mist," three men are walking: "Two of the men were tall and fair; one dark, loosely built, and of a smaller and slighter build."

In his September 1895 letter to Gilchrist, Sharp wrote: "You will read the third piece, "Summersleep," with mingled feelings, when you know it is an exact transcript of - Phenice Croft at Rudgwick, and that the three men are - you, Garfitt, and myself." Although the visit of Gilchrist and Garfitt to Phenice Croft must have occurred in February 1894, Sharp transposed it to late summer. The two tall, fair men are Sharp and Gilchrist, and the smaller Garfitt. They approach "a small hamlet of thatched, white-walled cottages" which is Buck's Green. Sharp, the tallest wayfarer, points "to a small square house set among orchard-trees, a stone's throw from the hamlet," which is Phenice Croft," and says: "There is my home." His "comrade," Gilchrist, replies slowly, "It is a beautiful place, and I envy you." Garfitt agrees, and the owner replies "I am glad you think so." At that, the shadows of the three men "leapt to one side, moved with fantastic steps, and seemed convulsed with laughter." Perhaps the grass on the side of the road 
understood the speech of the shadows. If so, it would know Gilchrist said in his heart: "There is something of awe, of terror, about that house; nay, the whole land here is under a tragic gloom. I should die here, stifled. I am glad I go on the morrow." Then Garfitt said in his heart "It may all be beautiful and peaceful, but something tragic hides behind this flooding sunlight, behind these dark woodlands, down by the water-course there, past the water-mill, up by that house among the orchard-trees." If the grass understood the shadows, "It would know that the tallest man [Sharp] who lived in that square cottage by the pleasant hamlet, said in his heart: 'It may be that the gate of hell is hidden there among the grass, or beneath the foundations of my house. Would God I were free! O my God, madness and death!'” The three men know the placid landscape overlays a natural world that is "red in tooth and claw." They also know what only their shadows express: the placidity of human life overlays a chaotic darkness of tragic impulses and the fear of obliteration.

Following that shadowy experience of fear and horror, the final paragraph restores the peacefulness of the land and of everyday life:

After another long silence, as the three wayfarers drew near, the dark man murmured his pleasure at the comely hamlet, at the quiet land lying warm in the afternoon glow. And his companion said that rest and coolness would be welcome, and doubly so in so fair and peaceful a home. And the tallest of the three, he who owned the house in the orchard, laughed blithely. And all three moved onward with quickened steps, through the hot, sweet, dusty afternoon, golden now with the waning sun-glow.

After drawing Gilchrist's attention to the third "Tragic Landscape," Sharp wrote, "I cannot explain aright: you must read into what you read." We recall that Elizabeth Sharp wrote of their residence in Buck's Green:

The quiet and leisure at Phenice Croft, the peace, the "green life" around were unspeakably welcome to my husband. Once again, he saw visions and dreamed dreams; the psychic subjective side of his dual nature predominated. He was in an acutely creative condition; and, moreover, he was passing from one phase of literary work to another, deeper, more intimate, more permanent. (Memoir 221) 
The transition was from the work of William Sharp to that of Fiona Macleod, which Elizabeth, reflecting no doubt the opinion of her husband, thought "deeper, more intimate, more permanent." At Phenice Croft, she continued,

he was testing his new powers, living his new life, and delighting in the opportunity for psychic experimentation And for such experimentation, the place seemed to him to be peculiarly suited. To me it seemed "uncanny", and to have a haunted atmosphere - created unquestionably by him - that I found difficult to live in unless the sun was shining. This uncanny effect was felt by more than one friend; by Mr. Murray Gilchrist, for instance, whose impressions were described by his host in one of the short "Tragic Landscapes". (Memoir 223)

In his September 1895 letter to Gilchrist, Sharp wrote ominously, "The most tragic \& momentous epoch of my life followed that visit of yours to Phenice Croft, \& is, so far, indissolubly linked with that day I met you, and that time." What, we must wonder, happened following the Gilchrist visit that so affected Sharp? His letters, beginning in late February, suggest the probable answer.

Sending a copy of Vistas to Edward Dowden on February 26, he asked him to "excuse so brief a note as I have been ill \& am still debarred from much use of the pen." On March 1, in a letter thanking Stanley Little for his positive notices of Vistas, Sharp wrote: "I should have written to you before this, but I have not been well: \& yesterday had to telegraph to a friend. I am now, however, pulling round all right. Please say nothing of this to Elizabeth. Tomorrow [Friday, March 2] I shall go up to town, \& come down with her on Saty, till Monday [March 3-5]. On that weekend [March 9-11] some friends are coming for a fortnight, of which I am glad." On March 5 he wrote again to Little:

Did I tell you how unwell I have been? I have had to 'cave in' completely. I am now nearly better - but for some time to come must write only for 2 or 3 hours daily at most: and, moreover, am not to be alone at all. Elizabeth (who is steadily gaining ground) returns to town in a couple of days: \& then Mr. and Mrs. Rinder come here on 'a working visit' to keep me company for a fortnight.... I must not write more.

Elizabeth, herself unwell, but improving, was with him until at least Wednesday March 7, and the friends, now identified as Edith and Frank Rinder, came on that weekend to stay for two weeks. 
The psychic experimentations that gave Phenice Croft an "uncanny" and "haunted atmosphere" had led Sharp to the "gate of hell... hidden there among the grass, or beneath the foundations" of his house and to exclaiming "Would God I were free! O my God, madness and death!" Shortly after Gilchrist and Garfitt visited Phenice Croft, Sharp suffered a nervous collapse that produced a state of depression so serious that his wife and Edith Rinder decided he should not be left alone. He should also stop his psychic experimentations, drastically reduce his imaginative work, and not write at all more than two or three hours a day. It was almost certainly this collapse Sharp described in his September 1895 letter to Gilchrist as "the most tragic \& momentous epoch" of his life. It recalls a letter he wrote to Hall Caine ten years earlier - on June 15, 1884 - in which he described a "sharp and sudden attack" and a narrow escape from rheumatic fever that left his hands so chilled and pained he could hardly hold a pen. The mental collapse at Phenice Croft may well have been accompanied by a physical collapse that endangered his weakened heart. He concluded his March 5 letter to Little as follows: "This is an unusual break-down for me. But, for one thing, I have been living the life of Imagination too fiercely of late. I think you will be surprised when you learn what I have done." These sentences connect his breakdown with his writing as Fiona Macleod and suggest that work, as yet unknown to Little, was initiating a splitting of self - masculine versus feminine - that contributed to his collapse.

In a March 27 letter to Gilchrist, Sharp apologized for being too unwell to write sooner and announced he was leaving Buck's Green:

My wife's health... has long been troubling me: and we have just decided that (greatly to my disappointment) we must return to Hampstead to live. Personally, I regret the return to town (or half town) more than I can say: but the matter is one of paramount importance, so there is nothing else to be done. We leave at midsummer.

Elizabeth's illness in the fall, continuing into the winter, her dislike of the atmosphere Sharp had created in Buck's Green, and her work as art reviewer for the Glasgow Herald had forced her to let a flat in London. Her husband's mental and physical breakdown was the last straw. He could not be left alone. They were fortunate to find someone to sublet the house, which they vacated on June 21. Sharp described his actions of the previous night: 
I took up a handful of grassy turf and kissed it three times, and then threw it to the four quarters - so that the Beauty of the Earth might be seen by me wherever I went and that no beauty I had seen or known there should be forgotten. Then I kissed the chestnut tree on the side lawn where I have seen or heard so much: from the springing of the dream flowers to the surge of the sea in Pharais (Memoir 236).

Elizabeth understood his reluctance to leave: "Phenice Croft had seen the birth of Fiona Macleod; he had lived there with an intensity of inner life beyond anything he had ever experienced" (Memoir 233).

After describing their decision to give up rural living in his letter to Gilchrist, Sharp demonstrated what many of his close friends found remarkable, his ability to quickly recover from any problems no matter how debilitating:

As for me, one of my wander-fits has come upon me: the Spring-madness has got into the blood: the sight of green hedgerows and budding leaves and the blue smoke rising here and there in the woodlands has wrought some chemic furor in my brain. Before the week is out, I hope to be in Normandy - and after a day or two by the sea at Dieppe, and then at beautiful and romantic Rouen, to get to the green lanes and open places, and tramp 'towards the sun'. I'll send you a line from somewhere if you care to hear.

He turned in the letter to Gilchrist's relative isolation in Derbyshire:

I think you should see more of actual life: and not dwell so continually in an atmosphere charged with your own imaginings.... part of the year should be spent otherwise - say in a town like London, or Paris, or in tramping through alien lands, France or Belgium, Scandinavia, or Germany or Italy, or Spain: if not, in Scotland, or Ireland, or upon our Isles, or remote counties.... Take your pen and paper, a satchel, and go forth with a light heart. The gods will guide you to strange things, and strange things to you. You ought to see more, to feel more, to know more, at first hand. Be not afraid of excess. "The road of excess leads to the palace of wisdom", says Blake.

Gilchrist must have told Sharp he too suffered from depression:

To be alive and young and in health is a boon so inestimable that you ought to fall on your knees among your moorland heather and thank the gods. Dejection is a demon to be ruled. We cannot always resist his tyranny, but we can always refuse to become bondagers to his usurpation. Look upon him as an Afreet to be exorcised with a cross of 
red-hot iron. He is a coward weakling, after all: take him by the tail and swing him across the moor or down the valley. Swing up into your best. Be brave, strong, self-reliant. Then you live.

Gilchrist was ten years younger than Sharp; it should have been easier for him to take the demon of dejection "by the tail and swing him across the moor or down the valley." Yet Sharp was sharing his own experience as a guide for Gilchrist.

Sharp did not escape to France before the week was out. On April 3 he wrote a long letter to Herbert Stone, a Harvard undergraduate who, with his friend and classmate Hannibal Ingalls Kimball, had established a publishing firm, Stone and Kimball, which would "accept only manuscripts of literary merit and publish them in an artistic form." In August 1894 the firm relocated from Cambridge to Chicago where Stone's wealthy father, Melville Elijah Stone, had founded and edited the Chicago Daily News. When Louise Chandler Moulton drew Sharp's attention to the enterprise and informed him that Stone had liked his Vistas, Sharp saw an opening. He proposed to Stone a volume of seven short stories titled The Rape of the Sabines, after one of its stories he had included in The Pagan Review. As it turned out, Stone and Kimball published an American edition of Vistas late in 1894, and the volume of short stories in 1895 under the less provocative title The Gypsy Christ and Other Tales. Stone and Kimball also published the early works of Fiona Macleod, which began to establish her reputation among America's literati. At the suggestion of Arthur Stedman, Sharp asked Stone to negotiate for the plates and stock of his Flower o' the Vine from Charles Webster and Company as the firm was being liquidated. If Stone took up that suggestion, the negotiations failed since that volume disappeared from view.

On April 8 Sharp told Arthur Stedman in a letter from Phenice Croft, "I am better, though not right yet." When he went to France is uncertain, but on April 22 he sent a card to Murray Gilchrist from Paris that promised a letter and declared "Here summer is come," and concluded "Some strange things happen in this world! Well - no more just now." Elizabeth joined him in Paris on April 30, and they both returned to London on May 3. Recalling that Elizabeth and Edith Rinder had decided Sharp should not be left alone, Edith may have accompanied 
Sharp to Normandy in mid-April and their time together in Dieppe and Rouen may have been the "strange thing" Sharp would share with Gilchrist when they next met.

The public aspect of the Fiona Macleod phase of Sharp's literary career began in May when Frank Murray published Pharais, a Romance of the Isles from his Moray Press in Derby. In a footnote to the dedication of Pharais to E. W. R. (Edith Wingate Rinder), Sharp said the word pharais is a "slightly anglicized lection of the Gaelic word Pàras = Paradise, Heaven. 'Pharais' properly is the genitive and dative case of Pàras, as in the line from Muireadhach Albannach, quoted after the title page, 'Mithich domh triall gu tigh Pharais' - 'It is time for me to go up unto the House of Paradise."' Muireadhach Albannach, spelled variously, was a Gaelic poet later known as Murdoch of Scotland. A portion of the poem from which Sharp quoted a line is found in the Dean of Lismore's Book.

In a May 4 letter, Sharp told Stanley Little he had asked Murray to send him a pre-publication copy of a Celtic romance written by a friend, a Miss Fiona Macleod. It was a successor to his Vistas in Murray's Regent's Library Series, and he was "specially interested not only in its author but in the book," which dealt with "the almost unknown life of the remoter isles of the Atlantic seaboard." No copies had been issued except one to him and two to Miss Macleod. He hoped Little would like the book and write a notice or review for The Academy or the Literary World. Prior to the formal publication of Pharais, Sharp had decided to create a separate identity for the supposed author and present her to the world as a real person.

As stated in the previous chapter, almost a year earlier, in a letter dated August 1893, Sharp told Catherine Ann Janvier he was writing "a strange Celtic tale" he planned to call Pharais, a Celtic word for paradise. In the tale, not yet book-length, he continued:

The weird charm and terror of a night of tragic significance is brought home to the reader (or I hope so) by a stretch of dew-wet moon-flowers glimmering white through the mirk of a dusk laden with sea mist. Though this actual scene was written a year or two ago - and one or two others of the first part of "Pharais" - I am going to re-write it, your letter having brought some subtle inspiration. 
So we know Sharp began writing passages in 1893 or even earlier for what became Fiona Macleod's Pharais, and he had no intention at the time of publishing it pseudonymously. Shortly after the release of creativity he experienced in Rome in 1891, he had begun looking for a means of capitalizing on his knowledge of the Hebridean landscape and Celtic lore. Finally, he was able to tell Murray Gilchrist, in a letter of December 20, 1893, his "long dreamed of Celtic Romance" was finished. A week later he wrote to Frank Murray, the Derby publisher,

I think the book will attract a good deal of notice, on account of the remarkable Celtic renaissance which has set in \& will inevitably gather weight: it touches, too, new ground - and, I think, in a new way. What is perhaps best of all is that it is written literally out of my heart - and indeed, though the central incident has nothing to do with me, most else is reminiscent.

He also told Murray he wished "to adhere rigidly to the 'Fiona Macleod' authorship." It had occurred to him the romance might be dismissed as inauthentic coming from the London editor and critic William Sharp. His contribution to the Celtic Renaissance would appear under a female pseudonym. As the name, he chose Fiona, unknown at the time in Scotland, which he thought a diminutive of Fionnaghal, and Macleod, the surname of Seamus Macleod, who filled his youthful mind with Gaelic lore.

Sometime between December 1893 and May 1894, he realized he would have to find a means for the fictitious author to communicate with her publishers and readers. So he enlisted his sister Mary, who lived with their mother in Edinburgh, to copy his Fiona letters and mail them in Scotland. Mary's distinctive handwriting became an essential feature of the deception. It was frequently cited as proof the writings were not the product of William Sharp, and it was principally through the letters that he conveyed Fiona's distinctive personality and established the fiction of her separate identity. Discreet, efficient, and available, Mary was a vital link in the two-step transmissions that contributed to the remarkable success of Sharp's second, subterranean literary career.

Sharp bolstered the deception by sharing with friends, critics, and publishers details about the reclusive writer. She was his cousin and married to a peripatetic Scottish laird who owned a yacht that whisked her away to avoid detection. Sharp regarded her highly, provided 


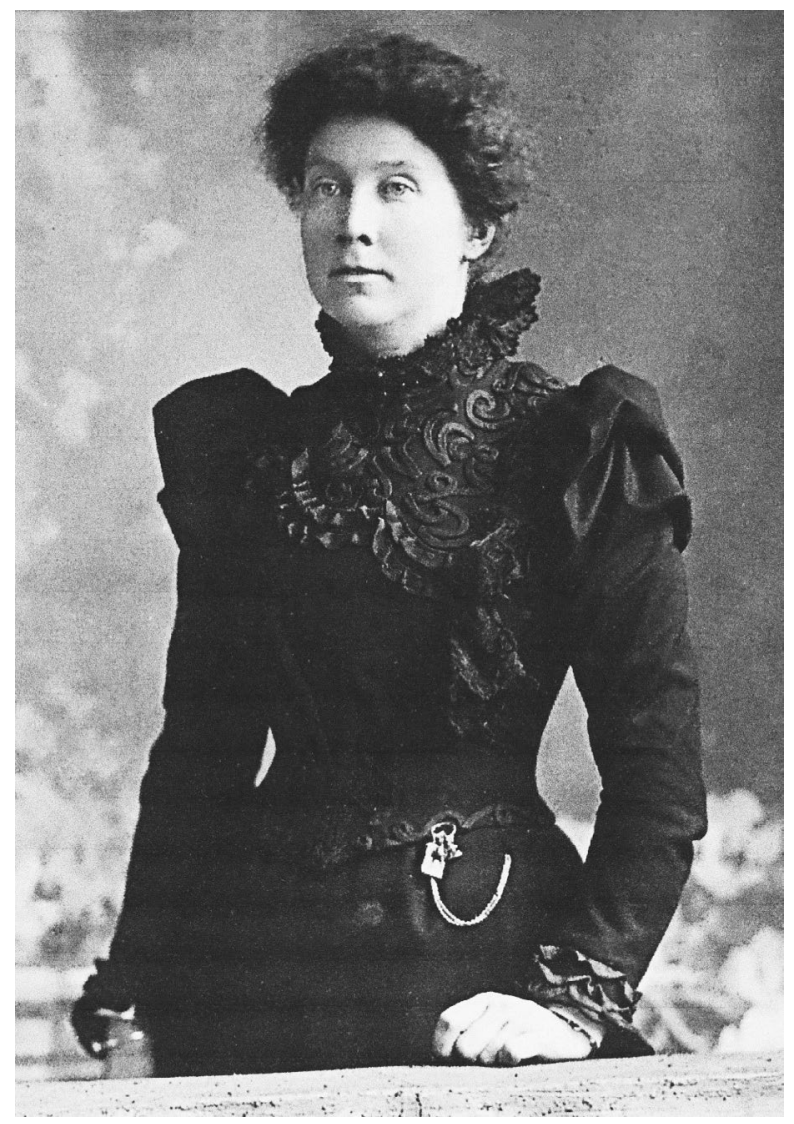

Fig. 14 Portrait of Mary Beatrice Sharp, William Sharp's youngest sister taken in the Davis Studios in Edinburgh in 1906. Mary provided the handwriting for Fiona Macleod's extensive correspondence. Courtesy of the Department of Rare Books and Special Collections, Dulles Reading Room, Firestone Library, Princeton University.

advice and assistance as needed, and respected her desire for privacy. He sometimes floated the impression that he and Fiona were more than close friends as they would go to remote locations together. In those instances, he seems to have conflated Fiona and Edith Rinder since they did go away together periodically. He often claimed he was unaware of her location in order to decline requests to meet her. When avid readers did turn up at her Edinburgh return address, she had just left to sail among the Hebrides. It was on those islands, after all, where she heard the tales and absorbed the atmosphere of her stories and poems. 


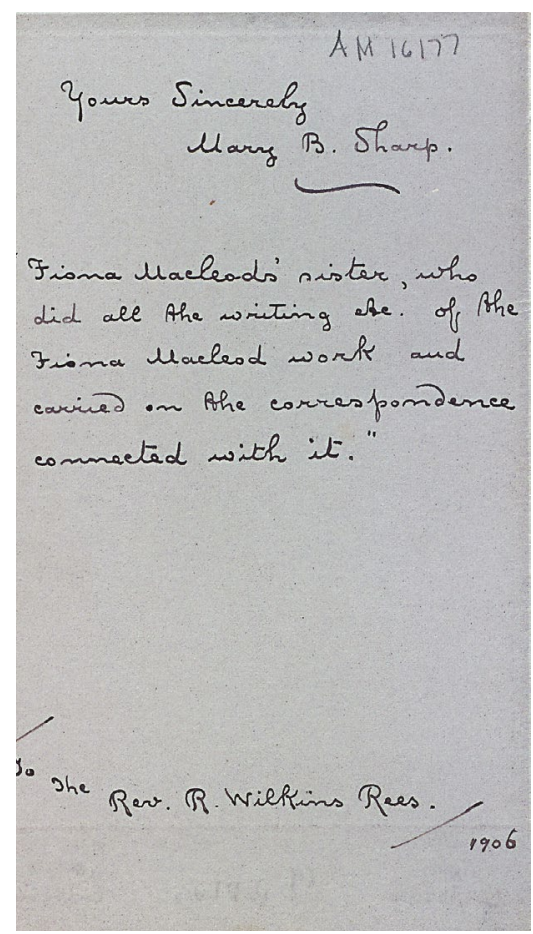

Fig. 15a. Verso of Fig. 4 in Mary Sharp's handwriting which was the Fiona Macleod handwriting. Inscribed to "To the Reverend R. Wilkins Rees. Yours Sincerely, Mary B. Sharp. Fiona Macleod's sister, who did all the writing of the Fiona Macleod work and carried on the correspondence connected with it."

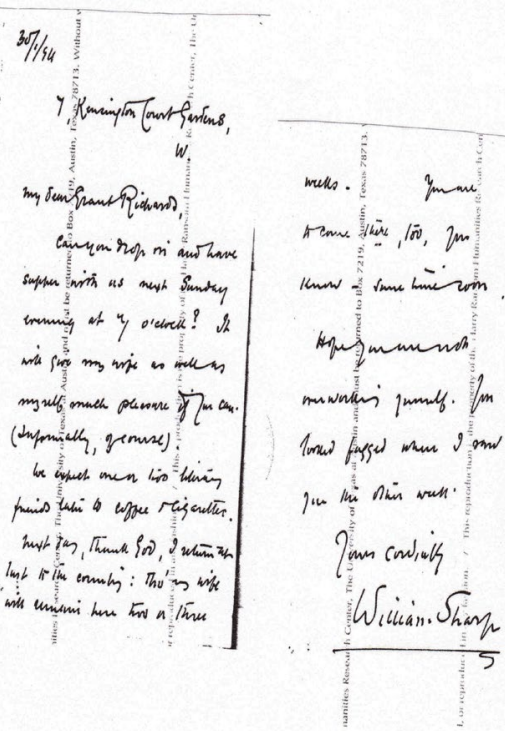

Fig. 15b. Letter to Grant Richards from William Sharp in his handwriting. Courtesy of the Harry Ransom Humanities Research Center, The University of Texas at Austin.

The first known letter from Fiona was written in mid-May to Grant Allen, a well-known writer and Sharp's good friend:

C/o Mrs. B. etc.

Dear Sir,

I have only now ascertained that you are in England. I was informed you were in the South of France. Some short time ago I asked Mr. Frank Murray of Derby to forward to you a copy of my just published romance Pharais. I now write to ask if you will accept it as a slight token of homage from the youngest and latest of Celtic writers to the most brilliant champion of the Celtic genius now living. I do not, however, send it by way of inveigling you to write about it, much as any word 
of yours would mean to me both in service and honour: but primarily because of your deep and vivid sympathy not only with nature but with the Celtic vision of nature - and, also, let me add, because of the many delightful hours I have enjoyed with your writings.

Believe me, | Faithfully yours,

Fiona Macleod

This letter, preserved in New York's Pierpont Morgan Library, is in William Sharp's handwriting. He sent it to Mary Sharp in Edinburgh for her to copy and send to Allen.

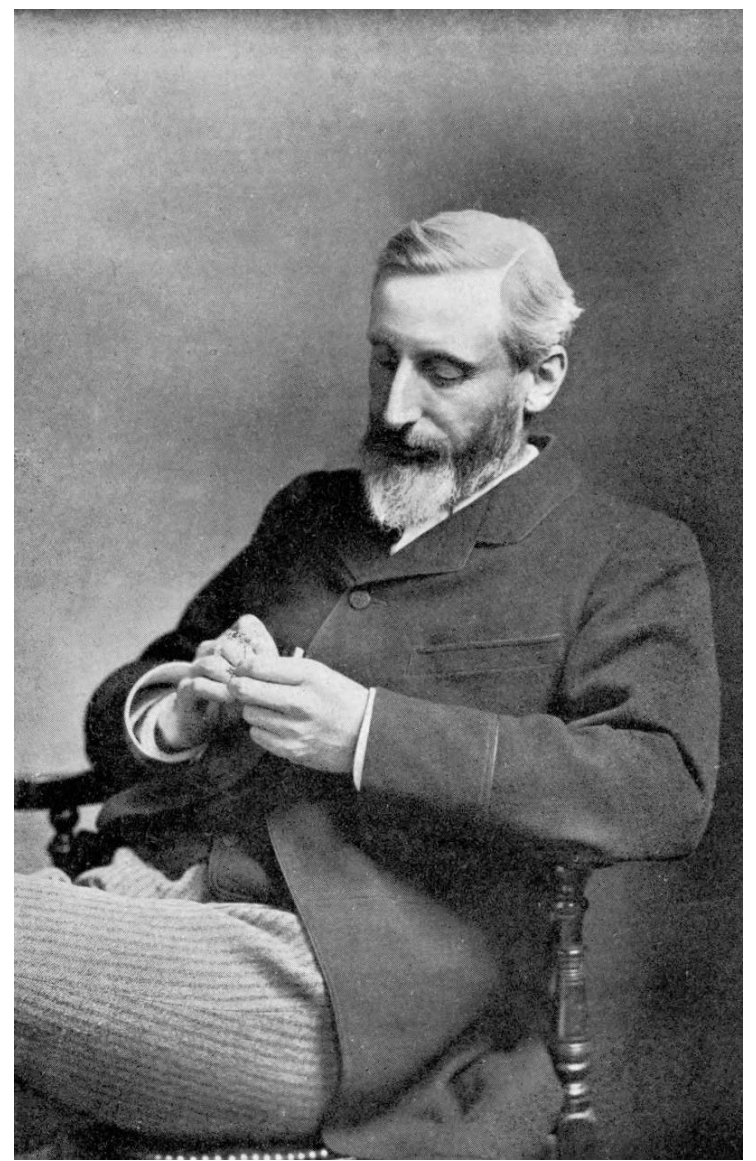

Fig. 16. Photograph of Grant Allen (1848-1899) by Elliott \& Fry (c.1899), Wikimedia, https:// commons.wikimedia.org/wiki/File:Portrait_of_Grant_Allen.jpg, Public Domain. 
This letter elicited a positive reply from Allen: Pharais, he wrote to Fiona "strikes me as a beautiful and poetical piece of work." He tempered his praise with a few words of criticism from an experienced and wellregarded writer to a novice. Interlarding English with Gaelic words was a trifle distracting. She should strive for a little more story and less pure poetry. "Perfection in literature lies in avoiding excess in any direction." He asked for some details about Fiona's life and expressed hope she would visit him and his wife who was much taken by Pharais (Memoir 228-29). Allen accepted the fiction Sharp was creating, but according to Elizabeth "Questions as to the identity of the author were already 'in the air"' (Memoir 230). In a Fiona letter to the publisher John Lane in June Sharp had her raise the issue directly: "You asked me in your note who told me to apply to you with The Mountain Lovers. It was my cousin, Mr. William Sharp. I hear that some paper says he wrote Pharais: and I sent a disclaimer at once to the Westminster Gazette." Something in that periodical, perhaps a review of Pharais, must have touched on the possibility that Sharp was the author. Even Grant Allen was suspicious as he said in a July 12 letter to Sharp:

As to Pharais, I will confess I read it with some doubt as to whether it was not your own production; and after I had written my letter to Miss Macleod, I took it to my wife and said "Now, if this is William Sharp, what a laugh and a crow he will have over me! Le Gallienne, who is stopping with us, was sure it was yours; but on second thoughts, I felt certain, in spite of great likeness of style, there was a feminine touch in it and sent my letter.

He continued:

All the same, however, I was not quite satisfied you were not taking us in, especially as your book with Blanche Willis Howard had shown one how womanly a tone you could adopt when it suited you; and I shan't feel absolutely at rest on the subject till I have seen the "beautiful lassie' in person. If she turns out to be W. S. in disguise, I shall owe you a bad one for it: for I felt my letter had just that nameless twinge of emotion one uses towards a woman, and a beginner.

Allen would be glad to meet Sharp's cousin in October, "supposing her to exist," when he hoped the Sharps would bring her to visit him and his wife in Hindhead, their village in Surrey. It is interesting to note in the context of this correspondence that Grant Allen wrote and published in 
1897 a novel - The Type-writer Girl - under the female pseudonym Olive Pratt Rayner. Presumably like Sharp, he thought a work so titled would be taken more seriously if by a woman.

These letters illustrate the problems Sharp encountered from the start maintaining the fiction of a real Fiona Macleod. A year later he was still trying to assure Allen of Fiona's existence. By that time their mutual friend Richard Le Gallienne, who saw from the start the linkage between Sharp's writings and Fiona's, was sure of the deception and said so in print. That so alarmed Sharp he sent Le Gallienne a letter telling him to "shut up." When next they met face to face, he told Le Gallienne the truth after obtaining a firm promise of confidentiality.

In early June Sharp sent from Fiona a copy of Pharais and positive quotes from several reviews to the publisher John Lane. He hoped to entice Lane into publishing the second Fiona romance, The Mountain Lovers. Sharp, as the lady, wrote:

Possibly you may care to make me an offer in advance for "The Mountain Lovers". It will be a book of about the same length as "Pharais", probably a little longer. The note that is dominant is the Return to Joy. The story deals with the love of two young mountaineers, Alan Gilchrist and Soreha Cameron: but there is an interweaving of dramatic and tragic episodes in the lives of those directly connected with the Mountain Lovers. For the rest, there is, in a more marked degree than in "Pharais", a constant recurrence to the intimate relationship we have, or may have, with Nature. It is here, I know, that I have "something to say": but I will not trouble you with details which, after all, in embryo, can be of no interest to anyone until duly and finally set forth.

He sent Lane the opening chapter of the new romance and promised the completed manuscript "by the end of August, or, possibly, a little earlier." He knew full well that Lane was the principal in the firm, but Fiona, unfamiliar with the London publishing scene, was not sure: "If I have been misinformed as to your being the literary representative or chief partner in your firm, I beg you to excuse the informality of my addressing myself to you direct." If Lane was unwilling to accept the book without seeing it, Fiona asks him to return the opening pages so she could find "a publisher on my own terms elsewhere." She would soon be going abroad for two or three months, so she hoped Lane would reply at his very earliest convenience. Though remote and a novice, 
Fiona could demonstrate some of Sharp's backbone in her dealings with Lane. The favorable reception of Pharais suggested there was money to be made by the Fiona deception, and Sharp set about acquiring it.

In a letter of July 7, writing as Sharp, he admonished John Lane for not responding to the early June Fiona Macleod letter offering him the "opportunity" to publish The Mountain Lovers. He was too pressed with his own work "to attend properly to other people's affairs." He had "quite enough trouble" arranging with Murray the publication of Pharais. He even had to read the proofs since "Miss [sic] Macleod when not on one of her visits to Edinburgh or Glasgow lives in a very remote spot." He had promised to see The Mountain Lovers through the press, but he could not "undertake all the preliminary 'skirmishing' as well." He is critical of both Miss Macleod and Mr. Lane: "What with an exasperatingly vagrant - if dear and lovely - cousin on the one hand, and an exasperatingly dilatory publisher on the other, the fate of a kindly intermediary who happens to be frantically busy is not a pleasant one!" The distinction between Sharp and his cousin is clearly drawn, and Lane is put on notice. Sharp further baited the hook by saying he thought he would arrange with Miss Macleod the publication of her next book, a volume of "fantasies, short stories, and poems called 'A Celtic Wreath'," with Macmillan in London and a Boston firm in America. The letter had its desired effect. Sharp was able to write again to Lane within a couple of weeks, this time as Fiona, to say she was glad Lane entertained her proposal favorably and set forth the terms she would require if Lane went on to publish the book. Whether or not Lane met all the terms, he did publish The Mountain Lovers in 1895.

At the beginning of August, Sharp went to the west of Scotland to stay with his mother and sisters who were on holiday in Kilcreggan on the Firth of Clyde. In a letter to Elizabeth he said he was learning legends and customs from "a Celtic Islesman from Iona" who gave him "a copy of an ancient MS. map of Iona with all its fields, divisions, bays, capes, isles, etc." He described a storm he seems to have enjoyed while out with the Islesman in his "two-sailed Wherry."

We flew before the squalls like a wild horse, and it was glorious with the shriek of the wind, the heave and plunge of the boat, and the washing of the water over the gunwales. Twice 'the black wind' came down upon us out of the hills, and we were nearly driven under water. He kept 
chanting and calling a wild sea-rune, about a water-demon of the isles, till I thought I saw it leaping from wave to wave after us.

He learned that rune and the rune of "the reading of the spirit" and the rune of the "Knitting of the Knots." On August 15, he returned to Edinburgh where Elizabeth joined him from London.

While there he wrote a long letter to Herbert Stone regarding the American edition of Vistas, which Stone and Kimball was publishing. The firm had initiated a small trade magazine called The Chap-Book to advertise its publications. The September 15 number would be devoted to William Sharp and Vistas. It would contain a poem by Sharp ("To E. C. Stedman"), an "appreciation" of Sharp's poetry by his friend, the Canadian poet Bliss Carman, and "The Birth of a Soul," a new "dramatic interlude," which would be included in the American edition of Vistas. He enclosed a photograph for The Chap-Book that had been taken in the spring by Frederick Hollyer. Sharp remained a very handsome man, only slightly greying at the age of thirty-nine. His frequent illnesses, physical and mental, had not yet taken their toll.

Sharp also included with his August 15 letter a dedication to $\mathrm{H}$. M. Alden for the American edition of Vistas in which he described the contents of the book as "vistas into the inner life of the human soul, psychic episodes," and acknowledged their debt to Maeterlinck, "the Belgian poet-dramatist" who had "introduced a new and vital literary form." Sharp and Alden had become good friends, and the dedication was "a tribute of affection and admiration" to one "I honor and esteem so highly." He had read one or two of the vistas to Alden, who was the editor of Harper's Magazine, during his visit to New York in the fall of 1891. While in Kilcreggan he sent Alden two articles for possible publication in Harper's. He hoped for the best because money was short. He described his condition to Alden: "What with illness \& consequent 3 or 4 months' idleness or next to idleness, my wife's long illness, \& serious financial distress, we have gone thro,' \& are still suffering from, a rather bad time lately." Alden responded positively as both appeared in Harper's in 1895: "Rome in Africa" in December and "The Hebrid Isles" in June. The editors he met during his two trips to New York had opened a new outlet for his writing and a welcome source of income. As 1894 progressed, Fiona Macleod opened another source, and that 
became a major factor in the effort to maintain the fiction of her separate identity. Were it to become generally known that Sharp was Fiona, the authenticity of the writings would be questioned. Moreover, questions might be raised about his sexual predilections as rumors circulated about Oscar Wilde that would result in his conviction for "gross indecency with men" in 1895. And such exposure, Sharp feared, would cause him to stop writing the Celtic romances thereby turning off the monetary spigot.

Shortly after Elizabeth joined her husband in Edinburgh, they left for the western isles and spent the next six weeks exploring and collecting materials. They went first to Oban, sailed to the Isle of Mull, and crossed to the west of Mull where for the first time Elizabeth experienced Iona. That small island's beauty, its ruins, and the restorations then in progress made a deep impression on her. Sharp frequently turned in the Fiona writings to the story of St. Columba who brought Christianity from Ireland to Scotland in the sixth century when he established a religious colony and built an abbey on Iona. Sharp succumbed to the romanticism Iona induces in visitors in a September response by Fiona to a letter from the Irish poet and novelist, Katharine Tynan-Hinkson.

I read your letter last night, at sunset, while I was lying on the Cruacan-Angeal, the hillock on the west where the angel appeared to St Columba.... It was a very beautiful sight to see the day wane across the ocean, and then to move slowly homeward through the gloaming, and linger awhile by the Street of the Dead near the ruined abbey of Columba. But these Isles are so dear to me that I think everyone must feel alike!

Sharp wanted to establish a close friendship between the two ladies as he hoped Fiona would become the foremost female writer in a Scottish Celtic Renaissance as Mrs. Hinkson had become for the Irish Celtic Renaissance. Iona was an ideal place to achieve that objective as it linked Scottish and Irish history. The impressions Sharp gained during this and subsequent visits provided the material for the Fiona Macleod essay "Iona" that formed part of The Divine Adventure in 1900. Fiona would become part of the lore of Iona where her books are available even today for purchase by tourists who descend on the island each year. After several more weeks exploring the islands south of Oban and hearing more stories, the Sharps returned at the end of September to their new residence in Hampstead. 
During the fall, Sharp worked on the stories and sketches that were published by Stone and Kimball in 1895 as William Sharp's The Gypsy Christ and Other Tales. In order to establish the separate identity of Fiona and maintain the welcome stream of income, he continued to publish under both names. The strain of dual authorship led to frequent illnesses, physical and mental. In October and November he wrote several William Sharp articles while also working on The Mountain Lovers, the Fiona short stories he had begun in August, and the poems that would appear in Fiona's From the Hills of Dream in 1896. In midOctober, he wrote to Theodore Watts in an attempt to repair a breach that had developed in their friendship. It included a poignant passage: "This has been a sad year, in the loss of friends: J. Addington Symonds, John M. Gray, Mrs. Augusta Webster, Roden Noel, Walter Pater. The death of the last named is a deep loss to everyone who loves what is beautiful and dignified and nobly helpful, in literature." First Symonds and then Pater befriended Sharp in the early 1880s and helped pave the way for his acceptance as an editor and writer.

In late October he informed Herbert Stone The Gypsy Christ was complete. In mid-November he told Murray Gilchrist he was busy writing articles "for Harpers, The Atlantic Monthly, Nineteenth Century, and three or four other monthlies, and weekly art-articles, etc." Of the titular story of The Gypsy Christ he wrote to Gilchrist: "The locale of this story is the moorland country where my dear friend \& comrade, Murray Gilchrist lives. I wonder what you will think of the tragic atmosphere I seem to have gained from your remote moorlands. There are descriptions and episodes which you will be able to read between the lines." It is unclear what Gilchrist might read between the lines of that story, and it is also unclear what Sharp meant by telling him he was "steadily gaining ground. The prolonged mental strain I was under being gone, the chief cause is removed." The "chief cause" may have been financial as the articles he was writing and the popularity of Fiona promised a more secure future. It may have been his removal from the environment of Phenice Croft and the psychic experiments he conducted there. It may have been that arrangements had been worked out between the two Sharps and the two Rinders that would enable Sharp and Edith to their relationship. In any event, they continued for several years to meet in remote places where Edith's presence made it 
easier for Sharp to assume the female persona and continue writing as Fiona.

In mid-December, he had Mary send a copy of Pharais to Catherine Janvier in New York with a letter saying the book had made "a deep impression here." He knew the author and asked Janvier to tell him what she thought of it. She recalled the August 1893 in which Sharp said he was working on "a strange Celtic tale called Pharais." When she recalled the letter and told Sharp he was certainly Fiona Macleod, he had no choice but to tell the truth in a letter of January 5, 1895 and extract from Catherine and her husband a pledge of secrecy. Sharp went to Scotland - St. Andrews and Edinburgh - for the three weeks preceding Christmas. Edith Rinder may have joined him for all or part of this escape from the fogs of London. After Christmas, his health was such that his doctor advised a rest near the sea so he and Elizabeth spent a week on the Isle of Wight in mid-January. 


\section{Letters: 1894}

\section{To Grant Richards, January 30, 1894}

7, Kensington Court Gardens, I W.

My dear Grant Richards, ${ }^{1}$

Can you drop in and have supper with us next Sunday evening at 7 o' clock? It will give my wife as well as myself much pleasure if you can. (Informally, of course).

We expect one or two literary friends later to coffee and cigarettes.

Next day, thank God, I return at last to the country: tho' my wife will remain here two or three weeks. You are to come there too, you know sometime soon.

Hope you are not overworking yourself. You looked fagged when I saw you the other week.

Yours cordially | William Sharp

ALS University of Texas at Austin

To Osborne, early 1894

7, Kensington Court Gardens, W.

My dear Osborne,

Thanks for your note. Could you \& Mrs. Osborne look in for coffee \& cigarettes, here, on this Sunday evening, anytime about or shortly after 8.

You could then meet Mr. \& Mrs. Rinder as well as give my wife \& myself great pleasure.

In great haste | Cordially yours | William Sharp 


\section{To John Lane, February 2, 1894}

7 Kensington Court Gardens I W | 2/2/94

Dear Mr. Lane

If you are at home and disengaged, and could look in upon us on Sunday evening (informally) any time about or after 8 o'clock, it would give my wife and myself great pleasure. We expect a friend or two to take coffee, smoke a cigarette, \& have a chat.

Yours sincerely, I William Sharp

ACS Princeton

To Richard Le Gallienne, February 9, 1894

Phenice Croft I Rudgwick I Sussex

My dear Le Gallienne

Herewith I send to you (1) "Pensieri Vani": by Fuller² I (2) "The Island" by Richard Whiteing ${ }^{3}$ । (3) The Promised photo of Holman Hunt's drawing of Rossetti at $27^{4}$ । (4) Advance copy of Vistas

Please let me have "Pensiori Vani" and "The Island" when you have read them.

I hope you will like Vistas. I will not at present tell you what I like best myself. The book is to be issued, I understand, on the 14th - i.e. nominally the 15th.

I hope that your wife is much better of her stay in the south $-\&$ that she, you, and the pretling are all flourishing.

Affectly your friend I William Sharp

9th Feby/94

ALS University of Texas at Austin 


\section{To J. Stanley Little, February 10, 1894}

7 K. Ct. Gdns. ${ }^{5}$ 1 10.2.94

My dear Boy

Thanks for your kind \& friendly letter.

I have just come here, \& find Elizabeth distinctly better on the whole.

I wish we could have met before your long departure. Will you still be in London on Saty forenoon next? I return to Rudgwick tomorrow but expect to be at the Club early on Saty.

In wild haste! I Ever yours affectly, I Will ALS Princeton

\section{To Robert Murray Gilchrist, [? February 14, 1894] ${ }^{6}$}

Rudgwick | Wedny

My dear Gilchrist,

I am glad you \& Garfitt can come. You will both be welcome.

I have to be away tomorrow, but I return on Friday.

Will you consult your own convenience as to the time of your coming - only please let me know if you decide upon the last train - tho', by the way, now that I think of it, I would rather, if suitable for you, that you come earlier than that.

I shall be coming from the south, \& shall be going to Rudgwick by the 3:25 branch-line from Horsham. We could travel together, if you like. In this case you would require to leave Victoria at 1:45 (or, if you prefer, London Bridge at 1:50): \& change at Horsham, where you would arrive about 3 o' clock.

If you would rather come later, there is a quicker train with a through division (ask in Guildford for the Cranleigh section of the train) which 
leaves Victoria at 3:55. If you get into the right carriage you need not get out at Horsham, \& would reach Rudgwick about 5:36. (This is the only train that has a through carriage).

There is another, the last, train which leaves at $4: 55$, \& gets to Rudgwick (via Horsham) about 7 o'clock.

I look forward to seeing you again, amico mio. ${ }^{7}$

Cordially yours I William Sharp

Remember me kindly to Garfitt, please.

ALS Sheffield City Archives

\section{To Edward Dowden. February 26, 1894}

Phenice Croft I Rudgwick | Sussex | 26/2/94

My dear Dowden

Pray accept the accompanying copy of my new book - a book truly of la vie intime - with my cordial greetings: \& at the same time excuse so brief a note as I have been ill \& am still debarred from much use of the pen. I hope you may find something to like in my "livre d'ame et de rive".

Ever yours sincerely | William Sharp

ALS TCD 


\section{To J. Stanley Little, [March 1, 1894]}

Thursday Night

\section{My dear Stanley}

I should have written to you before this, but I have not been well: \& yesterday had to telegraph to a friend. I am now, however, pulling round all right. Please say nothing of this to Elizabeth. Tomorrow I shall go up to town, \& come down with her on Saty, till Monday. On that week-end some friends are coming for a fortnight, of which I am glad. ${ }^{8}$

Many thanks, my dear boy, for all your friendly and generous help with Vistas. It is most good of you. I have not seen the $\mathrm{L} / \mathrm{W}^{9}$ or any save the $\mathrm{P} / \mathrm{O}^{10}$ as yet.

My dear fellow, you mistook me about your $\mathrm{P} / \mathrm{O}$ review - or, more likely, I wrote in such a way as to give you a wrong impression. I never dreamt of interfering with your admirable \& critical article. However, I must add that I have not been at all well lately - greatly overwrought - and if I have seemingly given way to any ungenerous or foolish irritation pray overlook it and forgive me.

I understand that there is to be a review in the Academy ${ }^{11}$ this Friday, if possible.

I enclose the MS. with renewed thanks.

Ever affectly Yours, | Will

ALS Princeton 


\section{To J. Stanley Little, [March 5, 1894]}

Monday Night I Rudgwick

\section{My dear Stanley}

I have recd. the gratifying notices from the West Sussex, the Belfast paper, \& the Colonies \& India. What a good fellow you are, to take so much heed for the welfare of a friend's book..$^{12}$ You are a generous chap, and I thank you most cordially. The $\mathrm{P} / \mathrm{O}^{13}$ notice came in most usefully for an early quotation. The other reviews I have seen are all respectful, \& one or two very gratifying: though most critics, public and private, seem a bit mystified by some things. Truly, as you recognise, it is a book of the heart: written con amore: \& out of the inner life. I am glad that the most unlike critics, from Wedmore ${ }^{14}$ to Le Gallienne, use the same epithets for the book, 'remarkable', 'intensely original', 'intensely individual'.

It seems to be attracting a good deal of attention $-\&$ a good deal of comment, adverse \& favourable. The $\mathrm{L} / \mathrm{P}$ edn..$^{15}$ is disposed of. 'Finis', I fancy, is the chief stumbling-block: then 'Lilith'.

There is to be a review of it in this coming Friday's Academy I understand. ${ }^{16}$

Did I tell you how unwell I have been? I have had to 'cave in' completely.

I am now nearly better - but for some time to come must write only for 2 or 3 hours daily at most: and, moreover, am not to be alone at all. Elizabeth (who is steadily gaining ground) returns to town in a couple of days: \& then Mr. and Mrs. Rinder come here on 'a working visit' to keep me company for a fortnight.

This is an unusual break-down for me. But, for one thing, I have been living the life of Imagination too fiercely of late. I think you will be surprised when you learn what I have done. I must not write more.

Your affectionate friend, I Will ALS Princeton 


\section{To [Richard Garnett], [mid-March, 1894]}

Phenice Croft I Rudgwick

My dear Poet,

I understand that at last my short review of your Poems is to appear in this week's "Academy" ${ }^{17}$ If perforce shorter than I would so much more willingly have made it, I have tried to say in it something adequate to your book's high \& rare merit, \& that may, moreover, send some new readers to it. You know how one is tied down in these matters.

The book gains upon me more and more. It is full of fine work, though, if you will permit me to say so, there seems to me some small portion of it that might have been omitted, not because that portion is not good of its kind but because it is not at your high level reach. Quite likely I am wrong: I give you simply my impression.

I have given my Review Copy of it to Mrs. Wingate Rinder, who, like myself, finds it full of a distinctive and individual charm. She is staying here just now, \& in sending you her kind regards adds that she hopes to quote (if you have no objection) your noble "Age" sonnet in her Introduction in the Poetic Interpretation of Nature.

I hope you have found something in Vistas to like.

Yours cordially | William Sharp

I find that that confounded Murray ${ }^{18}$ has sent out some of (\& possibly all) the few copies I directed him to dispatch - as if from himself. Of course, the copy you recd. is meant as from myself. I was too unwell at the time to undertake any extra work.

ALS University of Texas at Austin 


\title{
To Robert Murray Gilchrist, March 16, 1894
}

\author{
Rudgwick | 16 March
}

Your letter just reached me owing to a mischance.

It is impossible for me to write today: but I hope to be able to do so tomorrow.

W.S.

ACS Sheffield City Archives

To Robert Murray Gilchrist, March 27, 1894

Phenice Croft, I 27th March, 1894.

My dear Gilchrist,

You would have heard from me before this - but I have been too unwell. Besides, I have had extreme pressure of matters requiring every possible moment I could give. My wife's health, too, has long been troubling me: and we have just decided that (greatly to my disappointment) we must return to Hampstead to live. Personally, I regret the return to town (or half town) more than I can say: but the matter is one of paramount importance, so there is nothing else to be done. We leave at midsummer. As for me, one of my wander-fits has come upon me: the Spring-madness has got into the blood: the sight of green hedgerows and budding leaves and the blue smoke rising here and there in the woodlands has wrought some chemic furor in my brain. Before the week is out I hope to be in Normandy - and after a day or two by the sea at Dieppe, and then at beautiful and romantic Rouen, to get to the green lanes and open places, and tramp 'towards the sun'. I'll send you a line from somewhere if you care to hear.

And now, enough about myself. I have often meant to write to you in detail about your Stone-Dragon ${ }^{19} \ldots$. 
I believe in you, camerado mio, but you must take a firm grip of the reins; in a word, be the driver, not the driven. I think you ought to be able to write a really romantic romance. I hope The Labyrinth ${ }^{20}$ may be this book: if not, then it will pave the way. But I think you should see more of actual life: and not dwell so continually in an atmosphere charged with your own imaginings - the glamour through which you see life in the main at present.

Probably you are wise to spend the greater part of each year as you do: but part of the year should be spent otherwise - say in a town like London, or Paris, or in tramping through alien lands, France or Belgium, Scandinavia, or Germany or Italy, or Spain: if not, in Scotland, or Ireland, or upon our Isles, or remote counties.

It is because I believe in you that I urge you to beware of your own conventions. Take your pen and paper, a satchel, and go forth with a light heart. The gods will guide you to strange things, and strange things to you. You ought to see more, to feel more, to know more, at first hand. Be not afraid of excess. "The road of excess leads to the palace of wisdom", says Blake, and truly... Meanwhile let me send you a word of sunshine. To be alive and young and in health, is a boon so inestimable that you ought to fall on your knees among your moorland heather and thank the gods. Dejection is a demon to be ruled. We cannot always resist his tyranny, but we can always refuse to become bondagers to his usurpation. Look upon him as an Afreet ${ }^{21}$ to be exorcised with a cross of red-hot iron. He is a coward weakling, after all: take him by the tail and swing him across the moor or down the valley. Swing up into your best.

Be brave, strong, self-reliant. Then you live.

Your friend, I William Sharp

Memoir 234-35 


\section{To Edmund Clarence Stedman, March 31, $1894^{22}$}

Rudgwick: Sussex

Have been ill, or should have written long ere this. Since Xmas I have done next to nothing alas - \& even now am restricted to very little pen work. But in a week or so Richard ${ }^{23}$ will be himself again. Then the first long letter will be to you.

Meanwhile this, a copy of Vistas, which I hope you may like, \& my love and homage.

W.S.

ACS Columbia

\section{To Herbert Stuart Stone, ${ }^{24}$ April 3, 1894}

Phenice Croft | Rudgwick | Sussex | 3:April:94

My dear Sir

I hear from my friend, Mrs. Louise Chandler Moulton, that you were struck with my recent book "Vistas". I am glad that you like it, as I have heard of you not only from Mrs. Moulton but from my friend Geo. H. Ellwanger, ${ }^{25}$ and others.

As there is at present no American edition of Vistas $^{26}{ }^{26}$ will you accept the accompanying copy which I have pleasure in sending to you.

With it, I send a review of the book, from one of our leading literary periodicals (The Academy) - which may interest you.

When Mr. Ellwanger was in England some time ago, he read something of mine ("The Rape of the Sabines") which interested him extremely: \& I remember his urging me to send the series to which it belonged to you, if I wanted to publish in America. The name and address escaped my memory, however: and besides, I have been too busy. 
But it occurred to me that you might care to publish a volume of mine in America: I mean as a first publication. If you took it up you could either arrange yourselves as to an English edition, or act in concert with some English firm - though possibly you would find the other better for your own interests.

The book in question is a volume of short stories, all of them "études barbares" and, I think, unlike anything of the kind now before the literary public.

I thought of calling it, from the first story in the short series, "A King in Exile" but of course it is all the same to me if called after one of the others, say preferably "The Rape of the Sabines" or "A Village Leander" or "The Paranymph": but preferably "The Rape of the Sabines".

Here are the names of the stories: -

I. The Rape of the Sabines (Italy)

II. A King in Exile (London)

III. A Village Leander (Italy)

IV. The Paranymph (Greece)

V. The Judas Tree (Greece)

VI. The Ambitions of Zora* (Algeria)

VII. Pantherâ.* (Syria).

(*Instead of one of these, possibly a story to be called "The Gypsy Christ"). Herewith (with "Vistas") I send the only one of the series which has been printed. ${ }^{27}$ It came out under a pseudonym in the nowdefunct and much discussed "Pagan Review": and was, even among the innumerable papers that "went" for that "organ of the new movement", awarded singularly high praise.

Among those who know of its authorship there are several wellknown critics \& authors who urge me to bring it out along with the others.

Naturally, I prefer to have the book out first as an English publication - but after all it does not much matter, so long as it gets on both markets ultimately.

I take the utmost trouble with these stories, and write and rewrite till I am nearly satisfied as I am ever likely to be. Indeed, four at least of those I have named must be scrupulously rewritten before I let them leave my hands. 
From these data, therefore, do you feel inclined to undertake the book? If so, it will save time if I tell you my stipulations, which are

(1) that (unless a sum were offered which I should care to accept as a final settlement) I reserve copyright in both Countries, and publish on a royalty to be agreed upon.

(2) that on receipt of "copy" complete the sum of $£ 50$ (Fifty Pounds) to be sent to me as an advance on Royalties.

(3) that some satisfactory arrangement to come to as regards publication in England (preferably through an English firm as nominal publishers of the book here).

(4) that I receive proofs in page-form (in duplicate) - i.e. final revises for me to examine and pass.

(5) that, on publication, 12 copies be sent to me gratis.

If you care to entertain the idea of "The Rape of the Sabines" (the best name on the whole both on account of the mark the story made, and because the other conflicts with Alphonse Daudet's "Kings in Exile" $)^{28}$ will you kindly communicate with me at your earliest convenience - as I want to arrange definitely about this book within the next few weeks.

Yours faithfully | William Sharp

- Stone Esq

Messrs Stone \& Kimball

ALS NYPL, Berg Collection

To Frank Murray, [early April, 1894]

Grosvenor Club, I Bond St. W. I London I Monday 
Dear Mr. Murray

Herewith a dft note concerning "Pharais" \& "Fiona Macleod", which you can use either in extenso or adapt as you see fit.

I should like if practicable to see it in proof. If I received it on Wedny morning at Rudgwick (post early from Derby on Tuesday) I would telegraph if quite right - or anything requiring to be omitted or inserted. This wd give you time to issue with outgoing copies on Thursday, would it not?

Of course if it means further delay there is no actual need of my seeing the proof. (The printer must be careful with the Gaelic words)

I go back to Rudgwick tonight - \& tomorrow shall post to you the other promised matter ${ }^{29}$ from there, which is again my letter-address \& now uninterruptedly probably.

In haste, | Sincerely Yours, | William Sharp

ALS Huntington

\section{To Arthur Stedman, April 8, 1894}

Phenice Croft: Rudgwick: Sussex | 8/4/94

My dear Arthur

You will have recd. with my recent P/C a copy of Vistas which I sent you.

This is a P.S. to what I forgot to say then: to ask if you wd. kindly get from Brentano's, \& send to me, W. T. Price's "Technique of the Drama". ${ }^{30}$ It is priced at \$1.50 I think. I don't know if you have any small reserve of mine lying over: in any case let me know my indebtedness.

Ever yours, | W.S.

I am better, though not right yet.

ACS Columbia 


\title{
To Robert Murray Gilchrist, April 22, 1894
}

\author{
H. St. Romain | 5 Rue St. Roch | Paris | 22/4/94
}

Just received your letter. Hope to be able to send you a line soon. Here Summer is come. You would love it, if you were here - even in turbulent \& crowded Paris!

Some strange things happen in this world! Well - no more just now.

Yours in friendship | W. S.

ACS Sheffield City Archives

To J. Stanley Little, [May 4, 1894] $]^{32}$

Phenice Croft

My dear Stanley

I have asked Murray to send to you the book of a friend of mine, Miss Fiona Macleod, which he has just published or is just about to publish, as successor to my "Vistas". It is called "Pharais", 33 \& I am specially interested not only in its author but in the book as a Celtic romance - particularly as it deals with the almost unknown life of the remoter isles of the Atlantic seaboard. If you can do anything for Pharais either in the Academy or elsewhere you will not only gratify me as well as Miss Macleod but place me under a particular obligation. I am sure you will do what you can. Meanwhile I mustn't prejudice you in favour of the book - so will reserve what I think of it for another time. I arranged the publication with Murray. Today he sent me the accompanying notice which must have been from an advance unbound copy. It is from "The Newsagent" - a trade-periodical I believe. So far as I know no copies have been issued yet - except a couple to Miss Macleod and one to me. I particularly hope you will like the book. 
By the way, the book will probably be sent to you from Derby, at your Rudgwick address.

When do you think of coming here? Cotterell comes here for a few days, from Wednesday next - probably from Wedny till Monday. I have to be in town on Tuesday night next. Probably we shall meet at the Grafton on Wednesday next. I shall be there during the forenoon. I have a big commission in relation thereto.

The country is so lovely just now: blossoms, lark songs, the cuckoo, nightingales - everything suggestive of summer. Only, the summer warmth has not yet come: \& there has been a little too much rain.

Kindly let me have "The Newsagent" notice back. I send this note at once so that, if you are inclined, you may write to the $\mathrm{L} / \mathrm{W}^{34}$ or elsewhere for Pharais. Again, let me say how greatly I will be obliged if you can help the book at all.

What a long time it is since we had a walk \& chat together. I wish you were coming down this Whitsuntide. Could you perhaps this Sunday \& Monday. If you like to wire me tomorrow (Saty) to that effect: \& come down same evg.

Yours Ever, | Will

ALS University of British Columbia

\section{To Grant Allen, [mid-May, 1894]}

C/o Mrs. B. etc.

Dear Sir,

I have only now ascertained that you are in England. I was informed you were in the South of France. Some short time ago I asked Mr. Frank Murray of Derby to forward to you a copy of my just published romance Pharais. I now write to ask if you will accept it as a slight token of homage from the youngest and latest of Celtic writers to the most brilliant champion of the Celtic genius now living. I do not, however, 
send it by way of inveigling you to write about it, much as any word of yours would mean to me both in service and honour: but primarily because of your deep and vivid sympathy not only with nature but with the Celtic vision of nature - and, also, let me add, because of the many delightful hours I have enjoyed with your writings.

Believe me, I Faithfully yours, | Fiona Macleod ALS Pierpont Morgan

\section{To Arthur Stedman, May 22, 1894}

Rudgwick: 22nd May

Many thanks, my dear A., for the book just to hand: ${ }^{36}$ but you do not say if I am in your debt or not. I hope you have recd. the "Vistas" I sent to you all right.

Thanks for the suggestion abt Stone \& $\mathrm{K}:{ }^{37}$ taking the plates \& stock from W. \& Co. ${ }^{38}$ I shall write by this mail.

I am still "off the straight (of health)" but am steadily getting better. Love to you \& yours. Please note that after midsummer (25th June) my address will be as in margin.

W.S.

Rutland House, Greencroft Gardens I So. Hampstead, London.

ACS Columbia 


\section{To Herbert Stuart Stone, May 22, 1894}

Phenice Croft: | Rudgwick: | Sussex | 22nd May: '94

My dear Sir:

I thank you for your letter of the 4th inst, which I have just received on my return here from Paris.

I daresay you are right about "The Gipsy Christ" being a better title for the proposed volume than that of the story I sent you: though, on appearance in the defunct \& much discussed Pagan Review, the "Rape of the Sabines" was noted in almost every criticism in very laudatory terms.

However, as I say, I daresay you are right about "The Gipsy Christ" - particularly as the story is, if I may say so, one of the most striking in the series. I think I explained to you that in each of the stories I wished to strike the barbaric note.

Later, I hope to act on your suggestion: \& send the vol. to you complete. But it will be impossible for me to do so just now: as not only are two of the stories unfinished (or rather not reworked as yet), \& others have to be transcribed or copied - but I have urgent commissioned literary work on hand which, combined with my imminent removal from this remote Sussex house to London, will more than occupy every moment I can spare.

But before the end of July - and of course earlier, if I find it practicable, as I may - I hope to forward the book to you.

Meanwhile may I suggest that you negotiate with the liquidation of Messr. Chas. Webster \& Co. who publish[ed] my "Flower o' the Vine" volume, which was so well received in America. I understand the plates \& stock could be got for a very moderate sum. They published on a royalty. I would much like if you could take over the book. It consists of my "Sospiri di Roma" \& my "Romantic Ballads \& Poems of Phantasy" with a Memoir by Thos. A. Janvier and a portrait.

Believe me | Yours very truly | William Sharp

Herbert Stuart Stone Esq 


\title{
To Herbert Stuart Stone, May 23, 1894
}

\author{
Wednesday morning | 23rd May/ 94
}

Dear Sir,

In writing to you last night I forgot to say that from midsummer (24th June) my permanent letter-address will be I Rutland House I Greencroft Gardens I So. Hampstead I London

As you are going to issue "Vistas" in America, you may care to consult the long article upon it by Mr. George Cotterell in the Academy for March 3rd (No. 1139). I have just received a review of it today from the Yorkshire Herald, an important daily published in York, from which I extract the following closing sentence lest it should be of any use to you for quotation, though no doubt it would be better to draw upon the Public Opinion, Pall Mall Gazette, \& other better known papers, and the literary weeklies. "On this Vista ('The Passing of Lilith') Mr. Sharp has lavished a wealth of colouring and a profusion of imagery that make it singularly rich, but every one of the ten compositions in this volume has received as bold an imaginative treatment. There is in each of them the unmistakable mark of genius".

If you are reissuing Vistas will you kindly let me have a copy of the American edn.

Yours very truly | William Sharp

P.S. Please send me a catalogue of your publications \& forthcoming books.

ALS NYPL, Berg Collection 


\section{To John Lane, [early June, 1894]}

c/o Mrs. Balfour | 3. East Savile Road. I Newington | Edinburgh.

\section{Dear Sir.}

Herewith I send for your perusal (with stamped and addressed envelope for its return in due course) a Proof copy of a Celtic romance which has just been published through Mr. Frank Murray of Derby. ${ }^{39}$

You can judge so far from Pharais and the Preface whether you would care to publish a book by me. You will note that two works in preparation are announced on the page fronting the title. Darthûla is a romance of the time of Ossian, but I cannot rewrite it at present, and probably not for a year to come. It has been a dream with me for many years to write this book: but now I do not see my way to its accomplishment, unless I can obtain a commission that would justify me in devoting myself to it.

But possibly you may care to make me an offer in advance for "The Mountain Lovers". ${ }^{40}$ It will be a book of about the same length as "Pharais", probably a little longer. The note that is dominant is the Return to Joy. The story deals with the love of two young mountaineers, Alan Gilchrist and Soreha Cameron: but there is an interweaving of dramatic and tragic episodes in the lives of those directly connected with the Mountain Lovers. For the rest, there is, in a more marked degree than in "Pharais", a constant recurrence to the intimate relationship we have, or may have, with Nature.

It is here, I know, that I have "something to say": but I will not trouble you with details which, after all, in embryo, can be of no interest to anyone until duly and finally set forth.

I send you the prologue or opening chapter. The strange figure I introduce is really that shadowy half-human creature, of Scandinavian origin and Celtic adoption, Niokr (Nicker, Neckor, Nicor) the Soulless. He is, in "The Mountain Lovers", what the faun is in "Transformation", 41 a humanized link between our world and that of the brutes. The child Oona is also in the romance for a special and significant cause.

She and Niall come into it constantly, chiefly as background figures: save at the end, where once again Niall and she and the forest and the wind are alone. 
It is a book into which I have put much of what I have held most dear and intimate in life.

Possibly, you may not care to commission a book without seeing it. If this be so, and you cannot depart from your rule, I will ask you courteously to return the opening pages of "The Mountain Lovers" along with "Pharais") - so that I may endeavor to find a publisher on my own terms elsewhere. I may add that I was persuaded by a friend to publish "Pharais" through Mr. Murray, but that it does not suit me, or the end I have in view, to offer him "The Mountain Lovers".

If I have been misinformed as to your being the literary representative or chief partner in your firm, I beg you to excuse the informality of my addressing myself to you direct.

As I may be going abroad before long for two or three months, may I ask you to let me hear from you at your very earliest convenience. If favourably [disposed] to my proposal, please state what terms you can offer. (I should add that I could place the book in your hands, complete, by the end of August, or, possibly, a little earlier.

Yours very truly I Fiona Macleod

John Lane. Esq.

P.S. Pharais has been out only for two or three weeks - therefore few notices have appeared as yet. Those I have seen are in The Literary World, the Glasgow Herald, the Scotsman, Public Opinion, and The Newsagent: all most favourable, and each hails the book as something quite new and distinctive.

The Glasgow Herald: "It unfolds a beautiful and pathetic prose-poem of the Outer Isles of the West Highlands... . In the sense of Celtic character and the power and truth of the local colouring lies one great merit of the book. But the central figures of the story have a charm and a pathos rarely met with in modern fiction... . Miss Macleod has touched an extremely difficult subject with a delicate and artistic hand, and given us a powerful idyll that will linger in the memory of every sympathetic reader. The book is absolutely unconventional in treatment, and draws a fine capability in its author". 
The Scotsman: "The book makes a strong appeal to all who profess a special admiration of the Celtic genius in literature".

Public Opinion: "It is suffused with tragedy: no Greek dramatist conceived a more fateful narrative... . The book stirs one to the very depths of one's nature".

The Newsagent: "The work breaks new and almost untrodden ground, and is an acquisition to our latterday literature".

ALS University of Toronto Library

\section{To J. Stanley Little, [mid-June, 1894]}

Rudgwick | Wednesday

My dear boy,

It distresses me to learn that you are in deep trouble of some kind. I wish I could help you. Meanwhile I can give you only my deep sympathy. You know well that below all faults of manner I am genuine: and that you may trust me in all respects, as one gentleman another. Discount a lot of my "aggeravatin' ways" - they mean nothing but momentary devilry.

I have to be in town on Friday. I shall be at the Grosvenor Club in the forenoon (between $11 \& 12$ ) and again probably from 4 to 6 . Look in if you can.

It is a great pleasure to me that Pharais appeals to you so much. I felt sure it would have a certain appeal to an imaginative \& sensitive nature like yours. It will be a gratification to my friend to know how much you like it $-\&$ to read what you have generously written about it. It is a book written right out of the inner life of the author $-\&$ so ought to reach some people at least. I have just had a letter from Murray Gilchrist who had seen an early copy at Derby, where he was staying en route for his home on the moorlands. He writes of Pharais with rare enthusiasm: says "it is not a pregnant but a living book": \& wants to know all about 
its author \& what else she has done and is doing. Perhaps you will kindly send me the WR when it appears, as I don't know where to get it. ${ }^{42}$ Let me again thank you most heartily for what you have done.

We have found a tenant for Phenice Croft, from midsummer, on advantageous terms - you will be glad to hear.

Mrs. Barker died two nights ago, in great agony, dear soul. She is to be buried today, at Rudgwick.

Do not let certain things take too overwhelming a hold upon you.

Ever Yrs Affectly, I Will Very glad to hear about $\mathrm{S} / \mathrm{O}$ cheque. It was unexpected was it not - at least, so soon?

ALS Princeton

To Robert Murray Gilchrist, June 14, 1894

Rudgwick | 14/6/94

My dear Gilchrist

There is just a chance - only, as yet, a chance - that I may be able to spend 3 days or so at Eyam with you, if you can conveniently have me - from (or about) Saturday of next week, the 23rd.

Meanwhile please send me a line by return, to say if you can absolutely conveniently put me up, if I do manage to get away.

In great haste I Your friend I William Sharp ALS Sheffield City Archives 


\section{To Robert Murray Gilchrist, [June 19?, 1894]}

Rudgwick

\section{My dear Gilchrist}

Thanks. It must be Saturday, I find: also, it will, after all be most convenient for me to go [indecipherable] line. So I did have a Bradshaw, but some brute has gone off with it!

Shall send you exact word on Thursday night if I get to town Thurs: [portion of MS missing here] to see you - and the moorlands - again. ${ }^{43}$

Cordial regards to Garfitt.

Ever yours I William Sharp

ALS Sheffield City Archives

\section{To Horace Scudder, June 20, [1894] $]^{44}$}

Rutland House | Greencroft Gardens | So. Hampstead I London |

Wedny/20:June

Dear Mr. Scudder

I sent by Tuesday's mail via Southampton the Revised Proofs with note etc. ${ }^{45}$

I forgot to enclose a photo which I thought you might care to have. I got it at Biskra in the Sahara. It is of one of the White Fathers in the Desert Costume - a militant priest, certainly.

In 10 days or so I'll send you a copy of a monograph on "Fair Women" 46 (delightful subject!) I was asked some time ago to write. The publishers seem to be delighted with it - so I hope it will 'go' well. It is in great part what might be called A Fantasy of Fair Women.

As I am writing, let me suggest a novel idea for a magazine article. First, I must tell you, privately, that I am writing a novel in collaboration 
with Lady Colin Campbell: ${ }^{47}$ - broadly speaking, something in the nature of "A Fellowe and His Wife".

The widespread interest on the part of the public in the methods of literary work, and in collaboration in particular, suggests to me that an article on "Copartnery", by Lady Campbell and myself,, would be sure to attract attention. We have already discussed it, and intend to do it. We wd. treat of famous instances in Copartnery - e.g. Le Croix \& Berny ${ }^{49}$ etc. etc. etc., and of literary partnership, e.g. those of the Goncourts, ${ }^{50}$ Erckmann-Chatrian, ${ }^{51}$ Besant \& Rice, ${ }^{52}$ etc. etc.

I do not think any article has been 'a collaboration affair' before. And an article on Copartnery by two collaborators would 'take', I am sure.

If you like the idea will you communicate with me at your early convenience: \& also, if you commission it, what maximum length, and what rate of remuneration. I shd. add, it cd. not be despatched till near the end of October, or early in October at best: i.e. if not done before end of July.

This is my last day at Phenice Croft. Tomorrow we move. ${ }^{53}$ In many ways, I am very sorry to leave: but it does not at all suit my wife. Hampstead, fortunately, suits us both.

Cordial regards to you \& yours, I William Sharp

P.S. I forgot to say that Stone \& Kimball of Boston are, I understand, bringing out an American edn. of a recent book of mine, Vistas, of which I'll ask them to send you a copy: tho' at the moment I don't know when they are going to publish it.

ALS Harvard Houghton

To Elizabeth A. Sharp, [June 22(?), 1894]

\section{THE WHITE PEACE}

It lies not on the sunlit hill

Nor in the sunlit gleam

Nor ever in any falling wave

Nor ever in running stream- 
But sometimes in the soul of man

Slow moving through his pain

The moonlight of a perfect peace

Floods heart and brain. ${ }^{54}$

...Before I left I took up a handful of grassy turf, and kissed it three times, and then threw it to the four quarters - so that the Beauty of the Earth might be seen by me wherever I went and that no beauty I had seen or known there should be forgotten. Then I kissed the chestnut tree on the side lawn where I have seen and heard so much: from the springing of the dream flowers, to the surge of the sea in Pharais.

Memoir 236

To W. A. Dalt [late June, 1894]

C/o Mrs. B. Etc.

Dear Sir

Mr. Frank Murray has forwarded your letter to me. It gratifies me to learn that you care for Pharais as you do. It is so much a book of vision and dream that I doubt if its appeal can be a wide one.

The other two books are only "in preparation". There is certainly no chance of "Darthula" 55 being ready this year: and "The Mountain Lovers" will not be out till the late autumn at earliest.

Thanking you for your kind interest,

Yours faithfully | Fiona Macleod ALS NLS 


\section{To [John Lane], [June 22, 1894]}

C/o Mrs. Balfour | 3. East Savile Road I Newington I Edinburgh

My dear Sir

I wrote to you at the address you gave me, but have had no reply. I hope my letter has not miscarried.

I am probably going to Derbyshire tomorrow: but my letter address as above holds good. ${ }^{56}$

You asked me in your note who told me to apply to you with "The Mountain Lovers". It was my cousin, Mr. William Sharp. I hear that some paper says he wrote "Pharais": and I sent a disclaimer at once to the "Westminster Gazette" (where Mr. Grant Allen wrote about my book so favourably), tho' I do not know if it has appeared.

Please let me hear from you soon, as I want to make a definite arrangement.

Yours faithfully, I Fiona Macleod

ALS University of Toronto Library

\section{To James Mavor, July 2, 1894}

Rutland House | Greencroft Gardens | So. Hampstead | 2/7/94

My dear Mavor

Your undated card has just been forwarded to me at our new home (a flat in So. Hampshire) which please register as my permanent address.

I would be very glad to see you again but you give no address! So, perforce I can only throw myself upon your mother's courtesy. Please remember me to her kindly.

If this reach you in time, I hope to be at the Grosvenor Club (Bond St). at 4:15 on Friday of this week. 
William Sharp

We have just moved in: still in great confusion.

ACS University of Toronto Library

\section{To Robert Murray Gilchrist, [early July, 1894]}

Rutland House I Greencroft Gardens I So. Hampstead

My dear Gilchrist

Thank your stars you are not in town this hot weather. I long for the country - for the Eyam moors - for the northern seas.

I look back with singular pleasure to my stay with you - and thank you again for all your hospitality and friendly heed. ${ }^{57}$

The moors of your neighborhood have the large and abiding charm of the sea. I envy you \& Garfitt enjoying them this glorious weather.

I am not feeling quite up to the mark. For one thing I am still in deep anxiety - and shall be glad when the next week or two are over.

Then there is still such an infinite amount to do in the house before we are 'to rights', \& I can't settle to any work - and that alone is a most nervously perturbing thing particularly as both long overdue commissioned work \& imaginative work lying ready for birth in my brain are ever with me.

Once more, this is full season and many scores of acquaintances (not only Londoners but others, \& Americans, \& and foreigners) who make maddening claims upon one's time. Finally, there is this most trying heat.

I hope you will soon be able to revise "The Labyrinth" - \& having done so get on with a "today" romance at your highest tidal rise - the Spring tide of both brain and soul in one irresistible flood.

I hope you will keep me in affectionate remembrance - \& you may be sure that now \& always I am 
I will not forget the book for Hancock - but cannot attend to it for some days to come.

My cordial greetings to Garfitt.

ALS Sheffield City Archives

\section{To Edmund Clarence Stedman, July 3, 1894}

Rutland House | Greencroft Gardens | So. Hampstead | 3/7/94

My dear Stedman

I have received Miss Coleman's note about J. C. Woods. I hasten to answer it at once - in the midst of dire confusion, as we have just 'moved' from Sussex to our new home as above.

I have long been wishing to write to you - but my prolonged illness, \& then accumulated work \& correspondence, absence, \& 'moving' - to say nothing of engagements \& the great heat - have stood in the way. But you know my deep and sincere affection, \& and will forgive.

I know little of Mr. Woods. I have never met him, \& know no one who has his acquaintance. In the later editions of my Sonnets of This Century I printed two striking sonnets of his, which are admired by many people. So far as I know, he has published no volumes since his Child of the People. It seems to me the quickest \& and most satisfactory way is to send you his volume, \& a letter from him enclosed, so that you can judge for yourself. When you have done with it, perhaps Miss Coleman will kindly send it back to me.

Do let me be of any assistance to you I can. Any service I can give will be rendered lovingly \& freely. I am within easy enough reach of the Museum, \& the London Library. (I must except August \& September when I shall be in Scotland). Send me a P/C when you want anything.

You shd look into the new men in the new Canterbury vol. - Nature Poems, Edited by Mrs. Wingate Rinder. I have sent a P/C today to Scott to ask them to send you a copy. 
Love to you and yours | Ever affectionately | William Sharp Poor Roden Noel's death very sudden \& tragic. You will have heard of it. $^{58}$

ALS Princeton

\section{To John Lane, [July] 7, [1894] $]^{59}$}

Rutland House | Greencroft Gardens | So. Hampstead I Saturday 7th

My dear Lane

I take the opportunity of sending you my new house-address to say that I wish you would answer my cousin, Miss M. F. [sic] Macleod, about the book she has proposed to you.

I am too pressed with my own work \& direfully accumulated correspondence - on the head of all this 'moving' to attend properly to other people's affairs. I had quite enough trouble over Pharais (which I arranged for with Murray, \& of which I revised the proofs for Miss Macleod, who when not on one of her visits to Edinburgh or Glasgow lives in a very remote spot).

By my advice she wrote to you about her new book. I heard a good deal of it, in its first draft, last autumn, \& like it in some respects better than Pharais. She had either one or two letters from you - and thereafter has had no reply to the letter she wrote to you about terms.

Meanwhile I had written to her that if her negotiations with you fell through I know of two firms who would take up her book on advantageous terms - so if you do not wish to publish it I wish you would kindly say so at once.

She sends me today a delightful letter from George Meredith, full of high praise. I had a note from him myself about her book, in which after sending my cousin his greetings he says "Pharais is most admirable: pure Celtic salt. The book is one to fly sure to the mark". 
When such good judges as George Meredith, Grant Allen, and Theodore Watts, are enthusiastic I think a young writer like Miss Macleod may well be elated.

I have promised to see "The Mountain Lovers" through the press - but I really can't undertake all the preliminary 'skirmishing' as well. What with an exasperatingly vagrant - if dear and lovely - cousin on the one hand, and an exasperatingly dilatory publisher on the other, the fate of a kindly intermediary who happens to be frantically busy is not a pleasant one!

Miss Macleod tells me she hopes to have the new MS. completed $\&$ revised by the end of August. She wanted to send you for your next "Yellow Book" a remarkable short story called "The Sin-Eater": but I have advised her to hold this over in the meantime.

In the winter she wants to issue a small volume of fantasies, short stories, and poems, called "A Celtic Wreath": and I have advised her to keep "The Sin-Eater" for that book - or whatever it is to be called.

I think I will arrange for her with Macmillan here, \& with a Boston firm in America for "A Celtic Wreath" - but have been too busy as yet to do anything.

Meanwhile please say 'Yea' or 'nay' about The Mountain Lovers.

You can write about it either to me, or Miss Macleod. Her letter address in general is I C/o Mrs. Balfour I 3 East Savile Road I Newington | Edinburgh | but for this coming week she will be with my sister | C/o Miss Mary B. Sharp I 9 Up. Coltbridge Terrace I Murrayfield I Edinburgh

In haste

Yours sincerely | William Sharp

Please if possible send me a line for my receipt today, as I want to write to Edinburgh tomorrow.

I called yesterday on receipt of Miss Macleod's letter - but you were out: so I have had to write this long note after all — damn! 


\section{To Horace Scudder, July 7, 1894}

Rutland House | Greencroft Gardens | So. Hampstead | 7:July:94

Dear Mr. Scudder

Your note of the 29th $u l t o^{60}$ about proofs to hand today. I am sorry that the proofs I revised could not reach you in time - for every reason. The article $^{61}$ was written - and, later, revised, amidst severe pain and illness: and so I am afraid was not so satisfactory as it ought to be. However, I hope there is nothing seriously faulty as it now stands. I regret much the trouble it must have involved you in.

I am now much better - in fact almost quite well again: though the moving from Sussex to London was a fatiguing \& embarrassing [sic] business, particularly in this great heat.

You will receive either with this post or a few days later a copy of a monograph on the subject of "Fair Women" in painting and poetry which Mr. Philip Gilbert Hamerton ${ }^{62}$ asked me to write for him and his firm. Please accept it with my friendliest regard and remembrances to you \& yours.

I am now living close to our friend Frederick Shields, who, you will be glad to hear, is now more fortunate in his worldly affairs.

Hoping you and yours are well,

Yours cordially | William Sharp

Horace Scudder Esq

ALS Harvard Houghton 


\section{To Mrs. Henry Mills Alden, July 9, 1894}

Rutland House | Greencroft Gardens | So. Hampstead I London |

$9 / 7 / 94$

Dear Mrs. Alden,

I send you a hurried line from our new home (into which we have just entered) to say that I hope you are well, \& enjoying the Summertime \& to tell you that I have directed the publishers to send to you a copy of a monograph of mine on the delightful subject of "Fair Women" which Mr. Hamerton commissioned me to write. It is to be published today, I believe. I hope it may at once interest \& amuse you. My cordial \& affectionate greetings to you and your husband, \& kind remembrances to your daughters. I have been seriously unwell, but am now better. I hope H.M. is not overworking. Tell him I have a book of mine (mislaid for the moment) to send him soon. ${ }^{63}$

Ever sincerely yours, I dear Mrs. Alden, I William Sharp ACS University of Delaware Library

\section{To Mrs. Allhusen, ${ }^{64}$ July 9, 1894}

Rutland House | Greencroft Gardens | So. Hampstead I Monday

Dear Mrs. Allhusen

I am so sorry at the cause of your having to postpone my visit. I wired to you at once, stating that Friday will suit me quite as well: but pray do not hesitate to say if you would rather I did not come then. If you do not feel "up to the mark" on Thursday, or Friday morning, telegraph to me.

If I cannot come myself will you let a part of me come \& chat with you - in other words will you accept the copy of "Fair Women", a 
monograph by me which is to be published today I believe, \& which I have asked Messrs. Seeley \& Co. to send to you.

It may interest \& amuse you. When restricted to your sofa, \& unable to occupy yourself more satisfactorily than with the "thoughts on women" of

Yours most sincerely | William Sharp

ALS Bodleian Library

John Lane, [mid-July, 1894]

c/o Mrs. Balfour I 3 East Savile Road I Newington

Dear Sir,

On my return here from a flying visit to St. Andrews I found your letter awaiting me - along with four most gratifying reviews of "Pharais" (among them that of Mr. Grant Allen, which I read with keen pleasure), and three most kind and generous letters of interest and encouragement from authors and critics of high repute.

I thank you for yours. I am glad that you entertain my proposal favourably. I believe there is always a risk in books of this kind, of a relatively limited appeal: so I am willing to put myself in your hands as to the amount of royalty etc.; feeling confident that I am secure in so doing, if you will agree to the following stipulations on my part - i.e. I will leave the matter of ultimate remuneration with you, if

(1) You will pay me the sum of $£ 25$ on my delivery to you of the M.S. complete of "The Mountain Lovers".

(2) That my copyright be acknowledged by the payment of a royalty, to be fixed by you, upon all copies sold, either in this or in any other edition, after the advance of $£ 25$ has been worked off: the Royalty to be on an ascending scale, according to sales. (American edition under a royalty also: or else to be left to me to arrange for myself). 
(3) That my copyright becomes absolute after, say, your disposal of a second limited edition.

(4) That the book be published before Christmastide.

I hope this will be agreeable to you, as I would rather publish "The Mountain Lovers" through you than through any other firm.

I can promise you the MS. by the end of August at latest.

My movements are very uncertain at present. It is just possible I may be in London before the end of July, but it is much more likely I shall be in my remote island in the far north-west. Meanwhile, I am visiting friends in Edinburgh and the neighborhood: but at all times I prefer my correspondence to go to the house of my relative, Mrs. Balfour, where I am staying for a few days longer.

Thanking you for your prompt courtesy

Believe me I Yours very truly | Fiona Macleod

ALS Princeton

To Stone E Kimball, July 30, $1894^{65}$

Rutland House, | Greencroft Gardens, | So. Hampstead. I London | $30 / 7 / 94$

Dear Sirs

Herewith I enclose P/O for $\$ 1$ (4 1/2?) - for which please send me "The Chap-Book" from the beginning, \& for a year thereafter.

Yours truly | William Sharp Just off to Western Highlands for 2 months - but above address is my permanent address.

ALS NYPL, Berg Collection 


\section{To Henry Mills Alden, [early August, 1894] ${ }^{66}$}

[Kilcreggan, Argyll]

.. deal on hand to finish or revise within the next month - chiefly a vol. of the "Fellow \& His Wife" kind, a commissioned vol. of short stories, and a long article for The Nineteenth Century.

\section{Thursday}

Today's post has brought me a letter from a friend who encloses a cutting about Pharais which he saw a few days ago in some paper, though he does not give its name. As you may like to see it, I send it on to you. If you chance to remember, you might return it to me when you write next: but it doesn't matter if you forget.

The Steamer, which is very irregular, may come up the Sound at any moment now: so I must be ready with my letters. I enclose, separately, two letters [sic] for your editorial consideration. For every reason, financial and otherwise, I hope the Editorial Autocrat may be agreeable! What with illness \& consequent 3 or 4 months' idleness or next to idleness, my wife's long illness, \& serious financial distress, we have gone thro', \& are still suffering from, a rather bad time lately. But we are hopeful, \& look to the best.

My love to you and Mrs. Alden. I do hope her trouble is not now affecting her. Some months ago I felt as though she were very ill, but I hope I was mistaken. And how goes the successor to "The Following Love" (as I always think of your book)?

Ever affectionately Your Friend I William Sharp P.S. If you receive, and answer, the enclosed any time before the 15th Sept please direct to me at I 9 Upper Coltbridge Terrace I Murrayfield I Edinburgh I Otherwise to my London address. 


\section{To Elizabeth A. Sharp, [early August, 1894]}

Kilcreggan, Argyll

... I told you about Whistlefield? how it, and all the moorland parts about here just now, is simply a boggy sop, to say nothing of the railway works. I hope we'll have fine weather in Iona: it will be lovely there if we go...

I have made friends here with a Celtic Islesman from Iona who is settled here: and have learned some more legends and customs etc. from him - also got a copy of an ancient MS. map of Iona with all its fields, divisions, bays, capes, isles, etc. He says my pronunciation of Gaelic is not only surprisingly good, but is distinctively that of the Isles.

I have learned the rune also of the reading of the spirit. The 'influence' itself seems to me purely hypnotic. I was out with this man $\mathrm{McC}$ on Saty. night last in a gale, in a small two-sailed wherry. We flew before the squalls like a wild horse, and it was glorious with the shriek of the wind, the heave and plunge of the boat, and the washing of the water over the gunwales. Twice 'the black wind' came down upon us out of the hills, and we were nearly driven under water. He kept chanting and calling a wild sea-rune, about a water-demon of the isles, till I thought I saw it leaping from wave to wave after us. Strangely, he is a different man the moment others are present. He won't speak a word of Gaelic, nor be 'Celtic' in any way, nor even give the word as to what will be doing in the isles at this time or any other. This, however, I have noticed often: and all I have ever learned has been in intimacy and privily and more or less casually. On Sunday and Monday he avoided me, and would scarce speak: having given himself away and shown his Celtic side - a thing now more than ever foreign to the Celtic nature, which has become passionately reticent. But a few words in Gaelic, and a private talk, put all right again. Last night I got the rune of the 'Knitting of the Knots' and some information about the Dalt and the Cho-Alt about which I was not clear. He has seen the Light of the Dead, and his mother saw (before her marriage, and before she even saw the man himself) her husband crossing a dark stream followed by his four unborn children, and two in his arms who afterwards she bore still-born. 


\title{
To Herbert Stuart Stone, August 15, 1894
}

\author{
Rutland House, 5 Greencroft Gardens, So. Hampstead | London |
}

15:August:94

\section{Dear Mr. Stone}

Tho' I write as from my home address I send this note to you from Edinburgh, where I chanced to come yesterday from the West Highlands - whither I return in a few days. Fortunately, your kind letter, forwarded from London, arrived almost simultaneously. Had it been a few days later, I fear that I could not have met your wishes on any point - as I will have nothing with me in the Isles save what is needful.

(1) First, then, here is my portrait ${ }^{67}$ - a recent photograph taken this Spring. By a lucky chance, my sister here had duplicates, and has let me have the enclosed. It is considered a good likeness, and characteristic. Certainly, for reproduction, I prefer it to any other (that in The Idler two or three months ago was after the etching made of me in Rome in 1891, but not very good). You are cordially welcome to retain it, after you have reproduced it for The Chap-Book. It is taken of me sitting forward. Some people prefer its companion: but I have not one at hand, or at all now indeed.

(2) I have no unpublished poem of mine with me, and my memory for my own verses is worse than poor, being almost non-existent. To be more exact, I have one set of quatrains, but they were intended for an American periodical. However, I daresay something else will do as well, and so I send these "Lines to E. C. Stedman" ${ }^{68}$ If I can recall them, I will also add the unpublished dedicatory poem (in Italian) to my Sospiri di Roma. ${ }^{69}$ (I have written to a friend who has them, \& will send them on by following mail)

(3) Though I send it, I am a little less easy in my mind about handing over the new 'Vista' which I enclose for the American Edn. of Vistas; for it was to go this Autumn to a leading English monthly. True, it, "The Whisperer", was not settled upon, but only a 'Vista' to be chosen from 
the two or three unpublished pieces of this kind, written since Vistas was completed: but as it happens, I have no other at hand, and (apart from having my hands full with commissioned work) do not feel in the mood to write anything of the kind just now. By sending you 'The Whisperer', I may lose my other commission: for I do not return to London till the end of September. However, I'll chance it. Please let it be the last of the 'Vistas' in the new edition: unless you think this inadvisable, in which case let it immediately precede "The Lute Player": though I prefer that it should come last.

(4) This, and the (Dedicatory) Introduction to Alden ${ }^{70}$ of Harper's Mag: which I send herewith at your request, will enable you to have a copyright edition.

(5) I will think over your suggestion as to "Flower o" the Vine".

So far so good. What about the reprinting of Vistas? Can I see pageproofs before the book is struck off? I do not insist on this, but I hope it is feasible. There are a few minor alterations I would like to make - a word here and there, particularly in "The Père Hilarion" \& "The Northern Night": and, naturally, I would like to see proofs of the hitherto unpublished "The Whisperer" and the Introduction. I suppose my friend Bliss Carman (whose words about me in The Chap-Book I shall read with full appreciation) or some equally capable reader will overlook my text scrupulously if proofs cannot be sent to me.

In the circumstances, seeing that I benefit in no monetary way at all by the American edn., that I have given up a valuable evening (under great pressure of other work) to the Introduction you want, and that I give you "The Whisperer" instead of sending it where it would be well paid for, I do not think you will consider me unduly exigent when I stipulate that, on publication, you send me gratuitously Fifty (50) copies of Vistas. Please let me have a line from you as to this.

Somewhere among my papers here I think is a copy of The Chap-Book containing "A Northern Night". ${ }^{71}$ If so, it has my corrigenda, for there were some misprints in it. I'll send it, if I have it. (No: I find I have not got it with me. Do not print from The Chap-Book copy. If I can get a copy of Vistas soon I'll send one or two textual alterations).

Finally, as to "The Gipsy Christ" I must ask you to wait a little longer. Frankly, I cannot afford to do uncommissioned work at present: and 
I have important things to finish and revise. If you think you will be able to issue "The Gipsy Christ" (and other stories, as indicated to you) before Christmas, ${ }^{72}$ I will make a point of letting you have MS. complete by the end of October, or beginning of November at latest: as early as practicable. But please let me know about this by return.

It will save time if I give you my letter-address till the close (about 27th or so) of September: - I 9 Upper Coltbridge Terrace I Murrayfield | Edinburgh I After that date my home address as usual.

Pray give my most cordial greetings to Bliss Carman (who, I hope, received the article I wrote upon his book in The Academy $)^{73}$ and believe me, my dear Sir,

Most Sincerely Yours, I William Sharp

P.S. I forgot to say that of course the present dedicatory page to 'Elspeth H. Barzia ${ }^{74}$ must now come out, as replaced by the Introduction herewith.

ALS Huntington

To John Lane, August 16, 1894

9 Up. Coltbridge Terrace | Murrayfield | Edinburgh | 16:8:94

My dear Lane,

On reaching the above address yesterday from the West Highlands (whither I return - to Iona first - at the end of next week) I found your letter, forwarded from London - after some delay there on account of your having addressed it to 'Crescent Gardens' instead of to Greencroft Gardens.

If it had reached me a few days earlier I could have given you a direct answer from Miss Macleod - as she was with my people on Loch Goil. However, I am able to answer your question for her. She has not been well, and all writing was stopped for some weeks: but she is now better again. From what she told me, and from what I saw of "The Mountain 
Lovers" (nearly done, but unrevised), I know it will now be impossible for her to let you have the book before the middle of September - at earliest. I will write at once (I will see her end of next week) \& urge that she should undertake to let you have it by mid-September, if possible.

I think you will like it even better than Pharais. (Mr. Traill, by the way, followed up his notice of Pharais in the Graphic ${ }^{75}$ by a letter of high praise \& encouragement to Miss Macleod).

As for my own work - it is, alack, impossible that I can hand over the book until the end or near the end of October. ${ }^{76}$ All my MS \& material is in my London abode (now shut up) \& I will not be there again till the end of September $-\&$ there is still a good deal of final work to do to the book.

Hoping you are not overworking, \& that affairs continue to go well with you,

Cordially Yours I William Sharp

ALS University of Toronto

\section{To Herbert Stuart Stone, August 19, 1894}

9 Up. Coltbridge Terrace I Murrayfield, Midlothian I Scotland I $19 / 8 / 94$

Dear Mr. Stone,

Herewith the promised unpublished short autograph Italian poem, ${ }^{77}$ if you care for it for reproduction, tho' not to replace that to E. C. Stedman.

I have been advising my cousin, Miss Fiona Macleod (Author of the much talked of Celtic romance Pharais) - whose town-address near Edinburgh I am now staying at, with her and her people - to write to you about something she has on hand. At present, she does not appear inclined to do so - but I think she will do so later.

In haste, | Sincerely yours, I William Sharp 


\section{To [John Lane], [late August, 1894]}

Isle of Iona | Inner Hebrides.

My dear Sir

Mr. William Sharp wrote to me from Edinburgh with your message. I am to meet him and his wife shortly in Oban, and go to Perthshire with them: but meanwhile I must answer your message.

I have not been well, and all writing or headwork of any kind has been out of the question for more than a month past. I am now better; but, wandering (or rather sailing about) from island to island, as where I am at present, is not conducive to regular work: and besides, I am busy collecting from the Gaelic-speaking islesmen many notes, legends, and so forth, for a volume which I think of calling "A Celtic Wreath".

In the circumstances, I cannot promise you "The Mountain Lovers" till, say, the 15th of October. I trust this will not inconvenience you. Kindly note my change of address. I want all my correspondence addressed to me at my cousin's (Miss Mary Sharp Macleod) - but simply IMiss Fiona Macleod | 9. Upper Coltbridge | Murrayfield. | Midlothian. I I may have to go abroad in the late autumn, but if so $\mathrm{Mr}$. William Sharp will see to my proofs etc. for me.

Yours very truly | F.M. 


\section{To Stone \& Kimball, September 18, 1894}

The Postal order is made to "Stone\& Kimball" from William Sharp at my London address as below. Rutland House: Greencroft Gardens: So. Hampstead I London I $18 / 9 / 94$

\section{Dear Sirs}

Kindly send me by return 3 dozen (36) copies of "The Chap-Book" for September 15th (No. 9) for which I enclose Postal Remittance for 7s/6 (36 copies@5e)

Yours faithfully | William Sharp P.S. (I have not received the two preceding numbers, due on my subscription).

Location of MS uncertain

\section{To Katharine Tynan Hinkson, ${ }^{78}$ September, 1894}

Isle of Iona I September, 1894

Dear Mrs. Hinkson,

I am, in summer and autumn, so much of a wanderer through the Isles and Western Highlands that letters sometimes are long in reaching me. But your kind note (and enclosure) has duly followed me from Edinburgh to Loch Goil in eastern Argyll and thence deviously here. It will be a great pleasure to me to read what you have to say in the Illus. London News or elsewhere, and I thank you.

I wish you could be here. Familiar with your poetry as I am, I know how you would rejoice not only in the Iona that is the holy Icolmkill but also in the Iona that is Ithona, the ancient Celtic isle of the Waves, and the Iona that is I-na-Dhruidhheachna, the Isle of the Druids. There is a beauty 
here that no other place has, so unique is it. Of course it does not appeal to all. The Sound of Iona divides the island from the wild Ross of Mull, by no more than a mile of water; and it is on this eastern side that the village and the ancient Cathedral and ruined Nunnery, etc., stand. Here it is as peaceful as on the West side it is wild and grand. I read your letter last night, at sunset, while I was lying on the Cruac-an-Angeal, the hillock on the west where the angel appeared to St Columba. To the north lay the dim features of the Outer Hebrides: to the west an unbroken wilderness of waves till they fell against Labrador: to the south, though invisible, the coastline of Ireland. There was no sound save the deep hollow voice of the sea, and a strange reverberation in a hollow cave underground. It was a very beautiful sight to see the day wane across the ocean, and then to move slowly homeward through the gloaming, and linger awhile by the Street of the Dead near the ruined abbey of Columba. But these Isles are so dear to me that I think everyone must feel alike!

I add my permanent letter-address, and remain

Sincerely yours I Fiona Macleod

P.S. I enclose a gilliflower from close to St. Columba's tomb.

ALS NLS

\section{To Edmund Clarence Stedman, September 28, 1894}

Rutland House. I Greencroft Gardens. I So. Hampstead.

\section{Dear Poet and Friend}

It is my hope that this will reach you on your birthday, but whether before or after you will know that on the 8th my thoughts are with you. I will send some white-winged messengers to carry loving greetings and all manner of good wishes for your happiness, health, and general weal: so if you hear a flutter of wings about no. 137 on the 8th at dawn you will know the cause! I know no truer poet and no younger man: - in other words, you are one of the true heirs-male to Apollo. But one of my 
wishes, a humble one in a sense, is as important as any other: may you have leisure - happy leisure, serene leisure. We want more of you at your best, both as poet and prosaist. And, then, too may the bright Spirit of Youth, whom, being the poet you are, you love, send many radiant smiles upon you yet.

We are just back from Scotland. Among my recent acquisitions are some Chap-Books. One, you have doubtless seen, for it contains my Birthday Lines to your dear self. By a happy coincidence I found the original pencil draft when I was in Scotland $-\&$ so was able to send them to Stone \& Kimball. I was desirous of their appearance nearer your Birthday - but of course could not stipulate. My friend, George Cotterell (editor of theYorkshire Herald) with whom I stopped a night in York on my way South said a pleasing thing to me when he remarked that his appreciation of the verses was enhanced by his admiration of the dedicatee. He was one of the influential people to whom I gave your beautiful "The Nature of Poetry". By the way, he is a poet you should represent. His Poems: Old and New is to be published by D. Nutt at end of October. I suggested to him to send you a copy, but he informed me that he had already noted that a copy was to be sent to you. Your "Bohemia" is one of his most treasured favourites.

Talking of Poems, I would like the "Coves of Crail" lyric quoted by Carman in aforesaid Chap-Book to be in your anthology. You will have received ere this my letter in reply to your editorial communication.

I hope the Stone \& Kimball edn. of Vistas will attract some favourable attention. I have added a 'Vista' ("The Whisperer") and a dedicatory introduction to H. M. Alden in which you will find an allusion to yourself which I hope will please you. I have seen no proofs - \& I believe the book is to be pubd. immediately!

I am busy with work of many kinds - but all imaginative work of mine now undergoes a far more exigent control than hitherto, both in process and in revision. When I write again I will tell you something of my doings.

If you will send me an advance copy (i.e. say a week or so, for me to prepare an article) of your anthology, in due course, I'll do my best for it here.

My love to Mrs. Stedman: also to Arthur: \& kind remembrances to your fair \& diligent Secretary. My wife has just come in, \& sends her love too. She longs to see you both. And now Addio! - no, à rivedèrla! 
Ever Your Friend I William Sharp

ALS Pennsylvania State University

\section{To Horace Scudder, October 3, 1894}

Rutland House | Greencroft Gardens | So. Hampstead | 3/Oct/94

My dear Horace Scudder

I find that the mail goes in half an hour - so I must write only a brief note, \& to the point.

Herewith I send the promised article, which I have entitled "Some Personal Reminiscences of Walter Pater". ${ }^{79}$ In accordance with your wish, I have made it more 'reminiscent' than 'critical'. I hope it will please you, and all the many American \& English admirers of Pater who will read it.

I found that most of Pater's letters to me were of too personal an interest (generally about my own writings, or doings, or mere private details about his own life and occupations) - but I have quoted one or two that have also interest of another kind.

It is, perhaps, longer than you wanted. If so, you can cut out the printed cols on page 22a. This printed matter is my own, of course: but appeared in a Scottish daily newspaper so far back as 1889 - a paper now defunct ("The Scottish Leader") - and so to all intents is "fresh matter".

I suppose you saw a copy of the Chap-Book (Stone and Kimball) of Sept. 15th. I am assured that the separate photo there given of myself is a good one.

Excuse, meanwhile, this hurried note, and believe me always (with best regards to you and yours)

Yours most cordially | William Sharp 


\section{To Theodore Watts [-Dunton], October 11, 1894}

Rutland House, I Greencroft Gardens, I So. Hampstead. | 11/Oct./94

\section{My dear Watts}

If my memory is not at fault in reminding me that tomorrow is your birthday - will you let me send you my friendliest greeting \& good wishes: in both of which my wife joins cordially. May your new year be a very happy one - with health, and general weal, and blithe content.

In the old days, before your feelings towards me changed somewhat, you were not ill-pleased that (more Scoticè, looking upon the remembrance of a friend's birthday as a scrupulous, almost a religious observance) I used to drop you a line on each 12th Oct. Nor, I hope, will you be ill-pleased now: for the remembrance \& the good wish arise from an affectionate regard, and, I need hardly say, high esteem.

No doubt I have given you cause of irritation: as, in turn, I was resentful because of things repeated to me, said of me by you. Right or wrong, I don't think anything is to be gained now by going over the ground of complaint either may have, or may imagine against the other. For myself, I bear you nothing but good will: and hope you entertain something of the same feeling towards myself. It is a pity that between friends of material difference in age, differences and divergences are so apt to occur: but I like to believe that in most instances these are not fundamental, but only, as it were, the surface currents.

It is with singular pleasure I see, from an advt., that you are about to issue a volume of poetry. That it will be welcomed goes without saying: that it will be a success, I hope, and believe. It is, I suppose, to be issued soon?

This has been a sad year, in the loss of friends: J. Addington Symonds, John M. Gray, Mrs. Augusta Webster, Roden Noel, Walter Pater. The death of the last named is a deep loss to every one who loves what is beautiful and dignified and nobly helpful, in literature.

My wife and I have been in Scotland for two months - but are now back. I am much preoccupied with literary work of all kinds - my commissioned work alone much exceeding my present ability to cope with it in anything like the due time. 
Caine seems to be winning golden opinions and golden sovereigns and golden dollars by The Manxman. ${ }^{80}$

After October I shall be more settled in London - \& thus, perhaps, we may meet sometimes, here or there. Next week, I hope, or soon after, I intend to run down to see Geo. Meredith. He is very busy.

Again with all friendly greeting and good wishes, ever, my dear Watts,

Cordially yours, I William Sharp

P.S. I enclose a copy of some verses I wrote recently: - as a birthday card!

It may interest you to know that a new American edn. of my Vistas, with a Preface and some added matter, is to come out immediately (or, by this time is out) through that enterprising young firm, Stone \& Kimball, the Matthews \& Lane of the U.S.A.

Typescript from ALS at Brotherton Library, University of Leeds

\section{To Herbert Stuart Stone, [October] 20, [1894]}

Saty 20th.

Dear Mr. Stone

The promised volume of short stories "The Gypsy Christ" is now complete - and will be sent to you, with a letter, by next mail: i.e. on Wedny. the 24th., if none earlier.

I suppose Vistas is out before this?

In great haste, Sincerely Yrs, | William Sharp

ACS Huntington 


\title{
To Robert Murray Gilchrist, November 12, 1894
}

\author{
15, Greencroft Gardens, South Hampstead I 12/11.94
}

\section{My dear Gilchrist}

I thank you sincerely for your friendly remembrance: and for the pleasure you have given me by your delicately wrought and in every sense charming book. ${ }^{81}$ "Hercules" is a delightful story, for old or young. It is a vein you might work further with advantage: particularly by a combination of actuality and phantasy.

Since I last wrote to you I have been 'down' a good deal - but am now steadily gaining ground. The prolonged mental strain I was under being gone, the chief cause is removed. I have had trouble with my eyes, though: and must use glasses now when I write or read.

I have been and am very busy: more busy than I can tell. My immediate work - besides articles for Harpers, the Atlantic Monthly, the Nineteenth Century, and three or four other monthlies, and weekly art-articles etc. etc. - has been the completion of a volume called "The Merchant of Dreams" (fantasies and other imaginative pieces), ${ }^{82}$ and of the volume of short tales of a striking \& dramatic nature, collectively entitled (from the first \& largest story) "The Gypsy Christ". ${ }^{83}$

The locale of this story is the moorland country where my dear friend \& comrade, Murray Gilchrist, lives. I wonder what you will think of the tragic atmosphere I seem to have gained from your remote moorlands. There are descriptions and episodes which you will be able to read between the lines.

Is there any chance of your coming south this winter? I am going to Scotland for 2 or 3 weeks from the 1st of December: so don't come between 1st and Xmas! Before I go, I must fulfill my promise about your gamekeeper friend - but I am ever so overwrought by things to remember \& exigent daily matters to attend to.

My most cordial regards to your Mother \& sisters - and to Garfitt - \& my true affection to yourself.

Write to me about your work and yourself. Your letters are as scanty as a maid's baths. How goes the Labyrinth? Are you happy, \& have you the furor for work? 
Your Friend I William Sharp

ALS Sheffield City Archives

\section{To Horace Scudder, November 17, 1894}

Rutland House | Greencroft Gardens | So. Hampstead | 17/11/94

My dear Horace Scudder

This is just a hurried line to catch the mail - to tell you (1) with what interest I read your admirable article on "Marius the Epicurean", scholarly, thoughtful, and justly appreciative: and (2) what pleasure I have had in your very welcome "Childhood in Literature and Art". The book is one that will afford keen pleasure to many, and open many avenues of memory and perspectives of speculation.

It is not unlikely, in two or three months hence, that I shall be asked to write a monograph on The Children of Art, as a companion to my Fair Women: à propos of an important exhibition of "The Child in Painting" which is to be opened here next Spring. If so, I'll have occasion both to draw upon and to draw special attention to your delightful book.

No time for more just now.

Cordially yours | William Sharp

ALS Harvard Houghton

To J. Stanley Little, [December 1, 1894] ${ }^{84}$

En route for Scotland I (address - Mary's)

My dear Stanley 
My sincerest good wishes for you \& your happiness. I am sure you are right. May good luck be with you in all respects, dear old Chap.

I am afraid there is little chance at the Realm. Still, there may be. I think you might do well to write at once to C. N. Williamson, late (or present) ed. of Black and White who is going to bring out a new illustrated paper called The Hour. There is also their new magazine The Windsor (Ward Lock[?]). Perhaps The Hour would put you on its staff. I have no influence there though - \& can do nothing, in fact I only know of the project indirectly. Apropos of the African articles - I wd if I were you write to C. P. Scott, (or the present ed). of the Manchester Guardian, to the Liverpool Mercury, the Leeds Mercury, \& the Sheffield Times, \& Newcastle Chronicle (both daily \& weekly). Business matters etc. take me to Edinburgh for 2 or 3 weeks.

If possible, I think you wd. be wise to be married soon. But you know your own affairs. I am sorry about your father.

Again, with affectionate good wishes \& hopes for you dear Stanley - \& my respectful greetings to Miss Labluche.

Yours ever | Will

ALS Princeton

\title{
To Catherine Ann Janvier, mid-December 1894
}

\author{
South Hampstead I December 1894
}

... Herewith I am sending to you, through my sister in Edinburgh with whom I left it the other day, a copy of a book which has made a deep impression here. I know the author: and wish you would tell me just what you think of "Pharais" .85 ...

William Sharp

See note. 


\section{To Herbert S. Stone, December 22, [1894]}

Rutland House | 15 Greencroft Gardens | South Hampstead: London I
Saturday 22nd Decr.

Dear Mr. Stone,

Your letter of the 10th and the two copies of Vistas came to hand this morning.

Let me congratulate you (and myself!) on the format of the initial issue of your Green Tree Library. The originality, distinctiveness, and charm of this format should win wide appreciation. The type is excellent, the paper good, and the titular sections of the cover at once explicit and simple. The only thing I don't care for is the asterisk on the back \& front cover. The volume, externally, is like an April lime-leaf. Altogether, the book seems to me to reflect great credit upon your firm.

I hope the series will be a great success, and that Vistas will 'lead off' in a way to satisfy you. There is certainly an eager public for books on the lines of the Green Tree Library, if that public can be reached.

I am afraid the other copies cannot reach me before Christmas, but perhaps they will come in good time for New Year's Day. As all save 3 or 4 private-circle copies will go to men of note, friends \& confrères, Vistas should help to win further recognition here for your firm.

Herewith I enclose my cheque for fifteen shillings (the G. T. vols. are published at 5/- nett, are they not?) for which please send me the Maeterlinck volume and the Verlaine volume as soon as published, and also (by return if practicable) Hamlin Garland's vol. of essays "Crumbling Idols".

I have received the Chap-Book for Dec. 1st - but none of the others for which I subscribed in advance last summer (as detailed in a previous letter). Can I not have these missing parts, as I was a subscriber, namely, all after August 1st, except Septr. 15th till Nov. 15th inclusive.

I am sorry not to hear from you about "The Gypsy Christ". Some time ago I had an offer from an American firm anxious to publish some stories by me - but had to answer that I would let them know before Christmas, though I doubted being able to send anything this year. So now, as time is up, I must write \& decline definitely. 
I forget if I wrote to you that, when I sent the G.C. MS. I was uncertain as to the length of book you wanted. Let me add now that I do not say 'take it or leave it as it stands': for if you find it overlong for your purposes, I would suggest that the volume consist of, say, seven instead of ten stories: in which case the three to be set aside might be "The Burden of a Song", "Primavera di Capri", and any other you choose except the first three (The G. Christ, Madge o' the Pool, and The Rape of the Sabines).

If, however, you think of the book for the G. T. series - which, I take it, you do not purpose - I suppose that 3, or at most 4, stories would suffice: in which case I would suggest simply The Gipsy Christ, Madge o' the Pool and The Rape of the Sabines under the collective title "The G.C". ("The King" could be included or not as you prefer). For sake of dramatic contrast, a vol. consisting only of three such diverse pieces as "The G.C"., "Madge", and "The Rape of the Sabines" might be most effective. What do you think?

Having glanced again at Vistas, it has occurred to me that you might care to have for it a strange 'Drama of Destiny', called "The Tower of Silence". The same acute critic who wrote the long étude on Vistas from which you quote, said of it (in MS) that "it is the most remarkable and significant production the co-called Décadent or Fin-de-Siécle school": and added, that it involves such a tremendous dramatic situation, "that some may at first fail to see the vital spiritual possibilities suggested in the last act".

This may or may not be. I can send you no more than the first act: all that is typed, \& that not finally revised. It will show you the method: an extended use of that in Vistas, more actual, and with a poetic background of nature. (A strange problem of reversion in heredity, and a stranger psychological development, are the motive factors).

I had intended to publish this myself, semi-privately. I did this before, with my Sospiri di Roma, which I had printed for me in Italy, and 'published' through two paras. in the Athenaeum \& Academy, and with some privately issued order-slips. Without other advt. the whole edn. (a limited one of course) was taken up. Recently, six copies were sent to me from a relative to whom I had entrusted them: of which I was glad, for the book is now very rare, and almost impossible to get. It has an added interest (besides being the first volume in English of nothing 
but unrhymed irregular verse) in the fact that it was set up by Italian printers in a small printing-place in the ancient Temple of Hercules at Tivoli in the Sabine Hills, \& was printed under my supervision. I recollect, some months ago, intending to send you one of these copies: but don't think I did so. I now send it, for your acceptance, the last I shall ever have to give away: and please take with it my cordial greetings for Christmastide and 1895.

Please let me hear in due course what you think of this proposal: and kindly do not fail to return the type-copy herewith. I shall expect to hear from you at an early date about The Gypsy Christ, either as a 3-story volume or otherwise.

In haste, | Cordially Yours, | William Sharp

ALS Huntington

\section{To Herbert Stuart Stone, December 31, 1894}

Rutland House | Greencroft Gardens | South Hampstead | 31:Dec':94

Dear Mr. Stone,

Thanks for your letter of the 17th, to hand this morning.

I am glad you like the "Gypsy Christ" volume so well, and that you are willing to take it for publication.

A letter from me, à propos, will have crossed yours. I am still inclined to the belief that the volume would be more artistic in point of unity if it were shortened by one or two stories. For my own liking, I should say, let it comprise (1) The Gypsy Christ (2) Madge o' the Pool (3) The Rape of the Sabines

If this is too small a volume, then, say, "Fröken Bergliot" and either "The Coward" or "The Burden of Song".

There is an Italian story of mine, which I think is forceful, which Mr. Bliss Carman will remember - as it appeared in The New York Independent while he was editorially occupied there. I regret that I have 
no copy of "The Second Shadow" as it is called: \& cannot remember when it appeared ${ }^{86}$ I wrote it in Rome in either January or February of 1891 - and I think it appeared either in the Spring or Summer of the same year. I take it to be a much stronger story than "A Venetian Idyl" or "Primavera di Capri" - though too somber perhaps. If Mr. Carman happens to remember it, and should think sufficiently well of it to advise its inclusion, it could doubtless be obtained from the Independent office. If it be included, I should prefer the volume to be composed as follows: -

1. The Gypsy Christ | 2. Madge o' the Pool | 3. Fröken Bergliot | 4. The Second Shadow | 5. A Venetian Idyl | 6. The Coward I 7. The Rape of the Sabines

If it is not included, the best arrangement, I think, would be

1. The Gypsy Christ | 2. Madge o' the Pool | 3. The Coward | 4. A Venetian Idyl | 5. Fröken Bergliot | 6. The Rape of the Sabines

I think now, that there is rather too pronounced affinity between "A Venetian Idyl" and "Primavera di Capri" - and of the two I fancy the first-named more. In any case, perhaps both "The Burden of Song" and "The King" might be omitted. I am quite willing, however, to be guided by your wishers in these matters. Finally, if you prefer it, I would not object to this arrangement: ${ }^{87}$

I. Madge o' the Pool I II. The Rape of the Sabines I III. The Coward I IV. A Venetian Idyl | V. Fröken Bergliot | VI. The Gypsy Christ

I am glad you think so highly of "Madge o' the Pool". Your opinion as to its force and artistic unity concur with that of one of our ablest critics, who did me the honour (when he read it in M.S). of calling it a masterpiece.

As to what you say about "The Gypsy Christ", I daresay you are right: indeed, I am sure of it, and realized this some time ago. The plot is novel and remarkable, as you are good enough to imply in a generous incidental remark: and the story should be more concentrated and thus actualized. I thank you for your friendly criticism and suggestions. I will, therefore, give the story that kind of "revision for strength" which is practically a re-writing. Unfortunately, the only copy in existence is that in your possession. Both to avoid loss in transmission and to save 
time (a few months ago an important article was lost thus) are you willing to go to the expense of having the G.C. story set up in type, in "galley" say, and let me revise it in that form?

If not, I suggest that (if you are ready to go on with the book at once) you send me all or part of the remainder of the vol. in print for my revision - and at the same time let me have my copy of "The G. C.".: which I could rework, and send back with the proofs of the rest of the vol. (The G. C. could be type-written, and revised by me - so that no proofs of it need be sent). This arrangement would save time, and be advisable in every way. Of course, I prefer, if practicable, that the G. C. come to me in print. Otherwise, kindly see that it be registered.

As to terms, I am uncertain as to what you propose to do in the matter of English publication. Naturally, I would like the book to be issued here as well as in America. I am quite willing to leave the whole control in your hands. I will accept whatever royalty you suggest, as I am confident in your good intent and good faith: and know that you will make the best arrangement compatible with our joint interests. The last two or three books of mine published on the royalty system have been on a $15 \%$ royalty: though Osgood Mcllvain and Co. allowed a $20 \%$ royalty on "A Fellow and His Wife".

Against this frank acceptance of whatever royalty you can honestly allow, however, I set my request that, on publication, the sum of $£ 50$ (Fifty Pounds) be advanced to me on account of royalties.

Finally, may I stipulate that, on publication, 25 copies be sent to me gratis.

In the circumstances, I do not think you will find these suggestions unduly exigent?

The looked-for copies of Vistas are not yet to hand. I hope to have them in time for New Year's Day. The two early copies you so kindly sent to me have been much admired by those who have seen them. The title page, too, is very taking. I thank you again for all your heed and courtesy in this republication of Vistas.

Cordially yours, with sincerest good wishes for 1895 .

William Sharp

When the time comes near, do not forget to let me know beforehand about your visit to London. 
P.S. I am pleased that you like my article on Walter Pater in the Atlantic Monthly. ${ }^{88}$

I may add that I am today revising the proof of a long \& rather important article for (I believe) either the March or April issue of Harper's Monthly. ${ }^{89}$

And that reminds me: if you have not already done so, will you kindly send a copy of Vistas to the dedicatee, Mr. H. M. Alden, Editorial Offices, Harper's Magazine?

W.S.

ALS NYPL, Berg Collection 


\section{Notes}

\section{Chapter 1}

1 Most of what is known about William Sharp's early life is contained in William Sharp (Fiona Macleod) A Memoir, compiled by his wife Elizabeth A. Sharp (New York: Duffield \& Co., 1910), https://archive.org/details/williamsharpfion00shariala

2 The first two letters, the earliest that survive and both only fragments, were written to Elizabeth A. Sharp (hereafter E. A. S.) after Sharp returned from Australia and before he settled in London in the spring of 1878. The ellipses indicate deletions by E. A. S. in printing the letters in the Memoir.

3 This early poem has not survived.

4 John Elder was the brother of Adelaide Elder, one of E. A. S.'s closest friends. Their father, Alexander Elder, found an opening for Sharp as a clerk in the London office of the City of Melbourne Bank in Spring 1878, thus enabling him to move to London (Memoir 27). Sharp met Adelaide Elder upon his return from Australia in the summer of 1877. Since John Elder was then in New Zealand for his health, he and Sharp first met in the summer of 1878 and soon became close friends. "John was a graduate of Cambridge, a thinker and man of fine tastes, and his new friend (Sharp) found a great stimulus in the keen mind of the older man" (Memoir 29). Adelaide gave William Sharp a book of Rossetti's poems, and they led to Sharp's first visit to Rossetti in Cheyne Walk in September 1879. Although this fragment of a letter is dated October 23, 1880 in the Memoir (31), it was written prior to the publication of Sharp's sonnet entitled "Religion" in the Examiner in September, 1879.

5 Probably "On Reverence," which, according to Elizabeth Sharp's bibliography, was published in The Secular Review on May 17, 1879. There was no Sectarian Review. 
6 Ernest Belford Bax (1854-1926) was a barrister, author, musician, and philosopher Along with William Morris, he started the Socialist League. As the first to mount a sustained public campaign soliciting compassion for men and boys while denouncing gynocentric chivalry, he is considered the father of the "men's rights movement." As young Londoners, he and Sharp took long walks together in the late 1870s, but they drifted apart in the early eighties. For Bax's view of Sharp, see his Reminiscences and Reflections of a Mid and Late Victorian (New York: Thomas Seltzer, 1920). His principal works include; Jean-Paul Marat (1878), Kant's Prolegomena, etc., with Biography and Introduction (1882), Religion of Socialism (1886), The Roots of Reality (1907).

7 "Religion" appeared in The Examiner: A Sunday Paper on Politics, Literature, and Fine Arts (September, 1879).

8 Sharp's first meeting with Rossetti probably occurred in September 1879 for, as this letter indicates, he was corresponding with him in familiar terms in January, 1880. In 1899 Sharp thanked Adelaide Elder for introducing him to Rossetti's poetry "two and twenty years ago" (Memoir 35). Miscalculating, E. A. S. set the date of Sharp's first acquaintance with Rossetti's work as fall 1879 and of his first meeting with Rossetti as September 1, 1881 (Memoir 36). The 1899 letter to Adelaide Elder and Sharp's early letters to Rossetti support fall 1877 as the date of Sharp's discovery of Rossetti's poetry and fall 1879 as the date of Sharp's appearance at Rossetti's door in Cheyne Walk to present him with the letter of introduction from Sir Noel Paton, an event that changed the course of Sharp's life by providing entrance to the literary and artistic life of London. For more information about Paton, see note to July 25, 1881 letter to Rossetti.

9 "Dance" was not published and has not survived. Rossetti's "The Card Dealer" (1849) appeared in Poems (1870).

10 Alice Mona Henryson Caird (1854-1932), a novelist, critic, social reformer, girlhood friend of E. A. S., was married to James Alexander Henryson Caird of Casseneary, Creeton, Kirkeudbrichtsh on December 19, 1877. They had one son, Major A. H. Caird. Her publications include: Whom Nature Leadeth (1883), The Wings of Azrael (1889), Beyond the Pale: An Appeal on Behalf of the Victims of Vivisection (1897, The Morality of Marriage, and Other Essays on the Status and Destiny of Woman (1897). She was widely known, and by many disdained, for advocating changes in the marriage laws to grant women greater equality. E. A. S. dated this letter February 23, 1880, but it was written soon after Sharp's memorable private dinner with Rossetti on Friday, January 30. The invitation to that dinner prevented Sharp from continuing a letter to Mona Caird, and this letter describes the evening with Rossetti.

11 The completed "House of Life" was published in Ballads and Sonnets (London: Ellis and White, 1881). Sharp said the sonnet sequence "is, in the main, a record 
of individual emotions suggested by the presence and absence of embodied love ... - a House, not of Life, but of Love... . [They] are the record of what a poet-soul has felt, and we see that love meant with him a dream of happiness while present, a dream of regret and a sense of frustration when passed away, but not that it inspired him to action or made his ideals more impersonal, or gave his aspirations wings to escape from the desolate haunts of sorrow and despondency and vague half-real hopes. Therefore, it is not so much that Love was the soul of his genius, as that his genius lived and had its being in the shadow of Love" (Dante Gabriel Rossetti: A Record and a Study, 408-10).

12 Philip Bourke Marston (1850-1887) was a close friend of Rossetti and Sharp. After Marston's early death, Sharp edited and wrote introductory Memoirs to Marston's For a Song's Sake and Other Stories (London: Walter Scott, 1887) and Song Tide (London: Walter Scott, 1888). See note to Sharp's April 22, 1880 letter to Swinburne.

13 Watts-Dunton (1832-1914), a poet, critic, and novelist, was a close friend of Rossetti. Theodore Watts (1832-1914) became Theodore Watts-Dunton in 1898. In 1879, he and Swinburne took up residence at The Pines, Putney, where they lived until Swinburne's death in 1909. Watts-Dunton's publications include: The Coming of Love (1898), Aylwin (1899), Rossetti and Charles Wells (1908), The Poetry of the Renascence of Wonder (1916), Vesprie Towers (1916), and Old Familiar Faces (1916).

14 Moncure D. Conway's "William Kingdon Clifford" was tenth in the "Leaders of Modern Thought" series in Modern Thought, II (Feb. 1, 1880), 293-99. Clifford (1845-1879) was a mathematician, philosopher, and expert in classical and literary studies. His interest in Christian scholastic dogma was dispelled by his study of Darwin and Herbert Spencer. He was a follower of Berkeley and Hume and radically opposed the Hegelians. His posthumously published works include: Lectures and Essays, ed. F. Pollock and L. Stephen (1879), Common Sense of the Exact Sciences, ed. \& partly written by Karl Pearson (1885), and several mathematical studies.

15 Dr. James Martineau (1805-1900) was a Unitarian minister, a respected theologian, and a Professor of Philosophy in Manchester New College, the seminary in which he had been educated. He was the younger brother of the essayist and novelist, Harriet Martineau. His principal works are: Religion as Affected by Modern Materialism (1874), Modern Materialism (1876), Hours of Thought on Sacred Things (last series, 1876; 2nd series, 1879), Ideal Substitutes for God Considered (1879).

16 This letter precedes an undated letter to Rossetti in the Memoir (40-41) which responds to Rossetti's criticism of Sharp's sonnets.

17 Philip Bourke Marston. 
18 Thomas Henry Hall Caine (1853-1931), who later became a popular novelist, was a close companion of Rossetti in 1881 and 1882. Rossetti had suggested Sharp submit one or two sonnets for publication in Caine's Sonnets of Three Centuries (1882). Although Rossetti found fault in Sharp's first effort, two sonnets eventually passed muster and were included in the volume. Caine's Recollections of Dante Gabriel Rossetti and Sharp's Dante Gabriel Rossetti: A Record and a Study appeared in late 1882 following Rossetti's death in April. Richard Le Gallienne (Romantic Nineties, 1951, p. 20) recalled Oscar Wilde saying: "Whenever a great man dies, Hall Caine and William Sharp go in with the undertakers." To be sure, both writers were anxious to capitalize on their close relationship with Rossetti, but both books contain useful information.

19 William Michael Rossetti (1829-1919) was Dante Gabriel Rossetti's brother. His wife, Emma Lucy (1843-1894), was the daughter of the painter Ford Madox Brown, and she was also a painter. William Michael was educated at King's College School, London, and entered the Excise Office in 1845. His publications include Lives of Famous Poets (1878), The Life of Keats (1887), Dante G. Rossetti as Designer and Writer (1895), Memoir of Dante G. Rossetti (1895), and Some Reminiscences (1906). He edited works by the pre-Raphaelites, the romantic poets, and Chaucer's Troylus and Criseyde.

20 This letter was transcribed and published in The Sexual Tensions of William Sharp by Terry L. Meyers (New York: Peter Lang, 1996). Meyers states that arrangements were made for Phillip Marston to take Sharp to meet Swinburne at his home in Putney, probably in June, 1880. Meyers also reproduces a previously unpublished poem that accompanied this letter: "To Mr. A. C. Swinburne." The manuscript poem is housed in the Ransom Humanities Research Center at the University of Texas at Austin where its authorship was previously unknown. This transcription of the letters is from a photocopy of the manuscript.

21 Philip Bourke Marston (1850-1887), the son of John Westland Marston, a wellknown man of letters, was blinded at the age of three by the administration of belladonna in an effort to cure scarlet fever. He began writing poetry at an early age and published his first volume (Song-Tide and Other Poems, 1871) when he was twenty-one; his second (All in All: Poems and Sonnets, 1875) four years later; and a third (Wind Voices) in 1883. By then he had become a favored member of the circle of young men around Dante Gabriel Rossetti who introduced him to William Sharp in 1880. The two men became fast friends. Following Marston's death Sharp published a selection of his poems with an introductory Memoir in his Canterbury Poets Series (Song-Tide: Poems and Lyrics of Love's Joy and Sorrow) and a collection of his short stories containing the same Memoir (For a Song's Sake and Other Stories). Both were issued by the Walter Scott firm in 1888.

22 Robert Edward Francillon (1851-1919), a novelist and journalist, married Rosamund Barnett, the daughter of the musical composer, John Barnett. Between 
1872 and 1894 he was on the staff of the Globe. He belonged to a Pre-Raphaelite group which met at the home of Dr. Westland Marston, a dramatist and father of Philip B. Marston, where Rossetti and Swinburne, as well as Richard Garnett, William Morris, and Arthur O'Shaughnessy were often entertained. His works include: Earl's Dene (1870), Olympia (1874), A Dog and His Shadow (1876), Queen Cophetua (1880), Gods and Heroes, or The Kingdom of Jupiter (1892), Jack Doyle's Daughter (1894), and Mid-Victorian Memories (1914).

23 Julian Hawthorne (1846-1934), son of Nathaniel Hawthorne, was a novelist, journalist, historical writer, and biographer. He lived in London between 1874 and 1881. His publications include: Saxon Studies (1874), Gath (1875), Archibald Malmaison (1878), Sebastian Strome (1879), Dust (1882), Fortune's Fool (1883), Biography of Nathaniel Hawthorne (1885), History of Oregon (1888), and Shapes That Pass: Memories and Meditations (1928).

24 David Christie Murray (1847-1907), a novelist and journalist, wrote some thirty loosely plotted novels, many drawn from his experience as a reporter. His works include: A Life's Atonement (1879), Joseph's Coat (1881), Val Strange (1882), By the Gate of the Sea (1883), Rainbow Gold (1885), Aunt Rachel (1886), Autobiography: A Novelist's Notebook (1887), and Recollections (1908).

25 Published in The Human Inheritance; The New Hope; Motherhood (1882), this poem was the subject of an exchange of correspondence between Sharp and Violet Paget ("Vernon Lee") on the appropriate subject matter of poetry.

26 Rossetti's written response to these two poems - "Motherhood" and "The Dead Bridegroom" - is contained in a letter from Rossetti to Sharp dated January 1881 (Memoir 44).

27 Eugene Jacob Lee-Hamilton (1845-1907) was a poet-novelist and the halfbrother of Violet Paget who published under the pseudonym "Vernon Lee." In 1873 he was incapacitated by a nervous disease that kept him bed-ridden and completely dependent on his mother and half-sister until 1893-94 when, following his mother's death, he made an unexpected and complete recovery. He traveled to America in 1898 where he married the novelist, Annie E. Holdsworth, and returned with her to his mother's villa outside Florence. In later life, Eugene Lee-Hamilton and Violet Paget were almost entirely estranged. His works include Poems and Transcripts (1878); Gods, Saints, and Men (1880); The New Medusa (1882); Apollo and Marsyas (1884); Imaginary Sonnets (1888); The Fountain of Youth (1891); Sonnets of the Wingless Hours (1894) The Lord of the Dark Red Star (1903); Dramatic Sonnets, Poems, and Ballads, edited by William Sharp for the Canterbury Poets series in 1903; The Romance of the Fountain (1905); and Mimma Bella (1908).

28 Probably Gods, Saints, and Men. 
29 Frederic James Shields (1833-1911), a painter and illustrator influenced by the Pre-Raphaelites, was a friend of Rossetti, Ford Madox Brown, John Ruskin, William Holman Hunt, and Edward Burne-Jones. His most important work, begun in 1889 and finished a few months before his death, was a pictorial decoration of the walls in the Chapel of the Ascension on Bayswater Road in London.

30 Shortly after Sharp settled in London in the late spring of 1878, Alexander Elder, the father of Adelaide and John Elder, found him a position in the City of Melbourne Bank where he was bound as a clerk for three years. His banking career ended in August, 1891, when it became clear to him and his employers that he was unsuited to the work (Memoir 27, 53-54).

31 Auguste Comte (1789-1857) attempted to transform philosophy into religion by substituting the worship of humanity for the worship of God. His principal works include Cours de philosophie positive (1830-42), Catéchisme positiviste (1852), Système de politique positive (1851-54), Calendrier positiviste (1849).

32 Published in Sharp's first volume of poems, The Human Inheritance; The New Hope; Motherhood (1882).

33 Brackets as written. The ballad was probably "The Son of Allen" which Sharp included in Romantic Ballads and Poems of Phantasy (London: Walter Scott, 1889).

34 Arthur O'Shaughnessy (1844-1881) was the author of four volumes of poetry. A brother-in-law of Philip Bourke Marston, he was employed in the British Museum's Department of History. He died on Sunday, January 30, 1881, which dates this letter Thursday, February 3.

35 Probably "The Son of Allan."

36 Philip Bourke Marston.

37 Olivia Narney [Singleton] Garnett (d. 1903) was the wife of Richard Garnett (1835-1906), author and Keeper of Printed Books at the British Museum where he worked from 1851-1899. Her husband, considered "the ideal librarian," published extensively in both verse and prose and is best known for Relics of Shelley (1862) and The Twilight of the Gods (1903). She was also the mother of Edward Garnett (1868-1937). A well-known author and dramatist, he published A Censured Play: The Breaking Point (1907); Turgenef (1917); and Papa's War (1919). He was married to Constance (Black) Garnett (1862-1946), the highly-regarded translator of major Russian novelists.

38 This letter was sent to Elizabeth Sharp while she was in Italy during the early months of 1881 . 
39 Joaquin Miller (1841-1913) was the pseudonym of Cincinnatus Hiner Miller, "The Byron of Oregon." A horse thief, Portland lawyer, pony-express messenger, and newspaper editor, Miller fascinated the English who considered him "the frontier poet." His works include: Specimens (1868), Joaquin, et al. (1860), Pacific Poems (1890), Songs of the Sierra (1877), a Mormon play called The Danites of the Sierras (1877), an autobiographical Life Amongst the Modocs: Unwritten History (1873), and Memorie and Rime (1884).

40 Published in The Human Inheritance; The New Hope; Motherhood (1882). Eugene Lee-Hamilton and Violet Paget saw the poem in manuscript. Elizabeth probably showed it to them while she was in Italy.

41 This poem was never published (see Memoir 45).

42 Eugene Lee-Hamilton's first book of poems, Poems and Transcripts (1878).

43 Published in The Human Inheritance; The New Hope; Motherhood (1882).

44 Violet Paget (1856-1937), daughter of Matilda [Adams] Lee-Hamilton Paget and Henry Ferguson Paget and half-sister of Eugene Lee-Hamilton, was a prolific writer of fiction and works of history, philosophy, and sociology. She chose the pseudonym Vernon Lee, at the start of her career. Vernon reflects her desire to be taken seriously as a "male" writer, and "Lee" the influence of her older half-brother on her intellectual development. It was widely known in literary circles that Vernon Lee was Violet Paget. Her major works include Studies of the Eighteenth Century in Italy (1880), a pioneering work that brought to light the spontaneous national movement that developed in the music and drama of eighteenth-century Italy; Euphorion (1884); its sequel; Renaissance Fancies and Studies (1895); Genius Loci (1899); and The Spirit of Rome (1906).

45 Agnes Mary Frances Robinson (1857-1944) was the daughter of George Robinson, a London banker who was well known in the literary world of the eighties and nineties. He frequently entertained such luminaries as Henry James, Oscar Wilde, George Moore, and Thomas Hardy. Agnes began writing poetry at an early age and published her first book of poetry, A Handfull of Honeysuckle, in 1878 when she was twenty-one. That was followed by The Crowned Hippolytus of Euripides: With New Poems in 1881. In 1882 she married James Darmesteter, a well-known French orientalist, and moved to France. Her third book of poetry, An Italian Garden: A Book of Songs, appeared in 1886. After Darmesteter died in 1894, she married Emile Duclaux, Director of the Pasteur Institute. Her Collected Poems were published in 1901, and she continued writing poetry, much of it influenced by the horrors of both World Wars, until her death in 1944.

46 "Hand and Soul," a prose tale by D. G. Rossetti published in The Germ in January 1849, tells the story of a painting called "Figura Mistica di Chiaro 
dell'Erma." The tale describes a young man obsessed with art who imitates others to win the fame he so passionately desires. The allegory is centered on the figure of a lady who appears in a vision and instructs the young artist to paint her, saying "I am an image, Chiaro, of thine own soul within thee."

47 See March 10,1881 letter to Eugene Lee-Hamilton.

48 The reference is to a controversy over an article, "The Fleshly School of Poetry," which Robert Buchanan published under the pseudonym Thomas Maitland in the Contemporary Review (October, 1871). Exploiting a Victorian taboo on open sexuality, Buchanan launched a prudish attack on the "fleshly" treatment of physical passion in Pre-Raphaelite art, denouncing Swinburne and Rossetti for their degenerative influence on public morals. In a pamphlet called "Under the Microscope," Swinburne defended himself with an outburst of pornographic invective expressed in pseudo-Biblical language. Rossetti, in "The Stealthy School of Criticism" (Athenaeum, Dec., 1871), answered Buchanan's charge of "fleshliness": In my poetry "All the passionate and just delights of the body are declared - somewhat figuratively it is true, but unmistakable - to be as naught if not ennobled by the concurrence of the soul at all times."

49 Published in 1874.

50 Harry Buxton Forman (1842-1917), known for his painstaking editions of Keats and Shelley, worked for forty-seven years in the postal service and was an early advocate of a post office library, later becoming its secretary. He knew and supported Rossetti, Morris, and Meredith. His early works include: Our Living Poets (1871), the book Sharp refers to here, and Elizabeth Barrett Browning and Her Scarcer Books (1876). In 1887, in association with a London commodity broker and book collector Thomas James Wise, Forman began publishing what turned out many years later to be forged early editions of British writers. For more information, see https://en.wikipedia.org/wiki/Harry_Buxton_Forman

51 Emerson's “The Poet."

52 There is no record of its publication.

53 Studies of the Eighteenth Century in Italy (1880).

54 Sharp did not make his first trip to Italy until 1883 (Memoir 78-79). E. A. S. was in Italy in early 1881 (Memoir 44-49).

55 This edition has not been identified.

56 Christina G. Rossetti's Poems (1872). Christina Georgina Rossetti (1830-1894) was the sister of Dante Gabriel Rossetti. Her works include Goblin Market and Other Poems (1862) and A Pageant (1881). She also wrote nursery rhymes like 
Sing Song (1872), and children's tales such as Speaking Likenesses (1874). For the last 20 years of her life she produced mostly works with religious themes. These very popular books include Called to Be Saints (1881) and The Face of the Deep: A Devotional Commentary on the Apocalypse (1892).

57 Light of Asia was not written by Edward Bulwer-Lytton but by Sir Edwin Arnold. The full title is The Light of Asia; or, The Great Renunciation Mahabhinishkramana, Being the Life and Teaching of Gautama ... as told in verse by an Indian Buddhist (1879). In it, Arnold attempted "by the medium of an imaginary Buddhist votary to depict the life and character and indicate the philosophy of that noble hero and reformer, Prince Gautama of India, founder of Buddhism." It appeared in 1879 and was an immediate success, going through numerous editions in England and America. Arnold's other volumes of poetry: Indian Song of Songs (1875), Pearls of the Faith (1883), With Sadi in the Garden (1888), Potiphar's Wife (1892), Adzuma, or The Japanese Wife (1893), and Indian Poetry (1904), https:// en.wikipedia.org/wiki/Edwin_Arnold

58 Sharp seems to be saying that the Tauchnitz edition [Poems, ed. with a Memoir of the author by Franz Huffer (Leipzig: Bernhard Tauchnitz, 1873)] is cheaper than the paper edition.

59 Not published.

60 "The Wandering Jew" was not published.

61 Vernon Lee, "A Dialogue on Contemporary Morality," Contemporary Review, XXXVIV (1881), 682-707. As Sharp proceeds to indicate, Cyril, in this dialogue, was intended to be Sharp, while Baldwin speaks for Violet Paget.

62 "Spring Wind" was published in Sharp's first collection of poetry, The Human Inheritance; The New Hope; Motherhood (1882) and in T. Hall Caine's Sonnets of Three Centuries (1882). "A Poet's Greeting to a Brother Poet" was probably not published.

63 Sir Joseph Noel Paton (1821-1901) was a Scottish artist, illustrator and sculptor. He was also a poet who had a deep interest in, and knowledge of, Scottish folklore and Celtic legends. Most of his life was spent in Scotland, but he studied briefly at the Royal Academy in London in 1843 where he met John Everett Millais who asked him to join the Pre-Raphaelite Brotherhood. The invitation to be an official member of the Brotherhood was turned down by Paton although he painted in the Pre-Raphaelite style. Noel Paton's parents were damask designers and weavers, William and Elizabeth Sharp descended from three generations of muslin manufacturers, and the two families were close friends. Noel Paton played an important role in Sharp's establishment as a writer. He provided the introduction to Danial Gabriel Rossetti, who accepted 
him into his circle of fellow writers and painters. He was responsible for a letter Sharp received when he was desperately short of money in early 1883. The letter was from an unknown friend who had known his grandfather. In his own words, "He had heard from Sir Noel Paton that I was inclined to the study of literature and art. He therefore enclosed a cheque for two hundred pounds, which I was to spend in going to Italy to pursue my artistic studies" (Memoir 78-79). Sharp went to Italy that spring and immersed himself in the study of Italian Renaissance painters in Florence and Rome, https://en.wikipedia.org/ wiki/Joseph_Noel_Paton

64 This refers to either Poems or Ballads and Sonnets, both published in London by Ellis and White in 1881. With the exception of four new poems in Poems, both volumes were comprised of previously printed works.

65 Dinah Maria Mulock (1826-1887), the author of John Halifax, Gentleman (1854), married George Lillie Craik in 1864. Sir Noel Paton was a close friend of the Craiks, and he provided Sharp an introduction in 1880. Mrs. Craik was the godmother of Philip Bourke Marston who became a good friend of Sharp after Rossetti introduced them. According to Elizabeth Sharp, Mrs. Craik "had a house in Kent, at Shortlands, and to it she on several occasions invited the two young poets" [Sharp and Marston]. E. A. S. described one such visit in the summer of 1880 during which Sharp contracted a cold that led to rheumatic fever (Memoir 41-42).

66 Since Rossetti had multiple paintings titled Beatrice it is difficult to determine which Sharp refers to here. It is, however, most likely Beata Beatrix (1864), which, along with Dante's Dream, Sharp considered Rossetti's finest painting. Rossetti's paintings are marvelously reproduced and discussed in the Rossetti Archive: "The Rossetti Archive facilitates the scholarly study of Dante Gabriel Rossetti, the painter, designer, writer, and translator who was, according to both John Ruskin and Walter Pater, the most important and original artistic force in the second half of the nineteenth century in Great Britain." http://www. rossettiarchive.org/index.html

67 Dr. Westland Marston (1819-1890), the father of Sharp's friend Philip Bourke Marston, was a poetic dramatist, a member of the Dickens circle, editor of the National Magazine in 1837, and a poetry critic for The Athenaeum after 1863. His works include The Patrician's Daughter (1842), Strathmore (1849), Anne Blake (1853), A Life's Ransom (1857), A Hard Struggle (1858), Donna Diana (1863), The Favorite of Fortune (1866), Life for Life (1869), and Broken Spells (1873).

68 Possibly the wife of Viscount Stratford Canning, Stratford de Redcliffe (1786-1880). An important diplomat, he served for a time as ambassador in Constantinople. Lady Stratford (de Redcliffe) was born c.1807 and survived her husband's death. 
69 A portion of this letter appears in the Memoir (55-57).

70 Sir Noel Paton.

71 Philip Bourke Marston.

72 Rossetti created three paintings titled Dante's Dream. The first is a watercolor from 1855, and the second, to which Sharp is referring here, is an oil from 1871. It is, according to Sharp's book on Rossetti, the artist's largest painting, and its full title is Dante's Dream at the Time of the Death of Beatrice. It can be seen here: https://www.wikiart.org/en/dante-gabriel-rossetti/dante-s-dream The third Dante's Dream is an oil from 1878.

\section{Sir Noel Paton.}

74 Raphael's Sistine Madonna (1513), which is at the Gemaldegalerie in Dresden.

75 Frederick James Shields.

76 Noel Paton's sister, Amelia Robertson Paton (1820-1904), was a portrait painter and sculptor. Her early works consisted mainly of portraits of family and friends, but her professional career flourished after she married, at age fortytwo, David Octavius Hill (1802-1870), an Edinburgh landscape painter who was the first to use photography as an aid to painting. A highly respected sculptor, Paton was deeply involved in the artistic and intellectual life of Edinburgh. She sculpted busts of many Scottish dignitaries and created the statue of David Livingston in Princes Street Gardens, Edinburgh, and that of Robert Burns in Dumfries. The Paton and Sharp families were friends, and Elizabeth and Amelia were especially close, https://en.wikipedia.org/wiki/Amelia_Robertson_Hill

77 Probably The Poetical Works of Percy Bysshe Shelley, edited by Mary Shelley and published by Edward Moxon (London: 1839).

78 Either Poems or Ballads and Sonnets.

79 Marcus Bourne Huish (1843-1921) was an English barrister, writer and art dealer. He edited The Art Journal from 1881 to 1893, and he was the Director of the Fine Art Society at the time of this letter. Sharp had a temporary position at the Society's gallery in New Bond Street. He was hired for just six months "to form a section dealing with old German and English Engravings and Etchings," and he lost that position when the Society decided not to form the section. Had he been successful in urging Rossetti to agree to an exhibition in the gallery, he may well have been hired on a more permanent basis to organize that exhibit.

80 Frederick James Shields (1833-1911) was a British artist, illustrator and designer closely associated with the Pre-Raphaelites. 
81 Recognized artists whose works were exhibited in the Fine Art Society Gallery: William Holman Hunt (1827-1910), Samuel Prout (1783-1852), John Everett Millais (1829-1896), and Samuel Palmer (1805-1881).

82 George Frederick Watts (1817-1904) and Edward Burne-Jones (1833-1898). 


\section{Chapter 2}

1 This letter was written from Birchington, Kent, where Rossetti died on Easter Sunday, April 9, 1882.

2 Although he never finished it, Rossetti returned to work on his "Joan of Arc" during a short period of recovery shortly before his death in 1882 .

3 Robert Farquharson Sharp (1864-1945) was Elizabeth Sharp's brother and thus both a first cousin and brother-in-law of William Sharp, whose literary executor he became upon Elizabeth's death in 1932. He served in the Department of Printed Books in the British Museum from 1888 until 1929. His published works include Dictionary of English Authors (1897), Makers of Music (1898), Reader's Guide to Everyman's Library (1932), Short Biographical Dictionary of Foreign Literature (1933), and translations of Hugo, Bjornson, and Ibsen. On February 5, 1937, he read an essay entitled "I Remember William Sharp" on the BBC.

4 In the Memoir (63), this letter is misdated 1883.

5 This sonnet was not published until Mrs. Sharp printed it in the Memoir. Two other sonnets addressed to D. G. Rossetti appear in the section entitled "Sonnets, 1882-1886" in the Selected Writings of William Sharp, Uniform Edition Arranged by Mrs. William Sharp, Volume One, Poems by William Sharp (London: William Heinemann, 1912).

6 William Bell Scott (1811-1890), was a Scottish artist in oils and watercolors. He was also a poet and art teacher, and his posthumously published reminiscences give a chatty and often vivid picture of life in the circle of the Pre-Raphaelites; he was especially close to Dante Gabriel Rossetti. His publications include Poems (1854), William Blake: Etchings from his Works (1878), and The Little Masters (1880).

7 Edward Dowden (1843-1913), an Irish poet, essayist, biographer, and literary critic, was a Professor at Trinity College Dublin from 1892 until his death. He gave the Taylor Lectures at Oxford in 1889 and the Clark Lectures at Cambridge between 1892 and 1896. He is best known for his Shakespeare criticism and his two-volume Life of Percy Bysshe Shelley (1886). Among his publications are Shakespeare: A Critical Study of His Mind and Art (1875), Poems (1876), Introduction to Shakespeare (1893), Essays: Modern and Elizabethan (1910), and Poems (1914).

8 For more information about Dowden, see: https://en.wikipedia.org/wiki/ Edward_Dowden.

9 Notice by Theodore Watts (later Watts-Dunton) of Sharp's first book of poetry - The Human Inheritance; The New Hope; Motherhood - which was published by Elliot Stock in Spring 1882. 
10 Yorkshire Post.

11 A poet and essayist, James Thomson (1834-1882) was the author of "City of Dreadful Night" (1874) and a volume of that title which followed in 1880, in addition to Essays and Phantasies (1881), and Satires and Profanities (1884). In 1840 his father became paralyzed and his mother died in 1842. In 1853 the girl that he loved, Matilda Weller, died suddenly. Additionally, his insomnia, dipsomania, melancholia, poverty, alcoholism, and eventual homelessness are some of the "miseries" to which Sharp refers. He collapsed at Philip Bourke Marston's on June 1st and died on June 3rd.

12 Date from postcard on envelope.

13 Philip Bourke Marston.

14 James Thomson.

15 Sharp began his book on Rossetti (Daniel Gabriel Rossetti: A Record and a Study) in June 1882 within two months of Rossetti's death in April. It was published in December by Macmillan. The book was well-received and established Sharp's reputation as a critic. He later considered it a too-hasty project by a young man whose "judgement" was "immature" (Memoir 63-72).

16 Caine's Recollections of Dante Gabriel Rossetti was published by Elliot Stock in fall 1882 .

17 A journalist and novelist, William Tirebuch (1854-1900) was a friend of Hall Caine who lived in Liverpool. After a period of writing for the Liverpool Mail and the Yorkshire Post, he devoted himself to writing novels. He was the first to get a book about Rossetti into print after Rossetti died (Dante Gabriel Rossetti, 1882). Hall Caine and William Sharp were writing books on Rossetti in 1882, and each hoped to be the first to publish. It turned out that Tirebuch's book "was a slim essay on Rossetti's art with little about his life. It came out on June, 1882, and William [Rossetti] dismissed it as of no importance as the writer had not known Rossetti personally and was himself unknown." See Hall Caine. Portrait of a Victorian Romancer by Vivien Allen (Sheffield: Sheffield Academic Press, 1997), pp. 151-52.

18 This work became Dante Gabriel Rossetti: A Record and a Study.

19 The Human Inheritance; The New Hope; Motherhood.

20 For images of the Rossetti paintings identified in this letter, consult the Rossetti Archive: http://www.rossettiarchive.org/index.html

21 I.e. watercolour. 
22 "Found" is a famous unfinished painting by Rossetti.

23 Frederick Startridge Ellis (1830-1901 was a bookseller, author, and publisher (Ellis and White) who brought out works by William Morris and Dante Gabriel Rossetti and became their close friend.

24 Date from postmark, and addressed to Ellis at Hill House, Epsom. Sharp wrote this card on the 25th, a Thursday, after returning from seeing Ellis' Rossetti paintings in Epsom.

25 Philip Bourke Marston.

26 Mathilde Blind (1841-1896) was a German-born poet, translator, and friend of the Rossetti family. Her works include The Ascent of Man; The Heather on Fire; Dramas in Miniature; Poems of the Open Air; Tarantella: A Romance (1885); Madame Roland (1886); and George Eliot (1888).

27 This incomplete letter is taken from a summary which was transcribed by a Manx Museum staff member.

28 The "'unsold drawings" by D. G. Rossetti were sold at Christie's in 1883. The reference is to the "Supplementary Catalogue" Sharp included in his book on Rossetti.

29 On October 23, Sharp told W. M. Rossetti he would be going to Hampshire for a fortnight or more. This letter indicates he was staying in Northbrook House in Micheldever which was the country home of the Cairds. The Sharps stayed there frequently at the invitation of Mona Caird, a good friend of Elizabeth Sharp since their school days, who became a well-known advocate of women's rights. (See note to Sharp letter to Caird dated early 1880.) Built in the eighteenth century, Northbrook House is now a grade II listed building. The date of the letter is established by its reference to the proofs, which Sharp expected in a few days, of the wood-engraving of D. G. Rossetti's design which surrounds the sonnet he wrote about the sonnet. Sharp told Dowden on December 10, 1882 that Christina Rossetti and her mother had made the design containing the sonnet available to him for publication as the frontispiece for his study of Rossetti.

30 The New Medusa and Other Poems (1882). The book Sharp received from Richard Garnett was Selected Letters of Shelley with an introduction by Garnett which was published by Kegan Paul in 1882.

31 Sonnets of Three Centuries: A Selection, ed. T. H. Caine (1882).

32 Dante Gabriel Rossetti: A Record and a Study.

33 Frederick Langbridge (1849-1922) was a clergyman who lived for many years in Limerick. He wrote poems, plays, novels, and books for children. 


\section{The Human Inheritance; The New Hope; Motherhood.}

35 India ink is a simple black or colored ink once widely used for writing and printing.

36 In 1883 there were exhibitions of Rossetti's art at both the Royal Academy's Burlington House and the Burlington Fine Arts Club. The latter was offered as a supplementary and concurrent exhibition due to the supposed shortcomings of the Royal Academy's exhibition. The Royal Academy exhibit opened in December 1882, and the Burlington Club's opened on January 13, 1883. The London Times responded favorably to both: "the two Rossetti exhibitions now open will be remembered for a long time to come. They have dispelled more than one prejudice, and thrown a new light on the origin of a movement which has played an important part in the development of English art and of the external surroundings of English life" (January 15, 1883, p. 8).

37 For many years an imposing residence in Piccadilly, Burlington House was sold in 1854 to the British government for $£ 140,000$. The Royal Society occupied part of the house in 1857. The Royal Academy of Art moved to the main block in 1867 on a 999-year lease with rent of $£ 1$ per year. It soon became and remains a prestigious art school and a major art gallery. The Burlington Fine Arts Club was established in 1866 and occupied (until its demise in 1952) imposing quarters at 17 Savile Row. In addition to providing gallery space for exhibitions, it was a men's club for artists and art patrons. Daniel Gabriel Rossetti was a member as were James McNeill Whistler, John Ruskin, and William Michael Rossetti.

38 Sharp's four-month visit to Italy, which began in late February 1883, was made possible by the gift of 200 pounds from a friend of his grandfather who heard from Sir Noel Paton that Sharp was "inclined to the study of literature and art" (Memoir 78). Of all the letters Sharp wrote to his fiancé from Italy, only those she printed in the Memoir survive since she destroyed toward the end of her life all the letters she had received from him and most of those he received from others. That was a sad loss because the letters and fragments that survive contain the responses of a perceptive young man, heavily imbued with the work of the British Pre-Raphaelites, to the paintings, murals, and statuary of the Italian Renaissance. Not long after he returned to England, Sharp became the London art critic for the Glasgow Herald, a position he later turned over to his wife. Both William and Elizabeth Sharp attended not only the major art exhibits in London, but also for many years the annual Spring Salons in Paris. They wrote extensively about the art they observed there in the late 1880s and 1890s, a period in which the experimental work of French artists dominated the international art world.

39 The Brancaccio Chapel of the Santa Maria del Carmine is a landmark of Florentine art. Its frescoes were painted by Masolino, beginning in 1424, and by 
his pupil Masaccio, who worked until his death in 1428 at the age of 27. They were completed by Filippino Lippi in the 1480s. Many of the scenes are among Masaccio's masterpieces, and many artists of the 1400s and 1500s came to the chapel to sketch and discover how Masaccio achieved his dramatic effects.

40 Mrs. Smillie, Elizabeth Sharp's aunt, had a villa on the outskirts of Florence.

41 Ouida (Marie Louise de la Ramée) (1839-1909) was well known on the continent as well as in England and America for her stories and criticism. Her mother, Susan Sutton, was English, and her father, Louis Reme, French. When she was not traveling, she lived and worked at her Villa Farinola outside Florence. She wrote glamorous, unreal, but extremely popular stories. Among her most successful books were: Held in Bondage (1863), Chandos (1866), and Under Two Flags (1867).

42 William Wetmore Story (1819-1895) was an American sculptor, poet, and novelist who moved permanently to Rome in 1850. See note to Sharp's July 15, 1890 letter to Story. John Rollin Tilton (1828-1888), a close friend of Story, was a landscape painter who worked chiefly in watercolors. Also an American, he settled in Rome in 1852 and remained for the rest of his life.

43 Arthur Lemon (1850-1912) was a British painter who spent his early years in Rome and was, for ten years, a cowboy in California, where he painted Indians and wildlife.

44 John Arthur Lomax (1857-1923) studied in Munich and did his major work in Manchester and London.

45 Mrs. Smillie.

46 Giovanni Antonio Bazzi Sodoma (1477-1549) was a Lombard painter who worked at Monte Oliveto from 1505 to 1508, continuing the frescoes, "Scenes of the Life of St. Benedict that were begun by Luca Signorelli (1450-1523), an Umbrian painter and a pupil and collaborator of Piero della Francesca. Signorelli's "Legend of St. Benedict," a work known for its anatomical detail, its foreshortening, and its conveyance of pathos, was probably painted at Monte Oliveto in 1497.

47 Sharp wrote "The Tides of Venice" before he visited Italy. It was published in The Human Inheritance; The New Hope; Motherhood.

48 John Addington Symonds (1840-1893) settled in Switzerland in 1877 and remained there until his death, with regular trips to Italy, especially Venice. He and Sharp developed a warm friendship, and Symonds encouraged Sharp's literary pursuits throughout the eighties. 
49 William Dean Howells (1837-1920), a novelist, poet, and essayist, was a subeditor of The Atlantic Monthly under James T. Fields and editor-in-chief from 1872 until 1881. He wrote the "Editor's Study" column for Harper's Monthly from 1886 to 1891 when he left to edit Cosmopolitan for a year. He returned to Harper's in 1900 and wrote the "Editor's Easy Chair" until his death. Howells was the U.S. Consul in Venice from 1861 until 1865, and he returned frequently for visits. His works include: Poems (1873), A Modern Instance (1882), The Rise of Silas Lapham (1885), Modern Italian Poets (1887), A Hazard of New Fortunes (1890), Literature and Life (1902), Years of My Youth (1916), and The Leatherwood God (1916).

50 William Michael Rossetti married Emma Lucy Brown, the daughter of Ford Maddox Brown, in 1874.

51 E. A. S. confirms that Venice, where he enjoyed the "frequent companionship of John Addington Symonds" and long hours in the gondola, was the "crowning pleasure" of Sharp's Italian sojourn. He stayed there through May, spent June in the Ardennes with Elizabeth and her mother, and returned to London briefly in July before going on to Scotland to stay with his mother and sister at Innellan on the Clyde (Memoir 93).

52 Sharp is probably referring to the second of the two sales described by Oswald Doughty: "On July 5th [1882] and the two following days, the sale of Rossetti's household effects took place at Cheyne Walk. To William's [William Michael Rossetti] pleased surprise it produced, together with some of the pictures sold privately, about three thousand pounds... . It chanced to be Gabriel's birthday, May 12, 1883, when the remaining paintings were sold at Christie's for about the same sum as the household sale had realized; the total thus raised, almost six thousand pounds, proved sufficient to pay Rossetti's debts and even leave a small balance in hand." Oswald Doughty, Dante Gabriel Rossetti, A Victorian Romantic (New Haven: Yale University Press, 1949), 674.

53 Elizabeth Sharp in her Memoir states the portmanteau was lost when Sharp was returning to London from Innellan. This letter makes clear that it was lost on his way from London to Innellan to stay with his Mother \& sisters. It was found about a month after its loss with its contents, according to E. A. S., "in a soaked sodden condition, but still legible and serviceable." Elizabeth reported that his search for the portmanteau in the wet \& cold of Scotland caused him to become ill with rheumatic fever which attacked his heart when he returned to London in September (Memoir 94).

54 Although the enclosed poem is dated September 18, 1883, this letter was written in mid-to late-November. Sharp was "feeling better" after becoming seriously ill with rheumatic fever upon his return from Scotland in September. He is glad Caine was feeling better and that Sandown suits him. Caine went to live in a cottage near Sandown on the Isle of Wight at the end of October, 1883 
(Vivien Allen, Hall Caine, Portrait of a Victorian Romancer).

55 Wind Voices (London: Stock, 1883).

56 Sharp accepted Dinah Maria Craik's offer and spent March and April in her Dover house: 9 Hubert Terrace. He told Caine in a letter dated February 11, 1884 that he would be coming up from Dover each "Saty. till Monday - tho' not to Thorngate Road." He probably spent at least some weekends in London with Elizabeth at her parent's house, 72 Inverness Terrace, from which he could attend art exhibits on Saturday and keep up his reviewing for the Glasgow Herald. When he left Dover in early May, he crossed to Paris and stayed there until May 20. In October 1884, Mrs. Craik lent her Dover house to the Sharps for a portion of their honeymoon.

57 Edward George Earle Bulwer-Lytton, first Baron Lytton (1803-1873) was a prolific novelist, poet, critic, and Member of Parliament. His novels include Pelham (1828), The Last Days of Pompeii, 3 vol. (1834), King Arthur (1848), and The Caxtons, 3 vol. (1849). In 1883 his son, (Edward) Robert Bulwer-Lytton (1831-1891), a diplomat and poet, published The Life, Letters and Literary Remains of his father. The two volumes covered the period 1803-1832. There were no subsequent volumes. Lytton's wife, Lady Rosina (Doyle Wheeler) BulwerLytton, who was Irish, was also a novelist. They separated after about six years of marriage (1827-1836). In 1839 she published a novel called Cheveley, or the Man of Honour, in which her husband was cast as the villain.

58 Agnes Mary Frances Robinson (1857-1944). See note to Sharp's March 1881 letter to Violet Paget.

59 One of these books would have been his second volume of poems, Earth's Voices, etc. (1884).

60 The Poetical Works of John Keats, ed. H. Buxton Forman (1884).

61 Dante Gabriel Rossetti.

62 The New Medusa, and Other Poems.

63 New Arcadia, and Other Poems (London: Ellis and White, 1884).

64 Published in 1884.

65 All in All: Poems and Sonnets (1875).

66 Elizabeth Sharp.

67 Philip H. Caldron was born in France in 1833, went to England in his early boyhood, and began the study of art in London in 1850. He is best known for his 
painting “The Day of the Massacre of St. Bartholomew” (1863).

68 Earth's Voices: Transcripts from Nature: Sospitra and Other Poems (London: Elliott Stock) was published in June 1884.

69 Philip Bourke Marston.

70 The identity of this "Romance" is uncertain. Sharp's first published piece of prose fiction was "Jack Noel's Legacy: A Story for Boys" which appeared serially in Young Folks' Papers, 8 (London: James Henderson \& Co., Ltd.) in 1886.

71 Walter Pater (1839-1894).

72 I have been unable to identify Mr. Parsons.

73 Probably either Sharp's first volume of poetry, The Human Inheritance, or his second, Earth's Voices. If the latter, this letter would date after June 1884 when Earth's Voices was published.

74 Date from postmark on accompanying envelope. The letter was posted on Wednesday, February 13, 1884.

75 “Sospitra” appeared in Sharp's second volume of poetry Earth's Voices.

76 Sharp did add "A Fragment" to the title of "A Record" when it was published in Earth's Voices.

77 George MacDonald (1824-1905) was a poet, novelist, and fantasy writer. His reputation lies mostly in his fairy tales, examples of which are contained in Dealings with Fairies (1867), The Princess and the Goblin (1872), and Lilith (1895).

78 The home of E. A. S.'s parents with whom she lived.

79 "9 Herbert Terrace" was Dinah Maria Craik's house in Dover. On hearing of Sharp's serious illness and his need to be away from London in the winter of 1884, Mrs. Craik offered him the use of her Dover house. (See Sharp's letter to D. G. Rossetti of July 28, 1881.) In October 1884, she lent her Dover house to the Sharps for a portion of their honeymoon.

80 Although this letter is dated 10 April in the Memoir, Sharp's 26 April letter to Dowden (below) clearly states that he will be in Paris from 5 May until 20 May. This letter was therefore written on 10 May or thereabouts.

81 Paul Charles Joseph Bourget (1852-1935), a conservative French Catholic, wrote novels, short stories, plays, poetry, criticism and travel books. He was the author of Essais de Psychologie (1883), André Cornélis (1887), Le Disciple (1889), and Un Divorce (1904). 
82 Emile Hennequin (1858-1888) was a literary critic and the author of Edgar Allan Poe (1885), La Critique Scientifique (1888), and Etudes de Critique Scientifique (1890).

83 Madame Blavatsky (1831-1891) was Helena P. Hahn until she married General Nicephore Blavatsky (whom she left within the first year of marriage). Born in Ekaterionslav, Russia, she traveled through Europe and the Mideast between 1848 to 1873 . She first visited Paris in March 1873 and later that year went to America where she founded the Theosophical Society and became an American citizen. From America she went to India in 1878 and returned to Europe in February 1884. Subsequently, she spent a good deal of time in England, but continued her travels until her death in London in 1891. Her special brand of spiritualism - with elements of eastern religions and of the Kabbalah - was very attractive to young artists and intellectuals, chief among them $\mathrm{W}$. B. Yeats, in the eighties and nineties.

84 Eugène Müntz (1845-1902) was a historian of French art. Sharp's reference is to his Raphaël, sa vie, son oeuvre, son temps (1881).

85 Alphonse Daudet (1840-1897) and Emile Zola (1840-1902) were eminent French novelists.

86 Joseph Antoine Milsand (1817-1886) was a French critic and philosopher whose works include a book on Ruskin, L'Esthetique Anglaise (1864).

87 François Coppée (1842-1908) and Frederic Mistral (1830-1914) were poets, while Jean Richepin (1849-1926), a popular figure in the "Latin Quarter" of Paris, was a poet, novelist, and dramatist.

88 Adolphe William Bouguereau (1825-1905) was born at La Rochelle, studied art in Paris, and became a decorative painter, best known for his "The Body of St. Cecilia Borne to the Catacombs." FernandAnne-Piestre Cormon (1845-1924), also an artist, was a professor at L'École des Beaux Arts. Puvis de Chavannes (1824-1898) painted in a traditional manner though his works have imaginative power and complexity. Jules Breton (1827-1906) was a French poet who became a member of L'Académie des Beaux Arts in 1886.

89 Maurice Guillaume Guizot (1833-1892), a literary scholar, was appointed acting professor of the Department of French Language and Modern Literature at the Collège de France and, in 1874, was named to the Chair of Germanic Language and Literature at the same university. In 1882 he published a partial translation of Macaulay's essays on history and literature.

90 Earth's Voices.

91 James Cotton (1869-1916) became editor of The Academy in 1881. 
92 This pitiful letter is postmarked June 16, 1884, a Monday. It is written in a nearly illegible scrawl that demonstrates the pain Sharp was experiencing as he wrote. See the introduction to this section.

93 "\& bedroom damp" is written in the margin here.

94 Eric Sutherland Robertson who shared rooms with Caine and served as best man at Sharp's wedding on October 31, 1884. He edited the "Great Writers" series for Walter Scott, for which he wrote the Life of Henry Wadsworth Longfellow (1887). He was also the author of The Dreams of Christ, and Other Verses (1891), From Alleys and Valleys (1918), and The Limits of Unbelief; or Faith Without Miracles (1920). In the spring of 1887 Robertson assumed the chair of Literature and Logic at the University of Lahore. Upon leaving London, he had to vacate his position as editor of the "Literary Chair" in The Young Folk's Paper. He suggested William Sharp succeed him as Editor, and that position provided the Sharps with a modest steady income for three years. Sharp was asking Caine if he could sleep in Robertson's bed in the quarters they shared in Lincoln's Inn Fields. Caine had another house in Hampstead, perhaps unknown to Sharp, where he sent Sharp to be cared for by Mary Chandler and her maid. See the introduction to this section for more details.

95 When Sharp spent the night at Caine's Hampstead house in June, he saw that Mary Chandler was pregnant with Caine's child. As it happened, Mary had given birth to a son on 15 August 1884, and Caine had named him not Abel, but Ralph Hall Caine. Caine registered the birth on 15 September as the son of Thomas Henry Hall Caine, journalist, and Mary Alice Caine, formerly Chandler. Caine considered himself married to Mary, though he was not. They married in 1886 and enjoyed a long life together. 


\section{Chapter 3}

1 Apollo and Marsyas, and Other Poems (London: Eliot Stock, 1884).

2 Theodore Watts' review appeared in the issue of December 13, 1884, $764 \mathrm{ff}$.

3 This undated letter was enclosed with Sharp's 5 January letter to Eugene LeeHamilton.

4 Miss Brown (1884) was Violet Paget's first attempt at a novel. Peter Gunn, in Vernon Lee: Violet Paget, 1856-1935 (1964), notes: 'Ouida, who had experience in these matters, remarked that it showed signs of having been written at a gallop" (p. 99).

5 The essays collected in Euphorion (1884) were written by Paget over several years, and many were published earlier in periodicals.

6 Having run serially in the Liverpool Mercury in the fall of 1884, Shadow of a Crime, Caine's first novel, was published by Chatto \& Windus in late February 1885 and went through several editions. Well reviewed and widely read, this book launched Caine's forty-year career as a popular romantic novelist.

7 Sharp's friend and fellow Walter Scott editor Eric Robertson shared lodgings with Hall Caine in London.

8 Sharp was writing a review of Walter Pater's Marius the Epicurean for The Athenaeum. It appeared as the lead review in the 28 February issue (pp. 271-73). Though Athenaeum reviews were unsigned, Sharp sent a copy to Pater in the hope of ingratiating himself with the well-known Oxford don.

9 See note to Sharp's 22 May 1882 letter to Dowden.

10 Songs, Poems, and Sonnets of William Shakespeare, ed. by William Sharp (Walter Scott: London, 1885).

11 Dowden's Sonnets by William Shakespeare (London: C. K. Paul \& Co.) was published in 1881 .

12 John Cordy Jeaffreson (1831-1901) was the author of The Real Shelley, New Views of the Poet's Life, 2 vols. (London: Hurst and Blackett, 1885). Among his other books are Novels and Novelists, From Elizabeth to Victoria (1858), A Book About Lawyers (1866), and The Real Lord Byron (1883).

13 This MS poem is on a single sheet in the British Library.

14 Born at Ballyshannon in Donegal, William Allingham (1824-1889) was a friend of Tennyson, and associated with the Pre-Raphaelites. He edited Fraser's 
Magazine from 1874-1879. He was the author of Poems (1850), Day E Night Songs (1854), Laurence Bloomfield in Ireland (1864), Irish Songs and Poems (1888), and a posthumous volume entitled Varieties in Prose (1893).

15 Wilfred Scawen Blunt (1840-1922), poet, traveler, and explorer, served in the British diplomatic service from 1858-1870. Later he became an opponent of British imperialism and supported Egyptian, Indian, and Irish nationalist movements. In Ireland he was arrested and imprisoned for two months. His publications include Love Sonnets of Proteus (1881), Future of Islam (1882), Ideas About India (1885), Griselda: A Society Novel in Rhymed Verse (1893), and My Diaries (1919-1920).

16 James Ashcroft Noble (1844-1896) was a writer and critic and editor of The Athenaeum. Among his publications are Morality in English Fiction (1886), Impressions and Memories (1895), The Poets and the Poetry of the Century (1903).

17 Date from postmark on envelope.

18 All eventually appeared in the order listed here in Sharp's Sonnets of this Century.

19 Published by Walter Scott in the Canterbury Poets Series in December 1895.

20 See W. S. letter to W. B. Scott 22 April 1882, fn.

21 Date from postmark.

22 Robert Perceval Graves was a friend and biographer of Sir William Hamilton. He was the recipient of Hamilton's voluminous papers and letters upon the latter's death. Graves wrote the 2040-page Life of Sir William Rowan Hamilton, Including Selections from His Poems, Correspondence, and Miscellaneous Writings, 3 vol. (1882-1889; addendum, 1891).

23 Sir William Rowan Hamilton (1805-1865) was an important mathematician who also wrote poetry. He was friends with both Wordsworth and Coleridge. In 1827, while still an undergraduate, he was named Andrews Professor of astronomy at Trinity College in Dublin. He was the author of General Method in Dynamics (1834), Lectures on Quaternions (1853) and The Elements of Quaternions (1866).

24 Sharp was referring to the papers of Joseph Severn which were given to him by Severn's son Walter on the condition that he write a biography of the artist and diplomat who nursed Keats in his last illness in Rome. Elizabeth dated the occasion of this understanding as the early Spring of 1889 or 1890, but this letter shows it was much earlier, perhaps in the Spring of 1885. Elizabeth describes the occasion as follows: "'We spent a week-end in Surrey with some old friends of 
my mother, Sir Walter and Lady Hughes, and one morning Mr. Walter Severn, the painter, walked over to luncheon. He spoke about my husband's Life of Rossetti, then of the quantity of unpublished MSS he and his family had written by and relating to his father, Joseph Severn, the friend of Keats.' Finally, he proposed that his listener should take over the MSS, put them in form and write a Life of Severn, with, as the special point of literary interest, his father's devoted friendship with and care of the dying poet." Working on the Severn papers and life, according to Elizabeth, brought Sharp "into pleasant relationship not only with Mr. Walter Severn, and with Mr. and Mrs. Arthur Severn, but also with Ruskin, who he visited later at Coniston." (Memoir 168-69)

25 Sharp did not finish the Severn book until August 1891, and it was published (Sampson Low \& Co.) in February, 1892.

26 Wilfrid Meynell (1852-1948) was a newspaper publisher and editor and the husband of Alice Meynell (1847-1922) a writer, editor, critic, and suffragist, now remembered mainly as a poet. After marrying in 1877, the Meynells settled in Kensington and became the proprietors and editors of such magazines as The Pen, the Weekly Register, and Merry England.

27 This novel, here called False Lights, ran serially in The People's Friend as "The Deathless Hate." In 1888 it was published in three volumes as The Sport of Chance (London: Hurst and Blackett, Ltd.). See Memoir (121-29) for a discussion of its reception. Sharp began writing the work in the fall of 1885 and submitted it to The People's Friend for a contest. He did not win the prize of $100 £$, but the editor accepted it and published it serially beginning in early 1887.

28 It was changed to "A Deathless Hate." See previous note.

29 Sharp believed his serial novel would start running in The People's Friend in the Spring of 1886. It did not begin until early 1887.

30 George F. Ferris, Great Musical Composers: German, French and Italian, ed. with an introduction by Mrs. W. Sharp, The Camelot Classics (London: Walter Scott, 1887).

31 Frederick Langbridge, Sent Back by the Angels, and Other Ballad of Home Life (London: Simpkin \& Co., 1886).

32 Sonnets of this Century, edited and arranged, with a critical introduction on the sonnet by William Sharp (London: Walter Scott, 1886). It was published on 6 January 1886; thus the date of this letter. The book proved to be very popular, and was reprinted several times before Sharp made some revisions during the summer and fall of 1886 for a new edition. Sharp was hired by the Scott firm to prepare the anthology and later to revise it so he did not share in the book's long term financial success. He told Dowden (3 February 1886), however, that the 
publishers had "behaved very decently," to him, implying his satisfaction with the payment he received for the book from the Scott firm.

33 Of this letter and the two sonnets, Elizabeth Sharp wrote: "The opening of the new year 1886 - from which we hoped much - was unpropitious. A wet winter and long hours of work told heavily on my husband, whose illhealth was increased by the enforced silence of his 'second self"' (Memoir 124). By "second self" she meant his frame of mind in which he could focus on his creative writing. This letter and the sonnets were written in a state of dejection resulting from these circumstances. Soon after writing this letter, Sharp became seriously ill.

\section{Sonnets of this Century.}

35 Nothing came of Caine's plan to collaborate with Robert Buchanan on a dramatization of The Shadow of a Crime. The latter was published serially in the Liverpool Mercury in the fall of 1884 and in book form by Chatto \& Windus (London) in February, 1885. See Vivien Allen's Hall Caine, Portrait of a Victorian (Sheffield: Sheffield Academic Press, 1997).

36 The date "15-2-1886" is written at the top of the first page of the MS letter in another hand. It may have been taken from the postmark of the letter's envelope, and it is probably correct since only 100 copies were printed of the first edition of Sonnets of This Century. The hundred copies disappeared quickly and more were printed (reissued) very quickly. As subsequent letters demonstrate, Theodore Watts was assisting Sharp in preparing a revised second edition that appeared in fall, 1886.

37 J. E. Pfeiffer (d. 1889) was a German merchant who lived in London. He married Emily Jane (Davis) Pfeiffer (1827-1890) in 1853. She was a poet who prided herself on her ability as a sonneteer. Her many publications include Glan Alarch (1877), The Rhyme of the Lady of the Rock (1884), and Woman and Work (1888), for which she collected periodical articles on the social position of women.

38 Date from postmark on envelope. The absence of letters between February and August 1886 is due to Sharp's serious illness. See introduction to this section and Memoir, $125 \mathrm{ff}$.

39 Sharp had asked Watts to read the proofs of a revised edition of Sonnets of This Century. Page 314 of the second edition contains the notes to Swinburne's sonnets, and pages $320 \mathrm{ff}$ contain the notes to Watts' sonnets. A letter from Watts to Sharp in the Memoir (114-15) dated January 8, 1886 indicates Watts wanted to change the order of printing of his five sonnets in the first edition. He sent the revised sequence directly to the printer, but it was too late to make the change since the book was published on January 6 . The order was changed in 
the second and subsequent editions. Watts was especially concerned about his contributions and Swinburne's to the Sonnets volume and about what Sharp said about them in his notes. Sharp was grateful for Watts' input.

40 The publication of the revised edition was delayed until December.

41 Kidnapped; being the adventures of David Balfour in the year 1751 (London: Cassell \& Co., 1886).

42 Frederick William Robinson (1830-1901) wrote an enormous number of popular novels now forgotten.

43 Watts worked on this novel and discussed it with his friends for many years, and it was finally published - by Hurst and Blackett, London - in October 1898.

44 Sharp was ill during the early months of 1886 and contacted scarlet fever and phlebitis in the spring. That was followed by a life-threatening case of rheumatic fever. After ten straight weeks in bed, he was well enough in August to go with Elizabeth to Micheldever in Kent where the Cairds had lent them their house - Northbrook - for six weeks. There in the peace and warm sunshine Sharp recovered, but his heart was permanently damaged by this long bout of illness. He was only thirty years old at this time, and he was unable to work for most of the year. The Sharps were saved from financial ruin only by a "substantial check" from Alfred Austin who asked that it be repaid not to him but to "someone else who stood in need" (Memoir 125-26).

45 The Great Writers Series that Eric Robertson edited for Walter Scott.

46 No volume on either Borrow or Rossetti appeared in the Great Writers Series. Sharp's volume on Shelley was number 11 in the series, and was published in fall 1887.

47 For more about Mrs. D. O. Hill (Amelia Robertson Paton) see note to Sharp's letter to D. G. Rossetti dated September 22,1881.

48 Ford had been hired to paint twelve frescoes for the Great Hall of the recently completed Manchester Town Hall. He invited the Sharps to come to Manchester to see the eight frescoes he had completed in the hope their visit would produce a favorable review in the Glasgow Herald.

49 James Stanley Little (1856-1940) was a prolific writer of fiction and nonfiction. The son of Thomas Little, of Woodville, Forest Hill, London, and John Cockerell's daughter Lilla, he married the Viscountess Fanny Maude Therese de la Blache, and they had a daughter and a son. He lived variously in France, Italy, Switzerland, and Belgium as well as in England; at the time of his death 
he resided in Cichele, Parkstone, Dorset. He and Sharp became close personal friends during the late eighties. In the eighties he published What Is Art? (1884), My Royal Father: A Story for Women (1886), and Doubt (1888).

50 The Shelley Society sponsored a performance of Shelley's Hellas in London in October, 1886. Few notable people attended, and the event resulted in a grave financial loss to the Shelley Society [Sylva Norman, The Flight of the Skylark, The Development of Shelley's Reputation (Norman, OK: University of Oklahoma Press, 1954), 269-70)].

51 At the first meeting of the Shelley Society, on March 10, 1886, at University College, London, the Reverend Stopford Brooke substituted for W. M. Rossetti as the principal speaker. His audience consisted of about a hundred members of the Society. Before its dissolution in 1895 from lack of funds, the Shelley Society produced a few of Shelley's plays (Hellas among them) and printed several of his works. The Society's notebooks are largely a record of its internal politics (see Sylva Norman, The Flight of the Skylark, p. 268).

52 Oliver Madox Brown (1855-1874), the son of Ford Madox Brown, was a painter and writer. He published his first prose story, "Gabriel Denver," in 1873 and died the following year, at age 19, of blood poisoning after an attack of gout. He was a close friend of Philip Bourke Marston who published an article about him in Scribner's Monthly, 12 (1876), 425-28.

53 Sharp's next volume of poems was Romantic Ballads and Poems of Phantasy (London: Walter Scott, 1888).

54 Envelope postmarked November 27. Friday was November 26.

55 The Life of Percy Bysshe Shelley, 2 vols (London: Kegan, Paul, Trench \& Co, 1886).

56 Sharp's The Life of Percy Bysshe Shelley (London: Walter Scott) was published in 1887. It includes, following a table of contents, a single page "Note" which reads in part: "A special acknowledgment of indebtedness is due to Professor Edward Dowden, whose two comprehensive volumes on Shelley form the completest and most reliable record extant, and at the same time constitute the worthiest monument wherewith the poet's memory has yet been honored." 


\section{Chapter 4}

1 The Life of Percy Bysshe Shelley, Great Writers Series (London: Walter Scott, 1887).

2 I am indebted to Professor Terry Meyers for dating this letter.

3 What Is Art (1884). Seems to have been privately printed.

4 Richard Le Gallienne (1866-1947) went to London in 1889 to act as Literary Secretary for Wilson Barrett, an actor-manager who wrote a successful play, The Sign of the Cross (1895). There Le Gallienne became a frequent contributor to The Yellow Book and - along with Ernest Dowson, Lionel Johnson, Arthur Symons, and W. B. Yeats, among others - an original member of the Rhymer's club. Though ten years younger than Sharp, they became good friends. In the course of his life, Le Gallienne wrote nearly ninety books. Among them are twelve published in the 1890s: George Meredith: Some Characteristics (1890), The Book-Bills of Narcissus (1891), English Poems (1892), The Religion of a Literary Man (1893), Robert Louis Stevenson: An Elegy and Other Poems (1895), Quest of the Golden Girl (a novel, 1896), Prose Fancies (1896), Retrospective Reviews (1896), Rubaiyat of Omar Khayyam (1897), If I Were God (1897), The Romance Of Zion Chapel (1898), In Praise of Bishop Valentine (1898). After several visits to America, Le Gallienne settled there in 1903. In 1927, he began to visit Paris for long periods of time, and he moved permanently to France in 1930. See Richard Whittington-Egan and Geoffrey Smerdon's The Quest of the Golden Boy: The Life and Letters of Richard Le Gallienne (1962).

5 "Rossetti in Prose and Verse," National and English Review (formerly The National Review), 9 (March 1887), pp. 111-24. Sharp's footnote (pp. 122-23) reads as follows: "One of these [sonnets] may now be quoted with exceptional propriety. Since this article was written, Mr. Philip Bourke Marston - a wellknown poet and Rossetti's most ardent disciple - died suddenly, though after prolonged ill-health, at the early age of thirty-six. [Marston died on February 14, 1887.] As many will know, Mr. Marston was afflicted from childhood with blindness. Rossetti had for him a sincere regard: and in the collected works appears the following sonnet, which has hitherto been printed only in a critical biography of the older poet. The names of Mr. Marston's three books of poetry are Song-Tide, All-in-All, and Wind Voices." Sharp then reproduced Rossetti's sonnet: "To Philip Bourke Marston."

6 Editor of The Academy.

7 Sir Frank Thomas Marzials (1840-1912) succeeded Eric S. Robertson as editor of the Great Writers series for the Walter Scott firm. Marzials wrote the volumes on Dickens and Hugo and co-authored the volume on Thackeray (with Herman 
Charles Merivale). Eric Robertson, mentioned in the next sentence, was a close friend of Sharp's. (See note to Sharp's letter to Hall Caine dated 15 June 1884.) He had recently gone to India to occupy a chair of Literature and Logic at the University of Lahore (Memoir 127).

8 Probably a brother of Elizabeth A. Sharp.

9 May Clarissa Gillington's Byron's Poems was published by Elliot Stock in 1892. In addition to poetry, she wrote several books for children, as did her sister Alice E. Gillington.

10 Two more printings of this successful anthology appeared in 1886 and a second edition was published in 1887, which included a sonnet by May Gillington and the following note by Sharp: "A Miss Gillington has written and published some poetry of very considerable promise, for the most part as yet marked by a certain immaturity. A passion for the sea is manifest throughout her verse" (p. 289).

11 Richard Garnett, Life of Thomas Carlyle, Great Writers Series (London: Walter Scott, 1887).

12 An anthology of poems about the sea arranged by Elizabeth A. Sharp for the Canterbury Poets Series (London: Walter Scott, 1887).

13 The reference here is to Garnett's Io in Egypt and Other Poems, which was published in 1859. It was revised with additions and published as Poems in 1893.

14 Sharp's Life of Percy Bysshe Shelley was published as number 11 in the Great Writers Series (London: Walter Scott) in the autumn of 1887.

15 The Royal Jubilee Exhibition of 1887 was held in Manchester, England, to celebrate the Golden Jubilee of Queen Victoria's reign. It was opened by Princess Alexandra, wife of Edward, Prince of Wales, on 3 May 1887, and remained open for 166 days, during which there were 4.5 million paying visitors, 74,600 in one day alone. All manner of merchandize and crafts were exhibited in a huge hall, including paintings Sharp would review for the Glasgow Herald.

16 Philip Bourke Marston died after a prolonged illness on February 14, 1887 at the age of thirty-six. See note to Sharp's letter to Swinburne dated April 22, 1880.

17 Date from postmark.

18 Printed on stationary and crossed out: New Athenaeum Club, | 26, Suffolk Street, I Pall Mall.

19 Edward Dowden, "Victorian Literature," The Fortnightly Review, vol. 47, June, 1887, pp. 835-67. 
20 After taking his B.A. from Pembroke College, Cambridge in 1881, John Stuart Verschoyle (1853-1915) was appointed curate of the Church of the Holy Trinity, Marylebone, London in 1882. He entered enthusiastically into the city's intellectual and social life. He began functioning as associate editor of the The Fortnightly Review under the editorship of his friend Frank Harris in 1886, where he made most of the decisions and did most of the editing of the highly regarded publication. He left London in 1891 to serve as a Rector first in Suffolk and then in Somerset where he died in Taunton in 1915. After moving from London, he returned frequently and remained a well-known and respected figure in the city's literary and political circles.

21 Edward Silsbee was a sea captain from Massachusetts and an admirer of Shelley's poetry. "Many acquaintances called him 'Shelley mad' ... Richard Garnett, however, considered this maritime eccentric the best critic of Shelley he had heard" (Robert Gittings \& Jo Manton, Claire Clairmont and the Shelleys 1798-1879, New York: Oxford University Press, 1992, 235). Silsbee visited Claire Clairmont (see following note) in Italy in 1872 determined to gain access to her Shelley papers. Unable to purchase them, he moved into her apartment to read and study them. His efforts to obtain the papers, and the determination of Clairmont's niece, Paula, to marry Silsbee were described to Henry James by Eugene Lee-Hamilton. James drew upon the incident for his novella The Aspern Papers (1888) (Gittings, 236).

22 Clara Mary Jane Clairmont (1798-1879), who called herself Claire, was a stepdaughter of William Godwin and step-sister of Mary Godwin. When Shelley and Mary Godwin eloped, Claire accompanied them to the continent and remained with them throughout their excursion. That brought her in contact with Byron, of course, and their ensuing relationship produced a daughter, Allegra (18171822), who died of typhus after Byron assumed responsibility for her and placed her in a convent school. Clairmont traveled widely in Europe and became fluent in five languages. She lived in Russia, Germany, and France, before settling in Florence in 1870. She "contemplated writing a book to illustrate, from the lives of Shelley and Byron, the dangers and evils resulting from erroneous opinions on the subject of the relations between the sexes" (DNB).

\section{See note to Sharp's April 28 letter to Ford Maddox Brown.}

24 Ellen Louise Chandler Moulton (1835-1908), a writer of poetry, fiction, and children's stories, was married to the journalist and publisher William U. Moulton (d. 1898), who was also the editor of a weekly paper in Boston. She was prominent in literary and cultural circles in Boston, where she lived, and in Europe where she spent many summers. Her works include Juno Clifford (1855), Bed-Time Stories (1873), Poems (1877), Swallow Flights (1878), Miss Eyre from Boston, and Others (1889), and At the Wind's Will (1899). 
25 Tentative date from blurred postmark.

26 See note to Sharp's April 28 letter to Ford Maddox Brown.

27 Philip Bourke Marston (1850-1887), the son of John Westland Marston, a well-known man of letters, was blinded at the age of three by the administration of belladonna in an effort to cure scarlet fever. He began writing poetry at an early age and published his first volume (Song-Tide and Other Poems, 1871) when he was twenty-one.; his second (All in All, 1875) four years later; and a third (Wind Voices) in 1883. By then he had became a favored member of the circle of young men around Dante Gabriel Rossetti who introduced him to William Sharp in 1880. The two men became fast friends. Following Marston's death Sharp published a selection of his poems with an introductory Memoir in his Canterbury Poets Series (Song-Tide: Poems and Lyrics of Love's Joy and Sorrow) and a collection of his short stories (For a Song's Sake and Other Stories). Both were issued by the Walter Scott firm in 1888 .

28 "Obertoun, I Dumbartonshire" is printed on the stationary and crossed out.

29 Caine's The Deemster: A Romance in Three Volumes was published by Chatto \& Windus in London in November 1887. The book was very successful in English (52 editions by 1921), and it was translated into nine foreign languages. Sharp is proposing the sheets be sold to Appleton's, for whom Sharp served as an agent in these matters, and published simultaneously in the United States in order to establish U.S. copyright.

30 The October 1887 number of the Century Magazine contained an article by Edmund Clarence Stedman (see the "Life" section preceding Sharp's letters of 1889) on the younger generation of British poets, which was then published as a supplement to the thirteenth (Jubilee) edition of his Victorian Poets, the first edition of which, published in 1875, introduced the name "Victorian Poets" to define the British poets writing during Victoria's reign. He mentioned Sharp in the article in a section on Colonial Poets because of the Australian poems in Sharp's first volume of poetry, The Human Inheritance. According to Elizabeth, Sharp wrote a letter to inform Stedman he was not a Colonial, but a Scot." She reproduced one sentence of Sharp's letter to Stedman on page 129 of the Memoir and four more on page 150 (as given above). She must have had the entire letter along with many others her husband wrote to Stedman, but I have not located it. In his generous reply, quoted partially by Elizabeth, Stedman said he would mention Sharp preceding the section on Colonials in the forthcoming edition of Victorian Poets and would also mention Sharp's Rossetti book. These letters initiated a long friendship between Sharp and Stedman (Memoir 129).

31 Epipsychidion, ed. by S. A. Brooke, A. C. Swinburne and R. A. Potts, was published by the Shelley Society in 1887. The bibliography in Sharp's biography 
of Shelley, published in the fall of 1887, gives a date of 1886 for this work.

32 George Leon Little (1862-1941) was a landscape and portrait painter and the brother of J. S. Little. He painted the portrait of Ryder Haggard in 1886.

33 Probably Joseph William Gleeson White (1851-1898) who edited Ballads and Rondeaus; Chants Royal; Sestinas; Villanelles; Etc. for Walter Scott (Canterbury Poets) in 1887 and Book-Song: An Anthology of Poems from Books of Modern Authors for Elliot Stock in 1893. In 1896 and 1897 he served with C. H. Shannon as editor of The Pageant.

34 Next to this paragraph, Sharp wrote in the margin: "Our house, larger \& better than the one at West Kensington, is only ,60."

35 Caine's popular novel The Deemster (see note to Sharp's 1 September 1887 letter to Caine) was christened by Punch "The Boomster," and that name came to be applied also to its author as his fame grew, fed in part by his talent for selfpublicity. [Vivien Allen, Hall Caine, Sheffield: Sheffield Academic Press, 1997, p. 188]. The Deemster was successfully adapted to the stage in 1888 by Wilson Barrett, where it was titled Ben-my-Chree, and the play was revived several times over the next twenty years.

36 This novel was published by Hurst and Blackett, Ltd in late 1887 or early 1888 after running serially in The People's Friend (in Dundee) under the title $A$ Deathless Hate. The dedication to the three volume set: To I Theodore Watts | Poet-Romanticist-critic | These Pages I are I Affectionately Inscribed.

37 Unable to identify.

38 Alfred H. Miles (1848-1929) compiled and edited Poets and Poetry of the Century, nine volumes of which were published by Hutchinson between 1891 and 1894. Several were reprinted in later years.

39 The letter was written in early 1888 after the Sharps moved from West Kensington to South Hampstead. Richard Garnett's Emerson and Carlyle were both published in 1887 by Walter Scott in the Great Writers series.

40 Le Gallienne's My Ladies' Sonnets and Other "Vain and Amatorious" Verses, with Some of Graver Mood (Liverpool: privately printed, 1887). For Le Gallienne see note to Sharp's late February 1887 letter.

41 Although Mrs. Sharp states they took the house at 17a Goldhurst Terrace in the spring of 1887 (Memoir 141), this letter and Sharp's use of the Talgarth address in October 1887 indicate the move did not take place until early January 1888.

42 One hundred and four volumes appeared in the Canterbury Poets series 
between 1884 and 1922. Sharp became general editor of the series in 1885 and served until the early nineties.

43 Vol. XXIII, 943-59.

44 Under the Banner of St. James: A Romance of the Discovery of the Pacific (London: James Henderson and Sons, Ltd, 1887). Published serially in Young Folks Paper (XXI, 891-907) in 1887.

45 Jack Noel's Legacy: A Story for Boys (London: James Henderson \& Sons, Ltd., 1887). Published serially in Young Folks Paper in 1886.

46 Alexander Anderson (1845-1909), a Scottish poet, started his working life at a quarry, and then he became a surfaceman, or navvy, on the Glasgow and South-Western Railway. During the sixteen years he worked as a surfaceman he read and studied and taught himself French, acquired a knowledge of German, Italian and Spanish, and wrote poetry, some of which was published under the pseudonym Surfaceman. He served as Assistant Librarian at Edinburgh University from 1880 to1883 and again from 1886 to1905. From 1883 to 1886 he was Secretary of the Edinburgh Philosophical Institution. While still a surfaceman, he translated several poems of Heinrich Heine (1797-1856) from German. His poetry reflects his wide travels in Scotland: A Song of Labour and other Poems (1873), The Two Angels and other Poems (1875), Songs of the Rail (1878), and Ballads and Sonnets (1899). He also wrote many poems for children. His Later Poems was published posthumously in 1912.

47 Sharp's request must have been turned down as there is no record of his giving the proposed lectures.

48 This letter was probably written after Sharp's return from reviewing the Paris Salon in April.

49 Philip Bourke Marston's Wind-Voices, published by Stock in 1884.

50 Le Gallienne's review of Philip Bourke Marston's Song-Tides: Poems and Lyrics of Love's Joy and Sorrow, edited with an introductory Memoir by William Sharp (London: Walter Scott, 1888) appeared in The Academy, 33 (May 19, 1888), 337-38.

51 Sharp's Romantic Ballads and Poems of Phantasy was published in the spring of 1888 .

52 The Sharps lived at Wescam from January 1888 to Summer, 1890. The letter was probably written in early May, after Sharp returned from his annual trip to Paris.

53 Sir Noel Paton. 
54 See note to early May, 1888 letter to Le Gallienne.

55 Whitsuntide fell on May 20th in 1888.

56 Philip Bourke Marston.

57 Of this visit, Elizabeth Sharp recalled that Meredith and Sharp would have long conversations in the day, and at night Meredith would read to them from his novels: "The reader's enjoyment seemed as great as that of his audience, and it interested me to hear how closely his own methods of conversation resembled, in wittiness and brilliance, those of the characters in his novels" (Memoir 145).

58 See letter to Le Gallienne dated 22 May 1887.

59 Charles Grant Blairfinde Allen (1848-1899) was born in Canada and educated in France and in England where he graduated from Merton College, Oxford, in 1870. In his mid-twenties he became a professor at Queen's College in Jamaica. He left his professorship in 1876 and returned to England, where he turned his talents to writing and gained a reputation for his essays on science and for literary works. He published 30 novels and numerous other writings, including scientific articles praising Charles Darwin and advocating the theory of evolution. He sometimes used pen names such as "Cecil Power," "A. J. Arbuthnot Wilson," "Martin Leach Warborough," and as "Olive Pratt Rayner" he published a short novel entitled The Type-writer Girl. His best-known work, The Woman Who Did, published under his own name in 1895, created a firestorm as it main character was an independent woman who refused marriage and produced a child. His unconventional views on marriage were shared by Mona Caird and Elizabeth and William Sharp.

60 James Cotton, editor of the Academ.

61 The Wednesday after the Sharp's visit to Meredith at Box Hill was 23 May 1888 (Memoir 145).

62 E. A. S. identifies the novel as One of Our Conquerors, which was not published until 1891 (Memoir 145). Two of Meredith's novels were published in 1890: The Case of General Ople and Lady Camper and The Tale of Chloe: An Episode in the History of Beau Beamish.

63 The opening night of Ben-my-Chree, the adaptation of Hall Caine's The Deemster, was on May 17, 1888. See note to Sharp's fall 1887 letter to Hall Caine.

64 Norman Maccoll (1843-1905) was editor of The Athenaeum. His publications include Greek Sceptics from Pyrrho to Sextus (1869), Select Plays of Calderon (1888), and The Exemplary Novel of Cervantes (1902).

65 I have been unable to identify Mr. Osborne. 
66 The main letterhead of this stationery reads (left) Walter Scott, Publisher; (center) The Canterbury Poets, General Editor, William Sharp; and (right) 24 Warwick Lane, London, E.C. Below that at left is William Sharp and the return address.

67 Although this letter is written on 46, Talgarth Road stationery with the old address crossed out and the Wescam address written over it, it appears to postdate the letter of May 22, which mentions Le Gallienne's anticipated trip to London and promises to send Le Gallienne a copy of Romantic Ballads in a few days.

68 Sharp's brackets. Graham R. Tomson was the pseudonym for Rosamund Tomson (1860-1911), wife of J. Arthur Tomson. See note to Sharp's Fall 1888 letter to Richard Garnett.

69 Elizabeth Sharp stated (Memoir 140) that Walter Pater was one of the Sharps' frequent guests at their "Sunday informal evening gatherings" at Wescam. He came "during his Oxford vacation" in 1888 and at other times in 1888-90.

70 Romantic Ballads and Poems of Phantasy (London: Walter Scott, 1888).

71 Date from postmark.

72 Morayshire lies northwest of Aberdeen in Scotland. Roxburghshire lies south west of Edinburgh.

73 John Nichol (1833-1894) was Regius Professor of English Language and Literature at Glasgow University from 1862-1889. Sharp studied with him during his two years at Glasgow University - 1871-73 - and retained his valued friendship for many years. William Minto (1845-1893) was Professor of Logic and English at the University of Aberdeen.

74 Richard Garnett's Twilight of the Gods and other Tales was published in 1888 (London: T. Fisher Unwin). An "augmented" edition was issued in 1903 (London and New York: John Lane).

75 Henry Van der Weyde (1838-1924) was a Dutch-born English painter and photographer. His family emigrated to the United States in 1850, and he served in the American Civil War. He emigrated to England in 1870, and set up his photographic studio at 182 Regent Street in London in 1877. That year he became the first photographer to install and take portraits by electric light. He photographed many wealthy and well-known people, https://en.wikipedia.org/ wiki/Henry_Van_der_Weyde

76 Andrew Chatto (1841-1913) was the principal in Chatto \& Windus, a London firm that published works by many well-known writers in the latter half of the 
nineteenth and early twentieth centuries. Mrs. Caird was Mona Caird, a lifelong friend of Elizabeth Sharp.

77 The romance became eventually The Children of Tomorrow (London: Chatto \& Windus, 1890).

78 Romantic Ballads and Poems of Phantasy was privately printed for Sharp by Walter Scott in 1888.

79 Graham R. Tomson (1860-1911), ed., Greek Anthology, trans. by Garnett and others (London: Walter Scott, 1889). Born Rosamund Marriott Watson, Graham R. Tomson married at nineteen George Francis Armytage (1853-1921), a wealthy Australian with whom she had two daughters. In 1884 she published anonymously Tares (London: Kegan Paul, Trench, and Trübner), a volume of melancholy lyrics about love's transience with epigraphs from François Villon and D. G. Rossetti. In late 1884 she began a relationship with the painter Arthur Tomson (1859-1905), started calling herself Graham R. Tomson, divorced Armytage, and in 1887 married Tomson. In 1889 she successfully published under the pseudonym The Bird-Bride: A Volume of Ballads and Sonnets (London: Longmans, 1889), a volume aligned with aestheticism and with New Women movement in its exploration of marriage alternatives. Her A Summer Night (London: Methuen, 1891) aligned her with the decadents in its impressionism and representation of female desire. By 1892, she had become poetry critic for The Academy, art critic for The Morning Leader, President of the Literary Ladies, and the editor of Sylvia's Journal. In June 1894 she left Arthur Tomson and moved in with H. B. Marriott Watson (1863-1921). Tomson divorced her in 1895, but she never remarried. Her Vespertilia, and Other Verses was published in 1895 by John Lane at The Bodley Head. Though Vespertilia appeared under the signature of Graham R. Tomson, its author had renamed herself Rosamund Marriott Watson. Her reputation declined after Vespertilia, and she died at the age of 51 in 1911. She had counted Algernon Swinburne, William Morris, Christina Rossetti, and D. G. Rossetti among her early influences and, among her friends, Oscar Wilde, John Lane, W. E. Henley, Katharine Tynan, Alice Meynell, Violet Hunt, Elizabeth Pennell, and William Sharp. I am indebted to Linda K. Hughes for this information. See her Graham R.: Rosamund Marriott Watson, Woman of Letters (Athens: Ohio University Press, 2005), and biographies in The Yellow Nineties Online, http://1890s.ca/Contact_Us.aspx

80 Mathilde Blind. See note to Sharp ltr. to Watts of July 22, 1882.

81 Garnett's Twilight of the Gods and Other Tales.

82 Sharp's Life of Heinrich Heine was published (London: Walter Scott) in the Great Writers Series in fall 1888. Garnett wrote to Sharp on November 11, 1888 (Memoir 143-44) to say he had finished reading it and to congratulate him on the work. 
83 Olive Schreiner (1855-1920) was a South African novelist, political critic, and feminist. She had published The Story of an African Farm: A Novel in Two Volumes under the pseudonym "Ralph Iron" in 1883. Schreiner also wrote Woman and Labor (1911), From Man to Man (1926), and Undine (1928).

84 The North Wales Express was a weekly English language newspaper published in Caernarfon, Wales and edited by Robert Williams. A full-column and very positive review of Sharp's Life of Heine appeared anonymously in the issue of November 16, 1888. 


\section{Chapter 5}

1 This letter is included in a collection of letters to Richard Watson Gilder (1844-1909), who edited the Century Illustrated Monthly Magazine from 1881 until his death in 1909, and to Robert Underwood Johnson (1853-1937), who worked on the magazine under Gilder and served as editor from 1909-1913. A notation in the upper-left corner of the manuscript "ansd. 2/17/89" is in the same handwriting as similar notations on later letters addressed personally to Gilder. Gilder's editorship began when the Century Publishing Company bought out the Scribner interest in Scribner's Monthly (1870-1881) and renamed the magazine The Century Illustrated Monthly Magazine. By 1885 the Century had a huge circulation (over 200,000), but it began to decline in the nineties as its rising interest in feminism turned away many of its male readers. Also, the new photo-engraving techniques used by the competing ten- and fifteen-cent periodicals took its toll. Gilder's publications include The New Day (1875), The Poet and His Master (1878), Lyrics and Other Poems (1885), Lincoln's Genius for Expression (1909), and Grover Cleveland: A Record of Friendship (1910). Following his editorship of the Century, Johnson established the Hall of Fame at New York University and directed it from 1919 until 1937. In 1920 and 1921, he served as Ambassador to Italy. His works include Poems (published in 1902, enlarged in 1908, 1919, and 1931) and his Memoirs, Remembered Yesterdays (1923).

2 The novel was published as Children of Tomorrow: A Romance (London: Chatto \& Windus) in April 1889. It was issued in the United States in 1890 by F. F. Lovell \& Company.

3 A letter Sharp wrote to the Roberts Brothers Publishing Company in Boston has nearly identical wording. The third company that received a similar letter may have been F. F. Lovell and Company, which published the novel in the United States.

4 James Marshall Stoddart (1845-1921), who Sharp met when he visited Philadelphia in 1892, began editing Lippincott's Magazine in 1889, succeeding William Shepherd Walsh who was the editor when this letter arrived.

5 Sir George Brisbane Douglas (1856-1935), a Baronet, was a Scottish poet and a lecturer. Educated at Harrow and Trinity College, Cambridge, he combined the running of a large country estate with his literary and academic endeavors. The family seat was Springwood House, Kelso, in the Scottish Borders. His publications include Poems (1880), The New Border Tales (1892), Diversions of a Country Gentleman (1902), and The Pageant of the Bruce (1911).

6 Mrs. Hill was the sister of Sir Noel Paton. See note to Sharp's letter to D. G. Rossetti of September 22, 1881. 
7 James Mavor (1854-1925) was a social activist who lived in Glasgow and participated in several socialist organizations including the Fabian Society, the Social Democratic Federation, and the Socialist League. In 1894, George Bernard Shaw named a lead characters in his play Candida James Mavor Morell. In 1888 and 1889, Mavor edited The Scottish Art Review and in January through June 1890 that periodical's short-lived successor, The Art Review, which was published by Walter Scott through the good offices of William Sharp. In 1892 Mavor was appointed Professor of Political Economy at the University of Toronto where he chaired the Political Science Department until he retired in 1923. He was active in establishing the Toronto Art Gallery and the Royal Ontario Museum, and he wrote government reports on immigration, wheat production, workmen's compensation, as well as an Economic History of Russia.

8 A letter to Elizabeth Sharp from Mrs. Hill dated February 4, 1889 indicates she was sculpting a medallion of William Sharp, thus his sitting to her from 3 till 4.30. She hoped to get the medallion cast the week of February 4. Either she was still working on it in mid-February or she was sculpting a bust of Sharp, as she was wont to do of people she thought famous or special. Writing to her friend Elizabeth, addressed as Lilly, on the 4th, she was still under the spell of Sharp though he had gone: "I see so much of the growth of the Spirit in him, or expansion of Soul, I cannot put words upon it but you know the feeling of being in the presence of a Being from a higher Sphere?" This letter is in The Bancroft Library at the University of California, Berkeley.

9 Sir Patrick Geddes (1854-1932) was a man of many talents and interests. He established the Outlook Tower at the head of Edinburgh's High Street with its camera obscura and oversaw the building of Ramsay Gardens, a group of flats, artists' studios, and a student residence hall near the Outlook Tower. He was the central figure in the Scottish contingent of the Celtic Revival that began in the 1890s. Although Sharp was unable to meet him during this visit to Edinburgh, they met soon after and in 1895 Geddes named Sharp the Literary Editor of his Celtic-oriented publishing firm, Patrick Geddes \& Colleagues. Geddes went on to gain respect and fame as a city planner.

10 T. C. Martin, unknown friend of Mavor, perhaps the editor of The Leader.

11 Phoebe Anna Traquair (1852-1936), an illustrator, painter and embroiderer, was a prominent member of the Arts and Crafts movement. Joseph Thomson (1858-1894) was an explorer of Africa and a rival to Henry Morgan Stanley. Illness plagued his explorations, forced him to return permanently to England, and caused his early death. His best known book was Through Masai Land (1885). John Miller Gray (1850-1894) was an art critic and the first curator of the Scottish National Portrait Gallery. Sharp lamented his premature death in a letter to WattsDunton of October 11, 1894. 
12 Hall Caine's The Good Old Times was produced by Wilson Barrett at the Princess's Theatre in Oxford Street in February 1889. Barrett (1846-1904) was an actor, dramatist, novelist, and theater manager. His plays include Now-a-Days (1889), Pharaoh (1892), and The Sign of the Cross (1896). Barrett adapted several Caine novels for the stage, among them Ben-my-Chree (from The Deemster) (1888), The Manxman (1894), and The Bondman (1893).

13 Sharp's third volume of poems, Romantic Ballads and Poems of Phantasy, was published by the Walter Scott firm in 1888. Its sales exceeded expectations, and a revised edition was issued in late February 1889.

14 Norman MacColl (1843-1904) a native of Edinburgh, was a graduate of Downing College, Cambridge, where he excelled in classics and came to know Charles Dilke, proprietor of the Athenæum. In 1871 Dilke appointed him editor of the magazine for which Watts (later Watts-Dunton) served as Literary Editor. See Sharp's letter to Watts of 23 May 1888.

15 This incomplete letter is reproduced from a transcription/summary made by a staff member at the Manx Museum.

16 Sharp is referring to Caine's play Good Old Times, which was running in London.

17 The Manx's transcribed summary indicates this is Douglas Sladen, but Sharp was surely referring to Sir George Douglas with whom he was staying in Scotland when he wrote to Watts about Caine's play on 16 February 1889.

18 "Barrett's features were cast in a classic mould and his presence was manly and graceful. Hence his predilection for classical impersonations ... [H]is method of acting was usually stilted. In melodrama he presented heroic fortitude with effect. His dramas made no pretense to literature. They aimed at stage effect and boldly picturesque characterization without logical sequence or psychological consistency" (DNB, Supplement 1901-1911, p. 103).

19 Although lacking a salutation, this letter is from the Mavor Collection in the University of Toronto Library and was addressed to Mavor.

20 Henry Muhrman, an important impressionist painter best known as a watercolorist, was born in Cincinnati in 1854. He trained there and in Munich and died in Meissen, Germany, in 1916.

21 This reference dates the fragment as sometime in March 1889.

22 Date from postmark on envelope. Sharp became a candidate for this position in the spring of 1889 , but withdrew his candidacy before the election after consulting with his doctor (Memoir 149). 
23 Thomas Wentworth Higginson (1823-1911) was a New England essayist, poet, biographer, historian, Unitarian minister, and abolitionist. He was also, notably, colonel of the first black regiment in the Union army from 1862-64 as well as the "discoverer" of Emily Dickinson. His publications include Harvard Memorial Biographies (1866), his only novel, Malbone (1869), Young Folks History of the United States (1875), and Carlyle's Laugh and Other Surprises (1904).

24 The Afternoon Landscape: Poems and Translations (1889).

25 American Sonnets, selected and edited and with an "Introductory Note" by William Sharp published by Walter Scott in May 1889. Sharp dedicated it to E. C. Stedman, "the Foremost American Critic," who helped in the selection process.

26 Afternoon Landscape.

27 John Stuart Verschoyle (1853-1915) was a member of an aristocratic Ireland family who received his B.A. from Pembroke College, Cambridge in 1881 and was appointed Curate of the Church of the Holy Trinity, Marylebone in 1882. In London he became a friend and supporter of Frank Harris and secured for him the editorship of the London Evening News in 1883 and of The Fortnightly Review in 1886. Verschoyle assisted Harris in his editing and became formally an assistant editor of The Fortnightly Review in 1889. While living in London between 1882 and 1891, he made many friends in the literary and political worlds. After he left the city to take up Rectorships in Suffolk and Somerset, he maintained a London residence where he continued to entertain many luminaries. Sharp here expresses hope that Verschoyle will arrange a mention or review of his Children of Tomorrow in The Fortnightly.

28 The Sharp's leaving for Paris on Friday May 5 establishes the approximate date of this letter.

29 Probably Le Gallienne's second book of poetry, Volumes in Folio (1889).

30 A painting by George Leon Little (1862-1941), J. Stanley's brother.

31 James Sutherland Cotton, editor of The Academy.

32 This letter from Elizabeth Sharp to Mavor establishes her as the author of "Sculpture at the Salon," which appeared unsigned [pp. 13-14] immediately following her husband's unsigned [pp. 12-13] review of the Salon paintings in the June 1888 edition of The Scottish Art Review.

33 The letter must have been written in late May after the Sharps returned from Paris. Sharp's Children of Tomorrow, referenced in the postscript, was published about May 10, 1889.

34 Several words are obscured and illegible at this point. 
35 William Ernest Henley (1849-1903) was a poet and critic who edited The Magazine of Art from 1882 to 1886 and The London, a society paper, from 1887 to 1889, when he became editor of the Scots Observer, an Edinburgh journal of the arts and current events. He continued in that position when the magazine was transferred to London and re-titled the National Observer in 1890. He resigned that editorship in 1894. Whoever began spreading the word that he was about to become editor of The Scottish Art Review must have confused that journal with the Scots Observer. A robust, outspoken conservative sympathetic to the growing imperialism of the time, Henley was not well regarded by William Sharp and his circle of friends. Among his publications are Book of Verse (1880), Views and Reviews (1890), Poems (1901), and In Hospital (1901).

36 A landscape painter, Arthur Tomson (1858-1905) was introduced to the Sharps by Andrew Lang in the mid-1880s and through them he met his second wife, Agnes Hastings, a childhood friend of Elizabeth Sharp's. The Tomsons remained close friends of the Sharps.

37 Robert Alan Mowbray Stevenson (1847-1900), cousin of Robert Louis Stevenson, was a painter and art critic for The Pall Mall Gazette. He wrote The Art of Velasquez (1895), Peter Paul Rubens (1898), and Velasquez (1899).

38 Perhaps one of Sharp's two books published in 1889: Children of Tomorrow by Chatto \& Windus in April and the anthology of American Sonnets by Walter Scott in the Canterbury Series.

39 Since there was only one Sunday 23rd in 1889, the letter dates early June, 1889.

40 Frank Dempster Sherman (1860-1916) was a poet, architect, mathematician, and genealogist. His publications include Madrigals and Catches (1887), New Waggings of Old Tales (1888), Little-Folk Lyrics (1892), and A Southern Flight (1905). Date from postmark.

41 Date from postmark.

42 Children of Tomorrow.

43 The Athenaeum notice appeared in the issue of 13 July 1889. I have not located the review in Public Opinion.

44 The first edition was published in 1888 and the second in 1889 , both by Walter Scott. A "Postscript to the Second Edition" indicates the edition contained one or two textual variations from the original readings and a new short lyric, "The Isle of Lost Dreams."

45 Probably Miss Eyre from Boston, and Others (1889). 
46 Scollard (1860-1932) graduated from Hamilton College in 1881, studied at Harvard and Cambridge Universities, and served as Professor of English Literature at Hamilton College from 1888-96. He published many volumes of poetry, among them Pictures in Song, 1884; With Reed and Lyre, 1886; Old and New World Lyrics, 1888; and Ballads, Patriotic and Romantic, 1916.

47 Edmund Clarence Stedman (1833-1908), banker, poet, and critic, was born in Hartford, Connecticut. After opening his own brokerage office in New York in 1864, he became known as the "banker-poet" and exercised considerable influence over the American literary establishment in the eighties and nineties. He became William Sharp's best friend in the United States, and Sharp's letters to him became increasingly intimate. Their relationship became that of a father and son sharing their most intimate experiences in coded language. Excepting the few letters or portions of letters Elizabeth used in the Memoir, we have only Sharp's side of the correspondence, but Stedman's is often reflected in Sharp's responses. Stedman produced many books, among them Poems Lyrical and Idyllic (1860), Poetical Works (1875), Victorian Poets (1875), Hawthorne and Other Poems (1877), Lyrics and Idylls: With Other Poems (1879), Poems Now First Collected (1894), and A Victorian Anthology (1895).

48 Sir Charles G. D. Roberts (1860-1945), a writer of poetry and fiction, was a professor of English Literature at King's College, Windsor, Nova Scotia, between 1885 and 1895. His works include Orion and Other Poems (1880), In Divers Tones (1886), New York Nocturnes, and Other Poems (1898), Barbara Ladd (1902), The Heart That Knows (1906), The Vagrant of Time (1927), and Selected Poems (1936).

49 Bracketed sections are Elizabeth's paraphrases.

50 James Wilberforce Longley (1849-1945), a judge and historian born in Paradise, Nova Scotia, edited The Halifax Chronicle and served as Attorney General of Canada between 1884 and 1896. He was the author of two biographies: Joseph Howe (1904) and Sir Charles Tupper (1916).

51 William Bliss Carman (1861-1929), a cousin of Charles G. D. Roberts, was a Canadian literary journalist, editorialist, and poet. He worked for various magazines, including the New York Independent (1890-92) and the Atlantic Monthly. After 1889, he spent the rest of his life in the U.S.A., although he was a frequent visitor to Canada. His reputation rests on his first collection of poems, Low Tide on Grand Pré (1893). His other works include Behind the Arras: A Book of the Unseen (1895), Ballads of Lost Haven: A Book of the Sea (1897), By the Aurelian Wall, and Other Elegies (1898), April Airs (1916), Later Poems (1921), Ballads and Lyrics (1923), Far Horizon (1925), Wild Garden (1929), and Sanctuary (1929).

52 Having traveled from St. John to the St. Lawrence River via the St. John River and overland to Rivière du Loup, Sharp made a side excursion up the Saguenay 
River for 100 miles to Ha! Ha! Bay before proceeding up the St. Lawrence to Montreal.

53 George Stewart (1848-1906) was an accomplished and celebrated editor and writer. In Saint John, New Brunswick, he founded and edited Stewart's Literary Quarterly Magazine from 1867 to 1872 . In 1879 he went to Quebec where he edited the Daily Chronicle until 1896. A voluminous writer, his chief works are Canada Under the Administration of the Earl of Dufferin (1878) and The Story of the Great Fire in St. John, New Brunswick (1877). The New Brunswick Literary Encyclopedia, w3.stu.ca/stu/sites/nble/index.aspx

54 Sir James MacPherson Le Moine (1825-1912), a charter member of the Royal Society of Canada, was an antiquarian and the author of Maple Leaves, 6 vol. (1863-1906), a collection of short sketches on the general and local history and legends of Canada. The site of a Huron village established in 1697, Lorette is now Loretteville, a suburb of Quebec.

55 Rev. Joseph Antisell Allen (1814-1900) was the father of Sharp's good friend Grant Allen. A clergyman of the Irish Church, J. A. Allen emigrated to Canada in 1840 where he married Catharine Ann Grant, the daughter of Charles William Grant, 5th Baron de Longueuil, a title created by Louis XIV in 1700, and the only title in Canada that is officially recognized. The Reverend Allen became the first Anglican minister of Holy Trinity Church on Wolfe Island, near Kingston, Ontario where Grant Allen was born in 1848. Allen was living in Alwington, an area of Kingston and the name of the great house in that area where Allen probably lived.

56 The accompanying note reads: THE NOOK. I HORSHAM ROAD.I DORKING. I July 27. | My Dear Father, | Just a line to introduce our very good friend William Sharp, whom you probably know as the author of a life of Rossetti, and of many graceful poems. He is his own best credential. If you like him half as much as we do, you will welcome him well. In haste (for we're just off) I Yours affectionately. I Grant.

57 Sherburne Hardy (1847-1930), a civil engineer, editor, novelist, poet, and later a diplomat, was a Professor of Mathematics at Dartmouth College. He edited Cosmopolitan for two years, 1893-95. His works include Francesca of Rimini (1878), But Yet a Woman (1878), The Wind of Destiny (1886), Passe Rose (1889), Aurélie (1912), and Things Remembered (1923).

58 John Henry Wright (1852-1908), a distinguished classical scholar and student of educational problems, left Johns Hopkins to become Professor of Greek at Harvard in 1887. Justin Winsor (1831-1897), a librarian and historian, was superintendent of the Boston Public Library from 1868 until 1877 when he became librarian at Harvard. His works include Bibliography of the Original 
Quartos and Folios of Shakespeare (1876) and (as editor), the Narrative and Critical History of America (1884-89), https://en.wikipedia.org/wiki/Justin_Winsor.

59 Arthur Sherburne Hardy.

60 Sharp first met William Dean Howells in Venice in 1883 (see letter dated 10 May 1883 to Elizabeth Sharp). See Chapter 2, note 49.

61 The Stedmans lived at 44 East 26th Street; Sharp probably arrived there on Tuesday September 17 as indicated in the previous letter to Stedman.

62 Henry Mills Alden (1836-1919) was managing editor of Harper's Weekly from 1863 to 1869 and then editor of Harper's Magazine until his death in 1919. His works include God in His World (1890) and Magazine Writing and the New Literature (1908). For more about Alden, see note to Sharp's letter to E. A. S. dated late September 1889.

63 Henry C. Bowen (1813-1896) a principal in the firm of Bowen and McNamee, wholesale dealers in silk, was one of the publishers of the New York Independent, a weekly religious journal, from 1848 to 1896 and edited the magazine from 1870 until 1896. Sharp published in the Independent between 1889 and 1893.

64 Richard Henry Stoddard (1825-1903), a poet, editor, and critic, was opposed to literary pretense and "Bohemianism." During the last thirty years of his life, his house was a favorite meeting place for literary men in New York. His works include Poems (1851), Songs of Summer (1857), Abraham Lincoln: A Horatian Ode (1865), The Book of the East (1867), and The Lion's Cub (1890).

65 Thomas Allibone Janvier (1849-1913), a native of New Orleans, worked in Philadelphia as a journalist with the Times, the Evening Bulletin, and the Press between 1871 and 1880. There he met and married in 1879 Catharine Ann Drinker (1841-1922), a member of the distinguished Drinker family. (She was an aunt and the namesake of the twentieth-century novelist Catherine Drinker Bowen.) For three years, starting in 1880, the Janviers traveled in Colorado, New Mexico, and Mexico. In 1883, they settled in New York's Greenwich Village, where they lived for a decade. In 1893, they began spending winters in Provence, stopping in London briefly while in transit. After this first meeting in 1889, the Janviers became close friends of both Sharps. "Mrs. Janvier was the first person on either side of the Atlantic to penetrate Sharp's disguise as Fiona Macleod, and she received a letter [from Sharp on Jan. 5, 1895] admitting the identity" (Dictionary of American Biography, vol. V., pp. 613-14). Thomas Janvier's publications include Color Studies (1885); The Mexican Guide (1886); The Aztec Treasure House (1890); Stories of Old New Spain (1891); Embassy to Provence (1893); In Old New York (1894); In Great Waters (1901); Henry Hudson (1909); and From the South of France (1912). 
66 Charles DeKay (1848-1935), an essayist and poet, was an editorial writer for the New York Times. His works include The Bohemian: A Tragedy of Modern Life (1878), Hesperus, and Other Poems (1880), The Vision of Nimrod (1881), The Vision of Esther (1882), and Bird Gods (1898).

67 This letter was written before Sharp sailed on the "Sierra" from New York to Liverpool, post-dated, and given to a florist to deliver with flowers to Stedman on October 8th, Stedman's birthday (see next letter).

68 Arthur Stedman was Edmund Clarence Stedman's son.

69 Sir Alfred East (1849-1913) was named to the Royal Academy in 1899. His paintings were widely displayed in Europe and the United States. He also wrote The Art of Landscape Painting in Oil Color (1906).

70 Thomas Robert Macquoid (1820-1912) was a prolific watercolorist and illustrator for, among other publications, the Graphic and Illustrated London News. His wife Katherine Sarah Macquoid (1824-1917) was an equally well-known travel writer and novelist. " 1889 " is written in pencil on the letter. Mid-October 1889 is a reasonable date since Sharp had just returned from the United States and Canada where he had been entertained by Roberts.

71 See note to November 6 card to Kineton Parkes (following).

72 Mary Elizabeth Mapes Dodge (1831-1905), an editor and children's writer, published adult fiction in The Atlantic Monthly, Harper's Magazine, and The Century. In 1870 she became an associate editor of Hearth and Home, and from 1873 until her death, she edited the juvenile magazine, St. Nicholas. Her works include Hans Brinker: or, The Silver Skates (1865), A Few Friends and How They Amused Themselves (1869), Rhymes and Jingles (1874), Along the Way (1879, republished in 1904 as Poems and Verses), Donald and Dorothy (1883), When Life is Young (1894), and The Land of Pluck (1894).

73 The date stamped on the postcard looks like 8/89, but Sharp was on his way to America on that date. Shortly after returning from the United States in mid- October, he went to Cologne to meet his wife, who had been staying with Mona Caird at Veldes in the Carpathian Alps during her husband's absence. The card's probable date is 6 November 1889, the day he also sent a card to Robert Underwood Johnson, which he dated and in which he says he had just returned from Germany. W. Kineton Parkes (1865-1938), a novelist and critic, edited Comus from November 1888 to October 1889. He also edited The Library Review in 1893-1894. His works include Shelley's Faith: Its Development and Relativity (1888), The Pre-Raphaelite Movement (1889), The Painter Poets, ed. for the Canterbury Poets Series (1890), Love a la Mode: A Study in Episodes (1907), Potiphar's Wife (1908), The Altar of Moloch (1911), The Money Hunt: A Comedy of 
Country Houses (1914), Hardware (1914), and The Art of Carved Sculpture (1931).

74 Mavor's response appears at the bottom of the telegram: "Glad to have poem Browning." Mavor was the editor of The Scottish Art Review and its shortlived successor, The Art Review, which appeared monthly from January to July 1890. Sharp's long elegiac poem (twelve stanzas) on Browning appeared in the February number of The Art Review. For more on Mavor, see note to Sharp's February 10, 1889 letter to him.

75 Shortly after Robert Browning died on December 12, 1889, Sharp agreed to write a biography of Browning for Walter Scott's Great Writers Series. Sharp's poem "In Memoriam: Robert Browning," appeared in the January 1890 issue of Belford's Magazine, a periodical published by Belford, Clarke, \& Co. in Chicago.

76 For Henry Bowen, see note to late September 1889 letter to Elizabeth Sharp.

77 This letter is interesting because it was dictated to Sharp's sister Mary and is in her hand. Several years later Sharp decided to reinforce the independent identity of Fiona Macleod by having Mary copy all her letters and send them from Edinburgh where she lived. Her handwriting became that of Fiona Macleod. This is the only instance discovered so far of Sharp's using Mary as an amanuensis prior to the advent of the Fiona Macleod letters in 1894.

78 Sharp's hand concludes the letter from this point.

79 A poem by Sharp entitled "Remembrance" appeared in the Century, which Gilder edited, in December 1891. See note to Sharp's letter dated 11 January 1889. 


\section{Chapter 6}

1 "Six months of life are enough for me; the seventh month I solemnly promise to the underworld [or the god of the underworld, or death]." This is a line of poetry quoted by Cicero in De Finibus, 2.7.22.

2 A Library of American Literature from the Earliest Settlement to the Present Time, ed. Edmund Clarence Stedman and Ellen Mackay Hutchinson, 11 vols. (1889-1890).

3 E. C. Stedman's son.

4 The Sharps vacated their house on Tuesday, June 24. This letter was written several days earlier.

5 George Meredith.

6 Sharp's edition of C. A. Sainte Beuve's Essays on Men and Women (London: David Stott, 1890). On February 22, 1890, Sharp had told Lane the Sainte Beuve volume would be dedicated to Meredith.

7 Date from postmark on card.

8 Sharp's "Fragments from the Lost Journals of Piero di Cosimo" appeared in the January and June numbers of The Art Review in 1890.

9 Robert Allan Mowbray Stevenson (1847-1900), a first cousin and close friend of Robert Louis Stevenson and a painter, was well known in the art world of Paris and London in the 1870s. After his marriage in 1881, he found his inheritance nearly exhausted and turned to teaching and writing about art. He last exhibited at the Royal Academy in 1885. He spent his later years as the art critic for The Pall Mall Gazette. He wrote The Art of Velasquez (1895), Peter Paul Rubens (1898), and Velasquez (1898). See note to Sharp's April 1889 letter to Mavor.

10 Sharp's The Life and Letters of Joseph Severn was published in London by Sampson Lowe, Marston \& Co. in March 1892.

11 The date, written in pencil on the first page of the manuscript, may have been taken from the postmark of the envelope which is missing. The content confirms the date approximately.

12 The Painter Poets Parkes was editing for Walter Scott's Canterbury Poetry Series. Sharp was general editor of the series. See letter dated May 29, 1890.

13 Mary Sharp was Sharp's unmarried sister who lived with their mother in Edinburgh. She occasionally did secretarial work for Sharp, and later she provided the handwriting for Fiona Macleod, a service essential for maintaining the fiction of her separate identity. 
14 Date from postmark. A note in a different hand at the top right of this postcard reads "Ansd Au 26.90."

15 William Wetmore Story (1819-1895) was an American sculptor, poet, and novelist who moved permanently to Rome in 1850. The Story's apartment became a gathering place for American and British artists and writers, among them the Brownings, Hawthorne, Thackeray, Lytton, and Henry James who wrote his biography. Roba di Roma (1862), according to Peter Gunn, is the novel in which Story's "humanity, humor and erudition are most clearly seen." Violet Paget, 1856-1935 (London: Oxford University Press, 1964), p. 45.

16 The Life and Letters of Joseph Severn (1892).

17 "The Coves of Crail" and "Paris Nocturne" were published in the July 3rd issue of The New York Independent, for which Bliss Carman was an editorial writer. See note to letter to Carman dated mid-May, 1890.

18 Mavor, who is leaving for a holiday in Ireland, must have been staying in Broadhurst Gardens, a street in north London not far from where the Sharps were staying with the Cairds in Hampstead.

19 On March 18, 1890, Sharp asked Mavor if Wedmore could review his Browning book in The Art Review. The review appeared in early July.

20 Sharp's "Piero di Cosimo" appeared in the January and June numbers of The Art Review.

21 See Sharp's letter to Eric Robertson on his birthday (February 18) in 1886 and the Introduction to the 1886 letters for more on the relationship between Sharp and Robertson. Sharp and Robertson were close friends in the mid-eighties, before Robertson left in the Spring of 1887 to fill a chair in literature and logic at the University of Lahore.

22 See mid-May letter to Bliss Carman.

23 Date from postmark on envelope. The Sharps were in the west of Scotland from mid-August until mid-September. See itinerary in Sharp's 15 August letter to Robertson.

24 Philip Bourke Marston, whose desk Sharp inherited after Marston's death in January 1887.

25 October 8th.

26 A Library of American Literature from the Earliest Settlement to the Present Time (1889-1890). 


\section{E. C. Stedman's son.}

28 This letter was written on the day the Sharps returned from Scotland to London where they were staying briefly with Elizabeth's mother before leaving for Germany. It was written two or three days before the proposed afternoon tea with Eric Robertson and George Meredith on Saturday which was October 4 in 1890. On Saturday, the 11th, the Sharps were in Heidelberg.

29 E. A. S. (Memoir 168) said they went to Clynder on the Gareloch, Argyll, in July, 1890, "to be near my husband's old friend, Dr. Donald Macleod, who, as he records in his diary, 'sang to me with joyous abandonment a Neapolitan song, and asked me to send him a MS. from Italy for Good Words, '" a Scottish magazine directed at evangelicals and nonconformists, particularly of the lower middle class. Donald Macleod (1857-1916), the Rector of Park Church in Glasgow and a repository of Gaelic lore, became Editor in 1872 and began to include more illustrations and fiction and fewer sermons. Sharp had spoken with Macleod about the possibility of his publishing, perhaps serially, Watts's novel Aylwin, and he now forwards Macleod's positive response to Watts.

30 Percy Macquoid (1852-1925) was a theatrical designer and a collector and connoisseur of English furniture. He wrote articles, largely for Country Life, and four books on the history of English furniture. He was the son of Thomas Robert Macquoid (1820-1912) a painter and editor who worked for several periodicals, among them Graphic and The Illustrated London News, and of Katharine Sarah Macquiod (1824-1917), who was also a painter, and an author of fiction and poetry. Sharp was a friend of Percy's parents, and Percy must have contacted Sharp about writing a book for Walter Scott. Elizabeth's mother was having a dinner party on Saturday, October 11 as send-off for Elizabeth and William who left for Germany on Sunday, October 12.

31 "American Literature," National Review, 17 (March 1891), 56-71. This is a review of Stedman's Library of American Literature.

32 Blanche Willis Howard (1847-1898), an American novelist who married Dr. Julius von Teuffel, the court physician of Württemberg, in 1890. She continued to write under her maiden name and collaborated with William Sharp on A Fellowe and His Wife (London: Osgood \& Mcllvain, 1892). Her other works include One Summer (1875), Aunt Serena (1881), Guenn: A Wave on the Breton Coast (1883), The Open Door (1889), No Heroes (1893), Dionysius the Weaver's Heart's Dearest (1899), and The Garden of Eden (1900).

33 This fragment of a letter to a friend appears in the Memoir (169-70) where it is introduced by Mrs. Sharp as follows: "Early in October my husband and I crossed to Antwerp and stopped at Bonn. The Rhine disappointed William's expectations." 
34 Margaret Wilson Oliphant (1828-1897) was a well-known and prolific writer of fiction and essays about literature. She was born in Scotland, but lived most of her life in England, near Wimbledon. Much of her work was published by Blackwood \& Sons, in Edinburgh. She is best known for her seven-novel series under the general title Chronicles of Carlingford. For a time, she was editor of Foreign Classics for English Readers, a series of books about foreign writers published by Blackwood \& Sons. This letter proposing a book on Sainte-Beuve for this series was probably addressed to Blackwood's, where his proposal would be reviewed by someone else if Mrs. Oliphant were no longer editor of the series. Sharp's proposal was not accepted by Blackwood's. See Elisabeth Jay, Mrs. Oliphant: A Fiction to Herself (Oxford: Oxford University Press, 1990).

35 Sainte-Beuve's Essays on Men and Women was published by David Stott in London in 1890. The essays were translated by William Matthews and Harriet W. Preston, and Sharp wrote a brief introduction.

36 Blanche Willis Howard.

37 Elizabeth Sharp's aunt.

38 "The Coves of Crail," which appeared in July, 1890.

39 The Reverend Frederick Langbridge (1849-1922) was a Church of Ireland clergyman in Limerick, and also a poet, novelist, and playwright. The author of many novels, among them The Dreams of Dania (1897), he was also a successful dramatizer of novels. His adaptation of A Tale of Two Cities (The Only Way) had a long run in London in 1899. Sharp is attempting to gain notice among reviewers and readers for one of Langbridge's publications.

40 Horace Elisha Scudder (1838-1902), editor, biographer, and juvenile writer, was a general editorial assistant for the publishers Hurd \& Houghton (later Houghton, Mifflin) and edited The Atlantic Monthly from 1890 to 1898. His works include Seven Little People and Their Friends (1862), Dream Children (1864), Stories and Romances (1880), Noah Webster (1882), Men and Letters (1887), George Washington: An Historical Biography (1890), Childhood in Literature and Art (1894), and James Russell Lowell: A Biography (1901).

41 "Dionysos in India" was published under the pseudonym William Windover in August 1892, in the first and only number of The Pagan Review, a periodical Sharp edited under the pseudonym W. H. Brooks. He wrote everything in the volume under various other pseudonyms.

42 In a letter dated July 25, 1890, Sharp encouraged Carman to publish a volume of his poems first in England, but that did not happen. Carman's first volume of poems, Low Tide on Grand Pré, was published in New York in 1893. The reference here must be to the appearance of one of Carman's poems in a periodical. 


\section{Chapter 7}

1 Richard Garnett (1835-1906), English librarian and author, entered the British Museum in 1851 as an assistant and rose to be superintendent of the readingroom in 1875. From 1890 to 1899, when he retired, he was the Keeper of Printed Books (or Chief Librarian), a post his father held for many years. He also wrote and published extensively. Among his publications were biographies of Carlyle (1887), Emerson (1887), Milton (1890), Edward Gibbon Wakefield (1898); a volume of original, fanciful tales, The Twilight of the Gods (1888); a tragedy, Iphigenia in Delphi (1890); A Short History of Italian Literature (1898); and Essays of an Ex-librarian (1901).

2 Elihu Vedder (1836-1923), a painter and illustrator of considerable merit, was born in New York of Dutch ancestry. Having decided to become an artist, he went to Europe to study and fell in love with Italy. He lived most of his life in Rome where he became a central figure in the expatriate life of the city. He is best known for his illustrations for the Rubaiyet of Omar Khayyam, the first edition of which was published with the poem in 1884 and sold out in six days.

3 Probably "Lilith," a prose outline of which he read to Elizabeth on January 9 (Memoir 176).

4 "Paris Nocturne" was printed in the December 25, 1890, issue.

5 On January 8, 1891, Sharp wrote in his diary: "After dinner copied out 'Rebirth' (Spring's Advent) to send to Belford's, and 'The Sheik' for The Independent" (Memoir 175). Neither poem was accepted for publication, but Elizabeth included "Spring's Advent" in her 1910 edition of the poems Sharp published under his own name. "The Sheik" remains a mystery. Sharp wrote a poem titled "The Sheik (A Portrait from Life)" in El Ah'bra, Morocco when he and Elizabeth visited North Africa in January/February, 1893. That poem, perhaps because of its homoerotic shadings, appears to exist only in a fair copy manuscript in private hands.

6 Elizabeth Sharp stayed in Rome until mid-March and then went to Florence (Memoir 181). Sharp stayed in Rome through the end of March to oversee the final proofing of Sospiri di Roma.

7 Sharp is commenting on the critical reception of Sospiri di Roma (1891).

8 Coulson Kernahan (1858-1953) was a writer of fiction, criticism, recollections, and imaginative and religious studies who co-edited, with Frederick LockerLampson, Lyra Elegantiarum (1891), a standard anthology of light verse. His works include A Dead Man's Diary (1890), Wise Men and a Fool (1901), In Good Company (1917), Swinburne as I Knew Him (1919), and Six Famous Living Poets (1926). 
9 Charles G. D. Roberts. See note to Sharp's letter to E. C. Stedman dated July $27,1889$.

10 Walter Severn (1830-1904), a painter, was the son of Joseph Severn, also a painter and a friend of John Keats. Severn in 1885 asked Sharp to write a biography of his father and, when Sharp agreed, loaned him a large trove of papers by and about Joseph Severn, including unpublished manuscripts and letters. For additional information about Sharp's Severn biography, see Memoir 168 and note to Sharp's December 1885 letter to Edward Dowden. Sharp wrote most of his Life and Letters of Joseph Severn in the summer of 1891, finishing it at the end of August, and it was published in March 1892 by Sampson Low \& Co. in London and Charles Scribner's Sons in New York. On August 24, 1891, he had lunch with Joseph Severn's youngest brother, Charles Severn, who was 86 years old. Charles confirmed what he had told Sharp the previous September that Keats composed his Nightingale ode after spending a night under a tree in Hampstead listening to the bird's song (Memoir 186).

11 "The Second Shadow: Being the Narrative of Jose Maria Santos y Bazan, Spanish Physician in Rome" was accepted by Bliss Carman and published in The Independent on August 25, 1892.

12 The Sharps went to Stuttgart so he could collaborate with Blanche Willis Howard on A Fellowe and His Wife.

13 The salutation and content of this letter indicate clearly it was addressed to Bliss Carman.

14 Charles G. D. Roberts. See note to Sharp's letter to E. C. Stedman of July 27, 1889.

15 I have been unable to identify this person.

16 Edmund and Laura Stedman; Catharine and Thomas A. Janvier.

17 The Life and Letters of Joseph Severn appeared in March 1892.

18 "The White Gull" (1892) is an elegy subtitled "For the Centenary of the Birth of Shelley."

19 The Life and Letters of Joseph Severn (1892).

20 William Sharp, "Joseph Severn and His Correspondents," Atlantic Monthly, LXVIII (Dec. 1891), pp. 736-48.

21 Richard Westmacott (1799-1872), the son of Sir Richard Westmacott, also a sculptor, was Professor of Sculpture at the Royal Academy from 1857 to 1867 and was a well-known writer and lecturer on art. 
22 George Richmond (1809-1896), an English painter and a member of Blake's circle, was a fashionable portrait painter.

23 Ruskin's letter included his first impressions of Venice and his criticism of English artists (particularly those of the Royal Academy) and English art: "It isn't of any use to try and do anything for such an age as this. We are a different race altogether from the men of old time: we live in drawing-rooms instead of deserts, and work by the light of chandeliers instead of volcanoes"' (p. 740, see note 2 ).

24 Seymour S. Kirkup (1788-1880) was a painter and one of a group of young men who were friends and disciples of William Blake. Later he settled in Italy and became a leader of Anglo-American literary society in Florence where he spent most of his life.

25 Thomas Fisher Unwin (1848-1935) founded the publishing house T. Fisher Unwin in 1882 and was a joint founder of the First Council of the Publishing Association.

26 The Life and Letters of Joseph Severn was published in March 1892.

27 "Joseph Severn and His Correspondents" was published in the December 1891 issue of Atlantic Monthly.

28 A second Sharp article on Severn, "Severn's Roman Journals," appeared in The Atlantic Monthly in May 1892, 631-44.

29 A Fellowe and His Wife (1892).

30 The Atlantic Monthly did not publish any poems by Sharp in 1891-1892.

31 "Wm. Sharp, Oct 8-'91" is written in another hand at the top left of the letter's first page. This is the date of Stedman's birthday and indicates approximately when the letter was received. Sharp regularly wrote birthday letters to Stedman after they met in New York in the summer of 1889, and many have survived. Also written in pencil on the top left of the first page: "J. B. Pond - show him" and "For Dr. Lambert from L. S. Y. [?]."

32 Again, Sharp puts his letter address in London at the top of the page.

33 "The Second Shadow, Being the Narrative of Jose Maria Santos y Bazan, Spanish Physician in Rome" was published in The Independent, 44 (August 25, 1892), $1205 \mathrm{ff}$.

34 The Sharps were in Stuttgart from early September to mid-October.

35 Derby: Frank Murray, 1891. 
36 Le Gallienne married Eliza Mildred Lee on October 22, 1891.

37 Edward John Trelawny (1792-1881) was a friend of Shelley and Byron and author of Recollections of the Last Days of Shelley and Byron (1858).

38 Rayner Storr (1835-1917) was the author of a concordance to the Latin original of the four books known as De Imitation Christi: Given to the World A. D. 1441, by Thomas a Kempis: With full contextual quotations by Rayner Storr (1910)."

39 William Ewart Gladstone (1809-1898), a graduate of Eton and Oxford, dominated British politics throughout the century. As head of the Liberal Party, he first served as Prime Minister in 1868-74.

40 Walter Severn, Joseph Severn's son.

41 Staff members in the British Museum's Department of Printed Books. See note to Sharp's early January 1891 letter to Garnett.

42 In the Memoir, E. A. S. prefaced this letter as follows: "The brilliant summer was followed by a damp and foggy autumn. My husband's depression increased with the varying of the year. While I was on a visit to my mother he wrote to me, after seeing me in the morning." Following the letter, she wrote: "His health was so seriously affected by the fogs that it became imperative that he should get into purer air so he decided to fulfill his intention of going to New York even though he had been forced to relinquish all ideas of lecturing." He began planning this trip to the United States when he was in Germany in September. See Sharp's late September 1891 letter to E. C. Stedman.

43 Edmund Schérer, Essays on English Literature, trans. George Saintsbury (1891).

44 Jules Breton, Life of an Artist: Art and Nature, trans. Mary J. Serrano (1891).

45 William Edmonstone Aytoun's Firmillian: or, the Student of Badajoz: A Spasmodic Tragedy (1854) was published under the pseudonym, T. Percy Jones.

46 Charles G. D. Roberts. See note to Sharp's July 27 letter to E. C. Stedman.

47 Like Bliss Carman, Clarence Winthrop Bowen (1852-1935) wrote for The Independent, and he served as publisher of that paper from 1896-1912. He was also an historian, his most famous work being The History of the Centennial Celebration of the Inauguration of George Washington as First President of the United States (D. Appleton, and the Committee on the Centennial Celebration of the Inauguration of Washington as President, New York: 1892), a beautiful book designed in part by the architect Stanford White and a monument of New York's gilded age. Bowen was one of the principal founders of the American Historical Association in 1884. 
48 Romantic Ballads and Poems of Phantasy (1881) and Sospiri di Roma (1891). This "new imaginative work" was the brief dramatic sketches Sharp published in 1894 as Vistas (Derbyshire, Moray Press). In his diary for October 1891 (Memoir 190-91), Sharp mentions that he has completed two "Dramatic Interludes" ("Northern Night" and "The Birth of a Soul") and has begun "The Passion of Manuel van Hoëk." All three works appeared in Vistas, the latter under the title "The Passion of Pere Hilarion."

49 The December 1891 number of The Atlantic Monthly contained Sharp's “Joseph Severn and His Correspondents."

50 This article became "Severn's Roman Journals" which appeared in The Atlantic Monthly in May 1892.

51 John Ruskin, Praeterita: Outlines of Scenes and Thoughts Perhaps Worthy of Memory in My Past Life, 3 vols. (1885-1900).

52 The proposed double article became one article: "Severn's Roman Journals," Atlantic Monthly, May 1892.

53 Meaning "potpourri".

54 Giacomo Antonelli (1806-1876) was premier of the first constitutional ministry of Pius XI.

55 John Gibson (1790-1866) was an English neo-classicist sculptor who spent most of his life in Rome.

56 Friedrich Oberbeck (1789-1869) was a German painter who made extensive use of religious symbolism and initiated a Pre-Raphaelite movement in Germany.

57 Charlotte Saunders Cushman (1816-1876) was a well-known and popular American actress who lived and traveled in London and Rome in the 1850s and 1860s.

58 Harriet Hosmer (1830-1908), an American sculptor and poet, studied under John Gibson in Rome. 


\section{Chapter 8}

1 For information about Le Gallienne, see Sharp's letter to him in late February 1887.

2 Hall Caine, a disciple and biographer of Dante Gabriel Rossetti, was a close friend of Sharp's in the early 1880s. Shortly after Rossetti died in 1882, Caine, a native of the Isle of Man, moved to Liverpool to work as a reporter for the Liverpool Mercury. For more about Caine, see note to Sharp's letter to Rossetti of March 1880.

3 The Book-Bills of Narcissus (Derby: Frank Murray, 1892).

4 Le Gallienne's English Poems (London: Elkin Mathews and John Lane, 1892).

5 Sharp's Life and Letters of Joseph Severn (London: Sampson Lowe, Marston \& Co: March, 1892).

6 Sharp visited Louise Chandler Moulton on January 26 or 27 while staying with the Scudders in Boston.

7 A Fellowe and His Wife (London: James R. Osgood, Macllvain \& Co., 1892, and Boston and New York: Houghton Mifflin \& Co., 1892).

8 Phillip Marston's A Last Harvest: Lyrics and Sonnets from the Book of Love, ed. Louise Chandler Moulton (London: Mathews \& Lane, 1892).

9 Sharp is describing his meeting with Walt Whitman on January 16. E. A. S. said this meeting took place on January 23 (Memoir 193-94), but the sequence of events described in these letters supports the earlier date.

10 Horace Elisha Scudder (1838-1902) gained prominence and power on the American literary landscape when he became editor of the Atlantic Monthly in 1890, a post he held until 1898. See note to Sharp's letter to Scudder dated November 15, 1890.

11 Henry Mills Alden (1836-1919), a descendent of John and Priscilla Alden who arrived with the Mayflower, was born in Vermont and graduated from Williams College, where his fellow students included James A. Garfield, John J. Ingalls, and his life-long friend Horace E. Scudder. After Williams, Alden spent three years at Andover Theological Seminary. Though he never entered the ministry, he often served as preacher at neighborhood parishes. Alden's literary career began while he was in the seminary with the acceptance of two articles by the Atlantic Monthly. They were sent to the magazine, unbeknownst to him, by his friend HarrietBeecher Stowe. When Alden moved to New York in 1861 to teach at a young ladies' school, he wrote some articles for The Times (New York) and the New York Evening Post. 
His connection with Harper and Brothers beganin 1862 when the publishing house commissioned him to write a guidebook for the Central Railroad of New Jersey. Alden soon became an assistant editor of Harper's Weekly, and in 1869, he was made editor of Harper's Magazine, a position he held for fifty years until his death in 1919. In addition to the monthly essays he wrote for Harper's Magazine, Alden published three books: God in His World (1890), A Study of Death (1895), and Magazine Writing and New Literature (1908). He also edited several volumes of American literature and short stories with William Dean Howells. A member of the American Academy of Arts and Letters, Alden received the honorary degrees of Doctor of Literature and Doctor of Laws in 1890 and 1907, respectively, from his alma mater, Williams College.

12 Letter dated by postmark.

13 Arthur Stedman, E. C. Stedman's son, served as Sharp's agent in dealing with

C. L. Webster \& Co., which published Sharp's Flower o' the Vine later in 1892.

The following itinerary of Sharp's second visit to America can be constructed from the internal evidence of his letter:

Wed. 1/13: Arrived in New York, stayed with the Stedmans at 137 West 78th.

Fri. 1/15: Went to Philadelphia and met with Horace Traubel and J. M.

Stoddart, editor of Lippincott's Magazine

Sat. 1/16: Visited Walt Whitman in Camden, New Jersey.

Sun. 1/17: Returned to New York.

Mon. 1/18 Wrote to E. A. S. regarding his visit to Whitman.

Thurs. 1/21: Wrote to Horace Scudder accepting invitation to stay at his home in Boston.

Fri. 1/22: Wrote to Arthur Stedman regarding Flower o' the Vine.

Fri. 1/22: Wrote $\mathrm{p} / \mathrm{c}$ to Louis Chandler Moulton: he would see her the following Tuesday or Wednesday in Boston.

Fri. 1/22: Accompanied H. M. Alden to Metuchen, N.J., and spent the weekend with him.

Mon. 1/25: Traveled to Boston and stayed with the Scudders in Cambridge. Tues. 1/26: Wrote to A. Stedman discussing plans to return to New York.

Wed. 1/27: Wrote to Laura Stedman discussing plans in N.Y.

Thurs. 1/28: Left Boston for New York and spent the night at A. Stedman's. Fri. 1/29: Returned to the E. C. Stedmans' and stayed until Tuesday.

Fri. 1/29: Letter to Horace Scudder re: proposed articles.

Sat. 1/30: Dined with Irene Jones Harland, Henry Harland's mother.

Sun 1/31: Spent the day with E. C. Stedman who had been in Philadelphia

Tues. 2/2/92: Farewell to the Stedmans and spent the night in a midtown hotel.

Wed. 2/3/92: Departed New York on the Majestic; thank you letter to Laura Stedman mailed from the pilot boat. 
14 F. J. Hall was an editor at C. L. Webster \& Co. and responsible for the negotiations with Arthur Stedman and Sharp regarding the firm's publication of Sharp's Flower o' the Vine: Romantic Ballads and Sospiri di Roma, introduction by Thomas A. Janvier (New York: 1892).

15 Thomas A. Janvier.

16 Stedman had asked Sharp to be his guest at a dinner meeting of the Author's Club on Thursday, January 28.

17 Leaves of Grass: Including Sands at Seventy, 1st Annex, Goodbye My Fancy, 2nd Annex: A Backward Glance o'er Traveled Roads (Philadelphia: The David McKay Company, 1891-92).

18 David McKay (1860-1918), a Scotsman, established a publishing firm in Philadelphia in 1882: The David McKay Company. The first book published by the firm was the ninth edition of Whitman's Leaves of Grass (1882).

19 Irene Jones Harland was the widow of a very successful New York lawyer and the mother of Henry Harland (1861-1905) who was well known in New York as the author of a series of sensational novels published under the pseudonym Sidney Luska. In 1887 Henry and his wife, Aline Merriam Harland, left New York for Paris and soon settled in London where he began to refine his prose style in a series of stories. His first widely read and widely acclaimed novel, The Cardinal's Snuff-box, was published in 1890. Harland is best known today for his advocacy of fin de siècle aestheticism. With Aubrey Beardsley, he founded in 1894 The Yellow Book which became the principal vehicle of the movement. He served as that periodical's literary editor and contributed many stories. He was plagued by physical and nervous disorders, and he died very young, following a protracted illness, in 1905 in Saint Remo.

20 Sharp returned to New York from his three-day stay in Cambridge with the Scudders on January 28, 1892 (a Thursday). This is the surviving section of a personal letter Sharp wrote to thank Scudder for his hospitality and to report he had seen Henry Mills Alden's wife who was very ill and in either a hospital or a nursing home in New York City. She would soon die, leaving Alden a widower. Scudder and Alden were college classmates and firm friends.

21 Sharp had planned to stay a week in Boston and prolong his stay in America, but while staying with the Scudders he received news that his brother Edward had died. He returned to New York on Thursday, January 28 and sailed for England on Wednesday, February 3 on the Majestic.

22 This is a business letter Sharp wrote to Scudder to ask if he would like to consider two articles on contemporary Belgium and French writers. He decided not to approach Houghton Mifflin directly about publishing a book consisting 
of these articles expanded and translations of some of the writers. He suggests that Scudder might broach that subject with the editors of the firm using this letter as a basis. A principal purpose of Sharp's trip to the United States was to gain more access for his writings among U.S. publishers and editors and thus to increase his visibility and income.

23 An article by Sharp entitled "La Jeune Belgique" was published in Nineteenth Century, 34 (Sept. 1893), 416-36.

24 There follows a list of sixty-five Belgian and French writers.

25 Sharp was at the publisher's office and wrote to Stedman on the firm's letterhead.

26 Possibly Daniel McIntyre Henderson, a Scottish poet and bookseller who emigrated to the U.S.A. in 1873 and became a bookkeeper with R. Renwick \& Sons, furniture makers. He had written poetry before his emigration, and he published two volumes of poetry in the United States: Poems: Scottish and American (1888) and A Bit Bookie of Verse (1906). He was best known for his ode to celebrate the hundred and fiftieth anniversary of Baltimore in 1880 and for a poem that honored his fellow Scottish emigrant: "Epistle to Andrew Carnegie." He would have known both Stoddart of Lippincott's Magazine and the Stedmans. If he had an office in Philadelphia, Arthur Stedman may have sent him, for transmission to Sharp, his letter introducing Sharp to Whitman.

27 Horace Traubel (1858-1919), editor, biographer, and poet, is best known for his friendship with Walt Whitman, who lived with Traubel's brother in Camden, New Jersey, across the river from Philadelphia. A native of Camden, Traubel visited the poet almost daily from the mid-1880s until Whitman died in March 1892. At the time of Sharp's visit in January 1892, Traubel worked as a clerk in a Philadelphia bank while also serving as Whitman's primary gatekeeper. He probably accompanied Sharp to Camden and was "the fair companion" who returned with Sharp to Philadelphia. After Whitman's death, Traubel began producing from his notes what would become a nine-volume biography of Whitman's final four years, With Walt Whitman in Camden (1964). Three volumes of this massive work were published before Traubel died, and the others appeared posthumously. One of Whitman's three literary executors, Traubel also edited The Complete Writings of Walt Whitman (10 vols., 1902).

28 Joseph Marshall Stoddart (1845-1921) was the editor of Lippincott's Monthly Magazine and a friend of Whitman's. Sharp discussed with him various stories and articles he might write for that important periodical.

29 Possibly Francis James Child (1825-1896), who became the first Professor of English Literature at Harvard in 1876. He edited Four Old Plays (1848), The 
Poetical Works of Edmund Spenser (1855), English and Scottish Ballads (1857-1858), and Poems of Sorrow and Comfort (1865). His five-volume collection of English and Scottish Popular Ballads (1883-1898) was a monumental achievement and remains the standard collection of English and Scottish folk music.

30 F. J. Hall. See note to January 22, 1892 letter to Arthur Stedman.

$31 \mathrm{~J}$. W. Young, a student or faculty member at Harvard, wrote a letter to Stedman asking if he would invite Sharp to lecture at Harvard on a subject of contemporary literature: "Quite a number of Harvard men are anxious to see and hear Mr. Sharp if he will consent to come to Cambridge." Laura Stedman must have sent Young's letter to Sharp since E. A. S. quoted from it in the Memoir (194-95).

32 Flower o' the Vine (1892).

33 Although Sharp considered publishing the short dramatic works under a pseudonym, the volume finally appeared under his own name in 1894 as Vistas. Sharp's interest at this time in pseudonyms was manifest, however, when, later in 1892, he edited The Pagan Review under a pseudonym and wrote all its contents under various pseudonyms.

34 (Henry) Austin Dobson (1840-1921), poet, essayist, and biographer, entered government service with the Board of Trade, where he remained until his retirement in 1901. His non-poetical works include biographies of Hogarth (1879), Fielding (1883), Richard Steele (1886), Oliver Goldsmith (1888), Horace Walpole (1890), Samuel Richardson (1902), and Fanny Burney (1903). His poetry was collected in the Complete Poetical Works (1923).

35 A portion of the manuscript is unreadable here. When the book appeared it was dedicated "To Edmund Clarence Stedman with Homage and Love."

36 Regarding the death of Sharp's brother.

37 Edgar Fawcett (1847-1904) was a successful novelist Sharp met in New York. His best known novels - Purple and Fine Linen (1873) and New York (1898) - were satirical studies of New York high society. He also wrote Solarion (about a dog given human intelligence) and Douglas Duane (on scientific bodyswitching), as well as The Ghost of Guy Thryle (which features astral projection as a means of interplanetary travel).

38 James Clarence Harvey (1859-1917) was a poet.

39 A Fellowe and His Wife (1892).

40 There is no evidence of such a commission. 
41 “Primavera di Capri," Good Words, 33 (1892), 396-411.

42 Janvier's The Uncle of an Angel, and Other Stories (1891).

43 “Editor's Study," Harper's, 84 (Feb. 1892), 478-79.

44 Henry and Aline Merriam Harland; Irene Jones Harland. See note to Sharp's letter to Laura Stedman of January 27, 1892.

45 Austin Dobson, Eighteenth Century Vignettes, 3 vols. (1892-1896).

46 John Charles Van Dyke (1856-1932) was a prolific writer on art and art history.

47 Principles of Art: Part I: Art in History; Part II: Art in Theory (1887).

48 James Stanley Little, who was educated at King's College Cambridge, lived for a time with his brother George, an artist, in Buck's Green, Rudgwick, Sussex. He became a good friend of William and Elizabeth Sharp after he found them a house to let in Buck's Green. He was the First Executive Secretary of the Society of Authors (1888-90) and Honorable Secretary of the Shelley Society (1886-87). He was the principal organizer of a Shelley Centenary Celebration at Horsham in 1892. He was actively involved in the movement to reform the Royal Academy. Among his many publications: What is Art (1884), The United States of Britain (1887), A Vision of Empire (1889), The Wealdon Painters (1892), A Wealdon Tragedy (1894) and The Life and Work of W. Q. Orchardson, RA (1897).

49 Possibly The Library Review, published from 1892-1893.

50 George Léon Little (1862-1941).

51 I have been unable to identify her.

52 Walt Whitman died on March 26, 1892.

53 “Walt Whitman," The Athenaeum, 96 (April 2, 1892), 436-37. Watt's lengthy article on Whitman damned him for lack of intelligence and criticized his poetry, especially Leaves of Grass, for its lack of meter, its unintelligibility, and its amazing indecency "that has done no harm. It is merely the attempt of a journalist to play 'the noble savage' by fouling with excrement the doorstep of Civilization." One can see why Sharp, an admirer of Whitman, would strongly object to Watts' diatribe and share his views with Stedman who, along with many American critics, venerated Whitman and mourned his passing.

54 Henry Harland.

55 Alfred Austin (1835-1913), a political journalist who succeeded Tennyson as poet laureate in 1895, founded and edited, with William J. Courthope, The 
National Review. His works include Randolph (1854), The Human Tragedy (1862), The Tower of Babel (1874), Prince Lucifer (1887), Lyrical Poems (1891), Narrative Poems (1891), and The Garden That I Love (1894).

56 The rest of the manuscript is missing.

57 Probably The Literary World of April 9, 1892 in which Sharp's and Blanche Willis Howard's A Fellowe and His Wife was reviewed.

58 Sharp mentions later (see letter 151) a "Summer Shows" article written by Little for the West Sussex Gazette and reprinted as The Wealden Painters at the Summer Exhibitions, 1892 (Arundel: West Sussex Gazette Office, 1892).

59 Introduction to Flower o' the Vine (1892).

60 Jean Moréas (1856-1910) was the name taken by Iannis Pappadiamantopoulos, a Greek poet who adopted French culture and tastes. He began as a Symbolist and gradually moved toward poetry that was classical in theme, form, and style. Maurice Barrès (1862-1923) was a novelist, essayist and politician who studied law at Nancy and became active politically after 1889. Henri Cazalis (1840-1909) was a minor poet, doctor, and friend of Mallarmé who took the name Jean Lahor. He was interested in the occult. Jules Renard (1864-1910), a novelist, joined the original staff of Mercure de France, chief among the symbolist reviews. I have been unable to identify Eugène Holland or Leon Vaniers.

61 Catherine Janvier.

62 Stedman wrote a poem about Walt Whitman following his death that was published in the United States and England. He has sent Sharp a manuscript copy of the poem which Sharp says he will place in the edition of Whitman's poems Stedman gave him during his recent trip to America.

63 The reference is to Little's defense of Thomas Hardy's Tess of the D'Urbervilles against an article in the Quarterly Review that criticized the novel as unrealistic and contrary to the obligations of marriage. Little had given Sharp proof slips for an opinion piece by Little that would appear in the August issue of The Artist and Journal of Home Culture, a publication which promoted the arts. The complete sentence Sharp found praiseworthy: "Broadly considered physical beauty denotes intellectual beauty and right-living, though it is often only the legacy the unearned increment - of these things; and the desire to possess this beauty, perverted as that desire often is, is per se a healthy instinct making for beauty and righteousness in the race." Whether or not many men and women shared Little's opinion, Sharp believed the desire to possess physical beauty, though often perverted, more often generates intellectual beauty and righteousness.

64 Henry Hyde Champion (1859-1928), a socialist and one of the founders of the Independent Labor Party, was acting editor of the journal Nineteenth Century 
in 1892. Sharp was sending proof-slips of Little's "Hardy Counterblast" in the hope that Champion would recognize Little as ally in the liberal cause and ask him to contribute to the journal. A month later, on June 21, Sharp had to tell Little he had not been able to see Champion.

65 Date from postmark.

66 Date from postmark.

67 George Léon Little.

68 This single folded letter card is addressed to J. M. Stoddart Esq. I Editor I Lippincott's Magazine I Messrs. Lippincott \& Co. I Philadelphia. A received post mark in Philadelphia is dated June 2.

69 Elizabeth's illness forced Sharp to cancel a meeting with Henry Hyde Champion, editor of Nineteenth Century, where he would have praised Little as a potential contributor.

70 See note to March 9, 1892 letter to Little. E. A. S. said: “During a visit to the art critic, J. Stanley Little, at Rudgwick, Sussex, my husband saw a little cottage which attracted him and we decided to take it as a pied-a-terre." The Sharps were staying with Mona Caird at Northbrook, Micheldever during the first week of June while negotiations were taking place for the house in Sussex. On June 7 Sharp wrote in his diary: "Went down to Rudgwick, Sussex by appointment, and agreed to take the cottage on a 3-years' lease" (Memoir 199-200).

71 E. C. Stedman's "The Nature and Elements of Poetry" appeared first in eight installments in The Century Magazine, 43-44 (March-Oct., 1892), 752-761, 821829, 143-152, 180-189, 365-374, 613-622, 661-669, and 859-869. The essays were then published as a book in the fall of 1892 .

72 Later named Phenice Croft.

73 This idea morphed into Sharp's Pagan Review which had no contributors but Sharp himself.

74 Heinrich Heine, Italian Travel Sketches. etc. Part I, trans. E. A. Sharp (1892).

75 Francis Turner Palgrave (1824-1897), the eldest son of Sir Francis Palgrave, the antiquarian, was the art critic for the Saturday Review, a regular contributor to the Quarterly Review, and Professor of Poetry at Oxford from 1885-1895. His works include: Idylls and Songs (1854), Hymns (1867), Lyrical Poems (1871), The Visions of England (1881), and the anthologies, Golden Treasury of English Verse (1861), The Children's Treasury of English Song (1875), and The Treasury of Sacred Song (1889).

76 Sharp sent Henry Hyde Champion a sample of Stanley Little's writing on May 19. 
77 Sharp's sister Mary, who did copying work for him from time to time and, crucially, would provide the handwriting for the letters Sharp would write as from Fiona Macleod.

78 J. Stanley Little, The Wealden Painters at the Summer Exhibitions, 1892, reprinted from the West Sussex Gazette (1892).

79 A story or article Little had written, which Sharp suggests he try to publish as a pamphlet or book.

80 The Wealdon Painters at the Summer Exhibitions (1892).

81 Jay ?, of Phenice Farm near Great Bookham, several miles north of Horsham, must have owned the house in Buck's Green the Sharps were letting and wished to name Phenice Croft.

82 Theodor Watts (later Watts-Dunton) was a well-known critic and a friend of Sharp's, and Water Crane (1845-1915) was an illustrator of children's books and a close friend of Little's.

83 Do you understand, my friend?

84 You may break, but shall not bend [me].

85 The following letter from Elizabeth A. Sharp to Stanley Little - one of several in the Princeton library - is included to demonstrate the close relationship they were developing.

86 Heinrich Heine, Italian Travel Sketches, etc. Part I, trans. E. A. Sharp (1892).

87 At this point two pages of the manuscript letter are missing. 


\section{Chapter 9}

1 Maud Howe Elliot (1854-1948), a daughter of Julia Ward Howe and Dr. Samuel Gridley Howe, wrote fiction, art criticism, travel narratives, and biography. Her best known book is Julia Ward Howe 1819-1910, published in 1915, for which she and her sisters, Laura E. Richards and Florence M. H. Hall with whom she collaborated, won the Pulitzer prize.

2 Sharp's reference to his trip to America in January 1892 and to settling into Phenice Croft establish the date of the letter as early July, 1892.

3 Louise Chandler Moulton.

4 Unable to identify.

5 The San Rosario Ranch (1884) and Atlanta in the South: A Romance (1886).

6 W. H. Brooks is the pseudonym Sharp adopted as editor of The Pagan Review, a periodical he planned to issue from his new home in Rudgwick. For the first and only number of this venture, he wrote all the pieces under different pseudonyms, as well as editing it pseudonymously.

7 Stopford Augustus Brooke (1832-1916), an Anglo-Irish clergyman, essayist, critic, and biographer, was influenced by Ruskin. His works include: Primer of English Literature (1876), Poems (1888), History of Early English Literature (1894), and Studies in Poetry (1907).

8 Edward Dowden. See note to Sharp's letter to Dowden on May 22, 1882.

9 Roden Berkeley Wriothesley Noel (1834-1894), son of Charles Noel, Lord Barham and Earl of Gainsborough, was a poet whose work reflected his leaning towards socialism, his concern with the oppressed, his love of nature, and his philosophical mysticism. His works include Behind the Veil (1863), A Little Child's Monument (1881), Essays Upon Poetry and Poets (1886), The People's Christmas (1890), and Collected Poems (1902).

10 Richard Garnett. See note to letter from Sharp to Garnett of early January 1891.

11 Henry Buxton Forman (1842-1917) was a bibliographer and antiquarian bookseller whose literary reputation is based on his bibliographies of Shelley and Keats. In 1934 he was revealed to have been in a conspiracy with Thomas James Wise (1859-1937) to purvey large quantities of forged first editions of Georgian and Victorian authors.

12 John Nichol (1833-1894), a Scottish poet and biographer, was Professor of English Language and Literature at Glasgow University from 1862 to 1889. 
During his brief period of study at Glasgow University, Sharp was deeply influenced by Nichol, and they became good friends. Nichol's works include Fragments of Criticism (1860), Byron (1880), The Death of Themistocles and Other Poems (1881), Robert Burns (1881), and Carlyle (1892).

13 Selsea Bill is a headland on the Selsea Peninsula, West Sussex.

14 The letter of the 10th may not have survived.

15 Sharp wrote a similar letter in 1887 objecting to being classified as a colonial poet in Stedman's Victorian Poets. In a new edition, he was placed with the Australian poets.

16 Sir Edmund Gosse (1849-1928) was a poet, novelist, and literary commentator who wrote with special insight on Restoration comedy and Ibsenite drama. His works include On Viol and Flute (1873), New Poems (1879), Firdausi in Exile (1885), and In Russet and Silver (1894).

17 The Pagan Review.

18 The eight papers Stedman published in The Century Magazine (see note to June 9, 1892 letter to Laura Stedman) were collected in a single volume titled The Nature and Elements of Poetry (1892).

19 The implication here is that Edith Rinder will be with him for at least part of his stay in the Highlands.

20 Sharp must have suggested Stedman donate an autograph copy of "Ariel," his poem about Shelley, to the Shelley Museum in Horsham if Stanley Little and others succeed in their campaign to establish it.

21 The Pagan Review was published on August 15, 1892.

22 Joseph Edmund Collins (1855-92) was born in Newfoundland, migrated to New Brunswick in 1875, and began to exercise a strong influence on Charles G. D. Roberts in 1880, when the two men were working in Chatham, Collins as the editor of a local newspaper (The Star) and Roberts as a teacher at the local Grammar School. Collins moved to Toronto in 1880 to take up an editorial position on The Globe and to New York in 1886 to become editor of a new periodical, The Epoch, where he continued to promote Roberts's poetry. He became a close friend of Bliss Carman after he too moved to the city in 1890. By that time, Collins had left The Epoch and his health had begun to deteriorate. In writing this letter to Carman, Sharp did not know that Collins had died in a New York hospital on February 23, 1892. After his death, Collins was recognized as the literary father of Roberts, Carman, and their generation of young poets.

23 Unable to identify. 
24 Charles G. D. Roberts.

25 Here Sharp implies more explicitly that Edith Rinder would be with him in the Highlands after August 30.

26 Edward Dowden (1843-1913). See note to Sharp's May 22, 1882 letter to Dowden.

27 E. A. S. added "And at the little cottage a solemn ceremony took place. The Review was buried in a corner of the garden, with ourselves, my sister-in-law Mary and Mr. Stanley Little as mourners; a framed inscription was put to mark the spot, and remained there until we left Rudgwick" (Memoir 207).

28 The Nature and Elements of Poetry (1892).

29 Baldwin was an Editor of The New York Independent and later of The Outlook.

30 "The Passing of Thomas," Harper's New Monthly Magazine, 85 (Aug. 1892), 439-454; and "The Efferati Family," Harper's New Monthly Magazine, 85 (Oct. 1892), 763-780.

31 Catherine Janvier.

32 Robert Murray Gilchrist (1868-1917) was a prolific writer of fiction and travel books. He was born in Sheffield and educated at Sheffield Grammar School. At twenty-one, he gave up his apprenticeship in the manufacture of cutlery, decided to become a full-time writer, and moved to a house called Highcliffe in Eyam, a village near Sheffield in Derbyshire. He became a popular writer of stories and novels many of which featured ghosts and supernatural phenomena. His works include Frangipanni (1893), Willowbrake (1898), The Labyrinth (1902), Natives of Milton (1902), Beggar's Manor (1902), The Dukeries (1910), The Peak District (1910), Scarborough and Neighborhood (1910), and The Chase (1921). See the Introduction to this chapter for more information.

33 Only one issue was published.

34 Le Gallienne's English Poems (London: Elkin Mathews \& John Lane, [1892]). An edition of twenty-five copies was privately printed in Edinburgh.

35 A reference to Philip Bourke Marston's For a Song's Sake.

36 Thomas Woolner (1825-1892) was a sculptor and poet, a friend of Rossetti, and one of the original Pre-Raphaelite brethren. Sharp's comment refers to Woolner having made two busts of Tennyson.

37 Sharp saw Austin at Tennyson's funeral. Tennyson died on October 6, 1892, and the funeral was on October 12. 
38 The Life and Letters of Joseph Severn (1892).

39 Austin became poet laureate in 1895 .

40 Alfred Henry Miles (1848-1929) was a prolific author, editor, anthologist, journalist, composer and lecturer who published hundreds of works on a wide range of topics, among them The Poets and Poetry of the Century, 10 vols. (London: Hutchinson, 1891-97) and The Universal Natural History, with Anecdotes Illustrating the Nature, Habits, Manners and Customs of Animals, Birds, Fishes, Reptiles, Insects, etc., etc. (New York : Dodd, Mead \& Co., 1895, en.wikipedia.org/ wiki/Alfred_Henry_Miles

41 Hutchinson \& Co. was an English book publisher, founded in 1887 by Sir George Hutchinson.

42 Sharp had written to the publisher of Miles' Poets and Poetry of the Century Series (Hutchinson \& Co.) proposing that he prepare a volume on Phillip Bourke Marston for the series. Before sending it he decided he had better check with the editor of the series and sent him (Miles) a copy of the letter he intended to send to Hutchinson (see October 31 letter above). Miles asked Sharp not to send the letter since he was doing all the selecting, editing, and writing for the series.

43 Theodore Watts, later Watts-Dunton, was poetry editor of The Atheneum.

44 A village in West Sussex.

45 The first and last portions of this letter are missing.

46 William Bell Scott (1811-1890) was a Scottish poet and painter. The publication of his posthumous Memoirs, Autobiographical Notes of the Life of William Bell Scott, in 1892 created a sensation with his comments on the leading literary men and artists of his time.

47 William Minto (1845-1893), a Scottish critic and novelist, edited the Autobiographical Notes of the Life of William Bell Scott. Edmund Gosse and Theodore Watts [-Dunton] were among his protégés. His works include $A$ Manual of English Prose Literature (1872), Daniel Defoe (1879), The Crack of Doom (1886), and Was She Good or Bad? (1889).

48 Sharp's review of Autobiographical Notes of the Life of William Bell Scot was printed in The Academy, 42 (Dec. 3, 1892), 499-500.

49 Little was planning an article on Rossetti.

50 Bognor is a locality in West Sussex where D. G. Rossetti leased Aldwick Lodge in 1875. He lived there from October 1875, to July 1876. 
51 Swinburne had attacked Autobiographical Notes of the Life of William Bell Scott for its inaccurate and unfair treatment of his and Watts-Dunton's relations with Rossetti in his later years. Sharp is giving Watts-Dunton, and perhaps through him Swinburne, a chance to review the manuscript of his review of the book and note inaccuracies or suggest additions before he submits it to The Academy.

52 James Cotton, editor of The Academy.

53 Thomas Gordon Hake (1809-1895) was a physician, a poet, and a friend of Rossetti. Sharp refers to Hake's Memoir of Eighty Years, which was published by Bentley in 1892.

54 W. Kineton Parkes (1865-1938), novelist and art critic, was on the staff of the Nicholson Institute at Leek. An expert on the silk industry of Leek, he and his wife were heavily involved in the social and artistic life of the town. From November 1888 to October 1889, he edited Comus, and in 1893-94 the Library Review. Parkes's works include Shelley's Faith: Its Development and Relativity (1888), The Pre-Raphaelite Movement (1889), The Painter Poets, ed. for the Canterbury Poets Series (1890) (Sharp was the editor of this series), Love a la Mode: A Study in Episodes (1907), Potiphar's Wife (1908), The Altar of Moloch (1911), The Money Hunt: A Comedy of Country Houses (1914), Hardware (1914), and, most significantly, The Art of Carved Sculpture (1931).

55 George Meredith.

56 Sharp's article of Maeterlinck appeared in the March 1892 issue of The Academy.

57 Date from postmark.

58 Stedman's The Nature and Elements of Poetry (1892).

59 John Charles Van Dyke (1856-1932) was an American art historian and critic. The two books mentioned are How to Judge a Picture (New York: Chautauqua Press, 1889) and Principles of Art: Pt. 1. Art in History; Pt. 2. Art in Theory (New York, Fords, Howard, \& Hulbert, 1887).

60 Edmund Clarence Stedman, The Nature and Elements of Poetry (1892).

61 A. C. Swinburne, “The New Terror,” The Fortnightly Review, 52 (Dec. 1, 1892), 830-833.

62 William Bell Scott.

63 Pre-Raphaelite Brotherhood.

64 Dante Gabriel Rossetti. 
65 William Bell Scott.

66 The manuscript ends, and the remainder of the letter is lost.

67 This is an autograph letter card postmarked December 7, 1892 from Horsham and addressed to Kineton Parkes Esq, The Library, Nicholson Institute, Leek, Staffordshire.

68 Sharp's review of William Bell Scott's autobiography.

69 George Meredith.

70 Address on lettercard: 14 Henrietta Street I Covent Garden W.C. I London. Date from postmark on card.

71 The novel Sharp wrote jointly with Blanche Willis Howard was published in London by James R. Osgood, McIlvain \& Co. in 1892 and in Germany in the Tauchnitz Collection of British Authors, vol 2813.

72 Elkin Mathews (b. 1851), a publisher and bookseller, founded The Bodley Head Publishing Co. in 1887 with John Lane. The partnership was dissolved in 1894.

73 Date from postmark.

74 Date from postmark.

75 J. J. Robinson was an editor of the West Sussex Gazette and a friend of Stanley Little who wrote frequently for the Gazette. Robinson and Little were the two Honorary Secretaries of the Committee to organize a Centenary Celebration to mark the 100th anniversary on August 4, 1892 of the birth of Percy Bysshe Shelley in Horsham, Sussex and to solicit funds to establish in Horsham a Shelley Library and Museum, which survives as the Shelley Gallery in the Horsham Museum.

76 Perhaps a notice of The Pagan Review in the West Sussex Gazette written by Little, who wrote frequently for the paper.

77 Date from postmark.

78 Sharp had arranged with Joseph Cotton, editor of The Academy, to write an article about Stedman's Nature and Elements of Poetry, but he did not follow through.

79 The Phenice Croft address on the stationery is crossed through and "Permanent address after March" is written next to it. The Sharps would be away from England until March, and they would use the address of E. A. S.'s mother to receive mail while away. 
80 The Sharps originally planned to travel to Sicily overland via the Gotherd Pass, Milan, and Florence, leaving on January 2. Their decision to travel by ship delayed their departure. 


\section{Chapter 10}

1 Dr. Ward to be identified. Anne Jean Marie René Savary, 1st Duke of Rovigo (1774-1833), was a French general and diplomat. In 1812, Napoleon awarded him the duché grand-fief (a rare, nominal but hereditary honor extinguished in 1872) of Rovigo in Italy. He was among the last to desert the emperor at the time of his abdication in April 1814 and among the first to welcome his abortive return from Elba in 1815, when he became inspector-general of gendarmerie and a peer of France. Sharp's friend, Prof. E. Savare d'Odiardi, must have been his grandson and a physician who had settled in London. He continued to identify himself as the Duc de Rovigo, though the title seems to have been abolished in 1872. In the September 29, 1886 issue of The Lancet he published an article entitled "New Pneumo-dynamometer and Spirometer." There he is identified as President of the General Society for the Welfare of the Blind.

2 Fortunatus the Pessimist (1892).

\section{Prince Lucifer (1887).}

4 The Leon MS may have been an article by George Leon Little, a painter, or an article written about him by Stanley Little, his brother. In a letter to Stanley Little on April 16, 1890, Sharp said he admired Leon's work and added: "You may be sure that whenever it is practicable for me to put in a spoke anywhere 'will' shall not lag behind 'can."' He then suggested Little encourage his brother to try placing his work in a Glasgow gallery where Sharp could do more for him in his capacity as art critic for the Glasgow Herald. D. C. T. may have been an editor at the Walter Scott publishing firm to whom Sharp had sent the manuscript. See Sharp's letter to Little dated 22 January 1893.

5 Date from postmark.

6 Edmund Clarence Stedman and Thomas and Catherine Janvier.

7 Date from postmark.

8 L. L. was George Leon Little, Stanley Little's brother. See note to Sharp's letter to Little dated January 7, 1893.

9 Robert Farquharson Sharp, Elizabeth Sharp's brother.

10 The Walter Scott publishing company. Sharp's January 7 letter implies that D. C. T. of that firm agreed to publish the manuscript, but not immediately.

11 E. A. S. included three letters Sharp wrote "to a friend" from Africa (Memoir 208-14). This is the first of the three. Had that friend been anyone other than Edith Rinder, E. A. S. would have given the name. And only for Edith would 
Sharp have taken time to write in such detail about the scenery and atmosphere of North Africa.

12 The editor at Walter Scott Publishing Co has turned down the George Leon Little manuscript. See Sharp to Little, January 7 and 22, 1893.

13 Date from postmark.

14 Robert Farquharson Sharp is E. A. S.'s brother. Madge was one of William Sharp's sisters.

15 Sharp had agreed to contact Robert Farquharson Sharp - his first cousin, Elizabeth's brother, and on the staff of the British Museum's Department of Printed Books - regarding a job for Charles William Dalmon. Dalmon (18621938) was a minor Sussex poet and a friend of Stanley Little. He became a film designer in the 1920s and joined the British Union of Fascists in 1934.

16 This letter-card is postmarked April 4, 1893, which was a Tuesday.

17 Possibly Alice Mangold Diehl (1846-1912), a prolific writer of popular novels.

18 Frank Frankfort Moore, I Forbid the Banns, The Story of a Comedy which was played seriously, 4 th ed., 3 vols. (1893).

19 Sharp's business letter to Alden proposed a poem for publication that Alden accepted ("kind and considerate editorial" response). A poem by Sharp entitled "The Weaver of Snow" appeared in Harper's in March 1894.

20 God in His World (1890), Alden's most recent book. For more about Alden, see note to Sharp's January 21, 1892 letter to Horace Scudder.

21 François de Malherbe (1555-1628), French poet and critic. "But she bloomed on earth, where the most beautiful things have the saddest destiny; and Rose, she lived as live the roses, for the space of a morning".

22 Nina Francis Layard was an American poet whose lyrics appeared in Harper's Magazine and other American periodicals. Longman's had published her volume entitled Poems in 1890. She has sent Sharp a manuscript of a second volume of poems. The letter suggests Sharp was unaware of her published volume of poems.

23 The letter was sent to officials at Swan Sonnenschein \& Co. who had agreed to publish a new biography of D. G. Rossetti, a work Sharp began but never finished.

24 Kinneton Parkes edited the Library Review from 1892 to 1898. 
25 Date from postmark on letter card. Sharp had tried to see Little in the middle of the night to discuss several matters, but his house was dark. This card was written the next morning in Horsham station, where Sharp was about to board a train to spend a week on the Isle of Wight while E. A. S. was in Paris for the Salons.

26 See note to Sharp's May 4, 1893 letter to this firm.

27 Library Review.

28 Postmark on letter card.

29 The book for which Sharp thanks Garnett is probably Poems, which was published in 1893. In the spring of 1894 Sharp wrote as follows to Garnett: "I understand that at last my short review of your Poems is to appear in this week's "Academy". If perforce shorter than I would so much more willingly have made it, I have tried to say in it something adequate to your book's high \& rare merit, \& that may, moreover, send some new readers to it. ... The book gains upon me more and more. It is full of fine work."

30 The word "no" written in the upper left-hand corner of the letter indicates that Gilder accepted none of Sharp's suggested articles for the Century Magazine. Articles by Sharp on North Africa were published elsewhere: "French African Health Resorts" appeared in the December 1893 issue of Nineteenth Century; "The New Winterland of French Africa" in the January 1894 Nineteenth Century; "Tclemcen and Its Vicinage" in the February 1894 Art Journal; "Cardinal Lavigerie's Work in North Africa" in the August 1894 Atlantic Monthly; and "Rome in Africa" in the June 1895 Harper's Monthly.

31 The Fallen City and Other Poems, Will Foster (Edinburgh and London: William Blackwood and Sons, 1892).

32 The following note appears on the reverse of the letter in a hand that is not Sharp's: "Houghton Mifflin say no. Write Sharp to that effect: 20:Oct:93:" The individual to whom Sharp's letter is addressed must have proposed an edition of Oliver Wendell Holmes' poetry in Walter Scott's Canterbury Poets series, of which Sharp was General Editor. As Sharp suggested in the postscript, that individual pursued the matter with Houghton Mifflin, publisher of Oliver Wendell Homes, and received a negative response.

33 These must be proofs of Sharp's notice of Philip Bourke Marston's Poets and Poetry of the Century. See Sharp's letter to Alfred H. Miles dated 31 October 1892.

34 The word "Decline" is written in the upper lefthand corner of the letter's first page. In the upper right-hand corner is a note in Johnson's hand: "I do not see anything for us in these suggestions. R.U.J. We have articles on Lang, Coleridge, 
\& others for which we have been long in finding room." See Sharp's letter of June 3, 1893 to Richard Watson Gilder proposing articles on North Africa, which Gilder declined. Gilder was editor and Johnson assistant editor of the Century Magazine in New York.

35 Richard Watson Gilder.

36 Andrew Lang.

37 Robert William Buchanan (1841-1901), a Scottish poet, novelist, and playwright, is known for his attack on Rossetti and the PreRaphaelites, "The Fleshly School of Poetry," in the 1871 Contemporary Review. After a controversy, he withdrew his charges and dedicated his novel, God and Man, to Rossetti. Robert Louis Stevenson (1850-1894). Sir James Matthew Barrie (1860-1937), the Scottish journalist, novelist, and playwright, noted for his use of whimsy and best known as the author of Peter Pan (1904). His works include Quality Street (1901), The Admirable Crichton (1902), What Every Woman Knows (1908), and The TwelvePound Look (1910). Henry Duff Traill (1842 1900), a poet and journalist, was on the staffs of The Pall Mall Gazette, St. James's Gazette, and the Daily Telegraph; and edited The Observer and Literature. His best work was done as a critic and literary biographer. Among his works are Central Government (1881), Recaptured Rhymes (1882), Coleridge (1884), Sterne (1889), Saturday Songs (1890), and The New Fiction and Other Essays on Literary Subjects (1897). With J. S. Mann he edited The Building of Britain and the Empire (London: The Waverley Book Company, Ltd., 1909). Walter Chalmers Smith (1824-1908), a Scottish poet and clergyman of the Free Church, wrote narrative, colloquial works under the pseudonyms, "Orwell" and "Hermann Knott." His works include The Bishop's Walk (1861), Borland Hall (1871), Hilda Among the Broken Gods (1878), and A Heretic (1890). John Davidson (1857-1909), a Scottish poet, playwright, and novelist, wrote melancholy "tragedies and testaments," and poems and plays espousing his "gospel of philosophic science." His works include The North Wall (1885), The Wonderful Mission of Earl Lavender (1891), Fleet Street Eclogues (1893), The Last Ballad (1899), and Testaments, 5 vols. (1901-1908).

38 Thomas Miles Richardson, Jr. (1813-1890), a painter who worked primarily in watercolors, became an Associate of the Old Water Colour Society in 1843 and a Member in 1851. He was also a member of the Royal Academy in Scotland. From 1843 until his death, he exhibited his work over 800 times.

39 Henry Arthur Jones (1851-1929) was a playwright who wrote and produced more than sixty plays during his lifetime. His best-known works include The Silver King (1882), Judah (1890), Saints and Sinners (1894), Michael and His Lost Angel (1896), The Liars (1897), Mrs. Dane's Defence (1900), and Whitewashing Julia (1903). 
40 Perhaps the wife of Sir James Knowles (1831-1908) the English architect and editor who designed among other buildings Lord Tennyson's house at Aldworth. In 1860 he published The Story of King Arthur. In 1870 he became editor of the Contemporary Review, and in 1877 he founded and edited the Nineteenth Century.

41 Elizabeth Robins Pennell (1855-1936) was an American writer who lived in London most of her adult life. She was "an adventurous, accomplished, selfassured, well-known columnist, biographer, cookbook collector, and art critic." Her Life of Mary Wollstonecraft was published in 1884 and the biography she wrote with her husband, The Life of James McNeill Whistler, was published in 1911. Many well-known writers and painters frequented her London salon. Her husband was Joseph Pennell (1857-1926), an American artist who, like his friend James McNeill Whistler, went to Europe and made his home in London. He produced numerous books, but was best known as a lithographer and as an illustrator of others' books.

42 Charles W. Dalman.

43 Vistas was published by Frank Murray in Derby in 1894 and in the United States by Stone and Kimball in the same year.

44 Pierre Loti's (pseudonym for Louis Marie Julien Viaud) Pêcheur d'Islande was published in Paris in 1886. The first British edition, edited by R. J. March, was published in London in 1891.

45 Sharp's new biography of Rossetti was not completed. Sharp's new "onevol. Novel" would become Pharais, and his "vol. of short stories" was probably Comedy of Woman, also never published. His "French studies" was possibly Chansons d'Amour. See Sharp's diary for December 1893 (Memoir 215-17).The article in the September 1892 Nineteenth Century was "La Jeune Belgique."

46 Pharais: A Romance of the Isles (The Regent's Library, Derby: F. Murray, 1894) was the first of Sharp's works published under the name Fiona Macleod. Catherine Janvier included portions of this letter in "Fiona Macleod and her Creator William Sharp" which appeared in the North American Review in 1907 (Vol. 184, No. 612, pp. 718-732). She loaned many of her letters from Sharp to Elizabeth for her to use in the Memoir, and portions of this letter are printed there (224-25). I have not located the manuscript letter, but I have included in this transcription passages omitted by both writers. Mrs. Janvier used the letter to demonstrate that Sharp claimed authorship of Pharais many months before he decided to publish it as the work of Fiona Macleod. When Sharp had a copy of Pharais sent to Catherine Janvier in December 1894, claiming it was the work of a woman friend, she recalled the moon-flower exchange in this letter and elicited the truth from Sharp (see Sharp letter to Catherine Janvier dated January $5,1895)$. 
47 This story became Wives in Exile: A Comedy in Romance (London: Grant Richards, 1898).

48 See the Introduction to Chapter Nine for more information about Gilchrist.

49 Murray had told Sharp he could afford to offer only ten pounds for the projected romance. Sharp rejected that offer, but told Murray he would accept that amount for Vistas, which Murray published in the spring of 1894 (Memoir 216-17).

50 Date from postmark.

51 Sharp meant to say he wanted to stop in Derby on his return to London to talk with Frank Murray with whom he was arranging the publication of his Vistas.

52 The date is written in another hand.

53 Perhaps a work by Little never published.

54 This must have been the etching Charles Holroyd made of Sharp in Rome in February 1891.

55 Shortly after Gilchrist moved to Highcliffe in Eyam in 1888, Garfitt joined him there, and the two men continued to live together until Gilchrist's death from a sudden bout of pneumonia in the spring of 1917. The two men were close friends of Edward Carpenter, the socialist poet and advocate of Uranianism, who lived with his companion, George Merrill, nearby at Millthorpe. Gilchrist and Garfitt were ardent cyclists and began driving a motor car in 1909. (See a pamphlet by Clarence Daniel entitled "Eyam - The Milton of Robert Murray Gilchrist: Portrait of a Victorian Village." Of unknown date, a copy of the pamphlet was kindly provided by the staff of the Sheffield City Archives. Eyam was the model for the village Gilchrist called Milton in his works of fiction.) There is more about Garfitt and Gilchrist in the Introduction to Chapter Nine.

56 Henry Austin Dobson (1840-1921) was a well-known English poet and essayist.

57 Gilchrist's novel Frangipanni (1893) was the first volume published by Frank Murray, the Derby bookstore owner, in his Regent's Library series. Sharp stopped to see Murray on his way to London after visiting Gilchrist. Fiona Macleod's Pharais (1894) was the second, and William Sharp's Vistas (1894) was the third. These volumes were finely printed on excellent paper.

58 Internal evidence and the return address establish the date.

59 Scudder commissioned none of the articles proposed here, but he did publish in the Atlantic Monthly in August 1894 an article by Sharp entitled "Cardinal 
Lavigerie's Work in North Africa." Sharp's friend Henry Mills Alden published in Harper's Magazine his "Rome in Africa" in June 1895 (91:95-116).

60 The painter Frederic Shields (1833-1911).

61 Born in 1821, Ford Madox Brown was a distinguished painter, teacher, and close friend of D. G. Rossetti. Through his own work and his influence on Millais and Holman Hunt as well as Rossetti, he was a central figure in the PreRaphaelite movement in British art.

62 Date from postmark.

63 See Sharp's May 1, 1893 letter to Layard in which he comments on the manuscript she sent him. In that letter he told Layard he doubted anyone would publish the book. He was clearly wrong, as she has sent him the published volume. He may have forgotten his earlier response, but he expresses in both letters his admiration for the poem entitled "Sweet Peas."

64 Perhaps William Clavell Ingram (1834-1901) Dean of Peterborough Cathedral. Ingram has proposed a volume for one of Walter Scott's series.

65 This note accompanied a Christmas gift to the Stedmans.

66 This etching by Scott appeared as the frontispiece of the first edition of Sharp's Vistas. It is an etching of one of Blake's designs for Milton's Paradise Lost and portrays Adam and Eve in an embrace and Satan, entwined as a serpent, hovering above them. 


\section{Chapter 11}

1 Grant Richards, (1872-1948) was a British publisher and writer. Recognizing his interest in publishing, Sharp's good friend Grant Allen, his uncle, found a job for him with the wholesale booksellers Hamilton, Adams \& Co when he was only sixteen in 1888. Two years later, he secured a position with W. T. Stead's Review of Reviews as an editor and reviewer. In 1897, he opened his own publishing house under the imprint Grant Richards and published, among other works, Grant Allen's The Evolution of the Idea of God: An Inquiry into the Origins of Religion. In 1898, he issued works by two major authors: George Bernard Shaw (Plays Pleasant and Unpleasant) and A. E. Housman (A Shropshire Lad). Years later, he wrote and published eight novels under his own imprint and two Memoirs: Memories of a Misspent Youth, 1872-1896 (London: Heinemann, 1932), Author Hunting by an Old Literary Sportsman: Memories of Years Spent Mainly in Publishing, 1897-1925 (London: Hamish Hamilton, 1934). [Dunbarton Oaks Research Library and Collection: https://www.doaks.org/resources/bliss-tylercorrespondence/annotations/grant-richards]

2 Henry Blake Fuller's The Chevalier of Pensieri-Vani (1890).

3 (London: Longman's and Company, 1888).

4 William Holman Hunt (1827-1910) was a Pre-Raphaelite painter who contributed designs to The Germ in 1850. He published his Memoirs, PreRaphaelitism and the Pre-Raphaelite Brotherhood, in 1903. A drawing of Rossetti at twenty-five, executed by Hunt in 1853, is reproduced in Volume I of Hunt's Memoirs.

\section{Kensington Court Gardens.}

6 The date of this letter is uncertain, but Wednesday, February 14, 1894 seems most likely. In a December 21893 letter to Gilchrist, Sharp said he would not be able to go north to visit Gilchrist in December or January and asked if there was a chance of Gilchrist coming south. Later in December [around the 20th] he wrote to Gilchrist: "You are to come here in the early Spring, remember!" Mid-February is not early Spring, but the sequence of events as evidenced in subsequent correspondence argues for this February date and Friday/Saturday, February 16/17 for the Gilchrist/Garfitt visit to Phenice Croft.

7 In a letter of September 26, 1895, Sharp wrote to Gilchrist, “The most tragic \& momentous epoch of my life followed that visit of yours to Phenice Croft, \& is, so far, indissolubly linked with that day I met you, and that time." He also said he had described a walk he and Gilchrist and Garfitt took during their visit to Phenice Croft in one of the "Tragic Landscapes" he published in The Sin-Eaters as the work of Fiona Macleod. That brief sketch and its implications are described 
in some detail in the "Life" section of this chapter. Here it can be noted that Sharp became very ill in the latter half of February 1894 and this illness, which lasted for several months, appears to have resulted from his psychic experiments and the conflict between what Elizabeth Sharp described as "the two forces in him, or the two sides of his nature." That conflict, which was brought strikingly to the surface as he began to write as Fiona Macleod, "produced a tremendous strain on his physical and mental resources; and at one time between 1897-98 threatened him with a complete nervous collapse." (Memoir 223). The first such collapse seems to have occurred following the visit of Gilchrist and Garfitt, and that must have been what he had in mind when in 1895 he told Gilchrist that his visit was followed by "the most tragic \& momentous epoch of my life".

8 These friends were the Rinders who must have come on the weekend of March 10/11 to stay with Sharp at Phenice Croft for two weeks. See letter dated March $5,1894$.

9 This review appeared in Literary World on Saturday, May 5, 1894.

10 Public Opinion, see letter dated February 26, 1894 to Little.

11 This review appeared on Saturday, March 3, 1894.

12 Sharp's Vistas (1894).

13 Little's notice of Vistas appeared in Public Opinion on February 16, 1894.

14 Sir Frederick Wedmore (1844-1921) wrote essays on literature and art and contributed to The Guardian and The Times Literary Supplement edited by his wife, Millicent Wedmore. Among his works are Studies in English Art (1876); Etching in England (1895); Fine Prints (1897); and Life of Honore de Balzac (1890).

15 The first edition of Vistas, printed on large paper [L/P], was limited to 400 copies.

16 This laudatory review by George Cotterell dates the letter. It appeared in the number dated Saturday, March 3, 1894, 182-83. After brief summaries of each vista, the concluding sentence: "It is a book of rare excellence and real charm: a book to read and re-read until the vistas beyond vistas which it contains have revealed their full beauty and significance."

17 Sharp's review of Garnett's Poems appeared in The Academy no.1141.

18 Frank Murray, the Derby bookseller who printed Sharp's Vistas, edited and published Derbyshire Notes and Queries between October 1892 and December 1898 and compiled and published A Bibliography of Austin Dobson in 1900. In his October 7, 1893 letter to Gilchrist, Sharp said he learned from Frank Murray that 
Austin Dobson was his cousin.

19 The Stone Dragon and Other Tragic Romances (1894).

20 The Labyrinth: A Romance (1902).

21 An evil demon.

22 Date from postmark.

23 A mistake or private reference.

24 Herbert Stuart Stone (1871-1915) was the son of Melville Elijah Stone, a distinguished journalist, book collector, and patron of authors, who founded the Chicago Daily News and was its editor until 1888. In 1893, while still at Harvard, Stone and his fellow undergraduate Hannibal Ingalls Kimball (1874-1933) founded a publishing firm, Stone and Kimball. A bibliography of American first editions was their first jointly-issued book. Their policy was to accept only manuscripts of literary merit and to publish them in an artistic form. After earning their bachelor's degrees, they moved the firm to Chicago in August 1894 where Stone's father could help them financially. In May 1894 they began publishing The Chap-Book to publicize their books. Aubrey Beardsley and Max Beerbohm contributed to the periodical, and Toulouse-Lautrec designed posters for their publications. Among authors on the Stone and Kimball list were Hamlin Garland, George Santayana, Gilbert Parker, and Robert Louis Stevenson. Ingalls Kimball bought out Stone in 1896 after Melville Stone withdrew his financial support. Stone entered publishing again in Chicago as Herbert Stone and Company with the assistance of his younger brother Melville E. Stone, Jr. George Bernard Shaw's authorized editions were published by the Herbert Stone firm, which continued publishing until 1905.

25 George Herman Ellwanger (1848-1906) was an American writer whose works included The Garden Story (1890); In Gold and Silver (1892); Love's Demesne, A Garland of Contemporary Love Poems (1896); Idyllists of the Country Side; (1896) and Pleasures of the Table, An Account of Gastronomy (1902).

26 Stone and Kimball published an American edition of Vistas late in 1894 in their Greentree Library Series.

27 "The Rape of the Sabines" was included in the Pagan Review in 1892. Sharp wrote under various pseudonyms all the material in the single issue of that periodical.

28 Les Rois En Exile (1879)

29 Probably some other material to be included in Pharais. 
30 W. T. Price's Technique of the Drama (1892).

31 Sharp must have left for Normandy shortly after writing his April 8 card to Arthur Stedman, (in accord with the plans he sent Gilchrist on March 27). He had reached Paris by April 22. Several references suggest that Edith Rinder accompanied Sharp on this holiday in France.

32 This letter was written on May 4, the Friday of the week before Whitsunday. Easter was on March 25 in 1894, and Whitsunday was seven weeks later on May 13. Since Little could not come to Rudgwick on Whitsunday, Sharp wonders if he can come the weekend before Whitsunday. In a letter to Stanley Little on May 3 Elizabeth Sharp said she and her husband had just returned from Paris where she spent only three days. Sharp was in France for at least the last two weeks of April. On March 17 he told Gilchrist he hoped to be in Normandy before the week was out "and after a day or two by the sea at Dieppe, and then at beautiful and romantic Rouen, to get to the green lanes and open places, and tramp 'towards the sun."' The trip was delayed for almost a month.

33 Sharp's Pharais: A Romance of the Isles was published under the pseudonym Fiona Macleod by Frank Murray in Derby in May 1894.

\section{Literary World.}

35 This letter is not in the Fiona Macleod handwriting, which was that of Mary Sharp, the writer's sister, but in Sharp's own. It is, therefore, the original, which Sharp forwarded to Mary for her to copy into the Fiona Macleod hand. The return address - "C/o Mrs. B. etc" - is incomplete, and there is a note in the Fiona Macleod hand above the address to the effect that the letter was copied and sent to Allen. Preserved by Mary, E. A. S. used it in the Memoir and returned it to the Allen family along with other letters from her husband to Grant Allen. For information about Grant Allen, see the note to Sharp's letter to Richard Le Gallienne of May 22, 1888. It is interesting to note Grant Allen wrote a novel, The Type-writer Girl (1897), and published it under the feminine pseudonym, Olive Pratt Rayner.

36 Price's Technique of the Drama. See note to Stedman dated April 8, 1894.

37 Stone \& Kimball Publishing Company.

38 The reference here is to Flower o' the Vine, a volume of Sharp's poetry published by C. L. Webster and Company in 1892. Since that firm was in liquidation, Stedman had raised with Sharp the possibility that Stone and Kimball might purchase the plates at a good price and issue a second edition.

39 Pharais: A Romance of the Isles was published in May 1894.

40 The Mountain Lovers was published by John Lane (London) in the summer of 1895. 
41 Transformation was the title of the original 1860 British edition of Nathaniel Hawthorne's The Marble Faun.

42 Little has written a favorable review of Pharais, perhaps for the journal Public Opinion. W. R. may have been the June issue of the Westminster Review, which contained a review of Mona Caird's Daughters of Danae.

43 Sharp left Phenice Croft permanently on June 21 and moved to South Hampstead. Two days later, on Saturday 23, he went to Derbyshire to visit Gilchrist and Garfitt in Eyam. He may have gone on to Scotland for a few days, but that is uncertain.

44 Horace Elisha Scudder (1838-1902) edited The Atlantic Monthly from 1890 until 1898.

45 Sharp's "Cardinal Lavigerie's Work in North Africa," Atlantic Monthly, 74 (August, 1894), 214.

46 Sharp's Fair Women in Painting and Poetry (London: Seeley and Company, 1894). The book was published in July.

47 Lady Colin Campbell [Gertrude Elizabeth Blood] (1857-1911) was the youngest daughter of Edmund Maghlin Blood of Brickhill, County Clare, Ireland. She married Lord Colin Campbell, who was the youngest son of the eighth Duke of Argyll. Her publications include Darell Blake (1889); Etiquette of Good Society (1893); Ninety-second Thousand (1911); A Woman Walks in the World (1903). Sharp's plan to write a novel with her came to nothing.

48 Sharp's idea of collaborating on an article on copartnery came to nothing.

49 Paul Lacroix (1806-1884) was a French novelist, historian, and miscellaneous writer. Among his numerous works are Contes du Bibliophile Jacob (1831); La Dance macabre (1832); Convalescence du vieux conteur (1832-38); Romans relatifs a l'histoire de France aux XV et XV siecles (1838); and Curiosites de l'histoire des arts (1858); Berny was the pseudonym used by Louis Bergeron (1811-1890) who was the author Entre femmes, causerie intime (1892).

50 Edmund Louis Antoine Huot de Goncourt (1822-1896) and Jules Alfred Huot de Goncourt (1830-1870) were novelists, historians, and art critics. Among their joint works are La Lorette (1853); Histoire de La Societe Francaise pendant la Revolution (1854); Portraits Intimes du XVIII Siecle (1857-58); Les Hommes de Lettres (1860); Germinie Lacerteux (1869).

51 Erckmann-Chatrian is the joint pseudonym of Emile Erckmann (1822-1899) and Alexandre Chatrian (1826-1890), French novelists whose works include L'Ami Fritz (1873); Le Brigadier Frederic (1874); Les Vieux de la Vieille (1881). 
52 Walter Besant (1836-1901) and James Rice (1843-1882) were British novelists whose joint publications include The Golden Butterfly (1871); Ready-Money Moritboy (1872); 'Twas in Trafalgar's Bay (1897); The Chaplain of the Fleet (1881).

53 This letter establishes the date Sharp moved from Phenice Croft to Rutland House.

54 According to E. A. S. (Memoir 235-36), her husband wrote this poem the night before he left Phenice Croft. The poem was later included in Sharp's volume of poetry entitled From the Hills of Dream which was published as the work of Fiona Macleod. in 1896.

55 "Darthool and the Sons of Usna" appeared in Fiona Macleod's The Laughter of Peterkin (London: Archibald, Constable and Company, 1897). No separate book on the Darthula story was published.

56 Sharp left London on June 23 for Derbyshire where he spent three days with Gilchrist and Garfitt in Eyam. At this early point he was conflating Fiona's movements with his own. The trip establishes the probable date of the letter, which is in the Fiona handwriting.

57 As the previous card to Mavor indicates, Sharp was back in London by July 2. He may have gone on to Scotland for a few days (June 17 to July 2).

58 Roden Noel, an accomplished and well-known poet, died on May 16, 1894 at the age of 60 in a train station in Mainz, Germany.

59 The letter can be fully dated because it was certainly written in 1894 and July was the only month in which the seventh fell on Saturday.

60 For ultimo: of the preceding month.

61 "Cardinal Lavigerie's Work in North Africa" appeared in the August Atlantic Monthly.

62 Philip Gilbert Hamerton (1834-1894) was an editor, writer on art, landscape painter, and etcher. His books include Thoughts About Art (1862); Etching and Etchers (1866); Contemporary French Painters (1867); The Intellectual Life (1873). He also wrote several romances, and reprinted (1888) articles he had written for The Portfolio: Artistic Monographs, a periodical he began editing in 1869 . Sharp's Fair Women in Painting and Poetry constituted the July 1894 number of The Portfolio. Later in the year it was published in book form by Seeley \& Co. in London and Macmillan \& Co. in New York.

63 Probably the British edition of Vistas.

64 Probably Adelaide Louisa Allison (c.1855-1936) who married Christian 
Wilton Allhusen (1840-1924) in 1874.

65 This letter is marked with a large initial (" $G$ ") extending over its major contents.

66 The first portion of this letter is missing.

67 Sharp's portrait appears in The Chap-Book, 1 (September 15, 1895), 218. The photograph was taken by Frederick Hollyer.

68 “Lines to E. C. Stedman,” The Chap-Book, 1 (September 15, 1894), 212.

69 Probably Sharp's “Dedica,” The Chap-Book, 2 (January 15, 1895), 216.

70 Henry Mills Alden.

71 “A Northern Night," The Chap-Book, 1 (June 15, 1894), 60

72 The Gipsy Christ and Other Tales (Chicago: Stone \& Kimball, 1895).

73 "Low Tide on Grand Pré: A Book of Lyrics," The Academy, 45 (January 6, 1894), 7-8.

74 Anagram of Elizabeth Sharp.

75 The Graphic was a British weekly illustrated newspaper first published on December 4, 1869 by William Luson Thomas's company Illustrated Newspapers Limited. The influence of The Graphic within the art world was immense. It continued as a weekly under this title until July 1932 when it ceased publication after 3,266 issues, https://en.wikipedia.org/wiki/The_Graphic

76 The identity of this projected book by William Sharp is uncertain. The only book of Sharp's published by John Lane was Fiona Macleod's The Mountain Lovers.

77 Sharp's poem entitled “Dedica." See letter to Herbert Stone dated August 15, 1894.

78 Katharine Tynan-Hinkson (1861-1931) was an Irish poet and novelist. Among her numerous works are New Poems (1911); The Cure of Castle Eagle (1915); The Middle Years (1916); The Golden Rose (1924); A Fine Gentleman (1929); Twenty-five Years: Reminiscences (1913). The manuscript of the letter used here, in William Sharp's hand, is in the National Library of Scotland. Katharine TynanHinkson printed in her Memoir, volume II, The Middle Years (127), the version she received, which is Mary's copy in the Fiona Macleod hand. A comparison of the two versions indicates that Mary made some minor changes when she copied Sharp's letter. E. A. S. printed this letter in the Memoir (238). 
79 The Atlantic Monthly, 74 (December 1894), 801-14.

80 A novel by Hall Caine. "Heinemann published the Manxman on 3 August, 1894. It was an immediate and huge success, already reprinting on the 17 th. By mid-September it had sold 34,000 copies. Caine wrote in awe to Heinemann, stunned by the way the money was rolling in, far more than his previous books had earned. By 1913 the book had sold half a million copies and been translated into 12 languages. It was published simultaneously in New York by Appleton's and had an enormous success in the States, making Caine a household name there." (Vivien Allen, Hall Caine: Portrait of a Victorian Romancer, Sheffield: Sheffield Academic Press, 1997.)

81 A collection of Gilchrist's stories entitled The Stone Dragon and Other Tragic Romances (London: Methuen, 1894). "Hercules" is one of the stories in the volume. In their introduction to Gilchrist's The Basilisk and Other Tales of Dread (Ash-Tree Press: Ashcroft, British Columbia, 2003), John Pelan and Christopher Roden praise The Stone Dragon: "Among the great works of this period is a collection of the fantastic by one contributor to The Yellow Book, Robert Murray Gilchrist (1868-1917). Gilchrist is an author little-known today, but his collection is revered by aficionados of the genre as one of the most desirable, both for its literary merits and its near-legendary rarity.... Such is the rarity of the volume [The Stone Dragon] that even facsimile reprints vanished in short order following their publication, and a first edition of the book heads the wants-list of many world class collectors."

82 The stories intended for that volume, which was not published, may have appeared in Ecce Puella: And Other Prose Imaginings (Elkin Mathews: London, 1896).

83 The Gipsy Christ and Other Tales (Stone and Kimball: Chicago, 1895). It appeared in Britain as Madge o' the Pool: The Gipsy Christ and Other Tales (Archibald Constable: Westminster, 1897). Whereas the American publication contained seven tales, the British publication contained only four.

84 "Dec 494 " is written at the top of the letter in a hand that is not Sharp's. That was probably written by Little as the day he received the letter. Sharp told Gilchrist (letter of 12 Nov 94) that he was going to Scotland "for 2 or 3 weeks from the 1st of December."

85 Catherine Janvier quoted this passage from a William Sharp letter in her article entitled "Fiona Macleod and her Creator William Sharp" that appeared in the North American Review (184.612 (April 5), 1907). The passage followed Christmas greetings to the Janviers. She went on to quote from a letter she received from Sharp dated August 12, 1893 in which he said he was working on "a strange Celtic tale" called Pharais. She did not recall this letter when she 
read the copy of Pharais, but she did recall describing in a letter to Sharp a field of "mist-veiled daisies," and there they were in Pharais. When she reminded Sharp of this image and declared he was certainly Fiona Macleod, he had no choice but to tell the truth and pledge the Janviers to secrecy, which he did in a letter dated January 5, 1895.

86 "The Second Shadow," The New York Independent, 44 (August 25, 1892), 1205 ff.

87 The stories in The Gypsy Christ (Chicago: Stone \& Kimball, 1895) appeared in the following order: "The Gypsy Christ," "Madge o' the Pool," "The Coward," A Venetian Idyl," “The Graven Image," “The Lady in Hosea," "Fröken Bergliot."

88 "Some Personal Reminiscences of Walter Pater," The Atlantic Monthly, 74 (December 1894), 801-14.

89 “Rome in Africa," Harper's, 91 (June, 1895), 95-116. 



\section{Appendix}

\section{Letter location}

American Antiquarian Society

Baylor University

Browning Library

British Library

Brown University Library

Colby College's Miller Library

\section{Recipients of letters}

\author{
Clarke, December 20, 1887 \\ Robert Browning, December 10, 1882
}

Algernon Charles Swinburne, April 22, 1880

Hall Caine, [June 5, 1882]

Theodore Watts, October 12, 1883

Theodore Watts, [May 23, 1888]

Theodore Watts-Dunton, May 7, [1891]

Theodore Watts-Dunton, [November 18, 1892]

Emma Lucy Rossetti, June 5, 1883

H. Buxton Forman, November 6, [1891]

Maud Howe Elliott, [July 8 or 9? 1892]

Eugene Lee-Hamilton, [late December, 1880]

Eugene Lee-Hamilton, March 10, 1881

Violet Paget ("Vernon Lee"), March [17?], 1881

Violet Paget, May 16, 1881

Eugene Lee-Hamilton, November 18, 1882

Eugene Lee-Hamilton, [early], 1884

Eugene Lee-Hamilton, January, 1885

Violet Paget, [January 5, 1885] 
Columbia University Rare Book and Manuscript Library, Kenneth Lohf Papers
Edmund Clarence Stedman, August 17, [1889]

Edmund Clarence Stedman, [September 22, 1889]

Mrs. Stedman, October 12, [1889]

Edmund Clarence Stedman, [December 15?, 1889]

Edmund C. Stedman, June 14, 1890

Edmund Clarence Stedman, September 22, 1890

Edmund Clarence Stedman, October 22, 1890

Edmund Clarence Stedman, November 4, 1890

Arthur Stedman, [January 22?, 1892]

Mrs. Edmund Clarence Stedman, [January 27, 1892]

Arthur Stedman, [February 2?, 1892]

Mrs. Edmund Clarence Stedman, February 3, 1892

Mrs. Edmund Clarence Stedman, [February 13, 1892]

Arthur Stedman, [February 16?, 1892]

Mrs. Edmund Clarence Stedman, February 23, 1892

Arthur Stedman, [March 7, 1892]

Edmund Clarence Stedman, April 23 [1892]

Arthur Stedman, May 21, $1892^{1}$

Mrs. Edmund Clarence Stedman, [June 7?, 1892]

Arthur Stedman, [?June 11], 1892

Edmund Clarence Stedman, August 13th, [1892]

Edmund Clarence Stedman, September 28, 1892

Edmund Clarence Stedman, October 28, 1892

Arthur Stedman, November 29, 1892

Edmund Clarence Stedman, December 14, 1892

Arthur Stedman, [December 23, 1892]

Arthur Stedman, January 16, 1893 
Dartmouth College Library

Edinburgh City Libraries Harvard University, Houghton Library, Henry Elkin Widener Collection

Huntington Library, San Marino, California
Edmund Clarence Stedman, March 31, 1894 Arthur Stedman, April 8, 1894

Arthur Stedman, May 22, 1894

Edmund Clarence Stedman, April 13, 1892

Charles Webster \& Co., [mid April, 1892]

[Swan Sonnenschein and Company], May 4, 1893

Alexander Anderson, February 10, 1888

William Wetmore Story, July 15, 1890

Horace Scudder, November 15, 1890

Horace Scudder, September 18, 1891

Horace Scudder, September 19, 1891

Horace Scudder, [?early December, 1891]

Horace Scudder, December 29, 1891

Horace Scudder, [January 21, 1892]

Horace Scudder, January 29, 1892

Horace Scudder, June 20, [1894]

Horace Scudder, July 7, 1894

Horace Scudder, October 3, 1894

Horace Scudder, November 17, 1894

Horace Scudder, [October 10, 1893]

James Cotton, [Spring, 1887?]

Edmund Clarence Stedman, September 17, [1889]

Richard Watson Gilder, [early October, 1889]

Richard Watson Gilder, [late October, 1889] Robert Underwood Johnson, November 6, 1889

Edmund Clarence Stedman, June 17, 1890

[Bliss Carman], September 3, $1891^{2}$

Richard Watson Gilder, June 3, 1893

Robert Underwood Johnson, July 15, 1893

Frank Murray, [early April, 1894]

Herbert Stuart Stone, August 15, 1894

Herbert Stuart Stone, August 19, 1894

Herbert Stuart Stone, [October] 20, [1894]

Herbert S. Stone, December 22, [1894] 
Indiana University, Lilly Library

Library of Congress,

Moulton Collection

Manx Museum, Isle of Mann

National Library of Scotland
Dante Gabriel Rossetti, [March 1880]

Louise Chandler Moulton, [?July 3, 1887]

Louise Chandler Moulton, July 13, 1889

Louise Chandler Moulton [mid-January, 1890]

Louise Chandler Moulton, August 23, 1890

Louise Chandler Moulton, January 12, 1892

Louise Chandler Moulton, January 21, [1892]

Louise Chandler Moulton, June 20, 1893

Louise Chandler Moulton, July 15, 1893

Hall Caine, [June 15, 1882]

Hall Caine, [July?, 1882]

Hall Caine, [?September, 1882]

Hall Caine, [early August, 1883]

Hall Caine, [November, 1883]

Hall Caine, [February 11, 1884]

Hall Caine, [March, 1884]

Hall Caine, [June 15, 1884]

Hall Caine, August 26, 1884

Hall Caine, [mid-February, 1885]

Hall Caine, [?February, 1886]

Hall Caine, September 1, 1887

Hall Caine, [early November, 1887]

Hall Caine, [March 4, 1889]

Hall Caine, March 19, 1889

Hall Caine, January 6, 1890

Hall Caine, January 23, 1890

Mrs. Oliphant, October 30, 1890

W. A. Dalt, [late June, 1894]

Katharine Tynan Hinkson, September, 1894

Editor, Blackwood's Magazine, August 21, 1891

Editor of Blackwood's Magazine, November 28, 1892

Editor of Blackwood's Magazine, December 5, 1892

Frank Murray, July 19, 1993

Frank Murray, December 27, 1893 
Newberry Library,

Chicago

New York Public Library,

Berg Collection

New York University, Fales Library

Northwestern

University Library

Oxford University,

Bodleian Library

Pennsylvania State University,

Pattee Library

Pierpont Morgan Library,

New York, NY
Herbert Stuart Stone, May 22, 1894

Buxton Forman, [1883]

Harry Buxton Forman, [1883]

Mrs. David Octavius Hill, [late January, 1889]

[John Lane], February 22, 1890

[John Lane], [June 20, ?1890]

Herbert Stuart Stone, April 3, 1894

Herbert Stuart Stone, May 23, 1894

Stone \& Kimball, July 30, 1894

Herbert Stuart Stone, December 31, 1894

[?early 1888]

Wilfred Meynell, [late 1885?]

Wilfred Meynell, [late 1885?]

November 8, 1886 [?early 1888]

Richard Watson Gilder, December 18, 1889

Bliss Carman, [mid-May, 1890]

Bliss Carman, [August 13?, 1892]

Frederick Langbridge, November 13, [1890]

Mrs. Allhusen, July 9, 1894

A. Williams, [?November, 1888]

Edmund Clarence Stedman, July 27, 1889

Edmund Clarence Stedman, September 28, 1894

[Mrs. E. C. Stedman], [mid-December, 1893]

Frederick Langbridge, December 2, 1882

The New York Independent, [January, 1888]

Andrew Chatto, [Fall 1888]

Thomas Wentworth Higginson, [April, 1889] 
Princeton University,

Firestone Library,

Rare Books and

Special Collections
W. Kineton Parkes, [May 29, 1890]

Bliss Carman, December 8, 1891

Arthur Stedman, [January 26, 1892]

J. D. Marshall, February 19, 1892

Mr. Parsons, [1884]

Frederick Langbridge, [?January 5, 1886]

J. Stanley Little, [mid-October, 1886]

J. Stanley Little, January 3, 1887

J. Stanley Little [January?, 1887]

May Clarissa Gillington, [Spring, 1887]

J. Stanley Little, [mid-October?, 1887]

J. Stanley Little, October 27, 1887

J. Stanley Little, [October 31, 1887]

Theodore Watts, [mid-October, 1888] 1888 [late 1888]

J. Stanley Little, May 4, 1889 early June, 1889

Henry Chandler Bowen, December, 1889 John Lane, [February 14, 1890]

John Lane, [March 21, 1890]

J. Stanley Little, April 16, 1890

J. Stanley Little, July 10, 1890

J. Stanley Little, [March 9, 1892]

J. Stanley Little, [mid-April, 1892]

J. Stanley Little, [April 23?, 1892?]

J. Stanley Little, May 19, 1892

J. Stanley Little, May 25, 1892

J. Stanley Little, June 20, 1892

J. Stanley Little, June 4, 1892

J. Stanley Little, June 21, 1892

J. Stanley Little, June 22, 1892

J. Stanley Little, June 24, 1892

J. Stanley Little, June 30, 1892

J. Stanley Little, July 10, 1892

J. Stanley Little, October 8, 1892

J. Stanley Little, October 9, 1892

Alfred H. Miles, November 4, 1892

J. Stanley Little, [November, 1892]

J. Stanley Little, [November ?15, 1892]

J. Stanley Little, [December 8, 1892] 
Elkin Mathews, December 11, 1892

J. Stanley Little, December 11, 1892

J. Stanley Little, [December 13, 1892]

J. Stanley Little, [December 17, 1892]

Dr. Ward, early 1893

J. Stanley Little, January 7, 1893

J. Stanley Little, January 22, 1893

J. Stanley Little, [early February, 1893]

J. Stanley Little, March 29, 1893

J. Stanley Little, April 3, 1893

J. Stanley Little, May 7, 1893

J. Stanley Little, May 10, 1893

J. Stanley Little [July 27, 1893]

J. Stanley Little, [early August, 1893]

J. Stanley Little, [September 23, 1893]

Louise Chandler Moulton, [October 9, 1893]

J. Stanley Little, November 28, 1893

William Clavell Ingram, December 14, 1893 Osborne, early 1894

John Lane, February 2, 1894

J. Stanley Little, February 10, 1894

J. Stanley Little, [March 1, 1984]

J. Stanley Little, [March 5, 1894]

J. Stanley Little, [mid-June, 1894

Edmund Clarence Stedman, July 3, 1894

John Lane, [mid-July, 1894]

J. Stanley Little, [December 1, 1894

Robert Murray Gilchrist, August 18, 1893

Robert Murray Gilchrist, September [10?], 1893

Robert Murray Gilchrist, September 23, 1893

Robert Murray Gilchrist, October 7, 1893

Robert Murray Gilchrist, December 20?, 1893

Robert Murray Gilchrist, [?February 14, 1894]

Robert Murray Gilchrist, April 22, 1894

Robert Murray Gilchrist, June 14, 1894

Robert Murray Gilchrist, [June 19?, 1894] 
Smith College Library

Stanford University Library

SUNY at Buffalo Library

Trinity College,

Dublin Library

University of British Columbia

Library, Special Collections
Robert Murray Gilchrist, [early July, 1894]

Robert Murray Gilchrist, November 12, 1894

Robert Murray Gilchrist, August 18, 1893

Bliss Carman, July 25, 1890

Bliss Carman, February 3, 1891

Bliss Carman, October 15, 1891

Bliss Carman, June 11, 1892

Richard Watson Gilder, September 30, 1889

John M. Gray [mid-April, 1890]

The Editor, Lippincott's Magazine, January 26,1889

Edward Dowden, May 22, 1882

Edward Dowden, July 16, 1882

Edward Dowden, [December 10, 1882]

Edward Dowden, April 30, 1883

Edward Dowden, April 26, 1884

Edward Dowden, [May 21, 1884]

Edward Dowden, July 22, 1885

Edward Dowden, [November 12, 1885]

Edward Dowden, November 14, 1885

Edward Dowden, [December, 1885]

Edward Dowden, February 3, 1886

Edward Dowden, [November 26, 1886]

Edward Dowden, November 27, 1886

Edward Dowden, [early January, 1887]

Edward Dowden, [June 7, 1887

Edward Dowden, [?August, 1887]

Edward Dowden, November 14, 1887

Edward Dowden, [March 18, 1889]

Edward Dowden, September?, 1892

Edward Dowden, [December 20?, 1892]

Edward Dowden, February 26, 1894

William Bell Scott, [April] 22, [1882]

William Michael Rossetti, July 21, 1882

Alfred H. Miles, December 31, 1887

Frederick Wedmore, [mid-April, 1890]

Alfred H. Miles, October 31, 1892 
Alfred H. Miles, June 30, 1893

J. Stanley Little, [May 4, 1894]

University of California Berkeley,

E. C. Stedman, July 21, 1890

University Research Library,

Bancroft Collection

University of California Los

John Stuart Verschoyle, [May 1 or 2, 1889]

Angeles, William Andrews Clark

John Stuart Verschoyle, [mid-May, 1890]

Library

John Stuart Verschoyle, August 20, 1890

University of Delaware Library,

Richard Watson Gilder, February 22, 1890

Newark

[Henry Mills Alden], April 19, 1893

University of Illinois at Urbana

William Allingham, November 11, 1885

Library, Rare Book Room

Mrs. Henry Mills Alden, July 9, 1894

Henry Mills Alden, [early August, 1894]

University of Iowa Library

Bliss Carman, [mid-July, 1891]

University of Kentucky,

Nina F. Layard, November 29, 1893

W. Hugh Peal Collection

University of Leeds,

Theodore Watts [-Dunton], July 27, 1882

Brotherton Library

Theodore Watts [-Dunton], February 18, 1884

[Theodore Watts, October 12, 1885]

Theodore Watts [-Dunton], February 15, [1886]

Theodore Watts, [October 1 or 2, 1890]

Theodore Watts [-Dunton], [October 11, 1890]

Theodore Watts [-Dunton], [November ?14, 1892]

Theodore Watts [-Dunton], October 11, 1894

Theodore Watts [-Dunton], [November 19, 1892]

Theodore Watts [-Dunton], [December 7, 1892]

Will Foster, June 21, 1893 
University of Texas Austin, Ransom Richard Garnett, [Early November, 1882] Humanities Research Center Richard Le Gallienne [late February, 1887] Richard Garnett, [Spring, 1887] [Richard Garnett], [Early 1888] Richard Le Gallienne, [late January?, 1888] Richard Le Gallienne, [early May, 1888] Frederick Shields, [early May, 1888] Richard Le Gallienne, [May 19, 1888] Richard Le Gallienne, [May 22, 1888] Richard Le Gallienne, [early June, 1888] Richard Le Gallienne, July 7, 1888 Richard Garnett, [Fall, 1888] Richard Garnett, [mid-March, 1889] Richard Le Gallienne, May 9, 1889 Frank Dempster Sherman, July 9, 1889 Richard Garnett, [early January, 1891] Richard Le Gallienne, [late October, 1891] Richard Le Gallienne, January 6, 1892 Richard Le Gallienne, October 7, 1892 Richard Garnett, [June?, 1893] Grant Richards, January 30, 1894 Richard Le Gallienne, February 9, 1894 Richard Garnett], [mid-March, 1894

University of Toronto, Thomas Fisher Rare Book Library, James Mavor Papers
James Mavor, [February 8, 1889]

James Mavor, [February 10, 1889]

[James Mavor], [mid-March, 1889]

James Mavor, May 10, 1889

James Mavor, [late May, 1889]

Joseph Antisell Allen, [September 16, 1889]

James Mavor, December 14, 1889

James Mavor, March 18, 1890

James Mavor, June 12, 1890

James Mavor, July 7, 1890

James Mavor, [mid-July, 1890]

John Lane, [early June, 1894]

[John Lane], [June 22, 1894]

James Mavor, July 2, 1894

John Lane, [July] 7, [1894]

John Lane, August 16, 1894

[John Lane], [late August, 1894] 
University of Wisconsin-Milwaukee, Mr. Osborne, June 4, 1888

Golda Meir Library

Clinton Scollard, July 19, 1889

E. C. Stedman, October 6, 1889

Kineton Parkes, July 13, 1890

Kineton Parkes, November 19, 1892

W. Kineton Parkes, December 7, 1892

Messrs. Williams \& Norgate, December 10, 1892

Kineton Parkes, May 10, 1893

Wake Forest University

Charles Webster, March 23, 1893

Washington University Libraries

Horace Scudder, [January 29, 1892]

Yale University,

Robert Lewis Stevenson, December 14, 1886

Beinecke Library

Arthur Stedman, January 4, 1890

Alfred Austin, [October 14?, 1892]

Alfred Austin, January 1, 1893 



\section{List of Illustrations}

1. Dante Gabriel Rossetti in 1850 at the age of 22. A portrait by William Holman Hunt (c.1883), Wikimedia, https:// commons.wikimedia.org/wiki/File:William_Holman_ Hunt_-_Portrait_of_Dante_Gabriel_Rossetti_at_22_years_ of_Age_-_Google_Art_Project.jpg, Public Domain.

2. An albumen print of Dante Gabriel Rossetti. Taken by Charles Lutwidge Dodgson (Lewis Carroll) (1863), Wikimedia, https://commons.wikimedia.org/wiki/ File:Dante_Gabriel_Rossetti_001.jpg, Public Domain.

3. Hall Caine, The Manxman, as caricatured in Vanity Fair. John Bernard Partridge (1896), Wikimedia, https:// en.wikipedia.org/wiki/File:Hall_Caine_Vanity_Fair_2_ July_1896.jpg, Public Domain.

4. Photograph of William Sharp taken by an unknown photographer in Rome in 1883. Reproduced from William Sharp: A Memoir, compiled by Elizabeth Sharp (London: William Heinemann, 1910).

5. Photograph of Edward Dowden. Robinson (c.1895), Wikimedia, https://commons.wikimedia.org/wiki/ File:Portrait_of_Edward_Dowden.jpg, Public Domain.

6. George Meredith, no later than 1913, in Robert Louis Stevenson: A Bookman Extra Number 1913 (London: Hodder \& Stoughton), p. 138, Wikimedia, https://commons. wikimedia.org/wiki/File:George_Meredith\%27s_Portrait. jpg

7. Arthur Ellis (c.1894). Photograph of Richard Le Gallienne. Wikimedia, https://commons.wikimedia.org/wiki/ File:Richard_Le_Gallienne,_by_Alfred_Ellis.jpg, Public Domain. 
8. An 1897 photograph of Edmund Clarence Stedman (1833-1908) an American poet, critic, essayist, banker, and scientist. Wikimedia, https://commons.wikimedia.org/ wiki/File:Edmund_Clarence_Stedman_cph.3a44372.jpg

9. Blanche Willis Howard, in F. E. Willard, A Woman of the Century: Fourteen Hundred-seventy Biographical Sketches Accompanied by Portraits of Leading American Women in all Walks of Life (Buffalo, N.Y.: Moulton, 1893), p. 735, Wikipedia, https://commons.wikimedia.org/wiki/ File:BLANCHE_WILLIS_HOWARD_VON_TEUFFEL._A_ woman_of_the_century_(page_745_crop).jpg

10. Walt Whitman, aged 37, from the frontispiece to Leaves of Grass (Fulton St., Brooklyn, N.Y, 1855). Steel engraving by Samuel Hollyer from a lost daguerreotype by Gabriel Harrison (1854), Wikimedia, https://commons.wikimedia. org/wiki/File:Walt_Whitman,_steel_engraving,_July_1854. jpg, Public Domain.

11a. Early 20th century photograph of Buck's Green, Rudgwick, Sussex. CRudgwick Preservation Society. Courtesy of Roger Nash, Chair, Rudgwick Preservation Society, https:// www.rudgwick-rps.org.uk, all rights reserved.

11b. Mid-20th Century photograoph of Buck's Green, Rudgwick, Sussex from a post card purchased there. Phenice Croft, now the Toll House, is across the road from the building, now white, which housed the shop. (OThe Francis Frith Collection, https://www.francisfrith.com/ bucks-green/bucks-green-the-village-c1965_b587001

12. Portrait of Edith Wingate Rinder taken by an unknown photographer (c.1894). Courtesy of the family of Mrs. Rinder.

13. Photograph of William Sharp in 1894 by Frederick Hollyer. Reproduced from Poems by William Sharp. Selected and Arranged by Mrs. William Sharp (London: William Heinemann, 1912).

14. Portrait of Mary Beatrice Sharp, William Sharp's youngest sister taken in the Davis Studios in Edinburgh in 1906. Courtesy of the Department of Rare Books and Special Collections, Dulles Reading Room, Firestone Library, Princeton University. 
15a. Verso of Figure 4 in Mary Sharp's handwriting which was the Fiona Macleod handwriting. Inscribed to "To the Reverend R. Wilkins Rees. Yours Sincerely, Mary B. Sharp. Fiona Macleod's sister, who did all the writing of the Fiona Macleod work and carried on the correspondence connected with it."

15b. Letter to Grant Richards from William Sharp in his handwriting. Courtesy of the Harry Ransom Humanities Research Center, The University of Texas at Austin.

16. Photograph of Grant Allen (1848-1899) by Elliott \& Fry (c.1899), Wikimedia, https://commons.wikimedia.org/ wiki/File:Portrait_of_Grant_Allen.jpg, Public Domain. 



\section{This book need not end here...}

\section{Share}

All our books - including the one you have just read - are free to access online so that students, researchers and members of the public who can't afford a printed edition will have access to the same ideas. This title will be accessed online by hundreds of readers each month across the globe: why not share the link so that someone you know is one of them?

This book and additional content is available at:

https://doi.org/10.11647/OBP.0142

\section{Customise}

Personalise your copy of this book or design new books using OBP and thirdparty material. Take chapters or whole books from our published list and make a special edition, a new anthology or an illuminating coursepack. Each customised edition will be produced as a paperback and a downloadable PDF. Find out more at:

https://www.openbookpublishers.com/section/59/1

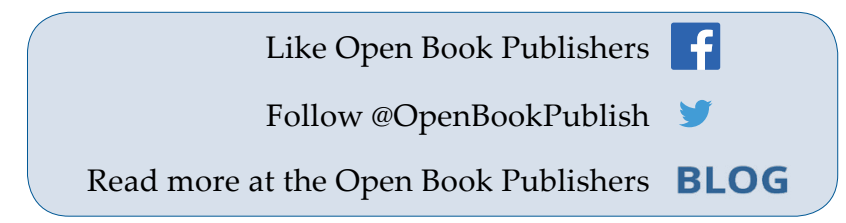




\section{You may also be interested in:}

\section{A Fleet Street in Every Town}

The Provincial Press in England, 1855-1900

By Andrew Hobbs

https://doi.org/10.11647/OBP.0152

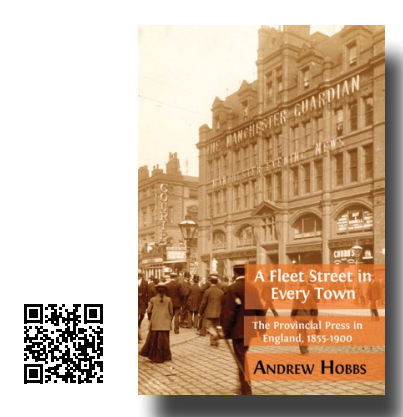

Verdi in Victorian London

Verdi in

Victorian London

By Massimo Zicari

https://doi.org/10.11647/OBP.0090

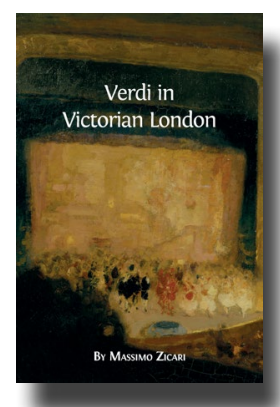

Dickens's Working Notes for Dombey and Son

By Tony Laing

https://doi.org/10.11647/ОВР.0092

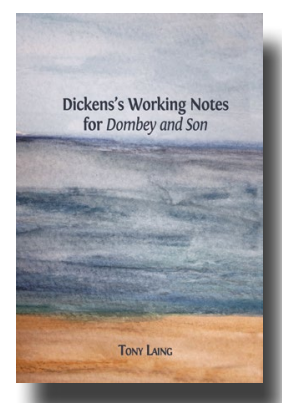




\section{The Life and Letters of William Sharp and "Fiona Macleod"}

\section{Volume 1: 1855-1894}

\section{Wiluiam F. HaLloran}

William Sharp (1855-1905) conducted one of the most audacious literary deceptions of his or any time. Sharp was a Scottish poet, novelist, biographer and editor who in 1893 began to write critically and commercially successful books under the name Fiona Macleod. This was far more than just a pseudonym: he corresponded as Macleod, enlisting his sister to provide the handwriting and address, and for more than a decade "Fiona Macleod" duped not only the general public but such literary luminaries as William Butler Yeats and, in America, E. C. Stedman.

Sharp wrote "I feel another self within me now more than ever; it is as if I were possessed by a spirit who must speak out". This three-volume collection brings together Sharp's own correspondence - a fascinating trove in its own right, by a Victorian man of letters who was on intimate terms with writers including Dante Gabriel Rossetti, Walter Pater, and George Meredith - and the Fiona Macleod letters, which bring to life Sharp's intriguing "second self".

With an introduction and detailed notes by William F. Halloran, this richly rewarding collection offers a wonderful insight into the literary landscape of the time, while also investigating a strange and underappreciated phenomenon of late-nineteenth-century English literature. It is essential for scholars of the period, and it is an illuminating read for anyone interested in authorship and identity.

As with all Open Book publications, this entire book is available to read for free on the publisher's website. Printed and digital editions, together with supplementary digital material, can also be found here:

www.openbookpublishers.com

Cover image: Photograph of William Sharp, 1894

Cover design: Anna Gatti

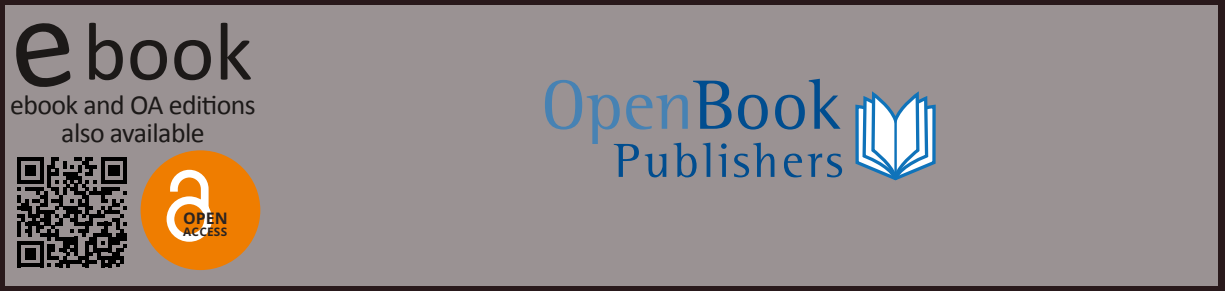

